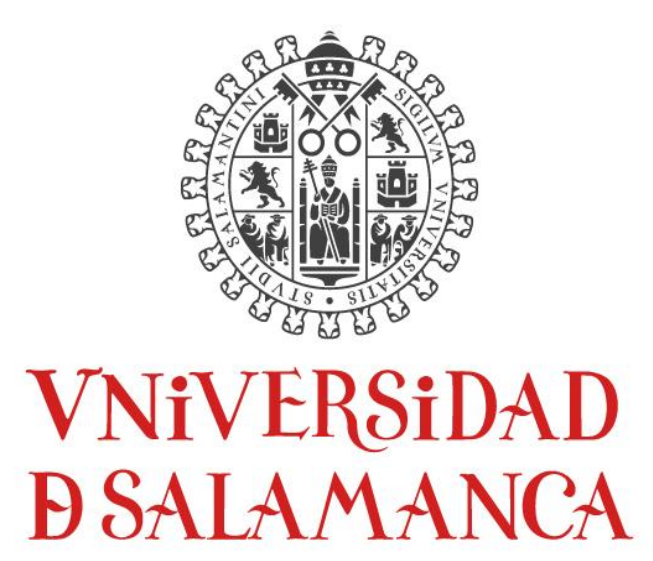

CAMPUS DE EXCELENCIA INTERNACIONAL

Departamento de Derecho Público General

Área de Ciencia Política y de la Administración

Doctorado en Procesos Políticos Contemporáneos

Tesis Doctoral

\title{
CLIENTELISMO EN DEMOCRACIA: \\ FACTORES EXPLICATIVOS DE LA POLÍTICA PARTICULARISTA EN LA REPÚBLICA DOMINICANA 1996-2010
}

\author{
Presentada por: \\ Ana Belén Benito Sánchez \\ Directores: \\ Leticia M. Ruiz Rodríguez, Universidad Complutense de Madrid \\ Iván Llamazares, Universidad de Salamanca \\ Salamanca \\ Enero 2015
}




\section{AGRADECIMIENTOS}

Esta tesis pone el punto y aparte a un camino que comenzó en 2005 como alumna del Programa Procesos Políticos Contemporáneos de la Universidad de Salamanca (USAL). En estos diez años ha sido constante el apoyo institucional y personal de los miembros del Área de Ciencia Política de la USAL, al igual que continuo ha sido el aprecio que he recibido durante mi estancia en la República Dominicana gracias al trabajo y al prestigio de todos ellos.

El trabajo de campo de esta tesis doctoral fue posible gracias al apoyo financiero del Ministerio de Asuntos Exteriores de España (MAEC) y su Programa de Cooperación Científica, y de la Fundación Carolina como becaria del Programa de Formación Permanente. Ninguna de estas dos modalidades de ayuda a la investigación ha sobrevivido a los recortes. Con ello, tristemente se resienten la educación superior y la universidad pública, y se agranda aún más la brecha en la movilidad, especialización e inserción de españoles en organismos internacionales.

Gracias también a la Facultad Latinoamericana de Ciencias Sociales (FLACSO-RD), al Observatorio de Migrantes del Caribe (OBMICA), a la biblioteca Profesor Juan Bosch (FUNGLODE) y especialmente al Centro de Gobernabilidad y Gerencia Social (CEGES-INTEC), por abrirme tan generosamente sus puertas en Santo Domingo durante las diferentes etapas de mi investigación.

Finalmente, gracias a mis padres Ramón Benito y María Sánchez y a mi hermana María José por su apoyo incondicional cuando la inspiración, el ánimo y las becas flaqueaban, y gracias a mi tutora Leticia María Ruiz por alentarme y acompañarme siempre en este largo camino.

Gracias a todos.

Salamanca, Enero de 2015 
«Realizábamos uno de los acostumbrados recorridos de Navidad por la provincia. Llevábamos música, alegría y distribuíamos canastas de alimentos y golosinas a las empobrecidas familias. Pero, además, se repartían unos sobrecitos amarillos, donados por empresarios amigos, que contenían algunos regalos para la ocasión. Se impresionó al ver la multitud que se abalanzaba sobre uno de los encargados de hacer la distribución y me dijo: "Presidente, ¿ha visto cómo el compañero Pedro se ha convertido, de repente, en un lider?" (...) Entonces, lo miré y le dije: "Observe lo siguiente. Vamos a pedirle que le entreguen los sobrecitos al compañero Manuel, dirigente provincial, para que él continúe el reparto y a ver qué pasa". Así ocurrió y la muchedumbre rápidamente abandonó a Pedro y se desplazó hacia el compañero Reyes, quien empezaba a hacer la repartición de los sobrecitos. Entonces le pregunté: "¿Qué tal, qué le parece? Míre el gran lider que en cuestión de segundos se ha convertido el compañero Manuel, ahora encargado de repartir los sobrecitos". No pudo contener la risa. Habia aprendido la lección»

Leonel Fernández

Presidente de la República Dominicana (1996-2000; 2004-2008; 2008-2012) Periódico Nacional Listín Diario, 10 de febrero de 2014

\section{[Clientes pobres pero ricos en votos]}

«Manos que dan esperan. Yo quiero que usted entienda presidente [del Senado], que si usted se compromete con nuestro sector, las tres asociaciones presentes aqui nos comprometemos formalmente con usted a tratar dentro de nuestras posibilidades a ayudarlo a que sea Presidente [del Estado]. Lo que queremos no es un intercambio sino una ayuda para que este sector tan pujante, tan dinámico en la economía, pueda resurgir»

Luis Taveras

Presidente Asociación Nacional de Importadores de Vehículos (2014-2016) Periódico Nacional El Caribe, 14 de marzo de 2014

[Clientes ricos pero pobres en votos] 


\section{ÍNDICE GENERAL}

\section{INTRODUCCIÓN}

\section{CAPÍTULO 1. ELEMENTOS TEÓRICOS Y METODOLÓGICOS PARA EL ESTUDIO DE LA POLÍTICA PARTICULARISTA}

1.1. CONSIDERACIONES TEÓRICAS 23

1.1.A) Política Particularista y Representación en Democracia. 23

1.1.B) Factores explicativos del lado de la Oferta 27

$\checkmark$ Cómo inciden las Relaciones del Estado con los Partidos en la política 27 particularista

$\checkmark$ Cómo inciden las Relaciones Partido-Partido en la política particularista $\quad 30$

1.1.C) Factores explicativos del lado de la Demanda 32

$\checkmark$ Cómo inciden las Relaciones del Estado con la Ciudadanía en la política $\quad 32$ particularista

1.2. CONSIDERACIONES METODOLÓGICAS

1.2.A) Objetivos y preguntas de investigación $\quad 35$

1.2.B) La variable dependiente y sus indicadores $\quad 36$

$\begin{array}{ll}\text { 1.2.C) Las variables independientes } & 45\end{array}$

1.3. RECAPITULACIÓN DISEÑO DE INVESTIGACIÓN E INDICADORES DE $\quad 49$ MEDICIÓN PARA EL CASO DOMINICANO

\section{CAPÍTULO 2. La variable dependiente: DIAGNÓSTICO Y MEDICIÓN DE LA POLÍTICA PARTICULARISTA EN LA REPÚBLICA DOMINICANA}

2.1. INTRODUCCIÓN

2.2. CLIENTELISMO ELECTORAL: Beneficios selectivos a cambio de voto

2.3. CLIENTELISMO DE PARTIDO: Influencia partidista a cambio de apoyo político

2.4. CLIENTELISMO OFICIAL: Recursos públicos a cambio de apoyo oficial

2.4.1. Particularismo Ejecutivo: Asistencialismo particularista

2.4.2. Particularismo Burocrático: Patronazgo estatal

2.4.3. Particularismo Legislativo: Representación prebendalista

$\checkmark$ 2.4.3.A) ¿Qué proponen los Diputados?: Proposiciones de ley presentadas ante la Cámara de Diputados (1998-2010)

$\checkmark$ 2.4.3.B) ¿Qué conceden los Diputados?: Gastos Fondo de Gestión Legislativa o "barrilito" (2008-2009).

2.5. LA MOVILIZACIÓN Y AGREGACIÓN PARTICULARISTA DE INTERESES EN LA REPÚBLICA DOMINICANA EN PERSPECTIVA COMPARADA 


\section{CAPÍTULO 3. Variables Independientes (I): FACTORES QUE DETERMINAN LA POLÍTICA PARTICULARISTA DESDE LA OFERTA}

3.2. RELACIONES ESTADO-PARTIDOS

1) El pasado del escenario institucional en la República Dominicana 104

2) Las reglas del juego $\quad 110$

$\checkmark$ Voto preferencial $\quad 110$

$\checkmark$ Tamaño de la circunscripción y fragmentación del territorio nacional 113

$\checkmark$ Desproporción, doble vuelta y umbral electoral $\quad 120$

$\checkmark$ Financiamiento $\quad 121$

3) La clase política dominicana ¿Políticos-empresarios o empresarios-políticos? 124

3.3. RECAPITULACIÓN 139

3.4. RELACIONES PARTIDO-PARTIDO 141

1) Competición y representación política en el sistema de partidos dominicano 143

$\checkmark$ Estabilidad sistémica y organización informal $\quad 145$

$\checkmark$ Voto personalista no programático $\quad 151$

$\checkmark$ Desideologización y ausencia de polarización $\quad 159$

$\checkmark$ Vocación nacional y focus distrital $\quad 165$

2) Si tú me dices ven: pactos, aliados y trashumantes en el sistema de partidos 170 dominicano

$\checkmark$ Pactos 1990-2010 175

$\checkmark$ Alianzas Electorales 2002-2012 $\quad 178$

$\checkmark$ La trashumancia partidaria en República Dominicana $\quad 184$

3) El enemigo en casa: caciques y facciones en los partidos políticos dominicanos $\quad 188$

$\checkmark$ Dos gallos en el mismo corral o cómo pelearse en el PRD $\quad 190$

$\checkmark$ El disenso en el PLD: de la excomunión a la cooperación 194

$\checkmark$ El neo caciquismo democrático reformista 196

3.5. RECAPITULACIÓN 200 


\title{
CAPÍTULO 4. Variables Independientes (II): FACTORES QUE DETERMINAN LA POLÍTICA PARTICULARISTA DESDE LA DEMANDA
}

\author{
4.1. INTRODUCCIÓN 203
}

4.2. RELACIONES DEL ESTADO CON LA CIUDADANÍA 207

4.2.A) CULTURA ORGANIZACIONAL EN LA REPÚBLICA DOMINICANA 207

1) La promoción estatal del poder empresarial $\quad 207$

2) El activismo civil subsidiado en la etapa de la consolidación democrática 211

3) Del exilio a los despachos: calamidades y conquistas del sindicalismo 217 dominicano

4.2.B) CAPITAL SOCIAL Y POLÍTICO: VALORES, ACTITUDES Y 230

PERCEPCIONES DE LOS CIUDADANOS DOMINICANOS

$\checkmark$ Autoritarismo $\quad 231$

$\checkmark$ Paternalismo 233

$\checkmark$ Populismo 235

$\checkmark$ Conservadurismo 237

$\checkmark$ Personalismo $\quad 242$

$\checkmark$ Confianza estratégica particularizada $\quad 244$

$\checkmark$ Participación y movilización social 246

$\checkmark$ Legitimidad democrática, descontento y desafección institucional 253

4.3. RECAPITULACIÓN 258

CAPÍTULO 5. CONCLUSIONES

5.1. PRINCIPALES HALLAZGOS y CONTRIBUCIÓN DEL ESTUDIO 259

BIBLIOGRAFÍA 273

$\begin{array}{lr}\text { SIGLAS } & 288\end{array}$

$\begin{array}{lr}\text { ANEXOS } & 289\end{array}$ 


\section{ÍNDICE DE TABLAS, GRÁFICOS y FOTOS}

\section{Capítulo 1}

Tabla 1.1.A.1

Tabla 1.1.A.2

Gráfico 1.2.B.1

Tabla 1.2.B.1

Tabla 1.2.B.2

Tabla 1.1.B.3

Tabla 1.2.B.4

Gráfico 1.2.B.1

Tabla 1.2.B.5

Tabla 1.2.B.6

Tabla 1.3

Gráfico 1.2.C.1

Capítulo 2

Foto 2.2.1

Tabla 2.2.1

Tabla 2.2.2

Gráfico 2.4.1.1

Gráfico 2.4.1.2

Foto 2.4.1.1

Gráfico 2.4.1.3

Gráfico 2.4.1.4

Foto 2.4.1.2

Foto 2.4.2.1

Gráfico 2.4.2.1

Gráfico 2.4.2.2

Tabla 2.4.3.A.1

Gráfico 2.4.3.A.1

Tabla 2.4.3.A.2

Tabla 2.4.3.A.3

Tabla 2.4.3.A.4

Tabla 2.4.3.A.5

Tabla 2.4.3.A.6

Tabla 2.4.3.A. 7

Tabla 3.4.3.B.1

Foto 3.4.3.B.1

Tabla 3.4.3.B.2

Tabla 3.4.3.B.3

Foto 3.4.3.B.2

Tabla 3.4.3.B.4
Clasificación del clientelismo según el agente y el objeto del intercambio

Propuesta tipología clientelismo

¿Qué proponen los diputados? (Indicador 1)

Clasificación Proposiciones de Ley por nivel de Particularismo y \% Total, 1998-2010 37

Ejemplos Proposiciones de Ley Representación General, 1998-2010

Ejemplos Proposiciones de Ley Representación Corporativa, 1998-2010

Ejemplos Proposiciones de Ley Representación Individual, 1998-2010

¿Qué conceden los diputados? (Indicador 2)

Clasificación Fondo Social o "barrilito" por nivel de Particularismo y \% Total, 2008-2009

Ejemplos Solicitudes "barrilito" 2008-2009

Recapitulación diseño de investigación e indicadores de medición para el caso dominicano

Relaciones que condicionan la mayor o menor prevalencia del particularismo

Reparto de comida y dinero en campaña electoral

Vio a algún partido o candidato realizar estas actividades en su vecindario (2010)

Participación en las elecciones congresuales de 2010 en función de la incidencia de determinadas actividades en su vecindario

Gasto en asistencia social y seguridad social en año electoral legislativas mayo 2006, Presupuestos Ejecutados 2006

Gasto en asistencia social y seguridad social en año electoral legislativas mayo 2010,

Presupuestos Ejecutados 2010

Entrega de regalos y servicios en las vacaciones de semana santa, día de las madres y apertura del año escolar por autoridades e instituciones publicas

Gasto en asistencia social y seguridad social en año NO electoral 2009, Presupuestos

Ejecutados 2009

Gasto en asistencia social y seguridad social en año NO electoral 2011, Presupuestos

Ejecutados 2011

Reparto de prebendas navideñas

Empleo público como recompensa partidista

Número de empleados incorporados al Sistema de Administración de Servicios Públicos

(SASP) del Despacho de la Primera Dama

Número de empleados incorporados al Sistema de Administración de Servicios Públicos

(SASP) del Programa "Solidaridad" del Gabinete Social de la Vicepresidencia, 2010-2012

Proposiciones de Ley según nivel de Particularismo (\%), 1998- 2010

Proposiciones de Ley según nivel de Particularismo por Legislatura y control del

Ejecutivo (\%), 1998-2010

Proposiciones de Ley por nivel de particularismo y partido, Legislatura 1998-2002

Proposiciones de Ley por nivel de particularismo y partido, Legislatura 2002-2006

Proposiciones de Ley por nivel de particularismo y partido, Legislatura 2006-2010

Ponderación Proposiciones de Ley de carácter INDIVIDUAL por número de representantes, Legislatura 1998-2002

Ponderación Proposiciones de Ley de carácter INDIVIDUAL por número de representantes, Legislatura 2002-2006

Ponderación Proposiciones de Ley de carácter INDIVIDUAL por número de representantes, Legislatura 2006-2010

Total Concesiones del Fondo de Gestión Legislativa o "Barrilito" (2008-2009) por nivel de extensión de beneficiarios y provincia

Anotación del intermediario en la solicitud y ejemplo ayuda bienes de club

Concesiones "Barrilito" por nivel de extensión de beneficiarios, partido y año electoral,

Provincia Nivel Alto IDH

Ejemplos solicitudes ayudas concedidas para toda la comunidad

Solicitud gestionada por bróker al servicio del diputado sin destinatario identificado

Red de intermediarios colaboradores por partido y provincia 
Tabla 3.4.3.B.5

Fotos 3.4.3.B.3

Tabla 3.4.3.B.6

Tabla 3.4.3.B.7

Fotos 3.4.3.B.4

Tabla 3.4.3.B.8

Tabla 3.4.3.B.9

Tabla3.4.3.B.10

Tabla3.4.3.B.11

Tabla3.4.3.B.12

Fotos 3.4.3.B.5

Gráfico 2.5.1

Gráfico 2.5.2

Tabla 2.5.1

Tabla 2.5.2

Gráfico 2.5.3

Capítulo 3

Gráfico 3.2.2.1

Gráfico 3.2.2.2

Gráfico 3.2.2.3

Tabla 3.2.2.1

Tabla 3.2.2.2

Tabla 3.2.2.3

Tabla 3.2.2.4

Tabla 3.2.2.5

Tabla 3.2.2.6

Gráfico 3.2.2.4

Gráfico 3.2.2.5

Tabla 3.2.2.7

Foto 3.2.3.1

Foto 3.2.3.2

Tabla 3.2.3.1

Tabla 3.2.3.2

Gráfico 3.2.3.1

Tabla 3.2.3.3

Tabla 3.2.3.4

Tabla 3.2.3.5

Tabla 3.2.3.6

Tabla 3.2.3.7

Tabla 3.2.3.8

Tabla 3.4.1.1

Gráfico 3.4.1.1

Gráfico 3.4.1.2

Foto 3.4.1.1

Tabla 3.4.1.2
Concesiones "Barrilito" por nivel de extensión de beneficiarios, partido y año electoral, Provincia Nivel Medio IDH

Utilización del Fondo Social en beneficio político del diputado

Concesiones "Barrilito" por nivel de extensión de beneficiarios, partido y año electoral,

Provincia Nivel Bajo IDH

Ejemplos solicitudes ayudas «barrilito» I

84

Acreditación filiación partidista en solicitud «barrilito»

Ejemplos solicitudes ayudas «barrilito» II

Ejemplos solicitudes ayudas «barrilito» III

Ejemplos solicitudes ayudas «barrilito» IV

Ejemplos solicitudes ayudas «barrilito» V

Ejemplos solicitudes ayudas «barrilito» VI

Facturas publicidad/visibilidad gestión del diputado en bienes y servicios patrocinados

Percepciones de los expertos acerca de los esfuerzos clientelares de los partidos y

efectividad de la movilización electoral por la distribución de beneficios selectivos (2009)

Percepciones de los expertos acerca de la efectividad en movilización clientelar y éxito en monitoreo del voto de los electores (2009)

Percepciones de los expertos acerca de la frecuencia y efectividad electoral del clientelismo en la República Dominicana (2009)

Percepciones de los diputados latinoamericanos acerca de la frecuencia de distribución o 96 promesa de bienes como incentivo para obtener votos (2009-2014)

Percepciones de los ciudadanos latinoamericanos. Escala Clientelismo en América Latina (2010)

Proyectos de Ley de carácter Individual según número de proponentes (\%), 1998-2010

Proyectos de Ley de carácter Corporativo según número de proponentes (\%), 1998-2010

Proyectos de Ley de carácter General según número de proponentes (\%), 1998-2010

Número y tamaño de las circunscripciones electorales en la República Dominicana

Proyectos de Ley Diputados Nacionales según número de proponentes y visibilidad, 2010-

2014

Nivel de inclusividad iniciativas de Ley presentadas por los 5 diputados nacionales, 200-

2014

Creación de municipios y distritos municipales, 1995-2010

118

Número de Síndicos (alcaldes) por partido, 1998-2016

Número de Regidores (concejales) por partido, 1998-2016

Índice de desproporcionalidad elecciones legislativas, 1978-2010

118

119

120

Nep Electoral y Nep Parlamentario legislativas, 1978-2010

121

122

Financiamiento Partidos Mayoritarios, 2008-2014

Personalización de la gestión de servicios públicos

127

128

130

Familiares en política de los diputados dominicanos

Dedicación exclusiva tareas parlamentarias diputados dominicanos, 1994-2016

131

131

Actividad que compagina con la de diputado, 1994-2016

Diputados que ocupan la presidencia de asociaciones empresariales, Legislatura 2010-2016

134

136

Evolución expertise institucional de los diputados dominicanos, 1994-2010

137

138

Importancia concedida a los grupos de interés según expertise institucional de los diputados dominicanos, 1994-2010

Razón principal elección del diputado según nivel de expertise institucional, 1994-2010

138

Familiares en política según nivel expertise institucional diputados dominicanos, 1994-2010

Factores que contribuyen a la estabilidad del sistema de partidos dominicano

Evolución del voto de los principales partidos en las elecciones legislativas, 1978-2010

147

147

Interpenetración partido-Estado 148

Condicionantes favorables para estructurar y mantener sistemas de partidos

151 
Tabla 3.4.1.3

Tabla 3.4.1.4

Gráfico 3.4.1.3

Tabla 3.4.1.5

Tabla 3.4.1.6

Tabla 3.4.1.7

Tabla 3.4.1.8

Gráfico 3.4.1.4

Gráfico 3.4.1.5

Gráfico 3.4.1.6

Tabla 3.4.1.9

Tabla 3.4.1.10

Tabla 3.4.1.11

Gráfico 3.4.1.7

Gráfico 3.4.1.8

Gráfico 3.4.1.9

Tabla 3.4.1.12

Gráfico 3.4.1.10

Gráfico 3.4.1.10

Tabla 3.4.1.13

Tabla 3.4.2.1

Tabla 3.4.2.2

Tabla 3.4.2.3

Tabla 3.4.2.4

Tabla 3.4.2.5

Tabla 3.4.2.6

Tabla 3.4.2.7

Tabla 3.4.2.8

Tabla 3.4.2.9

Gráfico 3.4.2.1

Tabla 3.4.3.1

Tabla 3.4.3.2

Capítulo 4

Gráfico 4.1.1

Gráfico 4.1.2

Tabla 4.2.A.2.1

Tabla 4.2.A.2.2

Tabla 4.2.A.2.3

Tabla 4.2.A.3.1

Gráfico 4.2.A.3.1

Gráfico 4.2.A.3.2

Tabla 4.2.A.3.2

Tabla 4.2.A.3.3

Tabla 4.2.A.3.4

Tabla 4.2.A.3.5

Tabla 4.2.A.3.6

Tabla 4.2.A.3.7
Índice de estructuración programática de los sistemas de partido

¿Por qué razón cree Ud. que ha sido elegido como diputado?, 1994-2010

Peso programa y campaña en razones de elección diputados dominicanos, 1994-2016

Responsabilidad del Estado en la creación de empleo, 1994-2016

Responsabilidad del Estado en la provisión de pensiones de jubilación, 1994-2016

Nivel de control del Estado en la provisión de agua, luz y transporte, 2006-2016

Opiniones diputados dominicanos sobre el aborto y matrimonio del mismo sexo, 1994-2016

Peso de la ideología en las razones de la elección de los diputados dominicanos, 1994-2016

Auto ubicación ideológica diputados dominicanos, 1994-2010

Distribución de las auto ubicaciones ideológicas diputados dominicanos, 1994-2016

Evolución desviaciones típicas auto ubicaciones ideológicas, 1994-2016

Varianza de medias auto ubicaciones ideológicas, 1994-2010

Porcentaje de voto según ubicación en la escala izquierda-derecha

¿A quién representa durante su actividad parlamentaria?, 1998-2010

Diputados representan a electores de la provincia en su labor parlamentaria por partido político, 1998-2010

Aspecto más importante de la actividad parlamentaria, 2002-2010

Aspectos más importantes de la actividad parlamentaria por partido político, 2002-2010

Importancia de atraer recursos para su provincia, 1998-2010

En caso de conflicto entre necesidades de provincia y el partido, ¿cómo votaría? 1998-2010

Lo más importante para ganar y ser reelegido, 2010-2016

Tipología cooperación estratégica

Criterios de asignación de cargos y empleos del Pacto por la Gobernabilidad y el Desarrollo

Local y Nacional, 2006

Polarización Cámara de Diputados de la República Dominicana, 1994-2016 180

Volatilidad electoral agregada elecciones legislativas, 1978-2010 182

Resultados elecciones legislativas, 2002-2010

Alianzas totales elecciones legislativas, 1994-2010

Volatilidad electoral agregada elecciones presidenciales, 1978-2012

Resultados elecciones presidenciales, 2000-2012

Alianzas electorales totales elecciones presidenciales, 2000-2012

Diputado debe conservar escaño si se pasa a otro partido durante la legislatura, 1998-2016 186

Las tres caras del faccionalismo

Las tres caras del faccionalismo en la República Dominicana

189

198

Relación causal cultura organizacional y política universalista/particularista 204

Relación causal cultura política y política universalista/particularista 206

Transferencias directas a Organizaciones No Gubernamentales en Presupuestos Formulados, 215 2005-2012

Concesiones del Fondo de Gestión Legislativa o "barrilito" asignadas a asociaciones

216

vecinales por nivel de inclusión de beneficiarios, 2008-2009

Concesiones del Fondo de Gestión Legislativa o "barrilito" asignadas a asociaciones

vecinales por tipología de la finalidad de la ayuda, 2008-2009

Tipología sindicatos según interés representado, acción y beneficios de la negociación

217

Promedio registro de sindicatos en el Ministerio de Trabajo, 1956-1995

221

222

222

Registro sindicatos en Ministerio de Trabajo en la etapa de la consolidación democrática, 223 1996-2010

Registro sindicatos en Ministerio de Trabajo en la dictadura, transición y alternancia, 1956-

224 1995

Relación de pactos colectivos y empresas registradas, 1997-2011

Concesiones del Fondo de Gestión Legislativa o "barrilito" asignadas a sindicatos y

organizaciones profesionales por nivel de inclusión de beneficiarios, 2008-2009

Concesiones del Fondo de Gestión Legislativa o "barrilito" asignadas a sindicatos y 
Tabla 4.2.A.3.8 Gráfico 4.2.B.1

Tabla 4.2.B.1

Gráfico 4.2.B.2

Tabla 4.2.B.2

Foto 4.2.B.1

Gráfico 4.2.B.3

Gráfico 4.2.B.4

Foto 4.2.B.2

Tabla 4.2.B.3

Tabla 4.2.B.4

Tabla 4.2.B.5

Gráfico 4.2.B.5

Gráfico 4.2.B.6

Foto 4.2.B.3

Gráfico 4.2.B.7

Tabla 4.2.B.6

Tabla 4.2.B.7

Tabla 4.2.B.8

Tabla 4.2.B.9

Tabla 4.2.B.10

Tabla 4.2.B.11

Tabla 4.2.B.12

Tabla 4.2.B.13

Tabla 4.2.B.14

Gráfico 4.2.B.8

Gráfico 4.2.B.9

Gráfico 4.2.B.10

Gráfico 4.2.B.11

Gráfico 4.2.B.12

Gráfico 4.2.B.13

Tabla 4.2.B.14

Tabla 4.2.B.15

Tabla 4.2.B.16

Tabla 4.2.B.17

Tabla 4.2.B.18

Gráfico 4.2.B.14

Gráfico 4.2.B.15

Gráfico 4.2.B.16

Tabla 4.2.B.19

Tabla 4.2.B.20

Gráfico 4.2.B.17
Transferencias a ONG's del Ministerio de Trabajo en Presupuestos Nacionales, 2005-2012

Actitudes autoritarias según pertenencia política , 2004

Relación apoyo al sistema y tolerancia política, 2004-2012

Apoyo a la democracia estable en perspectiva comparada en América Latina, 2010

Visión del Presidente como padre, 1994-2004

Paternalismo campaña

Paternalismo campaña

Apoyo al populismo en América Latina, 2008

Apoyo al populismo en la República Dominicana, 2008

Providencialismo campaña

Sentimiento de inseguridad en la República Dominicana,1994-2012

Propensión a la externalidad en la República Dominicana,1994-2004

Aceptación intervención de lo religioso en la vida política, 1994-2004

Representación femenina en la Cámara de Diputados, 1998-2016

Representación femenina en el Senado, 1998-2016

Personalismo campaña

Clasificación proposiciones de Ley Generales de contenido Testimonial, 1998-2010

Confianza interpersonal en la República Dominicana,2004-2010

Otros indicadores de confianza en la República Dominicana,2004-2008

Los partidos defienden intereses y necesidades, 1997-2004

Percepción de la corrupción, 2004-2012

Percepción de la inseguridad, 2004-2012

Participación y abstención elecciones presidenciales, 1978-2012

Participación y abstención elecciones legislativas, 1978-2010

Participación en protestas en el último año, 2006-2012

Libertad de expresión sin temor a la represión, 1994-2004

Participación en reuniones de organizaciones cívicas, 2006-2010

Impacto del perfil organizativo en el clientelismo, 2004

Relación entre participación cívica y asistencia a reuniones de partidos, 2010

Distribución de las ofertas clientelistas por participación cívica y política, 2010

Porcentaje de ciudadanos que trabajó para partidos o candidatos, 2012

Porcentaje de ciudadanos que trató de convencer a otros para votar por un partido, 2012

Porcentaje de ciudadanos que trató de convencer a otros para votar por un partido,19942012

Apoyo a la democracia en la República Dominicana, 2001-2012

Valoración funcionamiento de los servicios públicos en la República Dominicana, 19942004

Eficacia del gobierno en la República Dominicana, 2006-2012

Evolución de los servicios del gobierno local en la República Dominicana, 2006-2012

Confianza en las instituciones en la República Dominicana, 2012

Confianza ciudadana en las instituciones en la República Dominicana (I), 2004-2012

Confianza ciudadana en las instituciones en la República Dominicana (II), 2004-2012

Ningún interés en la política en la República Dominicana, 2006-2012

Simpatía partidaria en la República Dominicana, 2006-2012

Simpatía partidaria en América Latina, 2012 


\section{INTRODUCCIÓN}

El clientelismo necesita de la pobreza. Esta premisa acompañó a los primeros trabajos que se acercaron al fenómeno del particularismo en política desde una perspectiva desarrollista, considerándolo un resabio de sociedades tradicionales que desaparecería con la modernidad (Tarrow 1977; Landé 1977; Eisenstadt y Lemarchand 1981). La sobredimensión de los condicionantes de la demanda impregnó estos análisis de un carácter determinista en el que el mal funcionamiento del Estado encontraba justificación en los pseudo ciudadanos guiados por la moralidad, el afecto y la subordinación en su interacción pública. La pobreza se convertía así en la variable independiente necesaria y suficiente que explicaba los vínculos clientelares de los países de renta baja con democracias no consolidadas.

El trabajo seminal de Shefter (1994) marcaría un punto de inflexión en el estudio del clientelismo al introducir en el debate los condicionantes del lado de la oferta. Bajo esta óptica dual -y su terminología "suply side/demand side"- el nivel de empoderamiento ciudadano pierde la condición de suficiencia y carácter unidireccional, para ser analizado desde una perspectiva dinámica y relacional. En consecuencia, líderes y ciudadanos enfrentan sendas circunstancias institucionales, partidistas y de legado histórico que influyen en la elección de la estrategia particularista en el ejercicio de la representación política de unos, y en la aceptación de beneficios divisibles por parte de los otros. La conceptualización del particularismo como estrategia política (Piatonni 2001) y como un modo de accountability entre principal y agente (Kitschelt 2012) ha permitido a la literatura evidenciar la ubicuidad del clientelismo más allá de la ruralidad (Auyero 1997), así como su instrumentalidad en democracias modernas consolidadas (Piatonni 2001, Brusco, Nazareno y Stokes, 2004; Schedler y Manríquez 2004; Stokes 2005; Kitschelt y Wilkinson 2007). En la evolución del clientelismo tradicional al moderno clientelismo, la democracia ha fortalecido la capacidad de negociación de los clientes, las relaciones ya no son tan verticales ni asimétricas y el nexo directo con el patrón convive con una red de intermediarios y brokers. En el escenario de la democratización, el vínculo particularista entre políticos y electores se somete al tamiz de la valoración de costes e incentivos y su naturaleza ha mutado hacia una de carácter más instrumental/racional y menos moral/sentimental.

Siguiendo esta línea de investigación, la presente tesis doctoral tiene como propósito indagar cuáles son los determinantes del intercambio particularizado en la República Dominicana desde la Oferta [instituciones, reglas electorales, clase política y competencia interpartidista] y desde la Demanda [nivel macro y micro de la cultura política] a través de tres tipos de relaciones:

1) Relaciones Estado-Partidos,

2) Relaciones Partido-Partido y

3) Relaciones Estado-Ciudadanía.

La elección de la República Dominicana obedece a su especial significación en los valores de la variable dependiente (VD). En 2010, el país ocupaba el primer lugar en la escala de clientelismo en la Región según El Barómetro de Las Américas (LAPOP 2010:216), en reparto de prebendas en campaña electoral por parte de los candidatos a legisladores (PELA 2010) y se situaba en la comparación mundial entre los tres países más clientelares junto a Senegal y Mongolia (Kitschelt y Kselman 2011:33). Estas encuestas de opinión pública de ciudadanos, élites y expertos, insinúan en la liza política otras realidades de índole económica íntimamente relacionadas, tales como ser uno de los países con menor porcentaje de gasto social por habitante y de elevada desigualdad en América Latina (CEPAL 2010:37; ONU Hábitat 2013). Y es que este modo racional de relación 
directa entre ciudadanos y políticos deriva en un ejercicio particularizado de responsiveness en donde los costes no se reparten entre las categorías abstractas de votantes, sino que los individuos obtienen una gratificación inmediata en forma de empleo, trasferencias focalizadas, reglas favorables de regulación o contratos con el Estado.

Después de tres décadas de política carismática (1966-1996) y rol protagónico de los caudillos Joaquín Balaguer (PRSC), Juan Bosch (PLD) y Francisco Peña Gómez (PRD), comienza en 1996 la etapa de la consolidación democrática en la República Dominicana. Desde entonces, el país ha experimentado un proceso de modernización económica y de reforma del Estado que debería haber impulsado la redistribución (Kuznets 1955) y modelado el tipo de representación política en democracia (Landé 1977). En el periodo 2004-2012, la economía dominicana creció por encima de la media de sus vecinos latinoamericanos (4,7\%PIB). Solo en los años 2005-2006 el crecimiento interanual del PIB alcanzó el 9,3\% y 10,7\% (OECD 2008), siendo hoy un país de renta media alta que ha dejado de ser prioridad para los organismos internacionales de la ayuda oficial al desarrollo (AOD).

Esta pujanza económica y el arraigo de la democracia electoralista deberían haber confirmado los mejores augurios de las teorías económicas de la democracia y sus efectos redistributivos (Meltzer y Richard 1981) y de aquellas que profetizaban que la modernización del Estado acabaría con las relaciones clientelares en la representación política (Eisenstadt y Lemarchand 1981). En esta aparente paradoja, la República Dominicana adquiere relevancia como objeto de estudio deductivo que corrobore las hipótesis defendidas por la literatura instrumentalista del clientelismo (Schedler 2004, Levitsky 2007; Kitschelty y Wilkinson 2007) y su flexibilidad dinámica o "resilience through adaptability» (Piatonni 2001:2; Hopkin y Mastropaolo 2001). La explicación de cómo y por qué asumen los costes e incentivos los actores dominicanos permitirá extraer conclusiones que contribuyan al conocimiento científico en torno al arraigo y preservación de los vínculos particularistas en otras democracias emergentes.

A pesar de la diversidad de investigaciones que sitúan al país a la cabeza del ejercicio particularizado de la representación, han sido escasos los análisis que aborden empíricamente su estudio. Así, bajo el concepto de "neopatrimonialismo" la obra seminal de Hartlyn (1998) aportaba la explicación histórico institucional en los albores de la consolidación democrática. Años más tarde, este argumento será retomado por Marsteintredet (2004) mostrando cómo la debilidad del control entre poderes en la República Dominicana ha influido en el ejercicio prebendario de la política. Los estudios de Mitchell (2009) sobre los programas de reparto de comida y de Schrank (2009) acerca de la profesionalización de los inspectores de trabajo, han evidenciado el poder selectivo de los actores dominicanos contemporáneos en la orientación de las reformas dictadas desde el exterior. Mientras que tales reformas han sido aceptadas en el marco del Tratado de Libre Comercio (TLC) en el turismo o el mercado laboral, los actores se resisten a abandonar las viejas prácticas clientelares en la política social. Desde la óptica sociológica, los trabajos de Lozano $(2010 ; 2013)$ centran la explicación en la inexistencia de sujeto democrático como principal obstáculo en el cambio hacia un modo de relación indirecto entre ciudadanos y políticos. También desde la demanda, autores como Espinal, Morgan y Seligson, (2006; 2008; 2010) se han aproximado al fenómeno del clientelismo en el país a partir de las actitudes y valores democráticos de los dominicanos. 


\section{Estructura de la Tesis}

El trabajo que aquí se presenta analiza los factores explicativos de la persistencia y adaptabilidad de la política particularista desde una perspectiva diacrónica, sistémica, multicausal y relacional. Con este propósito y a partir de lo anteriormente planteado, la tesis se estructura en cinco capítulos:

El Capítulo Primero establece los parámetros teóricos y metodológicos que guían esta investigación. En él se exponen los principales argumentos defendidos por la corriente instrumentalista en la explicación del particularismo en democracia y cuyo nexo causal procede de tres enfoques teóricos: "History matter» (March y Olsen 1984; Thelen y Steinmo 1992; Shefter 1994; Papakostas 2001), "Insitutions matter» (Shugart y Carey 1992; Kiewiet y McCubbins 1991; Putnam 1994; Shefner 2001) y «Politicians matter too» (Kitschelt 2000; Warner 2001; Piattoni 2001; Alcántara 2013). Para la operacionalización de la VD, se aporta una nueva clasificación del particularismo a partir de la elaborada por Corzo (2002) teniendo en cuenta la naturaleza de los recursos y del momento en que se produce el intercambio. Así, se distingue un "Clientelismo Electoral", uno de "Partido" y un "Clientelismo Oficial". Este último -anteriormente denominado por Corzo como "burocrático"- permite ahora advertir el bien público asignado en cada uno de los escenarios representativos: un "Particularismo Ejecutivo", uno "Burocrático" y un "Particularismo Legislativo". En la última sección del capítulo se presenta, a modo de síntesis, la guía metodológica-conceptual de la investigación detallando los indicadores de medición para el caso dominicano.

El Capítulo Segundo tiene por objetivo medir la VD y constituye la parte del análisis empírico descriptivo de esta tesis. Para ello, se presentan las expresiones particularistas de movilización y agregación de intereses en la República Dominicana en tiempo de elección y contiendas internas entre candidato-elector [Clientelismo Electoral]; entre político-político [Clientelismo de Partido]; y entre las autoridades públicas y los ciudadanos en el ejercicio del mandato de representación y/o designación [Clientelismo Oficial]. En esta última categoría, se utilizan cuatro indicadores para medir las expresiones del fenómeno en los diferentes escenarios y agentes públicos intervinientes:

$\checkmark$ El gasto del Gobierno Central en las partidas presupuestarias de "Asistencia Social" y "Seguridad Social" (2006-2011)

$\checkmark$ El número de empleados incorporados el Sistema de Administración de Servicios Públicos del Programa "Solidaridad" y del Despacho de la Primera Dama (2010-2012)

$\checkmark \quad$ Las Proposiciones de Ley elevadas desde la Cámara de Diputados y aprobadas para ser sometidas a trámite parlamentario (1998-2010)

$\checkmark$ Las regalías otorgadas por los diputados a través del Fondo de Gestión Legislativa o «barrilito» en sus circunscripciones (2008-2009)

La mayor disponibilidad de datos en el escenario legislativo permite comparar distintas administraciones y gobiernos desde el inicio de la consolidación democrática hasta la actualidad. El análisis longitudinal de los cambios y continuidades en la asignación de derechos selectivos y favores personales revela el papel de mediador-conseguidor del diputado dominicano en una interacción característica de los "empresarios políticos" y "servidores del distrito" descritos por Siavelis y Morgenstern (2008). La promoción de intereses parroquiales y la nula fiscalización, apuntarían a una distribución de tareas que confirmaría en el país la antítesis del "secreto de la eficiencia" (Amorim Neto y Santos 2003) en la relación Legislativo-Ejecutivo (Cox 1987) y la imposibilidad de concretar políticas públicas a nivel nacional en el Legislativo dominicano. 
En el Tercer Capítulo se identifican los factores que determinan el particularismo desde el lado de la Oferta y se exploran las principales hipótesis planteadas por la literatura en la Relación EstadoPartidos y en la Relación Partido-Partido en el país.

La primera variable en la relación del Estado con los Partidos es el timing de la burocratización y la movilización a la política de masas. En estos dos momentos fundacionales se gesta la división entre el espacio de la política y el del Estado e influyen en la preferencia de los partidos por el patronazgo. La segunda variable son las reglas que regulan la conducta de los actores y la tercera, quiénes son aquéllos que aspiran y se dedican a la política. El análisis de la incidencia de estos tres condicionantes en la República Dominicana muestra el peso histórico del Partido Reformista Social Cristiano (PRSC) y de su líder Joaquín Balaguer en la dirección de la coyuntura transicional, ejemplificando el modus operandi del "partido internamente movilizado" (Shefter 1994) con acceso al patronazgo como herramienta de movilización en ausencia de profesionalización administrativa y debilidad del Estado de Derecho. Con respecto a la segunda, la combinación de voto preferencial y circunscripciones pequeñas particularizan hoy la vinculación entre políticos y electores debilitando el intercambio indirecto mediado por programas, mientras que el proceso de descentralización nacional apunta a la utilización del territorio como prebenda política. Por su parte, el perfil predominante del político dominicano es el de un empresario con vínculos familiares y escasa formación política que accede a las instituciones sin dejar de administrar sus actividades privadas.

Las relaciones Partido-Partido se estudian en tres dimensiones: competición, cooperación y conflicto partidario. Con respecto a la primera de ellas, la forma en que compiten los partidos puede predecir la mayor o menor probabilidad de ofertar beneficios particularizados. Las decisiones de elección social (identidad programática) y de acción colectiva (organización) que han de adoptar los protagonistas afectan al estilo de la representación y a la eficacia universal o particular de las políticas. En este capítulo se argumenta que los partidos dominicanos son modernos partidos clientelares atrápalotodo que cuentan con una maquinaria institucionalizada pero altamente informal. La maquinaria está compuesta por redes de intercambio multinivel en las que los actores disfrutan de cierto grado de autonomía en el ejercicio de su accountability y responsiveness.

En esta contienda que gira en torno a quién puede repartir más y mejor, no es obstáculo que el partido no hable como una sola voz colectiva, por lo que hay espacio para que afloren vínculos afectivos relativos a las cualidades del agente, la reputación moral y otros de naturaleza racional retrospectiva como el dinamismo resolutivo del diputado en su distrito. Con este ejercicio de dispensador de recursos aumenta la reputación de eficacia del político por la que será recompensado con la reelección. A nivel sistémico, la competición interpartidaria en la República Dominicana se entabla en condiciones de oligopolio. En estas circunstancias, tal y como demostraran Kitschelt y Wilkinson (2012), cuando en las elecciones se decide quién controlará los recursos públicos y un pequeño cambio en el apoyo electoral puede significar un gran cambio en el control del patronazgo, los actores carecen de incentivos para pasar de un modo de relación racional directo a uno indirecto programático.

Una de las aportaciones de este trabajo de investigación es la ampliación del foco de atención en las relaciones partido-partido, analizando no solo cómo compiten, sino cómo colaboran y por qué pelean los políticos. Para ello, se presenta un modelo de cooperación estratégica en el que se tipifican las diferentes formas de interacción según quiénes sean los protagonistas [élites, partidos o candidatos], en una orientación dicotómica [particularista versus generalista] determinada por el repertorio de incentivos y costes asociados. La capacidad de las élites para cooperar y alcanzar acuerdos puede ponerse al servicio de acuerdos nacionales que fomenten el desarrollo, pero también para alcanzar objetivos inmediatos que benefician al establishment político a costa del 
debilitamiento institucional. Como muestra este trabajo, desde que en 1978 tuviera lugar la segunda transición a la democracia, se observa en la República Dominicana un patrón de colaboración en el que predomina el consenso pragmático, el interés por la propia supervivencia institucional y el acceso patrimonialista a los recursos del Estado.

El nivel de extensión de estos resultados de la coordinación estratégica pertenecen al universo de los bienes privados y de club y por tanto, son indicadores de un modo de relación entre partidos propicio para el intercambio particularizado.Para corroborar esta tipología se precisan nuevos estudios de caso y en perspectiva comparada que aporten evidencia adicional acerca de la cooperación en condiciones de legitimidad clientelar en las vecinas democracias emergentes. Por último, en la tercera de las dimensiones se presentan las relaciones de conflicto para mostrar que el faccionalismo como estrategia racional frente a las discrepancias potencia la lealtad personal frente a la partidista, dificulta la cooperación intrapartidaria en la agregación de intereses colectivos y genera un sistema particularizado de lealtades y recompensas.

En el Cuarto Capítulo se identifican los factores que influyen en la política particularista desde el lado de la Demanda y se exploran las principales hipótesis planteadas por la literatura en la Relación del Estado con la Ciudadanía dominicana.

La aproximación macro sociológica a la cultura organizacional de un país propuesta por Papakostas (2001) permite identificar el tipo de relación -fronteriza o interconectada- entre las organizaciones sociales y políticas. La interconexión y dependencia limitan la beligerancia de la acción colectiva sesgando la relación con los actores civiles, que se convierten en clientelas competitivas para obtener favores públicos. En este apartado se argumenta que en la República Dominicana la atomización de los intereses de clase y del activismo sindical han generado múltiples agentes de la acción corporativa en todos los niveles de renta. Por ello, en la etapa de la consolidación democrática no hay en el país espacios de oportunidad para la acción colectiva o la concertación social, sino para una de carácter sectorial corporativa.

En la segunda parte del capítulo se abordan los condicionantes de la demanda desde la dimensión micro sociológica. Para ello, se analizan las percepciones y actitudes de los dominicanos con el objetivo de perfilar los rasgos del paisaje actitudinal identificado como propicio para la persistencia del clientelismo en democracia. Como ha demostrado la literatura, existe un iter causal entre cultura política y nivel de inclusión de los resultados democráticos. En un escenario social de confianza generalizada, pluralismo, secularización, solidaridad y primacía de la colectividad frente al personalismo, es más probable la existencia de una sociedad civil cohesionada y proclive a la cooperación que a la competición clientelar. 
Finalmente, en el Capítulo Quinto se retoman los argumentos expuestos en esta tesis y se detallan los hallazgos de investigación tras el análisis descriptivo y explicativo de la política particularista en el contexto dominicano:

El repaso al repertorio de la acción particularista revela la arbitrariedad y el carácter selectivo del modus operandi de las autoridades dominicanas en el ejercicio de su mandato de representación o designación.

En el Ejecutivo, se confirma el potencial politizador de la asistencia focalizada denunciado por la literatura (Adelantado y Scherer 2008, Hevia 2010), ya que a pesar de que la pobreza se ha mantenido relativamente estable en el país, el gobierno tiende a vigorizar la asistencia particularizada en año electoral frente a la de vocación universal.

En la Administración, la contratación de funcionarios no responde al principio de utilidad pública que ha de guiar la prestación de servicios de manera estable, imparcial y profesional, sino que es utilizada al servicio de la carrera política del director de la agencia gubernamental de turno.

En el Legislativo, en el periodo 1998-2010 más de la mitad de las iniciativas tuvieron por objeto la promoción de intereses parroquiales en las que el diputado ejerció de conseguidor de derechos selectivos y favores personales. El tratamiento estadístico de los datos muestra que la relación entre particularismo y partido político es estadísticamente significativa. Las legislaturas en las que el PRD cuenta con la mayoría y domina el Ejecutivo son las más propensas a promover intereses particularistas. Por el contrario, cuando el Ejecutivo es controlado por el PLD, la representación de vocación particular tiende a disminuir, aunque es utilizada estratégicamente por todos legisladores en coyunturas económicas y electorales de especial relevancia. La legislatura 2006-2010 marca un punto de inflexión al alza en la representación del interés general en la Cámara de Diputados. Sin embargo, este cambio podría reflejar la predilección del oficialista PLD por otros escenarios como el asistencialismo selectivo a través del Ejecutivo o el patronazgo en la Administración, haciendo uso del control oligopólico de los recursos del Estado.

En el reparto del "barrilito" (2008-2009) se observa una estrategia de asignación de bienes que premia a los leales con bienes selectivos y trata de persuadir a opositores moderados con bienes de disfrute general, sin que existan diferencias significativas por partido. Sin embargo, es el oficialista PLD el que cuenta con la mayor red de brókeres para realizar este tipo de asignaciones y el que destina mayor número de regalías a colectivos determinados en la provincia con el nivel de empoderamiento socioeconómico más elevado. Esta diversificación confirma el patrón apuntado por Rosas y Hawkins (2008) en sus trabajos. La maximización de votos, la visibilidad de su mérito como gestor, la disponibilidad de recursos y el nivel de empoderamiento socioeconómico parecen influir en la decisión del diputado a la hora de elegir el nivel de inclusividad de las asignaciones en sus distritos.

La hipótesis defendida en este trabajo, sostiene que en relaciones Estado-Partidos, Partido-Partido y Estado-Ciudadanía, se generan espacios de oportunidad que los actores pueden aprovechar para hacer del particularismo la forma dominante o la forma residual de relación entre políticos y electores. El abordaje multicausal -mas allá de las secuencias culturales y económicas antes sobre estimadas por los teóricos de la modernización- demuestra que en la República Dominicana el clientelismo se ha adaptado al escenario de la consolidación democrática. 
Desde la Oferta, si bien las coyunturas históricas críticas (burocratización y transición) marcan el punto de partida sine qua non en los modos racionales de relación directa entre políticos y ciudadanos, ciertas características del sistema electoral (voto preferencial, tamaño de la circunscripción y financiamiento) han sido dispositivos a través de los cuales se ha adaptado y perpetuado el mandato particularizado de la representación. Cuando entre quienes ejercen de mediadores en las relaciones del Estado con los Partidos predomina el perfil de patrón privado con responsabilidades públicas, tal y como ocurre en el país, aumenta la probabilidad de que se promuevan intereses particulares en las instituciones nacionales, ya que el agente no es independiente.

En las relaciones Partido-Partido, se sostiene como hipótesis que los actores son capaces de sortear y manipular las restricciones institucionales haciendo uso de su poder de manipulación como político conseguidor. En la competición y la cooperación, los actores valoran estratégicamente los costes y alteran la estructura de incentivos para hacer de la política de racionalidad individual la más atractiva y la de menor coste en el corto plazo. Si bien en la República Dominicana los condicionantes favorables de largo plazo para estructurar un sistema de partidos programáticamente estructurado (SPPE) eran débiles (Kitschelt et al 2010), en la etapa de la consolidación democrática los actores nacionales no han aprovechado los espacios de oportunidad que se generan en el corto plazo -como la bonanza económica o las reformas institucionales- para (re)construir programáticamente la vinculación con los electores.

En las relaciones de conflicto entre actores, se argumenta que a mayor divisionismo mayor es el grado de particularismo en política. El faccionalismo dominicano afecta al grado de inclusividad del mandato de representación ya que dificulta la concepción unitaria o trabajo ideológico y se circunscribe a las instrucciones que los jefes políticos dan a sus sectarios. De esta manera, la confianza estratégica que domina en las relaciones ciudadanas, se reproduce en el interior de los partidos con los mismos efectos limitantes en la agregación de intereses.

El peso determinante de la racionalidad estratégica de los actores dominicanos cuando compiten, cooperan o pelean, confirma que el clientelismo es una cuestión de elección.

Desde la Demanda, se sostiene como hipótesis que las relaciones del Estado con la Ciudadanía han estado marcadas por la verticalidad y la interconexión, lo que ha contribuido a desdibujar los límites entre la vida civil y la del Estado. La fallida proletarización bajo la economía del azúcar en el siglo XIX tuvo un nuevo espacio de oportunidad para la conformación de un interés de clase en los noventa, cuando se inicia en la República Dominicana la transición hacia el modelo de zonas francas o maquilas. Sin embargo, este modelo de "industrialización sin desarrollo" (Chubb 1981) no ha articulado las demandas laborales ni ha posicionado a sus representantes como interlocutores sociales. Como resultado, la infraestructura social que sustenta la democracia en el país es más proclive a la competición que a la cooperación colectiva, ya que el cliente dominicano es un principal de voluntad atomizada. En este contexto, aumenta la probabilidad de que la interlocución política descanse en la relación instrumental particularizada con el agente. 


\section{Datos Utilizados}

La presente investigación es un estudio de caso diacrónico deductivo que apoyándose en teorías existentes, aplica las hipótesis formuladas por la literatura instrumentalista del clientelismo al contexto dominicano. Las aportaciones de este trabajo sobre la persistencia de la "política de nombre y apellido" en el escenario dominicano pueden contribuir al conocimiento acerca de cómo asumen los costes e incentivos los actores en otros escenarios y generar futuras líneas de investigación acerca del particularismo en democracia.

Los datos utilizados para llevar a cabo el diagnóstico y análisis del caso dominicano proceden de múltiples fuentes. Para conceptualizar la naturaleza particularista de la representación política se crearon dos bases de datos que se someten a diversas técnicas de estadística descriptiva e inferencial.

La primera de ellas está compuesta por las Proposiciones de Ley elevadas desde la Cámara de Diputados y aprobadas para trámite parlamentario en las legislaturas 1998-2002, 2002-2006 y 2006-2010. Un total de 1,863 proposiciones que se clasifican por el tipo de interés protegido [interés público, grupal/de club o interés personal]. La segunda la forman las Regalías del Fondo de Gestión Legislativa o "barrilito" concedidas por los diputados en su circunscripción durante los años 2008 y 2009. Cerca de 2,000 facturas de bienes y servicios dispensados en concepto de asistencia social y clasificados en función de su nivel de particularismo: para el disfrute de una persona [representación individual], de un colectivo determinado [representación corporativa], o para la generalidad de la comunidad [representación general]. El tratamiento estadístico de los datos desagregando por partido, año electoral y diferentes administraciones, permite identificar los puntos de inflexión en la VD desde 1998 hasta el año 2010. Y para medir el fenómeno más allá del escenario legislativo se estudian los presupuestos nacionales ejecutados y el registro de funcionarios del Ministerio de Administración Pública. Este diagnóstico sobre el clientelismo oficial en la República Dominicana se complementa con los datos de la encuesta "Expert Survey on CitizenPoliticians Linkages" (Herbert Kitschelt, dir.) de la Universidad de Duke, para situar al país en perspectiva comparada en la existencia de vínculos particularizados entre políticos y ciudadanos a escala mundial.

En la explicación de los factores que inciden en la persistencia del fenómeno clientelar se utilizan encuestas de diversa procedencia. Las opiniones de los diputados dominicanos (1994-2010) del "Proyecto Elites Parlamentarias Latinoamericanas" (PELA) de la Universidad de Salamanca (Manuel Alcántara, dir.) aportan información relevante acerca de la naturaleza de la competencia interpartidista en el país, el focus de la representación, trayectoria política y socialización. En este sentido, la base de datos del " Global Leadership Project" (GLP) de la Universidad de Boston (John Guerring, dir.) complementan la caracterización de la clase política nacional más allá del escenario legislativo. Para conocer las percepciones y actitudes de los dominicanos y su evolución, se manejan los datos del "Barómetro de las Américas" (LAPOP) de la Universidad de Vanderbilt (Mitchell A. Seligson, dir), así como de la "Primera Encuesta de Opinión Pública y Comportamiento Político" (OBSEROP) realizada por la AECID-PNUD (Mariano Tocal, dir.) con ocasión de las elecciones legislativas de 2010 en la República Dominicana.

Junto con la revisión de fuentes secundarias, se realizaron un total de cuarenta y ocho (48) entrevistas a profundidad a cuatro académicos, siete diputados, un senador, seis dirigentes políticos de partidos minoritarios, cuatro altos dirigentes de las fuerzas políticas mayoritarias, dos representantes sindicales, un abogado laboralista, cuatro representantes de organizaciones de la sociedad civil, tres funcionarios de alto rango de diversas instituciones nacionales, siete funcionarios de nivel inferior y a diez a jóvenes dirigentes de base. 
Se utilizaron además otras herramientas de investigación social de recogida de información a través de la observación directa participante y externa. Durante la estancia en el país y como parte del proyecto "Apoyo al proceso de modernización del sistema de partidos políticos en República Dominicana" (AECID-PNUD, 2008-2009) y del "Programa Permanente de Formación de Jóvenes Líderes de los partidos políticos en la República Dominicana" (IIDH-CAPEL-USAID, 2011-2012) se organizaron cinco grupos de discusión con actores clave de la política nacional dominicana en los que participé en calidad de asistente de investigación y consultora respectivamente.

El trabajo de campo se complementó con la participación en dos misiones de observación electoral en los comicios legislativos y municipales de 2010 y en las presidenciales de 2012. En la primera, como parte del contingente de observadores internacionales de la Organización de Estados Americanos (OEA) en la provincia de San Juan de la Maguana y en la segunda, como observadora itinerante en la ciudad de Santo Domingo de Transparencia Internacional. La cita con las urnas intensifica y visibiliza los recursos movilizadores en la campaña propios del denominado "clientelismo electoral", como el transporte de votantes al centro de votación, el reparto de regalos o la compra-venta de cédulas. Sin embargo, además de estos intercambios "espasmódicos y esporádicos" (Combes 2011:18) con los que tradicionalmente se ha asociado el fenómeno del clientelismo, la relación particularizada y los intercambios entre políticos y ciudadanos continúan más allá del día de la elección como trata de evidenciar esta investigación. 


\section{CAPÍTULO 1}

\section{ELEMENTOS TEÓRICOS Y METODOLÓGICOS PARA EL ESTUDIO DE LA POLÍTICA PARTICULARISTA}

\subsection{CONSIDERACIONES TEÓRICAS}

\subsection{A) Política Particularista y Representación en Democracia.}

Con el nombre de "Política Particularista" se identifica el modelo de competición caracterizado por la asignación selectiva de recursos estatales que los políticos llevan a cabo para maximizar sus probabilidades de reelección (Seddon, Gaviria Panizza y Stein 2002; Indridason 2007:5). La diferente forma en que los intereses particulares son presentados, promovidos y agregados se traduce en variadas expresiones particularistas en la arena política: constituency service, brokerage politics, pork-barrel politics, clientelismo, new fiscal populism, patronazgo o neopatrimonialismo entre otros. Todas ellas denotan la promoción de intereses particulares sin tener en cuenta -o incluso a costa- del interés general (Piatonni 2001:3). La atención prestada al clientelismo como uno de los subtipos más comunes de particularismo ha derivado en una práctica de referirse al "todo" (política particularista) por la "parte" (clientelismo), aunque la literatura reconoce tal diferencia y se utilicen indistintamente por razones de simplificación terminológica.

En los años 70, la ciencia política acogía el concepto de clientelismo heredado de la antropología política. Con él se identificaban las relaciones diádicas entre individuos de estatus desigual -el patrón/agente y el cliente/principal- fundamentadas en la reciprocidad, el afecto y el cara a cara, para intercambiar bienes no equiparables (Campbell, 1964; Lemarchand y Legg 1972; Pitt-Rivers 1971). Los primeros trabajos que describieron estas relaciones de poder en sociedades tradicionales y en transición, destacaban la mutua utilidad de contar con un aliado superior o inferior (Leca y Schemeil 1983) y el beneficio del intercambio de favores en la amistad instrumental que les unía (Roniger 1990).

La persistencia del particularismo a pesar de las cambiantes circunstancias sociales, económicas y políticas dio paso a una nueva aproximación analítica centrada en identificar los cambios y continuidades en la relación patrón-cliente obserdos en la mutación de clientelismo tradicional al moderno clientelismo de partido. En este proceso, la democracia ha fortalecido la capacidad de negociación de los clientes, las relaciones ya no son tan verticales ni asimétricas y el vínculo tiene ahora una naturaleza más instrumental (racional) que moral (sentimental). Los cambios en el diseño institucional y en la organización partidaria han afectado al carácter personalista y directo de la relación clientelar de antaño. Así, en los partidos atrápalo todo, la mediación directa ha sido sustituida por el anonimato del vínculo con el patrón colectivo y la descentralización ha impuesto una compleja red de clientelas sucesivas para el reparto de favores (Nouzelis 1985; Cazorla 1992; Papadopoulos y Vanner 1995). 
En el escenario de la democracia representativa, competencia y sociedad movilizada, la política particularista es definida como un modo de accountability y una estrategia política de los actores intervinientes:

$\checkmark$ Es uno de los mecanismos de vinculación racional entre principal-agente, consistente en un intercambio directo, contingente, predecible y supervisado (Kistchelt y Wilkinson 2012:16).

$\checkmark$ Es una estrategia política tanto de los patronos para adquirir, mantener y agrandar el poder, como de los clientes para proteger y promover sus intereses (Piattoni 2001:2).

Bajo esta concepción utilitarista del clientelismo, los actores realizan un cálculo de costes y beneficios posicionándose en el punto hipotético del eje de preferencias donde maximizan los beneficios unos, y donde obtienen el mayor número de votos otros (Antony Downs 1957; Arrow 1951; Elster 1986; Luce y Raiffa 1957). La desconfianza y la desigualdad en el acceso a los recursos desincentivan la cooperación en una interacción similar al "dilema del prisionero" (Tucker 1950), por lo que el bien individual será finalmente el ofrecido por los agentes y el preferido por el principal (Fiorina y Noll 1978; Gambetta 1988; Shefner 2001).

Como demostraran Medina y Stockes (2007), en ausencia de políticas fiscales redistributivas y cuando el partido oficialista tiene el control del acceso a los recursos, los partidos en la oposición que oferten bienes universales tienen pocas opciones de llegar al poder, a pesar de ser la opción más inclusiva y óptima en el largo plazo. La implementación de políticas universales conllevaría un aumento de impuestos para financiar la generalización de los bienes antes disfrutados de manera selectiva. Estos impuestos permitirían ofrecer mayores transferencias reduciendo así la importancia del bien distribuido selectivamente por el patrón. Por esta razón, el patrón del partido oficialista se mostrará contrario a la subida de impuestos, no por un componente ideológico, sino porque no conseguirá la reelección. En el caso de los clientes, la mejor opción es votar al partido del patrón, ya que de todas formas tienen asegurado el disfrute del bien universal ofertado por el partido programático si éste alcanzara el poder. Pero si el partido del patrón gana, quedarían excluidos del disfrute del bien selectivo cuando la red de monitoreo constate su deslealtad.

Con respecto a los criterios estratégicos de selección de beneficiarios para el disfrute del bien controlado por el agente, la academia se encuentra dividida entre quienes argumentan una asignación que premia a los votantes fieles (Nitcher 2008; Ansolabehere y Snyder 2003; De la Calle 2005) y aquéllos que por el contrario, apuntan a una asignación para persuadir a votantes opositores y/o indecisos (Stokes 2005). En una posición intermedia, trabajos como el de Rosas y Hawkins (2008) muestran un modelo de concesión estratégica de beneficios: bienes privados para votantes fieles (estrategia movilizadora) y bienes públicos para opositores moderados (estrategia persuasiva).

A la hora de identificar y clasificar las expresiones particularistas en democracia, son variadas las aportaciones de los autores. Mientras Corzo (2002) distingue entre clientelismo "electoral", de "partido" y "burocrático" si el agente es el candidato, el líder partidista o el intermediario de la red; Kitschelt (2007) diferencia entre clientelismo "empresarial", "social" e "híbrido", si los recursos entregados al principal son regulaciones de trato favorable, beneficios sociales o una diversidad de recursos respectivamente. 
Tabla 1.1.A.1. Clasificación del clientelismo según el agente y el objeto del intercambio

\begin{tabular}{|c|c|c|c|}
\hline \multirow{3}{*}{$\begin{array}{l}\text { Corzo } \\
(2002)\end{array}$} & \multirow{3}{*}{$\begin{array}{l}\text { ¿Quién es el } \\
\text { agente } \\
\text { del } \\
\text { intercambio? }\end{array}$} & $\begin{array}{l}\text { CLIENTELISMO } \\
\text { ELECTORAL }\end{array}$ & $\begin{array}{l}\text { El cliente da su voto al candidato a cambio de futuras } \\
\text { prestaciones cuando llegue al poder. }\end{array}$ \\
\hline & & $\begin{array}{l}\text { CLIENTELISMO } \\
\text { DE PARTIDO }\end{array}$ & $\begin{array}{l}\text { El cliente da su apoyo a un líder del partido a cambio } \\
\text { de acceder a los beneficios de poder de ese partido. }\end{array}$ \\
\hline & & $\begin{array}{l}\text { CLIENTELISMO } \\
\text { BUROCRÁTICO }\end{array}$ & $\begin{array}{l}\text { El cliente da su apoyo al intermediario para recibir el } \\
\text { trato preferente en la asignación de recursos. }\end{array}$ \\
\hline \multirow{3}{*}{$\begin{array}{l}\text { Kitschelt } \\
(2007)\end{array}$} & \multirow{3}{*}{$\begin{array}{l}\text { ¿Qué objeto } \\
\text { se } \\
\text { intercambia? }\end{array}$} & $\begin{array}{l}\text { CLIENTELISMO } \\
\text { SOCIAL }\end{array}$ & Beneficios focalizados y selectivos de política social \\
\hline & & $\begin{array}{l}\text { CLIENTELISMO } \\
\text { EMPRESARIAL }\end{array}$ & $\begin{array}{l}\text { Empresas públicas subsidiadas, capitalismo coordinado } \\
\text { (exenciones, trato favorable a sectores empresariales, } \\
\text { discrecionalidad de la autoridad regulatoria) }\end{array}$ \\
\hline & & $\begin{array}{l}\text { CLIENTELISMO } \\
\text { HÍBRIDO }\end{array}$ & Diversidad de recursos y grados de formalización \\
\hline
\end{tabular}

Fuente: Elaboración propia a partir de Corzo (2002) y Kitschelt (2007)

En este estudio sobre la política particularista en la República Dominicana se propone una nueva clasificación a partir de la tipología de Corzo (2000) añadiendo mayor especificación para distinguir no solo al agente, sino el escenario de la representación y la procedencia de los recursos asignados. Teniendo en cuenta la naturaleza de los recursos y del momento en que se produce el intercambio, se distingue en esta investigación un "Clientelismo Electoral", uno de "Partido", y un "Clientelismo Oficial". Este último -anteriormente denominado por Corzo (2000) como "burocrático"- permite ahora advertir el bien público asignado en cada uno de los escenarios representativos (Ver Tabla 1.1.A.2.). A continuación se conceptualizan cada uno de ellos:

La cercanía de la cita con las urnas activa la maquinaria del «Clientelismo Electoral». Los candidatos establecen un vínculo personal con los electores repartiendo o prometiendo bienes, regalos e incluso dinero para asegurar el voto de los electores. Estas prebendas se financian con los recursos privados del candidato y con los públicos que la autoridad electoral reparte entre las fuerzas legalmente constituidas, generalmente en proporción al número de votos obtenidos en pasadas contiendas. En el «Clientelismo de Partido», el intercambio particularizado se produce entre actores políticos individuales o colectivos. Las elecciones internas, convenciones y las elecciones nacionales activan los canjes particularizados entre facciones y alianzas para conseguir influencia en la organización, puestos directivos o acceso a las agencias públicas. La procedencia de los recursos también es mixta ya que además del financiamiento estatal los partidos pueden reciben donaciones que en algunos escenarios como el dominicano, sin que exista obligación legal de publicitar cuantía o procedencia de tal donación.

Por último, con el nombre de «Clientelismo Oficial» se denominan aquí las transacciones particularistas realizadas por autoridades, funcionarios y representantes nacionales por elección o designación en las que se intercambian bienes y servicios públicos. Dependiendo del agente y del escenario de la representación, se dispensan programas de asistencia, empleos en la Administración, derechos selectivos o favores personales. La relación entre principal y agente se extiende más allá de la contienda electoral, siendo constante durante la vigencia del mandato de representación o designación. De esta manera, dependiendo del grado de inclusividad del disfrute de los bienes asignados, se podrá hablar de una "representación general", una de carácter "corporativo" o una "representación individual". 
Tabla 1.1.A.2. Propuesta tipología clientelismo

\begin{tabular}{|c|c|c|c|c|c|}
\hline TIPOLOGÍA & \multicolumn{2}{|c|}{ RECURSOS INTERCAMBIADOS } & MOMENTUM & PROTAGONISTAS & $\begin{array}{l}\text { PROCEDENCIA } \\
\text { RECURSOS }\end{array}$ \\
\hline $\begin{array}{l}\text { CLIENTELISMO } \\
\text { ELECTORAL }\end{array}$ & \multicolumn{2}{|c|}{$\begin{array}{c}\text { Beneficios selectivos a cambio } \\
\text { de votos }\end{array}$} & $\begin{array}{c}\text { Elecciones } \\
\text { Representativas }\end{array}$ & Candidato-Elector & $\begin{array}{l}\text { Mixto } \\
\text { (públicos y } \\
\text { privados) }\end{array}$ \\
\hline $\begin{array}{l}\text { CLIENTELISMO DE } \\
\text { PARTIDO }\end{array}$ & \multicolumn{2}{|c|}{$\begin{array}{l}\text { Influencia partidista a cambio } \\
\text { de apoyo político }\end{array}$} & $\begin{array}{c}\text { Elecciones } \\
\text { Internas y } \\
\text { Representativas }\end{array}$ & Político - Político & $\begin{array}{l}\text { Mixto } \\
\text { (públicos y } \\
\text { privados) }\end{array}$ \\
\hline \multirow{4}{*}{$\begin{array}{l}\text { CLIENTELISMO } \\
\text { OFICIAL }\end{array}$} & \multicolumn{2}{|c|}{$\begin{array}{c}\text { Recursos públicos a cambio } \\
\text { de apoyo oficial }\end{array}$} & \multirow{4}{*}{$\begin{array}{l}\text { Relación } \\
\text { constante }\end{array}$} & \multirow{4}{*}{$\begin{array}{l}\text { Autoridad pública - } \\
\text { Ciudadano }\end{array}$} & \multirow{4}{*}{ Públicos } \\
\hline & $\begin{array}{l}\text { PARTICULARISMO } \\
\text { EJECUTIVO }\end{array}$ & $\begin{array}{l}\text { Programas } \\
\text { focalizados }\end{array}$ & & & \\
\hline & $\begin{array}{l}\text { PARTICULARISMO } \\
\text { BUROCRÁTICO }\end{array}$ & $\begin{array}{l}\text { Empleos en la } \\
\text { Administración } \\
\text { Pública }\end{array}$ & & & \\
\hline & $\begin{array}{l}\text { PARTICULARISMO } \\
\text { LEGISLATIVO }\end{array}$ & $\begin{array}{l}\text { Derechos selectivos y } \\
\text { favores personales }\end{array}$ & & & \\
\hline
\end{tabular}

El grado de discrecionalidad e inclusividad del ejercicio de responsiveness determinan el carácter particular o universal de la representación y su elección dependerá de los incentivos que enfrenten los políticos para comportarse como rent seekers o policy seekers. Los agentes que controlen los recursos en el Ejecutivo pueden implementar políticas públicas universales o decantarse por el asistencialismo personalista; en la Administración, frente a la gestión y acceso públicos imponer la gestión de patronazgo; y en la liza Legislativa, la representación nacional supeditarse a una de corte prebendalista. Tanto la responsiveness particular como la universal son manifestaciones de la dimensión sustantiva de la representación, entendida como la receptividad de los políticos a los intereses de los ciudadanos (Pitkin 1967). Este ideal sustantivo de la representación se alcanza cuando los gobiernos ejecutan políticas consideradas óptimas para los representados; cuando el mandato entre principal-agente se convierte en política pública; y cuando los principales sancionan o premian a los agentes por los resultados de tales políticas (Manin, Przeworski y Stokes, 1999:7). En esta tarea, el representante ha de actuar de forma independiente y los representados lo harán como protagonistas activos, no como meros sujetos necesitados de cuidado (Martínez 2004: 672).

En el análisis instrumental del comportamiento estratégico de los actores se asume como premisa que las secuencias institucionales -más que las culturales y económicas antes sobre estimadas por los teóricos de la modernización- influyen en las relaciones de intercambio de naturaleza política que se engendran en democracia: las relaciones del Estado con los Partidos, las relaciones PartidoPartido y las relaciones del Estado con la Ciudadanía. En las páginas siguientes se exponen las principales hipótesis planteadas en la literatura sobre la incidencia de variables de la oferta y la demanda que explican la persistencia de la política particularista en democracia. En esta triple dinámica relacional se desenvuelve el comportamiento estratégico de los actores partícipes del intercambio. 


\subsection{B) Factores explicativos del lado de la Oferta}

\section{$\checkmark \quad$ Cómo inciden las Relaciones del Estado con los Partidos en la Política Particularista}

La relación del Estado con los Partidos está determinada por el entorno institucional (reglas que dan acceso al ejercicio de la representación), los actores (particularidades de los que están al frente de las instituciones) y la historia (peso de la conformación del propio Estado):

Volver al estudio de la formación del Estado fue la premisa de los neoinstitucionalistas históricos para explicar la orientación de las políticas en el tiempo. Desde esta perspectiva, March y Olsen (1984), Thelen y Steinmo (1992) y Peters (2003) entre otros, sostienen que las decisiones que se adoptan en el momento fundacional de una institución, afectan al devenir de las políticas y al desempeño de los gobiernos en el largo plazo. La poderosa influencia del pasado sobre el presente y el futuro es retomada por Shefter (1994) para explicar el patronazgo en los Estados Unidos y Europa. En su "Teoría de la Experiencia Crítica" argumenta que el proceso de state-building es el momento fundacional en el que se gesta el grado de distinción entre el espacio de la política y el del Estado. Cuando la burocratización precede a la democratización, hay más posibilidades de crear y consolidar electorados para la autonomía burocrática ajenos a las particularidades partidistas. La profesionalización administrativa es garantía y requisito para el ideal de una Administración que sirve al interés general de forma ética y predecible. Por el contrario, la dominación partidista de la burocracia favorece la preferencia sesgada en el tratamiento administrativo y la representación particularista de intereses. Así, cuando las instituciones democráticas se crean antes de que se haya consolidado la centralización y profesionalización de la gestión administrativa, los partidos tendrán en la administración una fuente de recursos, y en el patronazgo, una herramienta de movilización (Shefter 1994:31). La diferencia en las secuencias de la burocratización y democratización explicarían según este autor, el carácter clientelar de la Democracia Cristiana Italiana y del Partido Socialdemócrata Austriaco o el más universalista de la Unión Demócrata Cristiana en Alemania.

El momentum transicional es otra de las coyunturas históricas clave identificadas por Shefter (1994) que influyen en que los partidos se vinculen con su electorado bajo reclamos clientelares o universalistas. Los partidos fundados por élites que ocupaban posiciones en el régimen predemocrático ("internally mobilized parties") tienden a estar orientados al patronazgo, ya que tienen acceso a los recursos del Estado y los utilizarán en la competencia que se inicia con la apertura transicional. Tal fue el caso del Partido Reformista Social Cristiano (PRSC) en la República Dominicana fundado por Joaquín Balaguer, quien fuera Secretario de Estado, Embajador y Presidente bajo la Era Trujillo. Por más de dos décadas Joaquín Balaguer -considerado el fundador del clientelismo en el país (Tejada 2007)- estuvo al frente de la política dominicana desde la apertura transicional en 1961. Dado que el acceso a los recursos públicos está restringido para los partidos externamente movilizados, las élites habrán de organizarse en base a reclamos programáticos y universalistas. Aunque la transición a la democracia es identificada aquí como un "punto de veto" o etapa de vulnerabilidad institucional que puede condicionar el futuro proceso de innovación política (Immergut, 1992), no tiene un poder determinista, ya que las vicisitudes de la competitividad pueden hacer que con el tiempo los actores, ante cambios en el contexto social, económico o político, alteren la forma en que se relacionan con su electorado.

El sistema electoral es la segunda de las variables institucionales identificadas por la corriente instrumentalista que afectan a la relación de los partidos con el Estado. Esta variable establece cómo

y quiénes acceden al ejercicio del poder. Determinadas características del sistema electoral pueden potenciar el particularismo en la movilización y representación de intereses en democracia. Tal es el caso de las reglas que focalizan la competencia entre candidatos y no entre partidos, como el voto preferente. En esta modalidad, la personalización de la competición entre compañeros de 
partido tiende a debilitar el intercambio indirecto mediado por programas. Cuando los electores pueden alterar el orden de la lista, en su deseo de diferenciarse del candidato opositor y del compañero de partido, los diputados buscan atraer recursos para su circunscripción o elaborar leyes reclamando crédito por ello en la rendición de cuentas electoral. Los trabajos de Ames (1995) sobre los diputados brasileños, demuestran la racionalidad del comportamiento del candidato que maximiza votos mediante la utilización estratégica de enmiendas presupuestarias que atraigan recursos al distrito.

De igual manera, a menor magnitud del distrito, mayor es la búsqueda de votos personales y mayor la probabilidad de que los intereses de la circunscripción se antepongan a los intereses nacionales (Carey y Shugart 1995).El número de representantes condiciona el intercambio particularista, aunque su influencia no parece estar muy clara. Si bien se ha asociado a los distritos uninominales con una mayor propensión clientelar, en los plurinominales también se generan incentivos estratégicos particularistas si, 1) los votantes pueden establecer su preferencia, 2) no se suman los votos de los integrantes de la lista y 3 ) el partido no tiene el control sobre la nominación (Kitschelt 2000:859). En la República Dominicana, la magnitud promedio de los distritos dominicanos se sitúa en el rango de las circunscripciones pequeñas -2 a 5 escaños- (Nohlen 2004:60), lo que limita las posibilidades representativas de las terceras fuerzas y acrecienta la desproporción. En este contexto, son menores las posibilidades de que lleguen a las instituciones nuevos partidos ajenos a la dinámica clientelar con un discurso de corte programático. Para contrarrestar la desproporción y el déficit representativo suelen establecerse estructuras distritales múltiples como la circunscripción nacional única para generar en los partidos una visión de política nacional desligada de los intereses parroquiales de su circunscripción (García Díez 2008:2). Por último, el ballotage y el umbral electoral estimulan los intercambios particularizados entre partidos, bien como pago por el apoyo aliado para evitar el 50+1 o para asegurar la propia supervivencia institucional.

El tercer eslabón en la relación Estado-Partidos tiene que ver con quiénes son los que acceden a las instituciones públicas. En la conquista de la "felicidad pública" (Arendt 1963) que han de perseguir los políticos, su profesionalización es variable explicativa del ejercicio de la representación ${ }^{1}$. Los políticos de calidad son aquellos que ejercen sus funciones de forma continuada, en exclusiva y cuentan con el talento, formación y la experiencia requerida (Alcántara 2012). Cuando las elites operan bajo estas circunstancias son más proclives a generar el bien común en los asuntos públicos. Diversos autores han clasificado a los políticos según los distintos niveles de profesionalización. Para Max Weber (1919), la remuneración distinguía entre aquellos que "viven de la política", de los que "viven para la política", mientras que la exclusividad diferenciaba entre políticos ocasionales, semi profesionales y profesionales. Asimismo, teniendo en cuenta la estabilidad de las funciones y la dependencia del partido, Panebianco (1982) hablaba del empresario político, el funcionario de partido y el funcionario experto, además de otras figuras como el político notable, el profesional de staff, el profesional camuflado y el semi profesional ${ }^{2}$. En estudios más recientes, Straus (2002) diferencia entre políticos amateurs puros, semi amateurs, semi

\footnotetext{
${ }^{1}$ Para un análisis detallado de la profesionalidad de las elites políticas, Ver CABEZAS, Lina M. (2012). Profesionalización de las elites legislativas en Bolivia, Ecuador y Perú. Tesis Doctoral, USAL.

${ }^{2}$ El empresario político surge al margen de los canales de selección partidaria; el funcionario de partido es un burócrata que lo hace funcionar, en puestos ejecutivos o representativos de la organización; el funcionario experto vive de la política pero no participa en la burocracia partidista; el notable vive de la política y su holgada situación económica le permite dedicarse a ella; el profesional de staff, es un especialista técnico que presta labores en el partido de forma no permanente; el profesional camuflado trabaja en las instituciones públicas pero se dedica a la política y es el partido quien le ayuda a ubicarse; el semi profesional es una variante entre el notable y el experto que no depende económicamente del partido con funciones no estables.
} 
profesionales y profesionales, según el nivel de experiencia en la competición y éxito electoral ${ }^{3}$. En el caso de los legisladores, además de la exclusividad, la especialización temática es otra de las variables que condiciona el desempeño de la representación (Rosenthal 1996; Uriarte 2000; Borchert 2003,). Si bien el dominio de ciertas áreas resulta beneficioso en aras de la mayor eficiencia de las comisiones legislativas, también se pueden dar actuaciones oportunistas (Krehbiel 2004), cuando ese conocimiento proviene del manejo de intereses privados en las áreas sobre las que se va a regular. En el caso de los legisladores dominicanos, su perfil empresarial de los diputados revela que más que especialización de las comisiones legislativas, se asiste a un proceso de cooptación de los espacios de la democracia para institucionalizar el particularismo propio de las denominadas "élites extractivas". Como argumentaran Acemoglu y Robinson (2006), éstas acceden a las débiles instituciones de las democracias emergentes para hacerlas favorables a sus intereses.

Este acercamiento al perfil de los actores permite identificar aquellas características de la clase política que particularizan el ejercicio de la política como espacio colectivo y limitan la conquista del bien común en los asuntos públicos. Puesto que los políticos estimulan y lideran los cambios en las instituciones, sus cualidades y características pueden afectar a su voluntad de implementar reformas orientadas al desarrollo democrático (Gerring, Keefer, Morrison y Oncel 2012). Si el capital político del que disponen se engendra en las redes familiares, los recursos provienen de sus actividades empresariales y su popularidad del trabajo asistencialista privado más que del compromiso con un partido político, se genera un escenario en el que el ejercicio de las funciones públicas queda enredado en círculos y lealtades superpuestas de confianza particularizada. En el caso de la República Dominicana, el empresario político -aquel que compagina su cargo con la actividad empresarial- y el profesional camuflado -aquel que labora en las instituciones pero trabaja para el partido a quien debe su puesto- son actores necesarios para la pervivencia y adaptación del clientelismo en democracia. Con respecto al primero, dado que las máquinas clientelares tienden a vivir por encima de sus posibilidades, el financiamiento público resulta insuficiente (Bicchieri y Duffy 1997) y se hace necesario acudir a los políticos con negocios para costear las campañas (Maiz 2005:24). El segundo, ejerce en las instituciones de bróker que activa y controla las redes multinivel de patronazgo en las instituciones públicas.

\footnotetext{
${ }^{3}$ Los amateurs puros no tienen experiencia previa y no tienen interés en seguir una carrera política, como el caso de personajes populares que de manera puntual acceden a cargos de representación; los semi amateurs han participado en política pero no han ganado ninguna elección, cuentan con cierta experiencia indirecta y suelen tener parientes en política; los semi profesionales han ganado elecciones a nivel local o regional, no son muy conocidos a nivel nacional pero cuentan con cierto grado de experiencia política; y los profesionales son aquellos que cuentan con una larga trayectoria, han ganado elecciones y ejercido funciones públicas.
} 


\section{$\checkmark \quad$ Cómo inciden las Relaciones Partido-Partido en la Política Particularista}

La existencia de patrones alternativos de accountability ajenos al modelo de gobierno de partido responsable en diferentes contextos institucionales, evidenció el carácter limitado de las estructuras formales para explicar el alineamiento entre ciudadanos y políticos en democracia. En la superación de este vacío explicativo, surge un nuevo corpus teórico que reorienta el análisis causal hacia la competencia partidista para prever la mayor o menor probabilidad de ofertar beneficios clientelares (Aldrich 1995; Kitschelt 2000; Piatonni et al 2001; Maiz 2005; Kitschelt y Wilkinson 2007). Se retoma así el papel decisivo de los actores en la elección de estrategias particularistas o de alcance universal en la articulación de tales vínculos. Como señala Warner (2001), «los políticos tienen un rol importante e independiente en la creación de electorados para el patronazgo o para la autonomía burocrática. Los materiales pueden estar ahí, pero son los políticos los que deben organizar y activar el sistema» (Warner 2001:150). Por lo tanto, si bien los políticos están constreñidos por las instituciones, son también capaces de sortearlas y redefinirlas (Piattoni 2001:18) y en consecuencia, ante circunstancias institucionales idénticas pueden darse resultados variados pues son libres de elegir bajo qué criterios se establece el nexo con los votantes y con otros actores en sus relaciones de competición.

Dentro de esta corriente que considera el particularismo un modo de accountability y responsiveness que resulta de la valoración racional de costes e incentivos, encontramos diferencias en cuanto a su interacción con otras variables independientes. Mientras que para Kitschelt (2007) la competencia interpartidista interactúa con los niveles de desarrollo; para Piatonni (2001) los actores están condicionados por la emergencia, transformación y declive de circunstancias institucionales e históricas, que hacen que el particularismo sea más o menos viable desde la oferta y más o menos aceptable desde la demanda. En ninguno de los dos caminos causales estas variables son determinantes, ya que la adopción de la estrategia clientelar es siempre una cuestión de elección. En el caso de los niveles de desarrollo, éstos solo determinan el coste y selección en el menú de opciones distributivas. Así, en contextos de renta baja, el exiguo coste de los votantes marginales hace que las élites gasten más en políticas clientelares que programáticas. Teniendo en cuenta el escaso valor de los bienes intercambiados con los clientes pobres, malgastar recursos en votantes que quizás voten al partido opositor, lastima pero no quiebra la economía nacional. Así lo han demostrado autores como Medina y Stockes (2007) en su modelo de competición clientelar en condiciones de subdesarrollo y ausencia de políticas fiscales redistributivas; y constatado empíricamente en los trabajos de Krishna (2007) y Wilkinson (2007) para el caso de India, entre otros. Por el contrario, en contextos de renta media y alta, el mayor coste de los bienes y servicios intercambiados obliga a los políticos a combinar y focalizar los beneficios directos selectivos y los públicos generalizados.

La manera en que los políticos movilizan su apoyo influye en la naturaleza de la representación y la calidad de la democracia (Przeworski 1985, Mainwaring y Scully 1995), además de ser un indicador de las posibilidades para su consolidación (Huntington 1968). En esta tarea, los actores políticos han de adoptar dos decisiones importantes: una de elección social (identidad programática) y otra de acción colectiva (organización). Ambas afectan al estilo de la representación y a la eficacia de las políticas. Con respecto a la primera, cuanto menor sea la presencia de vínculos ideológicos y mayor la competitividad, mayor será la probabilidad de que se oferten beneficios

particularizados. Bajo el prisma racional estratégico, la competitividad como variable explicativa de los modos de vinculación directa no está relacionada tanto con la fragmentación y volatilidad, sino con los incentivos que se generan en la contienda electoral. Los trabajos de Kitschelt y Wilkinson (2012) demuestran que cuando la competencia se desarrolla en condiciones de oligopolio -en las urnas se decide quién controlará los recursos públicos y un pequeño cambio en el apoyo electoral puede significar un gran cambio en el control del patronazgo- las élites no tienen 
incentivos para pasar de un modo racional de relación directa a uno indirecto redistributivo (Kitschelt y Wilkinson 2012:38). Los políticos se convierten así en actores de veto en el establecimiento de vínculos indirectos y abstractos («policy exchange») y competirán en su efectividad para distribuir bienes selectivos («targeted exchange») para hacerse con el control oligopólico de los recursos del Estado.

Con respecto a la decisión de acción colectiva, los actores han de acordar qué tipo de organización partidaria sirve de andamiaje a la movilización política. Esta decisión es indicador del nivel de institucionalización partidista de la que se derivan importantes repercusiones no solo en la eficacia de las políticas - particular o universal- sino en el más general proceso de consolidación democrática y legitimidad sistémica (Mainwaring y Torcal 2005). En este sentido, cuando la participación está mediatizada por brókeres locales, las elecciones las gana el partido que cuente con la mayor maquinaria política para "distribuir" bienes, no el candidato ideológico que prometa "redistribuir" costes entre las categorías abstractas de votantes (Hopkin 2002). En el caso de los partidos cartel informal (Katz y Mair 2004) como son los dominicanos, se trata de una maquinaria institucionalizada pero altamente informal en la que los actores disfrutan de cierto grado de autonomía en el ejercicio de su accountability y responsiveness. Esta descentralización del liderazgo es el precio que el partido tiene que pagar si quiere conservar un ejército de brókers que monitoreen a los votantes, lo que en la terminología de la autora se denomina "perverse accountability» (Stockes 2007:619). En este escenario, la agregación de intereses queda relegada a un segundo plano ya que no es obstáculo que el partido no hable como una sola voz colectiva.

También la competición en condiciones de oligopolio parece condicionar la racionalidad cooperativa estratégica entre partidos. Para los partidos que compiten en interacción sistémica tipo cartel informal, «mantener la estabilidad electoral es un asunto de vida o muerte, de ahí la importancia de la cooperación interpartidaria para asegurar que el votante descontento sea absorbido por el sistema de partidos existente» (Hopkin 2002:4). La ausencia de carrera administrativa y la debilidad programática, condicionan que las agendas consensuadas entre aliados sean sustituidas por el canje de puestos en las agencias del Estado, así como otros incentivos relacionados con la supervivencia personal en una interacción típica del denominado "Clientelismo de Partido". Los trabajos de Strom y Mueller (2000) y de Cheibub et al (2004) entre otros, muestran que los posibles conflictos de intereses se resuelven con la distribución de cargos en las áreas de responsabilidad ministerial.

En el caso de los partidos de patronazgo, se comparte con los aliados la gestión clientelar. La práctica aliancista pierde en este escenario su carácter pluralista para derivar en una apuesta por la mejor opción partidocrática, reproduciéndose en la relación entre partidos el mismo patrón particularista de la relación políticos-ciudadanos en la que se fragua la representación. En la República Dominicana, el aumento progresivo del respaldo electoral a los partidos aliados confirma la eficacia de una modalidad de presidencialismo pluralista en la que se comparte la gestión clientelar del Estado con sus aliados (Benito Sánchez 2010:752). Esta modalidad afecta al sistema de partidos dominicano, en el que proliferan nuevos patronos pero no nuevas opciones con capacidad de ejercer la oposición. El aumento de las expectativas clientelares por un lado, impide al partido oficialista dar satisfacción a todas ellas y por otro, incrementa la distancia y número de intermediarios entre el patrón y los nuevos clientes. Estos nuevos clientes se insertan en un círculo de confianza más cerrado -el del partido minoritario aliado- con menor competencia entre clientes, lo que les permite estrechar lazos con un patrón más accesible y que cuenta con la autorización del patrón principal para acceder al botín del Estado. Pero no se comparte el gobierno, que sigue quedando en manos del partido mayoritario y donde el hiper presidencialismo informal minimiza las posiciones ministeriales (Benito Sánchez 2014). 
Otra de las formas en que se relacionan los actores políticos es a través del conflicto. Las facciones por interés (Sartori 1980) o las client group factions (Beller y Belloni 1978) potencian la lealtad personal frente a la partidista, dificultan la cooperación intrapartidaria en la agregación de intereses colectivos y genera un sistema particularizado de lealtades y recompensas. La facción (inner circle) es la maquinaria que organiza las lealtades en círculos concéntricos similares a los descritos por Auyero (1999) según la cercanía con el jefe político. Como apuntara Geddes (1991), existe un nexo causal entre política particularista y faccionalismo al ser éste un obstáculo en la probabilidad de que se lleven a cabo reformas en la profesionalización de la administración, ya que el control por el patronazgo se traslada al ámbito interno del partido. Las dinámicas competitivas y degenerativas entre facciones promueven la rentabilidad sectarista particularizada tal y como evidenciara Boucek (2009) para el caso del Partido Liberal Japonés y la Democracia Cristiana Italiana en la década de los 70. De esta manera, cuanto mayor es el faccionalismo en el sistema de partidos, mayor será la dificultad de que éstos aborden el trabajo ideológico y en consecuencia, los candidatos emprenderán la movilización de su electorado en base a la distribución particularizada de beneficios.

\subsection{C) Factores explicativos del lado de la Demanda}

\section{$\checkmark \quad$ Cómo inciden las Relaciones Estado-Ciudadanía en la Política Particularista}

La reconsideración del lado de la demanda ignorado por Shefter (1994) para explicar el particularismo, implica acercarse a la cultura política como variable explicativa sin el determinismo de los primeros trabajos herederos de la antropología política (Lemarchand y Legg 1972; PittRivers 1971; Campbell, 1964). Bajo esta óptica, es un fenómeno social y político y no uno de naturaleza cultural o económica.

En su acercamiento al fenómeno del clientelismo, la ciencia política justificó su existencia en la falta de modernización del Estado y de la vida política que desaparecería con la consolidación de la democracia (Tarrow 1977; Landé 1977; Eisenstadt y Lemarchand 1981). Así, los teóricos de la modernización socioeconómica explicaron la arbitrariedad particularista de las élites en la existencia de una masa pobre y poco educada incapaz de entender los beneficios del intercambio indirecto e impersonal de largo plazo. Estos trabajos vaticinaban que con la urbanización e industrialización, las clases medias más empoderadas exigirían intercambios directos más costosos y se resistirían al pago de más impuestos o sobornos para tales fines, forzando su uso en bienes públicos colectivos. De esta manera, el crecimiento de las clases medias estaría asociado a la expansión del estado del bienestar universal y al declive de la política particularista (Randall 1988; Ware 1987; citado en Kitschelt 2000:13). Los primeros estudios sobre las relaciones de poder de las sociedades tradicionales identificaron la ruralidad, los sistemas de tenencia de la tierra y la falta de cohesión del campesinado, como el hábitat ideal para el afloramiento de las relaciones personales en la vida pública que inhibían la acción colectiva y el conflicto con los patronos (Gramsci 1970; Coleman 1990).

El cuestionamiento de la teoría de la modernización socioeconómica se inicia con los trabajos que muestran la falla en la secuencia lineal de los beneficios democráticos asociados al desarrollo. En primer lugar, no siempre el proceso de urbanización ha roto con los lazos del "familismo amoral" (Banfield 1958), el amiguismo y el parroquianismo de la competencia de clientelas. En algunos casos, estos vínculos tradicionales se han adaptado a la urbanización sin romper los lazos particularizados que convierten a los habitantes de la ciudad en anónimos y por lo tanto, 
reproduciendo en las urbes las estructuras de confianza y parentesco. Tal fue el caso de Grecia, que en las primeras etapas de la modernización se sirvió de un funcionariado procedente de las cadenas migratorias circulares que no atomizaron a sus integrantes. De esta manera, el funcionariado quedó envuelto en relaciones de mutua dependencia que dificultaban la transformación de los casos administrativos en casos impersonales (Papakostas 2001:42).

En otros escenarios, la complejidad y desconocimiento de los procesos burocráticos fomentó el surgimiento de una red de intermediarios en las relaciones de la masa pobre no educada con el Estado, en los que se reproducían los vínculos protectores de patronazgo de antaño. Así sucedió en la España de la Restauración (Moreno Luzón 1995:201) o en la actual India de los naya netas, que actúan como intermediarios de la casta de los intocables (Krishna 2007). También la literatura de los sistemas de partidos asumió la teoría de la modernización, vaticinando que aquellos sistemas orientados al patronazgo y al localismo devendrían más institucionalizados y programáticos con el desarrollo (Huntington 1968; Sartori 1986). Sin embargo, el particularismo en la representación de intereses en democracias consolidadas de renta alta como Bélgica o Japón (Scheiner 2007), o la posibilidad de institucionalización partidaria y sistémica sin programa (Kitschelt, Hawkins, Luna, et al 2010) han cuestionado el papel catalizador del nivel de desarrollo democrático y económico.

La persistencia de los vínculos particularistas a pesar de la modernización, ha debilitado el poder explicativo del empoderamiento ciudadano y el carácter unidireccional del desarrollo socioeconómico, para ser analizados ambos desde una perspectiva dinámica y relacional. En esta nueva lectura de los condicionantes de la demanda, no se trata por tanto de culpar a la cultura política de una comunidad, sino de advertir cómo ha sido modelada por las contingencias históricas en su relación con el Estado (Papakostas 2001:32). Las secuencias del proceso organizacional de actores colectivos como sindicatos y otras asociaciones civiles, determinan su forma de relación con el Estado. En este proceso, se generan espacios de oportunidad que harán del particularismo bien la forma dominante o bien la formal residual de relación (Piatonni 2001).

Esta aproximación macro sociológica a la cultura organizacional de un país propuesta por Papakostas (2001) permite identificar el tipo de relación -fronteriza o interconectada- entre las organizaciones sociales y políticas. Como evidencia el autor para los casos de Suecia y Grecia, las relaciones fronterizas aíslan del control político de la burocracia y de las particularidades de la vida civil, generando espacios de oportunidad para la política universalista. Por el contrario, la interconexión y dependencia, limitan la beligerancia y sesgan la relación con las clientelas que compiten entre ellas para obtener los favores públicos. La incorporación vertical, plebiscitaria y paternalista de las clases populares en el momento de la transición a la política de masas, favorece los vínculos particularistas entre políticos y electores. Por el contrario, una incorporación horizontal genera espacios de oportunidad para agregar intereses sociales y que las organizaciones ejerzan de mediadoras y no de subordinadas en las relaciones con el Estado.

En el caso de las clases dominantes, o los "clientes ricos pero pobres en votos", en la terminología de Kitschelt, la penetración de los grupos familiares y empresariales inhibe el surgimiento de un Estado universal imparcial, mientras que el aislamiento previene la representación particular de intereses (Papakostas 2001:40). Tal y como describieran Acemoglu y Robinson (2006; 2012), en democracia las "élites extractivas" se organizan y acceden a las débiles instituciones políticas y económicas haciéndolas más propensas a sus intereses, bloqueando la redistribución e institucionalizando el particularismo. En escenarios de "industrialización sin desarrollo" (Chubb 1981) como el dominicano, el clientelismo es la vía para mantener el control de las masas populares. Las acciones de las élites extractivas para atomizar los intereses de clase y el activismo sindical generan múltiples agentes de la acción corporativa en todos los niveles de renta. Por lo 
tanto, no habrá acción colectiva ni concertación social, sino una de carácter sectorial corporativa. En consecuencia, las clientelas no cooperan, compiten (Maiz 2005).

Desde esta perspectiva - pero en la dimensión micro sociológica- se retoma también el análisis del capital social para dibujar el paisaje actitudinal identificado como propicio para la persistencia y adaptación del clientelismo en democracia. Como han demostrado numerosos trabajos (Almond y Verba 1963; Putnam 1993; Uslaner 2002; Costa y Kahn 2003), exite un iter causal entre cultura política y nivel de inclusión de los resultados democráticos. En un escenario social de confianza generalizada, pluralismo, secularización, solidaridad y primacía de la colectividad frente al personalismo, es más probable la existencia de una sociedad civil cohesionada y proclive a la cooperación que a la competición clientelar. Cuando los ciudadanos se interesan en los asuntos públicos, se asocian y participan, el sistema político es más proclive a solucionar los problemas que afectan a toda la comunidad y se implementen políticas universalistas.

Por el contrario, actitudes como el conservadurismo o el personalismo frente a la abstracción anónima de la colectividad, restringen la confianza a grupos conocidos unidos por lazos de familia, amistad o compadrazgo político. Estos grupos, en su estrategia de relación con el Estado reivindican beneficios para aquellos que están dentro del circulo de confianza (asistencialismo particularista) frente a la solidaridad (política universal). En el caso de las nuevas democracias como la dominicana, el peso socializante del pasado incide negativamente en la valoración de las instituciones y la desafección deriva en una ciudadanía menos participativa (Torcal y Montero 2006; O’Donnell 1992). Esto repercute en la efectividad democrática, entendida como el nivel de inclusión de los resultados democráticos: mayor o menor nivel de particularismo en la representación política.

A partir del corpus teórico presentado, se sistematizan a continuación los parámetros metodológicos que guían la identificación de las expresiones del clientelismo oficial en la República Dominicana y la explicación de la persistencia de la política particularista en la etapa de la consolidación democrática 1996-2010. 


\subsection{CONSIDERACIONES METODOLÓGICAS}

\subsection{A) Pregunta de investigación}

En esta investigación se identifican las expresiones que adopta la política particularista en la República Dominicana (1996-2010) con especial atención a aquellas que tienen lugar en el escenario legislativo, y se exploran diversos factores que podrían explicar su persistencia en la etapa post caudillos desde una perspectiva instrumentalista (Kitschelt y Wilkinson 2012; Piatonni 2001; Shefter 1994; Warner 2001; Papakostas 2001). Con este propósito, el trabajo parte de un interrogante teórico a partir del cual se problematiza en torno al fenómeno del clientelismo:

OG: ¿Cuáles son los factores que hacen de la política particularista una estrategia viable de movilización y representación en democracia?

Este objetivo general (OG) se desagrega en tres objetivos de investigación específicos (OE) y preguntas $(\mathrm{Q})$ a las que pretende dar respuesta este trabajo:

OE1: Definir e identificar el clientelismo oficial y analizar longitudinalmente los cambios y continuidades del particularismo legislativo en la República Dominicana

Q11: ¿Cuál es el grado de particularismo en la política social del Gobierno y en la conformación de la Administración Pública dominicana?

Q12: ¿Cuál es el grado de particularismo en la actividad propositiva (nacional) y concesional (distrital) que realizan los diputados dominicanos?

Q13: ¿Qué elementos contextualizan los puntos de inflexión y cambios de tendencia observados?

OE2: Conocer la incidencia de los factores que determinan la política particularista desde la Oferta.
Relaciones
Q21: ¿La burocratización precede a la democratización en el país?
Q22: ¿La transición a la política de masas fue protagonizada por elites de partidos internamente movilizados?
Q23: ¿Qué características del diseño electoral dominicano favorecen el particularismo en la representación y movilización de intereses?
Q24: ¿Cómo afecta el perfil empresarial de los políticos al mandato de representación?
Q25: ¿Son los políticos dominicanos «guardianes idóneos de la cosa pública»?

\section{Relaciones \\ Partido-Partido}
Q26: ¿Cómo es la competencia entre partidos?
Q27: ¿Cómo negocian y qué intercambian los partidos políticos dominicanos?
Q28: ¿Por qué pelean los compañeros de partido?

OE3: Conocer la incidencia de los factores que determinan la política particularista desde la Demanda

Relaciones Estado-Ciudadanía
Q31: ¿Cómo fue la ubicación de la clase dominante y las clases populares en la vida política y social dominicana?

Q32: ¿Cómo es la estructura social de la cooperación en el país?

Q33: ¿Cuáles son los límites a la acción colectiva?

Q34: ¿Qué elementos de la cultura política inciden en la mayor predisposición de los dominicanos a aceptar la política particularista como estrategia viable de movilización y representación? 


\subsection{B) La variable dependiente y sus indicadores}

La VD en esta investigación es la Política Particularista observada a través de su manifestación en el gasto social (Ejecutivo), en el número de funcionarios (Administración Pública) y en la actividad propositiva y concesional de los diputados (Legislativo). El análisis descriptivo de la VD permite abordar el primero de los objetivos específicos (OE) de esta investigación:

OE1: Definir e identificar el clientelismo oficial y analizar longitudinalmente los cambios y continuidades del particularismo legislativo en la República Dominicana

Aunque la medición longitudinal se circunscribe al entorno legislativo, se reseñan otras expresiones del «Clientelismo Oficial». Así, para medir el patronazgo administrativo se utiliza como indicador el vaivén en el número de funcionarios contratados (2010-2012) y para medir el asistencialismo particularista del gobierno central se compara el gasto en seguridad social y en programas focalizados en los presupuestos nacionales (2006-2011). Ambos indicadores reflejan el impacto de las contiendas electorales en su oscilación.

En este estudio sobre los modos que adopta la representación política en democracia, se justifica la mayor atención otorgada a los intercambios ente principal y agente en la liza parlamentaria. El Congreso se convierte en unidad de análisis obligada y las acciones de los legisladores son las unidades de observación que caracterizan la representación y su evolución en el tiempo. El «Particularismo Legislativo» se define en este trabajo como la representación de intereses no generales que tiene lugar en las instituciones legislativas y que deriva en un ejercicio prebendalista e individualizado de la representación política. Esta sub categoría de «Clientelismo Oficial»se caracteriza por el intercambio de recursos públicos -bajo la forma de derechos selectivos y favores personales- a cambio de apoyo, en el que los legisladores ejercen de mediadores.

Al ser ésta una investigación sobre la actividad propositiva de los diputados, es decir, que no considera la suerte final del proyecto en el trámite parlamentario (éxito legislativo), se crea una clasificación específica para su medición y análisis. El acercamiento a la producción legislativa como variable dependiente ha aportado diferentes clasificaciones del tipo de leyes generadas. El Índice de Taylor-Robinson y Díaz (1999) elaborado según el nivel de agregación [individuales, locales, sectoriales, regionales y nacionales] y el efecto de las leyes [beneficiosas, contraproducentes, mixtas y neutras], ha sido enriquecido en ulteriores trabajos. Algunos autores introducido el tópico de las leyes [administrativas, económicas, honorificas, presupuestarias, política, sociales, cultural/científico/técnicas y medioambientales] (Amorim Neto y Santos 2003); mientras que otros han retomado las categorías de Lowi (1964) [distributivas, redistributivas y regulatorias] para determinar el carácter particularista o general de una ley (Mejía, Pérez Liñán y Saiegh 2006; Bertino 2012:7). La tipología que aquí se propone para medir el particularismo en las instituciones legislativas de la Republica Dominicana permite catalogar el desempeño de los diputados en sus diversas acciones más allá de la función estrictamente normativa.

Para medir el particularismo legislativo en esta investigación, se utilizan dos Indicadores. El primero está compuesto por las Proposiciones de Ley elevadas desde la Cámara de Diputados y aprobadas para trámite parlamentario en las legislaturas 1998-2002, 2002-2006 y 2006-2010. Este indicador nos sitúa ante la dinámica principal-agente de la teoría de la representación liberal en democracia (Hamilton 1788) y el acto de delegación por el que el agente representa los intereses públicos del ciudadano (Pitkin 1985) en el que no tienen cabida los mandatos particulares imperativos. El mandato entre el principal y el agente sigue un iter institucional de decisión que puede afectar al contenido y éxito de tal mandato: como la "agenda setting" de las comisiones o la conquista de apoyos para lograr su aprobación en las dos Cámaras. El resultado es un acto de legislación del que se derivan derechos y deberes ciudadanos. El Indicador 1 aporta por tanto 
información relevante acerca del ejercicio de la función normativa y la función de orientación de política pública del Poder Legislativo en la República Dominicana.

Gráfico 1.2.B.1. ¿Qué proponen los diputados?

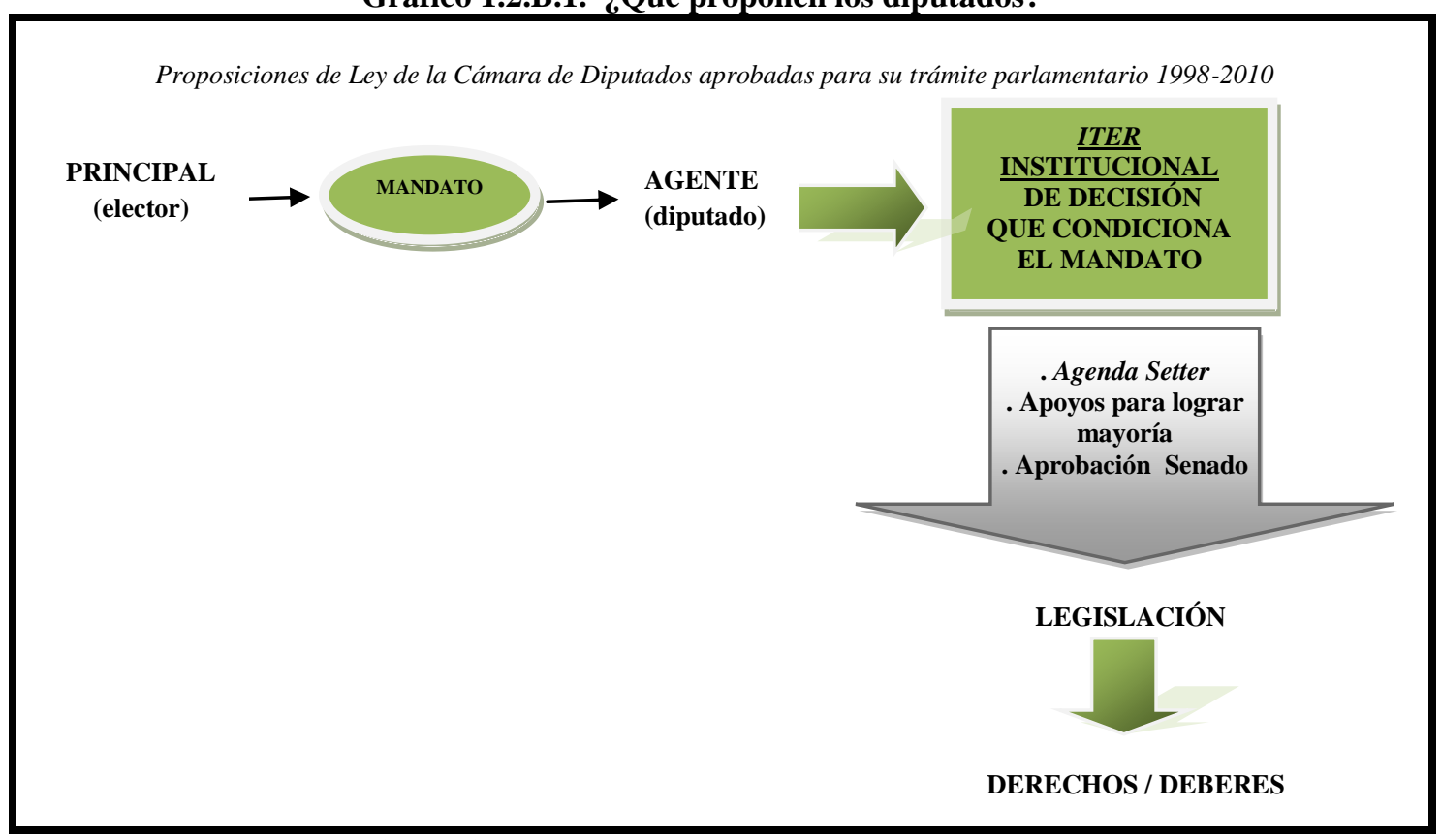

Fuente: Elaboración propia

En las tres legislaturas estudiadas, se analizan un total de 1,863 proposiciones que son clasificadas por el nivel de inclusión de los beneficiarios [representación general, corporativa e individual] dependiendo del tipo de interés protegido [interés público, grupal/de club o interés personal].

Tabla 1.2.B.1. Clasificación Proposiciones de Ley por nivel de Particularismo y \% Total, 1998-2010

\begin{tabular}{|c|c|c|c|c|c|}
\hline $\begin{array}{l}\text { NATURALEZA DE LA } \\
\text { REPRESENTACIÓN } \\
\text { SEGÚN NIVEL DE } \\
\text { INCLUSIVIDAD }\end{array}$ & GENERAL & \multicolumn{3}{|c|}{ CORPORATIVA } & INDIVIDUAL \\
\hline $\begin{array}{l}\text { ¿QUIÉNES SON LOS } \\
\text { REPRESENTADOS? }\end{array}$ & $\begin{array}{c}\text { CIUDADANOS } \\
\text { DOMINICANOS }\end{array}$ & POLÍTICOS & EMPRESARIOS & $\begin{array}{l}\text { GREMIOS } \\
\text { trabajadores }\end{array}$ & PARTICULARES \\
\hline $\begin{array}{l}\text { TIPO DE INTERÉS } \\
\text { PROTEGIDO }\end{array}$ & INTERÉS PÚBLICO & \multicolumn{3}{|c|}{ INTERÉS GRUPAL/CLUB } & INTERÉS PERSONAL \\
\hline FINALIDAD & $\begin{array}{ll}\checkmark & \text { desarrollo } \\
& \text { legislativo/ } \\
& \text { institucional } \\
\checkmark & \text { fiscalizadora } \\
\checkmark & \text { testimonial }\end{array}$ & \multicolumn{3}{|c|}{$\checkmark$ concesional } & $\checkmark \quad$ concesional \\
\hline $\begin{array}{c}(\mathrm{N}=1.863 \\
\text { proposiciones Ley })\end{array}$ & $49,7 \%$ & \multicolumn{3}{|c|}{$15,6 \%$} & $34,6 \%$ \\
\hline
\end{tabular}

Fuente: Elaboración propia 
Bajo la categoría de «representación general » se clasifican aquellas proposiciones de ley cuyos resultados democráticos puedan ser disfrutados por toda la ciudadanía sin posibilidad de restricción a un determinado grupo o individuo. El interés público protegido puede concretarse a través de una futura ley que tenga como finalidad el desarrollo legislativo o institucional de un determinado asunto; una finalidad fiscalizadora y presupuestaria; o el mero testimonio del que no se desprenden derechos y/o deberes. Estas últimas se sub dividen en «conmemorativas», cuando tienen por objeto la celebración de eventos de relevancia significativa en la historia dominicana; «declarativas» si tienen como propósito mostrar la adhesión del diputado a determinadas realidades o causas; «caudillistas» si persiguen nombrar alguna obra pública con el nombre de los caudillos Joaquín Balaguer, Juan Bosch o Francisco Pena Gómez; y «personalistas» si busca renombrar instituciones públicas con el de una persona reconocida en algún ámbito profesional o político. Esta desagregación de propósitos de las futuras leyes aporta además información sobre el peso de lo individual sobre lo colectivo y del personalismo en la memoria colectiva del país que serán analizados en el capítulo correspondiente a la cultura política.

La Tabla siguiente recoge ejemplos de cada una de las sub categorías de proposiciones de ley definidas por el carácter general de la representación.

Tabla 1.2.B.2. Ejemplos Proposiciones de Ley Representación General, 1998-2010

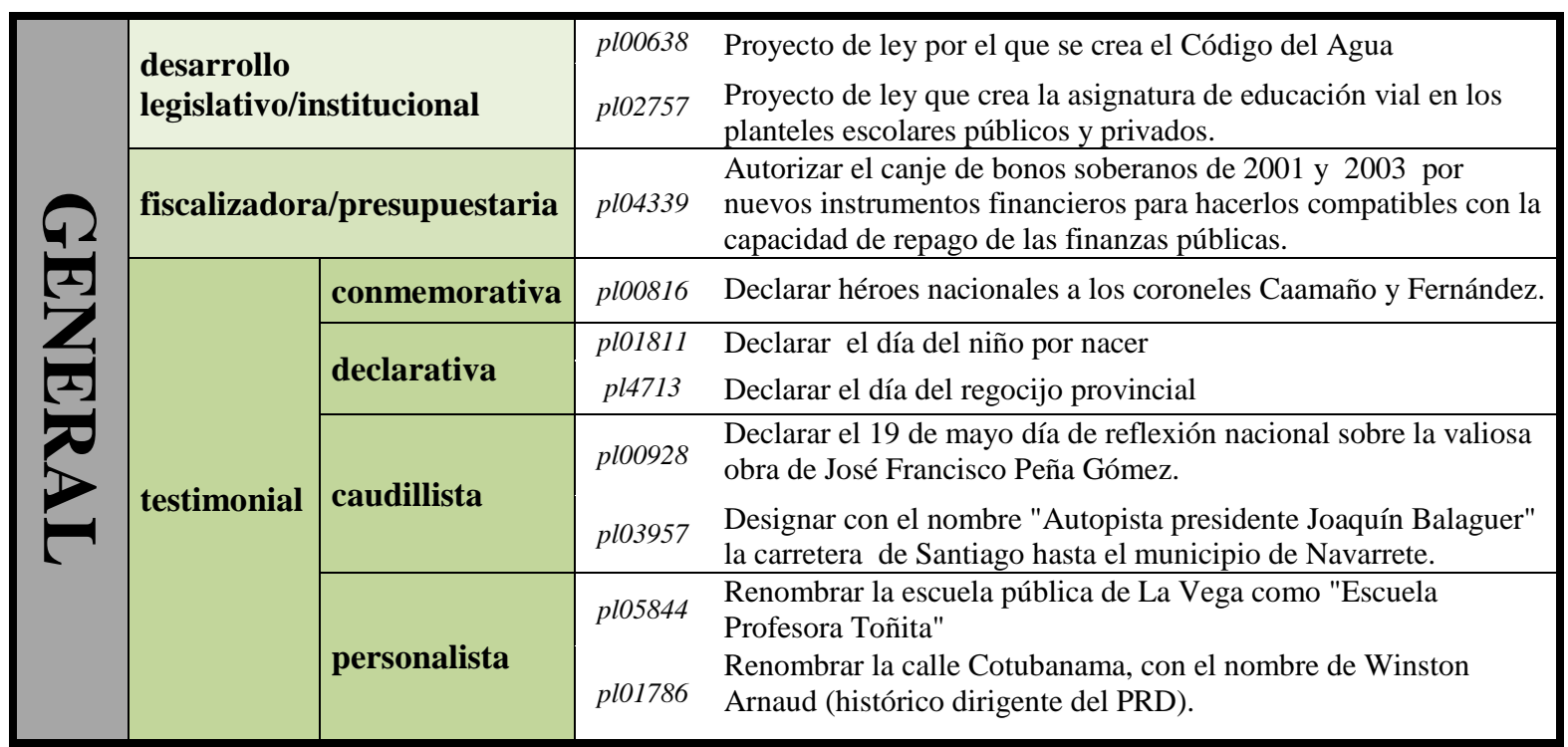

Fuente: Elaboración propia a partir de datos facilitados por la Oficina de Acceso a la Información Publica de la Cámara de Diputados de la Republica Dominicana.

Bajo la categoría de «representación corporativa» se clasifican aquellas proposiciones de ley cuyos beneficios democráticos solo pueden ser disfrutados por un grupo delimitado que comparte un mismo interés. Estos grupos de agraciados resultaron ser tres: empresarios, diversos colectivos de trabajadores o gremios, y la clase política. En los primeros, la finalidad radica en conceder algún tipo de exención o regulación favorable, en los segundos beneficios de club y en los terceros, la elevación de categoría territorial a un municipio dentro de la provincia del diputado.

Como se argumentará en el apartado dedicado a la competencia interpartidista, la promesa de elevación territorial se ha convertido en el premio que otorga el diputado a sus unidades administrativas inferiores en recompensa por la movilización proselitista. El uso del territorio como 
prebenda es una manifestación más del clientelismo entre élites políticas en el que se intercambia influencia partidista a cambio de apoyo político. La categoría administrativa municipal es la nueva fuente de puestos políticos y administrativos al servicio de la élite política local que surge al amparo de la descentralización. En los tres grupos de beneficiarios -empresarios, gremios y políticos- la intervención del diputado tiene una finalidad dispensatoria o concesional.

Tabla 1.2.B.3. Ejemplos Proposiciones de Ley Representación Corporativa, 1998-2010

\begin{tabular}{|c|c|c|}
\hline políticos & $\begin{array}{l}\text { pl00366 } \\
\text { pl01388 }\end{array}$ & $\begin{array}{l}\text { Proyecto de ley para elevar a distrito municipal la sección de } \\
\text { Maizal, del municipio Esperanza en la provincia Valverde. } \\
\text { Proyecto de ley para elevar el paraje El Ranchito a sección, en la } \\
\text { provincia de La Vega. }\end{array}$ \\
\hline \multirow{4}{*}{ gremios } & Pl03784 & $\begin{array}{l}\text { Proyecto de ley para modificar ley } 547 \text { que crea la caja de } \\
\text { pensiones y jubilaciones para choferes. }\end{array}$ \\
\hline & pl00747 & $\begin{array}{l}\text { Proyecto de ley para conceder un aumento de salario a los } \\
\text { servidores públicos, civiles y militares que desempeñen funciones } \\
\text { en la provincias de la región fronteriza. }\end{array}$ \\
\hline & pl03757 & $\begin{array}{l}\text { Proyecto de ley para condonar todas las deudas de las viviendas } \\
\text { de los proyectos agrarios a favor de los signatarios y familiares. }\end{array}$ \\
\hline & pl03956 & $\begin{array}{l}\text { Proyecto de ley para conceder una pensión mensual del estado a } \\
37 \text { ex-empleados del instituto nacional del algodón (INDA) }\end{array}$ \\
\hline \multirow{4}{*}{ empresarios } & pl01289 & $\begin{array}{l}\text { Proyecto de ley para modificar ley } 14-93 \text { sobre arancel de } \\
\text { aduanas y establecer tasa cero a la importación de sardinas, tunas, } \\
\text { bacalao y arenque. }\end{array}$ \\
\hline & pl01289 & $\begin{array}{l}\text { Proyecto de ley que libera del pago de impuestos a los } \\
\text { generadores o plantas eléctricas de hasta } 15 \text { kilos. }\end{array}$ \\
\hline & pl01687 & $\begin{array}{l}\text { Proyecto de ley para conceder un crédito fiscal de un } 80 \% \text { del } \\
\text { costo de la compra e instalación de calentadores de agua solares y } \\
\text { sistemas de producción fotoeléctrica y eólica. }\end{array}$ \\
\hline & pl01748 & $\begin{array}{l}\text { Proyecto de ley para modificar ley } 168, \text { y facilitar la exoneración } \\
\text { de impuestos en forma parcial de vehículos importados. }\end{array}$ \\
\hline
\end{tabular}

Fuente: Elaboración propia a partir de datos facilitados por la Oficina de Acceso a la Información Pública de la Cámara de Diputados de la Republica Dominicana

La Tabla 1.2.B.3. recoge ejemplos de proposiciones de ley definidas por el carácter corporativo de la representación en cada uno de los destinatarios. En el caso de los empresarios, todos los proyectos presentados por los diputados tienen por finalidad la exoneración, rebaja fiscal o régimen especial para determinados sectores de la industria y el comercio nacional. Esta intervención del Estado en la regulación económica por la vía de exenciones, reglas favorables particulares y subvenciones, es el contexto de capitalismo coordinado identificado por Kitschelt y Wilkinson (2012) como propicio para las relaciones de intercambio particularizado con los "clientes ricos pero pobres en votos". En cuanto a los gremios o diferentes cuerpos profesionales, el diputado ejerce de mediador ante el Estado en la concesión de un aumento salarial para los funcionarios de su provincia, para condonar las deudas de los trabajadores de un proyecto agrario, la concesión de una pensión para 37 trabajadores de una empresa pública, o una nueva conquista en el sistema especial de jubilación para el colectivo de transportistas (choferes).

Bajo la categoría de «representación individual» se clasifican aquellas proposiciones de ley cuyos beneficios democráticos solo pueden ser disfrutados por una sola persona. Todas las propuestas elevadas por los diputados dominicanos ante la Cámara y aprobadas para trámite parlamentario durante la última década tienen por finalidad conceder una pensión a un individuo. Como se 
argumentará, en ausencia de un sistema de previsión de contingencias de cobertura universal, la concesión de pensiones adopta un carácter prebendalista y arbitrario. La conquista de la pensión no es un derecho adquirido sino una regalía por la que compiten trabajadores contra trabajadores en un universo de clientes y patronos públicos que ejercen de mediadores: el senador y diputado, el gobernador de la provincia y con la descentralización, el síndico y el regidor. La Tabla siguiente muestra la discrecionalidad en la cuantía, que puede oscilar entre los \$1,000 USD a los 50 dólares mensuales. También la actualización de la asignación es un acto de liberalidad del diputado ajeno a criterios generalistas relativos a la inflación o categoría profesional.

Tabla 1.2.B.4. Ejemplos Proposiciones de Ley Representación Individual, 1998-2010

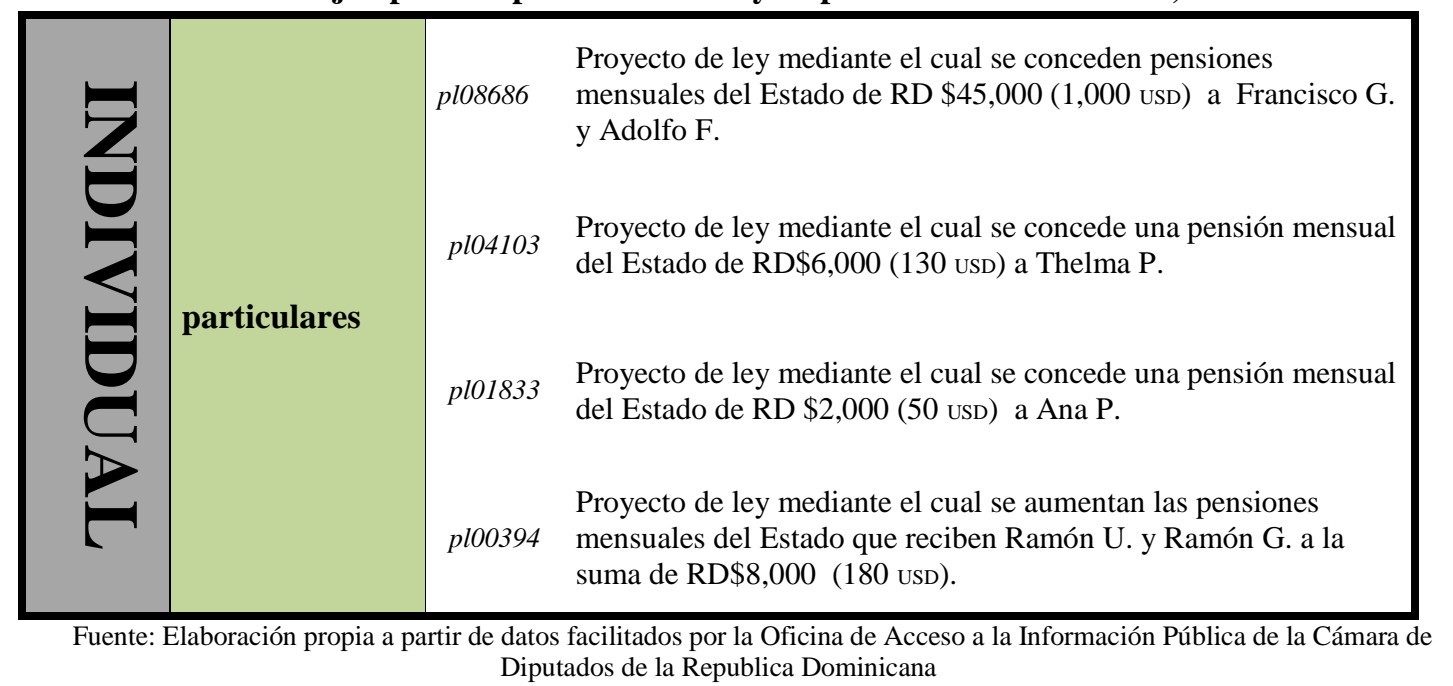

Los datos agregados tras clasificar el nivel de inclusividad de las proposiciones de ley de los diputados dominicanos en las tres legislaturas consideradas (1998-02, 2000-06 y 2006-10) arrojan un balance en el que predomina el ejercicio de la representación particularizada y prebendalista, ya que más de la mitad de las propuestas representan intereses individuales o de club (Ver Tabla 1.2.B.1. En la década objeto de estudio, el $34,6 \%$ de los proyectos sometidos a trámite parlamentario benefician a un solo individuo (representación individual) y el 15,6\% a determinados colectivos profesionales y empresariales (representación corporativa). Ambos escenarios cuestionarían la generalidad y abstracción que ha de caracterizar a las leyes en un Estado de Derecho y que son principios garantes de la previsibilidad y la seguridad jurídica.

Los resultados apuntarían también que el ejercicio de la representación política de los diputados dominicanos es una interacción característica de los "empresarios políticos" y "servidores del distrito" descritos por Siavelis y Morgenstern (2008). El tratamiento estadístico de los datos, desagregando por partido político, año electoral y diferentes administraciones, permite medir oscilaciones e identificar puntos de inflexión en la variable dependiente desde 1998 hasta el año 2010. A pesar de que los diputados dominicanos ocupaban el primer lugar en el ranking de preferencias redistributivas (Llamazares 2008:4), los datos de esta investigación revelan el carácter particularista de la labor legislativa en el Congreso nacional. El objetivo de este trabajo será por tanto, identificar el set de incentivos -desde la oferta y la demanda- que distorsionan la secuencia desde esta promesa redistributiva del diputado hasta el beneficio particular final. 
El segundo Indicador para medir la VD en el escenario legislativo lo forman las regalías del Fondo de Gestión Social concedidas por los diputados en su circunscripción durante los años 2008 y 2009. Un total de 2,016 facturas de bienes dispensados en concepto de asistencia social y clasificadas en función del nivel de agregación de las preferencias: para el disfrute de un individuo, de un colectivo determinado, o para la generalidad de la comunidad. Hasta el año 2008 no existía ningún tipo de control sobre este tipo de actividad pseudo filantrópica que los legisladores realizaban a través de sus propias fundaciones. Desde esa fecha estas donaciones han pasado a ser financiadas mensualmente con recursos públicos y sometidas a registro contable ante el Congreso.

Aunque el sobrenombre popular de "barrilito" deriva del anglicismo "pork barrel", no es una manifestación de este tipo de política en la que los legisladores estadounidenses compiten por atraer recursos para sus distritos, ya que en la versión dominicana se trata de una asignación fija determinada por el número de habitantes de la provincia y por la liberalidad de la autonomía presupuestaria de la que disfruta del Congreso Dominicano. El Indicador 2 nos sitúa ante la dinámica de la relación patrón-cliente de las tradicionales relaciones de patronazgo, en las que el cliente utiliza el canal particularizado de atención entre ambos para someter a la subjetividad del diputado la concesión del favor. El acto resultante no es un acto de legislación del que se derivan derechos y deberes, sino un acto de donación del que emana el compromiso moral de estar en deuda con la persona que le ayudó. Puesto que los diputados gestionan por esta vía recursos públicos, el Indicador 2 aporta información relevante sobre el ejercicio de la función de orientación de política pública y junto con el Indicador 1 permite caracterizar también el ejercicio de la función simbólica de representación del Poder Legislativo en la República Dominicana.

Gráfico 1.2.B.2. ¿Qué conceden los diputados?

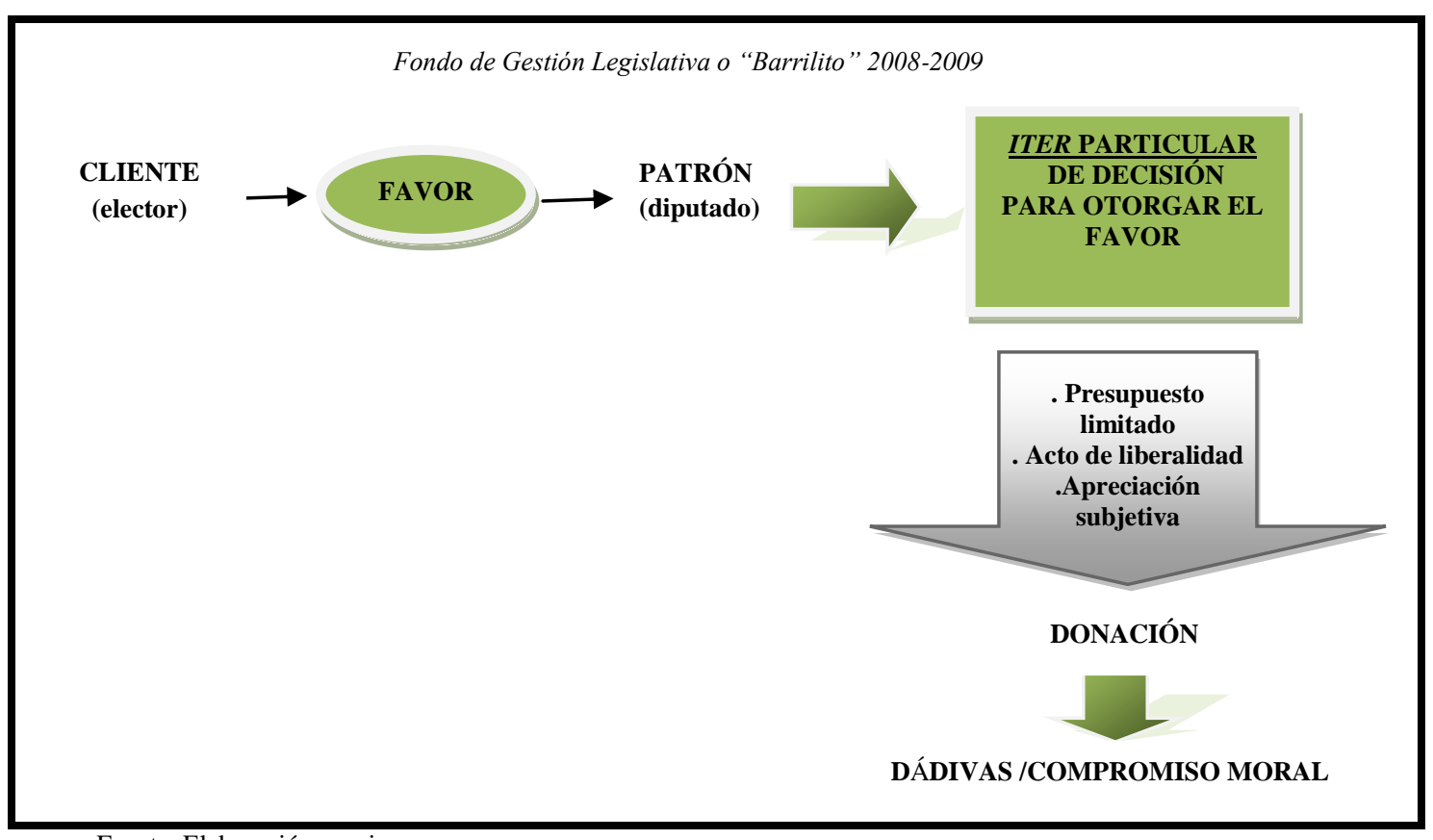

Fuente: Elaboración propia

Atendiendo al nivel de agregación de preferencias e inclusividad del disfrute de los beneficios, se clasifican bajo la categoría de "general» aquellas concesiones de cuyo disfrute no puede ser excluido ningún miembro de la comunidad [e.g, sufragar fiestas patronales del municipio- $p 2 b 71$; dispositivo seguridad tráfico Semana Santa-p3c14]; «corporativas», cuando se circunscriben a un 
grupo delimitado como una junta de vecinos, una asociación deportiva o un sindicato [e.g, uniformes deportivos para club infantil de baloncesto-p2a5]; e «individuales», cuando la prebenda es una regalía para un solo ciudadano [e.g, cubrir los gastos médicos de un paciente de la provincia-pla45]. Con esta información se elabora una base de datos desagregando el partido político del diputado, cuantía, solicitante, beneficiario y objeto (gastos médicos, educativos, materiales de construcción, infraestructura local o fines recreativos).

Los datos del solicitante aportan pistas acerca de la organización informal de los modernos partidos clientelares ya que además de los que acuden a pedir los favores del diputado para su propia causa, aparecen regularmente en el registro de solicitantes sujetos en busca de prebendas a favor de "personas de escasos recursos". Esta identificación del gestor intermediario pero no del destinatario final de la prebenda revela la presencia de la corte de brokers al servicio del diputado. Por otro lado, la repetida presencia de proveedores de servicios (e.g, la misma ferretería suplidora de los materiales de construcción o la misma farmacia en la que el diputado extiende el cheque para las medicinas) deja entrever por un lado, la red de amigos y "clientes ricos" que se benefician de los intercambios particularizados y por otro lado, la posible vulneración de los procedimientos de concurso que exige la Ley de Compras y Contrataciones del Estado No. 340-06.

Tabla 1.2.B.5. Clasificación Fondo Social o "barrilito" por nivel de Particularismo y \% Total, 2008-2009

\begin{tabular}{|c|c|c|c|}
\hline $\begin{array}{c}\text { NIVEL INCLUSIÓN } \\
\text { BENEFICIARIOS }\end{array}$ & GENERAL & CORPORATIVA & INDIVIDUAL \\
Provincia 1 & 0,1 & 18,2 & 81,6 \\
Provincia 2 & 1,7 & 10,6 & 87,6 \\
Provincia 3 & 4,6 & 10,8 & 84,6 \\
\hline (N= 2.016facturas & $\mathbf{1 , 7 3 \%}$ & $\mathbf{1 3 , 9 \%}$ & $\mathbf{8 4 , 2 \%}$ \\
\hline
\end{tabular}

Fuente: Elaboración propia.

Los datos agregados tras clasificar el nivel de inclusividad de las regalías de los diputados dominicanos en 2008 y 2009, arrojan un balance en el que predomina el ejercicio de la representación particularizada y prebendalista, ya que la mayoría de las concesiones representan intereses individuales $(84,2 \%)$, frente al $1,73 \%$ destinadas al disfrute de la comunidad. Las solicitudes que presentan los electores permiten además otro tipo de análisis de naturaleza cualitativa en el que advertir las relaciones de reciprocidad que se engendran en el círculo particularizado de la confianza partidista. Como muestran algunas de las cartas que a modo de ejemplo se reproducen a continuación, además de la lealtad partidista (carta 1, 4), los clientes muestran en la negociación su poder de movilización proselitista (carta 2) y el beneficio mutuo de la transacción (carta 3), rasgos estos dos últimos de la menor verticalidad de las relaciones en el clientelismo moderno. 
Tabla 1.2.B.6. Ejemplos Solicitudes Barrilito 2008-2009

CARTA 1

$$
\text { Provincia 3- }
$$

PRSC

16-Marzo-2008

Estimada Compatriota Diputada X

Cortésmente me dirijo a usted para pedirle una contribución y es que me hice el examen de la vista y necesito cambiar los lentes y no tengo dinero para ir a buscarlas, por lo que le pido me ayude con lo que pueda.

Pues me siento un poco mal ya que sin esos lentes no puedo ni caminar y si usted no me ayuda no podré caminar el día de las elecciones para ir a depositar ese voto "colorao" que tanto ansiamos echarle en la urna y que Dios nos ayude a quitarnos esas garras "blancas" de encima.

Son mis deseos para con usted, mi partido y la patria.

La saluda su compatriota $X$

\section{CARTA 3}

Provincia 1-PRD

21-Мayo-2009

Distinguida Diputada:

Sirva la presente para saludar y a la vez. felicitarla por el trabajo que ha venido haciendo por nuestra comunidad, esperamos que siga legislando por muchos años para que siga siendo la voz de los que no tienen voz en la Cámara de Diputados.

El móvil de esta carta es para solicitarle la colaboración en una paca de ropa (cargamento de ropa) para utilizarla en su nombre y al nombre de su fundación, para así yo también crecer políticamente ya que estoy aspirando a la presidencia de la juventud de la Zona J2.

Sin ningún otro particular se despide de usted, $X$.
CARTA 2

Provincia 3-

PRSC

18-Agosto-2008

Distinguida Compañera:

Reciba un cordial saludo con la esperanza de que todo marche bien para usted y su familia. Al momento de saludarle paso a informarle que he recibido una invitación de la UASD para participar en el seminario «Diseño Estratégico de Campañas Electorales Locales» del 28-29 Agosto.

El evento citado es sumamente atractivo de cara a la cercanía de las elecciones de medio término y a la convención de nuestro partido para seleccionar los candidatos al Congreso y los Ayuntamientos, es por eso que le extiendo una invitación para que asista. De nuestra parte, estoy asumiendo los costos de matriculación y de su parte correría la estadía y su presencia en esta importante experiencia.

Para quien suscribe sería un grato placer compartir con usted el conocimiento de las modernas herramientas del marketing político y solo espero su confirmación para proceder a efectuar el pago.

En espera de su confirmación le saluda con aprecio,

CARTA 4 Provincia 3PRSC

3-Junio-2009

Pláceme saludarle y a la vez felicitarle por tan valioso e importante paso que usted ha dado, por lo que la recibimos con sentimiento de trabajo.

Como usted sabe, esta esquela que le escribo es para recordarle que usted me prometió un inversor (generador eléctrico domestico), en el periodo pasado cuando logramos que usted fuera seleccionada por nosotros para Diputada de nuestra provincia el cual nos sentimos agradecidos por su actitud de trabajo y entrega.

Esta solicitud y recordación se la hacemos pues como usted sabe la energía eléctrica no nos permite trabajar y este inversor me ayudaría bastante en mi trabajo. La capacidad del inversor es de 2.5 baterías. En espera que su ayuda pueda llegar, pues con este equipo puedo seguir trabajando.

Muchas gracias. 
Los indicadores seleccionados para medir el particularismo legislativo a través de la actividad propositiva nacional y la actividad concesional distrital de los diputados dominicanos aportan información valiosa acerca de la naturaleza estratégica e instrumentalista de este modo de representación política en democracia:

1) Permiten identificar el objeto del intercambio de la relación particularizada tanto en los «clientes ricos pero pobres en votos» como en los «clientes pobres pero ricos en votos» (Kirschelt 2000). Mientras que el Indicador 2 muestra el canal particularizado de atención a estos últimos a través de bienes divisibles como alimentos o medicinas, el Indicador 1 es el canal institucional para los clientes ricos que solicitan exenciones a la importación, subvenciones comerciales o nuevas divisiones territoriales que conlleven asignación presupuestaria.

2) Evidencian que la relación entre patrón y cliente es constante. En todo sistema clientelar, las elecciones constituyen el momentum por excelencia en que este tipo de intercambio se hace más visible, pero no el único. La cercanía de la cita con las urnas visibiliza el efecto movilizador del clientelismo, pero los vínculos se mantienen en periodos no electorales en una interacción continua y donde las expectativas de reciprocidad forman parte de este mandato particularizado de representación entre principal-agente.

3) Muestran que en la liza legislativa se engendran vínculos particularizados de intercambio que activan el mandato de "apoyar al que me ayudó", asociado a la relación cooperativa entre diputado-elector. Mientras que el mandato entre principal-agente sigue un iter institucional que termina en un ejercicio de derechos y deberes (Indicador 1), el favor entre diputado-elector sigue un iter particular de decisión que finaliza en un acto de donación (Indicador 2). Sin embargo, como evidencian los datos de esta investigación, en el primero predominan las proposiciones de ley con un fin particularista y en el segundo, bajo la forma de donación también se asignan bienes que pueden ser disfrutados por toda la comunidad. 


\subsection{C) Las variables independientes:}

Con el objetivo de dar cuenta de aquellas variables que podrían explicar la persistencia del particularismo en la República Dominicana, se explora la incidencia de factores institucionales y partidistas [proceso de state builing; sistema electoral; clase política; competencia y cooperación interpartidista; conflicto partidario] y de aquellos otros de índole sociológica [nivel micro y macro de la cultura política] que boicotean la vocación universalista del ejercicio de la representación (oferta) y que predisponen a la ciudadanía a la competición clientelar limitando la cooperación colectiva (demanda). Esta estructura de incentivos selectivos que enfrentan los protagonistas se analiza desde el prisma de la intencionalidad y racionalidad (Arrow 1951; Elster 1986; Luce y Raiffa 1957), para evidenciar que impera la lógica de corto plazo de los actores individuales.

La explicación de particularismo procede del nexo causal que aportan los tres enfoques teóricos comprendidos en el marco teórico instrumentalista expuesto en la primera parte de este capítulo:

$\checkmark$ «History matter»: Las prácticas particularistas y universalistas son consecuencia de las diversas vías históricas a través de las que se dibujan las fronteras organizacionales (Papakostas 2001). El neoinstitucionalismo histórico (Thelen y Steinmo 1992) permite recuperar el papel de la formación del Estado -en interacción con patrones de movilización social y política- como factores clave de la presencia o ausencia de vínculos particularistas bajo condiciones democráticas. El timing de la extensión del sufragio universal en relación a la formación de un cuerpo de servidores civiles afecta al tipo de estrategia que los políticos adoptan para vincularse con su electorado (Shefter 1994).

$\checkmark$ «Institutions matter»: El diseño institucional afecta a la naturaleza de la representación (Shugart y Carey 1992), la responsabilidad electoral (Mainwaring y Torcal 2005) y a la calidad de la democracia (Zovatto 2010). En esquemas de hiperpresidencialismo -formal o informal- hay una suerte de división de tareas en las que el Ejecutivo asume la elaboración de políticas públicas nacionales mientras que los legisladores cultivan sus vínculos con grupos particulares a través de lazos clientelares (Kiewiet y McCubbins 1991). Determinadas instituciones electorales estrechan el vínculo condicionando la labor de los legisladores en una búsqueda de votos personales en la que los intereses de su circunscripción se anteponen a los intereses nacionales (Carey y Shugart 1995). El acercamiento a la cultura política como institución informal de nivel intermedio (Putnam 1993 ) permite identificar la mayor o menor predisposición de la ciudadanía dominicana a aceptar la política particularista como estrategia de movilización y representación. Las percepciones y actitudes de la ciudadanía configuran las expectativas de los actores. En contextos de ausencia de "cierre horizontal" en las redes sociales (Maiz 2005:10) y confianza particularizada, cooperar resulta difícil y la lógica individual impera (Fiorina y Noll 1978; Gambetta 1988; Shefner 2001).

$\checkmark$ «Politicians matter too»: Este enfoque retoma el papel decisivo e independiente de los actores políticos en la elección de estrategias -particularista o de alcance universal- para la articulación de vínculos y por tanto, en la creación de electorados para el patronazgo o para la autonomía burocrática (Warner 2001). El paso de un modo racional de relación directa (gratificación inmediata, divisible e individualizada) a uno indirecto redistributivo (los costes se reparten entre las categorías abstractas de votantes) depende de las opciones estratégicas que enfrentan los políticos (Kitschelt 2007). La concepción del particularismo como estrategia elegida racionalmente implica que los políticos están constreñidos por las instituciones pero también son capaces de sortearlas y manipularlas (Piattoni 2001:29; Maiz 2005). Como señalara Dowding (1991), el poder social de político facilitador- 
conseguidor, es un poder de manipulación, que cuenta entre sus opciones la de alterar la estructura de incentivos que enfrentan los actores para que la política particularista de racionalidad individual sea la más atractiva y la de menor coste en el corto plazo.

Esta investigación sobre el caso dominicano se aborda desde la triple dinámica relacional en que se desenvuelve el comportamiento estratégico de los actores.

La primera relación, la del Estado con los Partidos, analiza el fenómeno desde de la oferta siguiendo la lógica explicativa de Shefter (1994). La segunda de las relaciones que contempla la interacción Partido-Partido, explica el particularismo desde el poder de decisión apuntado por Kistchelt (2007) y el poder de la manipulación de las elites políticas defendido por Dowding (1991) y Piatonni (2001). La última de las relaciones, la del Estado con los ciudadanos, aborda los condicionantes explicativos del lado de la demanda desde la óptica de las oportunidades y condicionantes históricos defendida por Papakostas (2001). De esta manera, el acercamiento al fenómeno del particularismo en esta tesis doctoral tiene una pretensión ecléctica que persigue mostrar cómo dialogan oferta y demanda, y superar así las limitantes de los primeros enfoques que sobredimensionaban la demanda o de aquellos que sobre estiman el efecto estructural e individual de los actores en la oferta.

\section{Gráfico 1.2.C.1 Relaciones que condicionan la mayor o menor prevalencia del particularismo}

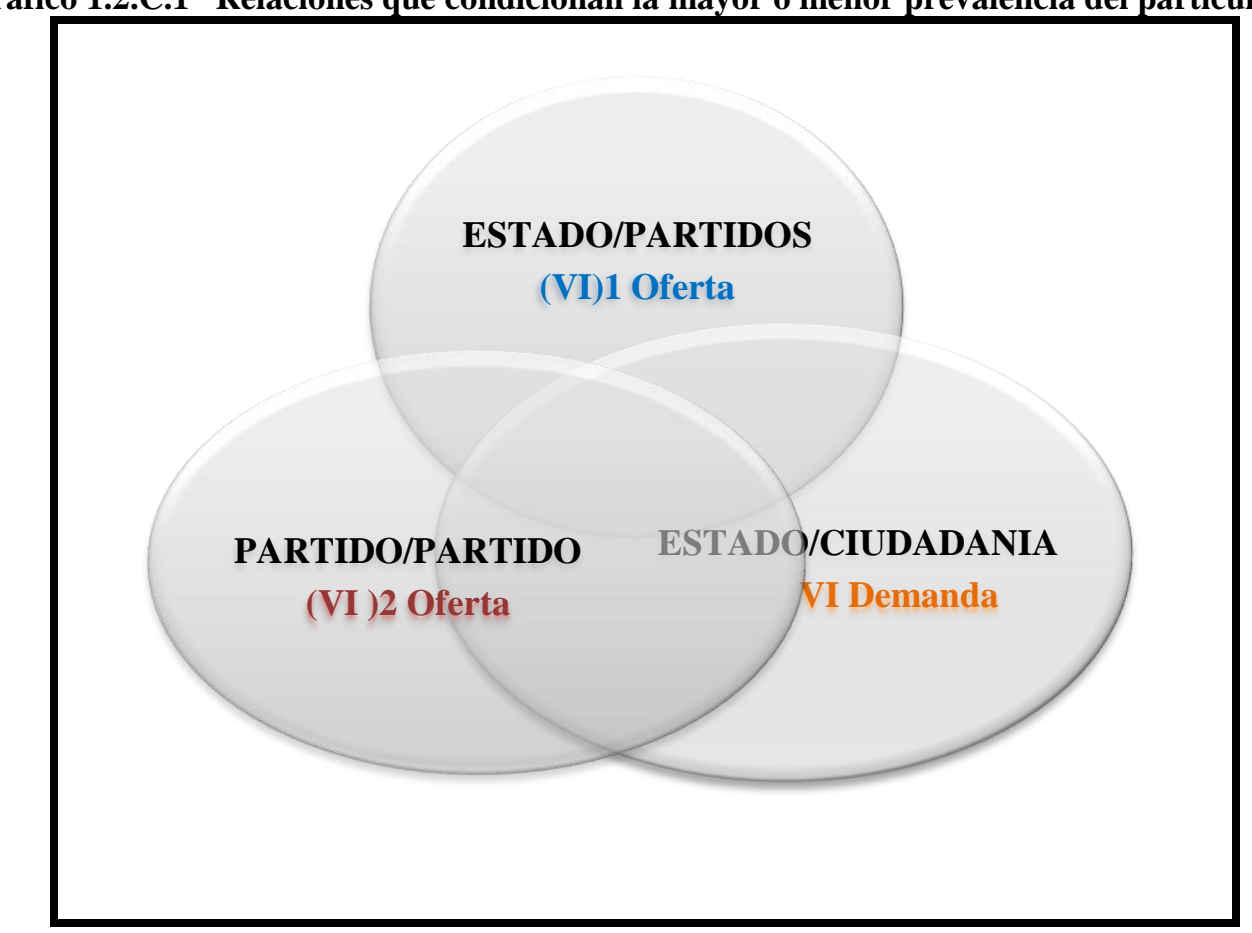

Fuente: Elaboración propia a partir de conceptos de Shefter (1994), Kitschelt (2007), Piatonni (2001), Dowding (1991) y Papakostas (2001). 
El marco teórico expuesto sustenta las siguientes hipótesis $(\mathrm{H})$ de partida en cada uno de los objetivos específicos de investigación $(\mathrm{OE})$ anteriormente descritos:

OE2: Conocer la incidencia de los factores que determinan la política particularista desde la Oferta.

H2.1: Relaciones Estado-Partidos:

$\checkmark$ La ausencia de profesionalización del servicio civil dominicano previa a la extensión del sufragio universal y el carácter de partido "internamente movilizado" de la fuerza política que dominó las coyunturas post transicionales, fueron experiencias críticas que determinaron la preferencia por el patronazgo de los partidos políticos dominicanos.

$\checkmark$ La combinación de voto preferencial y circunscripciones pequeñas particularizan el vínculo entre políticos y electores debilitando el intercambio indirecto mediado por programas y promueve el individualismo legislativo. El 50+1 requerido para evitar la segunda vuelta estimula las alianzas y el intercambio clientelar entre partidos a cambio del apoyo.

$\checkmark$ La búsqueda del bien común en las instituciones de la República Dominicana está en manos de patronos privados con funciones públicas. La compatibilidad de las funciones de representación legislativa con actividades empresariales genera un escenario en el que pueden surgir conflictos de intereses entre el fin primario institucional y el secundario corporativo que comprometa la universalidad e integridad del mandato.

H2.2: Relaciones Partido-Partido:

$\checkmark$ En la República Dominicana no se dieron los condicionantes estructurales de largo plazo para el establecimiento de un sistema de partidos programáticamente estructurado (SPPE) y los actores no aprovecharon los condicionantes favorables de corto plazo para implementar políticas redistributivas y limitar el particularismo.

$\checkmark$ La competición en el sistema de partidos dominicano se entabla en condiciones de oligopolio por lo que no hay incentivos para asumir el coste de la institucionalización programática. Al igual que sucede en mercados y empresas oligopólicas, los partidos dominicanos con opciones de poder son partidos oligopólicos responsables de la baja calidad de la democracia, con servicios públicos caros e ineficientes y que impiden la entrada a nuevos partidos, a quienes permiten solo el disfrute limitado del botín estatal.

$\checkmark$ La debilidad del vínculo programático fuerza la competencia interpartidista en torno a la capacidad de los actores de otorgar bienes («particularistic valence competition»).

$\checkmark$ Las estrategias de cartelización informal han dado continuidad al sistema de partidos dominicano y los nuevos actores han adaptado el vínculo al escenario de la consolidación, de tal manera que el clientelismo se hace resistente a través de la adaptabilidad. 
$\checkmark \quad$ Las relaciones de cooperación entre partidos tienen una naturaleza particularista. El reparto de las instituciones del Estado prima frente a la definición de una agenda de Estado en los asuntos clave o políticas públicas consensuadas entre aliados de gobierno.

$\checkmark$ Las facciones son la maquinaria informal que acompaña a los jefes políticos dominicanos que avivan el particularismo ya que afectan a la socialización de las elites, dificultan la agregación de intereses colectivos en el seno del partido, acentúan el personalismo en el trabajo parlamentario (diputados) y en el ejercicio de las funciones institucionales (servidores públicos).

OE3: Conocer la incidencia de los factores que determinan la política particularista desde la Demanda

H3.1. Relaciones Estado-Ciudadanía:

$\checkmark$ Los obstáculos a la acción colectiva en la República Dominicana derivan del carácter mutualista de las organizaciones sociales y sindicales, su dependencia de la subvención estatal y la atomización del interés de clase.

$\checkmark$ El peso socializante del pasado impregna de carácter autoritario, sentimental y personalista la relación con el líder, mientras que la coparticipación civil y política contamina la relación haciéndola porosa a las particularidades del círculo de confianza, bien por amistad, bien por preferencia partidista. 


\subsection{RECAPITULACIÓN DISEÑO DE INVESTIGACIÓN E INDICADORES DE MEDICIÓN PARA EL CASO DOMINICANO}

\section{Variable Dependiente}

\section{POLÍTICA PARTICULARISTA}

DEFINICIÓN

(Piattoni 2001)

(Kitschelt 2000)

\section{TIPOLOGÍA}

(Corzo 2002)

\section{Estrategia política}

Modo de accountability

\section{clientelismo electoral}

\section{clientelismo de partido}

\section{oficial}

clientelismo

(Benito 2014)
"Estrategia para la conquista, mantenimiento y engrandecimiento del poder político por parte de los patronos y estrategia para la protección y promoción de sus intereses por parte de los clientes. Su despliegue está determinado por una serie de incentivos y desincentivos. La difusión de la política particularista está asociada pero no determinada por la emergencia, transformación y declive de una serie de combinaciones de circunstancias institucionales e históricas que hacen que estas estrategias sean más o menos viables políticamente y más o menos aceptables socialmente.

Como estrategia política, [la política particularista] tiene la capacidad para adaptarse a las circunstancias existentes así como alterarlas. Aunque la mayor o menor probabilidad de su existencia depende del set de circunstancias - concebidas como costes e incentivos-, a partir de las cuales los patrones y los clientes valoran sus opciones y dedicen, su adopción en última instancia es siempre una cuestión de elección" (Piattoni 2001:2)

Mecanismo de vinculación entre principal y agente en democracia caracterizado por un intercambio directo, contingente, predecible y supervisado.

En la distribución de recursos se distinguen en el principal dos tipos de clientes: "clientes ricos pero pobres en votos" y "clientes pobres pero ricos en votos". De los primeros el agente recauda recursos privados para beneficiar a los segundos. A cambio aquellos reciben contratos públicos, exenciones, regulaciones normativas o juicios legales favorables, entre otros bienes y favores. (Kitschelt 2000; Kitcchelt y Wilkinson 2007)

\begin{tabular}{|c|c|}
\hline definición & momentum \\
\hline Beneficios selectivos a cambio & Elecciones \\
de votos & Representativas \\
\hline & Elecciones \\
\hline Influencia partidista a cambio & Internas y \\
de apoyo político & Elecciones \\
& Representativas \\
\hline
\end{tabular}

Recursos públicos a cambio de apoyo oficial a) particularismo ejecutivo $\checkmark \quad$ Programas focalizados

b) particularismo burocrático $\checkmark \quad$ Puestos en la Administración Pública

Relación constante

Gasto en "Asistencia Social" y "Seguridad Social" del Gobierno Central en Presupuestos Ejecutados 2006-2011

Empleados Incorporados al Sistema de Administración de Servicios Públicos del Programa «Solidaridad» 2010-2012 y del Despacho de la Primera Dama 2011-2012

c) particularismo legislativo $\checkmark$ Derechos selectivos y favores personales
Proposiciones de Ley Diputados aprobadas a trámite parlamentario 1 1998-2010

$$
(N=1,863 \text { proposiciones })
$$

Fondo de Gestión Legislativa o 2 "Barrilito" 2008-2009 ( $N=2,016$ facturas $)$ 


\section{Variables Independientes OFERTA}

\begin{tabular}{|c|c|c|}
\hline \multicolumn{3}{|c|}{ I. RELACIONES ESTADO - PAR' } \\
\hline dimensiones & preguntas de investigación & indicadores \\
\hline $\begin{array}{c}\text { A) } \\
\text { EL PASADO DEL } \\
\text { ESCENARIO } \\
\text { INSTITUCIONAL }\end{array}$ & $\begin{array}{l}\text { ¿La formación del Estado } \\
\text { precede a la creación de } \\
\text { las instituciones } \\
\text { democráticas o al revés? }\end{array}$ & $\begin{array}{l}\text { 1-Proceso de creación del } \\
\text { Estado Nación Dominicano } \\
\text { 2-Nivel de profesionalización } \\
\text { del servicio civil de carrera de la } \\
\text { Administración Pública } \\
\text { dominicana. }\end{array}$ \\
\hline $\begin{array}{c}\text { B) } \\
\text { LAS REGLAS } \\
\text { DEL JUEGO }\end{array}$ & $\begin{array}{c}\text { ¿Qué características del } \\
\text { diseño electoral } \\
\text { dominicano favorecen el } \\
\text { particularismo en la } \\
\text { representación y } \\
\text { movilización de intereses? }\end{array}$ & 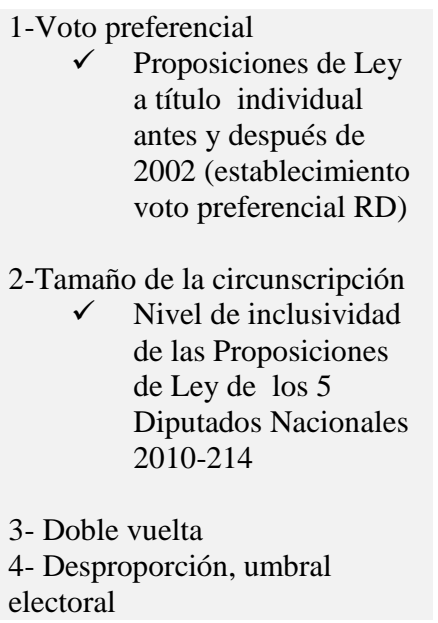 \\
\hline $\begin{array}{l}\text { C) } \\
\text { LA CLASE } \\
\text { POLÍTICA }\end{array}$ & $\begin{array}{c}\text { ¿Quiénes son los políticos? } \\
\text { ¿Son los políticos } \\
\text { dominicanos «guardianes } \\
\text { idóneos de la cosa } \\
\text { pública»? }\end{array}$ & $\begin{array}{l}\text { 1-Vínculos empresariales y } \\
\text { familiares de los líderes } \\
\text { dominicanos } \\
\qquad \quad \begin{array}{l}\text { Diputados que ocupan } \\
\text { la presidencia de } \\
\text { asociaciones } \\
\text { empresariales 2010- } \\
\text { 2016 }\end{array} \\
\text { 2- Índice de Expertise } \\
\text { Institucional diputados } \\
\text { dominicanos }\end{array}$ \\
\hline
\end{tabular}

relación causal

«History matter»

En proceso de state-building se gesta el grado de distinción organizativa entre el espacio de la política y el Estado. La dominación partidista de la burocracia favorece la preferencia sesgada en el tratamiento administrativo y la representación particularista de intereses

(Papakostas 2001).

Los partidos fundados por élites que ocupaban posiciones en el régimen anterior ("Internally mobilized parties") tienden a estar orientados al patronazgo. Cuanto más turbulenta sea la transición a la política de masas, mayor será la probabilidad de usar el clientelismo (Piatonni 2001).

\section{«Institutions matter»:}

El voto preferencial y el menor tamaño de las circunscripciones debilitan el intercambio indirecto mediado por programas. Búsqueda de votos personales, los intereses de la

circunscripción se anteponen a los intereses nacionales (Carey y Shugart 1995, Ames 1995). El ballotage, favorece el intercambio particularizado entre élites y partidos en pago por el apoyo de los aliados.

\section{«Politicians matter too»:}

Las cualidades y características de los políticos pueden afectar a su voluntad de implementar reformas orientadas al desarrollo democrático (Gerring, Keefer, Morrison y Oncel 2012).

La falta de exclusividad en el ejercicio político favorece el particularismo de las élites en las instituciones (Krehbiel 2004;Acemoglu y Robinson 2006), 


\section{Variables Independientes OFERTA}

\section{RELACIONES PARTIDO - PARTIDO}

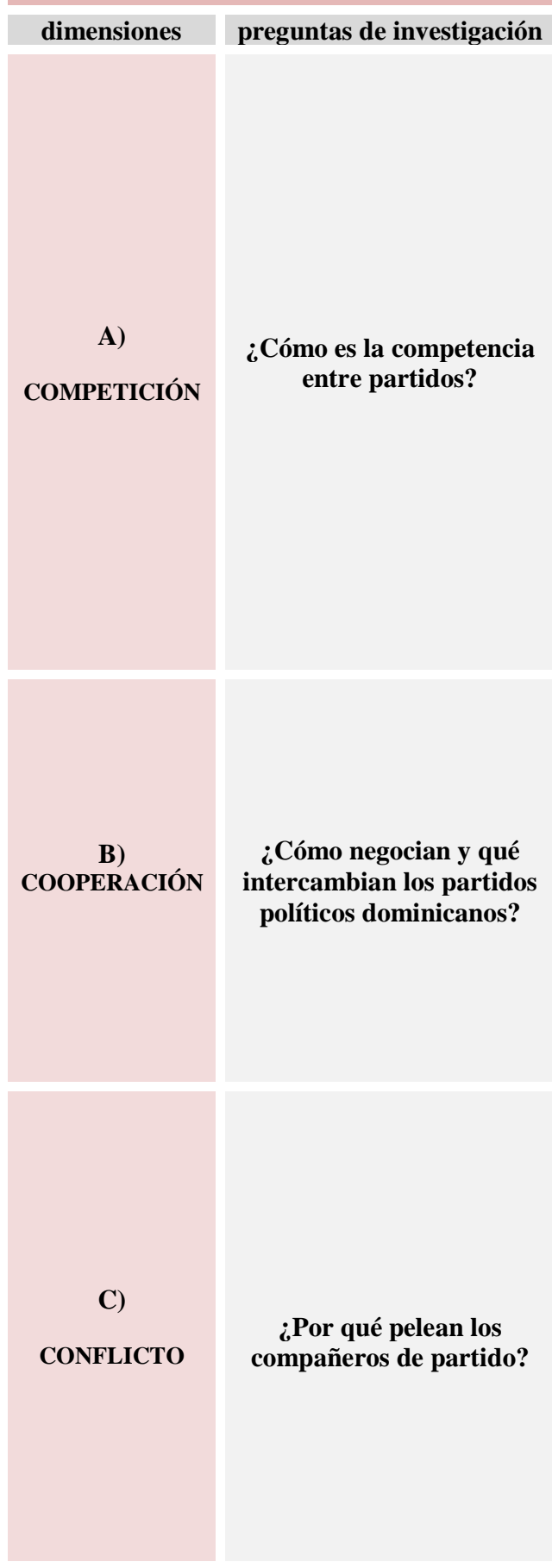

indicadores

1- Índice Estructuración

Programática del sistema de

Partidos (Kitschelt, Hawkins,

Rosas, Zechmeister 2020)

$\checkmark$ Dimensionalidad espacio ideológico

$\checkmark \quad$ Semánticas izquierdaderecha

$\checkmark$ Cohesión ideológica

$\checkmark$ Representación sobre issues

2- Institucionalización informal. Sistema partidos cartel informal

1-Número y objeto del historial de Pactos, Alianzas Electorales y Transfuguismo en el país 1978-2010

1-Tipificación motivación e interacción de salidas, voces y lealtades en los partidos dominicanos

2-Judicialización de la selección de candidatos

3-Sectarismo en la formación y en la socialización política

4-Particularismo legislativo vs iniciativas de la bancada relación causal

«Politicians matter too»:

Los políticos tienen un rol independiente en la creación de electorados para el patronazgo (Warner 2001, Piattoni 2001).

[Decisión de elección social]: Cuanto menor sea la presencia de vínculos programáticos e ideológicos y mayor la competitividad, mayor será la probabilidad de que se oferten beneficios particularizados (Kitschelt 2007).

[Decisión de acción colectiva]: La institucionalización condiciona la consolidación democrática, legitimidad y eficacia de las políticas (Mainwaring y Torcal 2005; Katz y Mair 2004). Cuando la participación está mediatizada por brókeres locales, gana el que cuenta con la mayor maquinaria política no el candidato ideológico (Hopkin 2002).

Cuanto menor sea la polarización y mayor la volatilidad y competitividad, mayor será la probabilidad y éxito de las alianzas (Reynoso 2011). Los conflictos de intereses se resuelven con distribución de cargos entre aliados (Strom y

Mueller 2000). La ausencia de carrera administrativa y la debilidad programática condicionan que las agendas consensuadas entre aliados sean sustituidas por el canje de puestos en

las agencias del Estado y otros incentivos relacionados con la supervivencia personal.

Las facciones por interés (Sartori 1980) o las client group factions (Beller y Belloni 1978) potencian la lealtad personal frente a la partidaria. Dificultan la agregación de intereses colectivos y genera un sistema particularizado de lealtades y recompensas para fidelizar el apoyo.

Son obstáculo en reformas pro profesionalización de la carrera civil, ya que el control del patronazgo se traslada al partido (Geddes 1991). Las dinámicas competitivas y degenerativas entre facciones promueven la rentabilidad sectarista particularizada (Boucek 2009). 


\section{Variables Independientes DEMANDA}

\begin{tabular}{|c|c|c|c|}
\hline \multicolumn{4}{|c|}{ III. RELACIONES ESTADO - CIUDADANÍA } \\
\hline dimensiones & preguntas de investigación & indicadores & relación causal \\
\hline $\begin{array}{c}\text { A) } \\
\text { NIVEL } \\
\text { MACRO } \\
\text { CULTURA } \\
\text { POLÍTICA }\end{array}$ & $\begin{array}{l}\text { ¿Cómo fue la ubicación de } \\
\text { la clase dominante y los } \\
\text { sectores populares en la } \\
\text { vida política y social } \\
\text { dominicana? }\end{array}$ & $\begin{array}{ll}\text { 3-Atomización de los intereses } \\
\text { de clase: } \\
\checkmark & \begin{array}{l}\text { Clasificación } \\
\text { sindicatos según tipo } \\
\text { de concertación que }\end{array} \\
& \begin{array}{l}\text { generan (1956-2010): } \\
\text { social, corporativa o } \\
\text { particularizada }\end{array} \\
& \\
\text { 4-Legitimidad y poder de } \\
\text { negociación de los actores } \\
\text { laborales: } \\
\checkmark & \begin{array}{l}\text { Pactos colectivos } \\
\text { registrados } 1997-2011\end{array}\end{array}$ & $\begin{array}{l}\text { Las secuencias del desarrollo sociopolítico } \\
\text { determinan la cultura organizacional de un país } \\
\text { y condicionan el tipo de relación -fronteriza o } \\
\text { interconectada- entre organizaciones sociales y } \\
\text { políticas (Papakostas 2001): } \\
\checkmark \quad \text { Relaciones Estado-clases populares: } \\
\text { integradora/horizontal versus incorporación/vertical } \\
\text { (paternalismo, plebiscitaria) } \\
\checkmark \quad \text { Relaciones Estado-clases dominantes: } \\
\text { aislamiento versus penetración social (influencia de } \\
\text { los grupos de interés, grupos familiares y } \\
\text { empresariales) } \\
\text { La incorporación vertical de los ciudadanos y la } \\
\text { penetración de los intereses económicos son } \\
\text { relaciones interconectadas entre Estado y } \\
\text { sociedad que favorecen la representación } \\
\text { particularista de intereses. } \\
\text { La atomización de los intereses de clase y del } \\
\text { activismo civil genera múltiples agentes de la } \\
\text { acción corporativa. No hay acción colectiva ni } \\
\text { concertación social, sino una de carácter sectorial } \\
\text { o corporativa. Como resultado, no existe } \\
\text { cooperación sino competición entre clientes } \\
\text { (Maiz 2005; Coleman 1990). }\end{array}$ \\
\hline $\begin{array}{c}\text { B) } \\
\text { NIVEL } \\
\text { MICRO } \\
\text { CULTURA } \\
\text { POLÍTICA }\end{array}$ & $\begin{array}{l}\text { ¿Qué elementos de la } \\
\text { cultura política inciden en } \\
\text { la mayor predisposición } \\
\text { de los dominicanos a } \\
\text { aceptar la política } \\
\text { particularista como } \\
\text { estrategia viable de } \\
\text { movilización y } \\
\text { representación? }\end{array}$ & 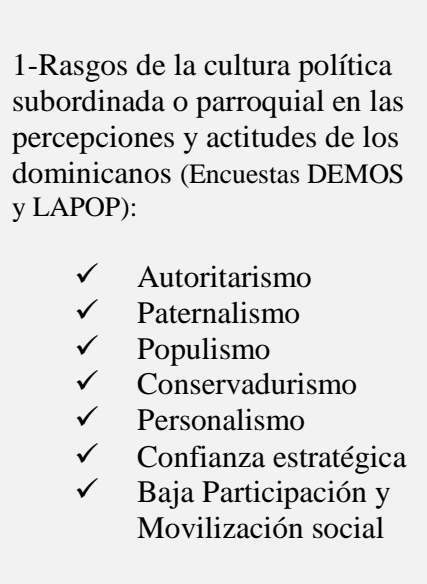 & $\begin{array}{l}\text { La presencia de capital social permite explicar las } \\
\text { diferentes formas de funcionamiento de las } \\
\text { instituciones (Putnam 1993). En estructuras } \\
\text { sociales verticales basadas en relaciones } \\
\text { autoritarias y niveles de confianza bajos, la } \\
\text { capacidad ciudadana para la acción colectiva y el } \\
\text { control del Estado también es baja. } \\
\text { En las nuevas democracias, el peso socializante del } \\
\text { pasado incide negativamente en la valoración de } \\
\text { las instituciones de la representación y la } \\
\text { desafección deriva en una ciudadanía menos } \\
\text { participativa (Torcal y Montero 2006). Esto } \\
\text { incide en la efectividad, entendida como el nivel } \\
\text { de inclusión de los resultados democráticos (+/- } \\
\text { particularismo). }\end{array}$ \\
\hline
\end{tabular}




\section{CAPÍTULO 2}

\section{DIAGNÓSTICO Y MEDICIÓN DE LA POLÍTICA PARTICULARISTA EN LA REPÚBLICA DOMINICANA}

\subsection{INTRODUCCIÓN}

El objetivo de este capítulo es mostrar una fotografía empírica de la política particularista en la República Dominicana en la etapa de la consolidación democrática. Para ello, se identifican los cambios y continuidades que permitan inferir si el particularismo es un fenómeno en auge o en decadencia en el país.

La aproximación empírica al fenómeno del particularismo en política ha estado tradicionalmente centrada en los intercambios que se producen meses antes de la cita con las urnas entre candidato y elector. En esta perspectiva reduccionista del clientelismo se califica de "compra de votos" la relación entre político y ciudadano, enfatizando equívocamente el carácter ilegal, esporádico y mercantil del vínculo (Banégas 2011; Cendales 2012). Las elecciones constituyen el momentum por excelencia en que estos intercambios se hacen más visibles, pero no el único. La cercanía de la cita con las urnas visibiliza el efecto movilizador del clientelismo, pero los vínculos se mantienen en periodos no electorales en una interacción continua, donde las expectativas de reciprocidad forman parte de este mandato particularizado de representación entre principal y agente.

En primer lugar se presenta el repertorio de la acción clientelar detallando cómo y qué intercambian los candidatos con los electores en tiempo de elecciones (Clientelismo Electoral) y los actores políticos entre sí en las contiendas internas y contiendas nacionales (Clientelismo de Partido). La medición empírica del particularismo se circunscribe al "Clientelismo Oficial", es decir, a los intercambios de recursos públicos realizados por el agente en su posición como autoridad (Ejecutivo), funcionario (Administración) o diputado (Legislativo) durante la vigencia de su mandado de designación o elección. A pesar de la distinción por razones analíticas, en la práctica estas categorías y actores suelen entrecruzarse. Tras conocer cuál es el grado de particularismo en la política social del Gobierno, en la conformación de la Administración Pública dominicana y en la actividad propositiva (nacional) y concesional (distrital) de los diputados dominicanos, se ubica al país en perspectiva comparada regional y mundial.

La especial atención a la acción clientelar en el legislativo se justifica en el propósito de contribuir a validar la perspectiva instrumentalista que afirma que el particularismo es un modo de accountability y que el intercambio entre principal-agente no es ilegal, no es esporádico sino constante y no es mercantil, sino que pertenece al universo de los modos posibles de representación política. Este foco de atención al legislativo es una de las aportaciones del trabajo al estudio del particularismo, ya que el acercamiento de la literatura al fenómeno clientelar se ha centrado en la distribución de bienes y servicios que realizan los representantes del gobierno central y/o municipal. El repaso a la actividad propositiva y distributiva de los diputados dominicanos (1998-2010) permite ponderar la dimensión del ejercicio particularizado y universal de la representación política y demostrar que la personalización y la selección, se imponen sobre la generalidad y la abstracción del mandato de representación. 
Como se relata en los apartados siguientes, en la etapa de la consolidación democrática (1996-2010) las legislaturas en las que el PRD cuenta con la mayoría de escaños la actividad propositiva de los diputados es más particularista. Por el contrario, en las legislaturas en las que el PLD domina el hemiciclo, disminuye significativamente la representación prebendalista. Sin embargo, esto no parece implicar un cambio de tendencia en el nivel de agregación de preferencias de la política dominicana, sino la predilección del PLD por el escenario Ejecutivo a la hora de realizar la asignación selectiva de bienes y concretamente, a través de programas de asistencia social focalizada.

\subsection{CLIENTELISMO ELECTORAL: BENEFICIOS SELECTIVOS A CAMBIO DE VOTOS}

El Clientelismo Electoral se caracteriza por el reparto de beneficios selectivos a cambio de votos en los meses previos a la cita con las urnas. Aunque la campaña electoral en la República Dominicana comienza oficialmente tres meses antes de la contienda (art. 87 Ley Electoral No.275), las actividades proselitistas se inician con medio año de antelación. Durante estos meses, los aspirantes a presidentes, vicepresidentes, diputados, senadores, alcaldes y regidores, intensifican su actividad prebendaría que incluye reparto de comida, materiales de construcción, operativos de salud, dinero o agua potable entre otros. El clientelismo como política del mejor postor promueve campañas poco informativas o centradas en la plataforma política y altamente persuasivas, basadas en las fortalezas del candidato o las circunstancias de la coyuntura. El habitual rechazo de los actores políticos dominicanos a realizar debates electorales entre candidatos revela la escasa atención al programa del candidato. Como se analiza en el apartado dedicado a la competencia interpartidaria de esta tesis, la campaña electoral se ha ido consolidando como un elemento decisivo en la motivación del voto, ocupando el protagonismo de otros referentes como la imagen del líder del partido o la ideología de épocas anteriores.

Foto 2.2.1 Reparto de comida y dinero en campaña electoral
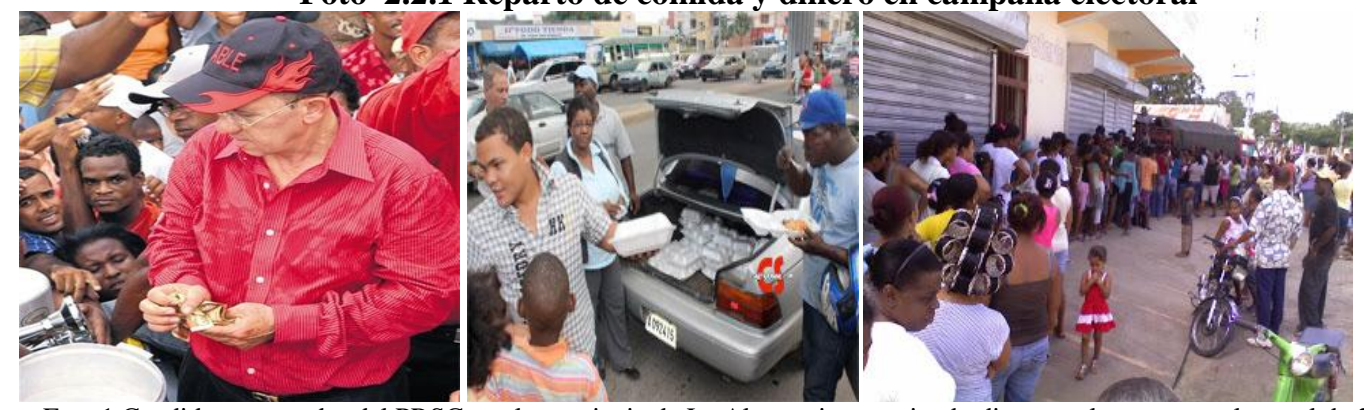

Fuente: Foto 1 Candidato a senador del PRSC por la provincia de La Altagracia repartiendo dinero en la campana electoral de 2010. Foto 2 Reparto de raciones de comida en acto de campaña del candidato presidencial del PRD en las elecciones de 2012 y Foto 3 Filas para el reparto de comida del candidato a alcalde del PLD en el municipio de Cevicos en las elecciones de 2010.

Durante la campaña son habituales la celebración de «bandereos» y «caravanas» ${ }^{4}$ en las que militantes y seguidores se reúnen alrededor de sus líderes y sirven para exhibir la fuerza y

\footnotetext{
${ }^{4}$ Los «bandereos» son reuniones de militantes y simpatizantes en cruces de calles y semáforos en donde exhiben las banderas del partido al ritmo de la música. El «caravaneo» es el recorrido en automóviles de los candidatos por los barrios al que siguen una corte de simpatizantes uniformados con los colores del partido en auto y a pie- formando una gran caravana. La mayoría de las veces son simples paseos musicales, ya que
} 
capacidad de atracción de los partidos ante la cercanía de la elección. Estas fiestas colectivas de pertenencia al círculo de confianza constituyen el arquetipo de "recurso expresivo" (Auyero 1997) intercambiado en la relación clientelar, a la vez que operan como canal de monitoreo y supervisión de la lealtad pública al candidato ${ }^{5}$.

Además de estas prebendas que se financian con recursos del propio del candidato y con la asignación que los partidos reciben en año electoral, es frecuente que los candidatos oficialistas de turno utilicen los recursos públicos a su disposición para distribuirlos con fines proselitistas. Durante el periodo de campaña de las elecciones legislativas de 2010, los partidos de la oposición denunciaron el uso de los recursos del Estado de los aspirantes oficialistas, tales como la instalación de las cocinas móviles del programa de Comedores Económicos, el reparto de electrodomésticos por parte de la Administración de Lotería tras el paso de la caravana política del PLD o el aumento de los beneficiarios del programa Solidaridad ${ }^{6}$. Una actividad a la que se unió el hijo del Presidente Fernández, quien donó equipo quirúrgico a hospitales como representante del Movimiento Juvenil No Partidista Pensamiento y Acción, pero acompañado en esta actividad por el senador peledeísta y la gobernadora de la provincia ${ }^{7}$. Las denuncias de la oposición llevaron a la JCE a decretar la suspensión de los planes sociales del gobierno como medida cautelar desde el día 14 al 17 de mayo $^{8}$, circunstancia que fue aprovechada por el partido oficialista que lanzó a los medios un nuevo eslogan: "El PRD no quiere que la gente pobre coma" (Benito 2013:419). Durante los dos meses previos a la cita con las urnas de mayo de 2010, el entonces Presidente Fernández inauguró 5 acueductos en San Francisco de Macorís, asfaltado de calles y remodelación del Arzobispado en Santiago y La Peña, entregó 440 apartamentos en Santo Domingo Oeste, escuelas en San Pedro de Macorís y Hato Mayor, puentes y carreteras en diversas provincias del país o "reinauguraciones" de hospitales como el De la Cruz en el municipio de Pedro Brand".

Lo mismo sucedió con ocasión de la campana electoral en las presidenciales de 2012. El Presidente Fernández se sumaba a la campaña en la que su esposa aspiraba a la vicepresidencia en una carrera de inauguraciones de carreteras, puentes y escuelas. El primer mandatario llegó a afirmar que "no le alcanzaba el tiempo para tantas inauguraciones y atender los asuntos del Palacio Nacional" 10. También se sumaron a la campaña los legisladores electos en 2010, que recorrieron el país para apoyar a sus respectivos líderes y dejaron en espera más de 200 iniciativas legislativas en el Congreso. Tampoco pidió licencia la Primera Dama y candidata vicepresidencial quien se defendía de las acusaciones de uso proselitista de su beneficencia alegando que no pediría licencia como esposa del Presidente ${ }^{11}$. El Programa de Comedores Económicos Móviles del Estado inició un tour por las provincias del país repartiendo alimentos y siguiendo la estela de la ruta de campaña oficialista. Este reparto de comida proporcionó al lobby avícola un beneficio que recibió en forma de cheque solo 5 días antes de las elecciones por un valor de $\$ 2.500 .000 \mathrm{USD}$, a pesar de ser ésta una deuda atrasada ${ }^{12}$.

no siempre hay discurso final del candidato. El partido sufraga los costes de gasolina a aquellos que hacen el recorrido con su moto o a pie.

${ }^{5}$ Para un análisis de este tipo de actividades Ver la Tesis Doctoral "The power of political parties. Political Participation, clientelism and remittances in the Dominican Republic" de Edward González Acosta (2009).

${ }^{6}$ Se repartieron 7.000 estufas de gas a nuevos beneficiarios del programa Solidaridad en las provincias de Dajabón, Elías Piña, Pedernales y Montecristi. En periódico Listín Diario de 14 de febrero de 2010.

${ }^{7}$ Ver periódico Listín Diario de 10 de marzo de 2010.

${ }^{8}$ Resolución 02-2010 JCE

${ }^{9}$ Ver noticias relacionadas en periódico Listín Diario de 10, $24-25,30$ y 31 de marzo y 23 de abril.

${ }^{10}$ En Periódico El Caribe de 27 de Abril de 2012.

${ }^{11}$ Ver noticia en periódico digital La voz de la nación, del 20 de enero de 2012.

${ }^{12}$ Ver noticia en periódico Diario Libre, del 16 de mayo de 2012. 
Esta intensa actividad presidencial no pasó inadvertida a la Misión de Observación electoral de la OEA. El Jefe de Misión Tabaré Vázquez adelantaba que una de las observaciones del Informe sería la recomendación al Presidente electo de no involucrarse en procesos electorales futuros (MOE 2012:3). Los partidos aliados al PLD también colaboraron en la campaña ofertando los recursos públicos adjudicados en la reparto de las legislativas del 2010. Mientras el Partido de Unidad Nacional (PUN) usaba el Instituto de Desarrollo y Crédito Cooperativo (IDECOOP) como sede de campaña, el Partido Quisqueyano Demócrata Cristiano (PQDC) al frente de la Administración General de Bienes Nacionales prometía a los parceleros un mes antes de las elecciones el certificado de propiedad de las tierras ocupadas. En el exterior, el personal consular de las Embajadas se ponía al frente de la movilización de los dominicanos residentes en Europa y Estados Unidos, un numeroso colectivo que constituye el 5,05\% del electorado y que por primera vez elegía a sus diputados de ultramar. Nueve días antes de la cita con las urnas, PRD, PLD, PUN y PQDC recibieron una tímida amonestación por parte de la JCE por el uso de los recursos públicos en campaña (Benito y Toribio 2013:292).

En las legislativas y municipales de 2010, el Proyecto "Observatorio de Comportamiento Político y Opinión Pública de la República Dominicana" (OBSEROP) de la AECID-PUND, indagaba acerca de la naturaleza de los bienes entregados y estrategias de movilización utilizadas con ocasión de la campaña electoral. Como muestra la Tabla 2.2.1 el transporte de votantes lideraba con un 65\% la frecuencia de este tipo de actividades. Le seguían en porcentaje el reparto de regalos con un 49,7\% de entrevistados que afirmaron haber visto en su vecindario este tipo de acciones. Desde las tradicionales "fundas" o bolsas de comida, juguetes, canastillas para embarazadas o útiles escolares con la cara del candidato a electrodomésticos y dinero en efectivo. El reparto de regalos es sufragado con los recursos propios del aspirante a legislador, síndico o regidor, mientras que los diputados y senadores que persiguen la reelección disponen además del Fondo de Gestión Social o "barrilito".

Tabla 2.2.1 Vio a algún partido/candidato realizar estas actividades en su vecindario, 2010

\begin{tabular}{|l|c|c|c|c|}
\hline & SI & NO & NS/NC & N \\
\hline Reparto de regalos & 49,7 & 42,7 & 7,6 & 1207 \\
Favores personales & 29,9 & 42,3 & 27,8 & 1207 \\
Transporte de votantes & $\mathbf{6 5 , 0}$ & 19,7 & 15,3 & 1207 \\
Compraventa de cédulas & 27,0 & 44,4 & 28,7 & 1207 \\
\hline
\end{tabular}

Fuente: Torcal (2010). Primera Encuesta de Opinión Pública y Comportamiento Político en la República Dominicana (OBSEROP)

En cuanto a los favores personales, un 29,9\% de los entrevistados afirmó haber sido testigo de este tipo de intermediación entre candidato y elector. Bajo esta categoría se encontrarían las promesas de acceso a determinados bienes públicos en los que el candidato ejerce de intermediario bróker en asuntos tales como la concesión de una beca de estudios o un puesto de trabajo. Mientras que el reparto de regalos, el transporte de votantes y la compraventa de cédulas forman parte del inventario de recursos a distribuir entre clientes de los niveles inferiores de renta, en la categoría de "favores personales" se encuentran también aquellas transacciones en las que el político ejerce de intermediario con clientes de los estratos socioeconómicos superiores. En este caso, la naturaleza de la transacción podría consistir desde una licencia de importación, un cargo de subsecretario o acceso a la carrera consular, entre otras. Por último, el $27 \%$ de los entrevistados dijo haber presenciado la compraventa de cédulas de identidad con ocasión de las elecciones legislativas y municipales de 2010. El día de la elección, activistas camuflados de viandantes merodean alrededor de los centros de votación a la conquista del indeciso o del opositor a quienes se les ofrece entre 500 y/o 1,000 pesos (10 y 20 USD\$) por asegurar su voto en las urnas. 
¿Estas prácticas condicionan la decisión de acudir a las urnas? Aunque la solidaridad recíproca es la base de la amistad instrumental que rige en las relaciones particularizadas, en la actualidad se ha acrecentado el poder del cliente de escoger a su patrón y de negociar la contrapartida de su apoyo (Combes 2011:28), por lo que aumenta también la incertidumbre acerca de su comportamiento. Como muestra la Tabla 2.2.2 los porcentajes de participación son mayores en presencia de las prácticas clientelares reseñadas, con una diferencia de un $4 \%$ en el caso de reparto de regalos; de un 3,3\% cuando se trata de favores personales; de un $6,9 \%$ con el transporte de votantes; y de un $4,8 \%$ cuando se trata de compra de cedulas de identidad. Por su propia naturaleza, el transporte de votantes destaca por ser la estrategia clientelar con mayor efecto movilizador el día de la votación. Pero una cosa es el efecto movilizador de acudir a depositar el voto y otra el cumplimiento de la obligación instrumental que conlleva la relación particularizada de intercambio. La deslealtad es posible y con ella, el riesgo de malgastar recursos en vano. La persistencia y adaptabilidad del clientelismo en la República Dominicana parece indicar que el porcentaje de cumplimiento en esta relación cooperativa -votar al que me ayudó- es elevada y suficiente para garantizar la rentabilidad de la inversión.

Tabla 2.2.2 Participación en las elecciones congresuales de 2010 en función de la incidencia de determinadas actividades en su vecindario

\begin{tabular}{|l|c|c|}
\hline \multirow{2}{*}{ Reparto de regalos } & \% PARTICIPACIÓN (N) \\
\cline { 2 - 3 } & Sí & NO \\
\hline \multirow{2}{*}{ Favores personales } & 80,0 & 76,0 \\
& $(551)$ & $(478)$ \\
\hline \multirow{2}{*}{ Transporte de votantes } & 78,5 & 75,2 \\
& $(343)$ & $(470)$ \\
\hline \multirow{2}{*}{ Compraventa de cédulas } & 79,4 & 72,5 \\
& $(727)$ & $(223)$ \\
\hline
\end{tabular}

Fuente: Torcal (2010). Primera Encuesta de Opinión Pública y Comportamiento Político en la República Dominicana (OBSEROP). 


\subsection{CLIENTELISMO POLÍTICO: INFLUENCIA PARTIDISTA A CAMBIO DE APOYO POLÍTICO}

En el Clientelismo de Partido los actores políticos individuales o colectivos se intercambian influencia partidista a cambio de apoyo político siguiendo el patrón instrumental que rige entre ciudadanos y representantes. Las convenciones y elecciones internas son el escenario en el que se exterioriza la lealtad instrumental que une a jefes políticos y dirigentes medios. Como se relata en el apartado dedicado a las relaciones de conflicto en los partidos, las facciones que tradicionalmente han anidado en el PRD, PLD y PRSC se enmarcan en la tipología de las "client group factions" de Beller y Belloni (1978). Estos "cuasi grupos dispuestos a la acción colectiva" (Moreno 1995) se caracterizan por el uso neopatrimonialista de los recursos partidistas en los que se atrincheran e intercambian como feudos privados (Benito 2014:533). Si el partido tiene acceso a los recursos públicos, se genera una dinámica cooperativa con los partidos aliados condicionada por el alto nivel de competitividad en la etapa post caudillos. En este caso, los partidos minoritarios son recompensados por el apoyo al oficialista con una especie de contrato de outsourcing para controlar a menor escala, las redes de patronazgo de las instituciones cedidas por el patrono o partido oficialista ${ }^{13}$.

$\mathrm{Al}$ igual que sucede en los intercambios particularistas entre representantes y ciudadanos en los que el acto concesional no conlleva empoderamiento ciudadano, esta regalía que se otorga a las fuerzas minoritarias aliadas no los convierte en partidos con opciones de gobierno que decidan políticas, sino en socios menores de la gestión clientelar de la Administración Pública dominicana. El proceso de descentralización ha abierto un nuevo espacio para los intercambios particularizados entre actores políticos de distintos niveles territoriales. Como se verá en el análisis de los Proyectos de Ley de los diputados dominicanos (1998-2010), la elevación de categoría territorial es la promesa que hace el diputado a sus unidades administrativas inferiores a cambio de la movilización proselitista. Esta dinámica ha amplificado el micro fraccionamiento del territorio dominicano y ha convertido la municipalidad administrativa en una prebenda.

\footnotetext{
${ }^{13}$ Tras las presidenciales de 2012, el presidente Medina ubicó a los dirigentes de los partidos aliados en la Administración Pública: Carlos Morales presidente del PRSC como Ministro de Exteriores; Federico Antún del PRSC en el Banco de Fomento de la Vivienda; Vinicio Castillo presidente de la FNP como Director General de Ética; José R. Taveras secretario general de la FNP como Director de Migración; Pedro Corporán presidente del PUN como Presidente del Instituto de Desarrollo y Crédito Cooperativo; Luis Acosta presidente de la UDC como Director de Desarrollo de la Comunidad; Rafael Peguero presidente del PPC como Director del Instituto para el Desarrollo del Suroeste; Elías Wessin presidente del PQDC como Director de Bienes Nacionales; José Francisco Peña presidente en funciones del BIS como Administrador de la Lotería; Maritza López presidenta del PAL como Administradora del Instituto de Auxilios y Viviendas; José González presidente del PTD como Director de Promoción de las Iniciativas Comunitarias; Radhames Zorrilla presidente del PCR como Director del Instituto de Estabilización de Precios; Antolín Polanco presidente del PASOVE como Director del Consejo Nacional de Población; Nelson Diez presidente del PDP como Embajador adscrito al Ministerio de Exteriores; y Andrés Vanderhorst hijo del presidente del PLRD como Director del Consejo Nacional de Competitividad. Ver Pérez, Omar, en Observatorio Político Dominicano, de 31 de agosto de 2012.
} 


\subsection{CLIENTELISMO OFICIAL: RECURSOS PÚBLICOS A CAMBIO DE APOYO OFICIAL}

Bajo la categoría de «Clientelismo Oficial» se clasifican las transacciones particularistas realizadas por autoridades, funcionarios y representantes nacionales por elección o designación en las que se intercambian bienes y servicios financiados con dinero público. Dependiendo del agente y del escenario de la representación, se dispensan: programas asistenciales (Ejecutivo), empleos en la administración pública (Burocracia) o derechos selectivos y favores personales (Legislativo).

Las páginas siguientes muestran el análisis empírico descriptivo en cada uno de los escenarios con el objetivo de diagnosticar el tipo de representación - general, corporativa o individual- que predomina en cada uno de ellos dependiendo del grado de inclusividad del disfrute del bien asignado.

\subsubsection{Particularismo Ejecutivo: Asistencialismo particularista}

Con el cambio de paradigma del modelo económico desarrollista al de tipo neoliberal, la política social en América Latina en las últimas dos décadas se ha caracterizado por la relevancia decreciente de la provisión universal frente al auge protagónico de la asistencia focalizada. Programas de transferencias como Bolsa Familia en Brasil, Progresa y Oportunidades en México, enfrentaron a principios de los 90's la deuda social de las nuevas democracias a través de subsidios dirigidos a los sectores más vulnerables. El éxito en la reducción de la pobreza extrema y la contención del conflicto social no evitaron el cuestionamiento de este tipo de programas por su posible utilización estratégica, la cooptación clientelar y la institucionalización de la desigualdad. La literatura ha puesto de manifiesto que la discrecionalidad y la personalización de la concesión focalizada tienden a debilitar la ciudadanía ya que generan desconfianza entre beneficiarios e inhiben la acción colectiva. Tal argumentación se sustenta en el hecho de que el subsidio se concibe como una ayuda y no como un derecho abstracto con respaldo institucional y legal (Adelantado y Scherer 2008:124). Por lo tanto, los ciudadanos no reclaman el ejercicio de un derecho sino que compiten entre ellos para entrar en la red de beneficiarios agraciados. Este tipo de programas sociales particularistas pueden convivir con programas de corte universalista, por lo que el predominio de uno sobre otro es considerado indicador de calidad del gasto público en democracia (Figueira 1998, Hevia 2011).

La República Dominicana se ha caracterizado por ser uno de los países de América Latina con menor gasto social por habitante (CEPAL 2010:37), que destina el menor porcentaje del Producto Interior Bruto (PIB) a las partidas de educación y salud (PNUD 2005) y uno de los países con mayor desigualdad (ONU-Habitat 2013). El Sistema Dominicano de Seguridad Social fue creado en el año 2001 bajo la administración del Presidente Hipólito Mejía (PRD) para cubrir los riesgos de vejez, viudedad, enfermedad, maternidad y riesgos laborales. A pesar del tiempo transcurrido, en 2012 este sistema de previsión de contingencias protegía solo al 47,1\% de la población dominicana, por lo que la universalización de su cobertura ha sido desde entonces el gran reto del sistema $^{14}$, y en particular, la implementación del régimen subsidiado que proteja a los trabajadores informales quienes constituyen el 56,5\% de la población activa del país. La endeble extensión de la protección integral y universal contrasta con el auge de los programas focalizados implementados con el cambio de administración.

\footnotetext{
${ }^{14}$ No todos los componentes tienen el mismo grado de cobertura y ejecución. El de maternidad empezó a operar en 2008 y el seguro de salud en 2012 cubría solo al 25\% de la población (ADESS 2013).
} 
La atención a los sectores más vulnerables a través de la asistencia focalizada se inicia en el año 2004 bajo la presidencia de Leonel Fernández y ha continuado en la actual administración del también oficialista Danilo Medina (2012-2016). La Administración de Subsidios Sociales (ADESS) gestiona hoy 7 programas de transferencias monetarias mensuales condicionadas y 3 no condicionados de los que se benefician cerca de 800.000 familias (SIUBEN 2014). Entre los primeros se encuentran el programa "Comer es Primero" (20 \$USD/mes), el "Incentivo a la Asistencia Escolar" (5 \$USD/mes), el "Bono Escolar Estudiando Progreso" (10 \$USD/mes), el "Incentivo a la Educación Superior" (10 \$USD/mes), el "Programa Bono Gas para Choferes"(80 \$USD/mes), el "Incentivo a la Policía Preventiva"(22 \$USD/mes), y el "Incentivo a los Alistados en la Marina de Guerra"(22 \$USD/mes). Las trasferencias mensuales no condicionadas se realizan a través de los programas de "Protección a la Vejez en Pobreza Extrema"(9 \$uSD/mes), el "Bono Gas" (6 \$usD/mes) y el "Bono Luz" (9 \$usD/mes).

Los beneficiarios directos -jefes de familia- de estos programas focalizados identificados con la llamada "Tarjeta Solidaridad", representaban el 9\% de la población dominicana y el 14\% del censo electoral en 2012. Para verificar si estas asignaciones de bienes selectivos se realizan con el propósito de movilizar y/o recompensar el apoyo al partido oficialista se analiza la evolución mensual desagregada de la partida presupuestaria "Servicios Sociales" en año electoral. Bajo este rubro general se contemplan los gastos en Educación, Salud, Vivienda, Agua potable, Servicios Municipales, Recreación y Cultura, Seguridad Social y Asistencia Social. El diagnóstico de la comparativa de la partida destinada a estas dos últimas -Seguridad Social y Asistencia Socialaporta pistas acerca de la mayor o menor vocación particularista del gasto social en el país.

Como muestran los Gráficos 2.4.1.1 y 2.4.1.2 en 2006 y 2010 -años de elecciones legislativas y municipales- la estabilidad del gasto en "seguridad social" contrasta con los vaivenes de la partida dedicada a la "asistencia social", con picos máximos que coinciden con los meses anteriores a la cita con las urnas e incluso ejecutadas en el mismo mes de mayo en que se celebran las elecciones. En los dos años considerados, el gasto en "asistencia social" vuelve a aumentar a partir de agosto, mes en que toman posesión los nuevos representantes elegidos en mayo.

Gráfico 2.4.1.1 Gasto en Asistencia Social y Seguridad Social año electoral Legislativas Mayo 2006, Presupuestos Ejecutados 2006

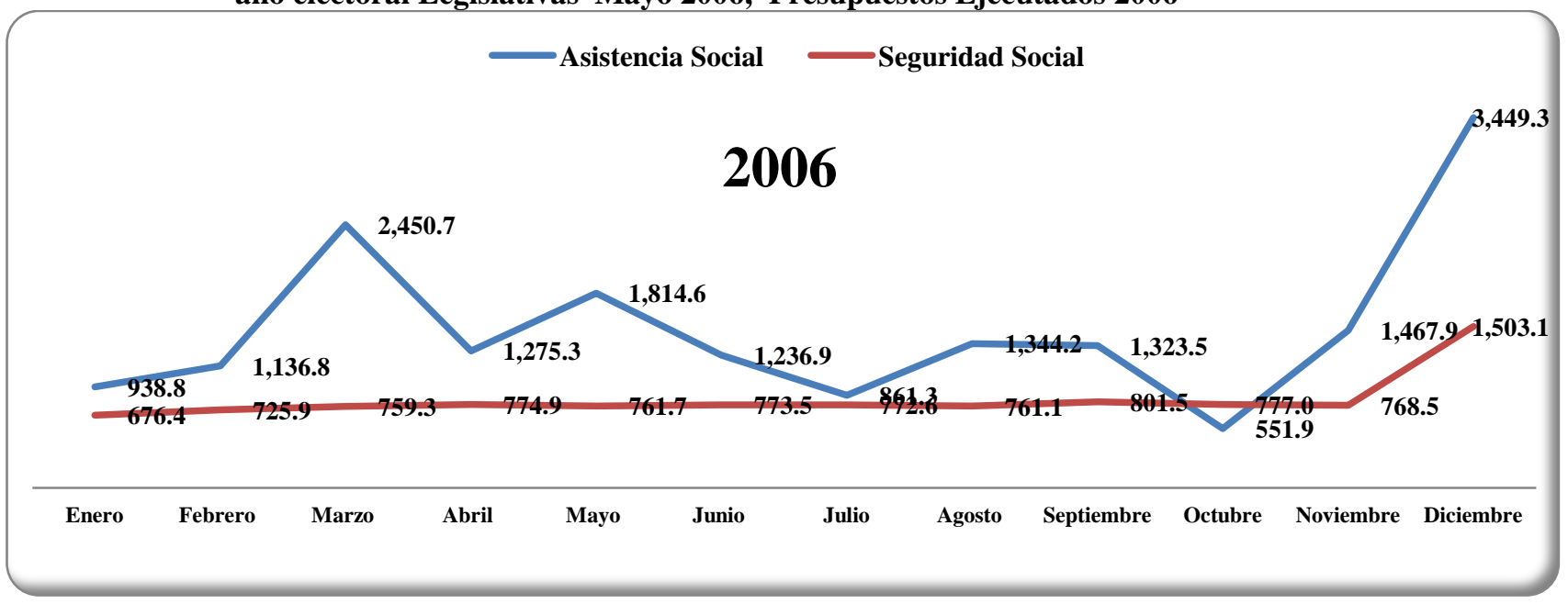

Fuente: Dirección General de Presupuesto (DIGEPRES), Ejecución Presupuestaria del Gobierno Central. Clasificación Funcional. Partida "Servicios Sociales" (Educación, Salud, Vivienda, Agua potable, Servicios Municipales, Asistencia Social, Seguridad Social, Recreación y Cultura, [Estadísticas http://www.digepres.com] Valores en millones DOP\$ 
Gráfico 2.4.1.2 Gasto en Asistencia Social y Seguridad Social año electoral Legislativas Mayo 2010, Presupuestos Ejecutados 2010

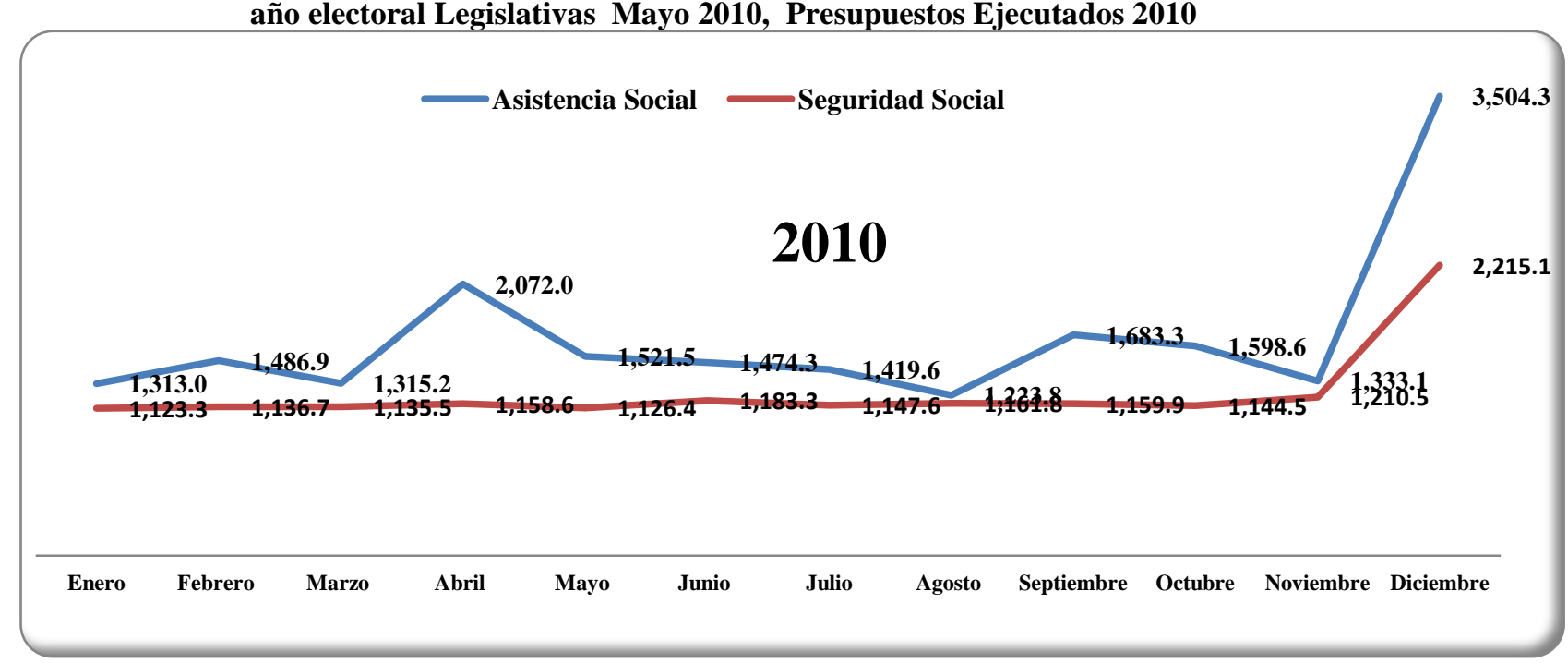

Fuente: Dirección General de Presupuesto (DIGEPRES), Ejecución Presupuestaria del Gobierno Central. Clasificación Funcional. Partida "Servicios Sociales" (Educación, Salud, Vivienda, Agua potable, Servicios Municipales, Asistencia Social, Seguridad Social, Recreación y Cultura, [Estadísticas http://www.digepres.com] Valores en millones DOP\$

Por el contrario, en año no electoral, como muestran los Gráficos 2.4.1.3 y 2.4.1.4 se invierte la tendencia y el gasto en "seguridad social" supera a la partida correspondiente a "asistencia social", si bien en ésta se observan picos crecientes en febrero-marzo, mayo y septiembre, que se corresponden con el tradicional dispendio con ocasión de la semana santa, el día de las madres y la vuelta al colegio respectivamente ${ }^{15}$.

Foto 2.4.1.1 Entrega de regalos y servicios en las vacaciones de semana santa, el día de las madres, y en la apertura del año escolar por autoridades e instituciones públicas

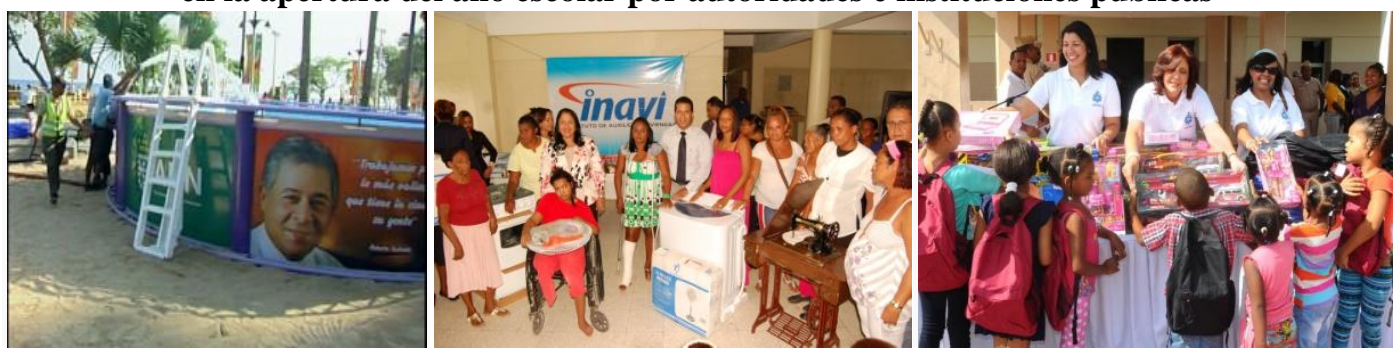

Foto 1: Piscinas públicas portátiles en Semana Santa financiadas por el alcalde del Distrito Nacional. Foto 2: Entrega de lavadoras, maquinas de coser y hornos por el día de la madre financiadas por el Instituto Nacional de la Vivienda.

Foto 3: Entrega de útiles escolares por las Fuerzas Armadas.

15 Ver noticias al respecto sobre el reparto de bienes en estas fechas conmemorativas en http://elnacional.com.do/administradora-del-inavi-entrega-regalos-por-motivo-del-dia-de-las-madres/ , y en http://enteraterd.com/page/2014/04/15/adn-anuncia-celebracion-semana-santa-en-guibia-con-instalacion-12piscinas/. 
Gráfico 2.4.1.3 Gasto en Asistencia Social y Seguridad Social año NO electoral 2009, Presupuestos Ejecutados 2009

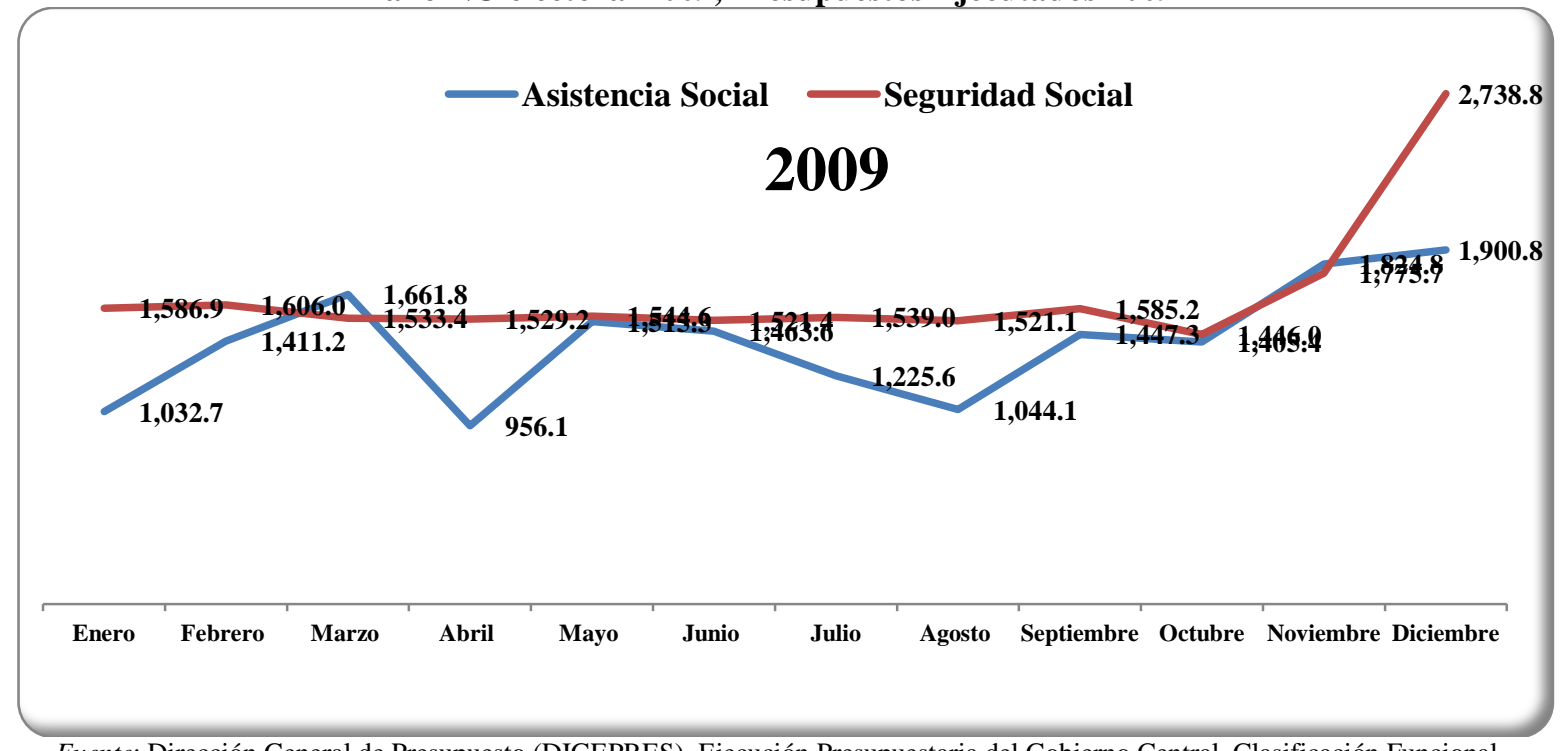

Fuente: Dirección General de Presupuesto (DIGEPRES), Ejecución Presupuestaria del Gobierno Central. Clasificación Funcional.

(Valores en millones DOP\$)[Estadísticas http://www.digepres.com]

Gráfico 2.4.1.4 Gasto en Asistencia Social y Seguridad Social año NO electoral 2011, Presupuestos Ejecutados 2011

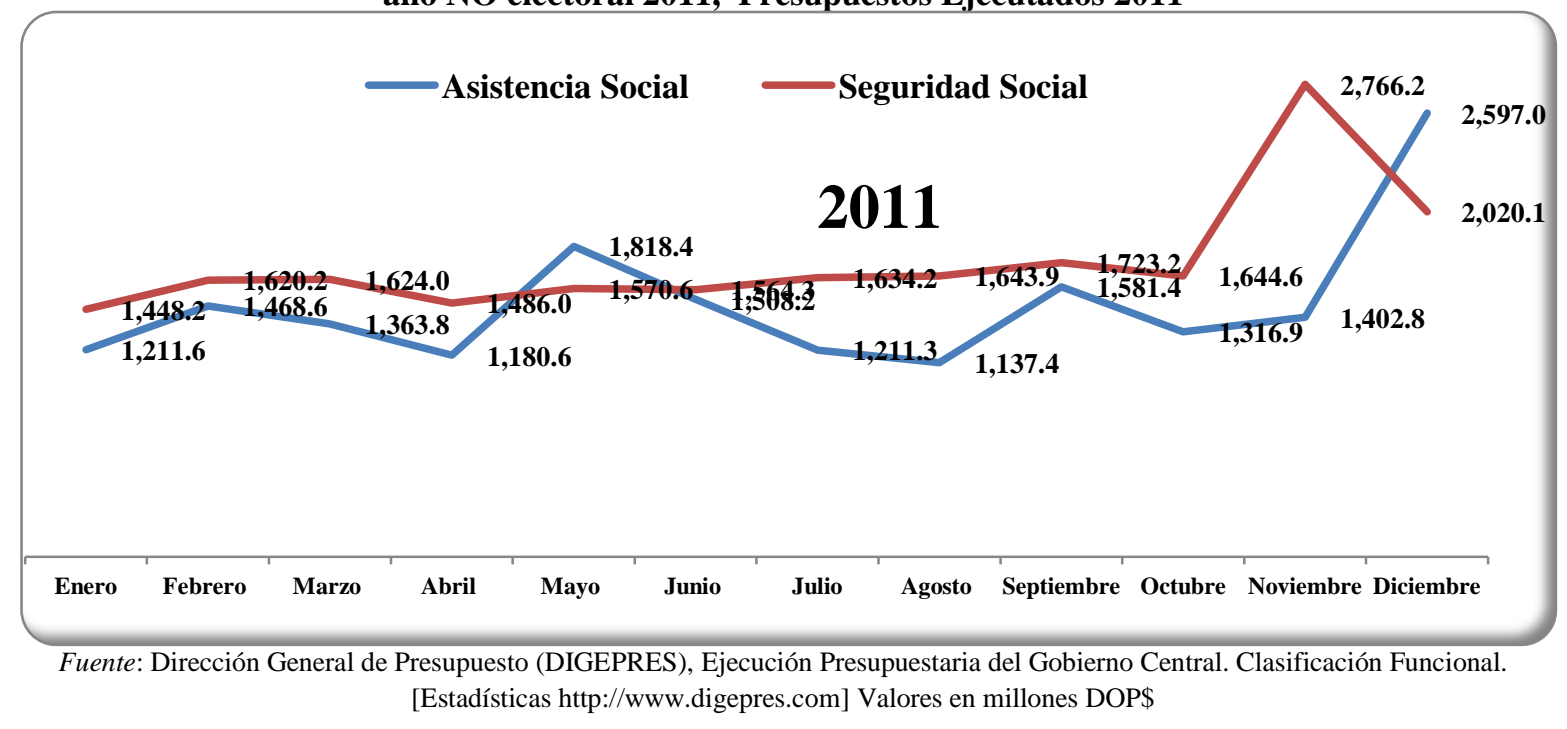

La tendencia común que comparten los cuatro años considerados independientemente de las citas electorales, es el pico máximo de gasto en el mes de diciembre tanto en la partida presupuestaria de corte particularista de "asistencia social" y también en la más universalista relativa al gasto en "seguridad social". Diciembre es el mes por excelencia del reparto prebendalista en el país. Una tradición inaugurada por Joaquín Balaguer en el que cada una de las agencias y funcionarios entregan canastas navideñas, alimentos o regalos y en la que participan autoridades nacionales, provinciales y municipales ${ }^{16}$. En el caso de la partida "seguridad social", el coste aumenta con el salario número 13 y el bono de navidad de los empleados.

16 Ver noticas sobre reparto de canastas navideñas en Noticias SIN, del 12 de enero de 2012 en http://www.noticiassin.com/2012/12/gobierno-repartira-miles-de-cajas-navidenas/ 
Foto 2.4.1.2 Reparto de prebendas navideñas
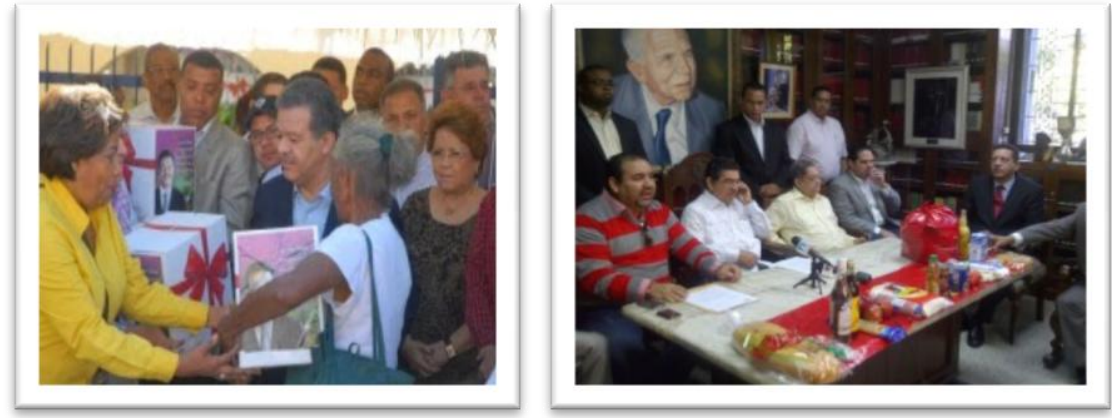

Foto 1: Entrega de canastas navideñas a cargo del Plan Social de la Presidencia.

Foto 2: Presentación de productos a entregar en la Fundación Balaguer con ocasión de la Navidad.

Este ejercicio particularista del gobierno central dominicano se complementa con una red descentralizada asistencialista en la que participan como brókeres los Ministerios y agencias públicas del país ${ }^{17}$. En la página web de Ministerios como el de Agricultura, el de Asuntos Exteriores $^{18}$, la dirección General de Compras y Contrataciones Públicas ${ }^{19}$ o la propia Junta Central Electoral $^{20}$, cuentan con una partida presupuestaria para repartir entre individuos y que generalmente se ejecuta en forma de becas de estudios para empleados o aquellos elegidos por la apreciación subjetiva del director de la agencia pública en cuestión ${ }^{21}$.

Los datos aquí mostrados revelan que el Ejecutivo intensifica la política particularista en año electoral mientras que tiende a priorizar la política de vocación universal en año no electoral, a pesar de que la población en situación de pobreza y pobreza extrema destinataria de los programas de asistencia social se ha mantenido constante a lo largo de la última década ${ }^{22}$. Estos resultados confirmarían el potencial politizador de la asistencia focalizada que autores como Hevia (2010), Takahasi (2007) o Rocha (2001) han evidenciado en democracias vecinas como la mexicana.

\footnotetext{
${ }^{17}$ Ver "Beneficiarios de Programas Asistenciales" del Ministerio de Agricultura en pág. Web de la institución en http://www.agricultura.gob.do/transparencia/beneficiarios/

${ }^{18}$ Ver "Beneficiarios de Programas Asistenciales" de Ministerio de Relaciones Exteriores en la pág. web de la institución en http://transparencia.mirex.gov.do/Lists/Becas2007/Vista\%20por\%20Ao.aspx

${ }^{19}$ Ver "Beneficiarios de Programas Asistenciales" de la Dirección General de Contrataciones Públicas en pág. Web de la institución en http://www.dgcp.gob.do/transparencia/index.php/programas-asistenciales.

${ }^{20}$ A pesar de que en su página web especifica que: «De acuerdo al Acta No.30-2010, evacuada por el honorable Pleno de ésta Junta Central Electoral, celebrada el 27 de diciembre del 2007, se dictaminó dentro de varios considerando lo siguiente: "Se descontinuará la práctica de disponer recursos para atender solicitudes de personas, tanto de fuera como de la institución, de ayudas de asistencia social, debido a que la JCE, no cuenta con un capítulo que regule esto y que esto imposibilita realizar estas labores y en consecuencia se decidió a partir del próximo año 2011, que las solicitudes de ayudas por razones humanitarias ó de carácter social serán canalizadas a las instituciones públicas de que dispone el Estado Dominicano, encargadas de proveer asistencia social ó por el plan de pensiones de la institución, sí correspondiere".» En los presupuestos ejecutados por la JCE de 2012, en la partida de "Transferencias corrientes al sector privado" en la categoría "Ayuda y donaciones a personas", en el primer trimestre del año de 2012 -año electoral presidencial- se entregaron 84,440.68 DOP. Ver presupuesto 2012 en http://www.jce.gob.do/transparencia/Presupuesto.aspx\#dltop

${ }^{22}$ En 2011 el 32,9\% de la población dominicana se encontraba en situación de pobreza y el 9,05\% en la indigencia, iguales porcentajes que en el año 2000 (PNUD 2013).
} 


\subsubsection{Particularismo Burocrático: Patronazgo estatal}

El origen de la separación entre administración y política hunde sus raíces en el liberalismo y la teoría clásica de la burocracia (Weber 1991). Para que la Administración Pública sea un ejecutor imparcial y neutral, el principio de mérito es una de las herramientas en la conquista de la profesionalización, abstracción y universalidad en el tratamiento de los casos administrativos. A pesar de los esfuerzos de reforma de la última década, la selección discrecional de personal y una burocracia unida por vínculos de lealtad personal y política al líder de turno, siguen caracterizando hoy la gestión de muchas de las democracias latinoamericanas (Ferraro 2009:206)

En el caso de la República Dominicana, la primera Ley de Servicio Civil y Carrera Administrativa se promulgó en 1991. Desde entonces, pocos han sido los avances en el establecimiento de la carrera civil, que recibió un nuevo impulso en 2008 con la creación del Ministerio de Administración Pública y la nueva Ley No.41 de Función Pública. En 2008, un total de 23.179 funcionarios (SASP 2008) habían sido incorporados a la carrera, lo que supone apenas el 6,22\% del total de servidores públicos dominicanos de la administración central. En agosto de 2012, este porcentaje ascendía al 10\% (MAP 2012). La estimación del mérito y la capacidad para el acceso a la carrera pública consagrados en el art. 138 de la Constitución Dominicana, puede realizarse por concurso (entrada) o por valoración del desempeño (permanencia).

Desde 2004 a 2012 solo 217 personas de los 479.400 funcionarios que laboraban en la Administración Pública dominicana accedieron por la vía del concurso, es decir un nimio 0,04\% del total y el 0,37\% de los servidores que pertenecen a la carrera administrativa (Nelson 2013:24). La preferencia por la opción de la valoración del desempeño de los que ya entraron frente al examen de acceso, podría imponer la subjetividad partidaria en la conformación del funcionariado dominicano y en todo caso, refleja la resistencia de los actores a desprenderse de esta herramienta de movilización y de responsiveness particularizada.

Puesto que el 61,38\% de los funcionarios dominicanos gana menos de 450 dólares al mes (MAP 2013), el coste del patronazgo en el país es bajo. Con cada cambio de administración, se suceden los relevos de funcionarios para ubicar a la camarilla del jefe de agencia. La manifestación corrupta del patronazgo en la Administración Pública se conoce popularmente como "botella". Con esta expresión se identifican en el país aquellos puestos con sueldo pero sin funciones reales que se distribuyen entre parientes y amigos de la persona con responsabilidad pública otorgados por la movilización proselitista en la campaña. Estos puestos no están en la nomina oficial sino en la llamada "nominilla"23. El entonces Presidente Fernández justificaba las "botellas" alegando:

«Aquí el Gobierno se cae cuando no pueda incorporar gentes de la sociedad a algún mecanismo de supervivencia. En España se cae si lo denuncian, aquí se cae si no lo practica ${ }^{24}$ (Fernández 2009).

Las fechas clave para el nombramiento de estos puestos son el 16 de agosto y el 27 de febrero, festividades nacionales en las que el Presidente de turno renueva mediante decreto los cargos en la Administración Pública. Durante las semanas previas al 16 de agosto, los aspirantes a subsecretarios, asesores, consultores y vicecónsules merodean alrededor del Presidente y su círculo

\footnotetext{
${ }^{23}$ En 2014, una auditoria de la Cámara de Cuentas denunciaba que en 2011-2012 un total de 412 personas figuraban como trabajadores del Ministerio de Obras Publicas pero no asistían a trabajar. En la categoría de guardas de seguridad 142 cobraban sin trabajar, en la sección de mantenimiento había otros 48 supuestos empleados. Ver noticia en Acento del 29 de octubre de 2014. En http://www.acento.com.do/2014/politica/8189923-caso-diaz-rua-iii-fiesta-y-nominillas-de-botellas

${ }^{24}$ En periódico Clave de 23 de septiembre de 2009. Declaraciones recogidas en abril 2009.
} 
de influencia en busca del ansiado decreto. Y como muestra anecdótica de la normalización del fenómeno de las "botellas", en agosto de 2012 unos grandes almacenes dominicanos publicitaban los nuevos envases de sus licores con el lema "Agosto, mes de las nuevas botellas", en las que aparecía la banda presidencial, la silla y la foto del Palacio de fondo, en clara alusión a esta práctica.

Foto 2.4.2.1 Empleo público como recompensa partidista
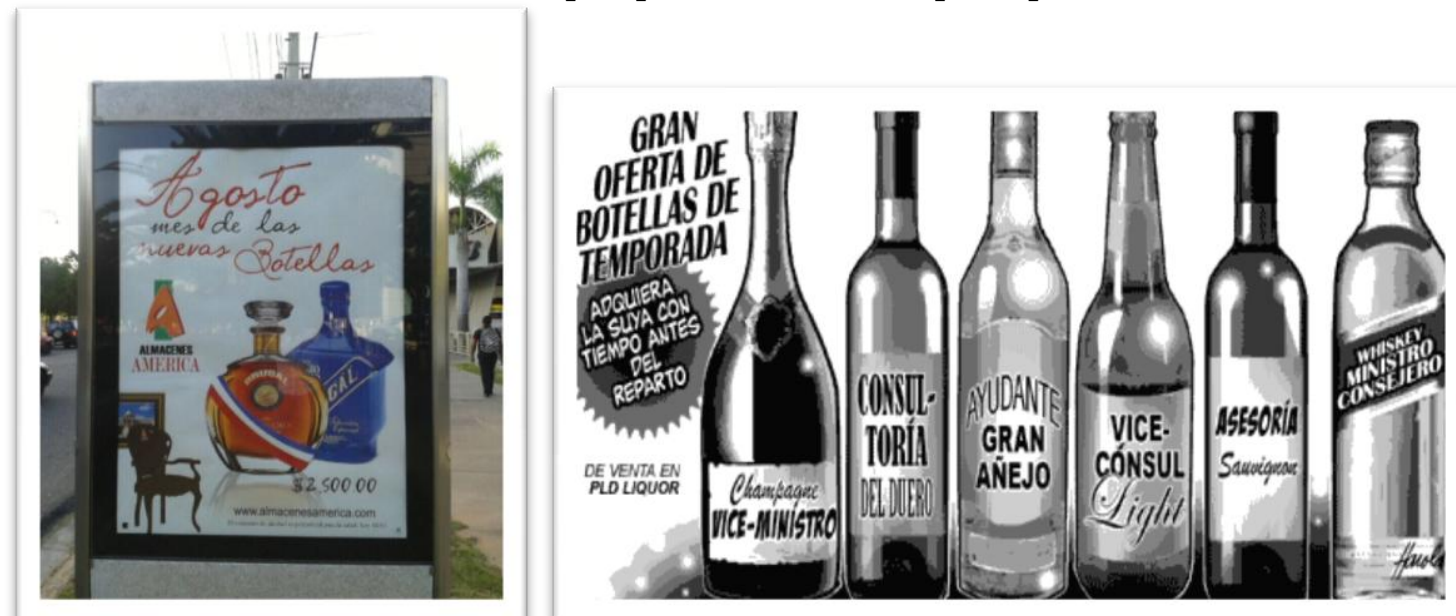

Fuente: Foto 1 tomada en la avd. Churchill, el 6 de agosto de 2012. Foto 2, Viñeta del periódico Diario Libre del 12 de junio de 2012 en la que se alude a la variedad de puestos en la administración que se otorgan bajo esta modalidad fraudulenta.

Para medir el grado de sometimiento de la Administración Pública dominicana a los ciclos electorales e intereses políticos de sus gestores, se presenta la evolución en el número de nuevos funcionarios dados de alta en el Sistema de Administración de Servidores Públicos (SASP).

El SASP nació con el propósito de inventariar y transparentar el número de empleados públicos, procesos históricamente caracterizados por la opacidad. Comenzó a operar en 2006 con el registro de los servidores públicos de la Sede Central del Gobierno y del Instituto de Administración Pública y no será hasta el año 2011 que ingresen en el sistema una treintena de agencias más. En 2014, unas 147 instituciones del Poder Ejecutivo central habían registrado sus funcionarios y se espera que en futuras etapas así lo hagan la administración descentralizada, los organismos autónomos y las instituciones del Poder Legislativo y Judicial ${ }^{25}$.

En primer lugar se muestra el registro de empleados públicos del Despacho de la Primera Dama, una oficina gubernamental a cargo de la esposa del mandatario de turno. En el periodo 2008-2012 gestionaba un programa de subsidios con un presupuesto tres veces mayor al que ejecutaba el Ministerio de la Mujer para el mismo ejercicio ${ }^{26}$. La entonces Primera Dama era además candidata vicepresidencial en las elecciones de 2012. Como muestra el Gráfico 2.2.1.B.1 en 2011 -año no electoral- el número de empleados se mantiene relativamente constante con ligeros aumentos frente a los picos en la contratación observados en 2012, año de la elección presidencial en que la directora de la institución era también candidata.

\footnotetext{
${ }^{25}$ Ver cronología de incorporación al SASP en aparatado "Implementación", en http://map.gob.do/sasp/

${ }^{26}$ En 2010 el Despacho de la Primera Dama contaba con un presupuesto de \$USD 19.590.767 y el Ministerio de la Mujer con \$USD 9.429.782.
} 
El pico máximo corresponde al mes de marzo, dos meses antes de la cita con las urnas en que el número de empleados aumenta un $28 \%$. Este incremento en el personal de la agencia pública es contraparte del aumento de las actividades asistenciales y que podría responder a los intereses proselitistas de la propia candidata. En agosto de 2012, la ex Primera Dama Margarita Cedeño de Fernández pasa a ser Vicepresidenta de la República Dominicana y el número de funcionarios de la institución se reduce un $87 \%$.

\section{Gráfico 2.4.2.1 Número de Empleados Incorporados al Sistema de Administración de Servicios Públicos (SASP) del Despacho de la Primera Dama}

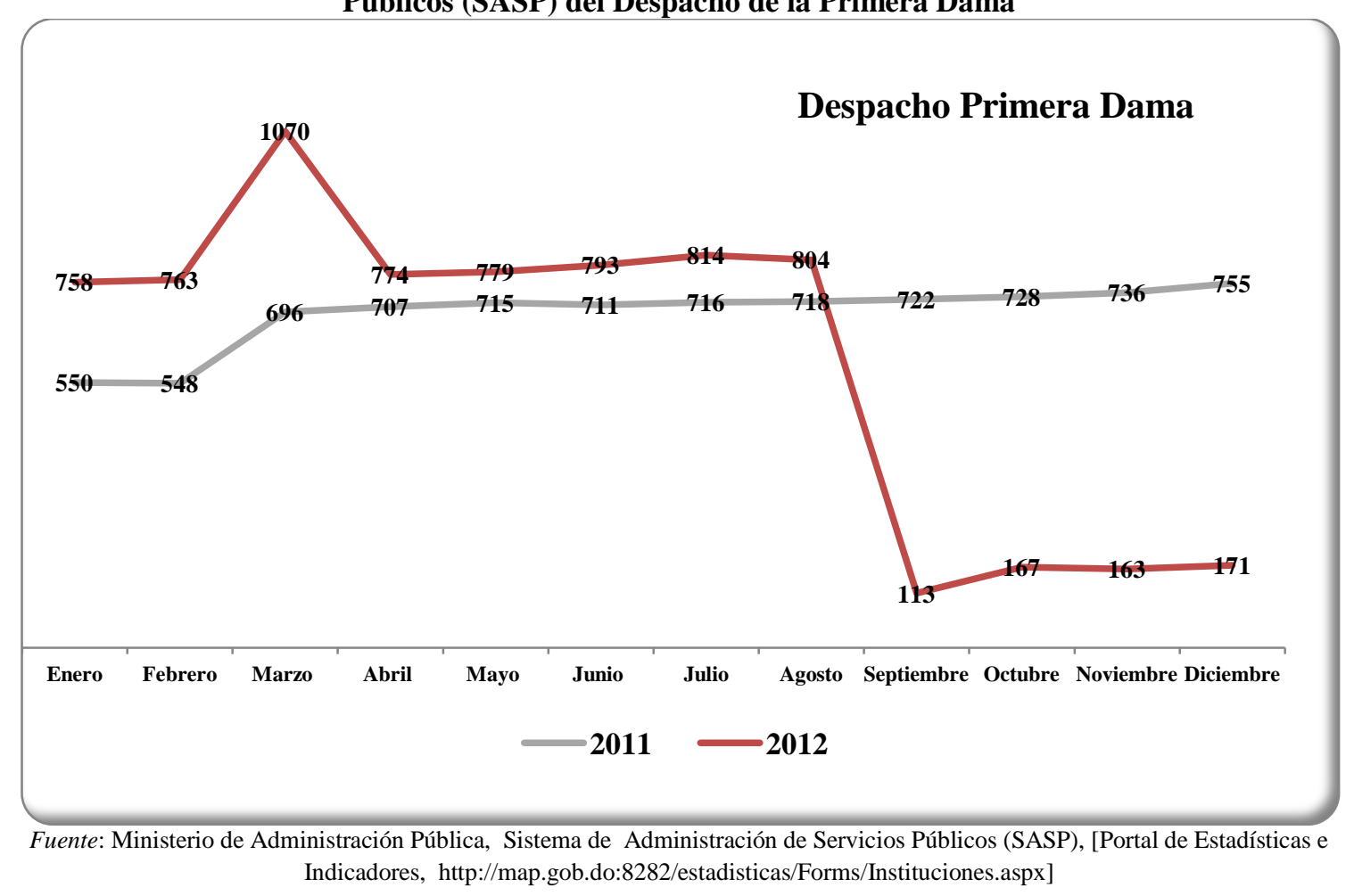

Similares vaivenes en la contratación se observan en el programa "Solidaridad" del Gabinete Social de la Vicepresidencia ${ }^{27}$. La estabilidad en el número de funcionarios durante 2011 -año no electoral- contrasta con el incremento de un 56,8\% tras las legislativas de mayo 2010 y el aumento de un $23 \%$ en el número de funcionarios tras las presidenciales de mayo 2012. En ambos casos, el empleo en la administración parece ser la recompensa por el apoyo en las urnas, ya que los picos máximos corresponden al mes de agosto, fecha en el que comienza el nuevo mandato de los legisladores y el del Presidente electo. Aunque el mayor pico de contratación puntual de funcionarios se realiza tras las elecciones legislativas, el Gráfico 2.4.2.2 revela el mayor poder presidencial en la estabilidad de la recompensa.

\footnotetext{
${ }^{27}$ Programa creado por Decreto Presidencial No. 536-05 y unificado en 2012 por Decreto Presidencial No. 388 al Programa Progresando del Despacho de la Primera Dama. A partir de 2012 se denomina "Progresando con Solidaridad".
} 
Gráfico 2.4.2.2 Número de Empleados Incorporados al Sistema de Administración de Servicios Públicos (SASP) del Programa «Solidaridad» del Gabinete Social de la Vicepresidencia, 2010-2012

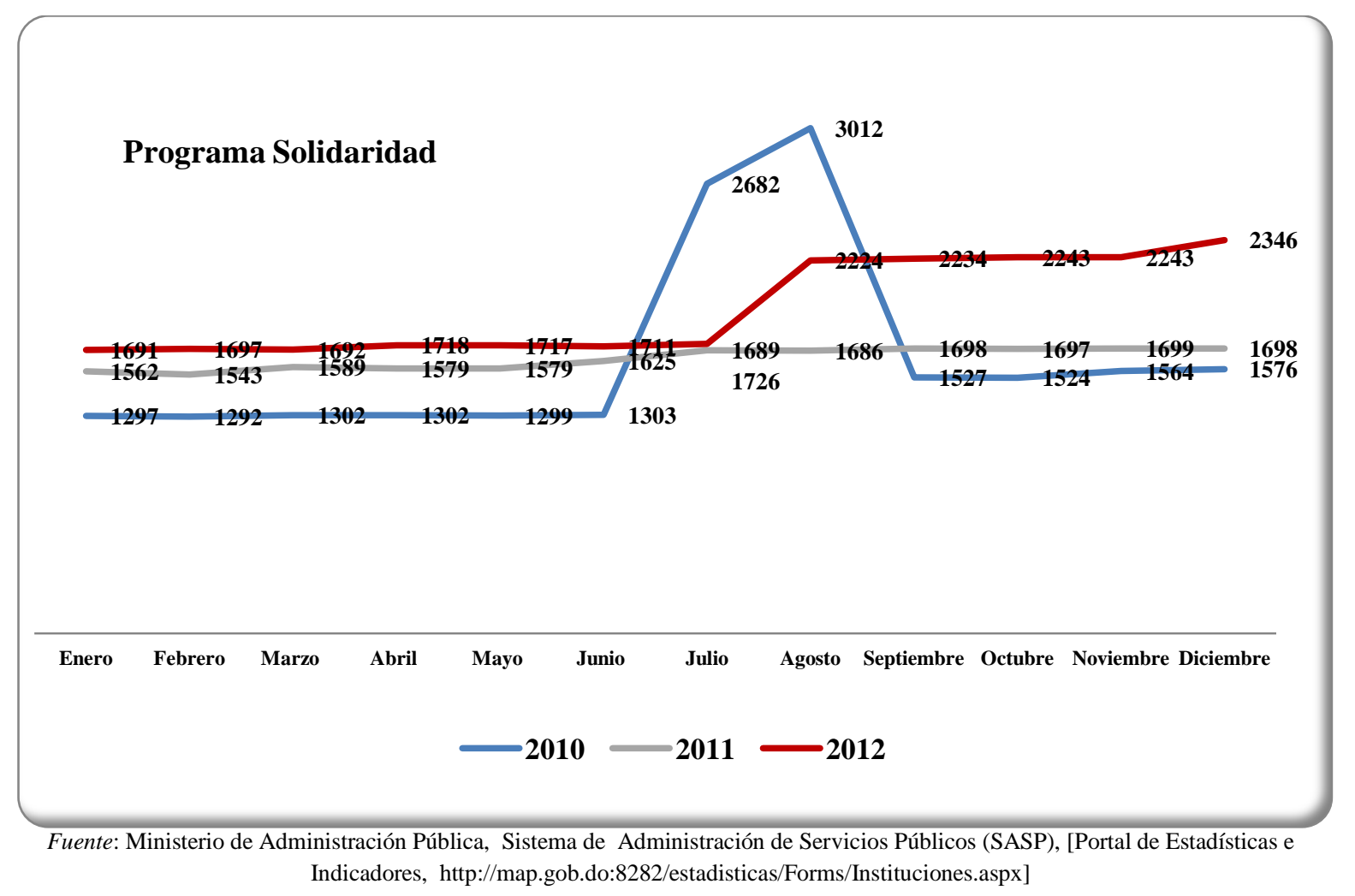

Estos datos de contratación revelan que el patronazgo en la República Dominicana es un arma al servicio del director de la agencia gubernamental de turno que se utiliza ex ante al servicio de su carrera política para movilizar electores y también una herramienta ex post para recompensar votos. 


\subsubsection{Particularismo Legislativo: Representación prebendalista}

Tras conocer el grado de particularismo en la política social del Gobierno dominicano y en la conformación de su Administración Pública, el siguiente paso es cuantificar este fenómeno a través de la observación de la actividad propositiva (nacional) y concesional (distrital) de los diputados dominicanos. En un estudio sobre la representación política en democracia, el Congreso se convierte en unidad de análisis obligada, ya que las acciones de los legisladores son indicadores del ejercicio de la función normativa, de la orientación de política pública y de la función simbólica de representación.

El «Particularismo Legislativo» se conceptualiza como la representación de intereses no generales que tiene lugar en las instituciones legislativas y que deriva en un ejercicio prebendalista e individualizado de la representación política. Esta sub categoría de «Clientelismo Oficial» se caracteriza por el intercambio de recursos públicos bajo la forma de derechos selectivos y favores personales a cambio de apoyo, en el que los legisladores ejercen de mediadores. Para conocer su alcance y evolución en la etapa de la consolidación democrática se clasifican según el nivel de inclusividad -generales, corporativas e individuales- las Proposiciones de Ley elevadas a trámite parlamentario de las legislaturas 1998-2002, 2002-2006 y 2006-2010, así como las regalías otorgadas a los electores de su distrito a través del Fondo de Gestión Social 2008-2009.

\subsubsection{A) ¿Que proponen los Diputados?: Proposiciones de Ley presentadas a trámite parlamentario en la Cámara de Diputados (1998-2010)}

El primer indicador para medir la VD en el escenario legislativo lo forman las 1.863 Proposiciones de Ley elevadas desde la Cámara de Diputados y aprobadas para trámite parlamentario en las tres legislaturas pasadas (1998-2010). Las proposiciones son clasificadas por el nivel de inclusión de los beneficiarios [representación general, corporativa e individual] dependiendo del tipo de interés protegido [interés público, grupal/de club o interés personal]. Este indicador ofrece una fotografía de cómo es la dinámica principal-agente y el acto de delegación por el que el legislador representa los intereses públicos del ciudadano dominicano. Los datos presentados revelan que en la República Dominicana los mandatos particulares y la micro política boicotean la generalidad y la abstracción que han de caracterizar el mandato legislativo en democracia.

La Tabla 2.4.3.A.1 recoge los porcentajes por periodo legislativo e interés protegido. El cómputo global en la primera década desde el inicio de la etapa de la consolidación revela que menos de la mitad de las Proposiciones de Ley de los diputados dominicanos $(49,7 \%)$ promueven el interés público. En la legislatura 2002-2006 este porcentaje se redujo a un 30,5\%. Por el contrario, aquellas que tenían como finalidad conceder una pensión a un elector de su circunscripción representaron el 34,6\% de la actividad propositiva de los diputados en la década estudiada. De nuevo la legislatura 2002-2006 destaca por el carácter particularista de la actividad propositiva y las iniciativas que solicitan la concesión de un derecho selectivo al margen del sistema de previsión general de contingencias alcanzan el 54\%. Estos picos máximos coinciden con la mayoría parlamentaria del PRD y los años en que este partido controlaba también el gobierno nacional. Por el contrario, cuando el Ejecutivo es controlado por el PLD y sus representantes son mayoría en el hemiciclo, disminuye el número de proposiciones en las que se protege el interés personal. Si bien este punto de inflexión puede interpretarse como un cambio de tendencia hacia la mayor vocación universal del Congreso dominicano, también puede ser reflejo de la interacción estratégica del partido oficialista en su posición de dominio. La legislatura 2006-2010 fue la primera en la que el PLD conquistó la mayoría absoluta y la primera en la historia democrática del país en la que el 
PRD no obtuvo representación en el Senado. En este contexto favorable, el poder de rechazo del PLD en el trámite parlamentario aumenta significativamente. De hecho, las proposiciones rechazadas en el periodo 2006-2010 aumentaron un 52,6\% con respecto a la legislatura pasada 2002-2006. En este poder de veto al inicio de la tramitación legislativa, el partido oficialista podría esconder la intención de limitar el papel de conseguidor que los diputados de la oposición poseen en sus distritos.

Tabla 2.4.3.A.1 Proposiciones de Ley según nivel de Particularismo (\%), 1998- 2010

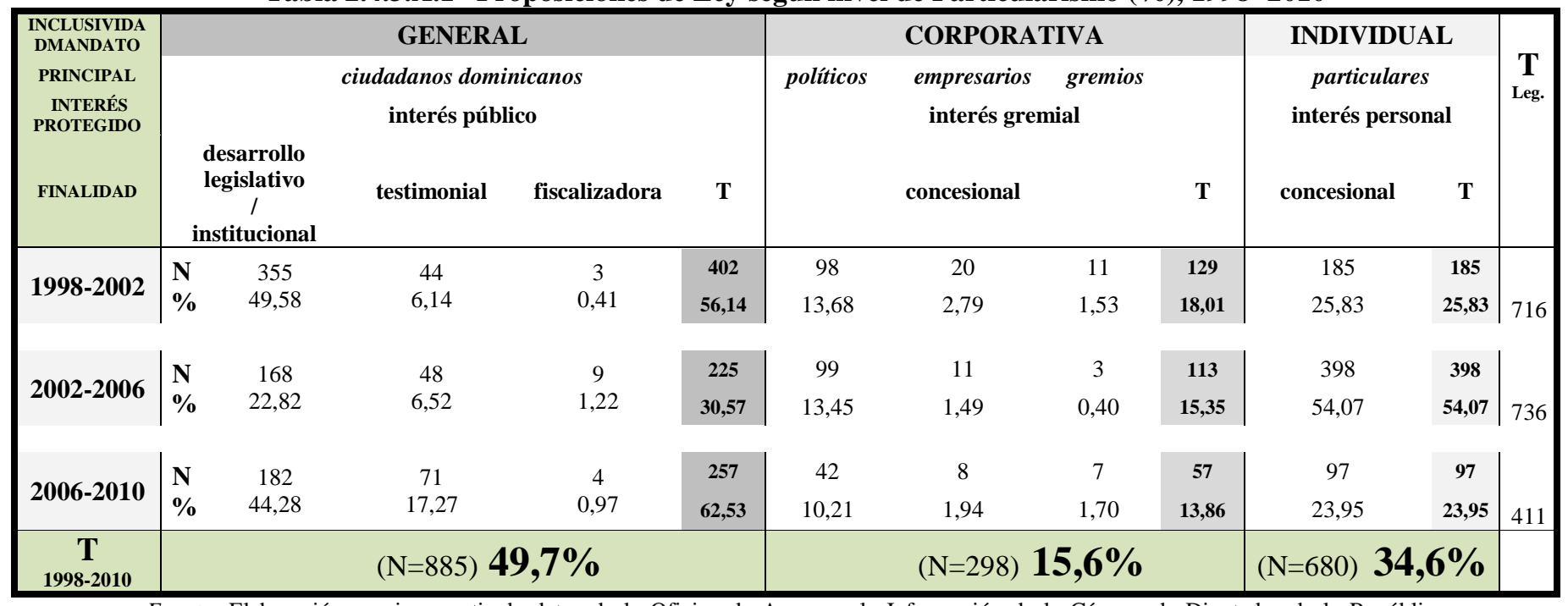

Fuente: Elaboración propia a partir de datos de la Oficina de Acceso a la Información de la Cámara de Diputados de la República Dominicana. Proposiciones rechazadas para su trámite parlamentario: en 1998-2002 (127); en 2002-2006 (590); en 2006-2010 (1247).

Gráfico 2.4.3.A.1 Particularismo Proposiciones por Legislatura y control del Ejecutivo (\%), 1998-2010

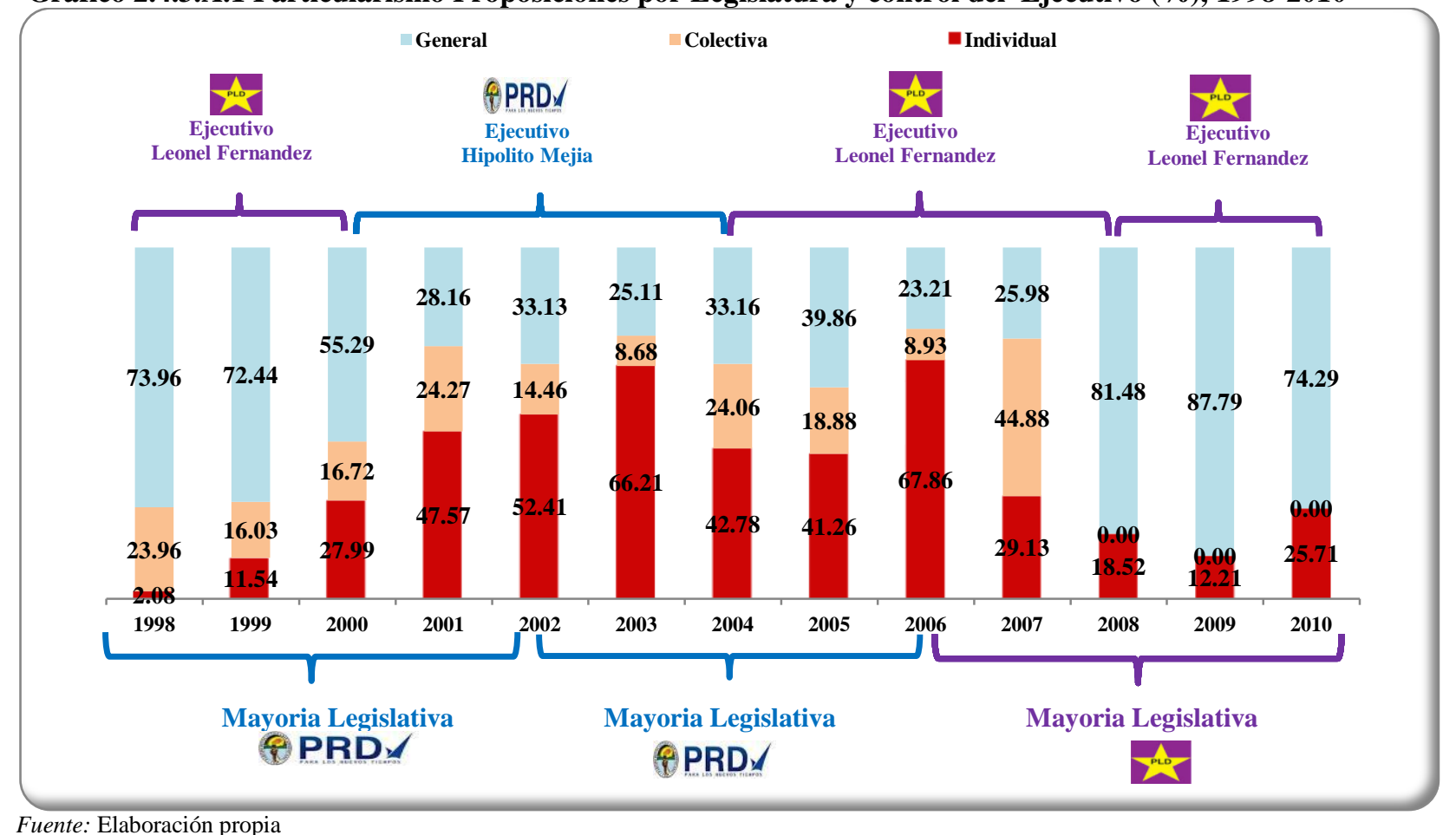


El análisis desagregado por Legislatura muestra que la relación entre particularismo y partido político es estadísticamente significativa. En el periodo 1998-2002, es el Partido Reformista Social Cristiano (PRSC) quien destaca por someter a trámite parlamentario el mayor número de proposiciones de naturaleza particularista. Esta es la primera de las legislaturas en las que el caudillo Joaquín Balaguer desaparece formalmente de la escena política nacional tras el «Pacto por la Democracia» que pone fin a la crisis por el fraude electoral de 1994. El PLD, que controlaba en aquel entonces el gobierno pero no el legislativo (dominado por el PRD) es el que presenta mayor número de iniciativas que promueven el interés general (80\%), frente al $50,6 \%$ de los representantes perredeístas.

Tabla 2.4.3.A.2 Proposiciones de Ley por nivel de particularismo y partido, Legislatura 1998-2002

\begin{tabular}{|c|c|c|c|c|c|c|c|c|c|c|c|}
\hline \multicolumn{12}{|c|}{ 1998-2002 } \\
\hline & & PLD & PRD & PRSC & PLD/PRD/PRSC & PLD/PRD & PRD/PRSC & PPC & FNP & Otras & Total \\
\hline \multirow{2}{*}{ General } & $\mathbf{N}$ & 77 & 131 & 51 & 24 & 12 & 11 & 4 & 4 & 74 & 388 \\
\hline & $\%$ & 80.2 & 50.6 & 40.2 & 55.8 & 27.3 & 52.4 & 30.8 & 80.0 & 81.3 & 55.5 \\
\hline \multirow{2}{*}{ Corporativa } & $\mathbf{N}$ & 9 & 53 & 17 & 11 & 22 & 3 & 3 & 1 & 7 & 126 \\
\hline & $\%$ & 9.4 & 20.5 & 13.4 & 25.6 & 50.0 & 14.3 & 23.1 & 20.0 & 7.7 & 18.0 \\
\hline \multirow{2}{*}{ Individual } & $\mathbf{N}$ & 10 & 75 & 59 & 8 & 10 & 7 & 6 & 0 & 10 & 185 \\
\hline & $\%$ & 10.4 & 29.0 & 46.5 & 18.6 & 22.7 & 33.3 & 46.2 & 0.0 & 11.0 & 26.5 \\
\hline \multirow{2}{*}{ Total } & $\mathbf{N}$ & 96 & 259 & 127 & 43 & 44 & 21 & 13 & 5 & 91 & 699 \\
\hline & $\%$ & 100 & 100 & 100 & 100 & 100 & 100 & 100 & 100 & 100 & 100 \\
\hline
\end{tabular}

Fuente: Elaboración propia

\begin{tabular}{|l|l|l|l|}
\hline Pruebas de chi-cuadrado 1998-2002 & Valor & gl & Sig. asintótica (bilateral) \\
\hline Chi-cuadrado de Pearson & $116,951(\mathrm{a})$ & 16 & 0.000 \\
Corrección por continuidad & 113.353 & & \\
Razón de verosimilitudes & 9.507 & 16 & 0.000 \\
Asociación lineal por lineal & 699 & 1 & 0.002 \\
N de casos válidos & & & \\
\hline
\end{tabular}

a. 6 casillas $(22,2 \%)$ tienen una frecuencia esperada inferior a 5. La frecuencia mínima esperada es ,90.

\begin{tabular}{|l|l|r|l|r|r|}
\hline Medidas simétricas 1998-2002 & & Valor & Error típ. asint.(a) & T aproximada(b) & Sig. aproximada \\
\hline Nominal por nominal & Phi & 0.409 & & & 0.000 \\
& V de Cramer & 0.289 & & & 0.000 \\
N de casos válidos & & 699 & & & \\
\hline
\end{tabular}

En la legislatura siguiente, la vocación generalista de la actividad propositiva de los representantes de los tres partidos desciende y en todos aumenta la promoción de los intereses parroquiales de sus distritos. En la bancada del PLD, del 10\% en 1998-2002 ascienden al 45\% las iniciativas que tienen por objetivo gestionar una pensión para un elector de su distrito; en el PRD del $29 \%$ pasan al 68\%; y en el PRSC del 46\% asciende al 62\%. Esta legislatura de 2002-2006 da inicio a la etapa post carismática ya que los tres caudillos históricos Bosch, Balaguer y Peña Gómez mueren entre 1998 y 2002. Con su desaparición comienza la progresiva desideologización del sistema de partidos dominicano y la importancia de la campaña en la conquista del electorado dominicano. Como se analizará en los apartados correspondientes al diseño electoral y a la competencia interpartidista, la pérdida del asidero ideológico que aportaban los líderes históricos es suplida por el vínculo más directo con el elector a través del voto preferencial utilizado por primera vez en las elecciones de 2002. La relación entre particularismo y partido político es estadísticamente significativa, siendo los representantes del PRD los más propensos a favorecer intereses de individuos concretos. A pesar de que los diputados perredeístas son mayoría en la Cámara y controlan el Ejecutivo, solo el 18,7\% de sus iniciativas son de carácter general. 
Tabla 2.4.3.A.3 Proposiciones de Ley por nivel de particularismo y partido, Legislatura 2002-2006

\begin{tabular}{|c|c|c|c|c|c|c|c|c|c|c|c|c|}
\hline \multicolumn{13}{|c|}{ 2002-2006 } \\
\hline & & PLD & PRD & PRSC & PLD/PRD/PRSC & PLD/PRD & PRD/PRSC & PLD/PRSC & PPC & FNP & Otras & Total \\
\hline \multirow{2}{*}{ General } & $\mathbf{N}$ & 26 & 51 & 48 & 27 & 7 & 4 & 5 & 6 & 8 & 23 & 205 \\
\hline & $\%$ & 45.6 & 18.7 & 26.1 & 39.7 & 33.3 & 11.1 & 62.5 & 35.3 & 72.7 & 62.2 & 28.8 \\
\hline \multirow{2}{*}{ Corporativa } & $\mathbf{N}$ & 5 & 35 & 22 & 22 & 7 & 16 & 1 & 1 & 0 & 2 & 111 \\
\hline & $\%$ & 8.8 & 12.8 & 12.0 & 32.4 & 33.3 & 44.4 & 12.5 & 5.9 & 0.0 & 5.4 & 15.6 \\
\hline \multirow{2}{*}{ Individual } & $\mathbf{N}$ & 26 & 187 & 114 & 19 & 7 & 16 & 2 & 10 & 3 & 12 & 397 \\
\hline & $\%$ & 45.6 & 68.5 & 62.0 & 27.9 & 33.3 & 44.4 & 25.0 & 58.8 & 27.3 & 32.4 & 55.7 \\
\hline \multirow{2}{*}{ Total } & $\mathbf{N}$ & 57 & 273 & 184 & 68 & 21 & 36 & 8 & 17 & 11 & 37 & 713 \\
\hline & $\%$ & 100 & 100 & 100.0 & 100 & 100 & 100 & 100 & 100 & 100 & 100 & 100 \\
\hline
\end{tabular}

Fuente: Elaboración propia

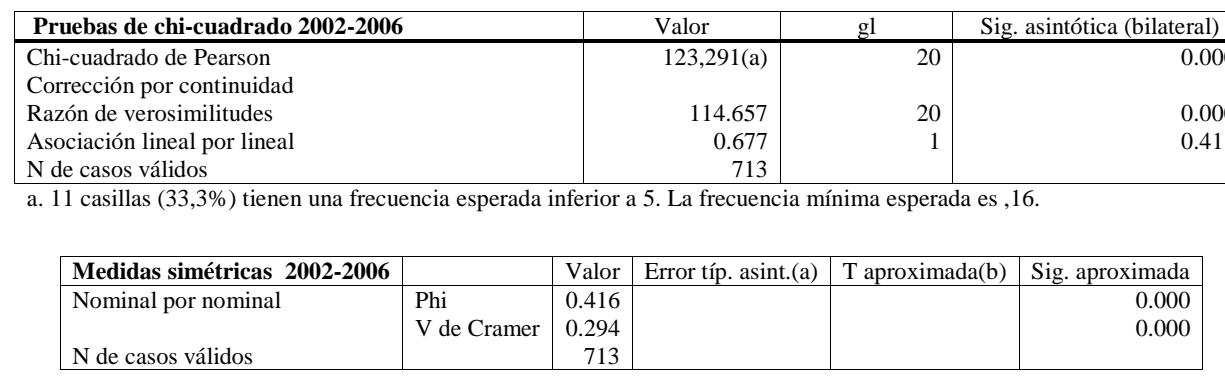

Por último, en la legislatura menos particularista de las tres estudiadas (2006-2010), aumenta el porcentaje de iniciativas que tienen como finalidad la promoción de intereses generales en los tres partidos mayoritarios, aunque son los representantes del PRSC los que más gestionan la concesión de pensiones para electores de su circunscripción $(55,3 \%)$, siendo la relación estadísticamente significativa. En este periodo, el partido con mayor número de representantes y que controla el Ejecutivo es también el que cuenta con más iniciativas generales que han sido aprobadas a trámite.

La actividad propositiva de los diputados ofrece información acerca del presidencialismo pluralista en la República Dominicana y de cómo son las relaciones Legislativo-Ejecutivo en el país. En las elecciones de 2006 PRD y PRSC concurren en alianza a las legislativas y municipales. Sin embargo sus representantes solo elevaron a trámite 5 iniciativas de naturaleza general de forma conjunta, frente a las 20 ocasiones en que así lo hicieron el oficialista PLD y los representantes del opositor PRD (Tabla 2.4.3.A.4). En la legislatura 2002-2006 (Tabla 2.4.3.A.3) estos dos enemigos históricos colaboraron más para satisfacer los intereses particulares de los electores de sus distritos $(44,4 \%)$ que para proponer leyes generales $(11 \%)$. Las tres legislaturas comparten la escasa actividad fiscalizadora del legislativo dominicano sobre la acción del gobierno, ya que estas iniciativas han representando entre el $0,41 \%$ y $1,22 \%$ del total de Proyectos de Ley presentados a trámite (Ver Tabla 2.4.3.A.1).

A pesar de que los representantes del PRD tienen mayoría en la Cámara de Diputados en 2002-2006 y controlan el Ejecutivo, solo un $18 \%$ de sus proposiciones elevadas a trámite tienen como finalidad promover intereses que benefician a la generalidad. Estos datos parecen apuntar a la distribución de tareas que confirmaría en el país la antítesis del "secreto de la eficiencia" (Amorim Neto y Santos 2003) en la relación Legislativo-Ejecutivo que identificara Cox (1987) y la imposibilidad de concretar políticas públicas a nivel nacional en el Legislativo dominicano. Como se argumentará en el capítulo dedicado a la cooperación estratégica entre partidos, en la etapa de la consolidación democrática la práctica aliancista en el país dista mucho del presidencialismo de coalición del Cono Sur y los acuerdos entre partidos son alianzas para ganar no para gobernar. 
Tabla 2.4.3.A.4 Proposiciones de Ley por nivel de particularismo y partido, Legislatura 2006-2010

\begin{tabular}{|c|c|c|c|c|c|c|c|c|c|c|c|c|}
\hline \multicolumn{13}{|c|}{ 2006-2010 } \\
\hline & & PLD & PRD & PRSC & PLD/PRD/PRSC & PLD/PRD & PRD/PRSC & PLD/PRSC & PPC & FNP & Otras & Total \\
\hline \multirow{2}{*}{ General } & $\mathbf{N}$ & 85 & 52 & 15 & 25 & 20 & 5 & 5 & 2 & 24 & 20 & 253 \\
\hline & $\%$ & 64.4 & 53.6 & 31.9 & 71.4 & 69.0 & 55.6 & 71.4 & 100 & 92.3 & 87.0 & 62.2 \\
\hline \multirow{2}{*}{ Corporativa } & $\mathbf{N}$ & 15 & 16 & 6 & 6 & 7 & 3 & 1 & 0 & 1 & 2 & 57 \\
\hline & $\%$ & 11.4 & 16.5 & 12.8 & 17.1 & 24.1 & 33.3 & 14.3 & 0.0 & 3.8 & 8.7 & 14.0 \\
\hline \multirow{2}{*}{ Individual } & $\mathbf{N}$ & 32 & 29 & 26 & 4 & 2 & 1 & 1 & 0 & 1 & 1 & 97 \\
\hline & $\%$ & 24.2 & 29.9 & 55.3 & 11.4 & 6.9 & 11.1 & 14.3 & 0.0 & 3.8 & 4.3 & 23.8 \\
\hline \multirow{2}{*}{ Total } & $\mathbf{N}$ & 132 & 97 & 47 & 35 & 29 & 9 & 7 & 2 & 26 & 23 & 407 \\
\hline & $\%$ & 100 & 100 & 100 & 100 & 100 & 100 & 100 & 100 & 100 & 100 & 100 \\
\hline
\end{tabular}

Fuente: Elaboración propia

\begin{tabular}{|c|c|c|c|c|c|c|}
\hline \multicolumn{3}{|l|}{ Pruebas de chi-cuadrado 2006-2010 } & Valor & gl & & asintótica (bilater \\
\hline \multicolumn{3}{|l|}{ Chi-cuadrado de Pearson } & $60,315(a)$ & 18 & & \\
\hline \multicolumn{3}{|l|}{ Corrección por continuidad } & & & & \\
\hline \multicolumn{3}{|l|}{ Razón de verosimilitudes } & 62.513 & 18 & & \\
\hline \multicolumn{3}{|l|}{ Asociación lineal por lineal } & 17.010 & 1 & & \\
\hline \multicolumn{3}{|c|}{\begin{tabular}{l|l}
$\mathrm{N}$ de casos válidos & \\
\end{tabular}} & 407 & & & \\
\hline \multicolumn{7}{|c|}{ a. 12 casillas $(40,0 \%)$ tienen una frecuencia esperada inferior a 5. La frecuencia mínima esperada es ,28. } \\
\hline Medidas simétricas 2006-2010 & & Valor & Error típ. asint.(a) & T aproximada & & Sig. aproximada \\
\hline Nominal por nominal & & 0.385 & & & & 0.000 \\
\hline & V de Cramer & 0.272 & & & & 0.000 \\
\hline $\mathrm{N}$ de casos válidos & & 407 & & & & \\
\hline
\end{tabular}

Para ponderar la actividad propositiva particularista en relación al peso de las bancadas, se calcula el coeficiente que mide el exceso o defecto de actividad teniendo en cuenta el porcentaje anual de iniciativas elevadas a trámite por los diputados de ese partido en relación a su control de los escaños parlamentarios $^{28}$. Como muestran las tablas siguientes, en la legislatura 1998-2002 los representantes reformistas son los que promueven más intereses clientelares durante los cuatro años de vigencia del mandato de representación. En la legislatura 2002-2006, de nuevo el PRSC es el que cuenta con un coeficiente de actividad superior en relación a su presencia en las instituciones legislativas en los años 2002, 2003 y 2006, mientras que el PRD lo hace en los años 2004 y 2005. Este partido pierde el control del Ejecutivo en las presidenciales de 2004, por lo que el repunte de la actividad propositiva concesional de los diputados del PRD podría estar compensando la falta de control de otros escenarios de la representación. El periodo 2006-2010 el PRD y especialmente el PRSC que en las elecciones de 2010 conquisto el $10 \%$ de los votos, se alternan en la sobreactividad particularista en una legislatura en la que el oficialista PLD cuenta con la mayoría de escaños.

Estos datos revelan el impacto de la procedencia de las elites en aquellos partidos «internamente movilizados» como es el caso del PRSC. Como se analiza en el capítulo dedicado al peso de la historia, en la transición a la política de masas los actores que ocupaban posiciones en el gobierno anterior con acceso a los recursos del Estado, tenderán a seguir utilizando el patronazgo como un arma de movilización de sus bases con el cambio a la democracia (Shefter 1994). Estas decisiones de elección social y de organización que se adoptan en momentos históricos coyunturales clave, tienden a condicionar la orientación de las políticas en el largo plazo.

\footnotetext{
${ }^{28}$ Se calcula dividiendo el \% de iniciativas particulares anuales tramitadas ese partido entre el \% de escaños de esa fuerza política. El valor 1 indica proporción entre iniciativas y peso del partido en la Cámara de Diputados; valores por debajo de 1 déficit de actividad; y valores por encima del 1 un exceso de actividad a la esperada teniendo en cuenta el número de representantes de esa fuerza política.
} 
Tabla 2.4.3.A.5 Ponderación Proposiciones de Ley de carácter INDIVIDUAL por número de representantes, Legislatura 1998-2002

\begin{tabular}{|c|c|c|c|c|c|c|c|c|c|c|c|c|c|c|c|c|c|c|c|c|c|c|c|c|}
\hline \multicolumn{5}{|c|}{1998} & \multicolumn{5}{|c|}{1999} & \multicolumn{5}{|c|}{2000} & \multicolumn{5}{|c|}{2001} & \multicolumn{5}{|c|}{2002} \\
\hline Partido & $N$ & $\%$ & $\begin{array}{c}\% \\
\text { esc. }\end{array}$ & Coef. & Partido & $N$ & $\%$ & $\begin{array}{c}\% \\
\text { esc. }\end{array}$ & Coef. & Partido & $N$ & $\%$ & $\begin{array}{c}\% \\
\text { esc. }\end{array}$ & Coef. & Partido & $N$ & $\%$ & $\begin{array}{c}\% \\
\text { esc. }\end{array}$ & Coef. & Partido & $N$ & $\%$ & $\begin{array}{l}\% \\
\text { esc. }\end{array}$ & Coef. \\
\hline PLD & 1 & 50.00 & 30.87 & 1.62 & PRD & 8 & 44.44 & 51.67 & 0.86 & PRD & 30 & 36.59 & 51.67 & 0.71 & PRD & 21 & 42.86 & 51.67 & 0.83 & PRD & 16 & 47.06 & 51.67 & 0.91 \\
\hline \multirow{11}{*}{ PRSC } & 1 & 50.00 & 10.73 & 4.66 & PRSC & 4 & 22.22 & 10.73 & 2.07 & PRSC & 23 & 28.05 & 10.73 & 2.61 & PRSC & 17 & 34.69 & 10.73 & 3.23 & PRSC & 14 & 41.18 & 10.73 & 3.84 \\
\hline & & & & & PLD & 1 & 5.56 & 30.87 & 0.18 & PLD & 6 & 7.32 & 30.87 & 0.24 & PLD & 2 & 4.08 & 30.87 & 0.13 & & & & & \\
\hline & & & & & PLD/PRD & 1 & 5.56 & 82.54 & 0.07 & PPC & 5 & 6.10 & 1.34 & 4.55 & PRD/PRSC & 3 & 6.12 & 62.39 & 0.10 & $\begin{array}{l}\text { PLD/PRD/ } \\
\text { PRSC }\end{array}$ & 3 & 8.82 & 93.27 & 0.09 \\
\hline & & & & & PRD/PRSC & 1 & 5.56 & 62.39 & 0.09 & PLD/PRD & 7 & 8.54 & 82.54 & 0.10 & $\begin{array}{l}\text { PLD/PRD/ } \\
\text { PRSC }\end{array}$ & 2 & 4.08 & 93.27 & 0.04 & PLD/PRD & 1 & 2.94 & 82.54 & 0.04 \\
\hline & & & & & PRSC/PPC & 1 & 5.56 & 12.07 & 0.46 & PRD/PRSC & 3 & 3.66 & 62.39 & 0.06 & & 1 & 2.04 & 1.34 & 1.52 & & & & & \\
\hline & & & & & PLD/PRD/PRSC & 1 & 5.56 & 93.27 & 0.06 & PLD/PRD/PRSC & 3 & 3.66 & 93.27 & 0.04 & PLD/PRD & 1 & 2.04 & 82.54 & 0.02 & & & & & \\
\hline & & & & & $\begin{array}{l}\text { PLD/PRD/PRSC/ } \\
\text { PRI }\end{array}$ & 1 & 5.56 & 93.94 & 0.06 & PRD/PRSC/UD & 1 & 1.22 & 63.74 & 0.02 & $\begin{array}{l}\text { PLD/PRD/PRSC/ } \\
\text { BIP/PPC }\end{array}$ & 1 & 2.04 & 95.27 & 0.02 & & & & & \\
\hline & & & & & & & & & & PRD/PPC & 1 & 1.22 & 53.01 & 0.02 & $\begin{array}{l}\text { PNVC/UD/PQD/ } \\
\text { MIUCA/CD }\end{array}$ & 1 & 2.04 & 4.02 & 0.51 & & & & & \\
\hline & & & & & & & & & & PRD/BIP & 1 & 1.22 & 52.34 & 0.02 & $\begin{array}{l}\text { PLD/PRD/ } \\
\text { PRSC }\end{array}$ & 2 & 4.08 & 93.27 & 0.04 & & & & & \\
\hline & & & & & & & & & & $\begin{array}{l}\text { PRD/PPC/ } \\
\text { MIUCA }\end{array}$ & 1 & 1.22 & 53.68 & 0.02 & PPC & 1 & 2.04 & 1.34 & 1.52 & & & & & \\
\hline & & & & & & & & & & PLD/PRSC/PPC & 1 & 1.22 & 42.94 & 0.03 & & & & & & & & & & \\
\hline Total & 2 & 100 & & & Total & 18 & 100 & & & Total & 82 & 100 & & & Total & 49 & 100 & & & Total & 34 & 100 & & \\
\hline
\end{tabular}


Tabla 2.4.3.A.6 Ponderación Proposiciones de Ley de carácter INDIVIDUAL por número de representantes, Legislatura 2002-2006

\begin{tabular}{|c|c|c|c|c|c|c|c|c|c|c|c|c|c|c|c|c|c|c|c|c|c|c|c|c|}
\hline \multicolumn{5}{|c|}{2002} & \multicolumn{5}{|c|}{2003} & \multicolumn{5}{|c|}{2004} & \multicolumn{5}{|c|}{2005} & \multicolumn{5}{|c|}{2006} \\
\hline Partido & $N$ & $\%$ & \% esc & Coef. & Partido & $N$ & $\%$ & \% esc & Coef. & Partido & $N$ & $\%$ & \% esc & Coef. & Partido & $N$ & $\%$ & \% esc & Coef. & Partido & $N$ & $\%$ & \% esc & Coef. \\
\hline PRD & 15 & 27.78 & 48.00 & 0.58 & PRD & 63 & 43.15 & 48.00 & 0.90 & PRD & 49 & 61.25 & 48.00 & 1.28 & PRD & 37 & 62.71 & 48.00 & 1.31 & PRD & 23 & 41.07 & 48.00 & 0.86 \\
\hline PRSC & 27 & 50.00 & 23.00 & 2.17 & PRSC & 47 & 32.19 & 23.00 & 1.40 & PRSC & 19 & 23.75 & 23.00 & 1.03 & PLD & 8 & 13.56 & 26.00 & 0.52 & PRSC & 14 & 25.00 & 23.00 & 1.09 \\
\hline PLD & 2 & 3.70 & 26.00 & 0.14 & PLD & 4 & 2.74 & 26.00 & 0.11 & PLD & 2 & 2.50 & 26.00 & 0.10 & PRSC & 7 & 11.86 & 23.00 & 0.52 & PLD & 10 & 17.86 & 26.00 & 0.69 \\
\hline PPC & 3 & 5.56 & 0.66 & 8.42 & $\begin{array}{l}\text { PLD/ } \\
\text { PRD/ } \\
\text { PRSC }\end{array}$ & 9 & 6.16 & 97.00 & 0.06 & PPC & 1 & 1.25 & 0.66 & 1.89 & $\begin{array}{l}\text { PLD/ } \\
\text { PRD/ } \\
\text { PRSC }\end{array}$ & 5 & 8.47 & 97.00 & 0.09 & $\begin{array}{l}\text { PLD/ } \\
\text { PRD/ } \\
\text { PRSC/ } \\
\text { FNP }\end{array}$ & 3 & 5.36 & 98.33 & 0.05 \\
\hline $\begin{array}{l}\text { PLD/ } \\
\text { PRD }\end{array}$ & 3 & 5.56 & 74.00 & 0.08 & $\begin{array}{l}\text { PRD/ } \\
\text { PRSC }\end{array}$ & 10 & 6.85 & 71.00 & 0.10 & $\begin{array}{l}\text { PRD/ } \\
\text { PPC } \\
\text { PLD/ }\end{array}$ & 1 & 1.25 & 48.66 & 0.03 & $\begin{array}{l}\text { PLD/ } \\
\text { PRSC } \\
\text { PLD/ }\end{array}$ & 1 & 1.69 & 49.00 & 0.03 & FNP & 2 & 3.57 & 1.33 & 2.69 \\
\hline $\begin{array}{l}\text { PRD/ } \\
\text { PRSC }\end{array}$ & 2 & 3.70 & 71.00 & 0.05 & PPC & 6 & 4.11 & 0.66 & 6.23 & $\begin{array}{l}\text { PRD/ } \\
\text { PRSC/ } \\
\text { PPC }\end{array}$ & 1 & 1.25 & 97.66 & 0.01 & $\begin{array}{l}\text { PRD/ } \\
\text { PRSC/ } \\
\text { PPC }\end{array}$ & 1 & 1.69 & 97.66 & 0.02 & $\begin{array}{l}\text { PRD/ } \\
\text { PRSC }\end{array}$ & 1 & 1.79 & 71.00 & 0.03 \\
\hline $\begin{array}{l}\text { PRSC/ } \\
\text { FNP }\end{array}$ & 1 & 1.85 & 24.33 & 0.08 & $\begin{array}{l}\text { PLD/ } \\
\text { PRD }\end{array}$ & 4 & 2.74 & 74.00 & 0.04 & $\begin{array}{l}\text { PLD/ } \\
\text { PRD/ } \\
\text { PRSC }\end{array}$ & 4 & 5.00 & 97.00 & 0.05 & & & & & & $\begin{array}{l}\text { PLD/ } \\
\text { PRD/ } \\
\text { PRSC }\end{array}$ & 1 & 1.79 & 97.00 & 0.02 \\
\hline $\begin{array}{l}\text { PRSC/ } \\
\text { PPC }\end{array}$ & 1 & 1.85 & 23.66 & 0.08 & FNP & 1 & 0.68 & 1.33 & 0.51 & $\begin{array}{l}\text { PRD/ } \\
\text { PRSC }\end{array}$ & 3 & 3.75 & 71.00 & 0.05 & & & & & & $\begin{array}{l}\text { PLD// } \\
\text { PRD/ } \\
\text { PRSC/ } \\
\text { PPC/ } \\
\text { FNP }\end{array}$ & 1 & 1.79 & 98.99 & 0.02 \\
\hline FNP & 0 & 0.00 & 1.33 & 0.00 & $\begin{array}{l}\text { PLD/ } \\
\text { PRSC } \\
\\
\text { PLD/ } \\
\text { PRD/ } \\
\text { PRSC/ } \\
\text { PPC/ } \\
\text { FNP }\end{array}$ & 1 & 0.68 & 49.00 & 0.01 & & & & & & & & & & & $\begin{array}{l}\text { PRD/ } \\
\text { PRSC/ } \\
\text { FNP }\end{array}$ & 1 & 1.79 & 72.33 & 0.02 \\
\hline Total & 54 & 100 & & & Total & 146 & 100 & & & Total & 80 & 100 & & & Total & 59 & 100 & & & Total & & 56 & & \\
\hline
\end{tabular}


Tabla 2.4.3.A.7 Ponderación Proposiciones de Ley de carácter INDIVIDUAL por número de representantes, Legislatura $2006-2010$

\begin{tabular}{|c|c|c|c|c|c|c|c|c|c|c|c|c|c|c|c|c|c|c|c|c|c|c|c|c|}
\hline \multicolumn{5}{|c|}{2006} & \multicolumn{5}{|c|}{2007} & \multicolumn{5}{|c|}{2008} & \multicolumn{5}{|c|}{2009} & \multicolumn{5}{|c|}{2010} \\
\hline Partido & $N$ & $\%$ & $\%$ esc & Coef. & Partido & $N$ & $\%$ & \% esc & Coef. & Partido & $N$ & $\%$ & $\%$ esc & Coef. & Partido & $N$ & $\%$ & $\begin{array}{l}\% \\
\text { esc }\end{array}$ & Coef. & Partido & $N$ & $\%$ & \% esc & Coef \\
\hline PLD & 7 & 35.00 & 52.81 & 0.66 & PRSC & 13 & 35.14 & 21.35 & 1.65 & PRSC & 5 & 50.00 & 21.35 & 2.34 & PLD & 9 & 42.86 & 52.81 & 0.81 & PLD & 2 & 22.22 & 52.81 & 0.42 \\
\hline PRD & 6 & 30.00 & 24.16 & 1.24 & PLD & 12 & 32.43 & 52.81 & 0.61 & PLD & 2 & 20.00 & 52.81 & 0.38 & PRD & 9 & 42.86 & 24.16 & 1.77 & PRD & 3 & 33.33 & 24.16 & 1.38 \\
\hline PRSC & 3 & 15.00 & 21.35 & 0.70 & PRD & 9 & 24.32 & 24.16 & 1.01 & PRD & 2 & 20.00 & 24.16 & 0.83 & PRSC & 3 & 14.29 & 21.35 & 0.67 & PRSC & 2 & 22.22 & 21.35 & 1.04 \\
\hline PLD/PRD & 1 & 5.00 & 76.00 & 0.07 & FNP & 1 & 2.70 & 1.12 & 2.41 & PLD/PRSC & 1 & 10.00 & 73.95 & 0.14 & & & & & & $\begin{array}{l}\text { PLD/PRD// } \\
\text { PRSC }\end{array}$ & 2 & 22.22 & 97.00 & 0.23 \\
\hline PRD/PRSC & 1 & 5.00 & 45.00 & 0.11 & PLD/PRD & 1 & 2.70 & 76.00 & 0.04 & & & & & & & & & & & & & & & \\
\hline PRSC/PPC & 1 & 5.00 & 21.50 & 0.23 & $\begin{array}{l}\text { PLD/PRD/ } / \\
\text { PRSC }\end{array}$ & 1 & 2.70 & 97.00 & 0.03 & & & & & & & & & & & & & & & \\
\hline $\begin{array}{l}\text { PLD/PRD/ } \\
\text { PRSC }\end{array}$ & 1 & 5.00 & 97.00 & 0.05 & & & & & & & & & & & & & & & & & & & & \\
\hline Total & 20 & 100 & & & Total & 37 & 100 & & & Total & 10 & 100 & & & Total & 21 & 100 & & & Total & 9 & 100 & & \\
\hline
\end{tabular}

Fuente: Elaboración propia 


\subsubsection{B) ¿Qué conceden los Diputados?: Fondo de Gestión Legislativa o «barrilito» (2008-2009)}

El segundo indicador para medir la VD en el escenario legislativo lo forman las regalías del Fondo de Gestión Social que los diputados otorgaron en su circunscripción durante los años 2008 y 2009. Un total de 2,016 facturas emitidas por la compra de bienes que serán clasificadas en función del nivel de agregación de las preferencias: para el disfrute de un individuo, de un colectivo determinado, o para la generalidad de la comunidad. Hasta el año 2008 no existía ningún tipo de control sobre este tipo de actividad pseudo filantrópica que los legisladores realizaban a través de sus propias fundaciones. Desde esa fecha, estas donaciones han pasado a ser financiadas mensualmente con recursos públicos y sometidas a registro contable ante el Congreso.

El Fondo de Gestión Social Legislativa es conocido informalmente como "barrilito" (senadores) y "cofrecito" (diputados), aunque el primero de los apelativos es el que ha acaparado la designación popular y el que se utiliza en este trabajo. Mientras que los senadores reciben entre \$USD 9,000 y \$usD 20,500 dólares mensuales -dependiendo de la población de sus provincias- los diputados reciben entre \$USD 1,200 y 2,500 dólares al mes. La notable diferencia entre ambas asignaciones confería al estipendio senatorial mayor atractivo para el objeto de esta investigación, sin embargo, la Oficina de Acceso a la Información del Senado solo proporciona datos agregados sin posibilidad de conocer los pormenores de destinatario y contenido de la solicitud del ciudadano. Estos detalles relevantes para conocer el nivel de particularismo fueron facilitados -aunque con ciertas restricciones- por el departamento correspondiente de la Cámara de Diputados de la República Dominicana. Además de estas asignaciones mensuales, diputados y senadores reciben dos estipendios puntuales para el asueto de Semana Santa y la festividad del Día de las Madres, en el que se reparten las tradicionales habichuelas con dulce, canastillas para embarazadas o lavadoras ${ }^{29}$. La competencia y la innovación ha influido en la naturaleza de los agasajos y los regalos también son hoy liposucciones y operaciones de estética ${ }^{30}$.

Ante las restricciones de tiempo y acceso a datos confidenciales de los beneficiarios, se eligieron tres provincias para analizar la naturaleza de la actividad concesional de los diputados dominicanos: las de mayor y menor nivel en el Índice de Desarrollo Humano (IDH) (PNUD 2010) y la situada en el nivel medio de empoderamiento ${ }^{31}$. En cada una de ellas se eligió al azar un diputado de cada una de las fuerzas con representación en la provincia. En la más rica (1) que cuenta con representación de los tres partidos se seleccionaron 3 diputados $^{32}$; en la de nivel medio (2) con representación del PLD y PRD dos diputados ${ }^{33}$; y en la provincia más pobre (3) se observó el comportamiento de los dos diputados del PLD y del PRSC ${ }^{34}$. Durante los años 2008-2009, estas siete unidades de observación manejaron \$USD 210,000 dólares y emitieron las 2,016 facturas que conforman las unidades de análisis en esta investigación. La muestra seleccionada representa el $4 \%$ del universo de los más de cinco millones de dólares (\$USD 5,340,000.00) que los 178 diputados dominicanos manejaron en concepto de asistencia social en sus distritos durante los dos años estudiados.

\footnotetext{
${ }^{29}$ Ver "Diputados confirman recibieron entre RD\$50 y RD\$100 mil para habichuelas con dulces" en Noticias SIN, del 23 de marzo de 2014. En http://www.noticiassin.com/2014/04/diputados-confirmanrecibieron-entre-rd50-y-rd100-mil-para-habichuelas-con-dulces/

${ }^{30}$ Ver "Edgar Contreras regala liposucción en acto de diputado", en periódico El Caribe del 25 de mayo de 2014. En http://www.elcaribe.com.do/2014/05/25/cirujano-edgar-contreras-regala-liposuccion-acto-diputado

${ }^{31}$ El Índice de Desarrollo Humano mide nivel económico, acceso a recursos y ejercicio de derechos en las provincias del país.

${ }^{32}$ Tres diputados observados de los 18 representantes de la provincia.

${ }^{33}$ Dos diputados observados de los 3 representantes de la provincia.

${ }^{34}$ Dos diputados observados de los 2 representantes de la provincia.
} 
Los datos agregados de la Tabla 3.4.3.B.1 muestran que en las tres provincias la mayoría de las donaciones benefician a una sola persona, con porcentajes que superan el $80 \%$ y son mínimas las regalías que benefician a la generalidad, representando entre el $1 \%$ y $4 \%$ del total.

Tabla 3.4.3.B.1 Total Concesiones del Fondo de Gestión Legislativa o "Barrilito" (2008-2009) por nivel de extensión de beneficiarios y provincia

\begin{tabular}{|c|c|c|c|c|c|c|}
\hline & \multicolumn{2}{|c|}{ Provincia 1} & \multicolumn{2}{|c|}{ Provincia 2} & \multicolumn{2}{|c|}{ Provincia 3} \\
\hline & $\mathbf{N}$ & $\%$ & $\mathbf{N}$ & $\%$ & $\mathbf{N}$ & $\%$ \\
\hline INDIVIDUAL & 716 & 81,4 & 560 & 87,6 & 423 & 84,6 \\
\hline CORPORATIVA & 160 & 18,2 & 68 & 10,6 & 54 & 10,8 \\
\hline GENERAL & 1 & 0,1 & 11 & 1,7 & 23 & 4,6 \\
\hline $\mathrm{T}$ & \multicolumn{2}{|c|}{$(\mathrm{N}=877)$} & \multicolumn{2}{|c|}{$(\mathrm{N}=639)$} & \multicolumn{2}{|c|}{$(\mathrm{N}=500)$} \\
\hline
\end{tabular}

Fuente: Elaboración propia a partir de datos facilitados por la Oficina de Acceso a la Información de la Cámara de Diputados de la República Dominicana.

El tratamiento estadístico de los datos muestra oscilaciones por partido y provincia, aunque como reflejan las tablas siguientes, no discriminan entre año electoral (2008) y no electoral (2009). Esta linealidad en los intercambios selectivos evidencia la naturaleza permanente del vínculo particularizado entre político y ciudadano. Atender a los electores del distrito es un modo de accountability en democracia que en el caso dominicano, por un lado interfiere en las funciones que corresponden a la administración central y los ayuntamientos, y por otro, viola el principio de equidad en la distribución de costes y beneficios que ha de guiar toda política pública, ya que son asignaciones guiadas por la apreciación subjetiva del diputado.

En la provincia 1, la de mayor nivel en el Índice de Desarrollo Humano (PNUD 2010), las unidades de observación (3 diputados) representan el 16,6\% de los 18 diputados que conforman el universo en esa provincia y gestionaron un total de \$USD 90,000 dólares ${ }^{35}$. Mientras que los dos diputados de la oposición (PRD y PRSC) dedican casi la totalidad de las ayudas a individuos concretos en porcentajes que oscilan entre el $98 \%$ y el $87 \%$, el diputado oficialista del PLD opta por dividir sus regalías entre bienes de club (52,3\%) y bienes selectivos a particulares $(46,8 \%)$ (Ver Tabla 3.4.3.B.2

Tabla 3.4.3.B.2 Concesiones "Barrilito" por nivel de extensión de beneficiarios, partido y año electoral, Provincia Nivel Alto IDH

\begin{tabular}{|c|c|c|c|c|c|c|c|c|c|c|c|c|}
\hline \multicolumn{13}{|c|}{ PROVINCIA 1} \\
\hline \multirow{6}{*}{$\begin{array}{l}\text { General } \\
\text { Corporativa } \\
\text { Individual }\end{array}$} & \multicolumn{6}{|c|}{$\begin{array}{c}2008 \\
\text { Año Electoral }\end{array}$} & \multicolumn{6}{|c|}{$\begin{array}{c}2009 \\
\text { Año NO Electoral }\end{array}$} \\
\hline & \multicolumn{2}{|c|}{ PLD } & \multicolumn{2}{|c|}{ PRD } & \multicolumn{2}{|c|}{ PRSC } & \multicolumn{2}{|c|}{ PLD } & \multicolumn{2}{|c|}{ PRD } & \multicolumn{2}{|c|}{ PRSC } \\
\hline & $\%$ & $\mathrm{~N}$ & $\%$ & $\mathrm{~N}$ & $\%$ & $\mathrm{~N}$ & $\%$ & $\mathrm{~N}$ & $\%$ & $\mathrm{~N}$ & $\%$ & $\mathrm{~N}$ \\
\hline & 0.0 & 0 & 0.0 & 0 & 0.5 & 1 & 0.0 & 0 & 0.0 & 0 & 0.0 & 0 \\
\hline & 52.3 & 57 & 1.9 & 2 & 8.5 & 18 & 45.9 & 50 & 5.0 & 5 & 11.5 & 28 \\
\hline & 46.8 & 51 & 98.1 & 101 & 90.6 & 192 & 54.1 & 59 & 95.0 & 95 & 87.3 & 213 \\
\hline Broker & 0.9 & 1 & 0.0 & 0 & 0.5 & 1 & 0.0 & 0 & 0.0 & 0 & 1.2 & 3 \\
\hline Diputado & 0.0 & 0 & 0.0 & 0 & 0.0 & 0 & 0.0 & 0 & 0.0 & 0 & 0.0 & 0 \\
\hline Total & 100 & 109 & 100 & 103 & 100 & 212 & 100 & 109 & 100 & 100 & 100 & 244 \\
\hline
\end{tabular}

Fuente: Elaboración propia a partir de datos facilitados por la Oficina de Acceso a la Información de la Cámara de Diputados de la República Dominicana.

\footnotetext{
${ }^{35}$ De los 18 legisladores de la provincia, 11 diputados (61\%) eran del oficialista PLD, 4 (el 22\%) eran representantes del PRD, y 3 (16\%) del PRSC.
} 
En contextos de alta competencia y recursos limitados como el dominicano, se tiende a diversificar el portafolio de opciones. La preferencia por la asignación de ayudas a colectivos obedece a la rentabilidad de la movilización corporativa. Los presidentes de sindicatos, de las juntas de vecinos, clubs deportivos o asociaciones de mujeres tienen el poder de negociar directamente con el patrón político y trasmitir la lealtad debida a sus asociados. Como muestra la foto siguiente, el intermediario advierte al diputado de la conveniencia de conceder la ayuda y escribe en el reverso de la solicitud: «ella es del grupo de la iglesia, suma muchos votos comunitarios». De esta manera, es menor el coste de la logística y mayor la rentabilidad electoral. En la asignación focalizada, el desperdicio entre gorrones u oportunistas es menor y el crédito del diputado como conseguidor no se diluye entre la generalidad de los habitantes del distrito.

Foto 3.4.3.B.1 Anotación del intermediario en la solicitud y ejemplo ayuda bienes de club

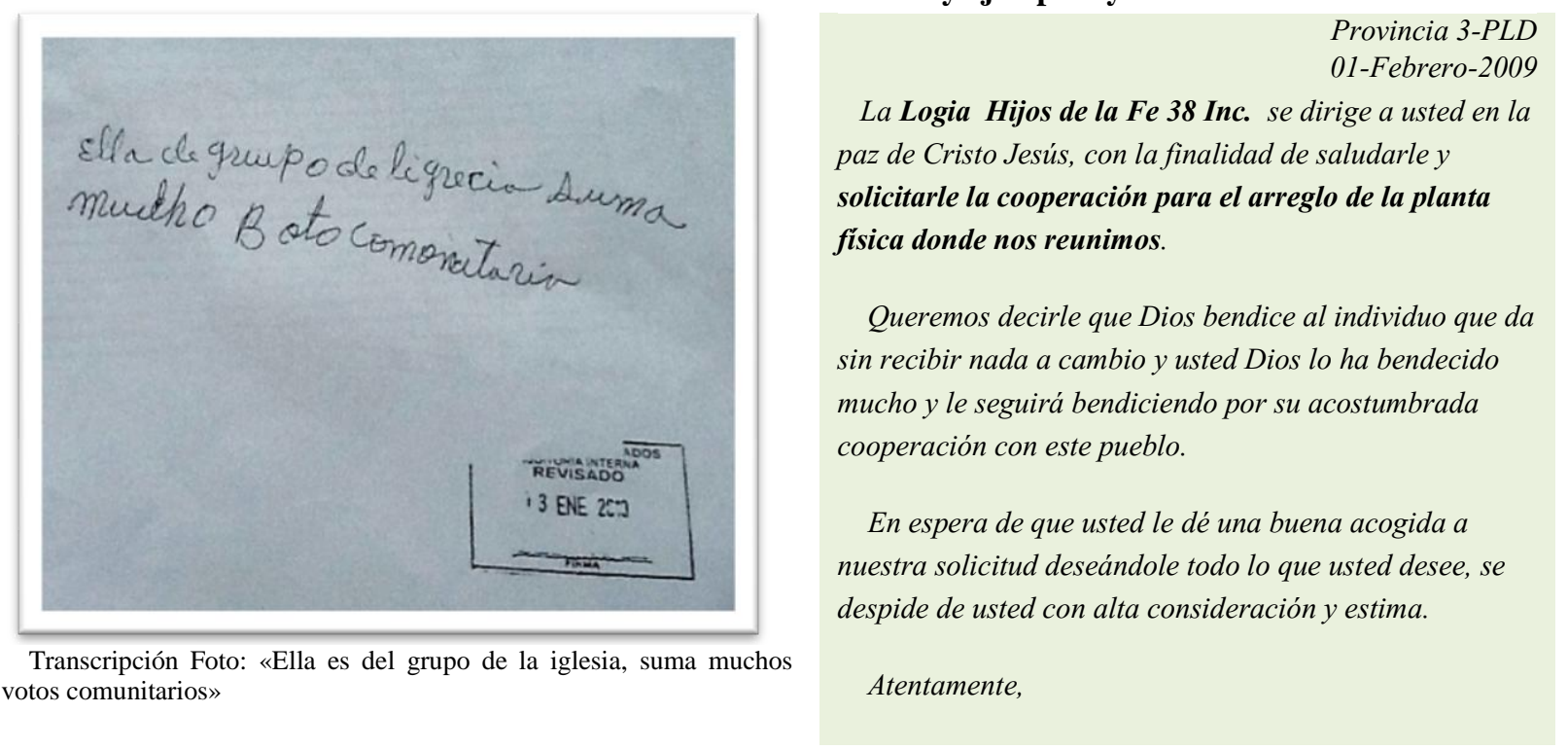

De las 877 ayudas de la provincia 1 , solo una $(0,1 \%)$ asigna bienes que puedan ser disfrutados por toda la comunidad. El tratamiento estadístico de los datos revela que cuanto mayor es el posicionamiento de la provincia en el IDH, menor es la inclusividad de la representación o disfrute de los bienes otorgados por los diputados. En la provincia 3, la más pobre del país, los diputados destinan mayor porcentaje de ayudas para bienes y servicios que pueden ser disfrutados por todos los munícipes. Estos datos validan el rechazo al determinismo del enfoque desarrollista que asocia pobreza y particularismo. Esta relación inversa entre el nivel de empoderamiento socioeconómico provincial y la extensión de los intereses representados podría obedecer a una elección estratégica del diputado para maximizar votos. En la provincia 3 (Tabla 3.4.3.B.6) donde el nivel de renta de la mayoría de sus habitantes es muy bajo y carecen de servicios básicos, una obra de infraestructura local le dará rédito personal al patrón/diputado y le ayudará a conquistar clientes de su contrincante. Por el contrario, en la provincia 1 (Tabla 3.4.3.B.2) con mayor nivel de renta y mejor acondicionamiento en cuanto a servicios públicos, el diputado puede obtener mayor crédito de la atención personalizada, ya que ese tipo de gastos en infraestructura o servicios para toda la comunidad son suplidos por la administración correspondiente. En los niveles intermedios de renta y disponibilidad de servicios públicos como en la provincia 2, los patronos optan por el nivel medio de extensión de beneficiarios a través de la atención colectiva focalizada (Tabla 3.4.3.B.5). 
Estas asignaciones generales no selectivas -de cuyo uso no se puede excluir a beneficiarios concretos- suelen tener por objeto sufragar las deficiencias en la infraestructura municipal (falta de agua corriente, corte del suministro de energía eléctrica, arreglar caminos vecinales...) y actividades recreativas o culturales para la comunidad, como sufragar las fiestas patronales entre otras (Ver Tabla 3.4.3.B.3).

Tabla 3.4.3.B.3 Ejemplos solicitudes ayudas concedidas para toda la comunidad

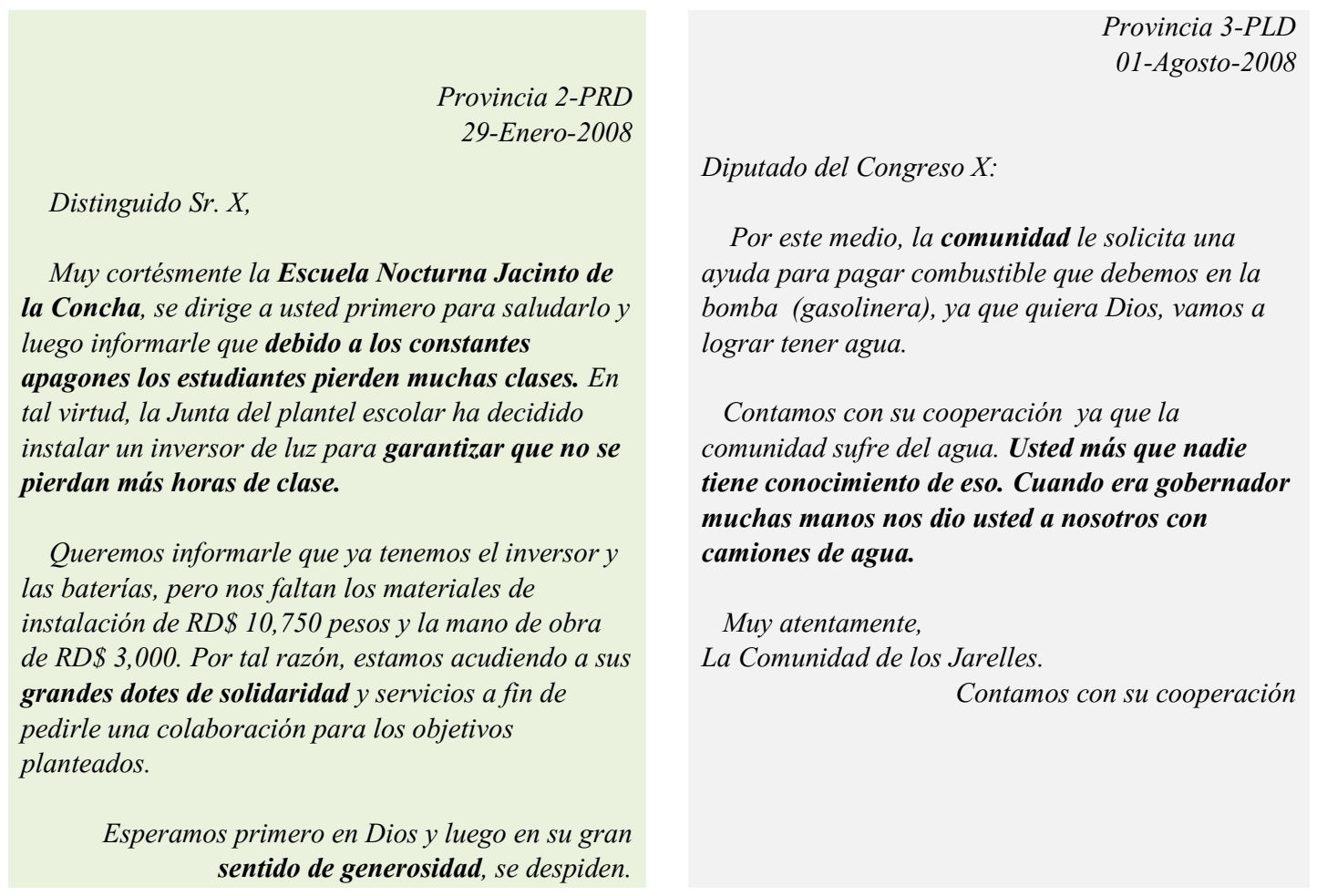

Además de catalogar la naturaleza de la representación por el nivel de inclusión de los beneficiarios -individual, corporativa y general- se incluyeron dos categorías ad hoc para tipificar regalías solicitadas por un mismo individuo pero gestionadas a nombre de terceros sin identificar, y también aquellas que benefician directamente al propio diputado.

Con respecto a las primeras, generalmente el beneficiario final de la ayuda es quien gestiona la solicitud ante el diputado. Es por ello que la ausencia de destinatario final identificado con nombre y apellido en la solicitud y la presencia continuada de estos intermediarios delatan la red piramidal de brókeres al servicio del legislador. En estas facturas tramitadas por los mismos brókeres a lo largo de los dos años aparece en el concepto de destinatario la leyenda: «para familias de escasos recursos». En la provincia 1, los brókeres son utilizados por el diputado del PLD y el del PRSC, aunque este último de forma muy limitada ( en 1 y 3 ocasiones respectivamente). 
Foto 3.4.3.B.2 Solicitud gestionada por bróker al servicio del diputado sin destinatario identificado

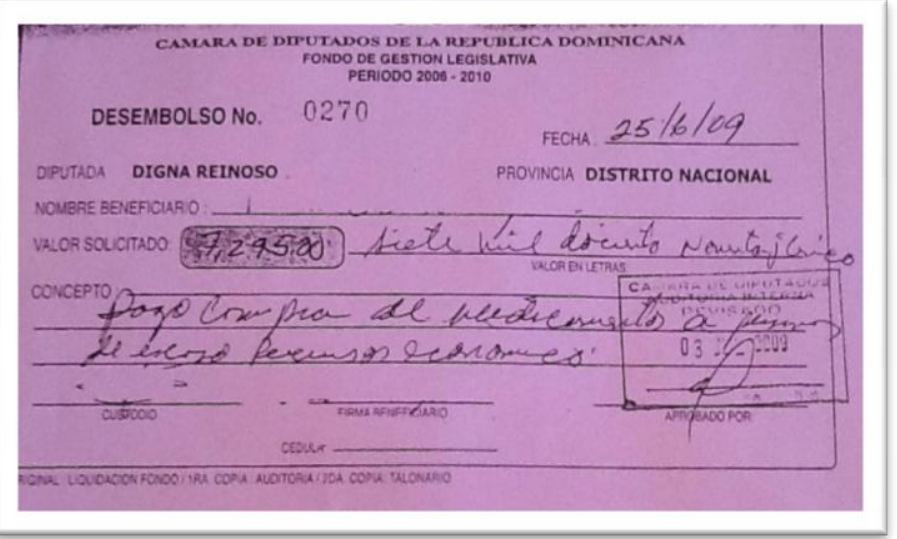

Transcripción: «pago compra de medicamentos a personas de escasos recursos económicos»

La presencia de los intermediarios que colaboran con el diputado en estas actividades asistencialistas aporta pistas acerca de la decisión de organización en los modernos partidos clientelares. El número de intervenciones de estos colaboradores es indicador del tamaño de la red piramidal de brókeres que conforman la maquinaria del partido. Al desagregar por partido y provincia se observan diferencias entre el oficialista PLD y los diputados del PRD y PRSC. Como muestra la Tabla 3.4.3.B.4 los diputados del oficialista PLD cuentan con una red de brókeres en las tres provincias y su número aumenta cuanto menor es el posicionamiento de la provincia en el Índice de Empoderamiento Humano. El acceso a los recursos del Estado a nivel nacional (gobierno central) y regional (gobernadores) permite al partido oficialista disponer de una red de intermediarios más compleja que la de sus opositores para atender a su mayor número de clientes.

Tabla 3.4.3.B.4 Red de intermediarios colaboradores por partido y provincia

\begin{tabular}{|c|c|c|c|c|c|c|c|c|c|c|c|c|}
\hline \multicolumn{13}{|c|}{ INTERMEDIARIOS POR PARTIDO } \\
\hline & \multicolumn{6}{|c|}{$\begin{array}{c}2008 \\
\text { Año Electoral } \\
\end{array}$} & \multicolumn{6}{|c|}{$\begin{array}{c}2009 \\
\text { Año NO Electoral } \\
\end{array}$} \\
\hline & \multicolumn{2}{|c|}{ PLD } & \multicolumn{2}{|c|}{ PRD } & \multicolumn{2}{|l|}{ PRSC } & \multicolumn{2}{|c|}{ PLD } & \multicolumn{2}{|c|}{ PRD } & \multicolumn{2}{|c|}{ PRSC } \\
\hline & $\%$ & $\mathrm{~N}$ & $\%$ & $\mathrm{~N}$ & $\%$ & $\mathrm{~N}$ & $\%$ & $\mathrm{~N}$ & $\%$ & $\mathrm{~N}$ & $\%$ & $\mathrm{~N}$ \\
\hline $\begin{array}{l}\text { Provincia } 1 \\
\text { (IDH Alto) }\end{array}$ & 5.6 & $\mathbf{1}$ & 0.0 & 0 & 50.0 & 1 & 0.0 & $\mathbf{0}$ & 0.0 & 0 & 100.0 & 3 \\
\hline $\begin{array}{l}\text { Provincia } 2 \\
\text { (IDH Medio) }\end{array}$ & 22.2 & 4 & 100.0 & 1 & -- & -- & 15.0 & 3 & 0.0 & 0 & -- & -- \\
\hline $\begin{array}{l}\text { Provincia } 3 \\
\text { (IDH Bajo) }\end{array}$ & 72.2 & 13 & -- & -- & 50.0 & $\mathbf{1}$ & 85.0 & 17 & -- & -- & 0.0 & 0 \\
\hline Total & 100 & 18 & 100 & 1 & 100.0 & 2 & 100 & 20 & 0.0 & 0 & 100 & 3 \\
\hline
\end{tabular}

Fuente: Elaboración propia a partir de datos facilitados por la Oficina de Acceso a la Información de la Cámara de Diputados de la República Dominicana.

En cuanto al contenido de estas solicitudes, los intermediarios gestionaron la compra de materiales de construcción, el pago de la matrícula de la universidad a estudiantes de la provincia, uniformes para clubs deportivos y la tramitación de cédulas de identidad en diversas Oficialías de la provincia. En 2011, se estimaba que el 3,9\% de la población dominicana carecía de registro civil (ONE 2011). La ausencia de este documento impide el ejercicio de derechos civiles y políticos tales como acceder al sistema público de educación universitaria o votar. En términos de la relación patróncliente, si es tu diputado quien te ayuda a adquirir el estatus de ciudadano, lo más probable es que se active la obligación moral de corresponder a ese acto de generosidad. 
Como muestra la transcripción de la solicitud gestionada ante la diputada de la provincia 1, dos meses antes de la elecciones presidenciales de 2008, la red de intermediarios gestionan los documentos de 15 personas en un sector dentro de la jurisdicción de la legisladora.

Provincia 1-PLD

28-Marzo-2008

Distinguida Diputada,

Les estoy solicitando por medio de la presente una ayuda económica para gestionar en las diferentes

Oficialias Civiles, actas de nacimiento para unas 15 personas que comprenden el sector del $81 / 2$ al 11 de la carretera Sánchez.

Atentamente,

Con respecto a la provincia 2 de nivel socioeconómico medio en el IDH (PNUD 2010), ésta cuenta con tres diputados, dos del oficialista PLD y uno del opositor PRD. Las unidades de observación en esta provincia son 2 de los 3 diputados y las unidades de análisis - 639 facturas de bienes por valor de \$USD 60,000 dólares- representan el 66,6\% del universo en la provincia. Como muestra la Tabla 3.4.3.B.5 la actividad concesional del diputado oficialista y el de la oposición sigue el mismo patrón sin que se aprecien diferencias significativas: ambos dedican más del $80 \%$ de las donaciones a particulares, más del $10 \%$ a bienes de club y entre el $1 \%$ y el $4 \%$ a bienes para el disfrute de toda la comunidad.

En esta provincia, aparecen asignaciones que se tipifican en la segunda de las categorías especiales. El diputado oficialista utilizó durante el 2008 y el 2009 parte del Fondo Social para bienes y servicios en su propio beneficio, tales como promocionarse en la televisión local, sufragar el alquiler o el salario del conserje de su propia oficina política en el municipio cabecera de la provincia (3,8\% en 2008 y $4 \%$ en 2009). Como se analizará en el capítulo dedicado a las elites políticas, el uso neopatrimonial y proselitista de los fondos públicos ha caracterizado la gestión de la res pública dominicana desde la primera transición en 1961.

Tabla 3.4.3.B.5 Concesiones "Barrilito" por nivel de extensión de beneficiarios, partido y año electoral, Provincia Nivel Medio IDH

\begin{tabular}{|c|c|c|c|c|c|c|c|c|c|c|c|c|}
\hline \multicolumn{13}{|c|}{ PROVINCIA 2} \\
\hline & \multicolumn{6}{|c|}{$\begin{array}{c}2008 \\
\text { Año Electoral }\end{array}$} & \multicolumn{6}{|c|}{$\begin{array}{c}2009 \\
\text { Año NO Electoral } \\
\end{array}$} \\
\hline & \multicolumn{2}{|c|}{ PLD } & \multicolumn{2}{|c|}{ PRD } & \multicolumn{2}{|c|}{ PRSC } & \multicolumn{2}{|c|}{ PLD } & \multicolumn{2}{|c|}{ PRD } & \multicolumn{2}{|c|}{ PRSC } \\
\hline & $\%$ & $\mathrm{~N}$ & $\%$ & $\mathrm{~N}$ & $\%$ & $\mathrm{~N}$ & $\%$ & $\mathrm{~N}$ & $\%$ & $\mathrm{~N}$ & $\%$ & $\mathrm{~N}$ \\
\hline General & 1.6 & 3 & 4.0 & 4 & & & 1.2 & 3 & 0.9 & 1 & & \\
\hline Corporativa & 10.3 & 19 & 15.0 & 15 & & & 8.1 & 20 & 13.2 & 14 & & \\
\hline Individual & 82.2 & 152 & 80.0 & 80 & & & 85.5 & 212 & 85.8 & 91 & & \\
\hline Broker & 2.2 & 4 & 1.0 & 1 & & & 1.2 & 3 & 0.0 & 0 & & \\
\hline Diputado & 3.8 & 7 & 0.0 & 0 & & & 4.0 & 10 & 0.0 & 0 & & \\
\hline Total & 100 & 185 & 100 & 100 & & & 100 & 248 & 100 & 106 & & \\
\hline
\end{tabular}

Fuente: Elaboración propia a partir de datos facilitados por la Oficina de Acceso a la Información de la Cámara de Diputados de la República Dominicana. 
Fotos 3.4.3.B.3 Utilización del Fondo Social en beneficio político del diputado

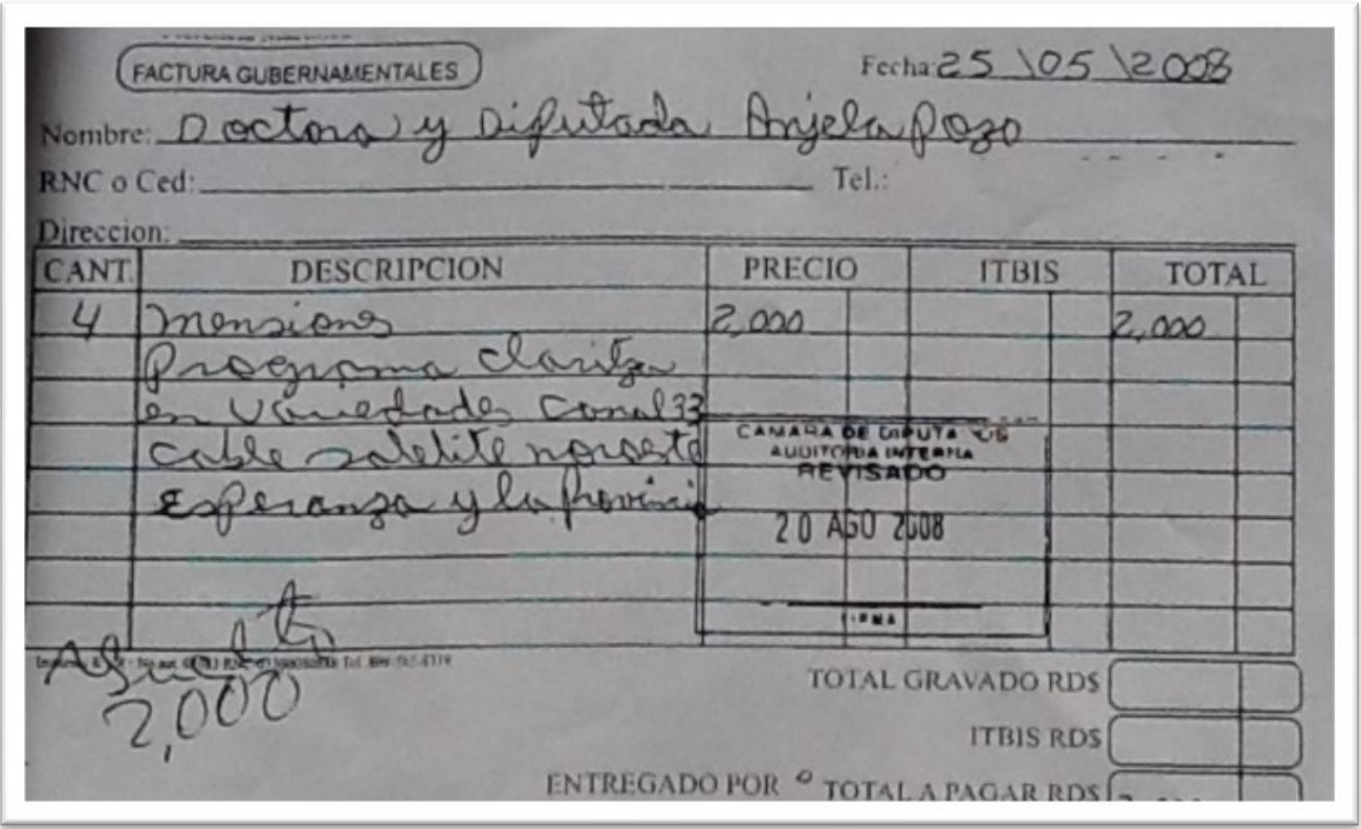

Transcripción: «4 menciones, programa Claritza en Variedades Canal 33, Cable Satelite Noroeste Municipio Esperanza y la Provincia»
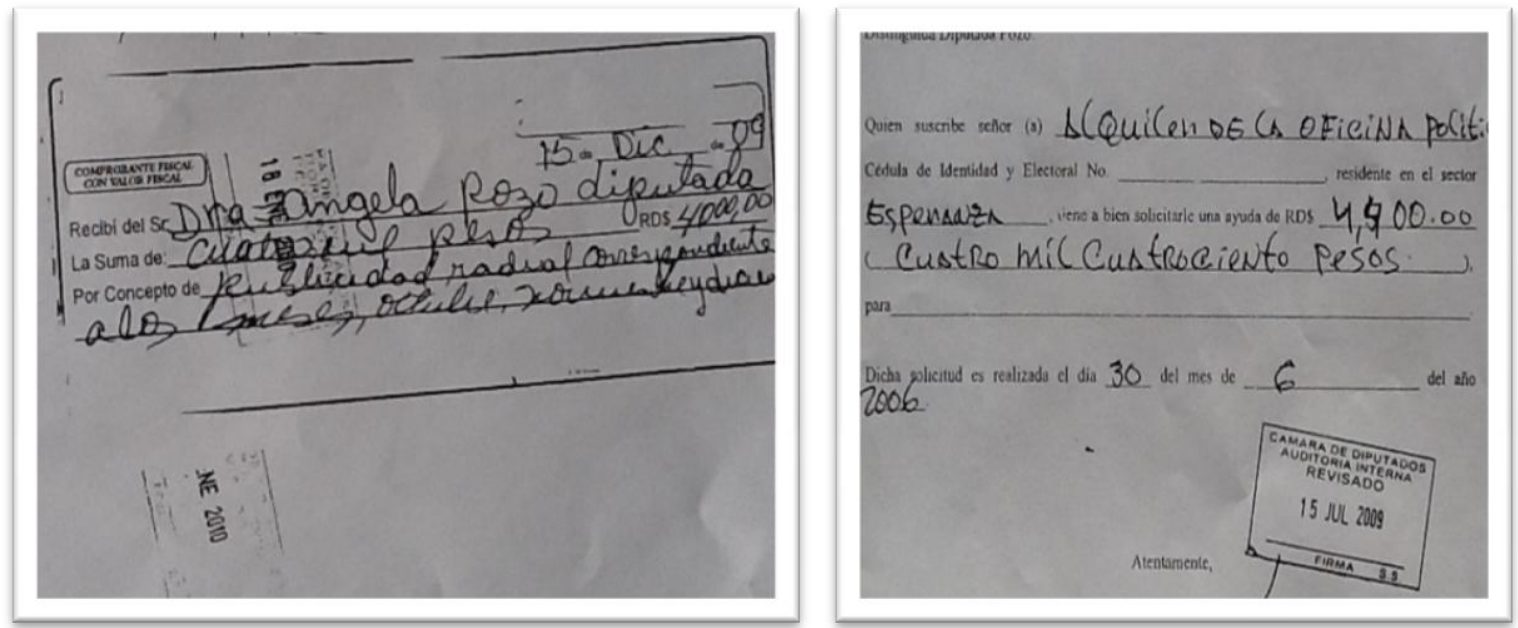

Transcripción: «4,000 pesos publicidad radial correspondiente a los meses de octubre, noviembre y diciembre». Transcripción: «Alquiler de la oficina política en el sector Esperanza, 4,500 pesos»

Por último, la provincia que ocupa la menor posición en el Índice de Empoderamiento Humano (IDH) y la más pobre del país cuenta con dos diputados en la Cámara. En este caso, no hay muestra representativa ya que las unidades de observación (2 diputados) coinciden con la población total. Los \$USD 60,000 dólares son distribuidas en 500 ayudas por los dos únicos patronos públicos que cohabitan en la provincia. 
Como muestra la Tabla 3.4.3.B.6, mientras que el diputado oficialista dedica el grueso de las donaciones a particulares (86\%), el opositor del PRSC reparte las asignaciones entre bienes selectivos de disfrute individual (66\%) y bienes de club a organizaciones comunitarias (28\%).

En esta provincia, el porcentaje de ayudas destinadas a obras y servicios para toda la comunidad aumenta con respecto a las otras dos provincias, especialmente en el caso del diputado reformista de la oposición. Esta diversificación podría responder a una estrategia maximizadora de votos propia de circunscripciones pequeñas donde es más visible la gestión del diputado conseguidor. En su deseo de diferenciarse del competidor premia a los leales con bienes selectivos para mantener su base de apoyo (estrategia movilizadora) y trata de conquistar indecisos con bienes de disfrute general en la competencia con su opositor (estrategia persuasiva). Esta interacción se asemeja al patrón observado en los trabajos de Rosas y Hawkins (2008).

En esta provincia, destaca además el número de ayudas gestionadas por la red de intermediarios al servicio del diputado oficialista (13 en 2008 y 17 en 2009), frente a la escasa (1) y nula presencia en las donaciones del diputado reformista del PRSC.

Tabla 3.4.3.B.6 Concesiones "Barrilito" por nivel de extensión de beneficiarios, partido y año electoral, Provincia Nivel Bajo IDH

\begin{tabular}{|c|c|c|c|c|c|c|c|c|c|c|c|c|}
\hline \multicolumn{13}{|c|}{ PROVINCIA 3} \\
\hline & \multicolumn{6}{|c|}{$\begin{array}{c}2008 \\
\text { Año Electoral } \\
\end{array}$} & \multicolumn{6}{|c|}{$\begin{array}{c}2009 \\
\text { Año NO Electoral }\end{array}$} \\
\hline & \multicolumn{2}{|c|}{ PLD } & \multicolumn{2}{|c|}{ PRD } & \multicolumn{2}{|c|}{ PRSC } & \multicolumn{2}{|c|}{ PLD } & \multicolumn{2}{|c|}{ PRD } & \multicolumn{2}{|c|}{ PRSC } \\
\hline & $\%$ & $\mathrm{~N}$ & $\%$ & $\mathrm{~N}$ & $\%$ & $\mathrm{~N}$ & $\%$ & $\mathrm{~N}$ & $\%$ & $\mathrm{~N}$ & $\%$ & $\mathrm{~N}$ \\
\hline General & 3.1 & 6 & & & 11.3 & 9 & 1.4 & 2 & & & 7.3 & 6 \\
\hline Corporativa & 4.1 & 8 & & & 21.3 & 17 & 4.2 & 6 & & & 28.0 & 23 \\
\hline Individual & 86.2 & 168 & & & 66.3 & 53 & 82.5 & 118 & & & 64.6 & 53 \\
\hline Broker & 6.7 & 13 & & & 1.3 & 1 & 11.9 & 17 & & & 0.0 & 0 \\
\hline Diputado & 0.0 & 0 & & & 0.0 & 0 & 0.0 & 0 & & & 0.0 & 0 \\
\hline Total & 100 & 195 & & & 100 & 80 & 100 & 143 & & & 100 & 82 \\
\hline
\end{tabular}

Fuente: Elaboración propia a partir de datos facilitados por la Oficina de Acceso a la Información de la Cámara de Diputados de la República Dominicana.

Estos datos apuntan a que la estrategia concesional de los diputados dominicanos podría interactuar con los niveles de desarrollo en la forma advertida por Kitschelt (2007), el nivel de competitividad, el acceso a los recursos como partido oficialista y el tamaño de la circunscripción.

Estas variables influirían en el portafolio de opciones distributivas de los legisladores en su provincia. A pesar de tales diferencias, en todas predomina la naturaleza particularista del ejercicio de responsiveness y la estabilidad de los intercambios, dada la ausencia de vaivenes que coincidan con la proximidad de las elecciones. 
El recorrido por el contenido de las cartas y formularios presentados por los electores evidencia cómo son las relaciones de reciprocidad en el moderno clientelismo de partido:

En la mayoría de las solicitudes, los electores exhiben su militancia y acreditan pertenecer al círculo partidista de confianza [«nosotros somos todos peledeístas (Carta 1); soy una mujer reformista en las buenas y en las malas (Carta 2); «es hijo del dirigente político del PRD (Carta 3)»; «recuerde que usted me prometió en el periodo pasado cuando logramos que usted fuese seleccionada diputada» (Carta 5)]. En otras, los clientes muestran su poder de negociación en la transacción [ «si usted no me ayuda no podré caminar el día de las elecciones para ir a depositar el voto...» (Carta 4)], advirtiendo del carácter instrumental de lealtad partidista:

\section{Tabla 3.4.3.B.7 Ejemplos solicitudes ayudas «barrilito» I}

CARTA 1

Provincia 1-PLD

10-Abril-2008

Distinguida compañera:

Le expreso un cordial saludo de liberación, confiando en su generosidad, quiero comunicarle que mi madre quedo viuda y en la calle en 2001 y nos comprometidos a coger un dinero prestado por un monto de RD\$15,000 en 2003 para la construcción de su casa.

En el 2003 en el gobierno del PRD el costo de la vida se elevó tanto que no pudimos seguir pagando lo acordado con la señora que nos prestó el dinero.

No tenemos con qué pagar ya que somos una familia bastante pobre y por eso nos dirigimos a usted compañera para que nos ayude. Nosotros somos todos peledeístas y yo soy miembro del Partido juramentada por el Prof. Juan Bosch en 1990, pertenezco al Comité Intermedio de la calle 13 en Villa María. Esperando en Dios Todopoderoso y en usted para que nos ayude, dándole las gracias.

Anexo copia del Carnet del Partido de nuestra madre.
CARTA 2

Provincia 3-PRSC

6-Enero-2009

Le pido esta ayuda porque la necesito urgentemente. Soy una mujer luchadora en las buenas y en las malas por el Partido Reformista. La he seguido todo y toda mi familia. Nunca nos ha ayudado en nada. Por la circunstancia que estamos viviendo le pido esta gran ayuda. Estas son mis necesidades: necesito techo de zinc, madera, cemento y arena.

Porque somos una familia que siempre en las buena y en las malas la hemos seguido sin ningún tipo de interés y como durante todo este tiempo le hemos pedido esta ayuda Sra. Diputada, seguiremos luchando esta y una vez más para volver a llevarla al Congreso yo y toda mi familia. 
Fotos 3.4.3.B.4 Acreditación filiación partidista en solicitud «barrilito»
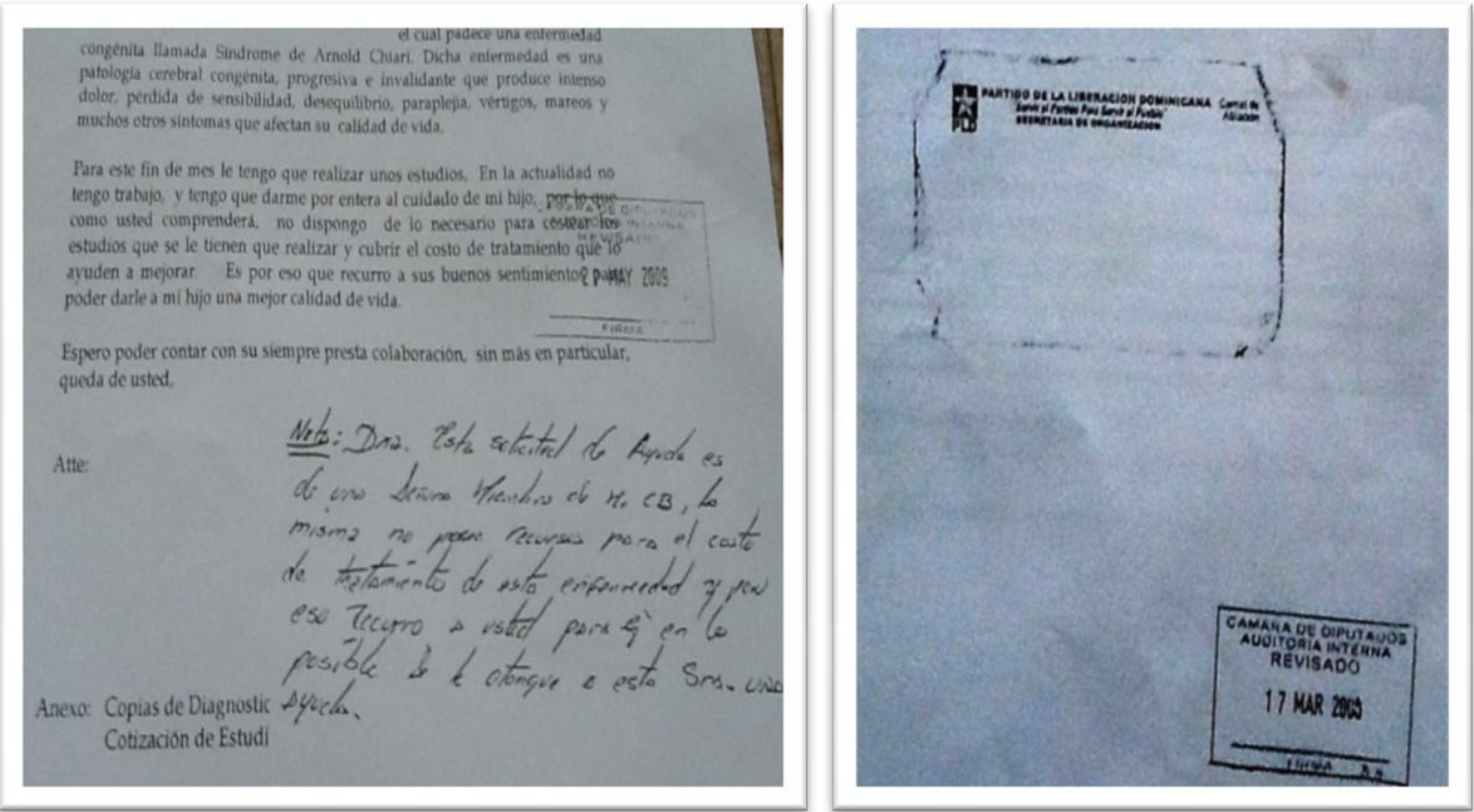

Transcripción: Nota a mano del intermediario en la concesión de la ayuda «Doña. Esta solicitud de ayuda es de una señora miembro del mi Comité de Base, la misma no posee recursos para el costo del tratamiento de esta enfermedad y por eso recurro a usted para si en lo posible se le otorgue a esta señora una ayuda». Foto 2. Copia del carnet de afiliado al PLD anexo a una solitud de ayuda.

\section{Tabla 3.4.3.B.8 Ejemplos solicitudes ayudas «barrilito» II}

\section{CARTA 3}

Provincia 1-PRD

3-Noviembre-2008

Por medio de la presente solicitamos su colaboración con el equipo de sonido, llámese micrófono, bocinas, etc... para la actividad «Noche de Explosión En busca de Libertad» pro fondos para recaudar el dinero de la fianza de libertad de $X$, hijo del dirigente político del PRD Xy su esposa $X$.

Actividad programada para el sábado 8 de noviembre de 2008, en la Cancha San Pablo a las $7.00 \mathrm{pm}$.

Esperamos que se haga presente su colaboración en esta noble causa.

$$
\text { CARTA } 4
$$

Provincia 3-

PRSC

16-Marzo-2008

\section{Estimada Compatriota Diputada X}

Cortésmente me dirijo a usted para pedirle una contribución y es que me hice el examen de la vista y necesito cambiar los lentes y no tengo dinero para ir a buscarlas, por lo que le pido me ayude con lo que pueda.

Pues me siento un poco mal ya que sin esos lentes no puedo ni caminar y si usted no me ayuda no podré caminar el día de las elecciones para ir a depositar ese voto "colorao" que tanto ansiamos echarle en la urna y que Dios nos ayude a quitarnos esas garras "blancas" de encima.

Son mis deseos para con usted, mi partido y la patria.

La saluda su compatriota $X$ 
Para este ejercicio particularizado de responsiveness es necesaria una red organizativa de la que no requieren aquellos partidos que han optado por la agregación colectiva de intereses. Los responsables de los comités de base e intermedios son enlaces clave para que el diputado pueda atender a los electores de su distrito [ «el evento es sumamente atractivo por la cercanía de las elecciones de medio término» (Carta 5); «para así yo crecer políticamente también»(Carta 6); «estoy decidida a trabajar de la mano con usted» (Carta 7); «soy presidenta del Comité Intermedio y el dinero irá destinado a la solución de prioridades del mismo, cuento contigo» (Carta 8)]. Todos ellos conforman una red de intereses mutuos al servicio de sus carreras políticas:

Tabla 3.4.3.B.9 Ejemplos solicitudes ayudas «barrilito» III

\begin{tabular}{|c|c|}
\hline $\begin{array}{l}\text { CARTA } 5 \\
\text { Distinguida Compañera: }\end{array}$ & $\begin{array}{r}\text { Provincia 1- } \\
\text { PRD } \\
\text { 21-Mayo-2009 }\end{array}$ \\
\hline $\begin{array}{l}\text { Al momento de saludarle paso a informarle que } \\
\text { he recibido una invitación de la UASD para } \\
\text { participar en el seminario «Diseño Estratégico de } \\
\text { Campañas Electorales Locales» del 28-29 Agosto. } \\
\text { El evento citado es sumamente atractivo de cara } \\
\text { a la cercanía de las elecciones de medio término y a } \\
\text { la convención de nuestro partido para seleccionar } \\
\text { los candidatos al Congreso y los Ayuntamientos, es } \\
\text { por eso que le extiendo una invitación para que } \\
\text { asista. De nuestra parte, estoy asumiendo los costos } \\
\text { de matriculación y de su parte correria la estadia y su } \\
\text { presencia en esta importante experiencia. } \\
\quad \text { Para quien suscribe sería un grato placer } \\
\text { compartir con usted el conocimiento de las modernas } \\
\text { herramientas del marketing politico y solo espero su } \\
\text { confirmación para proceder a efectuar el pago. } \\
\text { En espera de su confirmación le saluda con aprecio }\end{array}$ & $\begin{array}{l}\text { Distinguida Diputada: } \\
\text { Sirva la presente para saludar y a la vez } \\
\text { felicitarla por el trabajo que ha venido haciendo por } \\
\text { nuestra comunidad, esperamos que siga legislando } \\
\text { por muchos años para que siga siendo la voz de los } \\
\text { que no tienen voz en la Cámara de Diputados. } \\
\text { El móvil de esta carta es para solicitarle la } \\
\text { colaboración en una paca de ropa (cargamento de } \\
\text { ropa) para utilizarla en su nombre y al nombre de } \\
\text { su fundación, para así yo también crecer } \\
\text { políticamente ya que estoy aspirando a la } \\
\text { presidencia de la juventud de la Zona J2. } \\
\text { Sin ningún otro particular se despide de usted, X }\end{array}$ \\
\hline
\end{tabular}


Tabla 3.4.3.B.10 Ejemplos solicitudes ayudas «barrilito» IV

\section{CARTA 7}

Provincia 1-PLD

19-Enero-2009

Distinguida Diputada:

Reciba un caluroso saludo en nombre de nuestra comunidad y muy especialmente de nuestros jóvenes. Apreciada X, conocemos de su sentimiento $y$ motivación en ayudar a los más necesitados, en ese sentido le solicitamos su colaboración para el concierto de talentos denominado «Nada contra mi barrio», este pretende subir a la tarima a mas de 17 agrupaciones juveniles del barrio en los diferentes géneros musicales, jóvenes excluidos y muchas veces rechazados, será un evento inolvidable para nuestra comunidad, para dicho evento necesitamos alquilar el equipo de sonido, el coste de alquiler es de RD\$ 8,000 peso el cual no tenemos, por esto nos dirigimos a usted con le plena confianza de que nos apoyara. La actividad se celebrara el sábado 14 de febrero en la cancha del barrio.

En esta comunidad cuenta con una comunidad convencida de que USTED es la mejor opción para nuestra juventud, por lo que estoy decidida a trabajar de la mano con usted.

\section{CARTA 9}

Provincia 3-PRSC

3-Junio-2009

Pláceme saludarle ya la vez felicitarle por tan valioso e importante paso que usted ha dado, por lo que la recibimos con sentimiento de trabajo.

Como usted sabe, esta esquela que le escribo es para recordarle que usted me prometió un inversor (generador eléctrico domestico), en el periodo pasado cuando logramos que usted fuera seleccionada por nosotros para Diputada de nuestra provincia el cual nos sentimos agradecidos por su actitud de trabajo y entrega.

Esta solicitud y recordación se la hacemos pues como usted sabe la energía eléctrica no nos permite trabajar y este inversor me ayudaria bastante en mi trabajo. La capacidad del inversor es de 2.5 baterías. En espera que su ayuda pueda llegar, pues con este equipo puedo seguir trabajando.

Muchas gracias.

\section{CARTA 8}

Provincia 1-PLD

27-Marzo-2008

Honarable Diputada:

Después de un cordial y afectuoso saludo, tengo a bien apelar a tu solidaridad a los fines de contar con tu apoyo para la feliz ejecución de una actividad puntual que como presidenta del Comité Intermedio Emmna Tavares Justo del Sector Villa Juana he asumido.

El Comité ha decidido hacer una rifa cuyos fondos serán destinados a la solución de prioridades del mismo y para esos fines cuento contigo. Por tal motivo, personalmente te hago entrega de 10 boletas que tienen un costo de 1,000 pesos. ti.

En espera de tu comprensión y apoyo, queda de Atentamente,

\section{CARTA 10}

Provincia 3-PRSC 23-Marzo-2009

Distinguida Diputada:

Discúlpeme si le causo alguna molestia, pero quisiera que usted me ayudara con la siguiente solicitud que es la de RD\$15,000. Tengo 8 meses sin empleo y debo la Universidad, debo también la casa, hago esto porque sé que usted es la única persona a la que yo no dudaría un instante Diputada de su buena colaboración.

También recuerde Diputada que yo fui una de las personas que trabajó incansablemente en aquellos procesos de campañas políticas junto de otros compatriotas a cambio de nada y lo hacía por nuestro glorioso PRSC y el bienestar de la comunidad de Higuerito y si me tocara la oportunidad de hacerlo lo hiciera con mucho optimismo como siempre lo hice.

Espero tener una buena respuesta a mi teléfono. Me despido con un caluroso saludo reformista. 
Estos intermediarios y aspirantes a brókeres son a su vez clientes del patrón principal a quienes hay que atender:

Tabla 3.4.3.B.11 Ejemplos solicitudes ayudas «barrilito» V

\begin{tabular}{|c|c|}
\hline $\begin{array}{l}\text { CARTA } 11 \\
\text { Distinguida Licenciada: }\end{array}$ & $\begin{array}{r}\text { Provincia 1- } \\
P R D \\
\text { 11-Noviembre-2008 }\end{array}$ \\
\hline $\begin{array}{l}\text { La presente es para saludarle y a la vez solicitarle } \\
\text { una ayuda para terminar mis estudios universitarios } \\
\text { o un trabajo. Soy una persona joven y puedo } \\
\text { desempeñar cualquier área de trabajo. Siendo madre } \\
\text { soltera con un hijo de un año de edad, soy miembro } \\
\text { del Partido y he trabajado para las elecciones } \\
\text { presidenciales y congresionales. } \\
\text { La Sr. XX, con la cual he trabajado bastante para } \\
\text { su candidatura y el presidente del Comité } \\
\text { Intermedio XX, ambos le pueden dar referencia de } \\
\text { mí. } \\
\text { Esperando su respuesta favorable lo más pronto } \\
\text { que le sea posible se despide de usted. }\end{array}$ & $\begin{array}{l}\text { Muy cortésmente nos dirigimos a usted con la } \\
\text { finalidad de solicitar su ayuda en relación a la } \\
\text { situación por la que atraviese uno de nuestros } \\
\text { dirigentes más dinámico y leal. Se trata del } \\
\text { compañero X, quien además de haber sido sometido } \\
\text { recientemente a una intervención quirúrgica, } \\
\text { atraviesa por una situación de pobreza al extremo } \\
\text { que está a punto de ser desalojado de la vivienda en } \\
\text { la que vive alquilado y en la que está atrasado con } 5 \\
\text { meses a razón de RD\$2,000 mensuales. } \\
\text { El compañero es la persona que nos convoca las } \\
\text { reuniones a todos los nuevos presidentes de la } \\
\text { adecuación electoral de la Zona J, por lo que } \\
\text { agradeceríamos todo lo que puedas hacer por el } \\
\text { compañero señalado. }\end{array}$ \\
\hline
\end{tabular}

El cumplimiento de las promesas particularizadas legitima el mandato de representación de los diputados dominicanos. Por ello, todos tratan de visibilizar sus actividades concesionales en los distritos y obtener un rédito personal por la gestión que puedan hacer valer en su rendición de cuentas.

Así se desprende de algunas de las ayudas concedidas tales como pagar el alquiler a una empresa de transporte de moto-taxi cuyos trabajadores llevan el chaleco con el nombre y teléfono del diputado (Carta 13); patrocinar un equipo de baloncesto infantil cuyos uniformes llevan impreso el nombre del diputado (foto factura); realizar un curso de costura en la oficina política de la propia diputada (foto factura); o el patrocinio de las fiestas de una comunidad religiosa en el que se colocará la imagen del legislador (Carta 14). 
Tabla 3.4.3.B.12 Ejemplos solicitudes ayudas «barrilito» VI

CARTA 13

Provincia 2-PRD

06-Abril-2008

Distinguida Doctora:

Es un grato placer para nuestro Sindicato $\boldsymbol{X}$, poder dirigirnos a usted y poder saludarle.

Nuestro comunicado es sugerirle que queremos establecer una oficina en el municipio $X$ y se encuentra en escasos recursos económicos. $Y$ queremos ver en que usted puede ayudarnos, ya que nos hacen falta los equipos para la oficina, como son las computadoras, el escritorio, la silla, aire acondicionado, y el dinero para el alquiler de RD\$3,000 pesos del local donde el establecimiento pide esa mensualidad con un contrato de 6 meses.

$Y$ hemos entendido que usted como funcionaria del gobierno puede ayudarnos para que nuestro sueño se haga realidad, ya que queremos establecernos como institución que somos y hemos tratado de erradicar la delincuencia de nuestro municipio tratando de usar un carnet de identidad y un chaleco para que los pasajeros de todos los lugares tengan confiabilidad en nosotros y quedar establecidos más o menos el día 30 de enero de 2009.

Esperamos su colaboración en la brevedad posible. Muy atentamente,

La Directiva de XX.
CARTA 14

Provincia 1-PRSC

6-Mayo-2009

Que la paz de Dios y de nuestro Señor Jesucristo sea con ustedes y todo cuantos estén bajo su cobertura.

El móvil de esta carta es para solicitarles un apoyo financiero en un evento que nuestra iglesia ha montado denominado "Tiempo de Cosecha», donde se estará orando por la familia y el país entre otras actividades más. Dicho evento se llevara a cabo del 27 al 29 de marzo.

Su nombre será puesto en afiches, bajantes y publicaciones de agradecimientos al evento. Contamos con su apoyo, la Iglesia XX se lo agradecerá.

Gracias sean dadas por anticipadas por $\mathrm{su}$ colaboración con la obra de Dios.

Muy atentamente

Fotos 3.4.3.B.5 Facturas publicidad/visibilidad gestión del diputado en bienes y servicios patrocinados

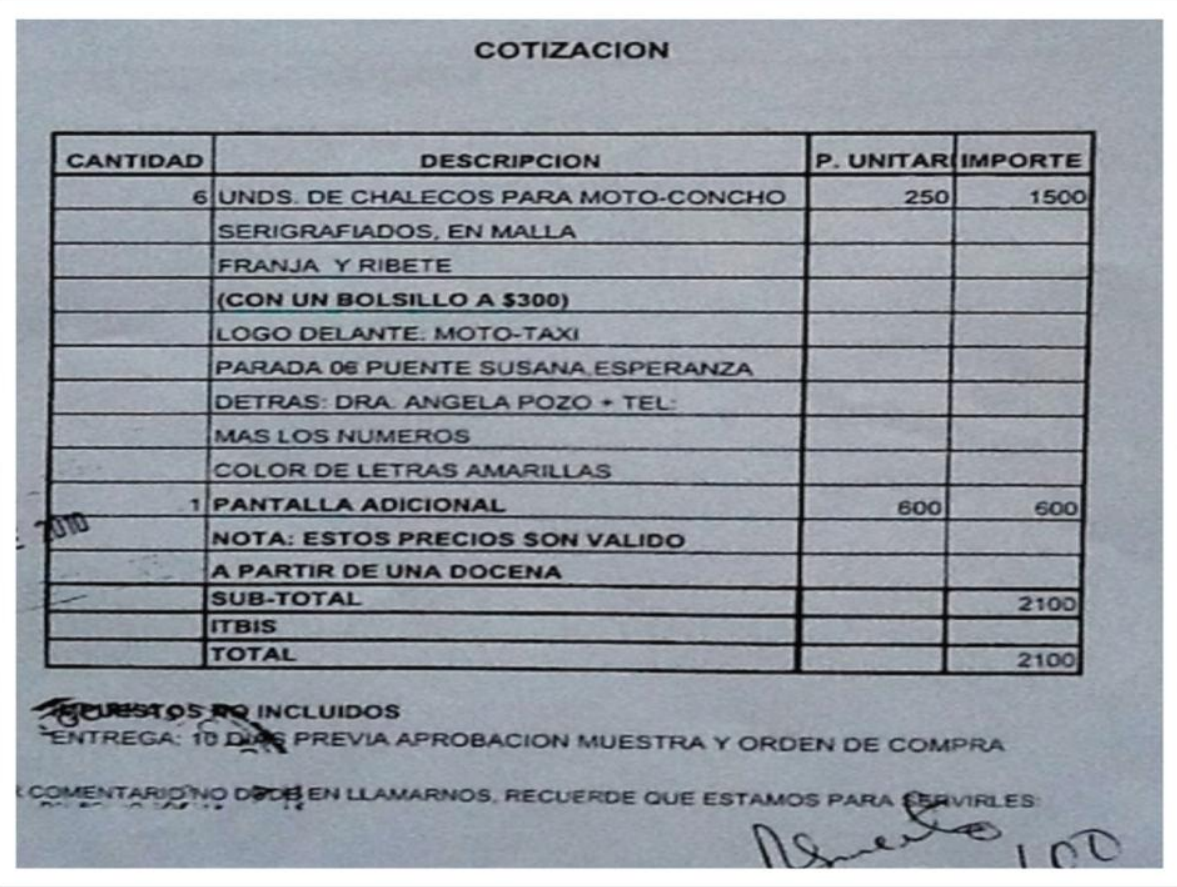

Transcripción: «Chalecos. Logo delante moto-taxi. Detrás Dra. Ángela Pozo (nombre diputada)» 


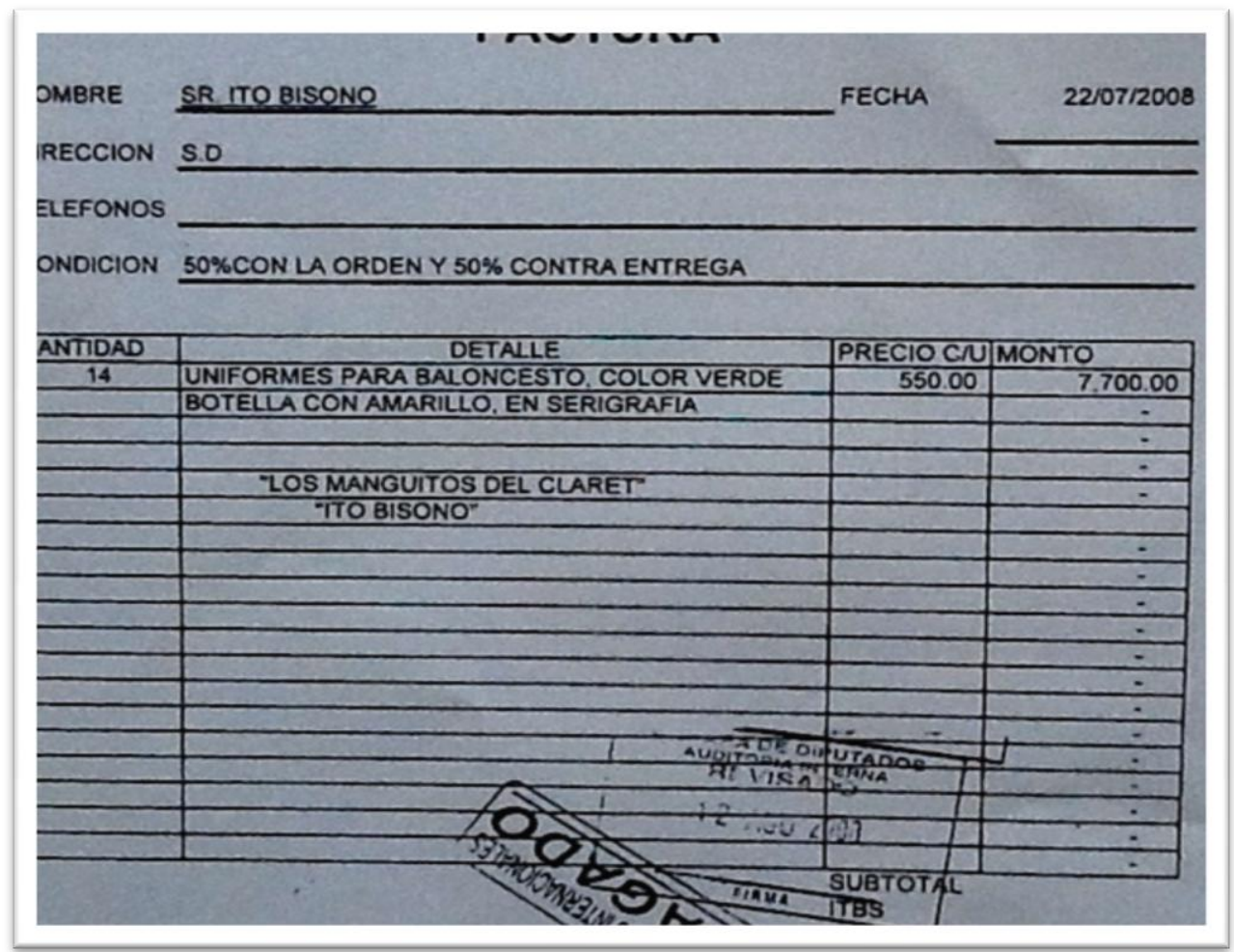

Transcripción: «Uniformes para baloncesto. Color verde botella con amarillo. Los manguitos del Claret (nombre equipo), Ito Bisono (nombre diputado)».

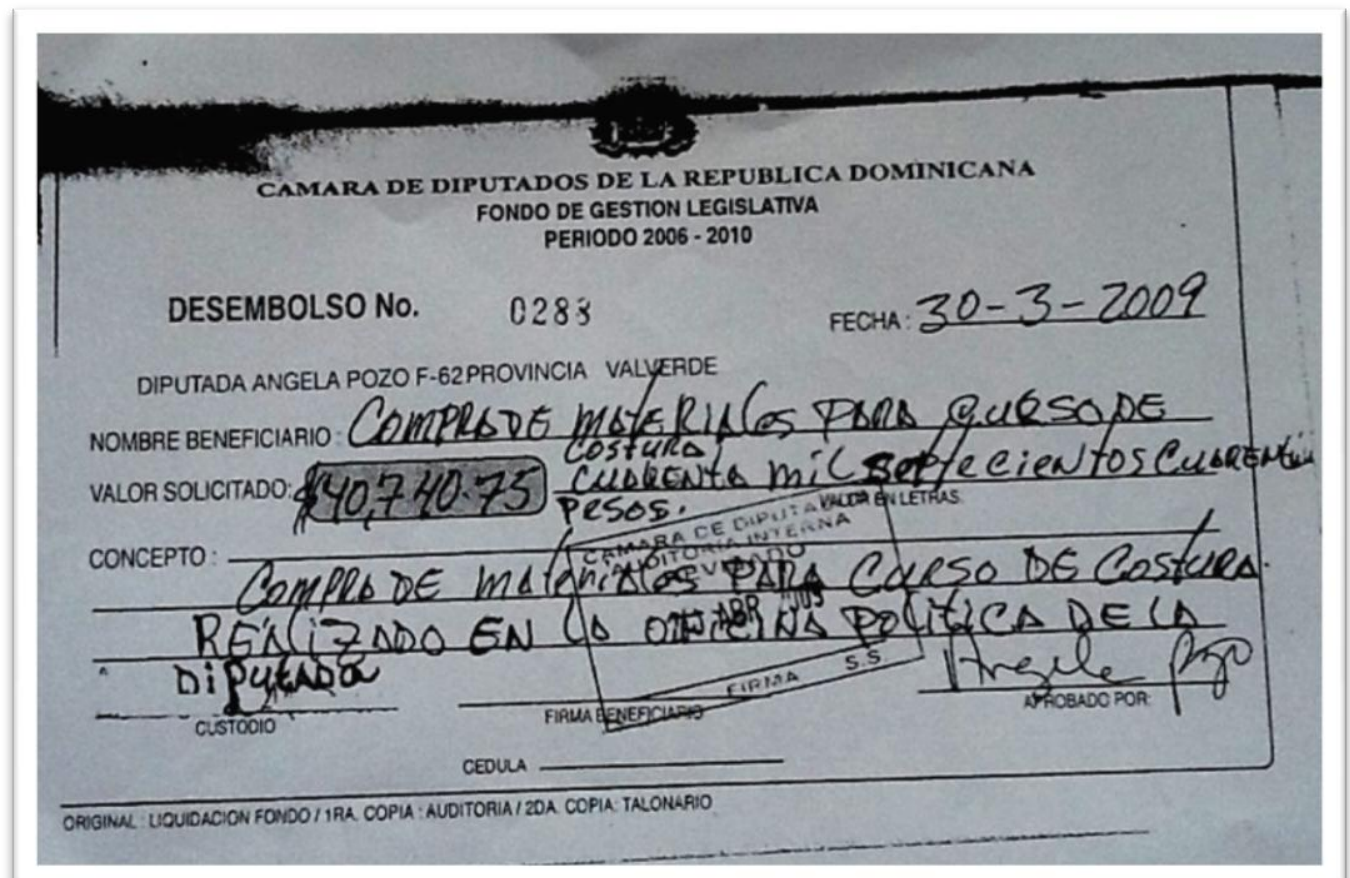

Transcripción: «Compra de materiales para curso de costura. Realizado en la oficina política de la diputada». 
Los datos presentados muestran la preferencia de los diputados dominicanos por el ejercicio particularizado de la responsiveness democrática. Si bien la naturaleza de estos fondos públicos hace que sea más proclive su uso hacia uno de corte prebendalista, el tratamiento estadístico de los datos revela que los diputados eligen estratégicamente el nivel de inclusividad de sus ayudas.

La estrategia de asignación de bienes parece seguir un patrón en el que se premia a los leales y se trata de persuadir a los opositores moderados con bienes de disfrute general. Estos últimos, aunque minoritarios (solo 35 ayudas de las 2,016 totales) se concentran en la provincia con menor empoderamiento socioeconómico y la más pequeña. La mayor visibilidad de las acciones del diputado frente a su opositor en este escenario podría influir en la orientación de la política pública distrital que gestionan a través de estas donaciones. Por el contrario, la mayor disponibilidad de recursos y redes de brókeres al servicio del partido oficialista parecen influir en que el PLD opte por diversificar su ayuda y asigne bienes de club a organizaciones sociales como organizaciones deportivas, culturales, juntas de vecinos o asociaciones religiosas, para maximizar votos en la provincia más rica. Un bien de club para una asociación de mujeres (comprar maquinas de coser) o para una organización deportiva (uniformes) es más costoso que una receta de medicamentos para una sola persona.

En la concesión de estas ayudas, el canal particularizado de atención entre político-elector y la liberalidad de la decisión del diputado desvirtúan los principios de publicidad, generalidad y equidad que deben garantizar la distribución de los fondos públicos. En cada distrito, además de los intermediarios al servicio del diputado, se genera otra red de suplidores (la tienda en la que el diputado manda compra los alimentos, la misma ferretería a la que deriva para la compra de materiales de construcción o la farmacia donde los electores pueden recibir sus medicinas pagadas por el diputado) que atenta contra el iter establecido en la Ley de Compras No.340-06 para la adquisición de bienes por parte de organismos y autoridades públicas. En la provincia 2, la diputada oficialista concedió 159 ayudas para raciones de alimentos (arroz y habichuelas) que reportaron a uno de los colmados (tiendas de ultramarinos) del pequeño municipio de Boca de Mao un beneficio de \$USD 3,000 dólares. En la misma provincia pero en el municipio de Pañuelo, el colmado encargado de sufragar las raciones de comida recibió \$USD 700 por el mismo concepto. Todos ellos son clientes de segundo nivel (pequeños empresarios) favorecidos por la subjetividad del diputado. Esta actividad concesional activa la reciprocidad asociada a la relación de cooperación que se gesta entre los clientes pobres (beneficiarios de la ayuda), los clientes de renta alta (suplidores de la beneficencia del diputado) y el legislador que ejerce de patrón conseguidor. Como se analizará en el capítulo dedicado al entorno institucional, son las propias agencias públicas las que se resisten a la aplicación de los procesos de unificación de protocolos, transparencia y mérito en la gestión administrativa ${ }^{36}$.

Las críticas a este instrumento de política asistencial, llevaron a la Presidencia de la Cámara de Diputados a retirar el Fondo de Gestión Social a los diputados en octubre de 2014, anunciando que a partir del 2015 el "barrilito" se destinaría a organizaciones públicas, privadas y ONGs que se dediquen a la atención sanitaria en cada provincia. De este modo, será repartido por la Presidencia de la Cámara siguiendo criterios de «credibilidad, manejo transparente de los recursos asignados y servicio a la población de escasos recursos ${ }^{37}$. Bajo esta aparente eliminación del

\footnotetext{
${ }^{36}$ En noviembre de 2014 el Tribunal Constitucional excluía a la Junta Central Electoral (JCE) de someter sus adquisiciones de bienes y servicios a la fiscalización de la Dirección General de Contrataciones Públicas y la Ley de Compras, poniendo fin a un litigio entre ambos organismos por las acusaciones de favoritismo en la contratación de los servicios para la gestión del nuevo documento nacional de identidad.

37 Palabras de Abel Martínez, Presidente de la Cámara de Diputados 2010-2016, en periódico nacional El Caribe del 16 de octubre de 2014, en http://www.elcaribe.com.do/2014/10/14/camara-diputados-elimina-
} 
"barrilito" se institucionaliza el papel de conseguidor del Presidente de la Cámara en detrimento de los legisladores de cada provincia, con el consecuente riesgo de que la asistencia social se tiña del color del partido oficialista de turno que controle este órgano legislativo. Por tanto, esta medida disminuye el número de patronos, pero los clientes siguen compitiendo para conseguir la regalía pública ya que los fondos del "barrilito" no se añadirán al rubro destinado a salud en los presupuestos nacionales.

A pesar de que su eliminación fue anunciada como una medida para acabar con el clientelismo, se trata de un remedio más mediático que efectivo, ya que la partida que reciben los diputados (\$225,000 usD/mes) dista mucho del medio millón de dólares que siguen recibiendo los 32 senadores mensualmente para este tipo de actividades. A partir del 2015, el partido con mayoría en la Cámara pasará a ser el patrón único de la asistencia social a través de la figura su presidente. Esta medida profundiza la desmaterialización, empresarialización de la política social y desresponsabilización del Estado como ya apuntaran Adelantado y Scherer (2008) para América Latina. Estos procesos se caracterizan por la sustitución de los derechos sociales por el asistencialismo, la provisión privada de la política social y el desentendimiento del Estado de su responsabilidad con el bienestar ciudadano reconduciéndola a un acto de voluntariado asistencial no sujeto a control de legalidad o justicia social (Adelantado y Scherer 2008:21). 


\subsection{LA MOVILIZACIÓN Y AREGACIÓN PARTICULARISTA DE INTERESES EN LA REPÚBLICA DOMINICANA EN PERSPECTIVA COMPARADA}

Como se argumentaba en la introducción de esta tesis, la selección de la República Dominicana como objeto de estudio obedece a su especial significación en los valores de la variable dependiente (VD). Distintas mediciones del fenómeno del particularismo en política sitúan al país a la cabeza del ejercicio particularizado de la representación en detrimento de la promoción del interés general. Las encuestas de opinión pública de expertos, élites legislativas y ciudadanos, revelan la renovada vigencia del clientelismo más de una década después del inicio de la consolidación democrática en 1996. Con respecto a la medición de los expertos, el Proyecto "Expert Survey on Citizen-Politician Linkages" de la Universidad de Duke, recoge desde 2008 las opiniones de especialistas nacionales acerca de la naturaleza de las prácticas democráticas en sus respectivos países. Esta base de datos con información de más de 500 partidos políticos y 90 países permite comparar cómo operan los mecanismos de accountability en diferentes contextos políticos, sociales y económicos. El Gráfico 2.2.1.1 muestra que Mongolia, Senegal y la República Dominicana son los tres países donde opera con mayor intensidad el vínculo particularizado entre político-elector, así como los más efectivos en asegurar el voto del principal en la contraprestación. En el continente latinoamericano, Uruguay ocupa la menor posición en intensidad y efectividad clientelar, mientras que Argentina le sigue de cerca a la República Dominicana en presencia y garantía de cumplimiento del intercambio. Por el contrario, en Paraguay, si bien se observan similares esfuerzos clientelares a los valorados por los expertos en Dominicana, como revela el Gráfico 2.5.1 la maquinaria de los partidos paraguayos parece ser menos eficaz en asegurar el voto de los beneficiarios.

Gráfico 2.5.1 Percepciones de los expertos acerca de los esfuerzos clientelares de los partidos (Y) y efectividad de la movilización electoral por la distribución de beneficios selectivos (X) (2009)

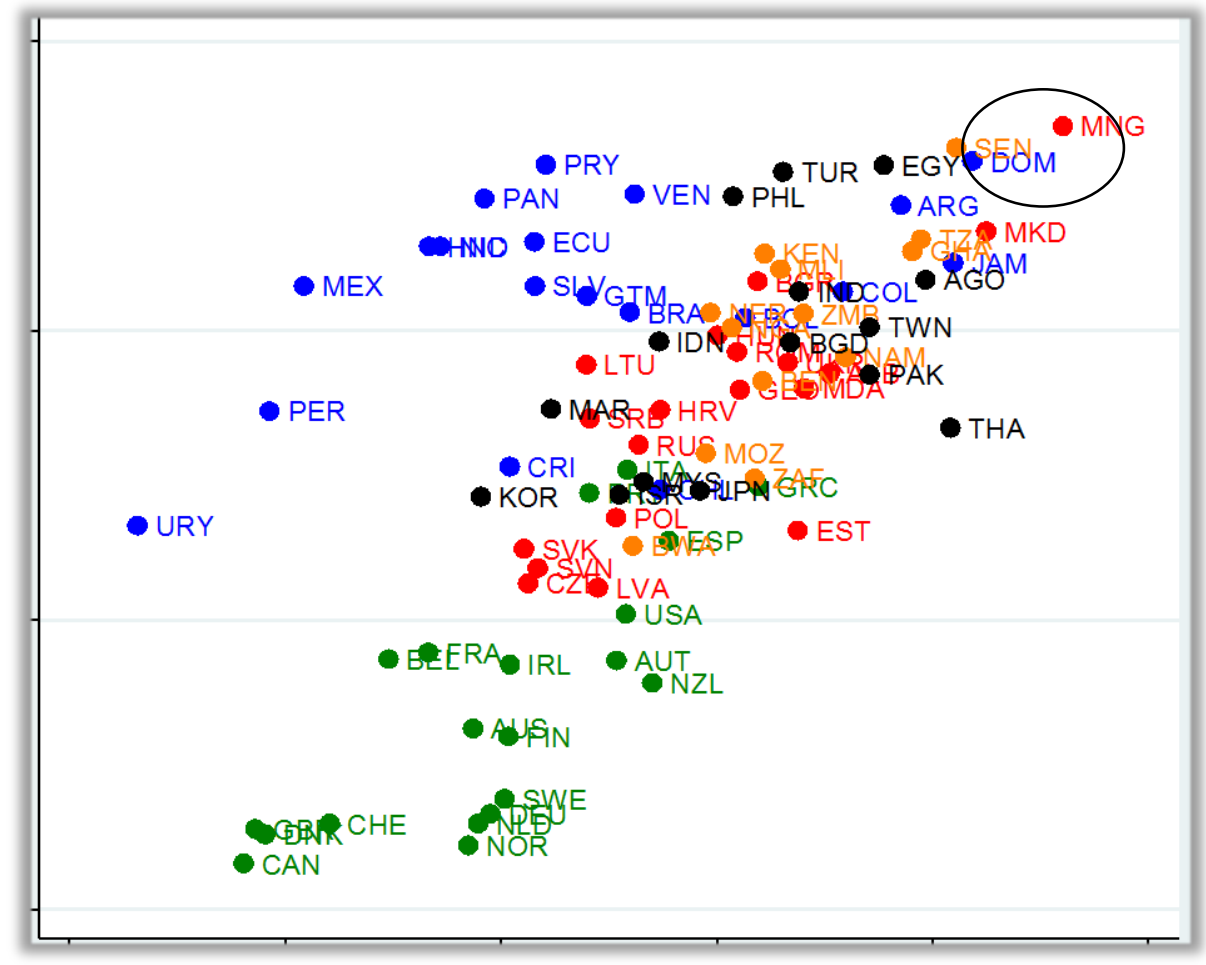

Fuente: Kitschelt y Singer (2009:13). Expert survey on citizen-politician linkages. Initial findings for the Dominican Republic in comparative perspective. Leyenda: AMÉRICA LATINA, ÁFRICA, ASIA/ORIENTE MEDIO, DEMOCRACIAS POST COMUNISTAS, DEMOCRACIAS CAPITALISTAS AVANZADAS 
En las democracias capitalistas avanzadas, Grecia e Italia lideran la comparativa aunque la primera parece ser más efectiva en lograr el voto del principal y la segunda más pródiga en el reparto de beneficios. En el lado extremo, Canadá es el país en el que son escasos los esfuerzos de los partidos en la distribución selectiva de bienes y cuando así lo hacen, resultan poco efectivos para conquistar el voto del elector.

Los partidos clientelares han de invertir en costosas estructuras de control para monitorear el comportamiento de los electores y evitar malgastar los bienes controlados por el partido en su rol de patrón. El carácter supervisado del intercambio es la cuarta de las características que acompaña a este modo racional de vinculación directo, contingente y predecible (Kitschelt y Wilkinson 2012:2016). El Gráfico 2.5.2 muestra el cruce entre la percepción de la efectividad de la movilización y el éxito en el monitoreo del voto, en el que de nuevo Mongolia y la República Dominicana ocupan las primeras posiciones, esta vez acompañadas por la República de Macedonia y cerca de Senegal.

El monitoreo en la República Dominicana se apoya en una compleja red informal de activistas. El día de la elección, esta red se sitúa estratégicamente en las puertas de los centros de votación. Puesto que el padrón electoral incluye la foto de los electores, les permite a los activistas ir cotejando quién vota y quién no. Como reconocía uno de ellos: «nuestra misión es ir viendo quién viene a votar y si a las tres de la tarde no se han presentado, entonces vamos a buscarlos a casa» (Benito Sánchez 2011:400). Como dato anecdótico, en las elecciones presidenciales de 2012, por primera vez la Junta Central Electoral (JCE) prohibió el uso de teléfonos móviles en los colegios electorales para evitar que los partidos recompensaran a aquellos que enseñaran la foto que confirmara su elección en las urnas ${ }^{38}$.

En este gráfico de dispersión, los países latinoamericanos se han desplazado hacia la derecha en el eje de la X, lo que revelaría su mayor inversión en maquinaria de control. Argentina, Colombia, Venezuela y Paraguay son, en opinión de los expertos consultados, las democracias más exitosas en monitorear el voto de los ciudadanos, a pesar de que las dos últimas sean menos efectivas en la movilización clientelar que las dos primeras. En las democracias capitalistas avanzadas, Irlanda es el país más exitoso en monitorear el voto de los electores a pesar de la casi nula efectividad de la movilización particularista, frente a España y Grecia que ocupan una posición intermedia en ambos ejes. En el continente africano. Benín y Botswana son los países con mayor y menor éxito respectivamente en las acciones de monitoreo, mientras que en Tailandia y Egipto son los más efectivos en movilización y monitoreo en Asia y Oriente Medio.

El análisis desagregado por partido revela los máximos esfuerzos y efectividad de la movilización en los tres partidos políticos mayoritarios de la República Dominicana (Tabla 2.5.1), siendo el PLD como partido oficialista el que en opinión de los expertos consultados, es el más hábil y exitoso en la distribución selectiva de beneficios. Con respecto al objeto de intercambio, los partidos dominicanos optan en mayor medida por la asignación de contratos públicos a empresas, empleos para los activistas y entrega de bienes materiales. Y en menor medida por el acceso preferente a programas asistenciales o la manipulación favorable en las comisiones regulatorias para favorecer intereses determinados (Kitschelt y Singer 2009:14).

38 Ver noticia al respecto en el periódico nacional El Caribe, del 19 de mayo de 2012, en http://www.elcaribe.com.do/2012/05/19/jce-prohibe-entrar-con-celulares-los-colegios-electorales 
Gráfico 2.5.2 Percepciones de los expertos acerca de la efectividad en movilización clientelar (Y) y éxito en monitoreo del voto de los electores $(\mathrm{X})(2009)$

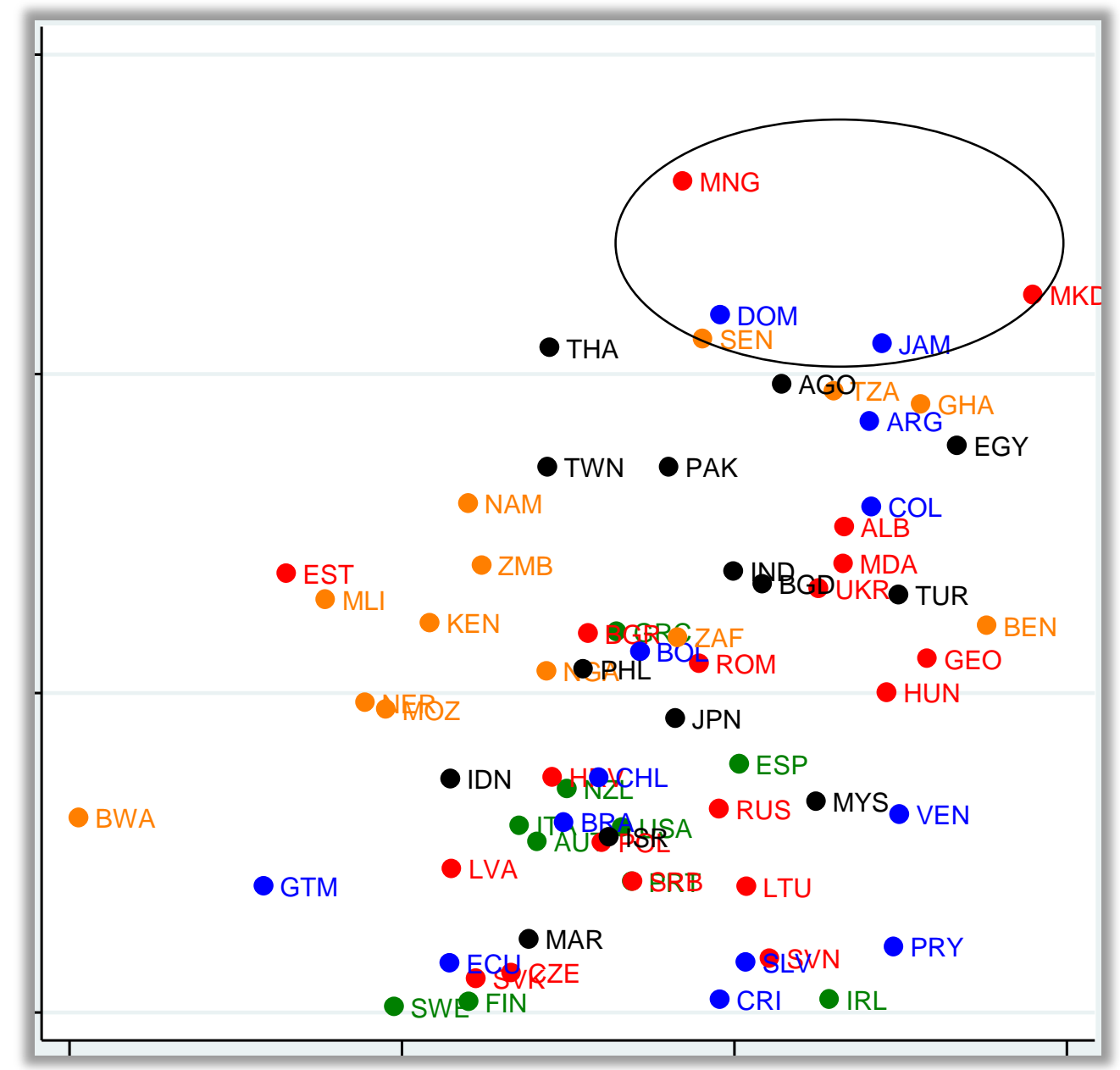

Fuente: Kitschelt y Singer (2009:18). Expert survey on citizen-politician linkages. Initial findings for the Dominican Republic in comparative perspective. Leyenda: AMÉRICA LATINA, ÁFRICA, ASIA/ORIENTE MEDIO, DEMOCRACIAS POST COMUNISTAS, DEMOCRACIAS CAPITALISTAS AVANZADAS

Tabla 2.5.1 Percepciones de los expertos acerca de la frecuencia y efectividad electoral del clientelismo en la República Dominicana (2009)

\begin{tabular}{|c|c|c|c|c|}
\hline & & PRD & PRSC & PLD \\
\hline $\begin{array}{l}\text { Intensidad de la distribución de bienes selectivos } \\
\text { (promedio puntuación en los } 5 \text { tipos de bienes) }\end{array}$ & PROMEDIO & 3.52 & 3.55 & 3.66 \\
\hline (1 ninguna intensidad, 4 máxima intensidad) & $\begin{array}{l}\text { PROMEDIO } \\
\text { DESVIACIÓN ESTÁNDAR }\end{array}$ & 0.62 & 0.67 & 0.5 \\
\hline Efectividad de la distribución de bienes selectivos en el éxito & PROMEDIO & 3.92 & 3.58 & 3.97 \\
\hline (1 ninguna efectividad, 4 muy efectiva) & DESVIACIÓN ESTÁNDAR & 0.79 & 1.16 & 0.65 \\
\hline
\end{tabular}

Fuente: Kitschelt y Singer (2009:14) Expert Survey on citizen-politician linkages. Initial findings for the Dominican Republic in comparative perspective. 
Igual diagnóstico resulta cuando se pregunta a la élite parlamentaria latinoamericana acerca de la frecuencia de los intercambios particularizados en sus respectivos partidos y países.

El Proyecto "Elites Parlamentarias Latinoamericanas" (PELA) de la Universidad de Salamanca, recoge desde 1994 las actitudes, opiniones y valores de los diputados de la región acerca de los diferentes aspectos de la democracia representativa. En este caso, las preguntas sobre clientelismo se introducen en la cuarta oleada de encuestas del proyecto, por lo que la comparativa se inicia en 2010 y solo con aquellas democracias que a partir de esa fecha renovaron sus parlamentos. Como muestra la Tabla 2.2.1.2, la República Dominicana lidera el listado de países en elevada frecuencia en la distribución de bienes particularizados y de club. Un 75\% de los diputados entrevistados así lo consideraron, frente al $45,7 \%$ de los diputados salvadoreños que afirmaron que este tipo de incentivos para obtener votos tenía mucha importancia en la competencia interpartidaria.

El país solo es superado por Honduras en el reparto de bienes de consumo, aspecto en el que el $87,8 \%$ de los diputados hondureños entrevistados reconocieron su máxima importancia en la conquista de votos. Aunque la envergadura de atender a los electores del distrito con bienes colectivos en la República Dominicana es la más elevada de la comparativa, destaca el focus distrital de los diputados argentinos $(52,1 \%)$ y el de los salvadoreños $(50,1 \%)$ que supera e iguala en importancia al reparto de bienes en sus respectivos países.

Tabla 2.5.2 Percepciones diputados latinoamericanos acerca de la frecuencia de distribución (o promesa) de bienes como incentivo para obtener votos (2009-2014)

\begin{tabular}{|l|c|c|c|c|}
\hline $\begin{array}{c}\text { ¿Podría decirme si se } \\
\text { utilizan en su país con } \\
\text { MUCHA frecuencia los } \\
\text { siguientes incentivos? }\end{array}$ & $\begin{array}{c}\text { BIENES DE } \\
\text { CONSUMO }\end{array}$ & $\begin{array}{c}\text { BENEFICIOS } \\
\text { PARA SU } \\
\text { COMUNIDAD }\end{array}$ & $\begin{array}{c}\text { ACCESO PREFERENCIAL A } \\
\text { OPORTUNIDAD DE TRABAJO }\end{array}$ & PROMEDIO \\
\hline República Dominicana & $\mathbf{8 5 . 7}$ & $\mathbf{7 0 . 9}$ & $\mathbf{6 8 . 4}$ & $\mathbf{7 5}$ \\
Honduras & 87.8 & 61 & 64.6 & 71.13 \\
Ecuador & 54.1 & 51.9 & 35.9 & 47.30 \\
Argentina & 46.5 & 52.1 & 40.3 & 46.30 \\
El Salvador & 50.1 & 50.1 & 37.1 & 45.77 \\
\hline
\end{tabular}

Fuente: Elaboración propia a partir de PELA, Universidad de Salamanca [Argentina 2009-2015; Ecuador 2013-2017; El Salvador 20122015; Honduras 2014-2018; Nicaragua 2012-2017; República Dominicana 2010-2016]. Se computa solo la opción "mucha importancia" de las cuatro posibles: mucha, alguna, poca, ninguna.

Por último, las opiniones de los ciudadanos latinoamericanos ratifican las percepciones de sus representantes legislativos y la de los expertos de las encuestas de opinión pública.

El Proyecto "Barómetro de las Américas" (LAPOP) de la Universidad de Vanderbilt analiza desde 2004 los cambios y continuidades en los valores democráticos de los ciudadanos del continente americano. En 2010 se preguntó por primera vez acerca de este tipo de promesas y distribución selectiva de favores y bienes ${ }^{39}$. De nuevo la República Dominicana destaca por ocupar el primer lugar en la escala de clientelismo elaborada con las respuestas de los ciudadanos de la región. El $18,4 \%$ de los dominicanos entrevistados dijeron haber recibido frecuentes ofrecimientos de favores $\mathrm{y}$ beneficios a cambio de votar a un partido, frente al escaso $3 \%$ de sus vecinos chilenos y

\footnotetext{
${ }^{39}$ CLIEN1. «En los últimos años y pensando en las campañas electorales, ¿algún candidato o alguien de un partido político le ofreció algo, como un favor, comida o alguna otra cosa o beneficio a cambio de que usted votara o apoyara a ese candidato o partido? ¿Esto pasó frecuentemente, rara vez, o nunca?».
} 
uruguayos. La escala del Gráfico 2.5.3 muestra el promedio en los distintos niveles de intensidad, por lo que el porcentaje total de entrevistados que recibieron algún tipo de ofrecimiento de distribución selectiva asciende al 22,2\%.

En el análisis de regresión realizado por LAPOP, el género y la edad eran variables estadísticamente significativas. Ser hombre y menor de 46 años en la República Dominicana aumentaba significativamente la probabilidad de recibir una oferta particularista, al igual que ser militante del PLD (LAPOP 2010:218). En este sentido, tal como sucedía cuando los expertos valoraban la intensidad y efectividad de los tres partidos dominicanos en su habilidad clientelar, el control de los recursos públicos con el que cuenta el partido oficialista de turno convierte a la fuerza política que controla el Ejecutivo en un agente dominante y privilegiado con respecto a sus opositores.

Gráfico 2.5.3 Percepciones de los ciudadanos latinoamericanos Escala Clientelismo América Latina (2010)

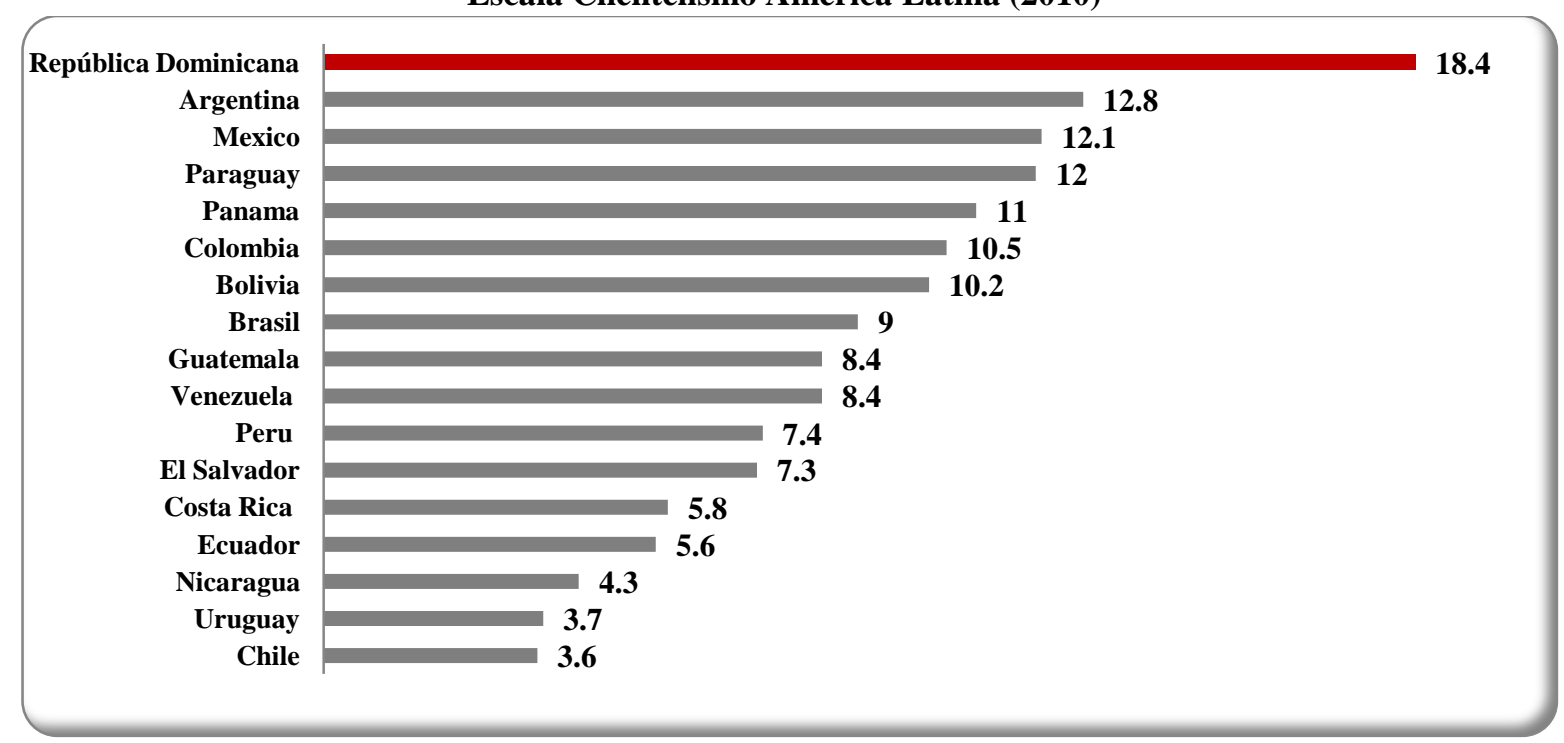

Fuente: Cultura política de la Democracia e la República Dominicana (LAPOP 2010:216). Escala de 0 a 100.

Tras la descripción de la política particularista y su contexto, en los siguientes capítulos se exploran las hipótesis planteadas por la literatura siguiendo la metodología del estudio de caso confirmador de teoría (Lijphart 1971). Se espera que el acercamiento al fenómeno desde el intercambio continuo que se genera en el escenario de la representación legislativa contribuya a avanzar en la construcción teórica en torno al carácter instrumentalista del particularismo en democracia. 


\subsection{RECAPITULACIÓN}

En las páginas previas se ha presentado una fotografía empírica del panorama de la Política Particularista en la República Dominicana. El capítulo se dividió en dos partes: la primera muestra el repertorio de la acción clientelar en los distintos escenarios de la representación y una segunda dedicada al diagnóstico acerca de cuán particularista es el país en perspectiva comparada.

En la medición del Clientelismo Oficial se utilizaron diversos indicadores cualitativos y cuantitativos para observar la presencia del fenómeno en el Ejecutivo, en la Administración y en el escenario Legislativo.

La comparación del gasto en "seguridad social" y "asistencia social" en los Presupuestos Nacionales (2006-2011) mostró la utilización estratégica de la asistencia focalizada y su preferencia en año electoral por parte del Ejecutivo, frente a la partida más inclusiva que representa el gasto público en los sistemas de protección universal. Y para evidenciar cuantitativamente que el patronazgo burocrático es un arma que se utiliza ex ante al servicio de la carrera política del funcionario de turno y una herramienta ex post para recompensar votos, se contextualizaron los vaivenes en la contratación de funcionarios dominicanos. El número de nuevos funcionarios dados de alta en el Sistema de Administración de Servidores Públicos (2010-2012) reveló el grado de sometimiento de la Administración Pública dominicana a los ciclos electorales e intereses políticos de sus gestores. Puesto que no se disponía de información del repertorio del particularismo ejecutivo y burocrático en distintas administraciones y periodos, se optó por el análisis minucioso del fenómeno en el escenario Legislativo para explicar la intensidad del caso seleccionado y contextualizar los cambios de tendencia desde la etapa de la consolidación democrática a la actualidad.

El repaso a la actividad propositiva y distributiva de los diputados dominicanos (1998-2010) evidencia que la personalización y la selección, prevalecen sobre la generalidad y la abstracción del mandato de representación. El tratamiento estadístico de las Proposiciones de Ley muestra que la relación entre particularismo y partido político es estadísticamente significativa. En el periodo 1998-2010 más de la mitad de las iniciativas tuvieron por objeto la promoción de intereses parroquiales en las que el diputado ejerce de conseguidor de derechos selectivos y favores personales en sus distritos. Las legislaturas en las que el PRD contaba con la mayoría y además dominaba el Ejecutivo, eran las más propensas a promover intereses particularistas. La legislatura 2006-2010 marca un punto de inflexión al alza en la representación del interés general en la Cámara de Diputados. Sin embargo, este cambio podría reflejar la mayor predilección del oficialista PLD por otros escenarios e instrumentos como el asistencialismo selectivo a través del Ejecutivo o el patronazgo en la Administración. Teniendo en cuenta el peso de los partidos en la Cámara, el coeficiente de ponderación de la actividad propositiva particularizada evidenció el predominio del PRSC en la tramitación de beneficios selectivos para sus electores durante las tres legislaturas, seguido en los últimos años por el PRD.

Con respecto a la utilización del Fondo de Gestión Social o "barrilito" se observa una estrategia de asignación de bienes que premia a los leales y trata de persuadir a los opositores moderados con bienes de disfrute general. Esta diversificación confirma el patrón apuntado por Rosas y Hawkins (2008). La maximización de votos, la visibilidad de su mérito como gestor, la disponibilidad de 
recursos y el nivel de empoderamiento socioeconómico parecen influir en la decisión del diputado a la hora de elegir el nivel de inclusividad de las asignaciones en sus distritos.

Para el dictamen acerca del grado de responsiveness particularizada y su ubicación en el contexto mundial y regional en la actualidad, se utilizaron las encuestas de opinión pública de expertos, élites legislativas y ciudadanos. El Proyecto "Expert Survey on Citizen-Politician Linkages" de la Universidad de Duke, situaba en 2009 a la República Dominicana en los primeros puestos en cuanto a esfuerzos clientelares de sus partidos y efectividad en la movilización junto con Senegal y Mongolia, así como en capacidad para monitorear el voto de los electores. A nivel regional, el Proyecto "Elites Parlamentarias Latinoamericanas" (PELA) de la Universidad de Salamanca, situaba en 2010 a la República Dominicana a la cabeza de los que utilizaban con mucha frecuencia la distribución de incentivos selectivos en la competencia interpartidaria. El 68,4\% de los diputados dominicanos afirmaron que la promesa de acceso preferencial a oportunidades de trabajo era muy importante para incentivar el voto de sus electores, frente al 35,9\% de los diputados ecuatorianos que así lo consideraban. También en 2010, el Proyecto "Barómetro de las Américas" (LAPOP) de la Universidad de Vanderbilt, consultaba a los ciudadanos latinoamericanos acerca de su participación en este tipo de intercambios. De nuevo la República Dominicana encabezaba el porcentaje con un $18 \%$ de entrevistados que dijeron haber recibido frecuentes ofrecimientos de favores y beneficios a cambio de votar a un partido, frente al escaso 3\% de sus vecinos chilenos y uruguayos. 


\section{CAPÍTULO 3}

\section{FACTORES QUE DETERMINAN LA POLÍTICA PARTICULARISTA DESDE LA OFERTA}

\subsection{INTRODUCCIÓN}

Tras el análisis empírico descriptivo de la política particularista en la República Dominicana y su manifestación en el escenario legislativo, se explora la incidencia de variables de la oferta y la demanda en la triple dinámica relacional en la que los protagonistas -políticos y ciudadanosdespliegan su comportamiento estratégico. En los siguientes epígrafes de este Capítulo se analizan las dos primeras relaciones sistémicas desde la oferta: la del Estado con los Partidos y la de los Partidos entre sí.

En la primera de las relaciones [Epígrafe 3.2.], el arraigo y preservación de los vínculos particularistas se sustenta en el poder explicativo del entorno institucional (la historia, las reglas que regulan el acceso a las instituciones de la representación y los actores que están al frente de ellas). En la segunda relación, el particularismo se explica desde el poder de decisión y manipulación de las elites políticas [Epígrafe 3.4].

Estos factores institucionales y partidistas boicotean desde la oferta la vocación universalista del ejercicio de la representación, pero ambos pueden ser redefinidos y/o esquivados por los actores políticos en los escenarios de oportunidad que se presentan. En la concepción instrumentalista del particularismo, los escenarios de oportunidad en los que se generan espacios para que sea la forma residual o la forma predominante de accountability en democracia, son producto de secuencias de naturaleza político institucional y no de raíz cultural o económica. La explicación de cómo y por qué asumen los costes e incentivos los actores dominicanos desde la intencionalidad y racionalidad, permitirá extraer conclusiones que contribuyan al conocimiento científico en torno la viabilidad del particularismo desde la oferta en otras democracias emergentes.

\subsection{RELACIONES ESTADO-PARTIDO}

Las relaciones del Estado con los Partidos están determinadas por el entorno institucional (reglas que dan acceso al ejercicio de la representación), los actores (particularidades de los que están al frente de las instituciones) y la historia (peso de la conformación del propio Estado y de los partidos).

Con respecto al peso de la historia en la orientación de las políticas en el largo plazo, se examina en la República Dominicana el momentum de la burocratización y de la movilización a la política de masas en la coyuntura transicional identificados por Shefter (1994). Ambos son factores desde la oferta que inciden en la orientación hacia el patronazgo de los partidos. Cuando las instituciones democráticas se crean antes de la existencia de un cuerpo centralizado de servidores públicos, la línea ente la vida del Estado y la vida de la política se diluye. Esta confusión es el escenario donde florece el particularismo burocrático. Como argumentan los neoinstitucionalistas históricos (Ikenberry 1994), una vez establecida la estructura deviene persistente a través de los mecanismos de reproducción. La pervivencia del andamiaje administrativo trujillista en la etapa de la 
consolidación democrática y la demora en la aplicación de leyes que limiten las particularidades de la vida civil y política en la burocracia dominicana, son indicadores del peso del legado histórico que obstaculiza el universalismo. Con respecto a la transición y la movilización a la política de masas, contrario a la teoría neoclásica acerca del perfil de los votantes, Shefter demuestra que es el modo de organización de los partidos y la procedencia de las élites, lo que determina su acceso a los recursos del Estado y en consecuencia, la orientación al patronazgo de los partidos políticos.

El sistema electoral es la segunda de las variables que condicionan la relación de los partidos con el Estado. Sus ochos componentes fundamentales -fórmula, magnitud de la circunscripción, umbral, tamaño de la asamblea, estructura y desigualdad del voto, ciclo electoral y posibilidad de unión de listas- tienen un potencial impacto en el sistema de partidos (Lijphart 1994). El objetivo de este apartado es identificar las características del diseño electoral dominicano que favorecen el particularismo en la representación y movilización política. A diferencia de sus vecinos latinoamericanos de la "tercera ola democratizadora" (Huntington 1991), las reformas al sistema electoral en la República Dominicana no tuvieron lugar inmediatamente después del proceso transicional, sino que hubo que esperar más de una década y en respuesta a la gran crisis política que se desató con el fraude electoral de 1994. La Ley Electoral de 1962 siguió regulando la cita con las urnas desde el inicio de la transición hasta 1997, fecha en que se promulga la Ley Electoral No. 275. A esta Ley le acompañaba el Proyecto de Ley de Partidos y Agrupaciones Políticas, que desde 1996 pasea entre las comisiones legislativas pendiente de aprobación, a pesar de que en estos casi 20 años los dos partidos que han alternado el poder han gozado de mayoría suficiente para su promulgación.

La primera de las dimensiones a estudiar es la estructura del voto. Desde el año 2002, los dominicanos tienen la posibilidad de mostrar sus preferencias y alterar el orden de los candidatos establecido por el partido. Con esta modalidad los compañeros de partido compiten entre ellos por lo que la cohesión interna puede verse afectada. Este escenario de competición interna tiene consecuencias a nivel sistémico, ya que las características personales de los candidatos individuales son más importantes para el éxito electoral que el referente programático partidario (Shugart, Valdini y Suominen 2005) y en las instituciones tiende a acrecentar el individualismo legislativo (Carey 2009). Con respecto a la magnitud del distrito, cuanto menor sea ésta mayor es la importancia que los representantes otorgan a la promoción de los intereses localistas de su circunscripción frente a los intereses generales de política nacional (Carey y Shugart 1995).

Como se detalla en los siguientes apartados, desde el año 2002 en que se instaura el voto preferencial las iniciativas individuales de los diputados dominicanos superan en porcentaje a aquellas elevadas por la propia bancada o las conjuntas mixtas. Este personalismo en el ejercicio propositivo es indicador de la escasa relevancia de la cohesión legislativa en la Cámara de Diputados del país. Asimismo, se argumenta que los distritos pequeños y la fragmentación de territorio dominicano por un lado acentúan el localismo del focus de la representación y por otro, limitan la fragmentación del sistema de partidos (Duverger 1954; Amorim Neto y Cox 1997). Como apuntara Cox (1997), estos obstáculos en el acceso a las instituciones por parte de las terceras fuerzas y la infrarrepresentación de los perdedores, fomentan el comportamiento estratégico de partidos y votantes. Con la mayor importancia del trabajo individual del candidato aumenta también el coste de las campañas y la importancia del financiamiento privado. En ausencia de límites y publicidad de las donaciones privadas en la legislación dominicana, existe el riesgo de que los intereses públicos estén condicionados por los intereses particulares de los financiadores y de que se acuda a los circuitos corruptos de intercambio para obtenerlo (Máiz 2005). 
La tercera variable que afecta a la relación del Estado con los Partidos es la relativa a quiénes ejercen de agentes ante las instituciones estatales. En esta tarea, las cualidades que les caracterizan pueden afectar a su voluntad de implementar reformas orientadas al desarrollo democrático (Gerring, Keefer, Morrison y Oncel 2012) y particularizar el mandato nacional de representación. En el siglo XVIII, los constitucionalistas americanos identificaron la sabiduría para discernir y la virtud para perseguir el bien común como las cualidades necesarias para alcanzar el ideal republicano de gobierno. Desde entonces, el acercamiento a los políticos como variable independiente ha dado lugar a una gama de conceptos tales como "profesionalismo", "profesionalización", "calidad de los políticos", "competencia política"... que tipifican quiénes son los que gobiernan y cuál es su relación con el nivel de calidad de la democracia (Alcántara 2012; Burns et al 2004; Katz y Sala 1996; Squiere 1993; Norris 1997). Los políticos que ejercen sus funciones de forma continuada, en exclusiva y cuentan con la formación y experiencia requeridas son los más proclives a generar el bien común en los asuntos públicos.

El objetivo de este apartado es hacer un repaso a las cinco fuentes de las que procede el capital para lanzarse a la arena política: la selección partidaria, la formación, la popularidad, la familia y los recursos económicos. Todas ellas construyen las habilidades y oportunidades para participar en política y por tanto, condicionan el papel del agente en su ejercicio de representación. La escasa relevancia del partido y la formación partidista frente al dinero para costear la campaña y la popularidad de sus labores asistenciales, enaltecen la figura del agente y subordinan el mandato. Este personalismo difumina el vínculo partidista y distorsiona la abstracción institucional del merito de la gestión pública, a la que siempre le acompaña la etiqueta del político conseguidor. El carácter endogámico es otro de los rasgos neopatrimoniales que definen a la clase política nacional además de ser manifestación de la confianza particularizada que rige en el país. Con respecto a la exclusividad, la compatibilidad de las funciones de representación de los diputados dominicanos con actividades empresariales, genera un escenario en el que pueden surgir conflictos de interés entre el fin institucional y el corporativo que comprometan la inclusividad del mandato.

Con los datos relativos al nivel de educación y años de experiencia legislativa, política, en cargos de representación y designación de los diputados dominicanos en el periodo 1998-2010, se elabora un "Índice de Expertise Institucional" para comprobar cómo afecta este perfil al ejercicio de la representación. Si las instituciones lideran los procesos de modernización, habrá que esperar que el mayor nivel de experiencia de los diputados dominicanos y el contacto con las instituciones en la etapa de la consolidación democrática haya limitado el ejercicio particularista que históricamente ha caracterizado la vida política en el país. El tratamiento estadístico de los datos demuestra por el contrario que a mayor nivel de experiencia, mayor es el porcentaje de parlamentarios que concedían mucha/bastante importancia a los grupos de interés a la hora de elaborar las leyes. El paso por las instituciones tampoco afianza el vínculo indirecto programático entre diputado y elector, ya que a partir de 1998 en que desaparecen los tres caudillos históricos, no se observa tendencia alguna que relacione experiencia y vínculos programático/ideológicos. Cuanto mayor es su paso por las instituciones, mayor es el porcentaje de legisladores que tienen familiares dedicados al ejercicio de la vida pública. Esta tendencia refleja en el ámbito legislativo la funcionalidad de las redes familiares como círculos de confianza particularizada que dan acceso al ejercicio de la vida pública. 


\section{1) El pasado del escenario Institucional}

\section{¿La formación del Estado precede a la creación de las instituciones democráticas o al revés?} ¿Cómo fue la transición a la movilización política de masas?

El objetivo de este apartado es explorar la hipótesis neoinstitucionalista de la influencia de las coyunturas históricas en las que se forman las instituciones en la orientación de las políticas a largo plazo (March y Olsen 1997; Hall y Taylor 1996; Knight 1992; Ostrom 1990). Según este enfoque, en el momento formativo de las instituciones las ideas y definiciones de las que se alimentan marcan el rumbo y fijan las condiciones para la racionalidad restringida de los actores. En consecuencia, el constreñimiento institucional de los protagonistas contemporáneos tiene raíces históricas y es producto de las decisiones de los actores del pasado. Una vez establecida la estructura, ésta deviene persistente a través de los mecanismos de reproducción, aunque también es susceptible de cambio ante procesos que erosionen el legado heredado (Ikenberry 1994). En el caso de la política particularista, el trabajo seminal de Shefter (1994) inaugura la atención al contexto institucional histórico en la explicación de la persistencia del patronazgo en Europa y Estados Unidos. A pesar de la especificidad histórica de los países, los actores comparten las mismas alternativas en la maximización de sus intereses mediante la acción institucional para perpetuar o descartar el particularismo burocrático. Así lo demuestra el autor en su "Teoría de la Experiencia Crítica" que se corrobora para el caso dominicano, como se relata a continuación.

El primero de los momentos críticos identificados por Shefter es el de la burocratización:

Si las instituciones democráticas se crean antes de que se haya consolidado la profesionalización de la gestión administrativa, los partidos tendrán en la administración una fuente de recursos a su disposición y el patronazgo será una de las herramientas de movilización política para alcanzar el poder (Shefter 1994:31). Este momento fundacional identificado por el autor resulta clave para establecer la frontera entre el espacio del Estado y el espacio de la política. Tal fue el escenario en la República Dominicana en la coyuntura transicional de 1961. Durante los treinta años de vigencia de la dictadura de corte sultanístico (Linz y Stepan 1996) de Rafael Leónidas Trujillo (1930-1961), el nepotismo, el ejercicio del poder como propiedad y la ausencia de límites entre lo público y privado, fueron señas de identidad de este régimen en el que el acceso al Estado fue caprichosamente controlado por el patrón. La preferencia sesgada en la relación Estado-política durante la Era Trujillo se teatralizó en el requisito de pertenecer al Partido Dominicano para ser funcionario $^{40}$. Se estima que durante los treinta años de dictadura trujillista, el $50 \%$ de la población dominicana estuvo afiliada al Partido Dominicano (Gleijeses 2011). El diagnóstico que realizara Jesús de Galíndez en 1956 sobre la Era Trujillo, revela el carácter arbitrario del diseño administrativo y la nula relevancia de las funciones ejecutivas de los estamentos públicos supeditados al mandato del Presidente:

«En estos 25 años de la Era Trujillo, son numerosas las ocasiones en que se ha modificado la ley orgánica de Secretarías de Estado para suprimir alguna, aumentarlas, fusionarlas, separarlas (...) En los últimos años ha habido también Secretarios sin cartera. De todos ellos destaca el presidente del Partido Dominicano, en típica confusión del partido y el gobierno (...) De todos modos, llama la atención que nunca ha existido el espíritu de equipo, no hay gabinete en el sentido de un grupo de hombres que juntos llevan a cabo una labor gubernamental, los Secretarios son meros ayudantes temporales del Presidente» (Galíndez 1956:229).

¿Cómo se refleja este legado o path dependency en la etapa de la consolidación democrática? La continuidad del andamiaje administrativo trujillista durante la época carismática de los tres caudillos (1966-1996) y la etapa de la consolidación democrática actual (1996-2010), ejemplifica la

\footnotetext{
${ }^{40}$ A los funcionarios se les descontaba el $10 \%$ del salario para financiar el partido.
} 
persistencia de las estructuras anunciada por los neoinstitucionalistas históricos (Ikenberry 1994). La Ley trujillista No.4378 de 1956 ha regido la organización administrativa dominicana hasta la promulgación en 2012 de la actual Ley Orgánica de la Administración Pública, aunque ésta se encuentra actualmente a la espera de desarrollo reglamentario para su aplicación. En el caso de los entes descentralizados, la Ley No. 3455 de 1952 estuvo vigente hasta 2007 en que fue aprobada la Ley No. 176 del Distrito Nacional y los Municipios. En esta última, perviven rasgos trujillistas como la subordinación orgánica de los Ayuntamientos al Ministerio de Interior y Policía, reminiscencia de aquella "supervigilancia" y tutela de los poderes que competían con el poder central (Olivares 2013:13).

Este carácter autocrático y excluyente del Estado dominicano no fue desmontado ni durante los gobiernos del reformista Joaquín Balaguer (1966-1978 y 1986-1996) ni bajo los gobiernos perredeístas de Guzmán o Jorge Blanco (1978-1986). Tampoco ha existido en la práctica un órgano central de coordinación, definición y control de las políticas del Gobierno, ya que ni el viejo Consejo de Gobierno ni el actual Consejo de Ministros pueden competir con la omnipresencia del Presidente o de su Ministro de la Presidencia. En este sentido, es importante señalar que desde el año 2007 el Consejo de Ministros ha pasado a estar bajo la dirección orgánica del Ministerio de Economía, Planificación y Desarrollo en virtud del nuevo Sistema Nacional de Planificación Pública, por lo que ha pasado a ser un órgano meramente administrativo y no uno de diseño colegiado de política pública.

El particularismo se alimenta hoy de la capacidad recaudatoria de la que disponen todas las agencias gubernamentales. El Estado carece de control sobre las recaudaciones de los ministerios y sus dependencias por concepto de donaciones privadas, tasas, impuestos o servicios prestados. Tales ingresos son cobrados y administrados libremente por las propias instituciones, sin obligación de rendir cuentas al Estado central. A pesar de que el Sistema de Cuenta Única fue creado en 2005 (Ley No. 567-05), la resistencia de los actores han impedido su establecimiento. En el año 2013, con ocasión de la implementación del plan piloto de Cuenta Única, se contabilizaron cerca de 6.000 cuentas bancarias operativas. Similar resistencia encuentra la recién promulgada Ley General de Salarios del Sector Público del Estado Dominicano No.105 del 2013 que pretende unificar los criterios de retribución salarial de los funcionarios. En este sentido, el Ministro de Administración Pública (2012-2016), comentaba al respecto:

"Sectores privilegiados [de la Administración] todavía se resisten a su aplicación y estarían intentando paralizar su aplicación mediante un recurso de inconstitucionalidad (...) La historia juzgará a quienes pretendan impedir su aprobación" (Camejo 2013) ${ }^{41}$.

Aunque la primera Ley de Servicio Civil y Carrera Administrativa se promulgó en 1991, no fue hasta 1994 que se aprueba el reglamento para su implementación. Desde entonces, pocos han sido los avances en el establecimiento de fronteras en las relaciones entre política y Administración. En el año 2005, de los 300.000 empleados públicos, apenas el 5\% del funcionariado dominicano había sido contratado y estabilizado en sus funciones en la primera década de vigencia de la Ley (Participación Ciudadana 2005). En 2008, el PNUD denunciaba el incumplimiento en la República Dominicana de la Ley del Defensor del Pueblo ${ }^{42}$, la Ley del Servicio Civil y Carrera

\footnotetext{
${ }^{41}$ Ver declaraciones del Ministro Ventura Camejo en en periódico Diario Libre de 12 de septiembre de 2013, en http://www.diariolibre.com/noticias/2013/09/12/i402073_ventura-camejo-denuncia-intentos-porobstaculizar-ley-general-salarios. Y en periódico El Nacional en

html http://elnacional.com.do/camejo-dice-la-historia-juzgara-quienes-impidan-aprobacion-ley-salarios/

${ }^{42}$ A pesar que la Ley No.19 fue promulgada en 2001, el primer Defensor del Pueblo fue elegido más de diez años después de la aprobación de la Ley. En mayo de 2013, el dominio oficialista de ambas Cámaras
} 
Administrativa, ni la Ley Orgánica de las Secretarías de Estado. Incumplimientos que permiten al Estado eludir su responsabilidad por la vulneración de los derechos del ciudadano en su relación con la Administración así como utilizar el patronazgo como herramienta de movilización política o retribuir la lealtad de los partidos aliados con cargos públicos gerenciales (Benito Sánchez 2010:770). La ausencia de reglamento que haga operativa la Ley Orgánica de la Administración Pública No. 247 del año 2012 y la demora en la aplicación efectiva del servicio civil de carrera, son indicadores de la resistencia de las fuerzas políticas dominicanas a abandonar su naturaleza de partidos de patronazgo. Estas dilaciones en la implementación de leyes que establecerían reformas percibidas como deseables, ilustran la tesis defendida por Geddes (1991) de falta de incentivos para fiscalizarse unos a otros y cambiar unilateralmente la situación.

Como se ha descrito en el capítulo dedicado a medir la variable dependiente de esta investigación, una parte de la responsiveness democrática consiste en ubicar a seguidores en puestos públicos reales o ficticios. La entrada en la burocracia dominicana sigue estando en manos de los partidos aunque en los últimos años y con el apoyo de la cooperación internacional, se han iniciado procesos de estabilización de la carrera ${ }^{43}$, si bien la subjetividad de la valoración del desempeño del funcionario podría acarrear favoritismos que desvirtúen el proceso. Tras la aprobación de la nueva Ley de Función Pública en el año 2008, el 25\% de los 98,339 empleados públicos del gobierno central han sido incorporados al servicio de carrera (ICAP 2010:262), por lo que el 75\% restante es todavía un botín estatal al servicio de los partidos. Tal disponibilidad de la burocracia es uno de rasgos sistémicos endógenos identificados por Mitchell (2010) que perviven de épocas pasadas gracias al cual las tres fuerzas tradicionales han sobrevivido y el sistema de partidos ha permanecido estable en la etapa de la consolidación democrática.

Ninguno de los gobiernos -reformistas, perredeístas o peledeístas- han impulsado la implementación efectiva del servicio civil y cada cuatrienio renuevan la plantilla de funcionarios tras el cambio de color de la Administración (Oviedo 2005:14), haciendo uso del poder presidencial consagrado en la Constitución de nombrar por decreto todos y cada uno de los puestos de la burocracia dominicana. Ni en la reforma constitucional de 2002 impulsada por un gobierno del PRD, ni en la más reciente de 2010 promovida por un gobierno del PLD, han limitado este poder presidencial sobre la Administración Pública.

A golpe de decreto presidencial, crece la nómina del Estado y se va conformando el cuerpo de funcionarios públicos en las altas instancias de la jerarquía administrativa, donde la meritocracia cede ante criterios particularistas como el amiguismo o el parentesco ${ }^{44}$. En la administración 2008-

permitió la elección de esta figura que quedó en manos de Zoila Medina, cercana al partido reformista aliado al oficialista PLD.

${ }^{43}$ Programa de Apoyo a la Reforma de la Administración Pública (PARAP) y Programa de Apoyo a la Sociedad Civil y Autoridades Locales (PASCAL) en ejecución y con un presupuesto de 7 millones de euros.

${ }^{44}$ En 2010 una auditoría de la Cámara de Cuentas denunciaba que el Instituto de Desarrollo y Crédito Cooperativo (IDECOOP) dirigido por Pedro Corporán -presidente del partido PUN aliado al PLD- tenía en nómina a 5 parientes directos y se pagaron salarios a personas que no cumplían con ninguna función, no tenían registros de asistencia y sin evidencia de labor realizada. Ver noticia en TV SIN, http://www.noticiassin.com/2013/01/no-es-nepotismoninguno-tiene-privilegios-que-transgredan-preceptosideales-de-la-administracion-publica/.

En 2013, la institución pública creada para asistir a los ciudadanos indigentes llamada Comunidad Digna dirigida por Juana Díaz, tenía a su hermana como encargada provincial de la agencia en Moca, a su sobrina como subdirectora de Acción Solidaria, su suegro como encargado de Servicios Generales, al cuñado de su hija como promotor de la institución en Santo Domingo Este y la imprenta de su hijo era suplidora de la institución. Ver noticia en periódico digital Acento, del 29 de enero de 2013. En http://www.acento.com.do/index.php/news/42912/56/Comunidad-Digna-ha-dignificado-las-vidas-de-sudirectora-parientes-y-allegados.html 
2012 un total de 325 Subsecretarios laboraban en las dependencias públicas nacionales, a pesar de que por ley han de existir 57. Como se especificaba en el capítulo dedicado al particularismo burocrático de esta investigación, el fenómeno alcanza dimensiones descomunales en el Servicio de Relaciones Exteriores, donde la carrera consular se ha convertido en un premio para políticos reformistas y aliados al oficialismo que fungen como agregados culturales, cónsules, vicecónsules, consejeros, secretarios o auxiliares de embajada ${ }^{45}$. Con 1,163 funcionarios, 660 diplomáticos y 503 consulares, la República Dominicana lidera la representación diplomática en el mundo, e incluso algunos países han rehusado acreditar más personal dominicano en su territorio ${ }^{46}$. Otras de las formas en que se manifiesta la institucionalización perversa del proceso de burocratización es en el fenómeno de la duplicidad de agencias públicas con funciones similares ${ }^{47}$. Desde 1962 la organización del Estado dominicano ha crecido exponencialmente y hoy más de 4.500 corporaciones dependen del Poder Ejecutivo (Collado 2014). Estos datos confirmarían en la República Dominicana la amenaza del «potencial antidemocrático de la burocratización de la administración» en contextos neopatrimoniales que identificara Mancilla (1991). En estos escenarios, el aumento de instancias y procesos no obedece a razones de eficiencia sino a la creación de espacios para recompensar clientelas, precipitando así el círculo vicioso de desfalco y corrupción administrativa (Mancilla 1991:118).

La movilización a la política de masas es la segunda de las coyunturas históricas críticas identificada por Shefter (1994):

Tras el asesinato del dictador en 1961, comienza la primera transición (fallida) que desemboca en el gobierno autoritario de Joaquín Balaguer en 1966, antiguo hombre de la dictadura trujillista. Como describiera Hartlyn (1998), el liderazgo político nacional transfirió estas tendencias neopatrimoniales del antiguo régimen al nuevo orden y la difusa separación entre lo público y lo privado siguió caracterizando la evolución de la política dominicana desde 1961. Los tres actores carismáticos protagonistas en las décadas siguientes -Joaquín Balaguer (PRSC), Juan Bosch (PLD) y José Francisco Peña Gómez (PRD)- recondujeron el conflicto al control del patronazgo por medio de partidos de corte personalista, un poder centralizado ejercido a través de vínculos de

\footnotetext{
${ }^{45}$ Ante las denuncias en los medios de comunicación denunciando los "funcionarios diplomáticos fantasmas" el Gobierno estableció el pago de dietas de viajes y alojamiento en el exterior solo para aquellos que pudieron acreditar que estaban en sus lugares de destino. De esta manera, en marzo de 2014 se redujo al 50\% el pago de estos servicios. Ver al respecto la noticia en periódico Diario Libre del 24 de marzo de 2014, en http://www.diariolibre.com/noticias/2014/03/24/i539511_malestar-relaciones-exteriores-por-pago-solo-delsalarios-viticos.html. Ver noticas al respecto en periódico digital Acento del 17 de junio de 2014 en http://acento.com.do/2014/politica/8149488-danilo-pasa-aplanadora-en-cancilleria-contralor-general-hizoinvestigacion-sobre-irregularidades/.

${ }^{46}$ Ver noticia en periódico nacional HOY del 21 de enero de 2012, en http://hoy.com.do/crece-y-crecenomina-del-servicio-exterior/

${ }^{47}$ Tal es el caso de la Dirección de General de Mantenimiento de Carreteras y Caminos Vecinales, perteneciente al Ministerio de Obras Públicas y Comunicaciones (MOPC), y la Dirección General de Embellecimiento de Carreteras y Avenidas de Circunvalación, dependiente de la Presidencia de la República. La Dirección de Supervisión y Fiscalización de Obras del MOPC comparte funciones similares con la Oficina de Ingenieros Supervisores de Obras del Estado (OISOE) dependiente del Poder Ejecutivo. En el área de investigación agrícola conviven tres organismos públicos con funciones similares: el Instituto de Investigaciones Agropecuarias y Forestales (IDIAF), el Centro para el Desarrollo Agropecuario y Forestal (CEDAF) y el Consejo Nacional de Investigaciones Agropecuarias y Forestales (CONIAF). Para la asistencia social de las comunidades barriales operan: la Comisión Presidencial de Desarrollo Barrial, la Comisión Presidencial de Desarrollo Provincial, el Proyecto Comunidad Digna, la Dirección General de Desarrollo de la Comunidad y el Fondo de Promoción a la Comunidad. Entidades como el Consejo Estatal del Azúcar (CEA) que antaño gestionaban los 12 ingenios azucareros de propiedad estatal, hoy perviven en el organigrama público con la misma nómina de empleados a pesar de que solo existan 3 y estén en régimen de arrendamiento.
} 
lealtad y dependencia y una mezcolanza de intereses publicoprivados en la acción de gobierno (Hartlyn 1998:40). La figura paternal autoritaria de la sociedad rural y conservadora que representaba Balaguer convivió con la también paternal figura de Juan Bosch, pero con el cariz de profesor y guía del pueblo (Lora 2010:77).

La primera transición dominicana estuvo marcada por la inestabilidad y la violencia. Al gobierno provisional de Joaquín Balaguer (1961-1962), le siguió la victoria del PRD de Juan Bosch en las elecciones de 1962. Iglesia y empresarios, intimidados unos por la oficialización de la educación y por el carácter obrerista otros de la nueva Constitución de 1963, prendieron la chispa que desencadenó el Golpe de Estado del 25 de septiembre. Las élites empresariales asumieron entonces el control del Estado en el Triunvirato (1963-1965) en un escenario de conflicto y levantamiento popular. Desatada la Guerra Civil y tras la intervención norteamericana del 28 de abril de 1965, la guerra popular entre constitucionalistas y golpistas termina con la victoria de estos últimos y con la vida de más de 4.000 dominicanos. Joaquín Balaguer, candidato de confianza de los EEUU, regresa del exilio y gana las elecciones de 1966. En este sentido y como destacara Piatonni (2001), cuanto más turbulenta sea la transición a la política de masas, mayor será la probabilidad de usar el clientelismo para evitar la victoria de partidos de corte programático revolucionario, como lo era en aquel entonces el opositor PRD.

Como demuestra en su estudio comparado acerca de los orígenes históricos de los partidos en EEUU, Alemania, Italia, Francia y Gran Bretaña, los partidos fundados por élites que ocupaban posiciones en el régimen pre democrático -partidos internamente movilizados- tienden a estar orientados al patronazgo. Dado su acceso privilegiado a los recursos del Estado, los utilizarán en la competencia que se inicia con la apertura transicional para mantener sus bases de apoyo y se servirán para ello de patronos locales y caciques políticos. Por el contrario, los partidos externamente movilizados sin posibilidad de entrar en el sistema distribuyendo beneficios particularistas, se ven obligados a establecer redes y vínculos con organizaciones de masa como sindicatos, ligas de campesinos, iglesias, etc y compelidos a fundamentar los incentivos en la ideología o en la solidaridad antes de llegar al poder (Shefter 1994:29).

Su "Teoría de la Experiencia Crítica" para explicar la naturaleza clientelar de los partidos políticos refuta la teoría neoclásica del patronazgo (Epstein 1967) que justificaba tal naturaleza en el bagaje social y en la herencia cultural de su cantera de votantes. Esto explicaría que a pesar de que los votantes de la Social Democracia alemana y de los Demócratas Cristianos italianos eran sectores de clase media y obreros industriales más propensos a respaldar beneficios programáticos, el primero era un partido programático y el segundo un partido de patronazgo. De igual manera, a pesar de que los votantes del Partido Demócrata de Indiana-Ohio y del Partido Socialista de la II República Española eran migrantes y campesinos sin tierra, en el primero la vinculación con sus bases era individual-particularista y en el segundo colectiva-ideológica (Shefter 1994:23).

El Partido Reformista (PR) fundado en 1963 por Joaquín Balaguer -quien fuera Subsecretario de la Presidencia (1936), Subsecretario de Relaciones Exteriores (1937), Embajador (1940-1949), Secretario de Educación (1949-1955), Secretario de Estado de Relaciones Exteriores (1955-57) y Vicepresidente y Presidente de la República Dominicana (1960-1962) durante la dictadura de Trujillo- ejemplifica el prototipo de partido internamente movilizado creado por elites del régimen anterior con acceso a los recursos del Estado y organización cacical. Considerado el fundador moderno del clientelismo en el país (Tejada 2007), su estrategia de relación con los sectores marginados se basó en la despolitización de las masas urbanas y campesinas a través del movimentismo. La organización partidaria se asentaba en directorios al frente de los cuales estaban los dirigentes provinciales legitimados por la relación personal y confianza que en ellos depositaba el caudillo (Jiménez Polanco 1999:386). Joaquín Balaguer se mantuvo en el poder por más de 20 
años (1966-1978 y 1986-1996) hasta que la crisis provocada por el fraude electoral de 1994 precipitara su salida negociada de la escena pública nacional.

Pero la historia no fija la naturaleza de la responsiveness democrática. Factores externos como crisis económicas, hiperinflación... o avatares internos pueden poner a prueba la fortaleza organizativa del partido y debilitar los vínculos programáticos o clientelares que construyeron los ancestros políticos (Shefter 1994:12). Tal viraje se produjo en el Partido Revolucionario Dominicano (PRD), ejemplo de partido externamente movilizado defensor de las libertades políticas y la justicia social. Creado en el exilio por opositores al régimen de Trujillo en 1939 y abanderado de la democracia popular, asentó la base de su fisonomía organizativa en los Círculos de Estudio de los Comités de Base (ya como PLD). En 1978, conquista el poder en la que sería la segunda transición dominicana. Los gobiernos del PRD (1978-1982 y 1982-1986) estuvieron condicionados por las luchas intestinas entre las facciones, el bloqueo en el Senado de mayoría balaguerista y la gran crisis financiera de 1984. Ante la pérdida de apoyo ciudadano y el descontento por la ausencia de la transformación social prometida, los ejecutivos perredistas orientaron su acción de gobierno hacia las ya conocidas prácticas clientelares. La grave crisis económica de los años ochenta supuso la desaparición del clivaje autoritarismo-democracia y surge el del desempeño económico en el sistema de partidos dominicano (Mitchell 2010). A partir de entonces, se refuerza la competición entre las principales fuerzas políticas alrededor de su efectividad para distribuir bienes selectivos ("targeted exchange") y se debilita su función movilizadora de clivajes representativos ("policy exchange"). 


\section{2) Las reglas del juego}

¿Qué características del diseño electoral dominicano favorecen el particularismo en la representación y movilización de intereses?

\section{$\checkmark \quad$ Voto Preferencial}

La legitimidad directa de la elección de los representantes en listas desbloqueadas en las que los electores pueden expresar su preferencia tiende a estrechar el vínculo entre electores y políticos. De ahí que algunos autores hayan identificado este tipo de elección como una de las variables que fomentan la política particularista en democracia. Como argumentaran Carey y Shugart (1995), el voto preferencial y la reelección consecutiva condicionan la labor de los legisladores en una búsqueda de votos personales en la que los intereses de su circunscripción se anteponen a los intereses nacionales. En su deseo de diferenciarse del candidato opositor y del compañero de partido, los diputados buscan atraer recursos para su circunscripción o elaborar leyes reclamando crédito por ello en la rendición de cuentas electoral (Muñoz 2011). Este deseo tiende a exacerbar el individualismo legislativo y disminuye el valor informativo de las posturas de los partidos frente a los votantes en una lucha entre candidatos individualistas que compiten por la atención limitada de los votantes (Carey 2009:239)

El sistema de voto preferencial con listas cerradas y desbloqueadas en la elección de los diputados dominicanos fue introducido por la JCE mediante la Resolución No.5/2001, siendo las elecciones del 2002 las primeras en las que los dominicanos pudieron alterar el orden de los candidatos de la boleta. Con esta medida, se pretendía limitar el poder de las cúpulas partidarias en la selección de candidatos y hacer del proceso uno más participativo y representativo. El comportamiento individualista de los diputados dominicanos que apuntara Carey (2009) se refleja en el personalismo legislativo que caracteriza su actividad propositiva tras la instauración del voto preferencial en 2002, incluso en aquellas futuras leyes donde el nivel de inclusividad o agregación de intereses es mayor.

Los datos del Indicador 1 de esta investigación muestran que la mayoría de las iniciativas legislativas se realizan a título individual a propuesta de un solo diputado, especialmente en aquellas de carácter concesional individual y por tanto, más propias de la relación de intercambio particularizado de apoyo político a cambio de un favor público (80,41\% en 2006-2010). Como muestran los siguientes gráficos, incluso en aquellas iniciativas de Ley que conllevan la representación de intereses generales, más de la mitad se hacen a título individual, siendo este porcentaje de un 60,31\% en la legislatura 2006-2010. En las tres tipologías de proyectos de Ley, en función de quiénes sean los representados -ciudadanos dominicanos, grupos concretos o individuos- la legislatura de 2002 en la que se utiliza por primera vez el voto preferencial, marca un punto de inflexión al alza en cuanto al trabajo en solitario de los diputados dominicanos. 
Gráfico 3.2.2.1 Proyectos de Ley de carácter Individual según número de proponentes (\%) 1998-2010

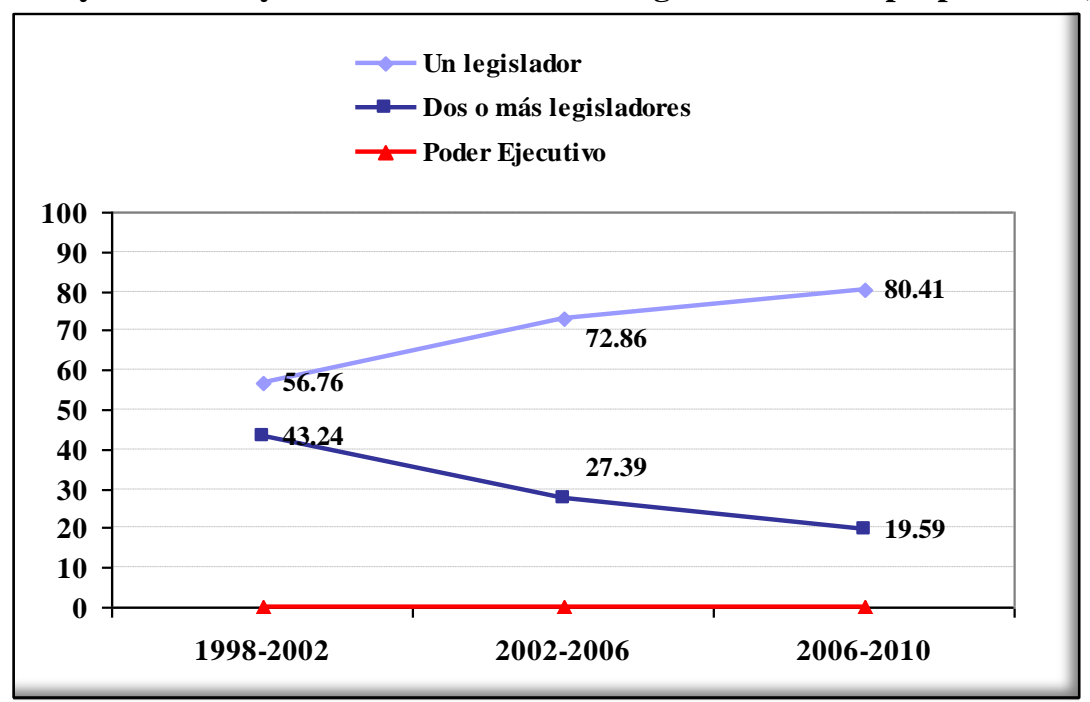

Gráfico 3.2.2.2 Proyectos de Ley de carácter Corporativo según número de proponentes (\%) 1998-2010

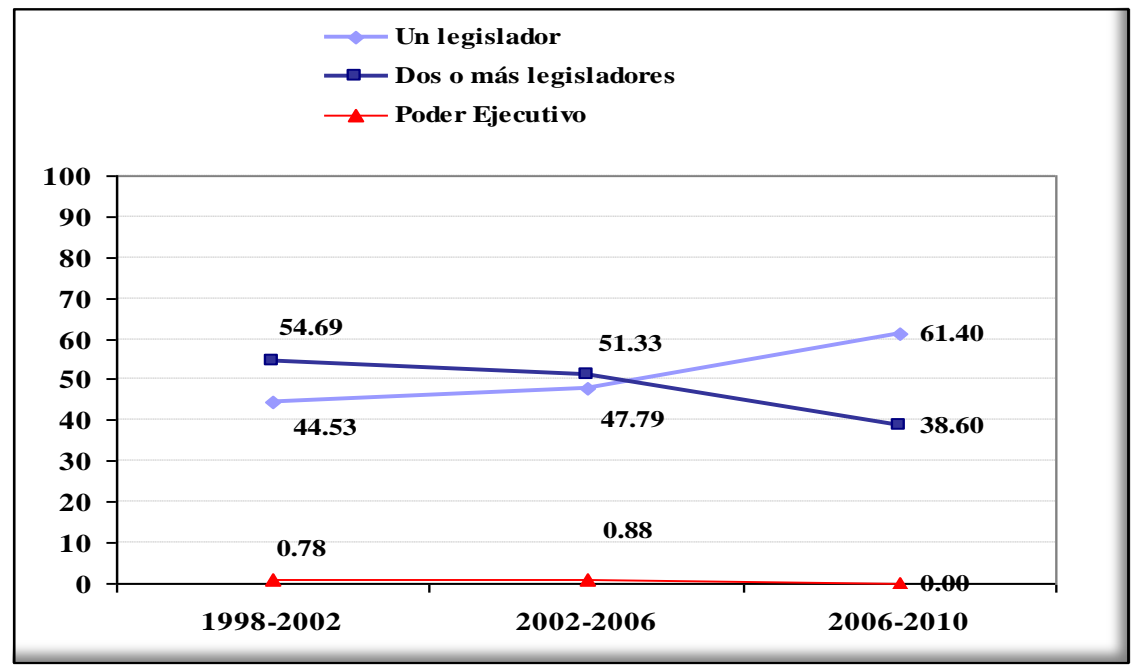

Gráfico 3.2.2.3 \% Proyectos de Ley de carácter General según número de proponentes 1998-2010

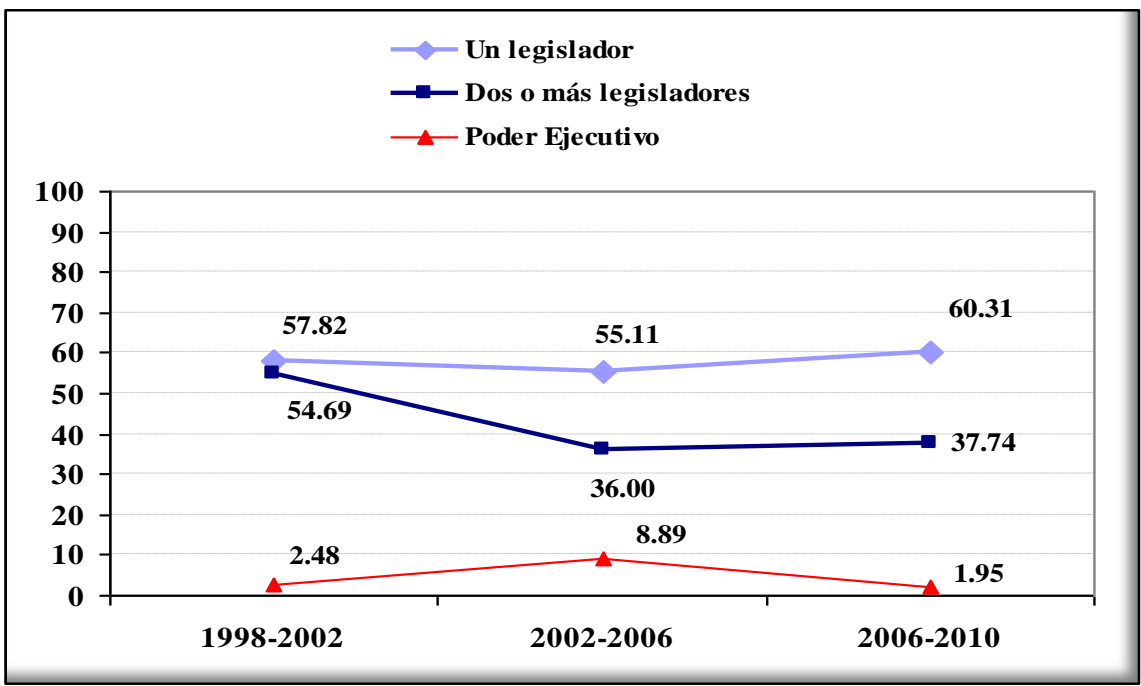

Fuente: Elaboración propia 
Como se analizará en el apartado dedicado a la competencia entre los actores políticos, el focus distrital está presente en el ejercicio de la representación de los legisladores dominicanos. Las percepciones de los diputados acerca de las razones que motivaron el voto de sus electores (PELA 1994-2010) muestran que en la actual legislatura 2010-2016, la valoración de su experiencia como diputado ocupa el tercer lugar en importancia después de la simpatía y la campaña. El escenario de la rendición de cuentas de los legisladores suele ser la página web personal o institucional en la que dan cuenta de los proyectos iniciados y de aquellas leyes aprobadas gracias a su gestión, para conocimiento de sus electores. Además de las iniciativas legislativas, mediante los denominados «Proyectos de Resolución», el diputado ejerce de bróker para la ejecución de bienes y servicios públicos en su provincia, en una interacción más propia del ejecutivo nacional o municipal ${ }^{48}$.

En un escenario de Legislativo subordinado y Presidente dominante como es el dominicano, el trabajo en solitario de los diputados parece ser el pago por no amenazar la cohesión partidaria parlamentaria, definida como la propensión de los miembros de un partido a votar en el mismo sentido (Ames 2000:35). Si bien estos datos acerca de la actividad propositiva individual de los diputados dominicanos indican que son pocas las ocasiones en los que el partido habla como una sola voz colectiva en la arena legislativa, ello no ha impedido que la agenda del Presidente se cumpla y que cierren filas en torno al líder de turno en los temas relevantes como el presupuesto nacional. Con este tipo de actividad legislativa particularizada no se requiere que el Congreso Nacional sea un lugar de debate entre bancadas. Como confirmaba un diputado no oficialista 5 meses después de las legislativas de 2010: «Como grupo, desde las elecciones nos hemos reunido solo dos veces...» ${ }^{49}$. Aunque sí precisa respetar la orden que llega desde la dirección partidaria superior. Y como ejemplo, sirva la jornada del 20 de octubre de 2011 en que aprobó el proyecto de ley de presupuesto del 2012 y en la que el Presidente de la Cámara de Diputados instigaba a sus señorías a votar la ley en 10 minutos, aprovechando la ausencia de legisladores de la oposición y eliminando de la agenda la lectura de las propuestas de enmiendas a la Ley ${ }^{50}$. Si la cohesión partidaria es producto de trueques individuales o retribuciones particulares, es una eventualidad difícil de cuantificar por su conexión con el fenómeno de la corrupción.

\footnotetext{
${ }^{48}$ Sirva como ejemplo la página web del diputado oficialista Juan Julio Campos Ventura, de la provincia de La Altagracia. Junto a los Proyectos de Ley sometidos, da cuenta de los «Proyectos de Resolución», en todos ellos ejerce de bróker para atraer a la provincia desde la construcción de un hospital al arreglo de una calle, o el reconocimiento a un empresario hotelero por su aportes al desarrollo de la provincia: Proyecto de Resolución que Solicita la Construcción de un Hospital Traumatológico en Higuey; Proyecto de Resolución que Solicita la Instalación de una Oficina para Expedir y Renovar Libretas de Pasaportes en Higuey; Proyecto de Resolución que Solicita la Construcción y Reconstrucción de las Calles de Higuey; Proyecto de Resolución que Solicita la Construcción de un Nuevo Liceo en Higuey; Proyecto de Resolución que Solicita la Construcción de la Carretera Higuey-Nisibón-Miches; Proyecto de Resolución que Solicita la Construcción de un Muelle en el Distrito Municipal de Boca de Yuma; Proyecto de Resolución que solicita la Construcción de un Hospital Público en el Distrito Municipal Turístico de Verón-Punta Cana; Proyecto de Resolución que Solicita la Construcción de un Liceo en la Comunidad de Benerito, Municipio San Rafael de Yuma; Proyecto de Resolución que Reconoce a Frank Rainieri, Presidente del Grupo Punta Cana, por sus valiosos aportes al Desarrollo Turístico en la República Dominicana. En http://www.camaradediputados.gob.do/app/app_2011/cd_diputados_det.aspx?id=689

${ }^{49}$ Entrevista realizada a diputado reformista el 14 de octubre de 2010.

${ }^{50}$ Ver video de la jornada en la Cámara de Diputados en http://www.youtube.com/watch?v=yr59x seX_JU y análisis en la prensa nacional al respecto, en periódico El Caribe del 26 de Noviembre de 20011 en http://www.elcaribe.com.do/2011/10/26/voten-honorables-voten-voten-fernando-casanova; en periódico Acento del 5 de Diciembre de 2012 en http://acento.com.do/2012/economia/27421-la-anje-no-quiere-otroespectaculo-de-voten-honorables-voten/
} 
Ante las críticas por el exacerbado personalismo de las contiendas de los últimos años y las luchas entre compañeros de boleta -a las que el Presidente de la JCE calificó de "canibalismo dentro del partido" ${ }^{21}$ - la JCE eliminaba el voto preferencial mediante Resolución No. 74/2010 con el argumento de proteger la institucionalidad partidista. Sin embargo, los legisladores volvieron a instaurarlo tres años después, esta vez por Ley y con la novedad añadida de que en la futura contienda del 2020 se utilizará también en la elección de los regidores (concejales) y vocales de distrito. Con la Ley No.157 de 2013 que restablece el voto preferencial en la República Dominicana se constata la falta de voluntad de los actores para asumir el coste de la institucionalidad partidista así como la vocación de continuidad del particularismo en la representación política, ya que se reproducirá a nivel municipal la competencia entre patronos locales. Y sirva como ejemplo que, siendo la figura del regidor una del poder legislativo local encargada de fiscalizar la gestión municipal, reclaman que se les conceda el derecho a tener su propio "barrilito" o fondo de asistencia social para atender a sus electores. Esta concesión de las elites políticas nacionales a las elites políticas locales podría atomizar la ya nimia agenda municipalista de los partidos dominicanos.

El punto de inflexión que ha marcado el voto preferencial en un escenario de larga tradición clientelar como el dominicano, indica que éste ha sido uno de los dispositivos a través del cual se ha adaptado y perpetuado el mandato particularizado de la representación. Por tanto, esta singularidad del sistema electoral dominicano no es variable sine qua non para la existencia del clientelismo, pero sí un factor potenciador.

\section{$\checkmark \quad$ Tamaño de la circunscripción y fraccionamiento del territorio nacional}

Cuanto menor es la magnitud del distrito, mayor es la importancia de los electores en la continuación de la carrera política de los diputados y menor es la capacidad de control de las cúpulas partidistas en el proceso (García Díez 2001:49). Si bien las circunscripciones pequeñas estrechan la relación entre políticos y electores -haciendo que ésta sea más proclive a la responsiveness y rendición de cuentas- también amplifica el localismo en la representación, con la consecuente amenaza de que la atención personalizada a los electores se imponga a la abstracción y generalidad del discurso. Como demostrara Guevara (2004) para el caso de Panamá, en escenarios caracterizados por la tradición clientelar, carencia de servicios públicos y sectores marginales, un sistema electoral basado en distritos pequeños tiende a reproducir el particularismo (Guevara 2004:96).

En la República Dominicana, la elección de los miembros de la Cámara de Diputados se realiza mediante la fórmula electoral de D’Hondt, con magnitudes de distrito que varían entre un mínimo de 2 y un máximo de 18 diputados a razón de un diputado por cada 50.000 habitantes o fracción superior a 25.000. La magnitud promedio de los distritos electorales dominicanos se sitúa en el rango de las circunscripciones pequeñas -2 a 5 escaños- (Nohlen 2004: 60). Como muestra la Tabla 3.2.A.2.1 en la actualidad el mapa electoral dominicano está conformado por 48 distritos electorales. La circunscripción electoral coincide con la demarcación de la provincia en 23 de ellas, y en las 9 más pobladas, la provincia se subdivide entre 2 y 6 circunscripciones. Las circunscripciones electorales con menor número de representantes son también las provincias más

\footnotetext{
${ }^{51}$ Palabras del Presidente de la JCE Roberto Rosario, en periódico Diario Libre de 13 de septiembre de 2013. En http://www.diariolibre.com/noticias/2013/09/13/i402104_roberto-rosario-voto-preferencial-dejcanibalismo-los-partidos-polticos.html
} 
pobres y las situadas en los últimos puestos en el Índice de Empoderamiento Humano (IDH) del PNUD (2010). Así, las provincias de Pedernales, Independencia y Bahoruco ocupan el puesto 32, 30 y 31 del IDH, mientras que la circunscripción III del Distrito Nacional con 7 diputados, la I de Santiago y la circunscripción III de Santo Domingo ambas con 8 diputados, ocupan la primera, la tercera y la octava posición en el Índice respectivamente.

En la liza legislativa, se ha demostrado la relación entre magnitud del distrito y niveles de cohesión legislativa, entendida como el grado en que los representantes del un mismo partido comparten creencias en torno a cuestiones de relevancia política (García Díez 2001:40). Los datos acerca del comportamiento individualista en la actividad propositiva de los diputados de la sección anterior aportan pistas sobre cómo se manifiesta la cohesión legislativa en la Cámara de Diputados de la República Dominicana. Para comprobar el efecto del mayor tamaño de la circunscripción en la limitación de la política particularista, lo siguiente será ver cómo es la actividad propositiva de los 5 diputados nacionales por acumulación, elegidos por primera vez en 2010 para comprobar si difiere tanto en contenido -representación general, corporativa o individual- como en la forma -iniciativa propia o conjunta- de la de sus colegas diputados provinciales. Este tipo de circunscripción a nivel nacional que se superpone sobre los niveles inferiores, se introduce como mecanismo corrector de la desproporcionalidad y con el objetivo de generar en los partidos una visión de política nacional y desligarlos de los intereses particularistas de los electorados de sus circunscripciones.

Tabla 3.2.2.1 Numero y tamaño de las circunscripciones electorales en la República Dominicana

\begin{tabular}{|c|c|c|c|c|c|c|}
\hline PROVINCIA & $\begin{array}{c}\text { CIRCUNSCRIPCI } \\
\text { ON } \\
\end{array}$ & $\begin{array}{c}\text { NÚMERO } \\
\text { DIPUTADOS } \\
\text { CIRCUNSCRIPCIÓN }\end{array}$ & $\begin{array}{c}\text { NÚMERO } \\
\text { DIPUTADOS } \\
\text { PROVINCIA }\end{array}$ & POBLACIÓN & IDH (PNUD, 2010) & $\begin{array}{c}\text { POSICIÓN } \\
\text { PROVINCIA } \\
\text { IDH (PNUD, 2010) } \\
\end{array}$ \\
\hline Pedernales & $\mathrm{I}$ & 2 & 2 & 38,941 & 0.112 & 32 \\
\hline Elías Piña & I & 2 & 2 & 70,589 & 0.145 & 31 \\
\hline Independencia & I & 2 & 2 & 54,785 & 0.19 & 30 \\
\hline Bahoruco & I & 2 & 2 & 118,987 & 0.252 & 28 \\
\hline Dajabón & I & 2 & 2 & 67,887 & 0.421 & 27 \\
\hline Hato Mayor & I & 2 & 2 & 89,578 & 0.417 & 24 \\
\hline Monte Cristi & I & 2 & 2 & 135,710 & 0.387 & 21 \\
\hline El Seibo & I & 2 & 2 & 115,889 & 0.316 & 17 \\
\hline Santiago Rodríguez & I & 2 & 2 & 164,941 & 0.274 & 15 \\
\hline San José de Ocoa & I & 2 & 2 & 82,458 & 0.473 & 11 \\
\hline Samaná & I & 2 & 2 & 168,265 & 0.486 & 9 \\
\hline Hermanas Mirabal & I & 2 & 2 & 103,974 & 0.492 & 6 \\
\hline Peravia & I & 3 & 3 & 298,747 & 0.413 & 23 \\
\hline Valverde & I & 3 & 3 & 207,447 & 0.381 & 20 \\
\hline Sánchez Ramírez & I & 3 & 3 & 157,457 & 0.465 & 13 \\
\hline María Trinidad $S$. & I & 3 & 3 & 140,784 & 0.471 & 12 \\
\hline Monseñor Nouel & I & 3 & 3 & 201,474 & 0.521 & 5 \\
\hline Monte Plata & I & 4 & 4 & 200,454 & 0.204 & 29 \\
\hline La Romana & I & 4 & 4 & 330,587 & 0.419 & 26 \\
\hline Аzиа & I & 4 & 4 & 256,981 & 0.301 & 16 \\
\hline Barahona & I & 4 & 4 & 226,898 & 0.271 & 14 \\
\hline La Altagracia & I & 4 & 4 & 335,677 & 0.488 & 7 \\
\hline Espaillat & I & 5 & 5 & 390,478 & 0.409 & 22 \\
\hline $\begin{array}{c}\text { San Juan de la } \\
\text { Maguana }\end{array}$ & $\begin{array}{l}\text { I } \\
\text { II }\end{array}$ & $\begin{array}{l}3 \\
2\end{array}$ & 5 & 300,476 & 0.349 & 18 \\
\hline Duarte & $\begin{array}{l}\text { I } \\
\text { II }\end{array}$ & $\begin{array}{l}4 \\
2\end{array}$ & 6 & 384,789 & 0.362 & 19 \\
\hline $\begin{array}{l}\text { San Pedro de } \\
\text { Macorís }\end{array}$ & $\begin{array}{l}\text { I } \\
\text { II }\end{array}$ & $\begin{array}{l}4 \\
2\end{array}$ & 6 & 418,850 & 0.522 & 4 \\
\hline Puerto Plata & $\begin{array}{l}\text { I } \\
\text { II }\end{array}$ & $\begin{array}{l}4 \\
2 \\
\end{array}$ & 6 & 490,733 & 0.558 & 2 \\
\hline La Vega & $\begin{array}{l}\text { I } \\
\text { II }\end{array}$ & $\begin{array}{l}6 \\
2\end{array}$ & 8 & 420,478 & 0.486 & 10 \\
\hline San Cristóbal & $\begin{array}{c}\text { I } \\
\text { II } \\
\text { III }\end{array}$ & $\begin{array}{l}4 \\
4 \\
3\end{array}$ & 11 & 859,741 & 0.419 & 25 \\
\hline
\end{tabular}




\begin{tabular}{|c|c|c|c|c|c|c|}
\hline Distrito Nacional & $\begin{array}{c}\text { I } \\
\text { II } \\
\text { III }\end{array}$ & $\begin{array}{l}6 \\
5 \\
7\end{array}$ & 18 & $1,484,789$ & 0.734 & 1 \\
\hline Santiago & $\begin{array}{c}\text { I } \\
\text { II } \\
\text { III }\end{array}$ & $\begin{array}{l}8 \\
4 \\
6\end{array}$ & 18 & $1,833,451$ & 0.524 & 3 \\
\hline Santo Domingo & $\begin{array}{c}\text { I } \\
\text { II } \\
\text { III } \\
\text { IV } \\
\text { V } \\
\text { VI }\end{array}$ & $\begin{array}{l}6 \\
4 \\
8 \\
6 \\
5 \\
7\end{array}$ & 36 & $2,995,211$ & 0.487 & 8 \\
\hline $\begin{array}{l}\text { Promedio tamaño } \\
\text { circunscripción }\end{array}$ & & 3.70 & 5.56 & & & \\
\hline
\end{tabular}

Fuente: Elaboración propia a partir de datos de la JCE, Oficina Nacional de Estadística (Censo 2006) y Oficina Desarrollo HumanoPNUD. Color marrón oscuro IDH muy bajo, color marrón IDH bajo, marrón claro IDH medio y color verde, IDH alto.

Los datos de esta investigación revelan que la circunscripción nacional parece limitar el deseo de visibilidad y reconocimiento por su gestión, ya que el $60 \%$ de las propuestas realizadas por estos 5 diputados nacionales son elevadas junto a diputados que pertenecen a otras bancadas. El personalismo en la actividad propositiva se reduce significativamente entre los diputados electos en la circunscripción de mayor tamaño - la nacional- frente a sus compañeros elegidos en la circunscripción provincial, tal como mostraba el capítulo 2 de esta investigación. Sin embargo, el mayor tamaño de la circunscripción nacional no parece fomentar el trabajo de estos diputados en el seno de sus propias bancadas parlamentarias. La Tabla 3.2.2.2 muestra que los diputados nacionales prefieren trabajar en solitario o con representantes de otras fuerzas políticas antes que con sus compañeros de partido. La elección estratégica de la visibilidad personal -aunque compartida- frente a la visibilidad (impersonal) partidista, podría ser producto del tradicional faccionalismo que aqueja a los partidos dominicanos y que se analizará en el capítulo dedicado a las relaciones partido-partido.

Tabla 3.2.2.2 Proyectos de Ley Diputados Nacionales según numero de proponentes y visibilidad, 2010-2014

\begin{tabular}{|c|c|c|c|c|c|c|c|c|c|c|}
\hline \multirow{2}{*}{\multicolumn{2}{|c|}{$\begin{array}{c}\text { Visibilidad } \\
\text { Personal }\end{array}$}} & \multicolumn{4}{|c|}{$\begin{array}{c}\text { Visibilidad } \\
\text { Personal Compartida }\end{array}$} & \multicolumn{4}{|c|}{$\begin{array}{l}\text { Visibilidad } \\
\text { Partidista }\end{array}$} & \multirow{2}{*}{ 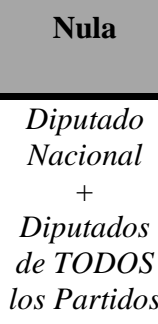 } \\
\hline & & \multicolumn{2}{|c|}{$\begin{array}{c}\text { Diputado } \\
\text { Nacional } \\
+ \\
1 \\
\text { Compañero de } \\
\text { Partido }\end{array}$} & \multicolumn{2}{|c|}{$\begin{array}{c}\text { Diputado } \\
\text { Nacional } \\
+ \\
2 \\
\text { Compañeros } \\
\text { de Partido }\end{array}$} & \multicolumn{2}{|c|}{$\begin{array}{c}\text { Diputado } \\
\text { Nacional } \\
+ \\
\text { Compañeros } \\
\text { del Partido } \\
\text { (más de 5) }\end{array}$} & \multicolumn{2}{|c|}{$\begin{array}{c}\text { Diputado } \\
\text { Nacional } \\
+ \\
\text { Grupo } \\
\text { Parlamentario } \\
\text { Partido }\end{array}$} & \\
\hline $\mathbf{N}$ & $\%$ & $\mathbf{N}$ & $\%$ & $\mathbf{N}$ & $\%$ & $\mathbf{N}$ & $\%$ & $\mathbf{N}$ & $\%$ & $\mathbf{N}$ \\
\hline 7 & 14.00 & 4 & 8.00 & 3 & 6.00 & 6 & 12.00 & 0 & 0.00 & 60.00 \\
\hline
\end{tabular}

Fuente: Elaboración propia a partir de datos Oficina de Acceso a la Información de la Republica Dominicana.

Y con respecto al contenido, los datos revelan que la circunscripción nacional también limita el particularismo en la representación, ya que de las 50 iniciativas presentadas por estos 5 diputados desde agosto de 2010 a agosto de 2014 , el $94 \%$ de ellas promueven intereses que benefician a toda la generalidad. 
Tabla 3.2.2.3 Nivel de inclusividad de las Iniciativas de Ley presentadas por los 5 diputados nacionales, 2010-2014

\begin{tabular}{|c|c|c|c|c|c|c|c|c|}
\hline \multicolumn{3}{|l|}{ GENERAL } & \multicolumn{3}{|c|}{ CORPORATIVA } & \multicolumn{3}{|c|}{ INDIVIDUAL } \\
\hline & $\mathbf{N}$ & $\%$ & & $\mathbf{N}$ & $\%$ & & $\mathbf{N}$ & $\%$ \\
\hline $\begin{array}{l}\text { Desarrollo } \\
\text { legislativo/institucional }\end{array}$ & 24 & 48.00 & Concesional Políticos & 3 & 6.00 & Concesional Particulares & 0 & 0.00 \\
\hline Fiscalizadora/Presupuestaria & 7 & 14.00 & Concesional Empresarios & 0 & 0.00 & & & \\
\hline Testimonial Declarativa & 5 & 10.00 & Concesional Gremios & 0 & 0.00 & & & \\
\hline Testimonial Conmemorativa & 9 & 18.00 & & & & & & \\
\hline Testimonial Personalista & 2 & 4.00 & & & & & & \\
\hline Testimonial Caudillista & 0 & 0.00 & & & & & & \\
\hline TOTAL (N=50) & & 94.00 & & & 6.00 & & & 0.00 \\
\hline
\end{tabular}

Fuente: Elaboración propia a partir de datos Oficina de Acceso a la Información de la Republica Dominicana.

Resulta significativo que las tres únicas propuestas que promueven intereses de colectivos determinados estén relacionadas con los intercambios que se dan entre elites políticas en el Clientelismo de Partido: una propuesta de exonerar la importación de vehículos a motor a ser disfrutada por los alcaldes de los municipios y distritos municipales ( $p l$ 05337) y dos propuestas para fraccionar el territorio nacional creando nuevos municipios y distritos ( $p l 02099$ y pl 04151 ). Esta última nos sitúa ante el fenómeno de la descentralización en la República Dominicana y su relación con la vinculación de las elites legislativas al territorio.

La fragmentación y la concesión de recursos han caracterizado el proceso de descentralización en detrimento de la autonomía política, administrativa y financiera de los gobiernos locales ${ }^{52}$. Hasta el año 2007 en que se aprueba la "Ley del Distrito Nacional y Los Municipios", la organización municipal descansaba en el marco legal heredado de la dictadura y hoy -al igual que en aquella época- bajo la dependencia institucional del Ministerio de Interior y Policía. La Ley No.17 de 1997 de "Participación de los Ayuntamientos en los Ingresos del Estado" constituyó la primera conquista legal del municipalismo dominicano, estableciendo un sistema de transferencias del gobierno central a los ayuntamientos y que en la actualidad está fijada en el $10 \%$ de los ingresos ordinarios del Estado ${ }^{53}$. El estatus municipal asegura una transferencia mínima mensual más un porcentaje que varía dependiendo del número de habitantes. Este instrumento legal incentivó la creación de unidades administrativas a un ritmo acelerado llegando a triplicar su número en tan solo 15 años, pasando de 87 en 1978 a 387 en la actualidad. Esto ha llevado a concentrar en $48.442 \mathrm{~km}^{2}$ de territorio y 10 millones de habitantes un total de 387 municipalidades, mientras que países como Nicaragua, con $129.494 \mathrm{~km}^{2}$ de extensión alberga 153 unidades descentralizadas, o Guatemala que con $108.890 \mathrm{~km}^{2}$ cuenta con 333 (Fernández 2012:3).

\footnotetext{
52 La estructura centralista y presidencialista deja sin efecto la limitada autonomía fiscal, política y administrativa de los municipios dominicanos, siendo de un 56,1 su posicionamiento en el Índice de Percepción de la Autonomía Municipal (DEMUCA 2011).

${ }^{53}$ Ley No.166 de 2003 de "Participación de los Ayuntamientos en los Ingresos del Estado".
} 
Puesto que el cambio de categoría territorial se gestiona en el Congreso, la promesa de elevación territorial se ha convertido en el premio que otorga el diputado a sus unidades administrativas inferiores en recompensa por la movilización proselitista ${ }^{54}$. El uso del territorio como prebenda es una manifestación más del clientelismo entre élites políticas en el que se intercambia influencia partidista a cambio de apoyo político. La categoría administrativa municipal es la nueva fuente de puestos políticos y administrativos al servicio de la élite política local que surge al amparo de la descentralización ${ }^{55}$. Como reflejaba el primero de los indicadores de Particularismo Legislativo de esta investigación, las proposiciones de Ley aprobadas para trámite parlamentario que tenían por objeto elevar la categoría territorial, representaron el 13,68\%, el 13,45\% y el 10,21\% de total de iniciativas en las legislaturas de 1998-2002, 2002-2006 y 2006-2010 respectivamente.

Las siguientes opiniones de un legislador oficialista y de un alcalde de la región este del país, confirman la utilización política de la fragmentación territorial y la amistad instrumental entre diputado y autoridades locales en el país:

\begin{abstract}
"En su mayoría, los proyectos [de elevación de categoría territorial] buscan controlar políticamente campitos y callejones que no cuentan con las características necesarias para cambiar de nivel. Y en la práctica, demuestra que los distritos municipales y municipios terminan como cacicazgos o aldeas controladas por los legisladores" (De la Cruz 2012).
\end{abstract}

«Yo he hecho mucho por mi diputada. La gente que le hizo la campaña, están todas colocadas en el Ayuntamiento» ${ }^{56}$

El criterio poblacional para determinar el monto de la transferencia ha establecido diferencias entre municipios, concentrando el grueso de la financiación en apenas 10 núcleos urbanos. Este sistema de pisos mínimos en la asignación de recursos a las municipalidades fue calificado por el BID (2010) como un "incentivo perverso hacia la creación artificial de distritos municipales, fragmentando los municipios y creando inadecuadas economías de escala para la gestión y prestación de servicios públicos a nivel local" (Ramírez 2010:7).

La Tabla 3.2.2.4 muestra el progresivo aumento de unidades locales, principalmente distritos municipales, con picos máximos que se corresponden con los años siguientes a cada contienda legislativa, lo que revela su uso como herramienta de movilización y prebenda. Durante las legislaturas de 2002 y 2006 en las que el PRD controlaba la mayoría de los escaños parlamentarios tiene lugar el grueso de la micro fragmentación del territorio nacional dominicano. En 2011 y tras la alarma nacional por el incremento de las demarcaciones territoriales, Congreso y Senado llegaron a un acuerdo para dejar morir este tipo de proyectos en el trámite parlamentario a la espera de que se apruebe la Ley de Ordenamiento Territorial ${ }^{57}$.

\footnotetext{
${ }^{54}$ La jerarquía ascendente de las entidades municipales reconocidas por la Ley son: el paraje, la sección, el distrito municipal y el municipio (Art. 22 y ss. Ley 176 de 2007).

${ }^{55}$ En las pasadas elecciones de 2010 se eligieron 155 alcaldes y suplentes, 1.149 regidores y suplentes, 229 directores de distritos municipales y 715 vocales.

${ }^{56}$ Confesión actor clave, alcalde oficialista electo en 2010, entrevista realizada el 15 marzo de 2012.

57 Ver noticia al respecto en periódico Diario Libre, de 8 de Abril de 2013 http://www.diariolibre.com/noticias/2013/04/08/i378298_aprobaran-nuevas-divisiones-territorio.html
} 
Tabla 3.2.2.4 Creación de municipios y distritos municipales 1995-2010

\begin{tabular}{|c|c|c|c|c|c|c|}
\hline Año & Municipios & $\begin{array}{c}\text { Distritos } \\
\text { Municipales }\end{array}$ & Total & $\begin{array}{c}\mathbf{N} \\
\text { por } \\
\text { Año }\end{array}$ & $\begin{array}{c}\% \\
\text { Aumento } \\
\text { Anual }\end{array}$ & $\begin{array}{l}\text { \% Aumento } \\
\text { Legislatura }\end{array}$ \\
\hline 1995 & 108 & 47 & 155 & 0 & 0 & \multirow{4}{*}{9,03} \\
\hline 1996 & 108 & 49 & 157 & 2 & 1.2 & \\
\hline 1997 & 110 & 50 & 160 & 3 & 1.91 & \\
\hline 1998 & 115 & 54 & 169 & 9 & 5.62 & \\
\hline 1999 & 115 & 67 & 182 & 13 & 7.69 & \multirow{4}{*}{36,68} \\
\hline 2000 & 115 & 80 & 195 & 13 & 7.14 & \\
\hline 2001 & 115 & 102 & 217 & 22 & 11.28 & \\
\hline 2002 & 125 & 106 & 231 & 14 & 6.45 & \\
\hline 2003 & 134 & 119 & 253 & 22 & 9.52 & \multirow{4}{*}{45,02} \\
\hline 2004 & 148 & 153 & 301 & 48 & 18.97 & \\
\hline 2005 & 148 & 167 & 315 & 14 & 4.65 & \\
\hline 2006 & 151 & 184 & 335 & 20 & 6.34 & \\
\hline 2007 & 155 & 226 & 381 & 46 & 13.73 & \multirow{4}{*}{15,52} \\
\hline 2008 & 155 & 230 & 385 & 4 & 1.04 & \\
\hline 2009 & 155 & 230 & 385 & 0 & 0 & \\
\hline 2010 & 155 & 232 & 387 & 2 & 0.51 & \\
\hline
\end{tabular}

Fuente: Elaboración propia a partir de datos de Beatriz Fernández (2012).

*Color naranja, año elecciones legislativas. Color azul, elecciones presidenciales.

El opositor PRD ha dominado la arena municipal dominicana controlando desde 1998 la mayoría de las sindicaturas (alcaldes) salvo en las elecciones de 2006 y 2010, en las que gracias al juego de las alianzas el PLD le arrebató esta posición, a pesar de ser el partido más votado ${ }^{58}$. Con respecto a los regidores (concejales), el PRD ha recuperado en 2010 el control de este cuerpo legislativo municipal tras el punto de inflexión del 2006, en el que la derrota presidencial de Hipólito Mejía en 2004 y la alianza con su enemigo histórico el PRSC acusaron su declive en las urnas.

Gracias a la fragmentación, los partidos minoritarios llegan a las instituciones de la representación municipal y a través de las alianzas con los mayoritarios, negocian espacios en los territorios. Mientras que en el nivel nacional los partidos aliados acceden a la red de patronazgo en la administración central, en el ámbito municipal, acceden a las Salas Capitulares de los distritos municipales, desde donde se deciden proveedores y funcionariado local, lo que popularmente se conoce como "empleomanía". En ausencia de autogobierno real, la autonomía de las unidades administrativas se reduce a la selección de los destinatarios del presupuesto según los límites establecidos: $25 \%$ personal, $35 \%$ servicios municipales, $40 \%$ infraestructura y $4 \%$ programas educativos, género y salud ${ }^{59}$.

Tabla 3.2.2.5 Número de Síndicos (Alcaldes) por partido 1998-2016

\begin{tabular}{|c|c|c|c|c|}
\hline & $1998-2002$ & $2002-2006$ & $2006-2010$ & $2010-2016$ \\
\hline PLD & 14 & 6 & 67 & 77 \\
PRD & 84 & 98 & 56 & 57 \\
PRSC & 8 & 10 & 28 & 16 \\
Otros & 0 & 2 & 4 & 5 \\
\hline Total & 106 & 116 & 151 & 155 \\
\hline
\end{tabular}

\footnotetext{
${ }^{58}$ En las elecciones municipales de 2010, el PRD obtuvo el 42,78\% de los votos y el PLD el 38,41\%, tras la sumatoria de los votos de los aliados, el PRD obtiene el 43,43\% y el PLD alcanza el 45,15\%.

${ }^{59} \mathrm{El}$ presupuesto de los 232 pequeños ayuntamientos del país oscila entre los RD\$ 600.000 (14,000 USD\$) hasta RD\$6,000,000 (140,000 USD\$).
} 
Tabla 3.2. 2.6 Número de Regidores (Concejales) por partido 1998-2016

\begin{tabular}{|c|c|c|c|c|}
\hline & $1998-2002$ & $2002-2006$ & $2006-2010$ & $2010-2016$ \\
\hline PLD & 209 & 151 & 412 & 355 \\
PRD & 323 & 359 & 342 & 490 \\
PRSC & 99 & 209 & 127 & 156 \\
Otros & 5 & 18 & 32 & 148 \\
\hline Total & 636 & 737 & 913 & 1,149 \\
\hline
\end{tabular}

Fuente: OPD, Observatorio Político Dominicano, FUNGLODE.

Teniendo en cuenta que la Región -y no la provincia- es la unidad básica para la formulación de políticas públicas, que la provincia no goza de personalidad jurídica ni autogobierno y que la Estrategia Nacional de Desarrollo -instrumento de planificación nacional de políticas públicas- no contempla la descentralización como eje estratégico, el focus distrital de los diputados dominicanos carece del marco legal para la agregación colectiva de intereses. Sin embargo, sí cuenta con la logística formal e informal para la articulación particularizada de vínculos a nivel local y de grupos de interés específicos: la Oficina Política del diputado en la provincia y las Fundaciones que preside $^{60}$. A través de ellas el diputado gestiona servicios de ambulancia para munícipes, cursos de formación, becas, ayuda a asociaciones y todo tipo de asistencia individualizada y de club.

En esta distribución particularizada de beneficios, el legislador cuenta -como rival o aliado- con el Gobernador de la provincia. Nombrado directamente por el Presidente, este representante del Poder Ejecutivo actúa de intermediario de las demandas comunitarias ante las instancias municipales y ministeriales y cuenta también con una asignación mensual para dedicar a planes de asistencia social $^{61}$. La debilidad -y en algunos casos la inexistencia- de un Plan Estratégico de Desarrollo Provincial podría convertir el reparto de fondos en un acto de liberalidad susceptible de manejo partidista en las que se premian o castigan lealtades, especialmente en aquellas provincias en las que el Gobernador oficialista convive con diputados, alcaldes y directores municipales del partido opositor. Además de los gobernadores provinciales, el diputado debe interactuar con la Liga Municipal Dominicana. Desde 1938, la Liga es la institución encargada de la gestión de las transferencias que han de recibir los municipios, además de otras funciones marginales de asesoría, fiscalización y aval de deuda local. Hasta el año 2007, el 55\% de su presupuesto debía ser repartido "entre los municipios menos favorecidos", una apreciación discrecional que convirtió a la Liga y a su todopoderoso Secretario General en el gran patrón de las municipalidades ${ }^{62}$. En su tarea de atender a los electores de su distrito, el diputado-bróker habrá de realizar gestiones para atraer

\footnotetext{
${ }^{60}$ Y como ejemplo, ver noticia acerca del diputado René Polanco (PLD), en acto de graduación de 170 jóvenes gracias al auspicio de su "Fundación Municipal Santo Domingo Norte", financiada por la Oficina Política de Simón Lizardo (Ministro de Hacienda 2012-2016) y dirigida por su mujer. En periódico La Verdad, de 2 de Septiembre de 2013, http://laverdad.com.do/index.php/otras-noticias-politicas/item/5826-fundaci\%C3\%B3ndel-diputado-del-pld-ren\%C3\%A9-polanco-grad\%C3\%BAa-cientos-de-j\%C3\%B3venes-m.

${ }^{61} \mathrm{La}$ asignación que manejan los Gobernadores Provinciales oscila entre los RD\$ 400,000 (9,500 USD\$) y los RD\$3,000,000 (71,000 USD\$) mensuales.

${ }^{62}$ Con la fragmentación territorial nace en 2008 la Asociación Dominicana de Distritos Municipales (ADODIM), con funciones similares a su contraparte la Liga Municipal. Ambas han estado salpicadas de acusaciones de corrupción, arbitrariedad y nepotismo y sus dos máximos responsables están siendo enjuiciados por las irregularidades de su gestión. El senador del PRSC por la provincia La Altagracia Amable Aristy Castro -conocido popularmente como "el cacique de Higuey"- ha combinado desde 1990 su puesto como legislador y candidato Presidencial, con el de Secretario General de la Liga Municipal Dominicana. En 2012 el Procurador General de la República reabrió el caso por corrupción ante las irregularidades detectadas por la Cámara de Cuentas durante su gestión 2006-2009. Ver noticia en http://www.acento.com.do/index.php/news/23685/56/Procurador-General-reabre-caso-de-corrupcion-contraAmable-Aristy-Castro.html. Pedro Richardson, Director Ejecutivo de ADODIM, actualmente está sometido a la justicia por estafa y violación de la Ley de Compras y Contrataciones del Estado. Ver noticia en http://www.lalupa.com.do/2013/10/9122/
} 
contratos e inversiones privadas o de mediador-conseguidor de las concesiones, subvenciones y regalías públicas del gobernador o de la Liga Municipal, cuyo crédito hará valer en la rendición de cuentas electoral. Este tipo de interacción se asemeja a la descrita en las categorías de "empresarios políticos" y "servidores del distrito" (Siavelis y Morgenstern 2008).

\section{$\checkmark$ Desproporción, umbral electoral y doble vuelta}

La desproporcionalidad es la diferencia entre el porcentaje de votos y el porcentaje de escaños (Loosemore y Hanby 1971). Mientras que las reglas proporcionales favorecen la inclusividad y la legitimidad, las de elección mayoritaria favorecen la estabilidad y la eficacia. El reto en los sistemas que combinan ambas es lograr el equilibrio entre estabilidad y representación (Colomer 2004). La República Dominicana es uno de estos sistemas mixtos, donde la elección de los diputados se hace siguiendo reglas proporcionales (método D’Hondt) mientras que los senadores se eligen por mayoría simple en distritos uninominales. En el periodo 1998-2006 la desproporcionalidad promedio era de 9,47 (Loosemore y Hanby 1971) o de 6,39 (Gallagher 1991), siendo de 0,17 el rango de exclusión (Bunker y Navia 2009:15).

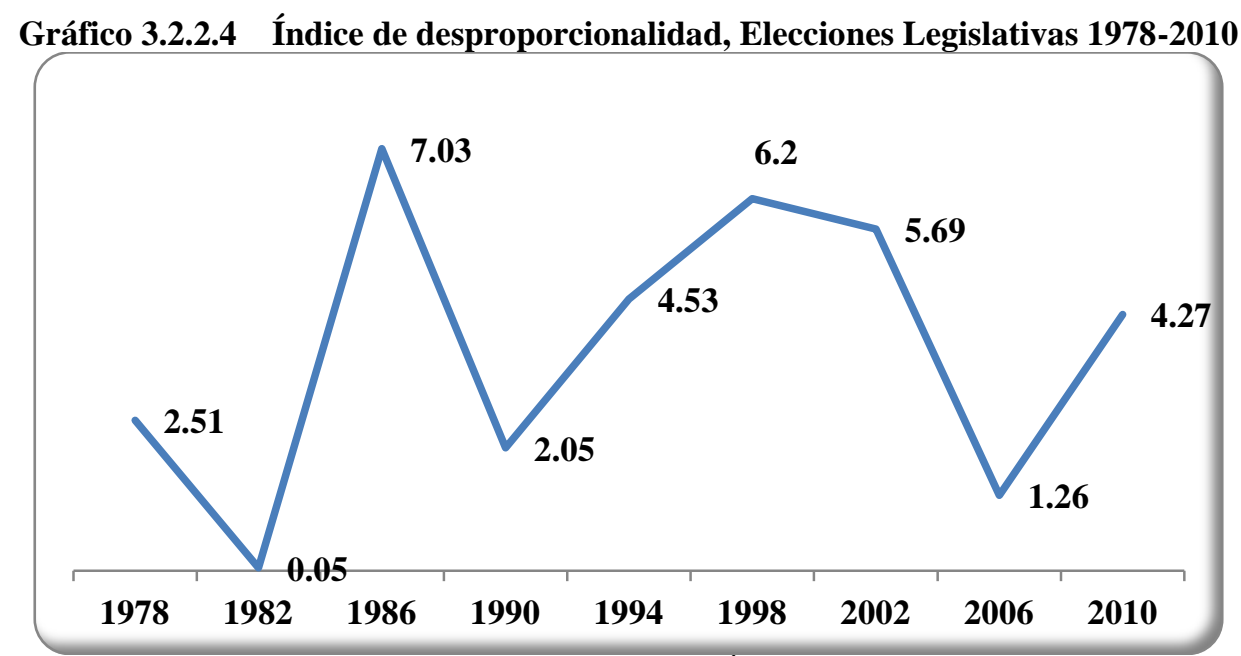

Fuente: Elaboración propia a partir de datos de la JCE. Índice de cuadrados mínimos de Gallagher.

La desproporción del sistema electoral, el umbral electoral y la doble vuelta afectan a la pluralidad e inclusividad de la representación en la República Dominicana. Por un lado, la desproporcionalidad hace que los tres partidos tradicionales de naturaleza clientelar PLD, PRD y PRSC estén sobrerrepresentados, mientras que el umbral electoral dificultaría la entrada de fuerzas políticas que enarbolen un discurso alternativo de movilización y representación. Si bien la doble vuelta puede incentivar la creación de coaliciones que agreguen intereses diversos (Crespo 2009) consensuando programas de gobierno con otras fuerzas políticas que amplíen inclusividad del mandato (intercambio indirecto entre partidos), en el escenario dominicano la doble vuelta ha revalorizado el precio de los partidos minoritarios y el intercambio directo particularizado entre aliados. Con las fuerzas aliadas débilmente programáticas, no se comparte el gobierno ni se deciden agendas políticas comunes, pero a cambio se les compensa con el acceso al patronazgo en la Administración. Como se analizará en el apartado dedicado las relaciones partido-partido, indicadores como la menor polarización (Axelrod 1970) y la mayor volatilidad (Cox 1997) en el sistema de partidos estimulan las alianzas entre actores que, en principio, ampliarían el universo de los intereses representados. Sin embargo, la competitividad en condiciones de oligopolio (Kitschelt y Wilkinson 2012) condiciona la racionalidad estrategia de los actores y reduce el 
intercambio entre partidos a la satisfacción de sus intereses particulares en una interacción propia del denominado "Clientelismo de Partido".

Como muestran los gráficos siguientes, el número efectivo de partidos electorales (NEPe) es ligeramente superior al número efectivo de partidos legislativos (NEPp) lo que habla de una desproporción relativa, siendo mínima en 1982 (0,05), máxima en 1986 (7,03), y en progresivo aumento desde 1994. En las legislativas de 2006, la desproporción era de 12,85 pasando a ser de 1,26 tras el cómputo del voto aliado. En las presidenciales de 2012, los partidos que osaron presentarse en solitario obtuvieron apenas el 1,37\% (AP), el 0,21\% (DxC), el 0,14\% (FA) y el $0,11 \%$ (APD). Al no haber alcanzado la barrera del 2\%, perdieron su registro. Por el contrario, aquellos partidos que apoyaron a los mayoritarios, quedaron doblemente protegidos: por la Ley Electoral (no pierden su registro) y si acompañaron al ganador, tienen asegurada presencia en las redes de patronazgo de las agencias públicas (Benito y Toribio 2013:311). En este caso, la fragmentación y la atomización de la oferta partidista que se reparte entre 26 fuerzas políticas se convierten en variables potenciadoras del intercambio particularizado entre actores políticos colectivos.

Gráfico 3.2.2.5 NEP Electoral, NEP Parlamentario legislativas 1978-2010

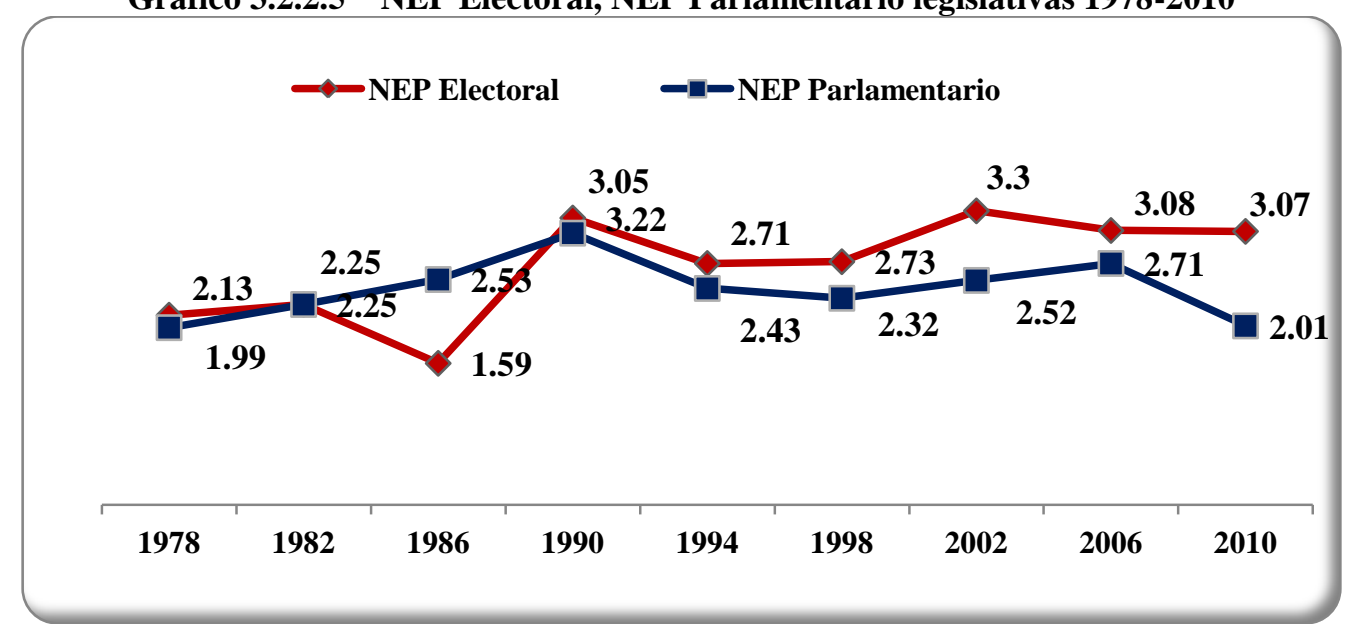

Fuente: Elaboración propia a partir de datos del OIR, Universidad de Salamanca (1994-2010).

Fórmula de Laakso y Taagepera $(1979 ; 1993) \mathrm{N}=\left(\sum \mathrm{p}_{\mathrm{i}}^{2}\right)^{-1}$

\section{$\checkmark \quad$ Financiamiento electoral}

Durante las dos décadas de competencia electoralista que siguieron a la transición de 1978, la compleja relación entre dinero y política estuvo marcada por el peligro de la penetración de los intereses particulares, ya que los partidos dominicanos dependían en exclusiva de las donaciones privadas. Para dotar de mayor equidad a la contienda y evitar que las conquistas públicas estuvieran mediatizadas en las instituciones por los intereses de los particulares que las sufragaban, la Ley No. 275 introduce por primera vez el financiamiento público regular. A pesar de las buenas intenciones de la Ley Electoral, ambos propósitos se han visto limitados en la etapa de la consolidación por la ausencia de requerimientos en límite y publicidad de las donaciones privadas, la desproporción en la asignación de los fondos públicos y la falta de voluntad sancionatoria de los órganos fiscalizadores. En la actualidad, los partidos dominicanos reciben el 0,50\% de los ingresos nacionales en año electoral y el $0,25 \%$ en periodo no electoral. El $80 \%$ de esta cantidad se reparte a partes iguales entre los partidos políticos mayoritarios, definidos desde el año 2005 como aquellos que superen el 5\% de los votos válidos en la última elección. La rebaja de la barrera electoral 
originaria del $8 \%$ en la definición de "partido mayoritario", obedece al acuerdo entre PLD, PRD y PRSC para protegerse frente a descalabros electorales. Con esta medida, el PRSC ha recibido la misma cantidad de dinero público en los últimos años a pesar de haber perdido más del $30 \%$ de sus votantes desde 1978. Un pago que compensa su alto valor como partido bisagra en el actual escenario de competitividad.

Tabla 3.2.2.7 Financiamiento Partidos Mayoritarios

\begin{tabular}{|l|cc|cc|}
\hline \multirow{2}{*}{} & \multicolumn{2}{|c|}{ 2008 } & \multicolumn{2}{c|}{ 2014 } \\
& \multicolumn{2}{|c|}{ AÑO ELECTORAL } & \multicolumn{2}{c|}{ AÑO NO ELECTORAL } \\
& $\begin{array}{c}\text { \% VOTOS } \\
\text { ELECCIÓN 2006 }\end{array}$ & \$ USD ANUAL & $\begin{array}{c}\text { \% VOTOS } \\
\text { ELECCIÓN 2012 }\end{array}$ & \$ USD ANUAL \\
\hline PLD & $\mathbf{4 6 , 3 5}$ & $6,453,377$ & $\mathbf{3 7 , 7 0}$ & $4,905,626$ \\
PRD & $\mathbf{3 1 , 0 3}$ & $6,453,377$ & $\mathbf{4 2 , 1 3}$ & $4,905,626$ \\
PRSC & $\mathbf{1 0 , 9 6}$ & $6,453,377$ & $\mathbf{5 , 8 7}$ & $4,905,626$ \\
\hline
\end{tabular}

Fuente: Elaboración propia a partir de datos de la JCE.

Mientras que la regularidad del financiamiento ha asegurado la estabilidad de los tres partidos tradicionales en la etapa post carismática, la falta de proporcionalidad limita las posibilidades organizativas de terceras fuerzas y la pluralidad del sistema. La veintena de partidos minoritarios se reparten el $20 \%$ sobrante, a razón del $12 \%$ a partes iguales entre los que obtuvieron menos del $5 \%$ de los votos y el restante $8 \%$, en proporción a los votos obtenidos por cada partido en las elecciones previas. Esta asignación de fondos públicos caracterizada por la proporcionalidad para los partidos minoritarios y por la gratuita generosidad igualitaria para los tradicionales a pesar de la diferencia de votos, es un agravio comparativo que dibuja un difícil escenario para aquellas fuerzas que se presenten ante el electorado con un discurso ajeno a la dinámica clientelar que impera en el país. Como se analizará en las secciones siguientes, la debilidad programática de los partidos dominicanos fuerza la competición hacia una en la que los actores se publicitan como suplidores de beneficios. Esta dinámica competitiva aumenta exponencialmente el coste de las campañas - que pueden oscilar entre los tres millones de pesos (81.000 \$USD) para un diputado y cinco millones (135.000 \$USD) para los senadores $-{ }^{63}$, haciendo insuficiente la aportación del Estado e incrementando la dependencia de la financiación privada. Puesto que las cúpulas directivas pueden decidir libremente el reparto de esos fondos públicos dentro del partido, ese dinero suele destinarse a la organización, dejando recaer el coste de la campaña en los recursos propios de los candidatos. De esta manera, como se verá en el apartado dedicado a la clase política dominicana, la figura del empresario-político con recursos se ha ido imponiendo en la arena pública:

«Ahora en el municipio presentamos una boleta electoral de banqueros, colmaderos ${ }^{64}$ y comerciantes... porque los dirigentes políticos, los que están preparados para dirigir el Estado no tienen capacidad económica. Tienen el liderazgo, pero viene un "Juan" con dinero y conquista, porque el elector está esperando que le den 100 pesos» (Benito y Rosales 2011:29).

Además del financiamiento establecido en la Ley Electoral, existe otro tipo de financiamiento informal e ilegal sufragado con los recursos públicos que distorsiona el fair play de la competencia interpartidista:

«El coste de las campañas depende de muchos factores. Si te apoya alguien del gobierno, por ejemplo, alguien que esté al frente de un Ministerio o de una agencia pública, pues tienes la suerte de contar con sus recursos, te pone esa maquinaria a tu servicio y te sale barata la campaña. Si tienes detrás a un grupo de empresarios como el Diputado X, pues seguro que la campaña será

\footnotetext{
${ }^{63}$ Johny Jones declaraba que en la campaña 2010 se gastó 675.000 USD, y una "caravana" rondaba los 120.000 USD para cubrir desplazamientos y prebendas a los simpatizantes. En El Nacional de 14-03-2010.

${ }^{64}$ Negocios de bancas de apuestas privadas y pequeños ultramarinos o mini supermercados.
} 
mucho más costosa o si regalas motores [ciclomotores] como hizo X en 2010, te puede salir por 25 millones de pesos [570,000 \$USD]. Pero en mi circunscripción hay sectores de clase media a los que no puedo ir con ese tipo de regalos o meterlos en una caravana para que salgan por las calles a mostrar su apoyo a mi candidatura ${ }^{65} \gg$.

Lo mismo ocurre con el acceso a los medios de comunicación públicos. De acceso gratuito y a disposición de todos los partidos "en condiciones de igualdad y equidad" (art.94 Ley Electoral No.275), pero en la práctica, al servicio del partido oficialista de turno. En las presidenciales de 2008, el monitoreo realizado por el capítulo nacional de Transparencia Internacional en el país constató que el $91 \%$ de la publicidad electoral en la televisión pública dominicana correspondía al candidato oficialista y sus aliados (Cueto 2011:494). Esta falta de equidad, controles en la financiación y uso de los medios de comunicación estatales, han sido denunciados por la Organización de Estados Americanos (OEA) en sus diferentes Misiones de Observación Electoral en el país ${ }^{66}$. La transparencia y eficiencia de los recursos son buenas prácticas que generan confianza en el sistema y refuerzan la legitimidad democrática. En este sentido, la debilidad de los organismos fiscalizadores nacionales como la JCE o la Cámara de Cuentas, ejemplifica el reto de la aplicación efectiva de los marcos regulatorios y sanciones por el uso indebido de fondos identificado por Gutiérrez y Zovatto (2011) en los países de la tercera ola democratizadora.

Aunque clientelismo y corrupción suelen equipararse erróneamente, son fenómenos distintos que no siempre viajan juntos aunque pueden converger (Corzo 2002:11). Esto ocurre cuando para mantener y reforzar las redes clientelares se acude a los circuitos corruptos de intercambio (Máiz 2005:3). La República Dominicana ejemplifica la progresiva imbricación de ambas redes que autores como Máiz (2005) identificaran en el contexto latinoamericano, ya que en 2012, el país ocupaba el puesto 118 del ranking de las 176 naciones más corruptas del mundo elaborado por Transparencia Internacional. Así, en el sistema nacional de control y auditoría, la Cámara de Cuentas de la República ocupa el primer lugar en la jerarquía de instituciones que luchan contra los depredadores de la cosa pública, pero también el último lugar en efectividad en el ejercicio de sus funciones. Sus eternas auditorías, la falta de profesionalización del personal, el uso arrojadizo de sus investigaciones entre políticos ${ }^{67}$, la escasez de recursos y la ausencia de sanciones, han hecho de este organismo un fiscalizador benévolo al servicio del partido oficialista de turno ${ }^{68}$.

Estos condicionantes muestran que la promulgación de la Ley Electoral en 1997 abrió un espacio de oportunidad para limitar la influencia de los mandatos particularistas asociados al financiamiento pero también que los actores políticos han usado su poder de manipulación (Dowding 1991) para redefinir y sortear tales constreñimientos institucionales (Piattoni 2001). En el financiamiento público, el acuerdo entre partidos para la distribución de los recursos asegura el feudo de los tres principales partidos clientelares y obstruye las posibilidades organizativas de terceras fuerzas. La laxitud de la regulación del financiamiento privado sigue haciendo permeables las instituciones a los interés privados, mientras que la politización de las instituciones de control obstaculiza la fiscalización de aquellos intercambios que además de particulares se muevan en la esfera de la ilegalidad.

\footnotetext{
${ }^{65}$ Entrevista con ex diputado oficialista (2006-2010) y senador (2010-2016), el 16 de septiembre de 2014.

${ }^{66}$ Ver declaraciones del Jefe de la MOE de la OEA, en periódico Clave Digital de 17 de mayo de 2010.

${ }^{67}$ El Director de Ética Gubernamental Vincho Castillo -aliado al PLD-, amenazaba al opositor Hipólito Mejía-PRD con sacar a la luz las auditorías realizadas a su gestión 2000-04 en respuesta a las acusaciones de corrupción del gobierno de Fernández (2008-2012). Ver La Lupa Sin Trabas, Núm. 28 del 18-09-2013.

${ }^{68}$ Hasta 2010 sus miembros eran nombrados por recomendación del Ejecutivo. Con la nueva Constitución, pasan a ser propuestos por la Cámara y refrendados por el Senado, pero esta disposición no se ha podido aplicar hasta la fecha, ya que la terna elegida por el mandatario anterior (Leonel Fernández), fue ratificada por el mandatario actual (Danilo Medina) ambos del mismo partido (PLD).
} 


\section{3) ¿Empresarios-políticos o políticos-empresarios?}

¿Quiénes son los políticos? ¿Son los políticos dominicanos «guardianes idóneos de la cosa pública» ${ }^{69}$ ?

El objetivo de este epígrafe es identificar las características de la clase política nacional que particularizan el ejercicio de la política como espacio colectivo y limitan la conquista del bien común en los asuntos públicos. Como se relata a continuación, el perfil del político dominicano es el de un empresario, con vínculos familiares y con escasa formación política, que accede a las instituciones sin dejar de administrar sus actividades privadas. Estas particularidades podrían afectar al ejercicio de la representación y que, en ocasiones, el interés colectivo esté mediatizado por sus propios intereses corporativos.

Las cinco fuentes de las que procede el capital para lanzarse a la arena política (Alcántara 2013:22) son: 1) selección partidaria, 2) formación, 3) popularidad, 4) legado familiar y 5) recursos económicos. A continuación se reflexiona sobre el modo en que cada una de ellas impacta en la mayor o menor probabilidad de llevar a cabo un ejercicio particularizado de la representación en democracia.

Con respecto a la selección partidaria, la Ley Electoral otorga amplia libertad a los partidos para la selección de candidatos a realizarse en convenciones regulares con arreglo a lo estipulado en su normativa interna ${ }^{70}$. A pesar de que los estatutos de los partidos establecen el órgano y el proceso de selección de candidatos en los distintos escenarios de la representación, los criterios se flexibilizan y se impone el dinero, la reserva de cuotas o la negociación de alianzas. Las prácticas clientelares se reproducen al interior de los partidos entre las facciones existentes y se reparten candidaturas para evitar crisis desestabilizadoras, lo que ha obligado en alguna ocasión a reformar los estatutos para legitimar estos arreglos informales. Las opiniones de los actores al respecto revelan que para conquistar la candidatura, el aspirante ha de contar con recursos propios, por lo que mantener una actividad productiva paralela le permitirá acceder y mantenerse en las instituciones:

«Hay dos [requisitos para ser candidato]: ser una figura pública reconocida y tener recursos. Si no tienes recursos ni lo intentes» (Mateos 2013:249).

«Los partidos no utilizan sus recursos para financiar candidaturas. Los recursos recibidos son usados en comisión, papeleos... Todo el que decide competir por puestos internos tiene que buscar recursos propios» (Benito y Rosales 2011:29).

«Lo que termina predominando es quien tenga más recursos, porque como hay tanta pobreza, el que tenga más recursos puede comprar más simpatía. Esto se está convirtiendo en un serio problema, por el hecho de que hay muchos problemas de formación política. Mucha de esta gente asume que como hace una inversión para llegar a ser diputado porque tiene que tener clientela, tiene que tener apoyo. Cuando llega al Congreso entiende que eso que invirtió lo debe sacar. Eso abre la puerta a la corrupción en el ejercicio del trabajo legislativo» (Mateos 2013:247).

Otra de las variables que inciden en la mayor profesionalización de la elite política es la formación partidaria. Ésta parece tener un peso poco relevante en la carrera política de los actores nacionales. Como aseguraba un juez de la Junta Central Electoral,

\footnotetext{
${ }^{69}$ Madison, James; Hamilton, Alexander; y Jay, John. The Federalist Papers (1788).

${ }^{70}$ En 2004 el poder Ejecutivo promulgó la Ley de Primarias Internas No. 286-04 estableciendo su obligatoriedad y simultaneidad en todos los partidos. Sin embargo fue declarada inconstitucional por la Suprema Corte de Justicia un año después bajo la argumentación de que atentaba contra la libertad de asociación política.
} 
«Sentarse en los escaños del Congreso Nacional, se aleja cada día más del alcance de los dirigentes medios de los partidos políticos. Sus méritos partidarios no son suficientes para pagar la millonaria inversión que se requiere para aspirar a una diputación o a una senaduría. Lo mismo ocurre con las alcaldías de los grandes municipios ${ }^{71} \gg$ (Olivares 2014).

La profesionalización de las futuras élites dirigentes se ve también afectada por el faccionalismo. La formación política en República Dominicana refleja el divisionismo caudillista: mientras que en el PRD los jefes políticos se atrincheran y rivalizan en recursos en torno al Instituto de Formación Política Peña Gómez, la Secretaría de Educación y Doctrina y el recién creado Centro de Estudios de Políticas Públicas ${ }^{72}$; en el PLD el Instituto de Formación Política Juan Bosch cohabita con FUNGLODE, think tank creado por el ex Presidente Leonel Fernández que opera como una escuela de cuadros en la que se forman los altos cargos de designación de las administraciones peledeístas ${ }^{73}$. En el PRSC la Escuela Nacional de Formación Política, convive con el Centro de Análisis de Políticas Públicas creado en 2007 por el diputado reformista Ito Bisonó. En el diagnóstico sobre el estado de la formación política en República Dominicana (AECID-PNUD: 2008) los responsables entrevistados identificaron como principales obstáculos la falta de coordinación entre programas y órganos formativos, así como el recelo a empoderar al contrario capacitando a futuros líderes cuya lealtad no corresponda con el jefe político de turno ${ }^{74}$. La lealtad sectarista se impone a la lealtad partidista y la facción (inner circle) es la maquinaria que organiza las lealtades en círculos concéntricos similares a los descritos por Auyero (1999) según la cercanía con el jefe político.

La parca relevancia del bagaje político se corresponde con la escasa importancia que los partidos conceden a la formación política de sus candidatos. Así lo evidenciaba el "Diagnostico sobre la Formación Política en República Dominicana" (AECID-PNUD 2008) destacando la falta de conciencia acerca de la tansversalidad de la formación, reducida a una serie de actividades que en la mayoría de los casos eran desconocidas fuera de las secretarías de formación de los partidos. La confusión entre la capacitación técnica para el trabajo público y el adoctrinamiento ideológicoprogramático era otra de las debilidades identificadas, además de su uso sectario como herramienta para fortalecer a una determinada facción y limitando así su función de renovación partidista ${ }^{75}$.

«Está asociado al crecimiento del clientelismo político y al ingreso en los partidos de nuevos sectores sociales ligados al ejercicio empresarial como bancas de apuestas y colmaderos. Ese sector ha

\footnotetext{
${ }^{71}$ Palabras del Juez de la Junta Central Electoral Eddy Olivares, en periódico digital Ecos del Sur, del 30 de abril de 2014. http://www.ecosdelsur.net/2014/04/opinion-cuantos-cuesta-una-candidatura.html

${ }^{72}$ El Centro de Estudios de Políticas Públicas fue creado en mayo de 2013 por Luis Abinader y como parte de las actividades de visibilidad y preparación de su candidatura presidencial por el PRD en las elecciones de 2016. Ver noticia en periódico 7 días de 13 de mayo de $2013 . \quad$ En http://www.7dias.com.do/index.php/noticias/140639/Luis_Abinader_presenta_a_la_sociedad_el_Centro_de_ Estudios_de_Politicas_Publicas\#.UcBs2ti_b1U

${ }^{73}$ Por sus aulas han pasado desde Roberto Rosario Presidente de la JCE, Margarita Cedeño Vicepresidenta, Yerení Berenice Fiscal del Distrito Nacional, Julio César Valentín Senador de Santiago, Ventura Camejo Ministro de Administraciones Públicas, Elías Wessin Administrador de Bienes Nacionales, Hamlet Melo Diputado por la Altagracia, Eddy Manzanillo Subdirector de Impuestos Internos o Leyda Margarita Piña jueza de la JCE. De manera oficiosa, Funglode ha pasado a ser la competencia informal del Instituto Nacional de Administración Pública Dominicano (INAP).

${ }^{74}$ En "Consultoría para la elaboración de un diagnóstico sobre los mecanismos de formación de los partidos en República Dominicana y elaboración de una propuesta de mejora", Leticia Ruiz Rodríguez (Consultora). Proyecto No. 00061534, AECID-PNUD, 2008.

${ }^{75}$ Consultoría para la elaboración de un diagnostico sobre los mecanismos de formación de los partidos políticos en la República Dominicana y elaboración de una propuesta de mejora. Santo Domingo, Leticia Ruiz Rodríguez (Consultora). AECID-PNUD Proyecto NO. 00061534.
} 
entrado con un poder que no viene del ejercicio político con militancia, ideología, concepto... sino del dinero» (Benito y Rosales 2011:20).

Como reflejaba el análisis de la variable dependiente de esta investigación la popularidad del candidato en su circunscripción proviene de su actividad asistencialista personal al frente de fundaciones privadas o donaciones de su actividad profesional. Estas experiencias son recogidas en el caso de los legisladores, en los CV institucionales de la página web de la Cámara a través de los cuales el diputado se presenta a sus representados:

«Desde hace 20 años instaló un consultorio médico en la sección de Barrancón, municipio Luperón, provincia Puerto Plata, en la que ofrece, cada sábado y domingo, consultas gratis, en jornadas que benefician a docenas de personas de aquí y de otras comunidades cercanas» ${ }^{76}$.

«Ingresó al PLD en 1986. Actualmente ocupa la presidencia del Comité Intermedio X. En lo social, posee una oficina donde ofrece servicios gratuitos de ambulancia y la utilización de carros fúnebres, agua gratuita, entre otras necesidades que los munícipes le plantean» ${ }^{77}$

«Realizando un arduo trabajo altruista y social en beneficio de la gente más desposeída de su adorada provincia, contribuyendo con sus conocimientos y aportes a resolver problemas críticos y esenciales de la comunidad, tratando de paliar un poco las carencias materiales e individuales que estos munícipes enfrentan en el día a día» ${ }^{78}$

«Dedicado al negocios de la banca de lotería, a través de su empresa ayuda con las donaciones de útiles deportivos» ${ }^{79}$.

Las actividades asistencialistas de las fundaciones de los legisladores conviven con las de la misma naturaleza pero derivadas de su ejercicio de representación ${ }^{80}$. Esta dualidad podría diluir el mérito individual del agente en el más abstracto y colectivo de la gestión pública institucional. Sin embargo, las dos son ejercidas enfatizando la persona del agente y no el mandato recibido del principal. La personalización en el ejercicio del poder cuenta con una larga tradición en el país. Durante la Era Trujillo el personalismo fue elevado a categoría de megalomanía. El dictador rebautizó la capital Santo Domingo con el nombre de Ciudad Trujillo y dio orden de colocar una lápida con su nombre en todo edificio construido durante su administración (Galíndez 2006: 335). Desde entonces, la identificación de obras y servicios públicos con el Presidente ha continuado a lo largo de los años. El lema de campaña "Esto... lo hizo Balaguer", ejemplifica la asociación

\footnotetext{
${ }^{76}$ Diputado PLD, provincia Puerto Plata Ver CV en http://globalleadershipproject.org/sites/default/files/cv/Dominican\%20Republic/Juan\%20Carlos\%20Quiñonez \%20Minaya.pdf

${ }^{77}$ Diputado del PLD, provincia Distrito Nacional. Ver CV en http://globalleadershipproject.org/sites/default/files/cv/Dominican\%20Republic/Rene\%20Polanco\%20Vidal.p df

${ }^{78}$ Diputada del PLD, provincia El Seibo Ver CV, http://globalleadershipproject.org/sites/default/files/cv/Dominican\%20Republic/Kenia\%20Milagros\%20Mejia $\% 20$ Mercedes.pdf

79 Diputado del PRD, provincia Santiago, circunscripción 3. Ver CV en http://globalleadershipproject.org/sites/default/files/cv/Dominican\%20Republic/Francisco\%20Antonio\%20Sa ntos\%20Sosa.pdf

${ }^{80}$ En el actual periodo legislativo 2010-2016 muchos diputados compaginan su labor representativa con la presidencia de fundaciones de beneficencia social como AMADC, ASODEMUSA, Fundación Centro de Acciones Comunitarias en Salud, Fundación Salud y Vivienda, ILAC, Asociación para el Desarrollo de Constanza, Fundación Construyendo Ciudadanos, CODEINCO, Fundación Progreso Oriental, Club Avance Social Para La Comunidad... entre otras. Ver CV en pagina web Cámara Diputados de la Republica Dominicana.
} 
personalista a la figura del líder y no a la más institucional del gobierno y su administración. Esta apropiación personalista de las obras y servicios se ha extendido con la descentralización y es común ver rehabilitación de parques, asfaltado de calles o reparto de agua potable con la foto del síndico, diputado o senador, en una nueva versión del neopatrimonialismo dominicano (Hartlyn 1998).

Foto 3.2.3.1 Personalización de la gestión de servicios públicos

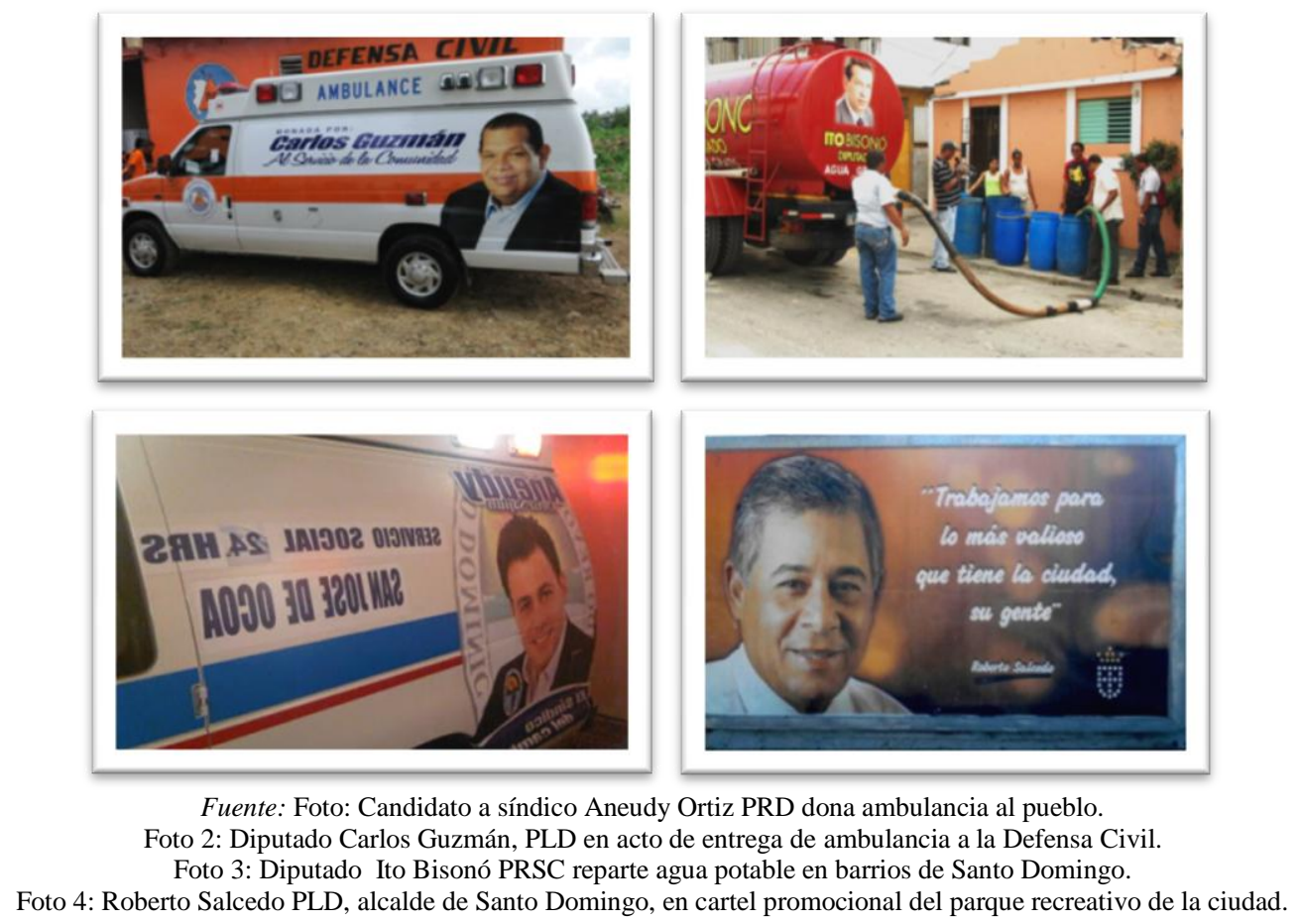

Durante los cuatro años de la administración de turno, es habitual que las obras y servicios públicos se publiciten con la imagen del Presidente o los colores del partido. En la cultura política dominicana los colores pierden el significado estético para revestirse de significación partidista. En décadas pasadas, en una población mayoritariamente rural y analfabeta, los colores eran el atajo informativo para el mensaje partidista y era común que simpatizantes pintaran sus casas con los colores del partido de su adscripción. En la campaña presidencial de 2012, ante el temor de que un cambio de gobierno diese fin a la popular Tarjeta Solidaridad (programa focalizado de subsidios) el candidato por el PRD anunciaba:

«Si vuelvo al Palacio lo único que hare será cambiar el color a las tarjetas (...) Si llego al poder habrá una rosadita para los compatriotas, la verdecita para ustedes (los seguidores del partido MODA aliado) y la morena para el Partido Revolucionario Dominicano ${ }^{81}$ »

Una frase que ilustra además la preeminencia de la amistad instrumental y el pago por el apoyo prestado en la asignación de la asistencia pública. En otras ocasiones, las obras son "selladas" con la identificación del periodo de la administración bajo la cual fueron ejecutadas. Esta especie de inventario/registro esconde una identificación partidista de obras y servicios públicos que dificulta su continuidad. Así lo confirmaba un actor clave entrevistado:

\footnotetext{
${ }^{81}$ Palabras del candidato presidencial Hipólito Mejía en el acto de conformación de la alianza con el partido MODA, en periódico HOY de 27 de febrero de 2012.
} 
«¿Usted cree que le van a dar mantenimiento a ese elevado (puente urbano)? Claro que no... porque como lo hizo Hipólito van a esperar a que se caiga en pedazos....Igual pasa con el metro... si gana el PRD ¿cree que van a construir más líneas? No, porque ese metro es de Leonel. No hay continuidad. Ninguno de los políticos va a trabajar en algo que hizo otro en otra administración» ${ }^{82}$.

Foto 3.2.3.2 Politización de la gestión de servicios públicos

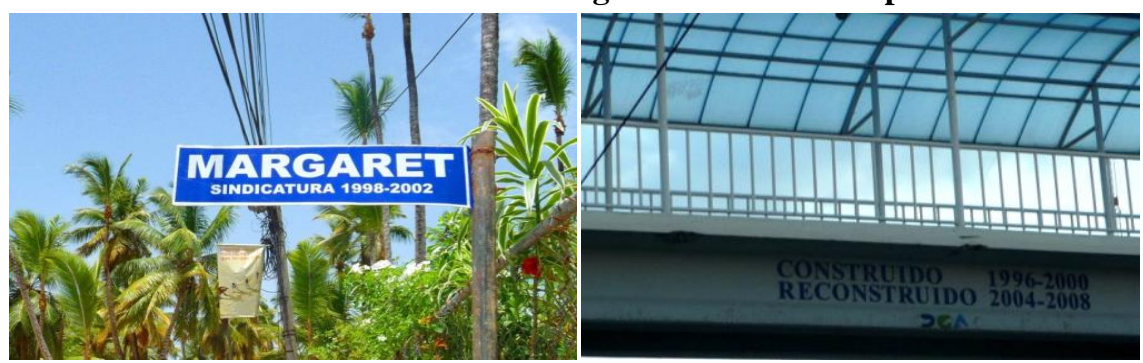

Fuente: Foto1: Las Terrenas en 21 de agosto de 2012, el nombre de la calle aparece rotulado con el periodo de la gestión municipal correspondiente. Foto 2: Puente de Santo Domingo, tomada el 10 de diciembre de 2012, donde constan los periodos presidenciales responsables de su construcción y remodelación.

Este reconocimiento individualizado sobre lo colectivo o institucional, se observa también en la propia Cámara de Diputados, donde las ocho Salas de Coordinación de Comisiones llevan el nombre de ocho diputados que ejercieron funciones de presidente de la Cámara -y salvo uno que falleció en 2008- todos continúan en el ejercicio de la vida pública y son políticos en activo: Rafaela Alburquerque 1999-2003 PRSC; Abraham Bautista 1978-1979 PRD; Luis José González 19971990 PLD; Hugo Tolentino Dipp 1982-1986 PRD; Rafael Peguero Méndez 1996-1999 PRD; Ramón Fadul 1995-1996 PLD; Norge Botello 1990-1994 PLD (†); Alfredo Pachecho 2003-2006 PRD. La medida adoptada en el hemiciclo de mayoría perredeísta cumple con el estricto reparto entre partidos: 4 para el PRD, 3 para el PLD y 1 para el PRSC y ejemplifica una vez más el reparto pragmático entre los partidos tradicionales.

El carácter endogámico es otro de los rasgos neopatrimoniales que definen a la clase política nacional además de manifestación de la confianza particularizada que rige en el país. Las redes familiares refuerzan la confianza entre miembros de un mismo grupo donde la unidad del clan es el valor supremo, lo que dificulta la acción coordinada con el resto de grupos que conforman la comunidad (Putnam 1994; Inglehart 1997). En los modelos de sociedad tradicional las redes familiares son asociaciones estratégicas que obstaculizan la movilidad social y el tránsito a una sociedad formalmente igualitaria. La historia dominicana ofrece numerosos ejemplos de prácticas nepotistas en la política. Durante la Era Trujillo "conquistaron" el escaño de diputado el padre, el hijo, los tíos, cuñados del dictador y ejerció como Presidente su hermano Héctor en 1954. Y bajo los gobiernos de Joaquín Balaguer, su hermana Enma fue la encargada de la asistencia social a través de "La Cruzada del Amor". En 1962, el diplomático John Bartlow hacia el siguiente diagnostico al respecto:

«En la República Dominicana, si uno la conoce bien, las cosas no son tan fáciles. La oligarquía de este país consta tal vez de una veintena de familias relacionadas entre sí. Han dirigido la República, proporcionando los presidentes y generales, han dominado las finanzas y los negocios durante más de cien años. Sus fortunas se basan en la tierra, el azúcar, el tabaco, el ron, el ganado, el arroz, el café, el cacao, el comercio y las finanzas. Están tan entremezclados por el matrimonio y las relaciones de sus antepasados, que solo ellos pueden explicar sus lazos de unión. Sus ramificaciones llegan a todas partes, pero el verdadero cogollo de la oligarquía lo constituyen una pocas familias, suele ser un hombre por lo general, no una gran figura pública, el que ayuda a todos los otros a tomar determinaciones cuando las cosas se ponen serias de verdad» (Bartlow 1975:129).

\footnotetext{
${ }^{82}$ Entrevista con actor clave realizada el 12 de abril de 2012.
} 
La visibilidad de los lazos hereditarios en la política dominicana continuó durante la segunda transición y en la etapa de la consolidación democrática. Durante el Gobierno del PRD (20002004) los hijos de los ex presidentes Guzmán (1978-1982) y Blanco (1982-1986) ocuparon cargos ministeriales ${ }^{83}$ y la sobrina del también presidente Bosch fungió como vicepresidenta. Padres, hermanos e hijos heredan la gestión de los asuntos públicos y los cargos de dirección en los partidos como se prorratean las vacantes en el consejo de administración de una empresa familiar $^{84}$. La extensión de los lazos de parentesco en la organización interna de los partidos es aún mayor en los partidos minoritarios. Es el caso del PRSD, el PRI, la FNP o el BIS donde padres e hijos participan de la jerarquía partidaria ${ }^{85}$. En alguno de ellos, la estructura es cooptada por todo el núcleo familiar como en el Partido Popular Cristiano, donde la presidencia recae en Héctor Peguero y sus tres hijos desempeñan las funciones de tesorero, dirigente de la juventud y delegado político ante la Junta Central Electoral. El empleo en las administraciones del PLD (2004-2008 y 20082012) ha estado dominado por un reducido número de familias que ocuparon cargos en las distintas agencias del Estado ${ }^{86}$. En la actual administración 2012-2016 los lazos familiares son visibles en los compromisos del partido oficialista con sus partidos aliados ${ }^{87}$.

${ }^{83}$ Sonia Guzmán, Secretaria de Industria y Orlando Jorge Mera, Presidente de INDOTEL y secretario general
del PRD.
${ }^{84}$ En 2013 España negaba el placet a Oscar Medina, hijo del Embajador dominicano en Madrid, a quien
quería traspasar el cargo tras terminar su misión diplomática. Francisco Peña Guaba fue el director de la
Administración de la Lotería Nacional durante el periodo 2008-2011 y le sustituyó su hijo Peña Tavárez en el
periodo siguiente 2011-2016. Amable Aristy fue el Secretario de la Liga Municipal Dominicana por más de
10 años y en 2010 asumió el cargo su primo Fidias Artisty. La esposa del presidente Leonel Fernández (20082012) es la actual vicepresidenta (2012-2016).

${ }^{85}$ El Partido Revolucionario Social Demócrata es liderado por Hatuey de Camps y su hijo Luís Miguel de Camps forma parte del comité político; el Partido revolucionario Independiente presidido por Trajano padre y Mirtilio Santana hijo; el Frente Nacional Progresista presidido por Vincho Castillo y su hijo Alexis forma parte de la directiva partidista; el Bloque Institucional Socialista presidido por Peña Guaba, hijo del histórico Francisco Peña Gómez.

${ }^{86}$ Los hermanos Pared Pérez: Presidente del Senado uno y en la Dirección Nacional de Investigaciones otro; Yomaira Medina, diputada hermana del actual presidente Danilo Medina (2012-2016); Alejandrina Germán Secretaria de Educación -hoy Ministra de la Mujer- sus hermanos Emigdio y Mariano encargado del Plan Social del Gobierno uno y Director de la Oficina de Desarrollo Provincial otro. El esposo de Alejandrina, José María Sosa fue Subsecretario Administrativo de la Presidencia y luego diputado; Los hermanos Montás: Temístocles Secretario Técnico de la Presidencia tiene a su hijo Juan Carlos como asistente, Rubén presidente de la Comisión Nacional de Energía, José alcalde de San Cristóbal y Gamalier gobernador de la provincia de San Cristóbal; Los hermanos Rojas: Bautista Secretario de Salud y Onofre a cargo de los Fondos Europeos de Desarrollo, sus primos Luís René y Juan Bautistas senador y Director de Seguridad Aeroportuaria respectivamente y la esposa de este último es vicesíndica de Santo Domingo Este; Los primos Félix Jiménez y Salvador, Ministros de Turismo y de Agricultura; Flavia García Secretaria de la Mujer y su esposo Euclides Gutiérrez Superintendente de Seguros, la hija de ambos Cónsul en Sevilla; Monchy Fadul Secretario de Trabajo y su sobrino dirige la Autoridad Metropolitana de Transporte; Andrés Vanderhorst al frente del Departamento Agropecuario y su hijo dirige el Consejo Nacional de Competitividad; Edudardo Selman fue Secretario de Estado sin cartera y su hermano Jorge representante del Centro de Exportaciones e Inversiones en Nueva York; Ignacio Ditrén director de la OMSA y su hermana María Elena directora del Museo de Arte Moderno; Simón Lizardo es Contralor de la República y Cristina Lizardo senadora; Claudio de los Santos en la Secretaría de Relaciones Exteriores y su hija Claudia Subsecretaria de Obras Públicas; Leonardo Matos Berrido gerente del Banco Nacional de Vivienda, puesto que ocupara anteriormente su hija, ahora diplomática; el Canciller de Relaciones Exteriores Carlos Morales Troncoso, tiene bajo su dirección a su hija Nicole y como asistente a su yerno Luis Bogaert. Familiares de este último, Miguel y Gerardo Bogaert también tuvieron puestos en la Cancillería de Relaciones Exteriores; Tania Pina Vila, Ministra Consejera en Estocolmo es hija del Consultor Jurídico del Poder Ejecutivo César Pina Toribio; David Puig Ministro Consejero en Francia es hijo de Max Puig Secretario de Medio Ambiente y su hermana Sulamita Subsecretaria de Cultura; Patria Dore es Secretaria de la Misión Dominicana en la UNESCO y su padre 
La extensión de los lazos familiares de los diputados dominicanos es similar al observado en el resto de países de América Latina. En 2010, el 51,6\% de los diputados tenía familiares en política frente al $53,7 \%$ de sus vecinos latinoamericanos (OIR 2010). Si bien dos décadas atrás los tres partidos contaban con porcentajes altos similares, descienden en 1998 y se recuperan al alza en las siguientes, siendo el PRSC quien lidera el porcentaje de familiares en política. A pesar de los vaivenes electorales, los reformistas parecen ser los más apegados al círculo familiar en la socialización política $^{88}$. De hecho, su debacle electoral ha reforzado la confianza particularizada de sus votantes ya que la "tradición familiar del elector", aumentó como una de las razones principales que han guiado la elección de sus diputados, por encima del programa o la experiencia del candidato ${ }^{89}$. En 2009 la prensa nacional destapó las prácticas nepotistas en las Oficinas Provinciales de los senadores, administradas por sus parientes y encargadas de repartir los 17.000 .000 millones de pesos (medio millón de dólares) que el Senado destina mensualmente a la asistencia social entre las comunidades $^{90}$. El fenómeno neopatrimonialista alcanza también la arena municipal y evidencia que la descentralización ha creado nuevos espacios de poder para los patronos locales, que ayudados por la ausencia de fiscalización municipal, han convertido los Ayuntamientos en feudos familiares privados $^{91}$.

Tabla 3.2.3.1 Familiares en política de los diputados dominicanos (\%)

\begin{tabular}{|l|c|c|c|c|c|}
\hline & $\mathbf{1 9 9 4 - 1 9 9 8}$ & $\mathbf{1 9 9 8 - 2 0 0 2}$ & $\mathbf{2 0 0 2 - 2 0 0 6}$ & $\mathbf{2 0 0 6 - 2 0 1 0}$ & $\mathbf{2 0 1 0 - 2 0 1 6}$ \\
\cline { 2 - 2 } & 65,0 & $\mathbf{6 3 , 6}$ & $\mathbf{5 5 , 2}$ & $\mathbf{7 2 , 7}$ & - \\
PLD & 61,5 & 38,2 & 45,2 & 55,4 & 56,8 \\
PRD & $\mathbf{6 9 , 0}$ & 25,5 & 47,4 & 53,8 & $\mathbf{5 8 , 3}$ \\
\hline
\end{tabular}

Con respecto a la exclusividad en el ejercicio de la representación política, el $42,7 \%$ de los diputados dominicanos se dedicaba a sus funciones de representación en exclusiva en el periodo 1994-2005; un porcentaje por debajo de la media regional latinoamericana que alcanzaba el 54,7\%,

Carlos Dore es asesor político del Presidente Leonel Fernández. Ver noticia en periódico Diario Libre, de 24 de Agosto de 2006.

${ }^{87}$ En 2014 fueron nombrados Pelegrín Castillo y Enrique Peynado ministro y viceministro del recién creado Ministerio de Energía y Minas. El primero es hijo del Presidente de la FNP y actual director del Departamento de Ética y el segundo es bisnieto de uno de los presidentes de la Era Trujillo (1938-1940) e hijo del vicepresidente en el gobierno de Balaguer (1994-1996) por el PRSC y su madre Margarita Álvarez es vicealcaldesa de Santo Domingo. Otros casos de relaciones de parentesco en la administración actual, Reinaldo Pared es presidente del Senado y secretario general del PLD, su hermano Sigfrido es ministro de las Fuerzas Armadas, su otro hermano Carlos es asesor del Presidente Danilo Medina y su sobrino es Subdirector del Centro de Exportación e Inversión de la República Dominicana (CEI-RD). Dos cuñados del Presidente Danilo Medina laboran como funcionarios de EdeEste y en la Superintendencia de Bancos.

${ }^{88}$ Los sucesores de Balaguer al frente del PRSC Jacinto Peynado y Morales Troncoso son nietos de presidentes trujillistas.

${ }^{89}$ Joaquín Ricardo, sobrino de Balaguer, ha sido Presidente en funciones del partido desde el año 2010 al 2014.

${ }^{90}$ Tras el escándalo, el Presidente del Senado canceló las nóminas de 23 familiares. En TV Canal Antena Latina, Programa "El Informe", de 2 de septiembre de 2009 y Periódico Listín Diario de 3 de septiembre de 2009.

${ }^{91}$ Durante la administración de Enrique Sued, alcalde de Santiago por el PRSC (1998-98 y 2002-06, 20062010) su hermana Benny Sued, fue directora del departamento de Plazas y Parques del Ayuntamiento; su sobrino Víctor García Sued administrador del cabildo; Yenén Cordero, esposo de su sobrina fue encargado de compras; su sobrina Wanda Gessell Candelaria Sued, fue encargada del Departamento de Protocolo; su primos Fernando Sued propietario del taller donde ser reparan los vehículos del ayuntamiento, y Clara Virginia Cortina Sued laboraba en el departamento de operaciones del cabildo; su prima Dalia Sued fue favorecida con la contrata para construir el tranvía en Santiago. 
el 59,9\% y el $57,7 \%$ en la primera, segunda y tercera ola de entrevistas llevadas a cabo por PELA ${ }^{92}$. Mientras que Colombia y Perú destacaban por ser los hemiciclos con mayor número de diputados a "tiempo completo" con un $86,3 \%$ y $84,1 \%$ respectivamente, en Honduras solo el $15,7 \%$ se dedicaba en exclusividad a sus labores parlamentarias (Martínez Rosón 2006).

Tabla 3.2.3.2 Dedicación exclusiva tareas parlamentarias diputados dominicanos (\%)

\begin{tabular}{|l|c|c|c|c|c|}
\hline & $\mathbf{1 9 9 4 - 1 9 9 8}$ & $\mathbf{1 9 9 8 - 2 0 0 2}$ & $\mathbf{2 0 0 2 - 2 0 0 6}$ & $\mathbf{2 0 0 6 - 2 0 1 0}$ & $\mathbf{2 0 1 0 - 2 0 1 6}$ \\
\cline { 2 - 6 } PLD & 7,7 & 55,9 & $\mathbf{5 9 , 1}$ & 37,5 & 45,9 \\
PRD & $\mathbf{3 4 , 5}$ & 57,4 & 36,8 & 34,6 & 44,4 \\
PRSC & 20 & $\mathbf{6 3 , 6}$ & 37,9 & 9,1 & -- \\
\hline Media & $\mathbf{2 5 , 5}$ & $\mathbf{5 8 , 3}$ & $\mathbf{4 2 , 9}$ & $\mathbf{3 3 , 3}$ & $\mathbf{4 5 , 1}$ \\
\hline
\end{tabular}

Fuente: Elaboración propia, a partir de datos de PELA (1994-2010)

Salvo el punto de inflexión de la legislatura de 1998 en que más de la mitad de los diputados entrevistados se dedicaban en exclusividad a sus funciones representativas, el hemiciclo dominicano está conformado en su mayoría por legisladores empresarios y profesionales liberales en ejercicio. Por el contrario, solo el $6 \%$ desempeñaba labores como político profesional en el seno de sus organizaciones en el periodo 1998-2010.

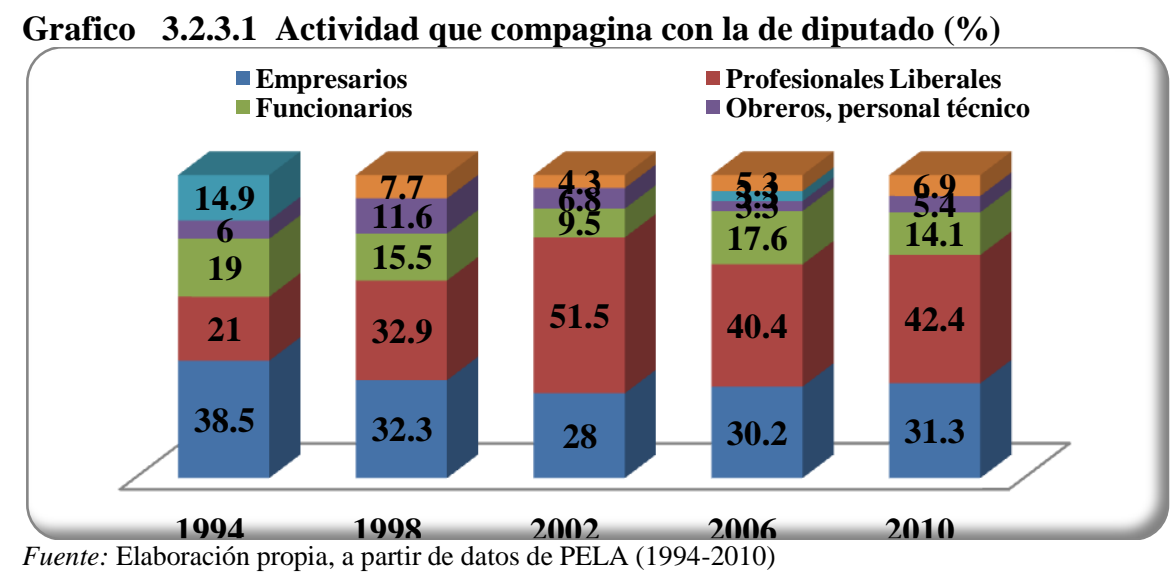

La compatibilidad de las funciones de representación con actividades empresariales genera un escenario en el que pueden surgir conflictos de interés entre el fin primario institucional y el eventual corporativo que comprometa la integridad del mandato. Si como apuntaran Shepsle y Boncket (2005) la Cámara de Diputados es ya un escenario complejo de ambición individual, grupos de interés y ciclos de mayorías, el perfil empresarial del legislador dominicano representa un obstáculo adicional a la cooperación que distorsiona el interés público. En el actual periodo legislativo 2010-2016 ocupan escaño de diputado los presidentes de organizaciones empresariales y profesionales que representan a los sectores productivos más relevantes del país. Como muestra la siguiente Tabla, 4 de los 6 diputados de la provincia de Duarte son los principales patronos privados de la comarca: el presidente de una cooperativa arrocera, el presidente de la asociación de supermercados, el presidente del gremio de constructores y el presidente de la asociación de agrupa a los productores agrícolas. Todos ellos, pertenecen a la comisión legislativa de asuntos agrícolas, obras públicas y comercio respectivamente. También ocupan escaño el presidente de los

${ }^{92}$ Primera ola de entrevistas 1993-2000, segunda ola 1997-2005, tercera ola 2001-2010. 
propietarios de taxi y de transportistas -ambos en la comisión legislativa de transporte de la Cámara- y representantes de los sectores privados menos interesados en que se desarrolle la red de autobuses públicos. De hecho, tras más de dos años, los autobuses adquiridos para la ruta alimentadora de la línea de metro, siguen recluidos en los predios de la OPRET por la presión del gremio de transportistas.

En los curriculum vitae que los propios legisladores cuelgan en la página web de la Cámara a modo de presentación y rendición de cuentan a sus representados, se aprecian los rasgos corporativistas de la representación política en el país. Así, el diputado y presidente de la Federación Nacional de Comerciantes Detallista de Provisiones, se presentaba con las siguientes palabras:

«El legislador y dirigente comercial ha encabezado la representación de su sector en foros nacionales e internacionales. A parte de su defensa del sector detallista, ha dejado testimonio de su trabajo en boletines, periódicos y programas de televisión. Es autor del libro "El Detallista del 2001" como herramienta para desarrollar estrategias que permita al colmado dominicano subsistir en la globalización» ${ }^{93}$.

O el diputado de Monte Plata y presidente provincial de la Asociación Dominicana de Profesores relata a modo de rendición de cuentas sus gestiones para obtener bienes de club para sus asociados:

«Solicitud presentada al Presidente de la República y al Ministerio de Educación a los fines de que se incluya en el Presupuesto de la Nación 2008 una partida de incentivos a los técnicos educativos nacionales, regionales y distritales» ${ }^{94}$.

Este perfil empresarial es un rasgo compartido por toda la clase política dominicana. El ex Presidente Mejía (2000-2004), empresario tabacalero y del mango, fue presidente de la Asociación Nacional de Agricultores; El que fuera Presidente del PRSC y actual Ministro de Relaciones Exteriores es nieto de un Presidente Trujillista perteneciente a una familia de empresarios del azúcar, ejerció de presidente del Consejo Nacional

del Azúcar; El empresario de la construcción Miguel Vargas fue Ministro de Obras Públicas en el gobierno de Mejía (200-2004); La ex diputada Alexandra Izquierdo fue presidenta de la Asociación Nacional de Compañías de Seguros y en los gobiernos de Balaguer dirigió la Superintendencia de Seguros; El Ministro de Industria y Comercio en el gobierno de Fernández (2008-2012) fue presidente de la Asociación de Industrias de la República Dominicana (AIRD); el Ministro de Agricultura Salvador Jiménez (2008-2012) es el fundador de la más importante cooperativa arrocera de La Vega; El diputado por la provincia de San José de Ocoa y presidente de la Federación Nacional de Comerciantes, fue el Dirección General de Control de Precios (20042006);o el diputado y empresario Milciades Franjul quien se desempeñó como Subdirector General de Exoneraciones (2004), organismo encargado de conceder las regalías tributarias.

\footnotetext{
${ }^{93}$ Ver CV en http://globalleadershipproject.org/sites/default/files/cv/Dominican\%20Republic/Pablo\%20Adon\%20Guzman. pdf

${ }^{94}$ Ver CV en http://globalleadershipproject.org/sites/default/files/cv/Dominican\%20Republic/Juan\%20Suazo\%20Marte.pdf
} 
Esta convivencia del perfil público y privado de los políticos dominicanos ejemplifica la tipología de capitalismo coordinado descrita por Kitschelt (2007) y escenario propicio del clientelismo de orientación empresarial («business-mediated clientelism») en el que se genera una atmósfera de cultura corporativa que incita a competir a los actores por la conquista de vínculos clientelares. En la distribución clientelar de recursos, estos «clientes ricos pero pobres en votos» reciben contratos públicos, exenciones, regulaciones normativas o juicios legales favorables entre otros bienes y favores. En cuanto a los legisladores, el perfil empresarial de los diputados nacionales revela que más que especialización de las comisiones legislativas, se asiste a un proceso de cooptación de los espacios de la democracia para institucionalizar el particularismo propio de las denominadas "élites extractivas". Como argumentaran Acemoglu y Robinson (2006), éstas acceden a las débiles instituciones de las democracias emergentes para hacerlas favorables a sus intereses. En este escenario, es probable que el expertise de los legisladores pueda dar lugar a las actuaciones oportunistas que advirtiera Krehbiel (2004) en la liza legislativa, ya que además del conocimiento especializado, tienen intereses privados en las áreas sobre las que van a regular.

Además de la tipología del empresario político, la ausencia de profesionalización de la administración y las redes de patronazgo controladas por el partido oficialista y sus aliados, necesita de otro de los perfiles políticos identificado por Panebianco (1982): el profesional camuflado. Este político pseudo profesional, labora en las instituciones pero trabaja para el partido a quien debe su puesto. Desde allí, controla las redes de patronazgo y organiza la movilización política en tiempos de campaña electoral, generalmente mediante la conformación de movimientos que en la República Dominicana reciben el nombre de "sector externo". 
Tabla 3.2.3.3 Diputados que ocupan la presidencia de asociaciones empresariales Legislatura 2010-2016

\begin{tabular}{|c|c|c|c|c|c|}
\hline & ISOCIACIÓN EMPRESARIAL & PARTIDO & PROVINCIA & $\begin{array}{l}\text { ACTIVIDAD } \\
\text { PRIVADA }\end{array}$ & $\begin{array}{l}\text { COMISION } \\
\text { LEGISLATIVA }\end{array}$ \\
\hline ANPA & $\begin{array}{c}\text { Asociación Nacional Productores } \\
\text { Agrícolas }\end{array}$ & PLD & \multirow{4}{*}{ Duarte } & $\begin{array}{l}\text { Empresario } \\
\text { Agrícola }\end{array}$ & Industria y Comercio \\
\hline CODIA & $\begin{array}{l}\text { Colegio Dominicano de Ingenieros y } \\
\text { Arquitectos y Agrimensores }\end{array}$ & PRD & & $\begin{array}{l}\text { Empresario } \\
\text { Constructor }\end{array}$ & Obras públicas \\
\hline ASOSUP & $\begin{array}{c}\text { Asociación Propietarios Supermercados } \\
\text { Provincia de Duarte }\end{array}$ & PRD & & $\begin{array}{l}\text { Propietario } \\
\text { supermercados }\end{array}$ & Comercio \\
\hline CA-EP & Consorcio Arrocero El Pozo & PLD & & $\begin{array}{l}\text { Empresario } \\
\text { Agrícola }\end{array}$ & $\begin{array}{c}\text { Asuntos } \\
\text { Agropecuarios }\end{array}$ \\
\hline ADETAXI & $\begin{array}{c}\text { Asociación Nacional Propietarios de } \\
\text { Taxi }\end{array}$ & PLD & \multirow{4}{*}{$\begin{array}{c}\text { Santo } \\
\text { Domingo }\end{array}$} & $\begin{array}{l}\text { Empresario del } \\
\text { Transporte } \\
\text { Privado }\end{array}$ & Transporte \\
\hline ASOFEDO & $\begin{array}{c}\text { Asociación Ferreteros de Santo } \\
\text { Domingo }\end{array}$ & PLD & & $\begin{array}{l}\text { Empresario } \\
\text { ferretero }\end{array}$ & Industria y Comercio \\
\hline ASOCLUDISNA & Asociación Clubs Deportivos DN & PLD & & $\begin{array}{l}\text { Propietario } \\
\quad \text { Clubs } \\
\text { Deportivos }\end{array}$ & Deportes \\
\hline FENACODEP & $\begin{array}{l}\text { Federación Nacional Comerciantes } \\
\text { Detallistas de Provisiones } \\
\text { Asociación Mayoristas de Provisiones } \\
\text { de Santo Domingo }\end{array}$ & PRD & & $\begin{array}{l}\text { Empresario } \\
\text { detallista }\end{array}$ & Industria y Comercio \\
\hline ADP & Asociación Dominicana de Profesores & PLD & \multirow{2}{*}{$\begin{array}{c}\text { Monte } \\
\text { Plata }\end{array}$} & $\begin{array}{l}\text { Funcionario } \\
\text { Educación }\end{array}$ & Educación \\
\hline FENATRANO & Federación Nacional de Transporte & PRD & & $\begin{array}{l}\text { Empresario del } \\
\text { transporte }\end{array}$ & Transporte \\
\hline ADP & $\begin{array}{c}\text { Asociación Dominicana de Profesores } \\
\text { Provincial }\end{array}$ & PLD & Nacional & $\begin{array}{l}\text { Funcionario } \\
\text { Educación }\end{array}$ & Educación \\
\hline CODIA & $\begin{array}{l}\text { Colegio Dominicano de Ingenieros y } \\
\text { Arquitectos y Agrimensores }\end{array}$ & PRD & Elías Pina & $\begin{array}{l}\text { Empresario } \\
\text { Constructor }\end{array}$ & Obras públicas \\
\hline ASOPER & $\begin{array}{c}\text { Asociación Profesional de Estaciones de } \\
\text { Radio }\end{array}$ & PLD & $\begin{array}{c}\text { La } \\
\text { Altagracia }\end{array}$ & $\begin{array}{l}\text { Propietario } \\
\text { estaciones radio }\end{array}$ & $\begin{array}{l}\text { Medios de } \\
\text { comunicación }\end{array}$ \\
\hline ASOGAVE & $\begin{array}{c}\text { Asociación Ganaderos de la Provincia } \\
\text { La Vega } \\
\text { Colegio Médico de La Vega }\end{array}$ & PLD & La Vega & $\begin{array}{l}\text { Empresario } \\
\text { Ganadero }\end{array}$ & Salud \\
\hline ASOGAMT & $\begin{array}{c}\text { Asociación Ganaderos de la Provincia } \\
\text { María Trinidad Sánchez }\end{array}$ & PLD & $\begin{array}{l}\text { Trinidad } \\
\text { Sánchez }\end{array}$ & $\begin{array}{l}\text { Empresario } \\
\text { Ganadero }\end{array}$ & Trabajo \\
\hline FENACO & Federación Nacional de Comerciantes & PLD & Ocoa & $\begin{array}{l}\text { Comerciante } \\
\text { distribuidor }\end{array}$ & Comercio \\
\hline
\end{tabular}

Fuente: Elaboración propia a partir de los CV colgados en la página web de la Cámara de Diputados de la Republica Dominicana. Su difusión y contenido es un acto voluntario de los diputados, no todos los legisladores lo hacen, por lo que no se han realizado análisis estadístico. Solo se han recogido los diputados que ocupan cargos directivos de primer nivel en las organizaciones (presidente, vicepresidente o tesorero). 
¿Cómo afecta este perfil al ejercicio de la representación en su paso por las instituciones dominicanas?

Tras conocer el perfil de corte empresarial y familiar de la clase política dominicana, lo siguiente será comprobar si particulariza el ejercicio de la representación y el acceso a las instituciones públicas. Como han destacado los neoinstitucionalistas (March y Olsen 1997), las instituciones son un valor en sí mismo pues limitan la discrecionalidad, el particularismo y son responsables últimas de la calidad de la democracia. En el día a día de las instituciones se reproducen los procedimientos mínimos de la democracia (Valenzuela 1992:62) y las decisiones que se adoptan en su seno tienen la habilidad de cambiar el statu quo (Marsteintredet 2004: 35). Si las instituciones lideran los procesos de modernización, habrá que esperar que el mayor nivel de experiencia de los diputados dominicanos y el contacto con las instituciones en la etapa de la consolidación democrática haya limitado el ejercicio particularista de la representación que históricamente ha caracterizado la vida política en el país. A pesar de que la élite parlamentaria es sólo una parte de la clase política dominicana, las funciones de formulación de políticas públicas y fiscalización que asumen los legisladores justifican la atención prestada a los diputados y el valor representativo de la muestra.

En esta investigación se utiliza el concepto "Expertise Institucional" definida como el sumatorio de la experiencia legislativa, política, en cargos de representación, de designación y el nivel educativo de los diputados entrevistados ${ }^{95}$. Este conjunto de experiencias en las instituciones son medidas en el índice creado y valoradas en sentido neoinstitucionalista, es decir, por su capacidad para facilitar la agregación e integración de intereses y preferencias. Agregar intereses en las instituciones implica sumar preferencias divergentes y adicionar otras nuevas compartidas por todos los ciudadanos a través del diálogo razonado (March y Olsen 1997:25). De esta manera, la actividad del día a día en las instituciones genera aspiraciones colectivas que deberán ser satisfechas por los gobernantes en los que los ciudadanos han delegado la formulación de políticas. El Índice de Expertise Institucional está basado en el Índice de Competencia Política (Alcántara 2008) definida como el conjunto de elementos que presuponen la existencia de destrezas para llevar a cabo la tarea política encomendada y medida en función de las variables "educación" y "carrera política". Si bien en el Índice de Expertise Institucional se utilizan estas dos variables, no se considera que éstas informen de la capacidad para ejercer sus funciones en sentido normativo (buenos y malos políticos), sino que la experiencia en las instituciones afecta al ejercicio a la representación en el sentido del ideal democrático de Sartori (2003) y en el más sustantivo de Morlino (2005).

La experiencia en política, en cargos de representación y de designación, aporta pistas sobre el nivel de institucionalización de los partidos políticos, pues indica que han adoptado decisiones de

\footnotetext{
${ }^{95}$ Está compuesto por tres variables en la legislatura 1994-1998 (educación 30\%; experiencia legislativa 30\%; y experiencia política 40\%); cuatro variables en la legislatura 1998-2002 y 2002-2006 (educación 30\%, experiencia legislativa $30 \%$, experiencia política $20 \%$ y experiencia de representación $20 \%$ ); y cinco variables en la legislatura 2006-2010 (educación 30\%; experiencia legislativa 30\%, experiencia política 13,5\%, experiencia de representación $13,5 \%$ y experiencia en cargos de designación 13,5\%). Esta diferencia en el número de variables responde a la mayor y más específica información disponible con la inclusión de nuevas preguntas en las sucesivas oleadas del proyecto PELA (1994-2009). Mientras que la experiencia política es cuantitativa continua etiquetada en "poca experiencia" (de 0 a 5 años), "media" (de 6 a 10 años), "alta" (de 11 a 20 años) y "muy alta" (más de 20 años), el resto de variables son categóricas dicotómicas (si/no), puesto que en el caso de la experiencia de representación la mayoría de los casos provenían del ámbito municipal (síndicos/regidores) y la variedad de cargos en el caso de la experiencia en designación, no permitía codificar cada una de las categorías. La mayoría de los legisladores tienen estudios universitarios medios y/o superiores, por lo que esta variable pasa a ser una cuasi constante.
} 
acción colectiva (organización) y de elección social (programa), han participado en elecciones ofertando un mandato definido entre principal-agente y han desempeñado funciones de gobierno donde ejercer el mandato de representación nacional por encima de intereses particularistas. Por su parte, la experiencia legislativa del diputado aporta información sobre el conocimiento de las tareas parlamentarias y es indicador junto con la variable educación, del nivel de profesionalización de la carrera parlamentaria en el país. La Tabla 3.2.a) 3.4 recoge la aplicación del índice en las cuatro legislaturas consideradas. En la escala de 0 a 100, los legisladores dominicanos se sitúan en el nivel de experiencia media (40-60), en tendencia ascendente cercana al nivel alto $(59,18)$ en la legislatura 2006-2010. Si a mediados de los noventa los legisladores del PLD eran los más experimentados, a partir de 1998 serán los diputados del PRSC los que ocupen las posiciones más altas en el índice. El PLD y el PRD comparten niveles y ritmo de evolución en las últimas décadas y en ambos desciende el nivel de expertise en 1998. Esta legislatura marca un punto de inflexión por sus efectos renovadores tras el "Pacto por la Democracia" de 1994. Con la retirada negociada de Balaguer, la separación de las elecciones en 1996 y la reforma de la Ley Electoral, comienza oficialmente la etapa de la consolidación democrática en el país. El éxito del PLD y PRD (que pasan de 13 a 49 y de 57 a 83 escaños respectivamente) entran a la Cámara diputados con menor experiencia y desciende su nivel de estudios, especialmente en el caso del PRD.

Tabla 3.2.3.4 Evolución Expertise Institucional de los diputados dominicanos

\begin{tabular}{l|c|c|c|c|}
\hline \multirow{4}{*}{ PLD } & $\mathbf{1 9 9 4 - 1 9 9 8}$ & $\mathbf{1 9 9 8 - 2 0 0 2}$ & $\mathbf{2 0 0 2 - 2 0 0 6}$ & $\mathbf{2 0 0 6 - 2 0 1 0}$ \\
\cline { 2 - 5 } PRD & $\mathbf{5 6 , 8 5}$ & 52,44 & 54,76 & 58,16 \\
PRSC & 52,96 & 49,7 & 54,78 & 58,0 \\
Media & 49,6 & $\mathbf{5 7 , 7 3}$ & $\mathbf{5 8 , 0 9}$ & $\mathbf{6 7 , 6}$ \\
Fuente: Elaboración propia a partir de datos de PELA (1994-2009). Sin experiencia o muy poca experiencia (0-20), \\
poca experiencia (20-40), experiencia media (40-60), alta (60-80), y mucha experiencia (80-100).
\end{tabular}

La Tabla 3.2. 3.5 muestra el aumento del porcentaje de diputados que van ingresando en la categoría de experiencia media en el transcurso de las legislaturas. El PLD se destaca en 1994 como la organización con mayor porcentaje de parlamentarios en la categoría alta de expertise $(42,9 \%)$ y que podría estar relacionado -además del limitado número de casos- con su tradición educativa interna y origen fundacional. A través de los llamados "Círculos de Estudios" el PLD estableció desde sus inicios una política de formación obligatoria para militantes y aspirantes a cargos electivos que abandonó tras su conversión en partido de masas. La dilatada militancia de sus miembros responde a que en su mayoría procedían de las filas del PRD, creado en el exilio en 1939. A partir de 1998, es el PRSC quien inicia el desplazamiento del grueso de sus diputados hacia la categoría de experiencia institucional alta, beneficiados por la inclusión en el índice de las variables relativas a la experiencia de representación y designación. El liderazgo de los diputados del PRSC en el índice obedece a la escasa renovación en las filas del partido y al acceso privilegiado a las instituciones por la vía de la designación y la representación durante más de 20 años de gobiernos balagueristas. Con el éxito electoral del PRD y PLD aumenta el porcentaje de legisladores que ocupan el nivel inferior de experiencia con respecto a la legislatura anterior $(26,1 \%$ PRD y 27,3\% PLD) frente al 5\% de los reformistas. En la legislatura 2006-2010 se confirman las tendencias anteriores: desplazamiento hacia la categoría alta de expertise institucional, destacando el caso del PRSC que duplica el porcentaje de diputados en dicha categoría y se distancia al alza en el nivel superior del índice. Esta mayor experiencia institucional evidencia también la falta de renovación de los cuadros del partido secuestrado por la vieja dirigencia. 
Tabla 3.2.3.5 Distribución de diputados dominicanos según nivel de Expertise Institucional (\%)

\begin{tabular}{|c|c|c|c|c|c|c|}
\hline \multicolumn{7}{|c|}{ Legislatura 1994-1998 } \\
\hline & $\begin{array}{c}\text { Sin y/o escasa } \\
\text { Experiencia }\end{array}$ & $\begin{array}{c}\text { Poca } \\
\text { Experiencia }\end{array}$ & $\begin{array}{c}\text { Experiencia } \\
\text { Media }\end{array}$ & $\begin{array}{c}\text { Experiencia } \\
\text { Alta } \\
\end{array}$ & $\begin{array}{c}\text { Máxima } \\
\text { Experiencia }\end{array}$ & $\begin{array}{c}\text { Total } \\
(\mathbf{N})\end{array}$ \\
\hline PRD & 6,9 & 17,2 & 44,8 & 31 & 0 & 29 \\
\hline PLD & 0 & 14,3 & 42,9 & 42,9 & 0 & 7 \\
\hline PRSC & 11,5 & 19,2 & 46,2 & 23,1 & 0 & 26 \\
\hline \multicolumn{7}{|c|}{ Legislatura 1998-2002 } \\
\hline & $\begin{array}{c}\text { Sin y/o escasa } \\
\text { Experiencia }\end{array}$ & $\begin{array}{c}\text { Poca } \\
\text { Experiencia }\end{array}$ & $\begin{array}{c}\text { Experiencia } \\
\text { Media }\end{array}$ & $\begin{array}{c}\text { Experiencia } \\
\text { Alta }\end{array}$ & $\begin{array}{c}\text { Máxima } \\
\text { Experiencia }\end{array}$ & $\begin{array}{l}\text { Total } \\
(\mathbf{N})\end{array}$ \\
\hline PRD & 0 & 26,1 & 71,7 & 2,2 & 0 & 46 \\
\hline PLD & 0 & 27,3 & 63,6 & 9,1 & 0 & 34 \\
\hline PRSC & 0 & 5,9 & 79,4 & 14,7 & 0 & 11 \\
\hline \multicolumn{7}{|c|}{ Legislatura 2002-2006 } \\
\hline & $\begin{array}{c}\text { Sin y/o escasa } \\
\text { Experiencia }\end{array}$ & $\begin{array}{c}\text { Poca } \\
\text { Experiencia }\end{array}$ & $\begin{array}{c}\text { Experiencia } \\
\text { Media }\end{array}$ & $\begin{array}{c}\text { Experiencia } \\
\text { Alta }\end{array}$ & $\begin{array}{c}\text { Máxima } \\
\text { Experiencia }\end{array}$ & $\begin{array}{l}\text { Total } \\
(\mathbf{N})\end{array}$ \\
\hline PRD & 0 & 5,3 & 73,7 & 21,1 & 0 & 57 \\
\hline PLD & 0 & 3,1 & 75 & 21,9 & 0 & 32 \\
\hline PRSC & 0 & 0 & 67,9 & 28,6 & 3,6 & 28 \\
\hline \multicolumn{7}{|c|}{ Legislatura 2006-2010 } \\
\hline & $\begin{array}{l}\text { Sin y/o escasa } \\
\text { Experiencia }\end{array}$ & $\begin{array}{c}\text { Poca } \\
\text { Experiencia }\end{array}$ & $\begin{array}{c}\text { Experiencia } \\
\text { Media }\end{array}$ & $\begin{array}{c}\text { Experiencia } \\
\text { Alta }\end{array}$ & $\begin{array}{c}\text { Máxima } \\
\text { Experiencia }\end{array}$ & $\begin{array}{l}\text { Total } \\
(\mathbf{N})\end{array}$ \\
\hline PRD & 0 & 3,8 & 53,8 & 38,5 & 3,8 & 26 \\
\hline PLD & 0 & 0 & 62,5 & 35,7 & 1,8 & 56 \\
\hline PRSC & 0 & 0 & 18,2 & 63,6 & 18,2 & 11 \\
\hline
\end{tabular}

Fuente: Elaboración propia a partir de datos de PELA (1994-2009)

Si como señalan los neoinstitucionalistas en las instituciones se generan aspiraciones colectivas, habrá que esperar que con el mayor nivel de experiencia la representación sea más inclusiva y los parlamentarios otorguen menos atención a los grupos que defienden intereses particulares. Para comprobar esta hipótesis se analiza cómo es la interacción de los legisladores y los grupos de interés en el marco de las instituciones ${ }^{96}$. El tratamiento estadístico de las opiniones de los diputados revela que durante las legislaturas 1998-02 y 2002-06, a mayor nivel de experiencia, mayor ha sido el porcentaje de parlamentarios que concedían mucha/bastante importancia a los grupos de interés a la hora de elaborar las leyes. Estos datos revelan que las instituciones importan, pero en el caso dominicano particularizan el ejercicio de la representación. En todas las categorías los porcentajes superan el $50 \%$, lo que confirma la historia de influencia de estos grupos en la política dominicana. La legislatura 2006-2010 marca un punto de inflexión y cambia la dirección de la tendencia descendiendo la deferencia concedida a mayor nivel de experiencia.

\footnotetext{
96 PELA (1994-2006), P56: "Hasta qué punto: mucho, bastante, poco o nada, tiene Ud. en cuenta la opinión de cada uno de los siguientes grupos, personas o instituciones cuando toma decisiones políticas? Los electores de su circunscripción, los líderes de su partido, la opinión pública en general, los afiliados de su partido, los medios de comunicación, otros diputados de su partido, los grupos de interés, los votantes de su partido, el gobierno".
} 
Tabla 3.2.3.6 Importancia concedida a los grupos de interés según Expertise Institucional diputados dominicanos (\%)

\begin{tabular}{|c|c|c|c|c|}
\hline \multicolumn{5}{|c|}{ Legislatura 1998-2002 } \\
\hline & $\begin{array}{c}\text { Poca } \\
\text { Experiencia }\end{array}$ & $\begin{array}{c}\text { Experiencia } \\
\text { Media }\end{array}$ & $\begin{array}{c}\text { Experiencia } \\
\text { Alta }\end{array}$ & $\begin{array}{c}\text { Máxima } \\
\text { Experiencia }\end{array}$ \\
\hline Mucho/Bastante & 66,70 & 74,70 & 85,70 & -- \\
\hline Poco/Nada & 33,30 & 25,30 & 14,30 & -- \\
\hline \multicolumn{5}{|c|}{ Legislatura 2002-2006 } \\
\hline & $\begin{array}{c}\text { Poca } \\
\text { Experiencia }\end{array}$ & $\begin{array}{c}\text { Experiencia } \\
\text { Media }\end{array}$ & $\begin{array}{c}\text { Experiencia } \\
\text { Alta }\end{array}$ & $\begin{array}{c}\text { Máxima } \\
\text { Experiencia }\end{array}$ \\
\hline Mucho/Bastante & 50,0 & 63,8 & 72,0 & 100 \\
\hline Poco/Nada & 50,0 & 36,3 & 28,0 & 0 \\
\hline \multicolumn{5}{|c|}{ Legislatura 2006-2010 } \\
\hline & $\begin{array}{c}\text { Poca } \\
\text { Experiencia }\end{array}$ & $\begin{array}{c}\text { Experiencia } \\
\text { Media }\end{array}$ & $\begin{array}{c}\text { Experiencia } \\
\text { Alta }\end{array}$ & $\begin{array}{c}\text { Máxima } \\
\text { Experiencia }\end{array}$ \\
\hline Mucho/Bastante & 100 & 78,3 & 67,7 & 25 \\
\hline Poco/Nada & 0 & 21,7 & 32,3 & 75 \\
\hline
\end{tabular}

Fuente: Elaboración propia a partir de datos de PELA (1994-2006). *Esta pregunta no se incluyó en el cuestionario de 1994.

El nivel de experiencia institucional tampoco se relaciona con el vínculo indirecto no particular entre legislador y elector. La Tabla 3.2.a) 3.7 revela que sólo en la legislatura 1994-1998 -última de las legislaturas en las que están presentes los tres caudillos históricos- cuanto mayor era el expertise de los parlamentarios, mayor era el porcentaje de los que consideraban que el programa del partido fue la razón principal que motivó su elección, especialmente en las categorías "media" y "alta". A partir de 1998, no se observa tendencia alguna que relacione experiencia y vínculos programático/ideológicos.

Tabla 3.2.3.7 Razón principal de la elección del diputado según nivel de Expertise Institucional

\begin{tabular}{|c|c|c|c|c|c|c|c|c|c|c|c|}
\hline \multicolumn{6}{|c|}{ Legislatura 1994-1998 } & \multicolumn{6}{|c|}{ Legislatura 1998-2002 } \\
\hline \multirow{8}{*}{$\begin{array}{l}\text { Programa } \\
\text { Falta opción } \\
\text { Otras } \\
\text { Líder } \\
\text { Campaña } \\
\text { Simpatía } \\
\text { Familia }\end{array}$} & $\begin{array}{l}\text { Sin y/o } \\
\text { escasa }\end{array}$ & $\begin{array}{l}\text { Poca } \\
\text { Exp. }\end{array}$ & $\begin{array}{c}\text { Media } \\
\text { Exp. }\end{array}$ & $\begin{array}{l}\text { Alta } \\
\text { Exp. }\end{array}$ & $\begin{array}{c}\text { Máxima } \\
\text { Exp. }\end{array}$ & \multirow{8}{*}{$\begin{array}{l}\text { Programa } \\
\text { Ideología } \\
\text { Experiencia } \\
\text { Líder } \\
\text { Campaña } \\
\text { Simpatía } \\
\text { Familia }\end{array}$} & $\begin{array}{l}\text { Sin y/o } \\
\text { escasa }\end{array}$ & $\begin{array}{l}\text { Poca } \\
\text { Exp. }\end{array}$ & $\begin{array}{c}\text { Media } \\
\text { Exp. }\end{array}$ & $\begin{array}{l}\text { Alta } \\
\text { Exp. }\end{array}$ & $\begin{array}{l}\text { Máxima } \\
\text { Exp. }\end{array}$ \\
\hline & 25 & 27,3 & 33,3 & 55,6 & -- & & -- & 15,8 & 10,5 & 28,6 & -- \\
\hline & 50 & 0 & 3,7 & 5,6 & -- & & -- & 10,5 & 11,8 & 0 & -- \\
\hline & 0 & 0 & 0 & 5,6 & -- & & -- & 5,3 & 13,2 & 14,3 & -- \\
\hline & 0 & 9,1 & 18,5 & 5,6 & -- & & -- & 5,3 & 18,4 & 0 & -- \\
\hline & 0 & 9,1 & 14,8 & 0 & -- & & -- & 42,1 & 19,7 & 28,6 & -- \\
\hline & 25 & 45,5 & 18,5 & 27,8 & -- & & -- & 21,1 & 25 & 28,6 & -- \\
\hline & 0 & 9,1 & 11,1 & 0 & -- & & -- & 0 & 1,3 & 0 & -- \\
\hline \multicolumn{6}{|c|}{ Legislatura 2002-2006 } & \multicolumn{6}{|c|}{ Legislatura 2006-2010 } \\
\hline \multirow{8}{*}{$\begin{array}{l}\text { Programa } \\
\text { Ideología } \\
\text { Experiencia } \\
\text { Líder } \\
\text { Campaña } \\
\text { Simpatía } \\
\text { Familia }\end{array}$} & $\begin{array}{l}\text { Sin y/o } \\
\text { escasa }\end{array}$ & $\begin{array}{l}\text { Poca } \\
\text { Exp. }\end{array}$ & $\begin{array}{c}\text { Media } \\
\text { Exp. }\end{array}$ & $\begin{array}{l}\text { Alta } \\
\text { Exp. }\end{array}$ & $\begin{array}{l}\text { Máxima } \\
\text { Exp. }\end{array}$ & \multirow{8}{*}{$\begin{array}{l}\text { Programa } \\
\text { Ideología } \\
\text { Experiencia } \\
\text { Líder } \\
\text { Campaña } \\
\text { Simpatía } \\
\text { Familia }\end{array}$} & $\begin{array}{l}\text { Sin y/o } \\
\text { escasa }\end{array}$ & $\begin{array}{l}\text { Poca } \\
\text { Exp. }\end{array}$ & $\begin{array}{l}\text { Media } \\
\text { Exp. }\end{array}$ & $\begin{array}{l}\text { Alta } \\
\text { Exp. }\end{array}$ & $\begin{array}{c}\text { Máxima } \\
\text { Exp. }\end{array}$ \\
\hline & -- & 0 & 12 & 0 & -- & & -- & 0 & 4 & 0 & 0 \\
\hline & -- & 25 & 0 & 7,4 & -- & & -- & 0 & 8 & 5,9 & 0 \\
\hline & -- & 25 & 4,8 & 11,1 & -- & & -- & 0 & 8 & 0 & 0 \\
\hline & -- & 25 & 12 & 7,4 & -- & & -- & 0 & 2 & 2,9 & 0 \\
\hline & -- & 25 & 32,5 & 25,9 & -- & & -- & 0 & 18 & 26,5 & 25 \\
\hline & -- & 0 & 36,1 & 44,4 & 100 & & -- & 100 & 56 & 64,7 & 75 \\
\hline & -- & 0 & 2,4 & 3,7 & -- & & -- & 0 & 4 & 0 & 0 \\
\hline
\end{tabular}

Fuente: Elaboración propia, a partir de datos de PELA (1994-2009)

Cuanto mayor es su paso por las instituciones, mayor es el porcentaje de legisladores que tienen familiares dedicados al ejercicio de la vida pública. Esta tendencia refleja en el ámbito legislativo la funcionalidad de las redes familiares como círculos de confianza particularizada que dan acceso al ejercicio de la vida pública. De nuevo la legislatura 1998-2002 destaca por su singularidad ya que 
en todas las categorías es mayor el porcentaje de diputados que dijeron no tener familiares en política. El éxito electoral de PLD y PRD trae al hemiciclo nuevas caras ajenas a los tradicionales círculos de influencia endogámica. Sin embargo, en las siguientes legislaturas se recupera la tendencia a pesar de que no hay cambios sustanciales en la composición de la Cámara, lo que indica que durante el transcurso de esos años se activaron las redes para ubicar a familiares de los diputados en cargos políticos. Estos datos revelan la doble vía del círculo de influencia familiar: se accede a la política por tradición familiar pero también a través del "salvoconducto" del aquel miembro que accede por primera vez a las instituciones.

Tabla 3.2.3.8 Familiares en política según nivel de Expertise Institucional diputados dominicanos (\%)

\begin{tabular}{|c|c|c|c|c|c|}
\hline \multicolumn{6}{|c|}{ Legislatura 1994-1998 } \\
\hline & $\begin{array}{c}\text { Sin y/o escasa } \\
\text { Experiencia }\end{array}$ & $\begin{array}{c}\text { Poca } \\
\text { Experiencia }\end{array}$ & $\begin{array}{c}\text { Experiencia } \\
\text { Media }\end{array}$ & $\begin{array}{c}\text { Experiencia } \\
\text { Alta } \\
\end{array}$ & $\begin{array}{c}\text { Máxima } \\
\text { Experiencia }\end{array}$ \\
\hline SI & 60 & 58,3 & 64,2 & 77,7 & -- \\
\hline NO & 40 & 41,6 & 35,7 & 22,2 & -- \\
\hline \multicolumn{6}{|c|}{ Legislatura 1998-2002 } \\
\hline & $\begin{array}{l}\text { Sin y/o escasa } \\
\text { Experiencia }\end{array}$ & $\begin{array}{c}\text { Poca } \\
\text { Experiencia }\end{array}$ & $\begin{array}{c}\text { Experiencia } \\
\text { Media }\end{array}$ & $\begin{array}{c}\text { Experiencia } \\
\text { Alta }\end{array}$ & $\begin{array}{c}\text { Máxima } \\
\text { Experiencia }\end{array}$ \\
\hline SI & -- & 26,3 & 37,3 & 28,5 & -- \\
\hline NO & -- & 73,6 & 62,6 & 71,4 & -- \\
\hline \multicolumn{6}{|c|}{ Legislatura 2002-2006 } \\
\hline & $\begin{array}{l}\text { Sin y/o escasa } \\
\text { Experiencia }\end{array}$ & $\begin{array}{c}\text { Poca } \\
\text { Experiencia }\end{array}$ & $\begin{array}{c}\text { Experiencia } \\
\text { Media }\end{array}$ & $\begin{array}{c}\text { Experiencia } \\
\text { Alta }\end{array}$ & $\begin{array}{c}\text { Máxima } \\
\text { Experiencia }\end{array}$ \\
\hline SI & -- & 25,0 & 42,8 & 66,6 & 100 \\
\hline NO & -- & 75,0 & 57,1 & 33,3 & 0 \\
\hline \multicolumn{6}{|c|}{ Legislatura 2006-2010 } \\
\hline & $\begin{array}{c}\text { Sin y/o escasa } \\
\text { Experiencia }\end{array}$ & $\begin{array}{c}\text { Poca } \\
\text { Experiencia }\end{array}$ & $\begin{array}{c}\text { Experiencia } \\
\text { Media }\end{array}$ & $\begin{array}{c}\text { Experiencia } \\
\text { Alta } \\
\end{array}$ & $\begin{array}{c}\text { Máxima } \\
\text { Experiencia }\end{array}$ \\
\hline SI & -- & 100 & 50,9 & 62,1 & 75,0 \\
\hline NO & -- & 0 & 49 & 37,8 & 25,0 \\
\hline
\end{tabular}

Fuente: Elaboración propia, a partir de datos de PELA (1994-2009)

\subsection{RECAPITULACIÓN}

En las páginas previas se han identificado los factores que determinan el particularismo desde la oferta. Para ello se ha explorado el poder explicativo del entorno institucional en las relaciones del Estado con los Partidos. Con este propósito se estudiaron el peso de la historia institucional, las reglas electorales y el perfil de aquellos que se desempeñan como agentes en la democracia representativa dominicana.

En primer lugar se explora la hipótesis neoinstitucionalista de la influencia de las coyunturas históricas claves en la orientación de las políticas en el largo plazo. El relato de las vicisitudes del proceso de state building y de la movilización a la política de masas confirma la aplicabilidad de la Teoría de la Experiencia Crítica defendida por Shefter (1994). La democratización precede al proceso de burocratización en la República Dominicana por lo que la separación entre la política y el Estado estuvo viciada desde sus orígenes. Este desajuste de tiempos fundacionales ha condicionado el devenir de la construcción institucional en la etapa de la consolidación 
democrática. Como muestra esta investigación, en el andamiaje institucional y administrativo actual perviven rasgos heredados del régimen anterior y los actores se resisten a la aplicación del nuevo marco legal. Con respecto al segundo momento fundacional clave, el transicional, éste fue dominado por el PRSC -partido internamente movilizado y con acceso al patronazgo- sentando las bases para el uso de los empleos públicos para la movilización política. Los datos aportados en esta investigación sobre el número variable de funcionarios, la duplicidad de instituciones o la debilidad de la carrera administrativa en el país, ejemplifican la amenaza del «potencial antidemocrático de la burocratización de la administración» en contextos neopatrimoniales que identificara Mancilla (1991), donde el aumento de instancias y procesos no obedece a razones de eficiencia sino a la creación de espacios para recompensar clientelas.

Con respecto a las características del sistema electoral, la investigación revela que desde el establecimiento del voto preferencial en el año 2002, se ha incrementado el trabajo en solitario de los diputados dominicanos. Los datos confirman que la visibilidad individual de su labor como conseguidores es preferida a la visibilidad partidista de las iniciativas conjuntas. Además del personalismo en el ejercicio de su labor parlamentaria, el particularismo legislativo se ve afectado por el tamaño pequeño de las circunscripciones dominicanas (promedio de 3,70). En este sentido, los Proyectos de Ley de los 5 diputados de la circunscripción nacional 2010-2016 muestran que estos diputados nacionales no están apegados a los intereses parroquiales como el resto de sus colegas electos en la circunscripción provincial. Si bien tienden a actuar menos en solitario, la significativa ausencia de iniciativas de la bancada partidista refleja que también los diputados nacionales siguen prefiriendo la visibilidad personal -aunque sea compartida con 2 o 3 compañerosque la visibilidad partidista. La investigación documenta que la fragmentación del territorio nacional convierte al legislador dominicano en un eslabón más en la dinámica de constituency service en el país en la que rivaliza como conseguidor con el gobernador o con el alcalde. Esta búsqueda de votos personales y el focus distrital debilita el intercambio indirecto mediado por programas entre principal y agente. En la segunda parte de este epígrafe, se consideran la doble vuelta y la ausencia de límites y publicidad del financiamiento privado en el aumento del patronazgo entre actores políticos y la dependencia de los intereses particularistas en el mandato de representación respectivamente.

$\mathrm{Y}$ con respecto a quiénes son los intermediarios en las relaciones Estado-Partidos, la falta de exclusividad en el ejercicio de las labores parlamentarias dibuja un perfil del político dominicano en el que predominan los patronos privados con funciones públicas. Este perfil apuntaría a la potencial amenaza de actuaciones oportunistas asociada a la profesionalización de las comisiones legislativas que señalara Krehbiel (2004) o la tesis de Acemoglu y Robinson (2006) acerca de la cooptación de las instituciones para perpetuar el particularismo y favorecer sus intereses. El Índice de Expertise Institucional elaborado con las opiniones de los diputados dominicanos (1994-2010) del Proyecto Elites Parlamentarias Latinoamericanas (PELA) muestra que, contrario a las bondades anunciadas por los neoinstitucionalistas, el paso por las instituciones de los legisladores dominicanos no ha extendido la inclusividad del mandato, ni ha fortalecido la vinculación programática. 


\subsection{RELACIONES PARTIDO-PARTIDO}

La literatura acerca de los modos de accountability y responsiveness en democracia ha puesto el foco de atención en cómo compiten los partidos para explicar la mayor probabilidad de ofertar beneficios particularizados (Aldrich 1995; Warner 2001; Maiz 2005; Kitschelt y Wilkinson 2007). El intercambio de votos y apoyo a cambio de decisiones públicas que conlleven asignación selectiva de beneficios es una estrategia racional elegida por los actores para conquistar o mantener el poder. Las decisiones de elección social (identidad programática) y de acción colectiva (organización) que han de adoptar los protagonistas afectan tanto al estilo de la representación como a la eficacia de las políticas. La manera en que los políticos movilizan su apoyo es indicador de la naturaleza y calidad de la democracia (Przeworski 1985, Mainwaring y Scully 1995) y predictor de las posibilidades para su consolidación (Huntington 1968). Este enfoque-«politicians matter too»retoma el papel decisivo e independiente de los actores políticos en la elección de estrategias particularistas o de alcance universal para la articulación de vínculos y su capacidad para adaptarse racionalmente al contexto. Como argumentan Kitschelt y Wilkinson (2007), en las nuevas democracias, la persistencia de la política particularista no depende solo de la pobreza o el desigual acceso a los recursos, sino de los incentivos estratégicos generados en la arena de la competición para mantener el tipo de relación racional directa de accountability entre principal y agente. La aportación de este trabajo de investigación radica en ampliar el foco de análisis en las relaciones partido-partido atendiendo no solo al "cómo compiten" sino al "cómo colaboran" y "por qué pelean".

El objetivo de este aparatado es analizar las Relaciones Partido-Partido en la República Dominicana en tres dimensiones: 1) competición, 2) cooperación y 3) conflicto, para identificar los incentivos estratégicos que enfrentan los actores y condicionan sus elecciones particularistas de relación con los votantes y con sus pares.

En primer lugar se presentan los rasgos definitorios de la competencia interpartidista dominicana, la cual gira en torno a la capacidad de los actores de otorgar bienes («particularistic valence competition»). La debilidad del vínculo programático entre representantes y representados frente a la hegemonía del nexo personalista (simpatía), incentiva la dinámica clientelar de la competencia entre partidos ofertándose como suplidores de beneficios concretos y no como redistribuidores abstractos de costes y beneficios («positional competition»). En esta contienda, que gira en torno a quién puede repartir más y mejor, afloran los vínculos de naturaleza afectiva relativos a las cualidades del agente o su intermediario como la reputación moral o el liderazgo, pero también otros de naturaleza racional retrospectiva como el dinamismo resolutivo del político en su distrito. Así, con este ejercicio de dispensador de recursos aumenta la reputación de eficacia del político por la que será recompensado con la reelección, tal y como mostraran Cain, Ferejohn y Fiorina (1987). Como se trata de evidenciar en los siguientes epígrafes, los partidos políticos dominicanos son modernos partidos clientelares atrápalotodo en interacción sistémica del tipo cartel informal. Cuentan con una maquinaria política institucionalizada pero altamente informal de redes de intercambio multinivel en las que los actores disfrutan de cierto grado de autonomía y descentralización en el ejercicio de su accountability y responsiveness. Esta descentralización del liderazgo es el precio que el partido clientelar tiene que pagar si quiere conservar un ejército de brókers que monitoreen a los votantes («perverse accountability») (Stockes 2007:619; 2005). En este escenario de voluntad popular atomizada y agregación individual-corporativa de intereses, no es obstáculo que el partido no hable como una sola voz colectiva. Al contrario, otorga al sistema la flexibilidad necesaria para legitimar el ejercicio de la representación política. En el caso de los diputados y senadores dominicanos, les permite ejercer de brókers resolutivos en su distrito y tener un comportamiento individualista en su labor legislativa a cambio de cohesión cuando el partido 
"baja línea"97 en los asuntos importantes en aras de la fluidez institucional. Esta defensa de intereses parroquiales, localistas y personales en el hemiciclo dominicano apunta a una política de "nombre y apellido" que parece ser la versión nacional de la división de tareas entre el Ejecutivo y el Legislativo y que garantiza el equilibrio del "secreto de la ineficiencia" identificado por Amorim Neto y Santos (2003).

Con respecto a la segunda dimensión en las relaciones Partido-Partido, la coordinación estratégica entre actores políticos puede ponerse al servicio de acuerdos nacionales que fomenten el desarrollo, pero también para alcanzar objetivos inmediatos que benefician al establishment político a costa del debilitamiento institucional. La capacidad de las élites para cooperar y alcanzar acuerdos más allá de los ciclos políticos resulta fundamental para establecer una agenda con rango de Estado que dé continuidad a las políticas públicas (Zovatto, 2010; Cox, 2010). Como muestra este trabajo, desde que en 1978 tuviera lugar la segunda transición a la democracia, se observa en la República Dominicana un patrón de colaboración en el que predomina el consenso pragmático, el interés por la propia supervivencia institucional y el acceso patrimonialista a los recursos del Estado. El nivel de extensión de estos resultados de la coordinación estratégica pertenecen al universo de los bienes privados y de club y por tanto, son indicadores de un modo de relación entre partidos que la literatura del clientelismo ha referido como propicio para el intercambio particularizado (Piattoni 2001). Para ello, se presenta un modelo de cooperación estratégica en el que se tipifican las diferentes formas de interacción según quiénes sean los protagonistas [élites, partidos o candidatos], en una orientación dicotómica [particularista versus generalista] determinada por el repertorio de incentivos y costes asociados. Tras presentar el modelo, se hace un repaso a los pactos, alianzas electorales y experiencias transfuguistas que han tenido lugar en la República Dominicana desde la transición hasta la actualidad para demostrar su conexión causal con la política clientelar.

La competitividad en condiciones de oligopolio -cuando una sola alternativa muy pequeña de gobierno es viable y tendrá el dominio de la asignación de los recursos públicos- (Kitschelt y Wilkinson 2012:38) parece condicionar la racionalidad cooperativa estratégica de los actores apostando por la mejor opción individual y/o grupal utilitaria en detrimento de la solución colectiva. Desde la racionalidad del dilema del prisionero, los partidos, al igual que los individuos, enfrentan los mismos incentivos desde la desconfianza para cooperar con otros, por lo que, como apunta Geddes (1994), aunque el cambio sea visto como deseable, no llegará a producirse salvo que todos los actores del sistema lo hagan simultáneamente. Teniendo en cuenta la nula la vocación generalista del historial de pactos en la República Dominicana, parece que existe la oportunidad pero no la voluntad. Para corroborar esta tipología se precisan nuevos estudios de caso y en perspectiva comparada que aporten evidencia adicional acerca de la cooperación en condiciones de legitimidad clientelar en las vecinas democracias emergentes.

Por último, en la tercera de las dimensiones se presentan las relaciones de conflicto para mostrar que el faccionalismo en la República Dominicana es la estrategia elegida por los actores políticos frente a las discrepancias. Esta opción potencia la lealtad personal frente a la partidista, dificulta la cooperación intrapartidaria en la agregación de intereses colectivos y genera un sistema particularizado de lealtades y recompensas. Como apuntara Geddes (1991), existe un nexo causal entre política particularista y faccionalismo al ser éste un obstáculo añadido en la probabilidad de que se lleven a cabo reformas en la profesionalización de la administración pública, ya que el control por el patronazgo se traslada también al ámbito interno del partido.

\footnotetext{
${ }^{97}$ Expresión popular dominicana para indicar que el máximo liderazgo del partido o del Estado marca una posición en un determinado asunto que han de obedecer sus compañeros de partido o representantes públicos en la escala inferior.
} 


\title{
1) Competición y representación política en el sistema de partidos dominicano
}

\author{
¿Cómo compiten los partidos políticos dominicanos?
}

El objetivo de este apartado es mostrar que las principales fuerzas políticas en el país no compiten en su función movilizadora de cleavages representativos ( «policy exchange») sino en su efectividad para distribuir bienes privados y selectivos («targeted exchange»). En este escenario y cuando la participación electoral está mediatizada por los brókeres locales, las elecciones no las gana el candidato ideológico sino el que cuenta con la mayor maquinaria política (Hopkin 2002). En un contexto de alta competitividad y de bajo nivel de desarrollo socioeconómico, el gasto en política clientelar es la opción estratégica elegida por los actores dominicanos para hacerse con el control oligopólico de los recursos del Estado. La competitividad como variable explicativa de los modos racionales de vinculación directa particularizada no está relacionada tanto con la fragmentación y volatilidad, sino con los altos incentivos estratégicos que se generan en la conquista electoral (Kitschelt y Wilkinson 2012:38):

1- Estrecha diferencia entre bloques de partidos identificados por los votantes como grupos alternativos de gobierno

2- Un mercado de votantes desvinculados capaz de inclinar la balanza a favor de uno u otro

3- En las elecciones se decide quién controlará los recursos públicos. Un pequeño cambio en el apoyo electoral puede significar un gran cambio en el control del patronazgo.

En sistemas altamente fragmentados y en los de partido hegemónico la competición es menor que en aquellos que operan en condiciones de oligopolio. En estos últimos, en contextos de desarrollo económico alto (e.g. Japón, Scheiner 2007) e intermedio (e.g. Argentina, Levitsky 2007), los políticos optan por un menú diversificado de políticas clientelares y programáticas condicionados por las limitaciones presupuestarias y por el rechazo de los votantes de renta media a las prácticas clientelares. Por el contrario, en los países de bajo nivel de desarrollo como el dominicano, la política clientelar deviene la mejor opción dado el bajo coste de los votantes marginales que en la relación clientelar se convierten estratégicamente en la terminología de Kitschelt en «clientes pobres pero ricos en votos».A modo ilustrativo, este escenario de competición y recompensa particularizada aparece retratado en dos intervenciones públicas del ex Presidente Leonel Fernández. La primera, en un acto de apoyo al candidato presidencial oficialista en las elecciones de 2012 en el que se anuncian los intercambios propios del Clientelismo Electoral: reparto de beneficios selectivos a cambio de votos. Además, revela el déficit que genera la discrecionalidad en la ejecución presupuestaria que suele acompañar a las gestiones de los gobiernos clientelares (Piattoni2001:16):

«Es por eso que ustedes han visto en esta primera etapa que no hemos arrancado en las encuestas en primer lugar, pero se debe a lo acontecido desde julio del 2010 a julio del 2011. Porque el FMI en el acuerdo que tiene con nuestro gobierno nos aplicó una política de restricción del gasto de $\$ 40.000$ millones de pesos, que no pudimos gastar excepto lo que estaba en el presupuesto (...) Pero el PLD volverá a ganar las elecciones del 2012 porque ya no existe la limitación impuesta por el FMI y el dinero se usará para en estos nueve meses [que quedan para que se celebren las elecciones] ejecutar un plan nacional de pavimentación y para que se sienta, le pediremos ayuda a Nicolás Maduro para que su país envíe barriles de AC-30 y con eso pavimentaremos medio país, lo que nos va ayudar de nuevo a conquistar el apoyo público (...) Y llevaremos a cabo también un plan nacional de distribución de alimentos con una repartición diaria de 30 mil raciones de comida cocida, equivalente a 10 millones de porciones en nueve meses a un precio módico de entre 2 y 3 pesos en 900 plazas agropecuarias para distribuir productos agropecuarios» (Fernández 2001) ${ }^{98}$.

\footnotetext{
${ }^{98}$ Ver noticia «Leonel admite PLD pierde apoyo; dice ganará con comida, asfalto y ferias agropecuarias. Anuncia usará $\$ 40.000$ millones en la campaña y promete enfrentar inseguridad», en Periódico "El Nuevo
} 
Y la segunda, en una de sus habituales editoriales en la prensa, donde se refleja la interacción con los «clientes ricos pero pobres en votos» más allá del momentun electoral en una relación de amistad instrumental ${ }^{99}$ :

«Realizábamos uno de los acostumbrados recorridos de Navidad por la provincia. Llevábamos música, alegría y distribuíamos canastas de alimentos y golosinas a las empobrecidas familias. Pero, además, se repartían unos sobrecitos amarillos, donados por empresarios amigos, que contenían algunos regalos para la ocasión. Se impresionó al ver la multitud que se abalanzaba sobre uno de los encargados de hacer la distribución y me dijo: "Presidente, ¿ha visto cómo el compañero Pedro se ha convertido, de repente, en un líder?" (...) Entonces, lo miré y le dije: "Observe lo siguiente. Vamos a pedirle que le entreguen los sobrecitos al compañero Manuel, dirigente provincial, para que él continúe el reparto y a ver qué pasa". Así ocurrió y la muchedumbre rápidamente abandonó a Pedro y se desplazó hacia el compañero Reyes, quien empezaba a hacer la repartición de los sobrecitos. Entonces le pregunté: "¿Qué tal, qué le parece? Míre el gran líder que en cuestión de segundos se ha convertido el compañero Manuel, ahora encargado de repartir los sobrecitos". No pudo contener la risa. Había aprendido la lección» (Fernández 2014).

En la transición del clientelismo tradicional al moderno clientelismo, la relación patrón-cliente ha ido perdiendo sus componentes originarios de dominación y es hoy menos jerarquizada, de naturaleza más instrumental, simétrica y racional (Kitschelt y Wilkinson 2007; Piattoni 2001; Levitsky 2007). Estas circunstancias han acrecentado el poder del cliente de escoger a su patrón y de negociar la contrapartida de su apoyo (Combes 2011:28). Y como muestra, sirvan de ejemplo las palabras del representante de ANADIVE, principal asociación empresarial de autos importados en su visita al actual Presidente del Senado y precandidato presidencial oficialista en la próxima contienda de $2016^{100}$ :

"Manos que dan esperan. Yo quiero que usted entienda presidente [del Senado], que si usted se compromete con nuestro sector las tres asociaciones presentes aquí nos comprometemos formalmente con usted a tratar dentro de nuestras posibilidades a ayudarlo a que sea Presidente [del Estado]. Lo que queremos no es un intercambio sino una ayuda para que este sector tan pujante, tan dinámico en la economía, pueda resurgir” (Taveras 2014).

Como da cuenta la prensa nacional, tras el encuentro «el Presidente del Senado instruyó a los senadores Tommy Galán, Amílcar Romero y Charles Mariotti reintroducir el anteproyecto que beneficia a los concesionarios de vehículos usados en la próxima sesión de los miércoles. Esta noticia muestra el poder de negociación de los clientes incluso con futuros patrones, así como el comportamiento individualista de los legisladores dominicanos, ya que este mandato imperativo particularizado no lo asume la bancada oficialista, sino la camarilla amiga del aspirante ${ }^{101}$.

Diario" de 30 de septiembre de 2011. Palabras del entonces Presidente Leonel Fernández en un acto de campaña en Nueva York con los residentes dominicanos y en presencia del Cónsul General en esa ciudad Máximo Corcino. Acto organizado por el Ex Cónsul General Rafael Evans dirigente de la coordinadora reeleccionista de apoyo a la candidatura de Leonel Fernández.

${ }^{99}$ Editorial del ex Presidente Leonel Fernández en el periódico Listín Diario del 10 de febrero de 2014, titulado «El poder y el liderazgo: entre puestos y sobrecitos». En http://www.listindiario.com.do/larepublica/2014/2/9/310109/El-poder-y-el-liderazgo-entre-puestos-y-sobrecitos.

${ }^{100}$ Luis Taveras, presidente de la Asociación Nacional de Importadores de Vehículos. Ver noticia "Reinaldo promete modificar Ley de Importación de Vehículos" en periódico El Caribe del 14 de marzo de 2014.En http://www.elcaribe.com.do/2014/03/14/reinaldo-promete-anadive-modificar-ley-importacion-vehiculos.

${ }^{101}$ Tras ser aprobado en el Senado y solo trece días después de la visita, el 27 de marzo de 2014 se sometió el Proyecto de Ley en la Cámara de Diputados para modificar la Ley No. 168/67 para exonerar del pago de impuestos en forma parcial a vehículos importados propuesto por ANADIVE. 


\section{$\checkmark \quad$ Estabilidad sistémica y organización informal}

En el camino hacia la institucionalización de la democracia en la República Dominicana ha habido dos importantes puntos de inflexión: la transición post trujillista (1961-1966) y la transición del régimen autoritario bonapartista de Joaquín Balaguer (1978-1982) (Lozano 2004). Durante más de tres décadas (1966-1998), la política nacional estuvo dominada por la competencia carismática alrededor del cleavage autoritarismo/democracia entre los viejos caudillos Juan Bosch del Partido de la Liberación Dominicana (PLD), Joaquín Balaguer del Partido Reformista Social Cristiano (PRSC) y José Francisco Peña Gómez del Partido de la Revolución Dominicana (PRD). En el lapso de tiempo en el que salen de la escena pública los tres líderes históricos (1998-2002) se inicia una nueva etapa en la competición política nacional. A pesar de que fueron muchos los que auguraron el colapso del sistema de partidos durante la que se vislumbraba como "tercera transición" dominicana, el tiempo ha evidenciado su estabilidad y fortaleza a través de un sendero que no ha transcurrido por la congelación del cleavage -camino nicaragüense- ni por su mutación en cleavage de clase -vía costarricense- (Mitchell 2010:53).

Tras casi una década, los partidos dominicanos se han adaptado al escenario de la democratización conservando el viejo estilo de la política de clientela y el manejo patrimonial del Estado. Aquella "cuasipoliarquía gerontocrática" (Jiménez 1999) de Bosch y Balaguer ha derivado en la etapa de la consolidación en un tipo de democracia que la literatura ha adjetivado como oligárquica, cleptómana y neopatrimonialista (Espinal 2006; Lozano, 2002; Hartlyn, 1994) o una subcategoría de democracia por las deficiencias en accountability horizontal (Marsteintredet 2004).

Como ha argumentado Mitchell (2010), la excepcionalidad de la estabilidad del caso dominicano radica en la conjunción de una serie de factores que favorecen el continuismo:

Tabla 3.4.1.1 Factores que contribuyen a la estabilidad del sistema de partidos dominicano

$\begin{array}{lll}\text { FACTORES } & \checkmark & \text { Integración económica con EEUU } \\ \text { EXÓGENOS } & \checkmark & \text { Emigración } \\ & \checkmark & \text { Proximidad con Haití }\end{array}$

$\checkmark \quad$ Barrera nivel nacional: reglas electorales mayoritarias favorecen a partidos tradicionales.

FACTORES $\quad \checkmark \quad$ Reglas proporcionales permiten entrada minoritarios sin amenazar nacionalización sistema partidos.

SISTÉMICOS $\quad \checkmark \quad$ Barrera nivel sub nacional: gobernadores trabajan para el partido oficialista

ENDÓGENOS $\quad \checkmark \quad$ Botín estatal -sector público grande y centralizado- al servicio de los partidos políticos

$\checkmark \quad$ Intervención estatal de la economía

$\checkmark$ Desaparece cleavage autoritarismo/democracia en 80's y surge cleavage desempeño macroeconómico

VOTANTES $\quad \checkmark \quad$ Estabilidad de las preferencias partidistas de una parte del electorado, alta identificación partidaria

$\checkmark$ Conservadurismo

PARTIDOS

$\checkmark \quad$ Han evitado la crisis de sucesión tras la muerte de los caudillos

$\checkmark \quad$ Flexibles, se han reconvertido en partidos de masas y no han permitido outsiders

$\checkmark \quad$ Financiamiento periódico y constante

$\checkmark \quad$ Fortaleza organización interna para sobrevivir en oposición y desechar opción autoritaria

$\checkmark \quad$ Centrismo

Fuente: Elaboración propia a partir Mitchell (2010). "An institutional anomaly, longevity and competition in Dominican Republic party".

Con respecto a los factores exógenos que contribuyen al statu quo Mitchell identifica la emigración como un elemento de estabilización y válvula de escape que frena la revuelta enviando al exterior a los frustrados. Se estima que más de un $15 \%$ de la población nacional está fuera de las fronteras 
dominicanas y que el 38\% recibe remesas de sus familiares emigrados (ENI 2012) ${ }^{102}$. En 2012, el $23,4 \%$ de los entrevistados afirmó recibir remesas del exterior, ocupando el primer lugar en la comparativa regional y en el tercero en el continente americano por debajo de Haití, Jamaica y Guyana (LAPOP 2012:249). En ese mismo año, el 31,9\% de los entrevistados manifestaba sus intenciones de irse a vivir o trabajar a otro país (LAPOP 2012:252). La integración económica con EEUU y la proximidad con el estado fallido de Haití son condicionantes exógenos adicionales que refuerzan la preferencia por la seguridad de lo conocido frente a otras opciones anti sistema. En las relaciones de vecindad con Haití, la sentencia del Tribunal Constitucional de 2013 que despoja de la nacionalidad a los hijos de migrantes haitianos en situación irregular desde 1929, ha puesto de actualidad el doble discurso estatal de trazar fronteras porosas para trabajar a la vez que obstáculos legales para el ejercicio de derechos ciudadanos de sus convecinos ${ }^{103}$.

Desde el lado de los votantes, Mitchell (2010) señala las elecciones de 1986 como aquellas en las que el tradicional cleavage autoritarismo/democracia perdió su peso con la crisis de los años previos a la contienda y la respuesta ciudadana de Abril de 1984 a las medidas de ajuste. Desde entonces, la valoración del desempeño macroeconómico y el crecimiento han condicionado la alternancia o la continuidad. Así sucedió en las presidenciales de 2004, celebradas en el escenario de la grave crisis fiscal del 2003 o en las elecciones de 2012 en las que el fantasma de la debacle financiera de los gobiernos de la oposición ocupó un espacio destacado en la campaña oficialista ${ }^{104}$. El carácter conservador del electorado dominicano (66,6 LAPOP 2008) así como el alto nivel de apoyo a los partidos tradicionales -bien en la forma de simpatía partidaria (63,4\% LAPOP 2012) o en la modalidad de trabajar para partidos durante la campana (16,8\% LAPOP 2012)- se han mantenido en el tiempo. En los tres aspectos, la República Dominicana ocupa los primeros lugares en la comparativa regional.

La estabilidad del voto de un tercio del electorado dominicano que vota por el PRD en cualquier circunstancia así como la disposición de cerca de un $20 \%$ dispuesto a votar al PRD si están insatisfechos con la gestión del PLD ha dado continuidad y flexibilidad al sistema desde que tuviera lugar la segunda transición en 1978 (Mitchell 2010:59). A pesar del pragmatismo del discurso y que los tres son partidos interclasistas, recientes datos de opinión pública revelan la importancia de la clase social en la conformación de las preferencias ya que en las legislativas de 2010, el voto al oficialista PLD disminuye conforme aumenta la renta del hogar, mientras que el voto al PRD se incrementa en las rentas más altas (OBSEROP 2010:19). De igual manera, el voto al PLD tiende a disminuir a medida que aumenta el nivel de estudios, siendo su porcentaje mayor de votantes entre aquellos con estudios primarios o menos. Este segmento poblacional es compartido con el PRSC, que también encuentra sus mayores apoyos en los votantes de menor nivel educativo.

\footnotetext{
${ }^{102}$ En EEUU hay registrados cerca de 900.000 dominicanos. En Puerto Rico residen 68.000 llegando a 140.000 computando los irregulares. En Europa residen cerca de 200.000 dominicanos, 160.000 en España.

${ }^{103}$ Una decisión de similar naturaleza a aquella por la que el Estado dominicano ya fuera condenado en 2005 por la Corte Interamericana de Derechos Humanos. Al momento de redactar esta Tesis, la República Dominicana está a la espera del dictamen de la CIDD acerca de la sentencia tras las observaciones preliminares en su visita al país.

${ }^{104}$ Ver documental «El peligro de olvidar» en http://www.youtube.com/watch?v=Qpkm0ct_EHk, entre otros.
} 
Gráfico 3.4.1.1 Evolución del voto de los principales partidos (\%), elecciones legislativas 1978-2010

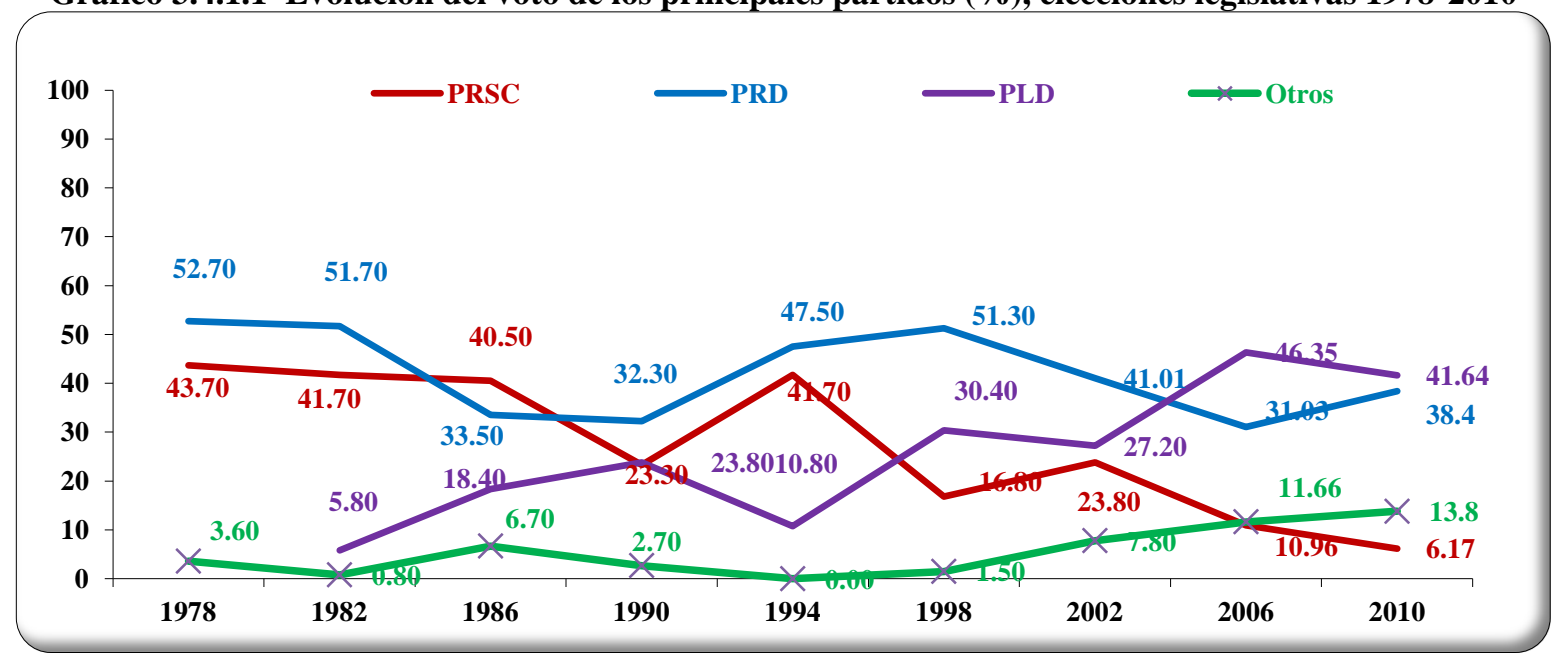

Fuente: Elaboración propia a partir de PELA (1994-2012)

Gráfico 3.4.1.2 Evolución del voto (\%) principales partidos, elecciones presidenciales 1978-2012

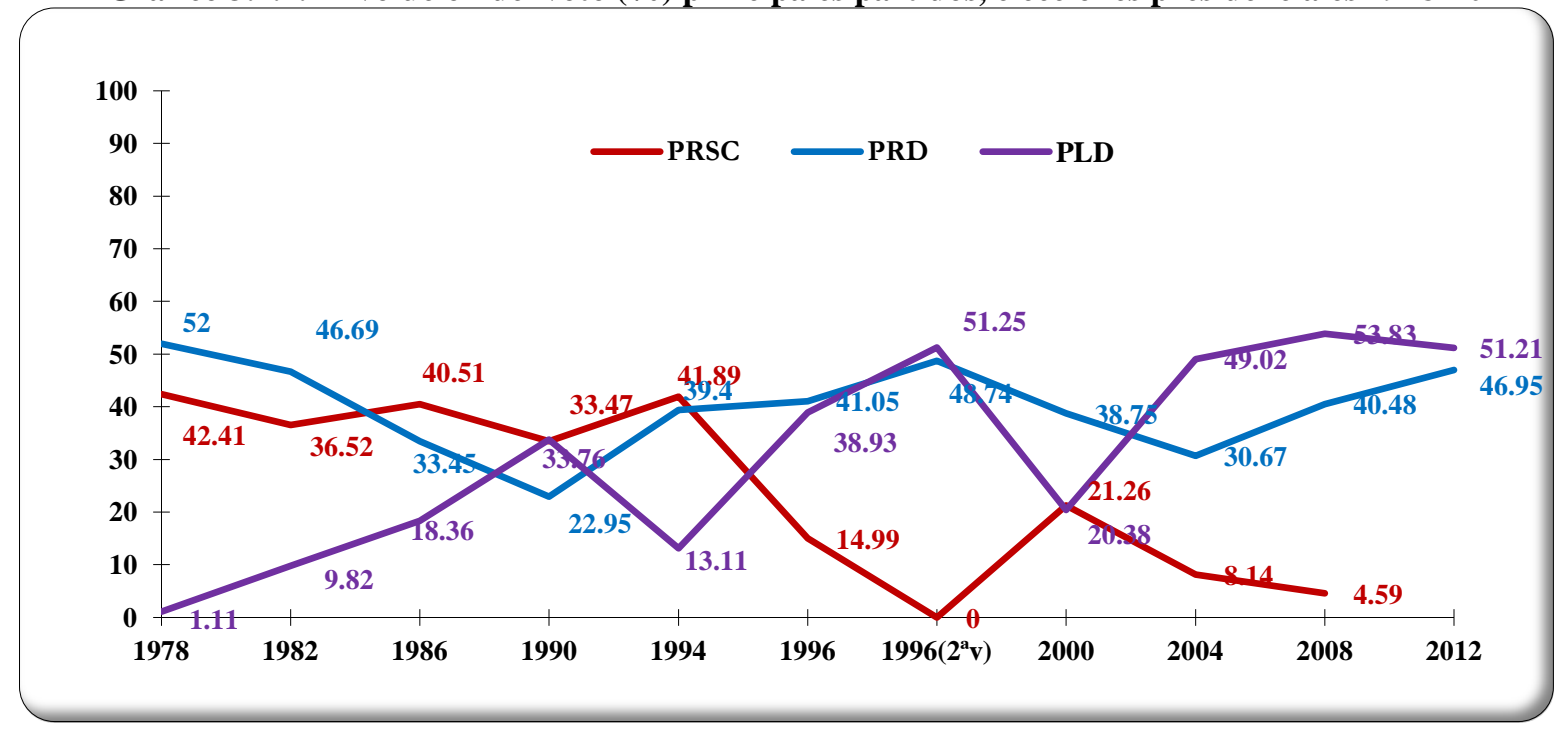

Fuente: Elaboración propia a partir de PELA (1994-2012)

Con respecto a la organización, PLD, PRD y PRSC solucionaron los problemas de liderazgo tras la muerte de sus respectivos caudillos sin que acontecieran las temibles crisis de sucesión, un hecho revelador de la fortaleza de sus organizaciones (Mitchell 2010:58). Si bien el PRSC ha lidiado con menor fortuna la tarea de mantener a su militancia alrededor de un liderazgo aglutinador, ha mostrado su pericia en el ejercicio de un liderazgo negociador en su posición de partido bisagra, conquistando espacios en las instituciones y en el control de las redes de patronazgo.

Al igual que ocurriera en la década de los 70's y 80's en los sistemas de partidos de algunas democracias de Europa del Sur, parte de esa estabilidad partidaria obedece a las estrategias de cartelización a través de las cuales el partido se fortalece como organización ( party in central office») y en las instituciones («party in public office») (Mair 1997). La desproporcionalidad y regularidad del financiamiento estatal más allá de las campañas revelan características sistémicas del tipo cartel en la República Dominicana en el que PLD, PRD y PRSC se protegen para no colapsar en sus etapas de oposición. Para el partido cartel, «mantener la estabilidad electoral es un 
asunto de vida o muerte, de ahí la importancia de la cooperación interpartidaria para asegurar que el votante descontento sea absorbido por el sistema de partidos existente» (Hopkin 2002:4). Como se analiza en los epígrafes siguientes, las alianzas electorales con los partidos minoritarios han devenido imprescindibles en la etapa de la consolidación para que los tres partidos tradicionales accedan a las instituciones de la representación, aunque en la etapa post carismática es el PRSC el partido bisagra como lo fuera entonces el PLD.

La fortaleza electoral y la estabilidad interna del partido cartel están estrechamente relacionadas con la disponibilidad de la generosidad estatal (Hopkin 2002:5). En los modernos partidos clientelares el uso del poder estatal puede variar desde el patronazgo selectivo para mantener a los activistas, la abierta distribución de dinero e incluso la generalización de la corrupción. En la República Dominicana durante los cuatro años de la administración de turno, suele ser práctica habitual publicitar las obras y servicios públicos con los colores identificativos del partido del gobierno. Lo institucional y público se convierte así en partidista. En campaña electoral, cuando el apremio de la competencia no deja espacio a las sutilezas, la asociación con las siglas del partido se hace de forma precisa y directa. Como puede apreciarse en la primera de las tres fotografías, los candidatos a la presidencia y vicepresidencia por el partido oficialista se publicitaban dos meses antes de las elecciones de 2012 en una valla en la que se leía: «El PLD en la calle. Plan de Asfaltado Nacional», con la intención de identificar este servicio público ofrecido por la Administración con un servicio del partido. Las tres imágenes ejemplifican la interpenetración partido-Estado y el carácter de agente privilegiado ante este último propia de los sistemas de partido cartel (Gunther y Diamond 2001).

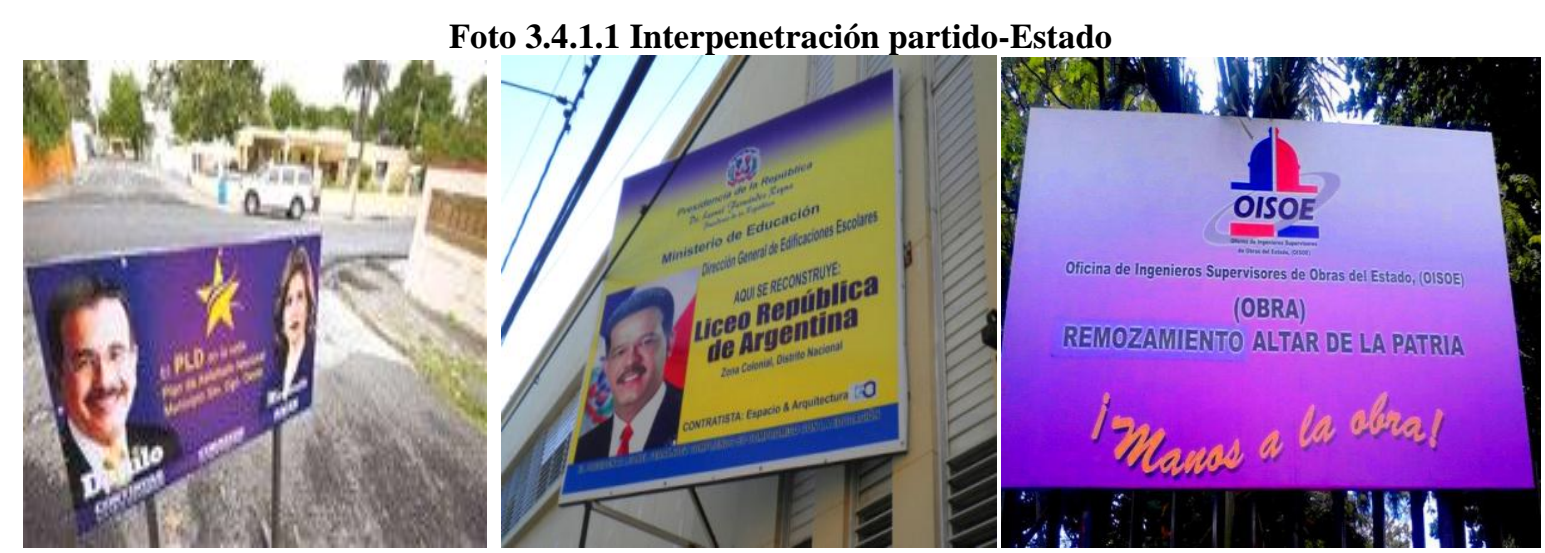

Fuente: Foto del periódico HOY, de 4 de febrero de 2012 donde se denunciaba la utilización partidista del plan de asfaltado de calles asociándolo con un servicio del PLD. En la segunda, foto propia. Valla publicitaria de obras de mejora en una escuela pública de la calle Mercedes en Santo Domingo, con un cartel con los colores del partido oficialista PLD amarillo y morado. En la tercera, cartel de las obras de rehabilitación del Parque Independencia con los colores del partido oficialista, abril de 2014.

Al igual que muchos partidos políticos en América Latina, República Dominicana cuenta con vastas organizaciones profundamente arraigadas pero predominantemente informales. La estructura descrita en los estatutos convive con la de naturaleza informal: redes de patronazgo que funcionan como maquinarias políticas, carreras de militantes favorecidas por el amiguismo y el dinero, poca fiabilidad del número de militantes ${ }^{105}$, "planchas consensuadas" que desvirtúan las elecciones

${ }^{105}$ El Senador de Santiago Julio Cesar Valentín comentaba la anécdota de que en el padrón electoral del PLD en su provincia encontró un comité de base en el que el presidente era el propietario de una clínica privada y los afiliados resultaron ser los pacientes e incluso algunos de los que fallecieron en él. Ver noticia en periódico Diario Libre de 24 de febrero de 2014, en http://www.diariolibre.com/dialogolibre/2014/02/24/i496541_roberto-rosario-vamos-sensibilizar-las-cpulaspara-aprobar-ley-partidos.html 
internas, reformas de estatutos que legitiman acuerdos extra estatutarios, estructura física que desaparece tras la campaña, asuntos de Estado o de partido que se tratan fuera de las sedes institucionales ${ }^{106}$, son solo algunas de las manifestaciones informales que inundan la vida partidaria en el país (Benito y Rosales 2011:16). Los partidos políticos dominicanos son partidos máquina altamente institucionalizados donde los canales informales son estructuras alternativas que compiten con las débiles e inefectivas estructuras formales. Teniendo en cuenta su funcionalidad alterar los resultados pretendidos por las formales- se podrían clasificar dentro de las llamadas «competing informal institutions» en la tipología de Helme y Levitsky (2004:728).

El carácter informal de la organización partidaria se refleja en el fenómeno del denominado "Sector Externo" al que recurren los partidos dominicanos en cada elección. Se trata de una estructura cuasi partidaria informal altamente institucionalizada pero sin respaldo estatutario. Estos movimientos de apoyo al candidato -y no al partido- son una red de comités afectivos y no programáticos reclutados por la promesa de recompensa particularizada. En las pasadas elecciones presidenciales de 2012 se contabilizaron cerca de 3.000 movimientos de apoyo a los dos candidatos Danilo Medina (PLD) e Hipólito Mejía (PRD), este último conocido popularmente como "papá". Movimientos de base gremial ("Joyeros con Papá", "Galleros con Danilo", "Odontólogos con Papá"); profesional ("Arquitectos con Danilo", "Profesionales egresados de Rusia y de Europa del Este con Danilo", "Empresarios Leonelistas con Danilo"); o incluso afectivo ("Sobrinos con Papá", "Movimiento Amigos de Danilo", "Los nietos de Amable con Papá")... en los que no hay un acto de inscripción formal en el partido, sino de juramentación simbólica.

La juramentación es un acto colectivo de exhibición de apoyo al candidato y esencial a la hora de verificar la lealtad al patrón que prima en todo partido clientelar ${ }^{107}$. Estas fiestas colectivas de pertenencia al círculo de confianza del candidato constituyen el arquetipo de "recurso expresivo" (Auyero 1997) intercambiado en la relación clientelar, a la vez que operan como canal de monitoreo y supervisión de la lealtad pública al candidato. Estas estructuras de base son

${ }^{106}$ En marzo de 2014, el Presidente Danilo Medina inició una ronda de conversaciones sobre el futuro Proyecto de Naturalización con los principales actores políticos y sociales del país. Esta ronda se hizo en la forma de visitas personales en los domicilios particulares de los políticos y no en las sedes de los partidos a los que pertenecen (PRD, PRSC, PRSD...) o las instituciones que representa (Iglesia Católica y Evangélica). El Presidente visitó a Luis Abinader, candidato vicepresidencial por el PRD (Ver noticia en http://www.elcaribe.com.do/2014/03/25/presidente-medina-consulta-luis-abinader-sobre-anteproyecto-

naturalizacion); a Hipólito Mejía candidato presidencial por el PRD (Ver noticia en http://www.acento.com.do/index.php/news/173187/56/Danilo-esta-reunido-con-Hipolito-desde-las-8-50-AMpara-hablar-sobre-la-TC-168.html); Miguel Vargas, presidente del PRD (Ver noticia en http://www.diariolibre.com/noticias/2014/03/27/i543991_presidente-habla-con-hiplito-meja-miguel-vargas-

sobre-proyecto-ley-naturalizacin.html); al Cardenal Nicolás de Jesús (Ver noticia en http://www.listin.com.do/la-republica/2014/3/28/316134/Medina-da-por-concluidas-las-consultas-sobre-leyde-naturalizacion-al); a Hatuey de Camps, presidente del PRSC (Ver noticia en http://www.cristianodigital.net/danilo-se-reunio-con-hatuey-y-hablara-con-evangelicos-sobre-

naturalizacion/); a Quique Antun, presidente del PRSC (Ver noticia en http://www.prsc.com.do/st/index.php/en/template/noticias-recientes/261-danilo-se-reune-con-quique-antuntratan-sobre-proyecto-ley-naturalizacion). Las reuniones para la reforma de los estatutos del PRSC se realizaron en la casa del senador reformista Amable Aristy Castro. Ver noticia en periódico HOY, de 28 de junio de 2009 se realizo http://hoy.com.do/el-prsc-cambia-estatutos-elegiran-a-carlos-en-agosto/

${ }^{107}$ Ver ejemplo de juramentaciones de opositores en campañas de pre candidatos presidenciales para las elecciones de 2016 en http://www.noticiassin.com/2014/03/ex-senador-mario-torres-deja-al-prd-y-sejuramenta-con-reinaldo/; juramentaciones de votantes en el exterior en http://www.labazuca.com/index.php/variedades/709-juramentan-sector-externo-hipolito-en-tarragona. Ver noticias de ejemplos de juramentaciones en partidos minoritarios en Periódico El Nuevo Diario del 10 de abril de 2012, en http://elnuevodiario.com.do/app/article.aspx?id=370572. 
agrupaciones ad hoc, subunidades autónomas lideradas por un bróker o aspirante a bróker con organización propia pero no integradas en la burocracia oficial partidaria:

«Ustedes están trabajando en el sector externo, donde todo el mundo es jefe porque tiene la libertad de formar grupos: un grupo de masa, un grupo estudiantil, un grupo de juventud, un grupo de damas, un grupo de vecinos» ${ }^{108}$

Las costosas estructuras de control se abaratan con estas redes compuestas por varios niveles de brókeres organizados piramidalmente:

«Vamos a movilizar más de un millón de personas el día de las elecciones y esto es posible gracias a un gran trabajo de planificación del sector externo (...) Los miembros y presidentes de movimientos recibieron cursos y charlas, por lo que están preparados para llevar a votar este 20 de mayo a los integrantes de los más de 1,400 movimientos que apoyan a Danilo Medina (...) Contamos con más de 20 mil medios alternativos, o sea, vehículos en manos de transportistas, sindicatos de choferes y federaciones de transportistas afiliadas al sector externo» ${ }^{109}$.

«La gran mayoría de la publicidad en afiches, periódicos, publicaciones en internet, radio y televisión, es costeada con esfuerzos y recursos propios, pero eso no es por amor al arte. Es por amor a nuestra gloriosa República Dominicana ${ }^{110}{ }$.

Dada la limitación de recursos públicos, la existencia de estas dos caras del partido genera no pocas complicaciones cuando se conquista el poder en la disyuntiva de recompensar carreras políticas (políticos profesionales) o el rendimiento de los operadores políticos de turno (brókeres del sector externo). Desde el lado de los votantes, esta dinámica de movilización es también indicador de una cultura política organizacional que refuerza la corporativización y la atomización de la voluntad popular en el país ${ }^{111}$.

\footnotetext{
${ }^{108}$ Palabras de Chito Naut, presidente del Sector Externo del candidato presidencial Danilo Medina en la provincia de Azua, en acto de juramentación llevado a cabo el día 1 de agosto de 2012, ver noticia en http://dominicanoshoy.com/index.php?id=58\&tx_ttnews\%5Btt_news\%5D=33360\&cHash=d7b246bda86e38f 200b4a3eba85f6cbd

${ }^{109}$ Palabras de Marius de León, coordinador de transporte del sector externo del candidato presidencial Danilo Medina. Ver noticia en periódico El Nacional el día 16 de mayo de 2012 http://elnacional.com.do/sectorexterno-danilo-medina-garantiza-flotilla-de-vehiculos-para-el-20-de-mayo/

${ }^{110}$ Palabras de Juan Aquino, coordinador general del sector externo del PLD en New Jersey, EEUU en acto de juramentación celebrado el día 26 de marzo de 2012, Ver noticia en http://www.elnuevodiario.com.do/app/article.aspx?id=280176

${ }^{111} \mathrm{La}$ disgregación del interés de clase y la competencia gremial puede observarse en la variedad de movimientos de apoyo a los candidatos. En Nueva York: Profesionales de la Salud con Danilo, Profesionales de la Belleza con Danilo, Enfermeras con Danilo. En República Dominicana: Taxistas Turísticos con Danilo, Profesores Universitarios con Danilo, Odontólogos con Danilo, Trabajadores portuarios con Danilo, Abogados orientales con Danilo. Ver listado de movimientos de apoyo a la candidatura presidencial de Danilo Medina en periódico Diario Libre de 11 de abril de 2012.
} 


\section{$\checkmark$ Voto personalista no programático}

Los sistemas de partidos programáticamente estructurados (SPPE) serían los únicos capaces de instaurar democracias plenas. Esta tesis es defendida por aquellos que consideran que el vínculo programático entre principal-agente es el que más se acerca al modelo de partido responsable y el que genera mayor nivel de gobernanza democrática (Kitschelt, Hawkins, Luna, Rosas y Zechmeister 2010). Estos autores utilizan un argumento estructuralista en el que la causalidad de largo plazo tiene un peso decisivo a la hora de explicar porqué se instaura este vínculo en los regímenes democráticos. Los SPPE son el resultado de una interacción de capacidades, oportunidades y conquistas políticas asumidas por todos los actores del sistema en un aprendizaje lento, acumulativo y de capas sucesivas. Mientras que las de largo plazo son condiciones necesarias pero no suficientes, las de corto plazo pueden erosionar e incluso eliminar el vínculo programático por sí solas, aunque carecen de potencial creador ex novo en ausencia de las primeras. Solo aquellos países con un cierto nivel de desarrollo económico previo a 1950; con competencia electoral ininterrumpida por periodos extendidos; y que implementaron políticas sociales vinculadas al modelo de industrialización por sustitución de importaciones (ISI), generaron vínculos en torno a temáticas redistributivas y por tanto, con capacidad para estructurar y mantener el SPPE en el tiempo (Kitschelt, Hawkins, Luna, et al 2010).

Tabla 3.4.1.2 Condicionantes favorables para estructurar y mantener sistemas de partidos programáticamente estructurados (SPPE)

\begin{tabular}{|c|ccc|}
\cline { 2 - 5 } & \multicolumn{1}{c|}{ CAPACIDADES } & OPORTUNIDADES & $\begin{array}{c}\text { BASTIONES DE LA BATALLA } \\
\text { POLÍTICA } \\
\text { (political stakes) }\end{array}$ \\
\hline Largo plazo & $\begin{array}{c}\text { Cierto nivel de desarrollo } \\
\text { económico en las épocas previas } \\
\text { a la II Guerra Mundial }\end{array}$ & $\begin{array}{c}\text { Largos periodos de competencia } \\
\text { democrática después de } 1945\end{array}$ & $\begin{array}{c}\text { Implementación de políticas de } \\
\text { atención social relativamente } \\
\text { extendidas }\end{array}$ \\
\hline Corto plazo & Boom económico & Reformas institucionales & Respuesta del partido en el gobierno \\
\hline
\end{tabular}

Fuente: Elaboracion propia a partir de Kitchelt, Hawkins, Rosas, Zechmeinster (2010) "Patterns of Programmatic Party Competition in Latin America".

La presencia de estos condicionantes de largo plazo en la República Dominicana ha sido débil. Tras la bonanza de la Primera Guerra Mundial por la demanda de azúcar, tabaco, café y cacao ("Danza de los Millones", 1918-1921) el país se sumió en una gran crisis económica a la que siguió el manejo sultanístico de la economía nacional durante la dictadura de Rafael Trujillo (1930-1961). El escenario de oportunidad democrática también estuvo ausente, ya que desde 1930 hasta 1978 el único periodo con plenas garantías fue el breve gobierno de Juan Bosch (1963). Con respecto a las conquistas o bastiones políticos de naturaleza redistributiva, el modelo de ISI implementado ente 1968-1974 no produjo los resultados esperados en el proceso de proletarización de la fuerza laboral ni en la conformación de un interés de clase. El alto grado de informalidad del mercado laboral limitó las políticas de protección social orientándolas hacia modelos clientelares de auxilio.

Para estos autores, es en el corto plazo donde los actores políticos cobran protagonismo ya que su accionar depende de cómo perciban los riesgos que afectan a sus intereses ante los cambios. Así, un boom económico puede hacer a los actores del sistema apostar por políticas más inclusivas que extiendan los beneficios de la protección o reformas institucionales -leyes electorales, descentralización del poder, etc- pueden particularizar o generalizar el vínculo entre representantes y representados. Ninguno de los condicionantes favorables de corto plazo han sido utilizados para implementar políticas redistributivas ni limitar el particularismo en la agregación de intereses en el país. Tras la grave crisis fiscal de 2003, República Dominicana recuperó el crecimiento en el 
periodo 2004-2012 a un ritmo del 4,7\% del PIB por encima de la media latinoamericana. A pesar del auge, no se han generado mecanismos que impacten en la calidad de vida de sus ciudadanos y el número de pobres aumentó de 2,6 a 4 millones en el mismo periodo. En la pasada década el $20 \%$ de la población más pobre recibió el 4,3\% del ingreso nacional, siendo el único país de la región latinoamericana donde el salario mínimo promedio real retrocedió en los últimos diez años (OIT 2011). En el caso de los legisladores, como se ha analizado en secciones precedentes de esta investigación, el establecimiento del voto preferencial en 2002 o la oficialización en 2006 de la asistencia social ("barrilito") que sustituía la opaca asignación de subvenciones a organizaciones de la sociedad civil, son decisiones de los actores que han erosionado el intercambio de votos por políticas. En el escenario gubernamental, programas como "Progresando", "Solidaridad" o el "Fondo Especial de Desarrollo Agropecuario" son ejemplos de políticas asistenciales focalizadas no universales.

El Índice de Estructuración Programática propuesto por estos autores cuenta con dos niveles de interacción: 1) entre élites y partidos y 2) entre élites y votantes. El nivel de estructuración programática depende de la mayor o menor presencia de los cuatro indicadores de los que se da cuenta en los apartados siguientes.

Tabla 3.4.1.3 Índice de estructuración programática de los sistemas de partidos

\begin{tabular}{|llll|}
\hline \multicolumn{1}{|c|}{ NIVELES } & & \multicolumn{2}{c|}{ INDICADORES } \\
& & \\
Políticos y partidos (elites) & $\checkmark$ & Dimensionalidad del espacio ideológico \\
& $\checkmark$ & Semánticas de izquierda y derecha \\
& $\checkmark$ & Cohesión ideológica de los partidos \\
Elites y votantes & & \\
\hline
\end{tabular}

Fuente: Kitchelt, Hawkins, Rosas, Zechmeinster (2010) "Patterns of Programmatic Party Competition in Latin America".

El programa es uno de los elementos definitorios del partido político moderno (Michels 1911) a través del cual se presentan al electorado los objetivos de acción política y posiciones respecto a los conflictos que genera la vida pública. La mayor o menor presencia de vínculos programáticos es indicador del nivel de institucionalización de los partidos políticos, con importantes consecuencias en el ámbito de la representación y la rendición de cuentas electoral (Mainwaring y Torcal 2005:3). La inexistencia de este atajo informativo estable dejará espacio a otros de naturaleza más contingente donde el personalismo, la valoración de los rasgos personales del candidato o la eventualidad de las campañas, condicionarán la decisión del votante.

Las percepciones de los legisladores dominicanos sobre las razones que fundamentaron su elección permiten caracterizar los vínculos entre ciudadanos y sus representantes en República Dominicana (PELA 1994-2010). Los datos de la Tabla 3.2.B.1.4 muestran que la simpatía -"inclinación afectiva entre personas, generalmente espontánea y mutua" ${ }^{12}$ - ha sido la motivación principal del voto durante los últimos veinte años, mientras que el programa ha ido perdiendo peso en la elección de los diputados dominicanos.

${ }^{112}$ Definición de la Real Academia Española, 2001 
Tabla 3.4.1.4 ¿Por qué razón cree Ud. que ha sido elegido diputado?

¿Y en segundo lugar? (\%) (1994-2016)

\begin{tabular}{|c|c|c|c|c|c|c|c|c|c|c|c|c|c|c|}
\hline \multirow{2}{*}{ TIPOLOGÍA MOTIVACIÓN } & \multicolumn{3}{|c|}{ 1994-1998 } & \multicolumn{3}{|c|}{ 1998-2002 } & \multicolumn{3}{|c|}{$2002-2006$} & \multicolumn{3}{|c|}{ 2006-2010 } & \multicolumn{2}{|c|}{$2010-2016$} \\
\hline & PLD & PRD & PRSC & PLD & PRD & PRSC & PLD & PRD & PRSC & PLD & PRD & PRSC & PLD & PRD \\
\hline Personalista & \multirow[b]{2}{*}{61,6} & \multirow[b]{2}{*}{44,8} & \multirow[b]{2}{*}{50} & \multirow[b]{2}{*}{67,6} & \multirow[b]{2}{*}{61,7} & \multirow[b]{2}{*}{90,9} & \multirow[b]{2}{*}{71} & \multirow[b]{2}{*}{73,7} & \multirow[b]{2}{*}{$\mathbf{7 2 , 4}$} & \multirow[b]{2}{*}{77,4} & \multirow[b]{2}{*}{88,5} & \multirow[b]{2}{*}{100} & \multirow[b]{2}{*}{63,2} & \multirow[b]{2}{*}{61,9} \\
\hline Simpatía (S) & & & & & & & & & & & & & & \\
\hline Contingente-Persuasiva & & & & & & & & & & & & & & \\
\hline Campaña $(C)$ & 15,4 & 27,6 & 40 & 32,4 & 40,4 & 18,2 & 22,6 & 49,1 & 48,3 & 49,1 & 53,8 & 30 & 44,7 & 46,2 \\
\hline Carismática & \multirow{2}{*}{61,5} & \multirow[b]{2}{*}{34,4} & \multirow[b]{2}{*}{40} & \multirow[b]{2}{*}{8,8} & \multirow[b]{2}{*}{25,5} & \multirow[b]{2}{*}{45,5} & \multirow[b]{2}{*}{32,3} & \multirow[b]{2}{*}{10,5} & \multirow[b]{2}{*}{31} & \multirow[b]{2}{*}{7,5} & \multirow[b]{2}{*}{0} & \multirow[b]{2}{*}{10} & \multirow[b]{2}{*}{13,2} & \multirow[b]{2}{*}{13,9} \\
\hline Líder $(L)$ & & & & & & & & & & & & & & \\
\hline Programática & & & & & & & & & & & & & & \\
\hline Ideología (I) & & & & 23,5 & 25,5 & 0 & 29 & 14 & 17,2 & 24,5 & 15,4 & 10 & 7,9 & 13,5 \\
\hline Programa $(P)$ & 61,6 & 68,9 & 20 & 41,2 & 29,8 & 0 & 12,9 & 17,5 & 20,6 & 9,4 & 7,7 & 0 & 18,4 & 5,4 \\
\hline Retrospectiva & & & & & & & & & & & & & & \\
\hline Experiencia $(E)$ & & & & 20,6 & 12,8 & 45,5 & 25,8 & 22,8 & 6,9 & 15,1 & 26,9 & 20 & 23,7 & 16,2 \\
\hline Experiencia Diputado (Ed) & & & & & & & & & & & & & 29,1 & 32,2 \\
\hline Tradicionalista & & & & & & & & & & & & & & \\
\hline Tradición Familiar $(F)$ & 0 & 6,9 & 20 & 5,9 & 4,3 & 0 & 0 & 8,8 & 3,4 & 5,7 & 3,8 & 30 & 0 & 10,8 \\
\hline
\end{tabular}

Fuente: Elaboración propia a partir de PELA (1994-2010), Universidad de Salamanca. Se suman los porcentajes de las dos respuestas y se resaltan en el color del partido las dos opciones con los porcentajes más altos.

En 1994, última de las contiendas en las que están presentes los tres caudillos, destaca el liderazgo programático de Bosch [61,6\% (P) 61,5\% (L)] y la naturaleza personalista del vínculo con el candidato $[61,6 \%(\mathrm{~S})]$ como motivación principal en los electores del PLD, frente al programático $[68,9 \%(\mathrm{P})]$ y de empatía con el aspirante $[44,8 \%$ (S)] en la elección de los diputados del PRD. La simpatía [50\% (S)] y el impacto de la campaña [40\% (C)] suplen la debilidad programática del PRSC, que recibe la misma importancia que la tradición familiar del votante $(20 \%)$. Las opiniones de los legisladores electos en 1994 confirman el escenario descrito en las contiendas de épocas pasadas entre liderazgos carismáticos de base programática y la efectividad de las campañas de Joaquín Balaguer, considerado el fundador del clientelismo post-trujillista (Tejada 2007; Lozano 2001; Hartlyn 1998).

En la legislatura 1998-2002, el efecto de los liderazgos disminuye significativamente en el PRD y PLD tras la muerte de Peña Gómez y la retirada de Bosch, a la vez que aumenta el peso de la empatía con el candidato y la campaña, pero no así en el PRSC, a pesar de la desaparición formal de Balaguer [45,5\% (L)]. La separación de la contienda presidencial y congresual consolida la campaña como elemento decisivo en las elecciones de 1998 y limita el efecto arrastre de los liderazgos presidenciales tradicionales. Destaca la ausencia total de vínculos programáticos e ideológicos en el PRSC y la valoración de la experiencia tras su declive electoral $[45,5 \%(\mathrm{E})]^{113}$. En los tres partidos el aprecio personal lidera las motivaciones que fundamentan la elección, destacando el caso de los legisladores reformistas con un 90,9\% (S). En el caso del PLD, el vínculo personalista tiene una base programática $[67,6 \%(\mathrm{~S}) ; 41,2 \%(\mathrm{P})]$, mientras que en el PRD el voto en opinión de sus diputados es resultado de la efectividad de los lazos de empatía y de la campaña [61,7\% (S); 40,4\% (C)]. A pesar de que en 1998 se celebran por primera vez elecciones separadas circunstancia a la que la literatura atribuye mayor protagonismo a la agenda programática legislativa- desciende su importancia casi a la mitad con respecto a la legislatura anterior, tendencia que se confirma en 2002 y 2006.

\footnotetext{
${ }^{113}$ Para este ejercicio de accountability y rendición de cuentas el PRSC repasaba en spots publicitarios con la figura de Don Chencho" -personaje popular que representaba al pueblo- las obras del líder al grito de: «Esto... Lo hizo Balaguer». Escuelas, calles, hospitales, viviendas, presas...por las que Joaquín Balaguer recibió el apelativo de "Presidente Constructor".
} 
En 2002, con la reducción del tamaño de las circunscripciones y el voto preferencial continúa el proceso de particularización de los vínculos entre diputado y elector. Simpatía y campaña serán de nuevo las razones principales que motivan la decisión del votante dominicano [73\% (S) y 49\%(C) en el PRD; 72\% (S) y 48\% (C) en el PRSC], salvo para los electores del PLD, para quienes el liderazgo de Leonel Fernández [32,3\% (L)] le sigue en importancia al vínculo más personal de la empatía con el candidato [71\% (S)]. En la legislatura 2006-2010 se confirma la tendencia anterior: simpatía hacia el candidato y efectividad de la campaña son referentes decisivos que guían el voto del electorado dominicano. Destaca la ausencia total del programa en los votantes del PRSC en esta legislatura en la que se unen en la "Alianza Rosada" con sus enemigos históricos del PRD. Una debacle programática que corroboran la dirigencia del partido:

«En mi partido ahora no tenemos muchos recursos... y solo nos queda vender la obra de Balaguer, la nostalgia y el agradecimiento por lo que le dio al pueblo dominicano» ${ }^{114}$

«Volver a Balaguer para volver al poder» ${ }^{115}$.

En la legislatura 2010-2016 simpatía y campaña siguen liderando las motivaciones de los votantes dominicanos en opinión de los legisladores entrevistados aunque perdiendo el vigor de legislaturas pasadas. Los liderazgos nacionales recuperan peso -Leonel Fernández (13,2\%) e Hipólito Mejía $(13,9 \%)$ - y aparece en escena la valoración de la gestión como diputado, ocupando este ejercicio de accountability el tercer lugar en importancia para el PLD y PRD $(23,7 \%$ y $32,2 \%$ respectivamente) ${ }^{116}$.

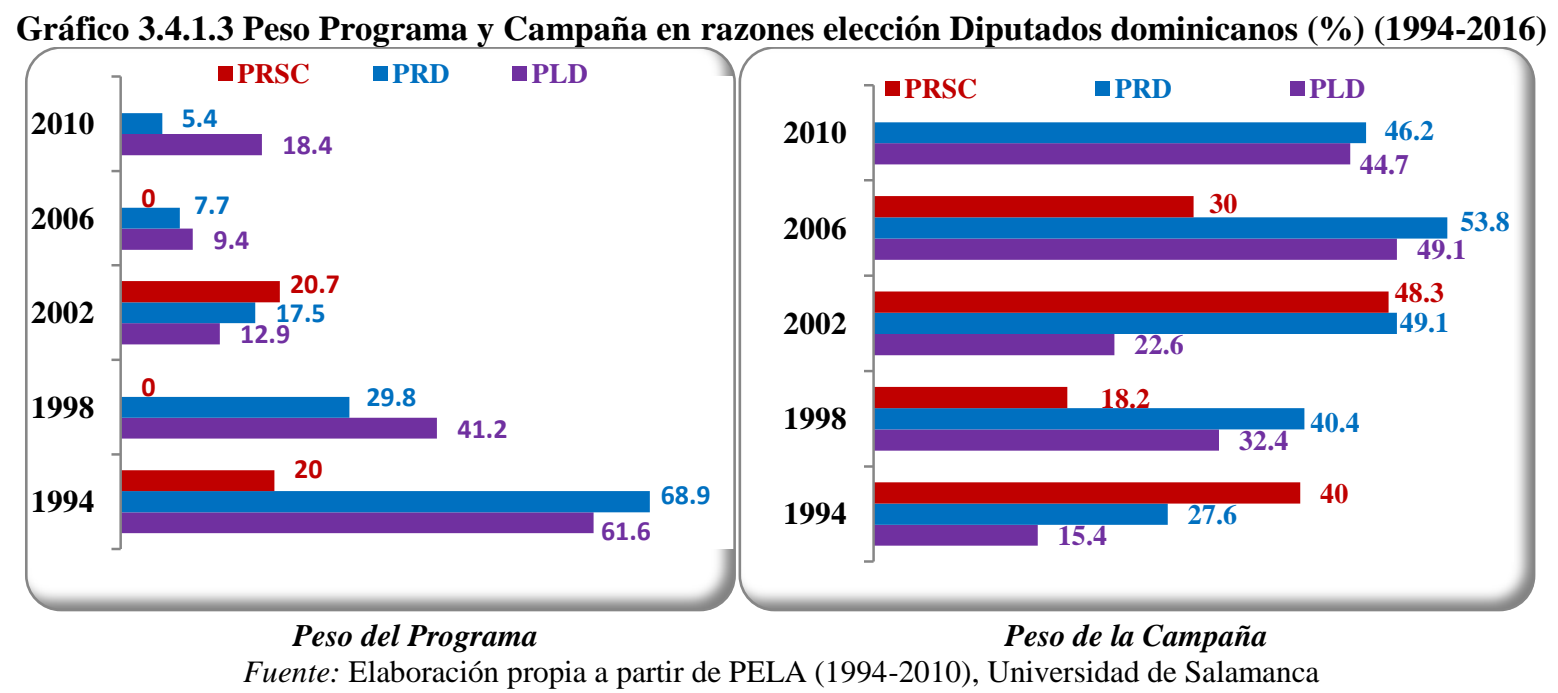

La campaña electoral comienza a despuntar en 1998 en el PLD y PRD coincidiendo con la desaparición de sus líderes Bosch y Peña Gómez, al igual que sucederá en las filas del PRSC tras la desaparición de Balaguer en 2002. Desde esa fecha, en los tres principales partidos el efecto

\footnotetext{
${ }^{114}$ Entrevista con dirigente de Nueva Generación Reformista, realizada el 5 de mayo de 2012.

${ }^{115}$ Anuncio radiofónico del candidato a la presidencia del PRSC en la próxima convención del partido en 2014, Amable Aristy Castro.

${ }^{116}$ Esta opción de respuesta fue introducida en el cuestionario de 2010. Los datos de futuras oleadas permitirán identificar tendencias en relación al ejercicio de accountability y su naturaleza particularizada o general.
} 
movilizador de la campaña le sigue en importancia a la simpatía del candidato. La campaña electoral comprende el conjunto de actividades organizativas y de comunicación que realizan los partidos políticos y sus candidatos con el fin de captar votos y puestos de poder. En un contexto de baja estructuración programática como es el dominicano, el impacto de las estrategias electorales cobra especial relevancia. Las campañas se tornan altamente persuasivas (centradas en las fortalezas del candidato y en las circunstancias de la coyuntura) más que informativas (centradas en la plataforma política), en una dinámica que la literatura del clientelismo denomina como la «política del mejor postor» y que se caracteriza por la guerra y promesas de subsidios entre candidatos (Piattoni 2001). En los últimos años, el déficit programático de las campañas electorales se manifiesta en la negativa de sus protagonistas a celebrar debates televisados entre candidatos ${ }^{117}$. La publicidad electoral en República Dominicana refleja la naturaleza particular y personalización de la representación, con spots que destacan las cualidades personales del candidato y escasas o nulas referencias al proyecto programático del partido. Anuncios como "Luisín Jiménez, un hombre de carácter al Senado"; "Yomaira, la diputada amiga"; "David Collado, un emprendedor al Congreso"; "Rafelín, por honesto y trabajador"; "César Augusto, un senador para la historia"; "Wenceslao Paniagua, el diputado que resuelve", "Carlos Castillo, tu verdadera mano amiga" o "Reinaldo, un senador ejemplar" 118 ... son ejemplo de los vínculos de lealtad personal entre legislador-elector y del carácter difuso del mandato entre el principal-agente. La ausencia de agenda legislativa es más evidente en los pequeños partidos. Y como muestra, sirva el anuncio radiofónico del Partido Liberal de la República Dominicana- La Estructura (PLRSD) que rezaba de la siguiente manera: "Vota La Estructura. Para que ganen los candidatos de Leonel" (Benito 2011:389).

La campaña electoral tiene en la República Dominicana un marcado carácter personal y directo, en el que predominan el «cara a cara» y el «puerta a puerta». Según los datos de la encuesta del Observatorio de Comportamiento Político y Opinión Pública de la República Dominicana (OBSEROP 2010), en las legislativas de 2010 casi la mitad de los entrevistados (42,3\%) dijo haber tenido contacto personal con miembros de los partidos políticos. Durante los largos meses de campaña son habituales las visitas de candidatos y activistas a barrios, clubs deportivos, juntas de vecinos, iglesias, asociaciones, centros comunales y en algunas ocasiones la socialización se realiza en las propias instalaciones de las agencias públicas ${ }^{119}$. Este contacto directo con el candidato tiene claros efectos movilizadores ya que en la contienda de 2010, elevó la participación 15,6 puntos porcentuales (Benito y Rodríguez 2014). El 85,2\% de los que fueron contactados personalmente durante la campaña acudieron a votar, frente al 69,6\% que también lo hicieron sin haber tenido tal relación. Y con respecto a la dirección, el voto a un partido aumentaba alrededor de 20 puntos entre los electores que habían sido contactados por miembros de ese partido, en comparación con los que no recibieron visita alguna (OBSEROP 2010: 42).

Siguiendo con las opiniones de los diputados entrevistados (PELA 1994-2010), tampoco se aprecian grandes diferencias en la representación sobre issues, existiendo afinidad en relación a los principales ejes programáticos del conflicto político:

Con respecto al eje neoliberalismo-estatismo, los diputados de los tres partidos han expresado su conformidad a la responsabilidad principal del Estado en la creación de empleo durante las dos

\footnotetext{
${ }^{117}$ Así sucedió en 2010, ante la invitación lanzada por la Asociación de Jóvenes Empresarios (ANJE), y en 2012 entre los candidatos Danilo Medina e Hipólito Mejía.

${ }^{118}$ Publicidad electoral en estación radiofónica "Zeta 101", elecciones legislativa y municipal de 2010.

${ }^{119}$ Durante la campaña presidencial de 2012, los partidos PLD, PRD, PUN y PQDC fueron amonestados por la JCE por el uso de recursos públicos con fines electoralistas. En el caso del PUN por usar el Instituto de Desarrollo y Crédito Cooperativo (IDECOOP) como sede de campaña.
} 
últimas décadas. En el PRD se ha mantenido constante con pequeñas fluctuaciones, mientras que en el PLD ha ido en progresivo aumento el porcentaje de legisladores que atribuyen al Estado la máxima responsabilidad en este ámbito. En la legislatura 2010-2016, los representantes de ambos partidos moderan su posición descendiendo en el escalafón de importancia concedida.

Tabla 3.4.1.5 Responsabilidad del Estado en la creación de empleo (\%) 1994-2016

\begin{tabular}{|c|c|c|c|c|c|c|c|c|c|c|c|c|c|c|}
\hline \multirow{2}{*}{$\begin{array}{l}\text { El Estado, más que la } \\
\text { empresa privada, } \\
\text { debería ser el } \\
\text { principal responsable } \\
\text { de crear empleos }\end{array}$} & \multicolumn{3}{|c|}{ 1994-1998 } & \multicolumn{3}{|c|}{ 1998-2002 } & \multicolumn{3}{|c|}{$2002-2006$} & \multicolumn{3}{|c|}{ 2006-2010 } & \multicolumn{2}{|c|}{ 2010-2016 } \\
\hline & PLD & PRD & PRSC & PLD & PRD & PRSC & PLD & PRD & PRSC & PLD & PRD & PRSC & PLD & PRD \\
\hline Muy de acuerdo & 23,1 & 44,8 & 60 & 47,1 & 66 & 54,5 & 59,4 & 68,5 & 73,1 & 65,5 & 66,7 & 70 & 34,2 & 38,9 \\
\hline Bastante & 15,4 & 17,2 & 5 & 26,5 & 17 & 36,4 & 34,4 & 27,8 & 23,1 & 25,5 & 25 & 0 & 60 & 50 \\
\hline Poco & 38,5 & 24,1 & 20 & 23,5 & 14,9 & 9,1 & 6,3 & 3,7 & 3,8 & 9,1 & 8,3 & 30 & 5,8 & 8,3 \\
\hline Nada & 15,4 & 13,8 & 15 & 2,9 & 2,1 & 0 & 0 & 0 & 0 & 0 & 0 & 0 & 0 & 2,8 \\
\hline
\end{tabular}

Fuente: Elaboración propia a partir de datos de PELA (1994-2009), Universidad de Salamanca.

El mercado de trabajo dominicano se caracteriza por el alto grado de informalidad $(55,72 \%$ de la fuerza laboral) y los bajos salarios (el $74 \%$ de los trabajadores formales reciben menos de USD\$450). Dentro del sector formal (44,27\%) la empresa privada ocupa al $64,7 \%$ de los trabajadores; un 5,8\% laboran como profesionales liberales; el 25,8\% son empleados del gobierno y el 3,5\% de empresas públicas ${ }^{120}$. A pesar del tamaño, la nómina del sector público no supone una carga excesiva a las arcas públicas ya que el 37,08\% de los funcionarios gana menos de USD\$ 235 y el 23,35\% menos de USD\$450 (SASP 2013) ${ }^{121}$. Estos datos acerca del tamaño y salarios públicos revelan la dimensión y entidad del Estado como patrón, por lo que la predilección de los legisladores dominicanos entrevistados sobre la responsabilidad estatal en la creación de empleos, más que indicadores de una filosofía estatista en la política industrial, podrían estar reflejando el dominio que disfruta cada partido oficialista de turno en el acceso al empleo público y que se conoce popularmente como "tren gubernamental ${ }^{122}$. Una facultad que forma parte del ejercicio de responsiveness para premiar a sus leales.

Los representantes de los tres partidos coinciden en mostrar su máxima conformidad a la responsabilidad principal del Estado en la provisión de sistemas de protección social. De nuevo en la legislatura actual 2010-2016, diputados oficialistas y de oposición moderan su postura estatista, ya que el porcentaje disminuye casi a la mitad con respecto a la legislatura anterior. Sin embargo, y en dirección opuesta a esta preferencia de los legisladores, el Sistema Dominicano de Seguridad Social es uno de carácter mixto compuesto por un sistema de capitalización individual $(93,2 \%$ de los cotizantes) y de reparto a cargo del Estado para sus empleados (6,67\% de los cotizantes). La potestad del Presidente y de la Cámara de Diputados para incluir beneficiarios en el reparto estatal, así como la autonomía de muchos organismos públicos en la reglamentación de sus planes de retiro acentúa el carácter particularista del sistema de jubilaciones en el país. Los principales actores de veto en la conquista de la universalidad y objetividad de los méritos para adquirir el derecho a la pensión pública han sido grupos de interés y presión estatales como el sindicato de maestros o el

\footnotetext{
120 Ver estadísticas del Observatorio del Mercado Laboral Dominicano (OMLAD) En http://www.omlad.gob.do/

${ }^{121}$ Ver estadísticas del Ministerio de Administración Pública, en Sistema de Administración de Servidores Públicos (SASP) en EstadísticasLaborales.aspx http://map.gob.do:8282/estadisticas

${ }^{122}$ Nombre con el que se denomina al aumento del aparato funcionarial dominicano y que con cada administración crece incorporando un nuevo "vagón" de empleados públicos. En una agencia gubernamental, el nuevo funcionario que accede por designación a un puesto con capacidad de designar subordinados, incorpora a su clientela, que en muchas ocasiones tendrá que convivir con los pocos funcionarios de carrera y las clientelas de pasados patronos.
} 
propio Banco Central ${ }^{123}$. El análisis del primero de los indicadores de Particularismo Legislativo de esta investigación mostraba la discrecionalidad en la argumentación del aumento y concesión de pensiones por parte de los legisladores, así como su papel de bróker con los electores de su circunscripción en esta tarea. Las proposiciones de Ley que tenían por objeto conceder y/o aumentar una pensión a un elector constituyeron el $25,83 \%$ de las proposiciones totales en la legislatura 1998-2002; el 54,07\% en 2002-2006; y el 23,95\% del total en el periodo legislativo 2006-2010.

Tabla 3.4.1.6 Responsabilidad del Estado en la provisión de pensiones de jubilación (\%) 1994-2016

\begin{tabular}{|c|c|c|c|c|c|c|c|c|c|c|c|c|c|c|}
\hline \multirow{2}{*}{$\begin{array}{l}\text { El Estado, más que el } \\
\text { sector privado, } \\
\text { debería ser el } \\
\text { principal responsable } \\
\text { de proveer las } \\
\text { pensiones de } \\
\text { jubilación }\end{array}$} & \multicolumn{3}{|c|}{ 1994-1998 } & \multicolumn{3}{|c|}{ 1998-2002 } & \multicolumn{3}{|c|}{$2002-2006$} & \multicolumn{3}{|c|}{ 2006-2010 } & \multicolumn{2}{|c|}{ 2010-2016 } \\
\hline & PLD & PRD & PRSC & PLD & PRD & PRSC & PLD & PRD & PRSC & PLD & PRD & PRSC & PLD & PRD \\
\hline Muy de acuerdo & $\overline{61,5}$ & $\overline{79,3}$ & 95 & 82,4 & $\overline{74,5}$ & 72,7 & 68,8 & $\overline{70,2}$ & 79,3 & $\overline{79,6}$ & 72 & 80 & 44,7 & $\overline{48,6}$ \\
\hline Bastante & 23,1 & 13,8 & 0 & 17,6 & 21,3 & 18,2 & 25 & 29,8 & 17,2 & 18,5 & 20 & 20 & 39,5 & 34,3 \\
\hline Poco & 15,4 & 3,4 & 5 & 0 & 4,3 & 9,1 & 3,1 & 0 & 3,4 & 1,9 & 8 & 0 & 15.8 & 17,2 \\
\hline Nada & 0 & 3,4 & 0 & 0 & 0 & 0 & 3,1 & 0 & 0 & 0 & 0 & 0 & 0 & 0 \\
\hline
\end{tabular}

Fuente: Elaboración propia a partir de PELA (1994-2010), Universidad de Salamanca. *94 y 98 Seguridad Social.

Tampoco se observan diferencias significativas en las opiniones que se refieren el control estatal en la gestión de servicios básicos como el agua, la electricidad o el transporte. En las dos legislaturas consideradas, los diputados dominicanos se sitúan en un nivel intermedio a favor de la gestión mixta público-privada, preferencia que concuerda con la prestación de estos servicios en la República Dominicana. Los grupos empresariales que controlan estos tres servicios básicos en el país ejemplifican la tipología de "clientelismo de orientación empresarial" ("business-mediated clientelism") descrita por Kitschelt (2007) propia del capitalismo coordinado y que se caracteriza por la peculiar interacción particularista de la red de empresas públicas y subsidiadas por el Estado, así como el grado de autonomía de la autoridad regulatoria. En el periodo 2004-2008 las subvenciones a estos sectores constituyeron el 14\% del gasto primario estatal y solo en el año 2007 estas exenciones representaron un sacrificio fiscal de USD\$280 millones ${ }^{124}$. La deficiente calidad de estos servicios básicos queda patente en algunos datos relativos a su prestación: la electricidad no está disponible el $20 \%$ del tiempo, con una media de 25 apagones por mes en 2012; la cobertura en zonas rurales es del 52,2\%, mientras que en la zona urbana es del 81,3\%; sólo el $11 \%$ de la población urbana cuenta con servicio continuo de agua potable; y en 2009 la potabilidad era de un 28,3\% (OMS 2012).

\footnotetext{
${ }^{123}$ Entrevista con el Prof. José Contreras, con ex profesor de la Universidad Autónoma de Santo Domingo y ex militante del Partido Comunista Dominicano, el día 3 de diciembre de 2013.

${ }^{124}$ En 2004-2008 las subvenciones fueron de RD\$110,300 mil millones de pesos. Ver Informes del Ministerio de Economía de la República Dominicana en http://www.economia.gob.do/4FF9D82A-67804571-B0AF-FB27FAE864D4/FinalDownload/DownloadId8C3A345BA0169F2798AF84469ECDF8FD/4FF9D82A-6780-4571-B0AF-FB27FAE864D4/mepyd/wpcontent/uploads/archivos/despacho/publicaciones/perspectivas-economicas-republica-dominicana.pdf
} 
Tabla 3.4.1.7 Nivel de control del Estado en la provisión de agua, luz y transporte (\%) 2006-2016

\begin{tabular}{|c|c|c|c|c|c|}
\hline \multirow{2}{*}{$\begin{array}{l}\text { ¿Qué nivel de control cree Ud. que debe tener el Estado sobre la gestión de servicios } \\
\text { públicos como el agua, la electricidad o el transporte? }\end{array}$} & \multicolumn{3}{|c|}{ 2006-2010 } & \multicolumn{2}{|c|}{$2010-2016$} \\
\hline & PLD & PRD & PRSC & PLD & PRD \\
\hline Los servicios públicos deben ser prestados y gestionados por el Estado & 10,7 & 11,5 & 18,2 & 34,2 & 25 \\
\hline Estado-Empresas Privadas & 53,6 & 53,8 & 45,5 & 42,1 & 41,7 \\
\hline Los servicios públicos deben ser prestados y gestionados por empresas privadas & 1,8 & 0 & 18,2 & 10,5 & 16,7 \\
\hline
\end{tabular}

Fuente: Elaboración propia a partir de PELA (1994-2010), Universidad de Salamanca

En relación al eje conservadurismo-progresismo en torno al cual se articulan posturas culturales y morales como la referida al aborto o al matrimonio del mismo sexo entre otras. La Tabla 3.2.B.1.8 muestra que si bien los porcentajes más altos de preferencias se sitúan en la opción de supuestos regulados, las posturas más reaccionarias -totalmente en contra del aborto- concitan más voluntades entre los legisladores perredeístas socialdemócratas y los reformistas de la democracia cristiana. Igual sucede en relación al matrimonio del mismo sexo, rechazado por el 80,6\% de los diputados del PRD frente al 62,2\% del partido oficialista. Esta aparente diferencia se diluyó con ocasión de la reforma constitucional de 2010, ya que el 75,2\% de los diputados (134) votaron a favor del artículo que consagraba la defensa de la vida desde el momento de la concepción, sin posibilidad de aborto por razones terapéuticas ${ }^{125}$.

Tabla 3.4.1.8 Opiniones de los Diputados dominicanos sobre el aborto y el matrimonio del mismo sexo (\%) 1994-2016

\begin{tabular}{|c|c|c|c|c|c|c|c|c|c|c|c|c|c|c|}
\hline & \multicolumn{3}{|c|}{ 1994-1998 } & \multicolumn{3}{|c|}{ 1998-2002 } & \multicolumn{3}{|c|}{$2002-2006$} & \multicolumn{3}{|c|}{$2006-2010$} & \multicolumn{2}{|c|}{ 2010-2016 } \\
\hline & PLD & PRD & PRSC & PLD & PRD & PRSC & PLD & PRD & PRSC & PLD & PRD & PRSC & PLD & PRD \\
\hline $\begin{array}{l}\text { Totalmente } \\
\text { en contra }\end{array}$ & 7,7 & 24,1 & 10 & 17,6 & 36,2 & 54,5 & 22,6 & 49,1 & 55,2 & 35,2 & 36 & 44,4 & 21,6 & 44,4 \\
\hline $\begin{array}{l}\text { Supuestos } \\
\text { regulados }\end{array}$ & 53,8 & 58,6 & 85 & 64,7 & 61,7 & 27,3 & 64,2 & 38,6 & 31 & 38,9 & 48 & 44,4 & 64,8 & 55,6 \\
\hline A favor & 38,5 & 17,2 & 5 & 17,6 & 2,1 & 9,1 & 12,9 & 12,3 & 13,8 & 24,1 & 16 & 11,1 & 13,5 & 0 \\
\hline Totalmente & contre & del mat & monio & mo se & & & & & & & & & 62,2 & 80,6 \\
\hline
\end{tabular}

Fuente: Elaboración propia a partir de PELA (1994-2010), Universidad de Salamanca

A la luz de las percepciones de los diputados entrevistados (PELA 1994-2010) el voto de los dominicanos no está basado en un programa en el que se definan paquetes de políticas, sino en los lazos de afecto que establecen con sus votantes y la confianza que en ellos generan como suplidores de bienes y servicios durante la campaña. La identidad de posturas de PLD, PRD y PRSC sobre los principales ejes del conflicto político reduce la batalla a la competencia acerca de quién está mejor capacitado para entregar sin que exista debate sobre la redistribución de costes y beneficios. La ausencia de mecanismos de agregación colectiva de intereses deja abierta la puerta a que esta entrega de bienes sea hecha siguiendo criterios particularistas de todo tipo.

\footnotetext{
${ }^{125}$ Durante el proceso de discusión y votación se organizaron frente al Congreso las llamadas "Vigilias por la Vida", en las que el máximo representante de la Iglesia Católica, el Cardenal Nicolás Rodríguez de Jesús advertía a los legisladores: «el pueblo dominicano está atento a su decisión, viendo quién apoya la vida y quién la muerte, y eso se reflejará en las votaciones». El diputado del PRD Radhamés Ramos, en su argumentación en contra del aborto aconsejaba a las mujeres que han sido violadas en relación a las opciones disponibles sin necesidad de practicase un aborto. Entre ellas que "se coloquen en una escalera de 6 peldaños y bajen de nalgas, para provocar un sangrado y así ya solo tienen que ir al médico que les haga la limpieza". En periódico Clave Digital de 18 de septiembre de 2009.
} 


\section{$\checkmark$ Desideologización y ausencia de polarización}

En la tarea de representación de intereses que han de llevar a cabo las fuerzas políticas, la ideología es la herramienta a través de la cual exteriorizar la identidad del partido y su posicionamiento en cuestiones simbólicas y políticas específicas (Rodríguez y Otero 2013:25). Este conjunto de ideas y valores relativos al orden político ha tenido un peso poco determinante en la decisión del votante dominicano en opinión de los legisladores dominicanos (PELA 1998-2010). Este atajo informativo muestra bajos niveles de vinculación entre político y elector, con descensos significativos en el caso del PLD, que pasa de un 24,5\% en 2006 a un 7,9\% en 2010; y con pequeños altibajos en los representantes del PRD.

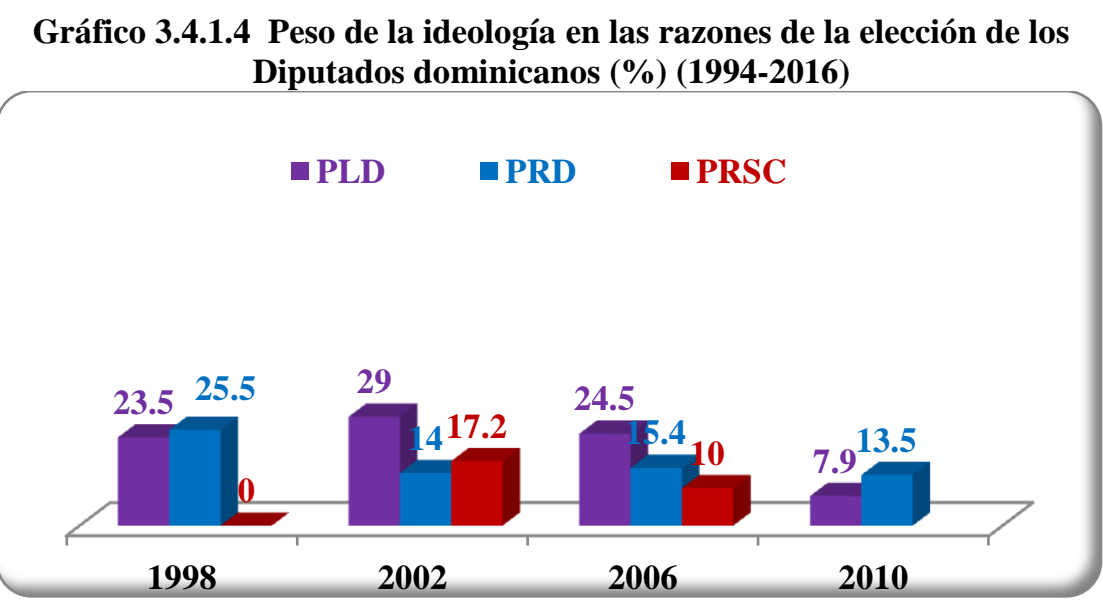

Fuente: Elaboración propia a partir de PELA (1994-2010), Universidad de Salamanca.

El desvanecimiento de la competencia ideológica es uno de los rasgos que marcan la adaptación del partido de masas al partido atrápalotodo, caracterizado por la reducción del bagaje ideológico, el fortalecimiento de los cuadros directivos, la devaluación de la militancia y un electorado heterogéneo (Kirchheimer 1966). En la República Dominicana la ideológia ha caído en desuso y ha dejado paso a otros instrumentes racionales para la realización de intereses pragmáticos aunque aquella lealtad personal típica de los partidos de cuadros pervive hoy en el cariz personalista del liderazgo político.

La debilidad del asidero ideológico de los partidos dominicanos con sus bases parece corresponder con el progresivo desvanecimiento de las fronteras que dividieron sus espacios ideológicos a lo largo de estas más de dos décadas. La estructuración de la competencia ha evolucionado desde la distinción hasta la moderación ideológica y hoy los tres partidos compiten y comparten el mismo espacio. La autoubicación ideológica media de la Cámara se ha mantenido estable en el espectro del centro, siendo la mínima en la legislatura de 1998-2002 (5,03) y la ubicación máxima 5,78 en 2002-2006 (5,78). El Gráfico 3.2.B.1.5 constata la tendencia hacia la convergencia ideológica y la competencia centrípeta en el sistema de partidos de la República Dominicana. 
Gráfico 3.4.1.5 Autoubicación ideológica de los Diputados dominicanos (1994-2010)

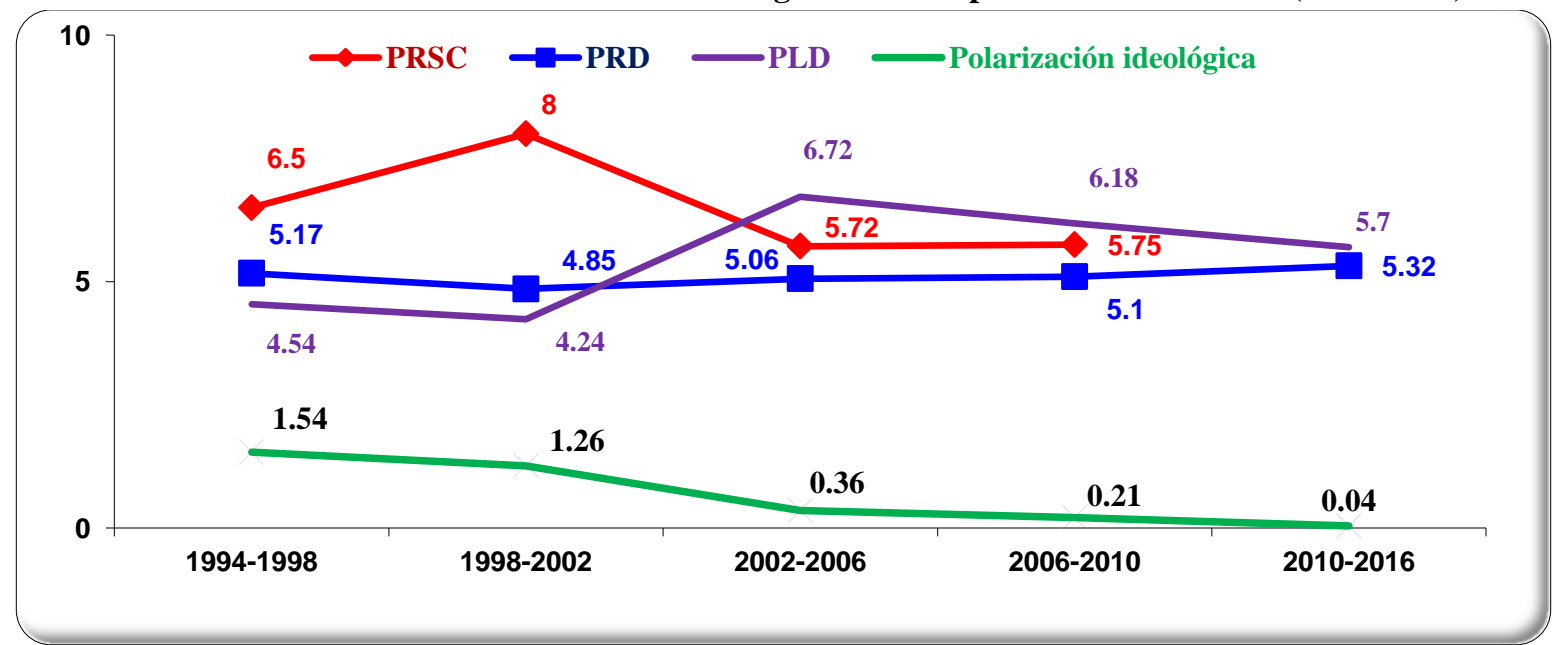

Fuente: Elaboración propia a partir de datos de PELA (1994-2009), Universidad de Salamanca.

El Partido Revolucionario Dominicano de Juan Bosch (PRD) nació en 1939 primero como una organización antitrujillista de ideología democrática popular, defensora luego de la dictadura con respaldo popular y finalmente socialdemócrata de la mano de José Francisco Peña Gómez en la transición. El Partido Reformista (PR) de Joaquín Balaguer nació en 1963 como un partido carismático puro defensor de la revolución conservadora. En 1985 se fusiona con el Partido Reformista Social Cristiano (PRSC) adquiriendo una fachada ideológica con la que competir en el escenario de la democratización. El Partido de la Liberación Dominicana (PLD) surge en 1973 como un partido carismático de cuadros abanderado de la liberación nacional y el marxismo y a partir de 1988 cohesionado en torno al «boschismo»: teoría y método político acerca de la sociedad dominicana ideada por su líder y profesor Juan Bosch (Jiménez Polanco 1999:430). La connivencia entre Balaguer y Bosch en 1996 para evitar el triunfo de Peña Gómez puso en evidencia que «pese a las diferencias, coincidían en el papel del Estado para afrontar el desarrollo. Ambos eran reformistas, uno desde la perspectiva conservadora-autoritaria y otro con un cariz modernizador. Los dos veían a los EEUU como un peligro nacional y los dos eran profundamente nacionalistas. Diferencias en el plano político y coincidencias estratégicas en el plano social, ideológico y cultural dieron como resultado un binomio personal de antagonismos públicos y callados acuerdos que definieron el sistema político dominicano por más de treinta años» (Lozano 2004:128).

La mayor evolución ideológica se ha producido en el PRSC, adscrito a la Organización Demócrata Cristiana de América, con un descenso de 2 puntos en la escala izquierda-derecha (Downs 1957). Por el contrario, PRD -afiliado a la Internacional Socialista- y PLD -antaño defensor del marxismo no leninista-, han experimentado un proceso de progresiva derechización. El análisis desagregado por partido revela la peregrinación ideológica hasta el escenario actual, donde los tres compiten por ser "atrápalotodo" en el espectro del centro derecha.

En la legislatura 1994-1998, destaca el grado de concentración de las preferencias de los diputados del PRD. Por el contrario, el PRSC muestra una distribución simétrica de sus autoubicaciones y la mayor dispersión (1,76 desv. típ.), mientras que el PLD muestra asimetría sesgada a la izquierda y relativa concentración de las preferencias, efecto también del limitado número de casos $(\mathrm{N}=7)$. El bloxplot de 1994-1998 muestra la última fotografía del espectro ocupado por las 3 ideologías caudillistas antes de la desaparición de sus líderes: el "peñagomismo" socialdemócrata, el "boschismo" estatista-reformista y el "balaguerismo" populista. En la legislatura 1998-2002, comienza la progresiva "derechización" de las preferencias ideológicas en el PLD y aumenta la 
dispersión de las autoubicaciones de sus legisladores. Una apertura ideológica que coincide con su expansión electoral, que pasa de tener 13 a 49 representantes, y confirma su transición de partido de cuadros a partido de masas. Con la derrota electoral del PRSC (que pasa de 50 a 17 escaños), se radicalizan las preferencias de sus parlamentarios, ya que el tercer cuartil ocupa los puntos más altos del espectro de la derecha. La salida formal de Balaguer de la escena electoral, provoca este efecto "reactivo" en las filas de su partido, situándose en la escala en una media de 8 puntos. En la legislatura 2002-2006, el salto ideológico y la dispersión son significativos en el PRD, que ha pasado de la concentración y distribución homogénea (94-98), al sesgo a la izquierda (98-02), a la progresiva derechización de sus preferencias y la mayor dispersión (desv. típ. 1,90). El PRSC por el contrario, comienza un viraje homogéneo hacia el centro. En la legislatura 2006-2010 se confirman las tendencias anteriores: asimetría sesgada a la derecha en el PRD, cuya ubicación media se sitúa en el centro-derecha $(5,72)$, aumentan los valores máximos y los outliers cercanos a la extrema derecha en el PLD y el PRSC confirma su viraje hacia al centro. En la actual legislatura 2010-2016 los dos partidos mayoritarios muestran figuras similares marcadas por la distribución simétrica de sus preferencias, aunque los mayores cambios se producen en el PRD, ya que disminuye el sesgo positivo a la derecha y aparece el negativo. En la filas del PLD no hay grandes cambios en la distribución de las preferencias ideológicas con respecto a la legislatura pasada, salvo que aumentan los outliners en la extrema derecha y que podría reflejar el transvase de representantes -bajo la forma de aliados y de tránsfugas- procedentes del reformismo balaguerista.

Gráfico 3.4.1.6 Distribución de las autoubicaciones ideológicas de los Diputados dominicanos

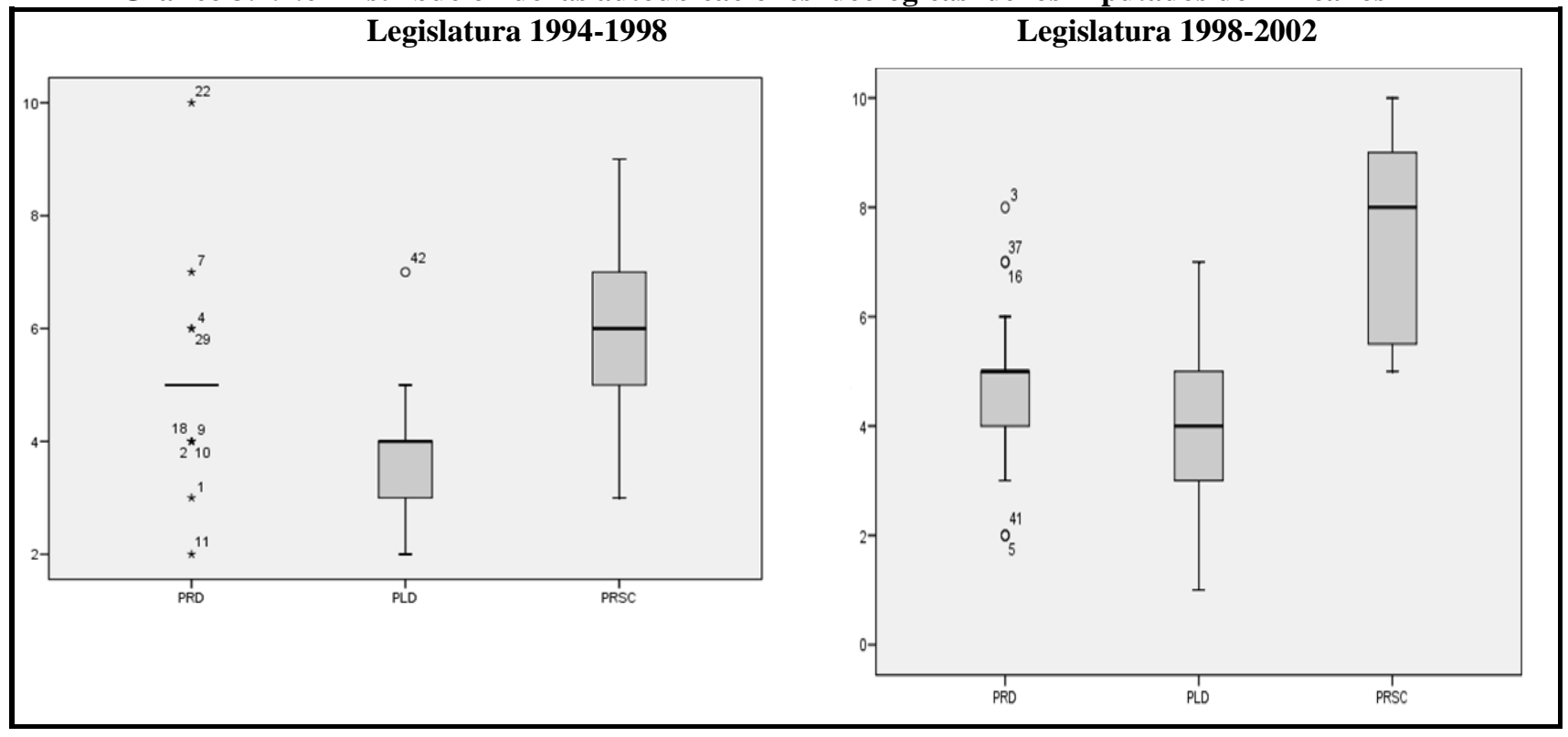



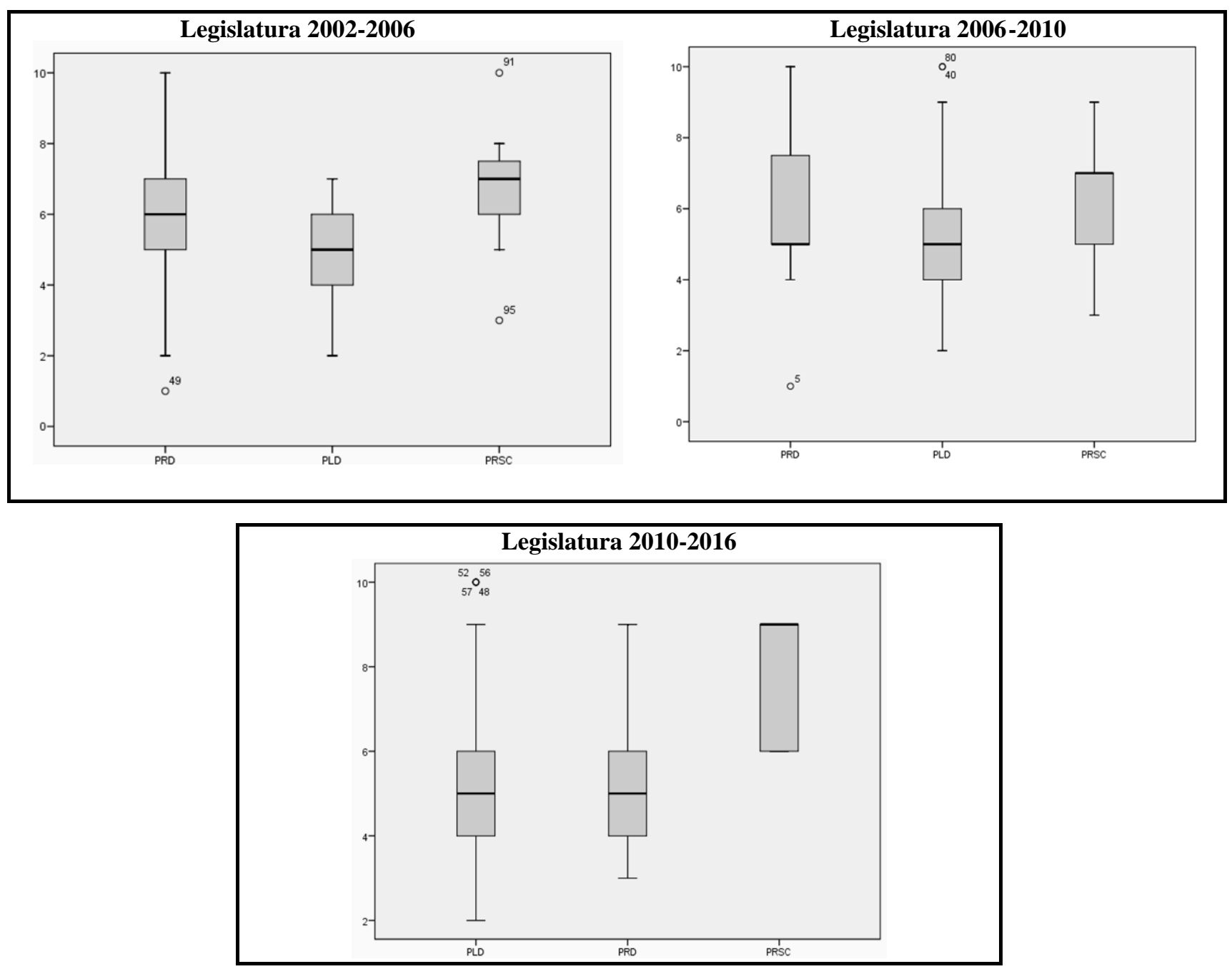

Fuente: Elaboración propia a partir de datos de PELA (1994-2009), Universidad de Salamanca.

La Tabla 3.4.1.9 muestra que la coherencia ideológica -definida como el grado de unidad en las preferencias y actitudes de los miembros de un partido (Rodríguez y Otero 2013:41)- se ha ido difuminando en la etapa de la consolidación democrática, ya que la dispersión de las preferencias ha ido en aumento. La mayor heterogeneidad de las identificaciones ideológicas se encontraba en las filas del PRSC en las dos legislaturas de la década de los noventa y disminuye tras la muerte de su líder. Posteriormente, será el PRD quien experimente la mayor dispersión en 2002 y el PLD en 2006, legislaturas en las que ambos ocupaban la mayoría de los escaños. En la actual legislatura, la dispersión disminuye en el PRD pero aumenta la heterogeneidad en el oficialista PLD, alcanzando un 2,18. Destaca el grado de dispersión entre los representantes del PRSC $(3,03)$ teniendo en cuenta que son solo 3 diputados.

Tabla 3.4.1.9 Evolución desviaciones típicas autoubicación ideológica

\begin{tabular}{|l|c|c|c|c|c|}
\hline \multicolumn{2}{|c|}{$\mathbf{1 9 9 4 - 1 9 9 8}$} & $\mathbf{1 9 9 8 - 2 0 0 2}$ & $\mathbf{2 0 0 2 - 2 0 0 6}$ & $\mathbf{2 0 0 6 - 2 0 1 0}$ & $\mathbf{2 0 1 0 - 2 0 1 6}$ \\
\hline PRD & 1,31 & 1,17 & $\mathbf{1 , 9 0}$ & 1,91 & 1,52 \\
PLD & 1,26 & 1,45 & 1,50 & $\mathbf{1 , 9 6}$ & $\mathbf{2 , 1 8}$ \\
PRSC & $\mathbf{1 , 7 6}$ & $\mathbf{1 , 8 9}$ & 1,36 & 1,77 & $\mathbf{3 , 0 3}$ \\
\hline
\end{tabular}

Fuente: Elaboración propia a partir de datos de PELA (1994-2009), Universidad de Salamanca. 
El test de ANOVA, constata que desde 1994 no han existido diferencias significativas en la ubicación ideológica entre los dos principales partidos PLD y PRD ${ }^{126}$. Sólo en los años noventa y en presencia de los caudillos históricos, las diferencias ideológicas eran significativas entre el PRSC y el PLD (1994-1998) y entre el PRSC con los dos partidos del sistema (1998-2002). Estas diferencias ideológicas del pasado no han impedido que PLD y PRSC sean en la actualidad socios de gobierno. A partir del año 2002, no se aprecian diferencias ideológicas significativas en la competencia interpartidista en República Dominicana. Las tres fuerzas políticas dominicanas compiten en el espacio de la derecha y centro derecha, ya que desde 1994 en que el PLD se ubicaba en el centro-izquierda $(4,24)$, ésta no cuenta con representación institucional.

Tabla 3.4.1.10 Varianza de medias autoubicaciones ideológicas (1994-2010)

\begin{tabular}{|c|c|c|c|c|c|c|c|c|c|}
\hline \multicolumn{5}{|c|}{ Legislatura 1994-1998 } & \multicolumn{5}{|c|}{ Legislatura 1998-2002 } \\
\hline $\begin{array}{c}\text { (I) } \\
\text { Partido } \\
\text { político }\end{array}$ & $\begin{array}{l}\text { (J) Partido } \\
\text { político }\end{array}$ & $\begin{array}{l}\text { Diferencia de } \\
\text { medias (I-J) }\end{array}$ & $\begin{array}{l}\text { Error } \\
\text { típico }\end{array}$ & Sig. & $\begin{array}{c}\text { (I) } \\
\text { Partido } \\
\text { político }\end{array}$ & $\begin{array}{c}(\mathbf{J}) \\
\text { Partido } \\
\text { político }\end{array}$ & $\begin{array}{c}\text { Diferencia } \\
\text { de medias } \\
\text { (I-J) }\end{array}$ & $\begin{array}{l}\text { Error } \\
\text { típico }\end{array}$ & Sig. \\
\hline \multirow[t]{2}{*}{ PRD } & PLD &, 846 & 653 & 600 & PRD & PLD &, 605 & ,343 &, 542 \\
\hline & PRSC &,- 900 & 412 & 099 & & PRSC & $-3,152(*)$ & 491 & 000 \\
\hline \multirow[t]{2}{*}{ PLD } & PRD &,- 846 & 653 & 600 & PLD & PRD &,- 605 & 343 &, 542 \\
\hline & PRSC & $-1,746(*)$ & 661 & 032 & & PRSC & $-3,758(*)$ &, 511 &, 000 \\
\hline \multirow[t]{2}{*}{ PRSC } & PRD & ,900 & ,412 & ,099 & PRSC & PRD & $3,152(*)$ & 491 & ,000 \\
\hline & PLD & $1,746(*)$ & 661 & 032 & & PLD & $3,758(*)$ &, 511 &, 000 \\
\hline \multicolumn{5}{|c|}{ Legislatura 2002-2006 } & \multicolumn{5}{|c|}{ Legislatura 2006-2010 } \\
\hline $\begin{array}{c}\text { (I) } \\
\text { Partido } \\
\text { político }\end{array}$ & $\begin{array}{l}\text { (J) Partido } \\
\text { político }\end{array}$ & $\begin{array}{l}\text { Diferencia de } \\
\text { medias (I-J) }\end{array}$ & $\begin{array}{l}\text { Error } \\
\text { típico }\end{array}$ & Sig. & $\begin{array}{c}\text { (I) } \\
\text { Partido } \\
\text { político }\end{array}$ & $\begin{array}{c}(\mathbf{J}) \\
\text { Partido } \\
\text { político }\end{array}$ & $\begin{array}{c}\text { Diferencia } \\
\text { de medias } \\
\text { (I-J) }\end{array}$ & $\begin{array}{l}\text { Error } \\
\text { típico }\end{array}$ & Sig. \\
\hline \multirow[t]{2}{*}{ PRD } & PLD &,- 050 &, 172 & 1,00 & PRD & PLD &, 049 & ,086 & 1,00 \\
\hline & PRSC & ,086 & , 179 & 1,00 & & PRSC & ,109 & , 126 & 1,00 \\
\hline \multirow[t]{2}{*}{ PLD } & PRD & 050 & 172 & 1,00 & PLD & PRD &,- 049 & 086 & 1,00 \\
\hline & PRSC & 136 & 201 & 1,00 & & PRSC & ,060 &, 115 & 1,00 \\
\hline \multirow[t]{2}{*}{ PRSC } & PRD &,- 086 & 179 & 1,00 & PRSC & PRD &,- 109 & , 126 & 1,00 \\
\hline & PLD &,- 136 & 201 & 1,00 & & PLD &,- 060 &, 115 & 1,00 \\
\hline
\end{tabular}

\begin{tabular}{|ccccc|}
\hline \multicolumn{5}{c}{ Legislatura 2010-2016 } \\
\hline $\begin{array}{c}\text { (I) } \\
\text { Partido } \\
\text { político }\end{array}$ & $\begin{array}{c}\text { (J) Partido } \\
\text { político }\end{array}$ & $\begin{array}{c}\text { Diferencia } \\
\text { de medias } \\
\text { (I-J) }\end{array}$ & $\begin{array}{c}\text { Error } \\
\text { típico }\end{array}$ & Sig. \\
PRD & PLD &,- 379 &, 449 &, 701 \\
& PRSC & $-2,676$ & 1,137 &, 070 \\
PLD & PRD &, 379 &, 449 &, 701 \\
& PRSC & $-2,297$ & 1,134 &, 136 \\
PRSC & PRD & 2,676 & 1,137 &, 070 \\
& PLD & 2,297 & 1,134 &, 136 \\
\hline
\end{tabular}

* La diferencia de medias es significativa al nivel .05
Fuente: Elaboración propia a partir de PELA (1994-2010), Universidad de Salamanca.

Del análisis anterior se deduce la debilidad y/o ausencia de los tres primeros indicadores que componen el índice de estructuración programática del sistema de partidos descrito por Kitschelt et al (2010) y por lo tanto, la mayor probabilidad de intercambiar votos por beneficios selectivos en lugar de votos por paquetes de políticas:

${ }^{126}$ ANOVA: 0,16 (1994-98); 0,00 (1998-2002); 0,79 (2002-2006); 0,67 (2006-2010); 0,65 (2010-2016). 
La ausencia de diferenciación entre los principales partidos con opciones de gobierno refleja la escasa dimensionalidad del espacio ideológico en la competencia política dominicana, primera de las condiciones para que opere la representación programática entre principal y agente. En cuanto al segundo de los condicionantes, referido a la existencia de una semántica normativa ya sea simbólica o sustantiva sobre el eje izquierda-derecha, no solo está ausente en el discurso político nacional, sino que parece existir una cierta confusión en su identificación entre el electorado. A pesar de que los dominicanos conciben la ideología en términos espaciales pues se ubican en la tradicional escala izquierda-derecha en las diferentes encuestas de opinión pública, no parece que doten de un significado concreto u orden de valores a dichos términos. Así lo evidenció el Observatorio de Comportamiento Político y Opinión Pública (OBSEROP) creado en 2010 en el marco del Proyecto «Apoyo al Proceso de Modernización del Sistema de Partidos en la República Dominicana» (PNUD-AECID 2008-2010) en el que se pedía a los entrevistados que identificaran los principios asociados a "ser de izquierda" y "ser de derecha". Sorprendentemente, la gran mayoría de valores e ideales presentados fueron asignados a la derecha. Así, el 76,7\% de los entrevistados asoció la palabra "solidaridad" con la derecha frente al 12,4\% que lo hizo en la izquierda y el 69,3\% ligó la palabra "igualdad" a ser de derechas frente al 16,6\% que ubicó este valor en la izquierda. En este sentido, llama la atención que el ideal "socialismo" fuese ubicado por el $67,9 \%$ de los entrevistados en el listado de principios que defiende la derecha y solo el 18,9\% lo incluyera en el listado de conquistas que persigue la izquierda (OBSEROP 2010:23).

El estudio concluye que «el eje izquierda-derecha tiene muy poca capacidad de discriminación en la República Dominicana, pues la abrumadora mayoría de los electores se ubica en el extremo derecha de la escala. Parece claro que, salvo para un pequeño porcentaje de la población, el término "derecha" tiene connotaciones positivas y eso les lleva a ubicar al partido con el que simpatizan en esa posición» (OBSEROP 2010:26). A pesar de ello, los datos revelaron que en las elecciones de 2010 se apreciaba una tendencia caracterizada por el aumento del apoyo al PLD conforme la ubicación se acercaba al extremo derecha en la escala, mientras que la tendencia era la inversa en el apoyo al PRD.

Tabla 3.4.1.11 Porcentaje de voto según ubicación en la escala izquierda-derecha (\%)

\begin{tabular}{|lccccc|}
\hline & PLD & PRD & PRSC & Otros & N \\
\hline Izquierda (1-2) & 37,5 & $\mathbf{5 2 , 4}$ & 8,1 & 2,1 & 83 \\
Centro Izquierda (3-4) & 42,7 & 50,8 & 4,3 & 2,2 & 29 \\
Centro (5-6) & 49,4 & 47,4 & 1,3 & 1,9 & 51 \\
Centro Derecha (7-8) & 55,1 & 33,6 & 6,9 & 4,4 & 47 \\
Derecha (9-10) & $\mathbf{6 2 , 6}$ & 32,1 & 3,1 & 2,3 & 509 \\
\hline
\end{tabular}

Fuente: Primera Encuesta de Opinión Pública y Comportamiento Político (OBSEROP 2010). Mariano Torcal (dir.)

Si bien esta tendencia está en consonancia con la orientación socialdemócrata del PRD, sorprende la ubicación ideológica de las bases sociales del oficialista PLD. Un partido marxista y boschista en su momento fundacional que encuentra hoy el grueso de sus votantes en la derecha y que podría deberse al trasvase de votantes del reformismo balaguerista.

Con respecto a la cohesión ideológica de los partidos políticos, como muestra la evolución de las desviaciones típicas de la Tabla 3.2.B.1.9 cada vez es mayor la heterogeneidad de las bancadas legislativas. La falta de correspondencia ideológica entre compañeros de escaño se reproduce y agranda entre legisladores y votantes ya que la ubicación ideológica de los dominicanos alcanzaba en 2010 un promedio de 7,41 (LAPOP 2010) mientras que la de sus representantes era de un 5,42 (PELA 2010). Esta brecha ideológica entre élites y ciudadanos era la mayor de la región latinoamericana y situaba a la ciudadanía dominicana orientada más a la derecha que sus élites, ya que el $36,37 \%$ de los entrevistados se ubicó en el valor 10 correspondiente a extrema derecha (Dosek 2011:14). 


\section{$\checkmark \quad$ Vocación nacional y focus distrital}

El abanico de combinaciones de la dimensión focus (qué intereses defienden los legisladores) y la dimensión estilo (qué consignas reciben), refleja la variedad de patrones en que se traduce el mandato nacional de representación. Marengui y García (2006) constataron la tendencia a la representación de intereses particularistas en América Latina en una pluralidad de modelos determinados por el propio diseño institucional, el legado histórico, los cleavages sociales y las prácticas informales (Marengui y García 2006:33). En la República Dominicana, tales condicionantes de la vinculación de las élites al territorio convierten al diputado en un bróker resolutivo en el distrito más que en un agente propositivo en el Congreso Nacional.

Teniendo en cuenta las opiniones expresadas por los diputados dominicanos (PELA 1998-2010), la mayoría de ellos afirmaron representar a todos los dominicanos en su ejercicio parlamentario, salvo en la legislatura 2002-2006 en la que la representación adquiere una naturaleza más distrital a la vez que más politizada, ya que aquellos que dicen representar a los electores de su provincia y a los votantes de su partido asciende al 36,7\% y 33,5\% respectivamente. Este punto de inflexión en la naturaleza de la representación en el país podría ser explicado por el efecto de la implementación del voto preferencial en las elecciones de 2002. El carácter territorial de la representación aumenta en la legislatura de 2006 (38,5\%) y desciende en la actual, situándose en el 22,5\% el porcentaje de diputados que identifican a los electores de la provincia como el principal que les ha otorgado su mandato de representación.

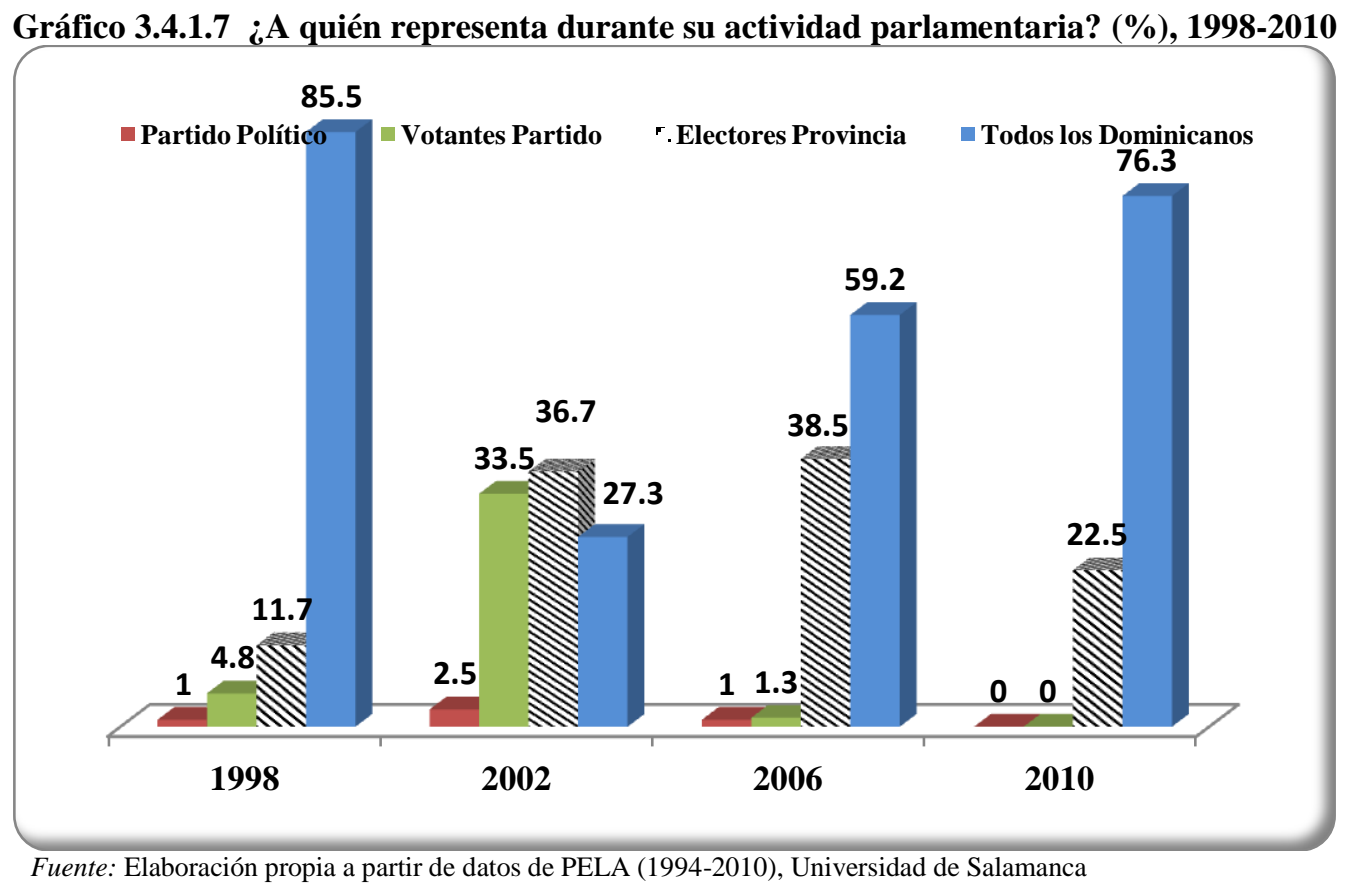

El análisis desagregado de la representación distrital por partido revela el aumento del número de legisladores que afirmaron representar a los electores de la provincia por encima del mandato nacional, con diferencias significativas entre los legisladores del PRD en $2002(49,1 \%)$ y los del PRSC en 2006 (54,5\%), cuando en ambos partidos la mitad de sus representantes así lo consideraban. 
Grafico 3.4.1.8 Diputados representan a electores de la provincia en su labor parlamentaria por partido político (\%), 1998-2010

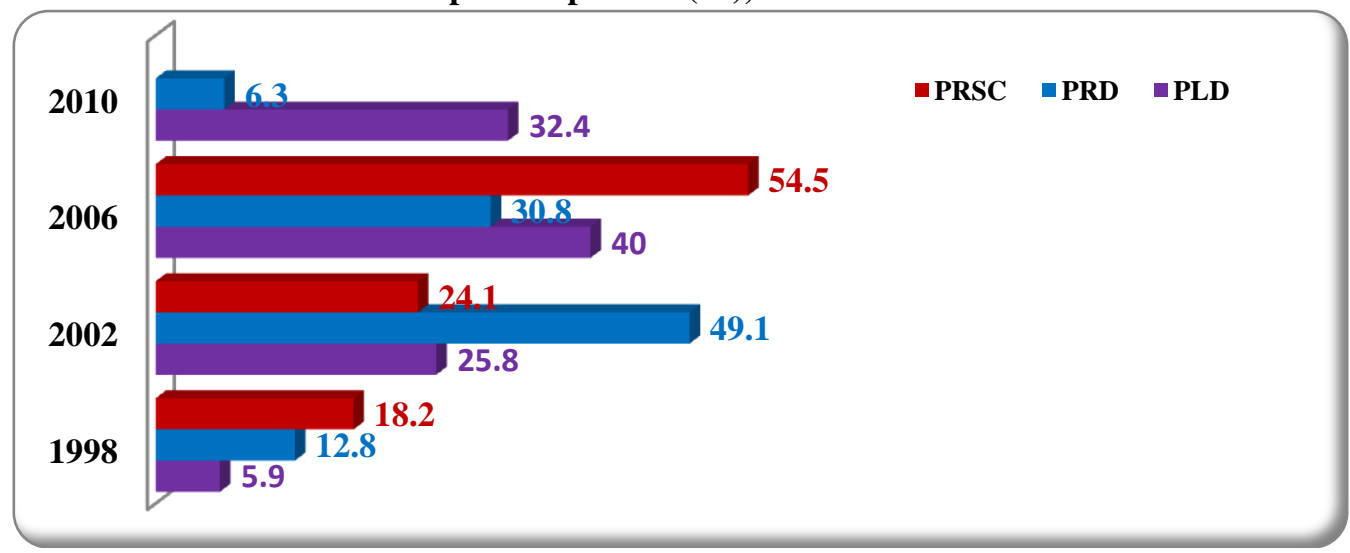

Fuente: Elaboración propia a partir de datos de PELA (1994-2010), Universidad de Salamanca

En el ejercicio de la representación política la función simbólica (representar a todos los ciudadanos) lidera el listado de tareas consideradas más importantes aunque en tendencia descendente. Le siguen en importancia la función normativa (elaborar leyes), solo superada en la legislatura 2006 por la defensa de los intereses de los electores del propio distrito $(28,35 \%)$. Destaca por el contrario, la escasa importancia otorgada a la función fiscalizadora (controlar al gobierno con un $0,9 \%$ y un $3,4 \%$ ) y la función de orientación de política pública (elaborar presupuestos, con un $0,9 \%$ y $0 \%$, así como resolver problemas del país, con un $6 \%$ y $6,7 \%$ ) en las pasadas legislaturas de 2002 y 2006.

Si bien la función normativa es una de vocación generalista, el primero de los indicadores de esta investigación revelaba que en su ejercicio propositivo impera el focus particularizado, ya que el $43,70 \%$, el $69,42 \%$ y el $37,81 \%$ de los proyectos de Ley presentados por los diputados dominicanos durante las legislaturas 1998-2002, 2002-2006 y 2006-2010, representaban intereses de tipo club (gremial o local) e individual.

Gráfico 3.4.1.9 Aspecto más importante de la actividad parlamentaria 2002-2010

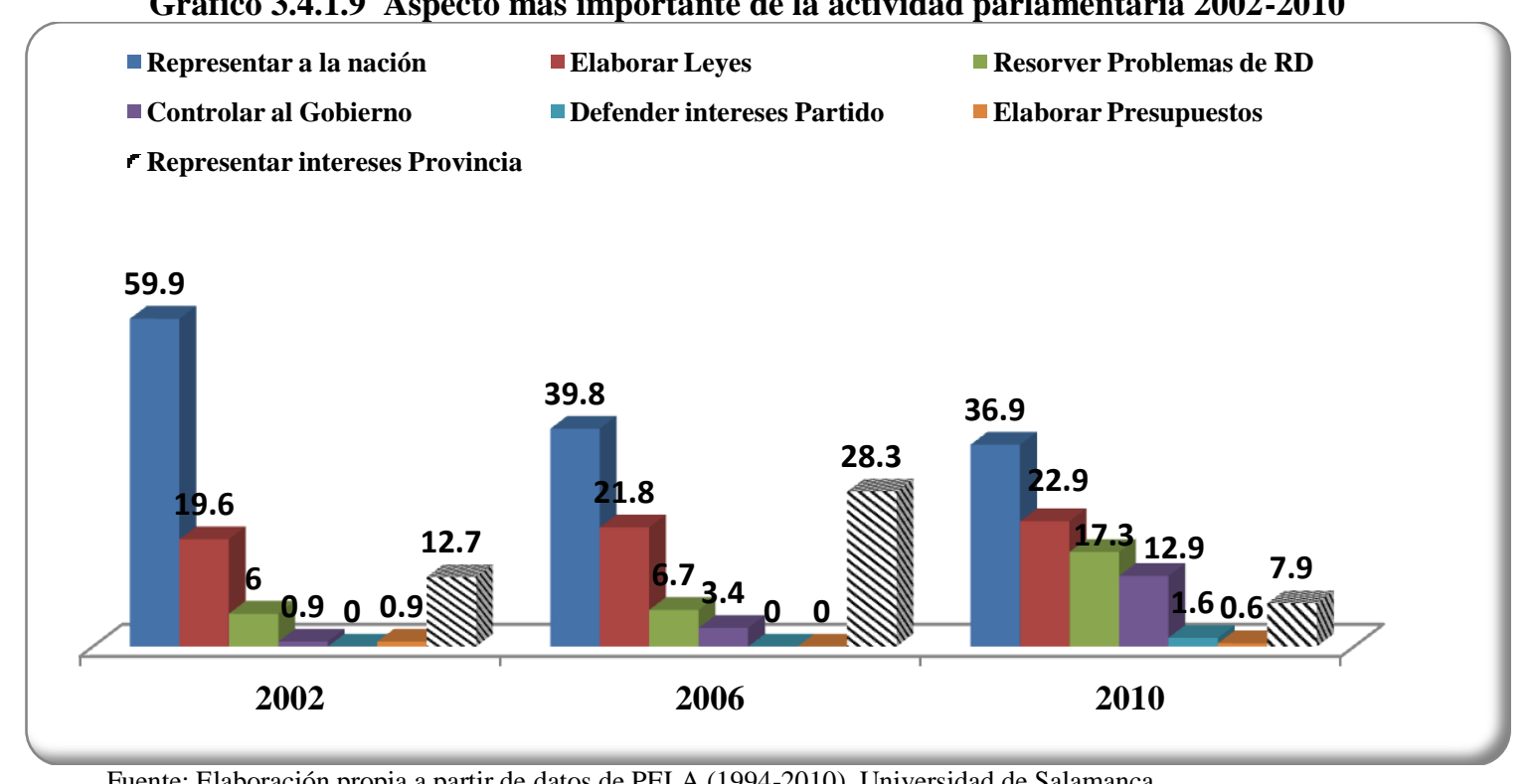

Fuente: Elaboración propia a partir de datos de PELA (1994-2010), Universidad de Salamanca 
El análisis desagregado por partido permite contextualizar las fluctuaciones en el peso de la naturaleza distrital en la vinculación de las élites políticas con los ciudadanos:

Al preguntar a los diputados electos cuáles eran las dos actividades más importantes de su labor parlamentaria, se observa que el focus distrital es el segundo aspecto más importante para peledeístas (PLD) y reformistas (PRSC) en 2002 y la primera para los perredeístas (PRD) en 2006. Durante estas dos legislaturas, la representación de los intereses de la provincia de los legisladores del PLD, PRD y PRSC se distancia significativamente de tareas de vocación más universalista como la de orientación de política pública y fiscalización. En la legislatura 20102016, se debilita el focus distrital en los dos partidos mayoritarios (21,6\% PLD y 8,5\% PRD) y cobra peso la de orientación de política pública en la dimensión relativa a la resolución de problemas del país $(35,1 \%$ PLD y $30,8 \%$ PRD).

Tabla 3.4.1.12 Aspectos más importantes de la actividad parlamentaria (\%), 2002-2010

\begin{tabular}{|c|c|c|c|c|c|c|c|c|}
\hline \multirow{2}{*}{$\begin{array}{l}\text { Durante su actividad parlamentaria, a } \\
\text { qué dos de los siguientes aspectos le da } \\
\text { Ud. más importancia }\end{array}$} & \multicolumn{3}{|c|}{$2002-2006$} & \multicolumn{3}{|c|}{ 2006-2010 } & \multicolumn{2}{|c|}{$2010-2016$} \\
\hline & PLD & PRD & PRSC & PLD & PRD & PRSC & PLD & PRD \\
\hline Representar a la nación & 80,6 & 61,4 & 69 & 50,2 & 50 & 45,5 & 59,4 & 50,4 \\
\hline Elaborar las leyes & 29 & $\mathbf{5 7 , 9}$ & 30,8 & 63,7 & 50 & 54,6 & 64,8 & 53,8 \\
\hline $\begin{array}{l}\text { Resolver los problemas de la República } \\
\text { Dominicana }\end{array}$ & 9,7 & 14,1 & 20,7 & 16,9 & 23,1 & 18,2 & 35,1 & 30,8 \\
\hline Controlar la actuación del Gobierno & 9,7 & 8,8 & 13,8 & 22,7 & 15,3 & 27,3 & 5,4 & 56,4 \\
\hline Defender los intereses de su partido & 22,6 & 10,5 & 3,4 & 1,9 & 0 & 0 & 8,1 & 0 \\
\hline $\begin{array}{l}\text { Elaborar los presupuestos Generales del } \\
\text { Estado }\end{array}$ & 16,1 & 8,8 & 3,4 & 1,9 & 3,8 & 18,2 & 5,4 & 0 \\
\hline Representar los intereses de su provincia & 29 & 38,6 & 58,6 & 42,8 & 57,7 & 36,4 & 21,6 & 8,5 \\
\hline
\end{tabular}

Con respecto a la tarea de controlar la actuación del gobierno, en todas las legislaturas el porcentaje más alto de respuestas corresponde al partido con menor número de escaños. Destaca la importancia otorgada por los legisladores del PRD en la actual legislatura, siendo la primera vez en esta década que el ejercicio de oposición por parte de una bancada no oficialista supera el $50 \%$ de las preferencias de los entrevistados y es considerada la tarea más importante de su actividad parlamentaria. Este porcentaje podría estar revelando el especial recelo que sienten los representantes del opositor PRD por el dominio del partido oficialista en las instancias de control entre poderes como la Junta Central Electoral, el Tribunal Supremo, la Cámara de Cuentas, los bufetes directivos de la Cámara de Diputados o el dominio absoluto del Senado. Este control de las instituciones de la democracia representativa y de los recursos del Estado, han llevado a los detractores del PLD a desautorizar las condiciones de la competencia del sistema de partidos calificándolas de "dictadura constitucional de la corporación PLD"127.

A pesar de que los diputados no hayan identificado como tarea más importante la representación de los intereses de la provincia, el focus distrital de la representación emerge en las cuatro legislaturas consideradas cuando se pregunta a los legisladores acerca de la importancia que conceden a la tarea de conseguir recursos para su circunscripción. El Gráfico 3.2.B.1.10 muestra que la

127 Ver noticias en periódicos nacionales El Siglo y Diario Libre, de Marzo de 2012. En http://elsiglo21.com/index.php/el-pais/36055-alertan-contra-dictadura-constitucional-del-pld y http://www.diariolibre.com/elecciones2012/2012/03/27/i329893_intelectuales-advierten-peligro-unadictadura-constitucional.html 
legislatura 2002 de nuevo supone un punto de inflexión, ya que se duplica la importancia concedida (pasa de un $48 \%$ a un $82 \%$ ) cuando a partir de esta fecha los electores tienen a su disposición la posibilidad de votar directamente por el candidato.

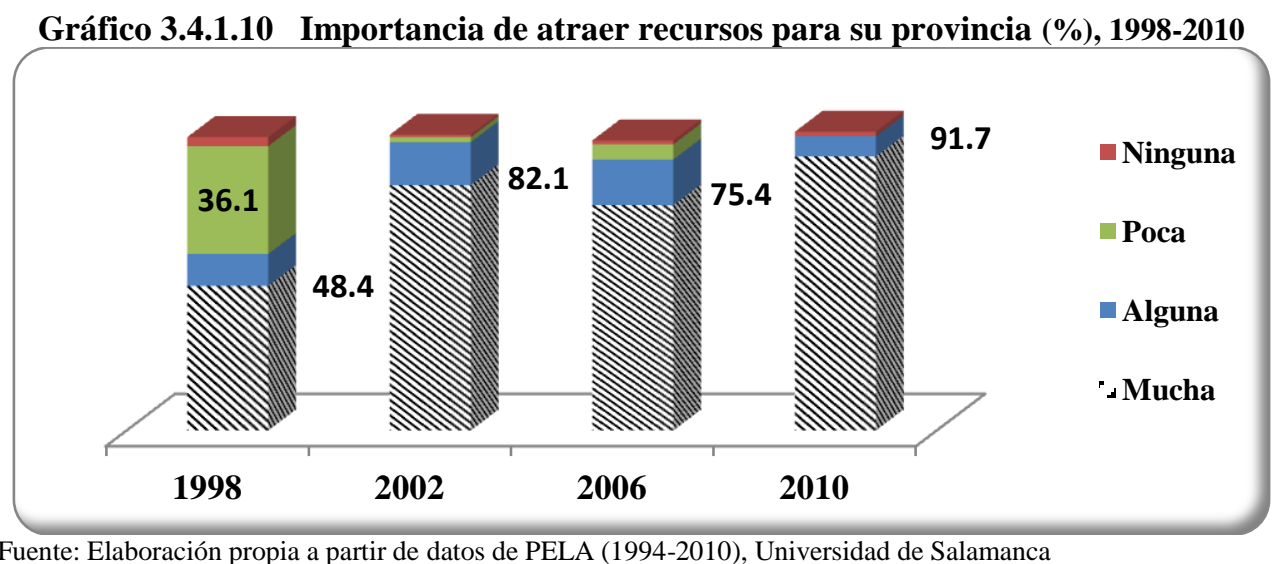

En caso de conflicto entre la posición adoptada por el partido político en una votación en el Congreso y los intereses de la provincia del diputado, estos últimos imperan según las opiniones de los entrevistados. El Gráfico 3.4.1.11 revela que los diputados dominicanos se sienten cada vez más independientes a la hora de ejercer su labor parlamentaria respecto a las instrucciones de sus partidos. Desde 1998, los temas morales y los de interés regional son las dos opciones identificadas por los parlamentarios dominicanos como aquellos que no deberían estar sujetos a disciplina de voto (PELA 1998-2010) ${ }^{128}$.

Gráfico 3.4.1.11 En caso de conflicto entre las necesidades de la provincia y las posiciones del partido político al que pertenece el diputado en la Cámara ¿Cómo votaría? (\%), 1998-2010

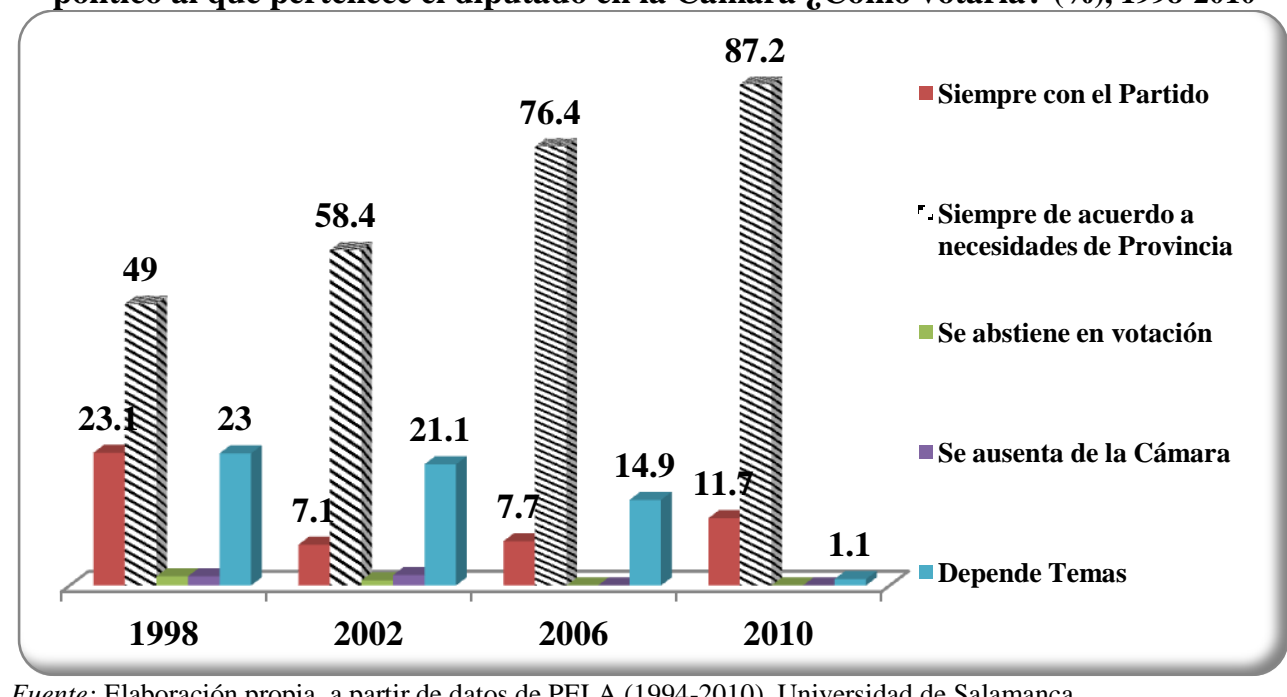

Fuente: Elaboración propia a partir de datos de PELA (1994-2010), Universidad de Salamanca

\footnotetext{
${ }^{128}$ En 2010, el 46,2\% de los diputados del PLD y el 25\% de los representantes del PRD consideraban que los temas morales no deberían estar sometidos a disciplina de voto. En cuanto a los temas regionales, así lo consideraron el 23,1\% en la bancada del PLD y el 37,5\% en la del PRD.
} 
Esta independencia en el estilo de la representación en que parecen imperar los juicios propios frente a los de la bancada del partido en la Cámara, se ve reforzada cuando se pregunta acerca de la fórmula para ganar elecciones y ser reelegido como diputado. En cuando a la primera, «tener presencia permanente» $\mathrm{y}$ «hacerse con una reputación local» parecen ser las claves para conquistar a los electores, lejos de fórmulas más generales de agregación de intereses como la de tener un programa; o de organización partidista, como contar con el apoyo de los líderes del partido. Ambas son indicadores de la vinculación personalista entre político-elector que hablan de un vínculo directo donde prima el contacto regular y de un anclaje no programático basado en virtudes de lustre social no racional. A la hora de la reelección, a la «presencia permanente» le acompaña en la fórmula de éxito electoral «atender a los electores del distrito» con un 30,6\% y un 42,4\% de legisladores del PLD y PRD que así lo consideraron. Aunque en el caso de los diputados oficialistas ya esta práctica era considerada importante por el 22,2\% de los entrevistados para ganar elecciones. La nula relevancia del líder del partido en la conquista del escaño es indicador del grado de autonomía con la que opera la maquinaria electoral del candidato a diputado en la campaña, cuyo financiamiento se nutre fundamentalmente de recursos propios. Igual sucede en la conquista de la candidatura a puestos de elección popular o interno:

«Los partidos no utilizan sus recursos para financiar candidaturas. Los recursos públicos recibidos son usados en la Comisión, papeleos... todo el que decide competir por puestos internos tiene que buscar recursos propios» (Benito y Rosales 2011:29).

Tabla 3.4.1.13 Lo más importante para ganar y ser reelegido (\%), 2010-2016

\begin{tabular}{|c|c|c|c|c|}
\hline \multirow{2}{*}{$\begin{array}{l}\text { Si tuviese que aconsejar a un colega sobre qué debería hacer un } \\
\text { candidato para ser electo, Ud. Le diría que } \\
\text { lo más importante es...? }\end{array}$} & \multicolumn{2}{|c|}{ Ganar elecciones } & \multicolumn{2}{|c|}{ Ser reelegido como diputado } \\
\hline & PLD & PRD & PLD & PRD \\
\hline Tener un programa & 13,9 & 8,8 & 5,6 & 0 \\
\hline Tener presencia permanente & 27,8 & 41,2 & 36,1 & 30,3 \\
\hline Regalar cosas & 2,8 & 0 & 2,8 & 3 \\
\hline Hacerse una reputación local & 33,3 & 29,4 & 22,2 & 18,2 \\
\hline Salir en la $T V$ & 0 & 8,8 & 2,8 & 3 \\
\hline Atender a los electores de su distrito & 22,2 & 8,8 & 30,6 & 42,4 \\
\hline Tener el apoyo de los líderes del partido & 0 & 0 & 0 & 0 \\
\hline
\end{tabular}

Fuente: Elaboración propia a partir de datos de PELA (1994-2010), Universidad de Salamanca

La opción «regalar cosas», con la que se ha identificado la práctica del clientelismo, no concita a penas las preferencias de los diputados dominicanos. Esta visión reduccionista del intercambio en política -que lo circunscribe al momentum electoral y a un acto de desprendimiento unidireccionalpoco tiene que ver con el vínculo estable del ejercicio de responsiveness y accountability particularizado de la relación clientelar (Kitschelt y Wilkinson 2007; Stockes 2005). Por el contrario, «presencia permanente»y «atender a los electores del distrito» dan cuenta del modo y estilo de la vinculación de las elites políticas al territorio, en las que el diputado se asemeja al de un bróker resolutivo en el distrito más que al de un agente propositivo en el Congreso Nacional.

Como se argumentó en el apartado correspondiente al sistema electoral dominicano, los determinantes de la vinculación de las elites políticas al territorio en un estado unitario pseudo descentralizado como el dominicano, se relacionan con el voto preferencial y la micro fragmentación nacional en la que el territorio pasa a ser una prebenda entre actores políticos nacionales y municipales. 


\title{
2) «Si tú me dices ven»: pactos, aliados y trashumantes en el sistema de partidos dominicano
}

\author{
¿Cómo negocian y qué intercambian los partidos políticos dominicanos?
}

Los primeros trabajos acerca de la coordinación entre partidos y élites políticas surgieron en la década de los noventa en el contexto del Parlamentarismo europeo (Strom 1990, Warwick 1994). En América Latina, el Presidencialismo de Coalición del Cono Sur ha acaparado en los últimos años tanto el análisis comparado de sus condicionantes (Amorin 1998; Altman 2000; Chasquetti 2001; Selaznik 2001; Inacio y Nuno 2005), como el de sus particularidades en estudios de caso (Chasquetti 2001; Amorin 2002; Siavelis 2004). Esta literatura sobre la coordinación estratégica de las élites políticas se ha centrado principalmente en el estudio de una de las posibles formas de cooperación -las coaliciones- (Cheibub, Przeworsky y Saiegh 2004) y en cómo éstas condicionan la definición de políticas y la distribución de cargos. Sin embargo, ha sido escasa la atención prestada a las prácticas de colaboración en sistemas políticos de baja estructuración programática así como al repertorio de vías para la cooperación formal e informal más allá del momentum electoral.

El objetivo de este epígrafe es mostrar que desde la segunda transición a la democracia se observa en República Dominicana un patrón de relación entre las élites políticas en el que predomina el consenso pragmático. Para ello, se presenta un modelo de cooperación estratégica en el que se tipifican las diferentes formas de interacción según quiénes sean los protagonistas [élites, partidos o candidatos], en una orientación dicotómica [particularista versus generalista] determinada por el repertorio de incentivos y costes asociados. La coordinación estratégica de las élites dominicanas se manifiesta en la práctica pactista entre líderes, partidos y candidatos. La motivación que subyace es el interés por la propia supervivencia institucional y el acceso patrimonialista a los recursos del Estado. El nivel de extensión de estos resultados democráticos pertenecen al universo de los bienes privados y de club y por tanto, son indicadores de un modo de relación entre partidos que la literatura del clientelismo ha referido como propicio para el intercambio particularizado (Piattoni 2001).

\section{Patrones de cooperación estratégica}

En función de quiénes sean los protagonistas, se presenta una propuesta de tipología de cooperación estratégica a la luz de los instrumentos utilizados en la República Dominicana.

Como muestra la Tabla 3.2.B. 2.1 hay tres instrumentos a través de los cuales se materializa la colaboración: 1) los pactos, 2) las alianzas y 3) el transfuguismo, que son utilizados por 1) las élites políticas, 2) los partidos o 3) los candidatos respectivamente. El nivel de inclusión del objeto o finalidad perseguida con el pacto, alianza o cambio de afiliación partidista determinará la orientación a) generalista o b) particularista. Mientras que en la primera, la extensión de los beneficios democráticos se difumina y va más allá de los artífices de la colaboración, en la de orientación particularista se circunscriben a los protagonistas y/o sus correligionarios, de tal manera que los beneficios intercambiados tienen una naturaleza privada o de club. La definición de políticas de Estado, la implementación de una determinada política pública o el realineamiento del sistema de partidos son propósitos de alcance universal o generalista. Por el contrario, el control partidista del patronazgo, la distribución de cargos y conquistar un lugar en la lista electoral representan fines de disfrute particularizado para los negociadores. La valoración de los costes y oportunidades que hacen los protagonistas condiciona la elección del objeto, con resultados diversos en el sistema de partidos y la democracia en el país. Cuanto menor sea la vocación generalista de la interacción política, más se apartará del modelo de "partido de gobierno responsable" y reorientará la responsiveness a una de tipo particularizado. 
El primero de los instrumentos es el Pacto. Con el compromiso interpartidario se busca fijar una política de Estado, alejar de la contienda electoralista la conquista de lo pactado y diluir el protagonismo del éxito entre todos los actores intervinientes. El pacto es el instrumento utilizado para sortear el inmovilismo institucional y promover medidas sociales, económicas y políticas que profundicen los resultados democráticos. Los Pactos de la Moncloa (España, 1977) o el más reciente Pacto por México (México, 2012) son ejemplos de concierto entre élites para consensuar la orientación del Estado Social de Derecho o extender el ejercicio de las libertades públicas respectivamente. En otros casos, como en Los Acuerdos de Paz (Guatemala, 1996) y de Chapultepec (El Salvador, 1992), el camino hacia la inclusión de los resultados democráticos discurrió por la adhesión al fin de la violencia social y política.

La definición de políticas de Estado es el objetivo de vocación generalista perseguido por los firmantes en favor de la fluidez institucional y la gobernabilidad democrática. Esta planificación conjunta de la actuación en asuntos nacionales clave difumina el éxito entre los participantes, por lo que se limita su rédito electoral partidista. Por el contrario, el control de los recursos del Estado evidencia una vocación particularista incentivada por el mantenimiento del statu quo, la supervivencia institucional, frenar la representación de otras fuerzas minoritarias o el acceso al patronazgo. Los costes asociados a este objetivo tienen que ver con el conflicto que se genera tanto al interior del partido por la facción o élite excluida, como en el resto de las fuerzas políticas que no disfrutan de los beneficios. El «Pacto por la Democracia, 1994» en la República Dominicana o el «Pacto de Toledo, 1995» en España, son ejemplos de negociación interpartidista de vocación universal. Y en el reverso particularista, el «Pacto de Solidaridad Económica, 1990» o el «Pacto por la Gobernabilidad y el Desarrollo Local y Nacional, 2006» ejemplos nacionales de acuerdos donde la transacción particularizada prima en la negociación. Fuera de las fronteras dominicanas y en un escenario de duopolio político (Tellería 2011) se catalogaría la cooperación entre Daniel Ortega y Arnoldo Alemán y "el pacto" que ha marcado el reparto de lo público en la cooperación bicaudillista de la última década en Nicaragua.

El segundo de los instrumentos es la Alianza Electoral. Las alianzas son la respuesta de los partidos políticos al reto de alcanzar el poder o de mantenerlo en un contexto de cambios en la competencia y competitividad (Reynoso 2011:14). Se trata de una modalidad de coordinación estratégica que disminuye el número de contendientes sin reducir el número de partidos. Este apoyo multipartidario suele ir acompañado de una agenda programática consensuada entre aliados -como en el Presidencialismo de coalición (Abranches 1988) de Chile o Brasil- y convierte a los legisladores en actores clave para aprobar la agenda del Presidente. Se genera entonces una cooperación entre poderes que autores como Linz (1990) o Valenzuela (1994) consideraron poco probable en los sistemas presidencialistas. Sin embargo, los gobiernos de coalición del Cono Sur han evidenciado que esta cooperación es posible y exitosa y ha sabido solventar los conflictos de intereses mediante la distribución de cargos ministeriales y técnicos entre aliados (Muller y Strom 2003; Santos 2006; Amorin 2006).

La vocación generalista de una alianza tiene como objetivo consensuar agendas programáticas que de alcanzar el gobierno, se convertirán en política pública, en detrimento de la distensión de las fronteras entre gobierno y oposición. Los casos de la «Concertación por la Democracia, 19902010» y «Por un Chile Justo, 2012» ${ }^{129}$ en este país del Cono Sur, el de la «Izquierda Plural» en España ${ }^{130}$ o el «Acuerdo de Santo Domingo, 1994» en la República Dominicana, serían ejemplos

\footnotetext{
${ }^{129}$ Coalición formada para las elecciones municipales de 2012, compuesta por el Partido Comunista de Chile , Izquierda Ciudadana, Izquierda Cristiana, el Partido por la Democracia y el Partido Radical Socialdemócrata.

${ }^{130}$ Coalición política constituida para las elecciones generales de 2011, formada por los partidos Izquierda Unida, Iniciativa per Catalunya Verds, Esquerra Unida i Alternativa, Chunta Aragonesista, Socialistas
} 
de concertación programática. En el reverso de la moneda, la conquista del poder perseguida con la alianza electoral también puede estar acompañada por objetivos o beneficios de club como no perder el registro o acceder a las redes del patronazgo en las instituciones en el caso de los partidos minoritarios aliados. Bajo esta modalidad de vocación particularista se catalogan las alianzas formalizadas por los partidos dominicanos en la etapa post carismática cuyos costes son la pérdida de identidad de los partidos minoritarios aliados o la cesión de parte del botín, en caso del partido oficialista ${ }^{131}$. Así sucedió en la alianza de los 13 partidos que acompañó al oficialismo en las presidenciales de 2012 o el «Bloque Progresista» que agrupaba a los partidos que apoyaban al hoy ex Presidente Leonel Fernández en las legislativas de 2010 y por el que recibían el apelativo de «leonelistas». Este cariz más personal que programático también estuvo presente en la heterogénea coalición de partidos alineados bajo la figura de Álvaro Uribe por el reparto burocrático y la pugna por la política regional en 2006. Si bien ambos casos comparten la lucha por contabilizar puestos, en el colombiano, los ministros de los partidos «uribistas» aliados gozaban de una relativa aunque tímida autonomía frente al Presidente (González 2006).

El tercero de los instrumentos es el Transfuguismo. Se entiende por transfuguismo cuando un representante elegido en las listas de un partido se pasa a las filas de otro antes de concluir el mandato de representación por el que fue electo. Esta alteración supone una estafa a la voluntad popular expresada en las urnas, así como una traición al mandato imperativo entre principal y agente (Seijas 2000). En los últimos tiempos se ha generalizado el uso del término "tránsfuga" extendiéndolo a todas las migraciones partidarias y no solo a aquellas que tienen lugar en las instituciones representativas. De esta manera, junto al mandato de representación de los cargos electivos (senadores, diputados, alcaldes y regidores) estaría también el mandato ideológico de los cargos de designación y cargos políticos. La diferencia de mandatos ha llevado a algunos autores a denominar a estos últimos "trashumantes" (Castellano 1994). La decisión de migrar a otra fuerza política puede ser explicada desde la óptica de la elección racional; un «deseo de mejorar sus expectativas, ya que suelen abandonar grupos que en su opinión les ofrecen pocas garantías de llevar a cabo sus políticas preferidas, facilitarles el acceso a cargos o permitirles la reelección» (Colomer 1990:253). El monopolio partidario en la selección de candidatos y los bajos costes de transacción, son factores determinantes a la hora de abandonar la formación política de origen y valorar el escenario de utilidad/oportunidad que ofrece el transfuguismo. Por la propia naturaleza de

Independientes de Extremadura, Batzarre, Los Verdes, Gira Madrid-Los Verdes, Els Verds del Pais Valencia, Els Verds Opció Verda, Canarias por la Izquierda, Iniciativa por El Hierro y el Partido Democrático y Social de Ceuta. La coalición obtuvo el 6,92\% de los votos, once parlamentarios y grupo parlamentario propio.

${ }^{131}$ Tras las elecciones presidenciales de 2012, el nuevo presidente Danilo Medina mediante decreto ubicó a los principales dirigentes de los partidos aliados en la Administración Pública: Carlos Morales Troncoso presidente del PRSC como Ministro de Relaciones Exteriores; Federico Antún Batlle del PRSC en el Banco Nacional de Fomento de la Vivienda y la Producción; Marino Vinicio Castillo presidente de la FNP como Director General de Ética e Integridad Gubernamental; José Ricardo Taveras secretario general de la FNP como Director General de Migración,; Pedro Corporán presidente del PUN como Presidente del Instituto de Desarrollo y Crédito Cooperativo; Luis Acosta Moreta presidente de la UDC como Director General de Desarrollo de la Comunidad; Rafael Peguero Méndez presidente del PPC como Director del Instituto para el Desarrollo del Suroeste; Elías Wessin Chévez presidente del PQDC como Director General de Bienes Nacionales; José Francisco Peña presidente en funciones del BIS como Administrador de la Lotería Nacional; Maritza Lopez presidenta del PAL como Administradora General del Instituto de Auxilios y Viviendas; Jose González Espinosa presidente del PTD como Director Ejecutivo del Fondo de Promoción de las Iniciativas Comunitarias; Radhames Zorrilla Ozuma presidente del PCR como Director del Instituto Nacional de Estabilización de Precios; Antolín Polanco presidente del PASOVE como Director Ejecutivo del Consejo Nacional de Población y Familia; Nelson Didiéz presidente del PDP como Embajador adscrito al Ministerio de Relaciones Exteriores; y Andrés Vanderhorst hijo del presidente del PLRD como Director Ejecutivo del Consejo Nacional de Competitividad con rango de Ministro. Ver Pérez, Omar, en Observatorio Político Dominicano, de 31 de agosto de 2012. 
esta modalidad de cooperación estratégica, cabría pensar que el nivel de extensión de los beneficios disfrutados no va más allá de aquellos que gozan sus protagonistas, sin embargo, el transfuguismo puede ser un instrumento para el realineamiento del sistema de partidos. El traspaso de lealtades de un partido a otro también permite a escisiones partidarias o fuerzas en proceso de disolución integrarse en el sistema de partidos. De esta manera, se reduce la oferta partidista pero se diversifica el espectro ideológico programático de la opción de acogida, quien también se beneficiaría del trasvase de estos electores que han quedado expuestos a la conquista.

El cambio de adscripción partidista puede hacerse con el fin de conseguir un mejor puesto en la lista electoral y el amparo privilegiado que otorga el partido de acogida. Bajo esta categoría se clasificarían las experiencias trashumantes y transfuguistas en la República Dominicana, aunque éstas últimas a relativa distancia de la dimensión que el fenómeno alcanza en la arena parlamentaria guatemalteca o brasileña ${ }^{132}$. La vinculación personalista entre políticos y ciudadanos minimiza el coste del voto de castigo por el incumplimiento del mandato de representación, aunque menoscaban la confianza de los ciudadanos en la clase política. Este tipo de colaboración tiene lugar también en contextos de competición programática y sistemas de partido institucionalizados como el español, donde a finales de los años 90 el «Acuerdo Sobre un Código de Conducta Política en relación con el Transfuguismo en las Corporaciones Locales» trataba de enfrentar el fenómeno ${ }^{133}$. Mientras que en España los partidos llegaron a un acuerdo para regular este acto de deslealtad política, en República Dominicana sigue siendo un tema pendiente en el Ante Proyecto de Ley de Partidos Políticos que lleva más de una década estancado en trámite parlamentario. Por otro lado, el transfuguismo puede ser el mecanismo para el realineamiento del sistema de partidos en momentos de especial relevancia política. Este tipo de reacomodo generalista y de carácter permanente puede realizarse a título individual -como hicieran algunos integrantes de UCD que pasaron a AP entre los años 1980 y 1982; en grupo -camino por el que optara en México parte de la dirigencia del PST que pasó a integrar en los ochenta las filas del PMS y que se reconvertiría en 1989 en el actual PRD; o la migración de todo el partido -reacomodo que se produjo en el PSP cuando se integró en 1978 al PSOE en la transición española o en IU cuando en 1986 albergó en su seno al histórico PCE.

132 En Guatemala, en la Legislatura 2008-2012, de los 158 congresistas 56 eran tránsfugas (35\% de los diputados). En Brasil, en la Legislatura 2003-2006, de los 513, un total de 193 cambiaron de afiliación (37,6\% de los diputados). En República Dominicana, en la Legislatura 2002-2006 solo un diputado del PRD y uno del PRSC pasaron a las filas del PLD.

${ }^{133}$ Firmado el 7 de Julio de 1998, renovado el 26 de Septiembre de 2000 y actualizado en el 2006 con la suma de nuevos firmantes. Ver documento en http://www.seap.minhap.gob.es/dms/es/areas/politica_local/sistema_de_informacion_local_-SIL/comision_de_seguimiento_del_pacto_antitransfuguismo/comision_de_seguimiento_del_pacto_antitransfugui smo/parrafo/012/1-2AcuerdoAntitransfuguismo-2006.pdf 
Tabla 3.4.2.1 Tipología cooperación estratégica

\begin{tabular}{|c|c|c|c|c|c|c|}
\hline & Instrumento & Orientación & Objeto & Incentivos & Costes & Ejemplos RD \\
\hline |: & Pactos & 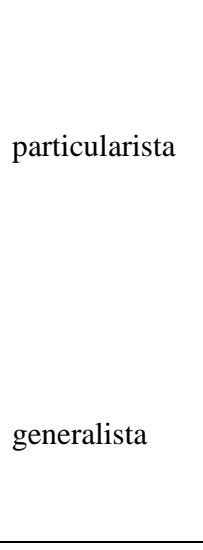 & $\begin{array}{l}\text { Control } \\
\text { partidista de los } \\
\text { recursos e } \\
\text { instituciones del } \\
\text { Estado }\end{array}$ & $\begin{array}{l}\text { Mantenimiento statu quo. } \\
\text { Supervivencia institucional. } \\
\text { Limitar la representación de } \\
\text { otras fuerzas políticas. } \\
\text { Acceso al patronazgo. } \\
\text { Fijar línea de actuación del } \\
\text { Estado en asuntos clave } \\
\text { para el desarrollo nacional. } \\
\text { Fluidez institucional. } \\
\text { Gobernabilidad } \\
\text { Democrática. }\end{array}$ & $\begin{array}{l}\text { Disconformidad/ } \\
\text { conflicto con la } \\
\text { facción o partidos } \\
\text { excluidos del pacto. } \\
\\
\text { Se reparte el éxito de } \\
\text { la conquista entre } \\
\text { partidos y se limita su } \\
\text { rédito electoral } \\
\text { partidista. }\end{array}$ & $\begin{array}{c}-\ll \text { Solidaridad Económica, } \\
\text { 1990» } \\
-« \text { Gobernabilidad, Desarrollo } \\
\text { Local y Nacional, 2006» } \\
-\ll \text { Pacto Corbatas } \\
\text { Azules,2009» } \\
\text {-Reparto } \\
\text { Financiamiento,2005 } \\
\text {-Umbral electoral, } 2010 \\
\text {-«Pacto por la Democracia, } \\
\text { 1994» }\end{array}$ \\
\hline 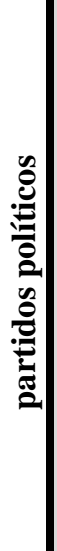 & $\begin{array}{l}\text { Alianzas } \\
\text { electorales }\end{array}$ & 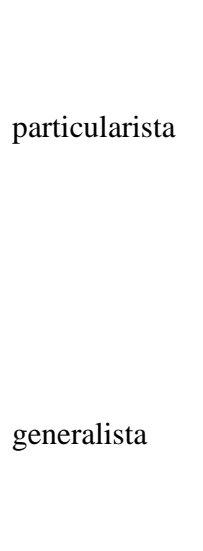 & $\begin{array}{c}\text { Definir Políticas } \\
\text { de Gobierno }\end{array}$ & $\begin{array}{l}\text { Mejores posibilidades de } \\
\text { elección del partido. } \\
\text { Salvar el umbral electoral. } \\
\text { Acceso al patronazgo. }\end{array}$ & $\begin{array}{c}\text { Pérdida de identidad } \\
\text { partidaria/autonomía } \\
\text { del partido minoritario } \\
\text { aliado. } \\
\text { Se comparte la cuota } \\
\text { de recursos. } \\
\\
\text { Se desdibujan } \\
\text { fronteras entre } \\
\text { gobierno y oposición. } \\
\text { Éxito compartido, } \\
\text { limita su rédito } \\
\text { electoral partidista. }\end{array}$ & $\begin{array}{c}\text {-«Alianza Rosada, 2006» } \\
\text {-«Bloque Progresista,2010» } \\
\text {-Alianzas Presidenciales } \\
\text { 2000-12 } \\
\text {-Alianzas Totales/Parciales } \\
\text { en Legislativas y Municipales } \\
02-10\end{array}$ \\
\hline : & $\begin{array}{l}\text { Transfuguismo } \\
\text { Trashumancia }\end{array}$ & particularista & $\begin{array}{l}\text { Puesto en la } \\
\text { lista electoral o } \\
\text { cargo directivo } \\
\text { en agencia } \\
\text { pública }\end{array}$ & $\begin{array}{l}\text { Supervivencia en el sistema } \\
\text { de partidos y en las } \\
\text { instituciones de la } \\
\text { representación de escisiones } \\
\text { de un partido y/o partidos } \\
\text { en proceso de disolución. }\end{array}$ & $\begin{array}{l}\text { Voto de castigo de } \\
\text { electores por estafa al } \\
\text { mandato de } \\
\text { representación. } \\
\text { Pérdida de confianza } \\
\text { en la clase política. }\end{array}$ & $\begin{array}{c}- \text { Ttrashumantes individuales } \\
-\ll \text { Balagueristas Auténticos, } \\
\text { 2010» } \\
-« \text { Consenso Electoral,2010» } \\
-« \text { Corriente } \\
\text { Balaguerista,2010» }\end{array}$ \\
\hline
\end{tabular}


La capacidad negociadora de la élite política dominicana ha sido identificada como elemento clave en la construcción de mayorías sorteando las parálisis en situaciones de gobierno dividido y presidentes minoritarios. Con estos propósitos, en la década de los noventa se firmaron dos pactos para remendar el letargo institucional provocado por el cuestionamiento de los procesos electorales. El primero de ellos en 1990. Para romper su aislamiento político Joaquín Balaguer firmaba el "Pacto de Solidaridad Económica", trasladando la crisis al ámbito de la economía, legitimando su gobierno y asegurándose que el empresariado rompía lazos con la oposición (Lozano 2004:106). En 1994 las sospechas dieron paso a la evidencia de fraude y agobiado por la presión internacional, el viejo caudillo firma el "Pacto por la Democracia". Se ponía así fin a la crisis estableciendo por vía constitucional el recorte de su mandato pero mantenimiento de los resultados de las municipales y congresuales, además de la no reelección presidencial inmediata, la doble vuelta y la creación del Consejo de la Magistratura. Si bien estas medidas estaban inspiradas en la democratización del país, al «permitirse la victoria electoral por medio de este proceso sumamente cuestionable, el país sufrió una regresión autoritaria hacia una régimen híbrido democrático-autoritario manteniendo sus características neo-patrimonialistas» (Hartlyn 1995:46).

Desaparecidos los caudillos y en la etapa de la consolidación, la lucha por la democracia ha dado paso al consenso por el reparto de las cuotas de poder entre actores.

El gran hito del consenso interpartidario adoptó la forma de "Pacto por la Gobernabilidad y el Desarrollo Local y Nacional”. Firmado en 2006, oficializó la fórmula para la distribución de puestos públicos entre partidos en los cabildos conocida como "empleomanía". Este pacto surgió como respuesta a los trágicos acontecimientos de Piedra Blanca, donde las disputas por la elección del bufete directivo de su Ayuntamiento se saldaron con la muerte de 4 personas ${ }^{134}$. Este suceso reveló la lucha entre los nuevos patronos surgidos con la descentralización por el control de los empleos públicos municipales. Un año después, los secretarios generales PLD, PRD y PRSC decidían el porcentaje partidario para la designación de los empleados públicos en una fórmula en la que la gobernabilidad se equiparaba al justo derecho de los ganadores a quedarse con el botín del Estado descentralizado y fidelizar a su clientela en las redes de patronazgo. Algunas de las estipulaciones del Pacto de 2006, que se renuevan y actualizan tras cada contienda son ${ }^{135}$ :

\footnotetext{
${ }^{134}$ El suceso ocurrió el 16 de agosto de 2005 en Piedra Blanca (Bonao), cuando dos dirigentes del PLD se presentaron a la oficina del síndico Contreras, donde éste negociaba con el regidor perredeísta Antonio Núñez la conformación del bufete directivo de la sala capitular. Las investigaciones destaparon una trama de sobornos y chantajes para hacerse con la dirección de la sala capitular y así controlar el patronazgo municipal.

${ }^{135}$ El 8 de agosto de 2012 Johnny Jones, Secretario General de la Liga Municipal Dominicana-PRSC, Ignacio Ditrén, Secretario de Asuntos Municipales del PLD, Víctor de Aza-PRD, y Reynaldo Lora del PRSC firmaban el Pacto por la Democracia y la Gobernabilidad Municipal con el objetivo de conformar bufetes directivos de consenso en los cabildos del país.
} 
Tabla 3.4.2.2 Criterios de asignación de cargos y distribución de los empleos del Pacto por la Gobernabilidad y el Desarrollo Local y Nacional ${ }^{136}$

\begin{tabular}{|c|c|}
\hline & CARGOS Y \% DE EMPLEOS PARA EL GANADOR \\
\hline VICTORIA DEL PARTIDO O & Presidencia de la Sala Capitular y Tesorero del Ayuntamiento \\
\hline VICTORIA DEL PARTIDO O & $\begin{array}{l}\text { Encargado de la Junta de Distrito Municipal, Tesorero, } 2 \text { suplentes y el } 60 \% \text { de los } \\
\text { empleos. }\end{array}$ \\
\hline $\begin{array}{l}\text { ALIANZA EN MUNICIPIOS } \\
\text { CON UN DISTRITO }\end{array}$ & «Principio de la Gobernabilidad»: un miembro y un suplente de la Junta de \\
\hline MUNICIPAL & $\begin{array}{l}\text { Distrito y el } 40 \% \text { de los empleados al partido o alianza que facilite la } \\
\text { gobernabilidad. }\end{array}$ \\
\hline $\begin{array}{l}\text { EMPATE EN LA SALA } \\
\text { CAPITULAR }\end{array}$ & $\begin{array}{l}\text { «Principio de la Gobernabilidad»: } 25 \% \text { de la empleomanía al partido o alianza } \\
\text { que facilite la gobernabilidad. }\end{array}$ \\
\hline $\begin{array}{l}\text { MAYORÍA EN LA SALA } \\
\text { CAPITULAR }\end{array}$ & $\begin{array}{l}\text { «Principio de la Gobernabilidad»: } 20 \% \text { de los empleos al partido o alianza que } \\
\text { facilite la gobernabilidad. }\end{array}$ \\
\hline
\end{tabular}

Fuente: Elaboración Propia a partir del Pacto de 2006.

Como reza el título de este pacto, el desarrollo local y nacional del país parece depender de la complacencia de los actores con el acceso a los recursos del Estado y poco con los niveles de calidad de servicios como la educación o la electricidad -sempiternos problemas que nunca han concitado la voluntad de los actores nacionales en un gran pacto de Estado- o con reformas democratizadoras como la elección del Defensor del Pueblo o la futura Ley de Partidos Políticos para las que parece imposible el consenso interpartidario y permanecen en un limbo que dura más de una década ${ }^{137}$.

En 2009 se firmaba el llamado "Pacto de las corbatas azules” entre el entonces Presidente Leonel Fernández y el líder del partido opositor Miguel Vargas Maldonado para consensuar la reelección no consecutiva y otros preceptos de la futura Constitución relativos a la nacionalidad, el número de legisladores y la unificación de las elecciones. Con este pacto se eliminaban 26 artículos previamente aprobados por los asambleístas, tan relevantes como el derecho a una Administración Pública honesta y transparente, la tutela de la salud pública, el derecho de los consumidores a bienes y servicios públicos de calidad, la sanción a personas que proporcionen ventajas a sus amigos o parientes ${ }^{138}$ y la prohibición del mandato imperativo a senadores y diputados ${ }^{139}$. Firmado a título individual y no en representación de sus respectivos partidos, fue criticado por la personalización caudillista del acuerdo, ya que favorecía los liderazgos individuales y debilitaba la institucionalidad

\footnotetext{
${ }^{136}$ Ver disposiciones completas en el Pacto Interpartidario entre el PLD, PRD y PRSC Por la Gobernabilidad y el Desarrollo Local y Nacional, firmado el 11 de agosto del 2006

${ }^{137}$ El Proyecto de Ley de Partidos y Agrupaciones Políticas se introdujo en la Cámara en 1996, desde entonces sigue en proceso de trámite. La Ley del Defensor del Pueblo data de 2001, pero ha pasado más de una década sin que el cargo haya sido asignado y cuya designación requiere el voto de los dos tercios de la Cámara. Al momento de la redacción de este artículo, fue elegida la Sra. Zoila Martínez, militante reformista y ex embajadora en Corea del Sur el 15 mayo de 2013. Su elección ha sido recurrida por defectos en el procedimiento y por ejemplificar el pago al PRSC por el apoyo en la pasada elección presidencial. Organizaciones como Amnistía Internacional había expresado la necesidad de no demorar más la elección del Defensor del Pueblo y que ésta recayese en una persona sin adscripción partidista. Ver al respecto noticias en http://elnuevodiario.com.do/app/article.aspx?id=330829

http://www.diariolibre.com/noticias/2013/05/17/i384052_habia-dejado-ese-sueno-hace-muchos-anos-perodios-quien-dice-cuando.html

${ }^{138}$ Se respetaba la sanción a los que beneficien a familiares, pero no a la red próxima de allegados y amigos, la red de influencia que la literatura sobre clientelismo denomina "amistad instrumental".

${ }^{139}$ Redacción original art. 89.4 proyecto Constitución: "Los legisladores electos no están ligados por mandato imperativo, son libres e independientes en la toma de decisiones en los asuntos sometidos a su aprobación, actúan siempre con apego al sagrado deber de representación del pueblo que los eligió ante quienes deben rendir cuentas". Se justificaba la eliminación alegando que el mandato fortalecería a los partidos.
} 
partidista $^{140}$. La ausencia de representante alguno por parte del PRSC o del resto de las fuerzas políticas ninguneaba a la oposición y allanaba el camino de las aspiraciones presidenciales de ambos candidatos (Benito 2011:385).

Aunque ajenos a la forma explícita del pacto, otros ejemplos del consenso entre las élites de los partidos mayoritarios que buscan su supervivencia institucional y desdibujan el propósito general de las normas, tuvieron lugar en 2005 y 2010 respectivamente. El primero de ellos, cuando la Junta Central Electoral (JCE) aumentó la cuota correspondiente a los partidos mayoritarios (del 75\% al $80 \%$ ) del total del financiamiento público, a la vez que rebajaba el límite del respaldo electoral al $5 \%$ para ser considerado partido mayoritario ${ }^{141}$. Gracias a esta decisión, el PRSC (con un 8,14\% de los votos en las presidenciales de 2004), recibía la misma cantidad que sus contrincantes PRD y PLD, que alcanzaron el $30,6 \%$ y el $49 \%$ de los votos respectivamente ${ }^{142}$. Un pacto entre caballeros tipo cartel que velaba un agravio comparativo y protegía a los partidos históricos ante hipotéticos y futuros descalabros electorales. La ausencia de proporcionalidad en el financiamiento iguala a la baja a los minoritarios -impidiendo su expansión organizativa- y remunera al alza a las tres fuerzas tradicionales ${ }^{143}$.

El segundo se constató en las elecciones legislativas de 2010. La nueva Constitución allanaba el camino de la representación de los partidos minoritarios con la inclusión de 5 diputados nacionales por acumulación para aquellos que superasen el $1 \%$ de los votos válidos. Sin embargo, estos propósitos quedaron anulados, ya que tres meses antes de la elección se aprobaba la Ley 37-10 que excluía del reparto a aquellos partidos minoritarios cuya alianza hubiese conseguido representación, quedando en manos de los dos partidos principales ${ }^{144}$. Aunque ajenos a la forma explícita del pacto, ambas decisiones -emanadas de órganos donde los partidos mayoritarios tienen representaciónresponden a la anuencia de las élites políticas en salvaguardar los espacios de la representación de las tres fuerzas políticas tradicionales y asegurar su financiamiento. A cambio, se cede el disfrute limitado de las redes de patronazgo.

Estos ejercicios de cooperación entre la clase política dominicana muestran que los beneficios partidistas priman frente a los de interés general como el establecimiento de un pacto de Estado en asuntos clave del desarrollo nacional, la representación plural en las instituciones, la proporcionalidad en el financiamiento público o el fomento de la carrera administrativa a nivel municipal. El rédito partidista e individual se impone frente al rédito institucional, corporativizando los beneficios de los resultados democráticos pretendidos.

\footnotetext{
${ }^{140} \mathrm{Al}$ elegir a Vargas Maldonado como su interlocutor, Leonel Fernández resolvía de facto la contienda que a nivel interno se estaba librando en las filas del PRD para renovar su equipo directivo, lo que desató la ira de Hipólito Mejía, quien aspiraba a ser candidato presidencial en 2012.

${ }_{141}$ Artículo 50 de la Ley Electoral. "El $80 \%$ de los fondos públicos se repartirán entre los partidos mayoritarios. a partes iguales. El resto (20\%) a repartir entre los demás partidos políticos".

${ }_{142}$ En las presidenciales de 2008 el PRSC obtuvo el 4,9\% de los votos, no alcanzando el 5\% requerido, y por lo que pasó a recibir 10 millones de pesos, frente a los 127.8 millones de pesos que le hubiesen correspondido de seguir en la categoría de "partido mayoritario".

${ }^{143}$ La ausencia de registro desagregado en el escrutinio de los votos impide a los partidos minoritarios conocer el alcance real de su fuerza de arrastre, importante para determinar su financiamiento. Si el elector marca al partido mayoritario y a uno de sus aliados, el voto se asigna al partido mayoritario, al igual que sucede si el elector decide marcar a dos partidos minoritarios de una misma alianza.

${ }^{144}$ De esta manera, los diputados nacionales quedaron en manos de los dos partidos principales -3 PLD y 2 PRD- mientras que APD, BIS, PQDC o el MODA, que alcanzaron 1,41\%, 1,36\%, 1,13\% y 1,44\%, respectivamente, no pudieron acceder al reparto de escaños. La diputada nacional por acumulación Guadalupe Valdez y ex Subsecretaria de Educación en la Administración de Leonel Fernández 2008-2012, se presentó por la lista del PLD y no por la de APD, partido al que pertenece.
} 


\title{
$\checkmark$ Alianzas Electorales en República Dominicana, 2002-2012
}

A falta de referentes programáticos que sirvan de base a la implementación de políticas públicas consensuadas, la negociación en República Dominicana se ha centrado en concertar el acceso a los puestos clave en la dirección de la Cámara Baja y cargos relevantes como la Liga Municipal o el Tribunal de Cuentas (Marstreintredet 2008). Las situaciones de gobierno dividido y presidentes minoritarios han sido una constante en la vida política del país y el entendimiento entre viejos enemigos como el PRD y el PRSC, no ha dificultado los trabajos en la Cámara ${ }^{145}$ :

\begin{abstract}
"Hasta ahora no registramos ningún proyecto en que el Gobierno, el Presidente y el partido hayan puesto algún interés que haya sido derrotado en la Cámara de Diputados, sino que, por el contrario, han sido aprobados. Pero entendemos que lo que estamos reclamando es justo. Cuestionamos la gran cantidad de reformistas que laboran en el organismo legislativo. Reclamamos que haya un manejo lo más transparente posible por parte de la presidenta de la Cámara en la distribución de los puestos administrativos del organismo legislativo o que al menos se le proporcione la cantidad equitativa que correspondería al PRD"146.
\end{abstract}

El buen entendimiento entre estos adversarios históricos se materializaría en 2006 en la llamada "Alianza Rosada", por la que presentaban candidaturas comunes en 28 provincias y en 3 nominaciones al Senado ${ }^{147}$. En ocasiones, estos arreglos institucionales han venido de la mano de ciertos mecanismos informales de "cooperación", como el pago directo a los legisladores a cambio de apoyo político, o el canje de escaños ${ }^{148}$. La negociación para fijar los términos de las alianzas se basa en determinar cuántos escaños corresponden a cada partido en las circunscripciones seleccionadas $^{149}$. El papel de las comisiones negociadoras es el de decidir quiénes serán los

\footnotetext{
${ }^{145}$ En el 2000, las negociaciones para apoyar al PRSC en un tercer periodo consecutivo en la presidencia de la Cámara Baja, los legisladores del PRD condicionaron su respaldo a la consecución de un "arreglo" para el reparto entre perredeístas y reformistas de los empleos en el órgano legislativo. Los nombramientos de libre designación en el poder legislativo se habían mantenido en un halo de informalidad y secretismo, hasta el punto de desconocer la cuantía de empleados bajo esta modalidad y categoría. En 2012 y en respuesta a la petición realizada por un particular a través de la Ley de Transparencia y Acceso a la Información, el Tribunal Constitucional obligó a la Cámara de Diputados a publicar el número, listado y sueldo de los asesores legislativos. Ver noticias en periódico Listín Diario de 27 de septiembre de 2012. La nómina de los asesores del Congreso en 2006 ascendió a 10.508.628 pesos (290.000 dólares) y la del Senado a 16.470.000 pesos (450.000 dólares). En 2007 el PLD contaba con 6 asesores, 3 el PRD y 14 el PRSC, en materias como relaciones personales, protocolo de ceremonias, bienes raíces, asuntos municipales.

${ }^{146}$ Palabras del diputado Hatuey de Camps, en periódico El siglo, de 9 de agosto de 2001.

${ }^{147}$ Un acuerdo de supervivencia política para el PRSC ya que en las presidenciales de 2004 pasaba de un 21,26\% de votantes al 8,14\%. Los acuerdos senatoriales incluían a Amable Aristy Castro (Presidente de la Liga Municipal Dominicana) en La Altagracia, Víctor Gómez Bergés, en Santo Domingo, y José Hazim Frapier, en San Pedro de Macorís.

148 Acerca de sobornos a legisladores denunciados ver noticias en periódico Listín Diario de 15, 23 y 24 de diciembre de 1998; Listín Diario de 12 del 8 de 2008; El País de 13 de mayo 2009 (el diputado reformista Ramón Rogelio Genao, denunció a Miguel Vargas Maldonado por el intento de soborno a una decena de legisladores del PRSC, ofertándoles candidaturas). Con ocasión de la reforma constitucional, el Presidente Hipólito Mejía en 2006, íba acompañado de un misterioso "hombre del maletín", quien recorría el hemiciclo "comprando legislador por legislador" para que aprobaran la fórmula de la reelección presidencial. Entrevista informante clave del PRD el 5 de agosto de 2009.

${ }^{149}$ En las negociaciones en torno a la reelección no consecutiva de la futura Constitución entre el entonces presidente Leonel Fernández y la cúpula del PRSC, se barajó la posibilidad de ofertar a este partido 10 senadurías a cambio de su apoyo en la futura votación, así como escaños en el PARLACEN, designados en aquel entonces directamente por el Presidente.. En periódico El Caribe de 13 de mayo de 2009 y Diario Libre de 28 de febrero de 2009
} 
candidatos respetando lo conseguido por las agrupaciones en la pasada contienda y negociar "el excedente" (Benito 2010:759):

\begin{abstract}
"Algunos piden senadurías, otros piden diputaciones y regidurías, esta semana nos reuniremos para hacer las contra-propuestas. Nosotros les decimos que mantengan lo que tienen y negociar en base a lo que no tenemos: es decir, lo que sacó el PRD en 2006. No todo, sino prorratear, pero como regla general que cada cual mantenga lo que ganó [...]. Habrá sus excepciones. Míra, cédeme allí que yo te cedo aquí. Cédeme acá que yo te cedo allá, ${ }^{, 150}$.
\end{abstract}

El nivel de competitividad entre las dos opciones mayoritarias PLD y PRD, ha cotizado al alza el precio de los aliados en la boleta electoral. La posibilidad de establecer alianzas totales y parciales en los distintos niveles de representación ha diversificado el número de negociadores, de incentivos y de recursos disponibles al patronazgo. Así, y a modo de ejemplo, en las elecciones de 2010 la candidata oficialista a alcaldesa por el municipio de Villa Bisonó, firmaban ante notario un acuerdo con representantes del partido APD en el que se comprometía a otorgar a los aliados «diez empleos en el Ayuntamiento Municipal de Villa Bisonó a distintos niveles y en los diferentes departamentos; RD \$10,000.00 [USD\$ 240] de ayuda mensual; dos obras municipales de un valor aproximado de RD $\$ 2,000,000.00$ [USD\$ 48,700.00] cada uno; 15 solares y 5 apartamentos» ${ }^{151}$. Un portafolio de opciones que compromete el patrimonio personal del financiador de la alianza, la transparencia en la concesión de obras públicas y la escala salarial de los funcionarios municipales. Si bien clientelismo y corrupción son fenómenos distintos, en ocasiones se cruzan y superponen. En determinadas circunstancias y cuando los normales mecanismos de reproducción del clientelismo no son suficientes, se incorporan circuitos de intercambio adicionales fuera de la legalidad. De esta manera, la corrupción es una vía para la readaptación y pervivencia de las redes clientelares (Máiz, 2003; 2005).

En este mercado aliancista, los partidos minoritarios cooperan entre ellos para maximizar sus oportunidades y evitar el coste de la sanción por la ilegalidad:

"Nosotros que somos un partido chiquito, con las alianzas negociamos para colocar a los nuestros en las instituciones, y entre partidos aliados nos ayudamos y hacemos lo que llamamos «el intercambio»: para evitar que denuncien el nepotismo en las instituciones que nos dan, le pido a alguien de otro partido que me nombre a uno de los míos, por ejemplo en Bienes Nacionales, y yo se lo coloco en La Lotería". ${ }^{152}$

Los recursos del Estado han resultado insuficientes para premiar lealtades a los amigos aliados tras la victoria y en la transacción se ha de recurrir al "rediseño institucional". En la administración 2004-2008, fueron nombrados 56 funcionarios con rango de Secretario de Estado y 320 Subsecretarios, a pesar de que por ley están contempladas 21 Secretarías de Estado y 57 Subsecretarías ${ }^{153}$. Los Ministros sin cartera son también imagen visible del pago tras las alianzas

${ }^{150}$ Entrevista a Reinaldo Pared Pérez, presidente del Senado y portavoz de la comisión negociadora del PLD y PRSC en periódicos Listín Diario y Hoy de 15 de septiembre de 2009.

${ }^{151}$ Ver Contrato firmado por Amantina Escarlett Gómez Garrido, Daysi María del Carmen Padilla Genao, Alejandro Acevedo Santos Cabrera y Paulino Peralta por el PLD y Jesús Peralta Disla, Nancy Altagracia Mercado Genao y Reynaldo Disla Polanco por el APD el 13 de mayo de 2010.

${ }^{152}$ Entrevista con actor clave de partido minoritario aliado al oficialismo.

${ }^{153}$ En la administración 2008-2012 las Secretarías de Mujer, Deportes, Juventud y Trabajo encabezaban el ránking de mayor número de funcionarios que se desempeñan como subsecretarios. Estas dos últimas en aquel entonces en manos de la Alianza por la Democracia (APD), partido aliado del oficialista PLD. El Bloque Institucional Socialdemócrata (BIS), contaba en el periodo 2008-2012 con 23 posiciones en el Ejecutivo peledeísta. El BIS obtuvo el 1,27\% de los votos en las presidenciales de 2008; el 2,53\% en las congresuales; y el 1,71\% en las municipales de 2006. En la administración del PLD 2008-2012, el BIS cuentó con las siguientes posiciones : 1 Secretario de Estado (Administrador de la Lotería Nacional); 2 
electorales. En la administración 2008-2012 se desempeñan como tales representantes del PRD, del FNP, PLRD, PRSC y del MIU ${ }^{154}$. Salvo aislados casos de cargos ministeriales de primer rango en manos del PRSC y APD, la mayoría son puestos de confianza de nivel superior a través de los cuales el partido aliado accede y controla la red de patronazgo en los niveles inferiores de la administración $^{155}$.

Siguiendo con los incentivos desde el sistema de partidos, la polarización (Axelrod 1970), volatilidad y competitividad (Cox, 1997), han sido identificadas por la literatura como determinantes de la cooperación estratégica entre partidos. Cuando la alianza no va acompañada de acuerdo expreso para implementar un paquete de políticas públicas consensuadas, la afinidad ideológica pasa a un segundo plano a la hora de elegir compañeros. En estos casos, la racionalidad pragmática impera sobre la afinidad ideológica. Como demostró Reynoso para el caso de México, la señalización (volatilidad y margen de la victoria) y la competitividad son condicionantes de la mayor probabilidad en las dinámicas de cooperación. Un escenario que se verifica en el actual patrón de competencia interpartidista en República Dominicana. La progresiva mutación del tripartidismo en la «democracia gerontológica» (Polanco 1999) hacia el bipartidismo «satelital» (Espinal 2010) en la etapa de la consolidación democrática, ha generado un escenario en el que PLD y el PRD compiten por atraer a los pequeños partidos que gravitan a su alrededor y cuyo apoyo sentencia en las urnas la alternancia o la continuidad.

Cuanto menor sea la polarización, mayor será la probabilidad y éxito de las alianzas. Como se argumentara en el apartado dedicado a la competición entre partidos de este Capítulo, teniendo en cuenta las autoubicaciones ideológicas de los diputados dominicanos (PELA 1994-2010) en la escala izquierda-derecha de Downs (1957), se ha producido una peregrinación ideológica desde la década de los noventa hasta el escenario actual, donde los tres principales partidos compiten por ser "atrápalotodo" en el centro derecha. La polarización en la Cámara de Diputados ha ido disminuyendo progresivamente hasta alcanzar un 0,04 en la legislatura actual ${ }^{156}$.

Tabla 3.4.2.3 Polarización Cámara de Diputados República Dominicana 1994-2016

\begin{tabular}{|c|c|c|c|c|}
\hline $\mathbf{1 9 9 4 - 1 9 9 8}$ & $\mathbf{1 9 9 8 - 2 0 0 2}$ & $\mathbf{2 0 0 2 - 2 0 0 6}$ & $\mathbf{2 0 0 6 - 2 0 1 0}$ & $\mathbf{2 0 1 0 - 2 0 1 6}$ \\
\hline 1.54 & 1.26 & 0.36 & 0.21 & 0.04 \\
\hline
\end{tabular}

Fuente: Elaboración propia a partir de PELA, Universidad de Salamanca

Subadministradores de la Lotería; 1 Subsecretario de Estado de Turismo; 1 Subsecretario de Estado de Medioambiente; 1 Subsecretario de Estado de Educación; 1 Subsecretario de Estado de Interior y Policía; 1 Subsecretaria de Estado de Relaciones Exteriores, y 2 vicecónsules; 1 Secretario administrativo de la Presidencia; 1 Subsecretario de Estado de Deportes; 1 Subsecretario de Estado de Agricultura; 1 Subsecretario de Obras Públicas; 2 Subsecretario de Estado de Trabajo; 1 Subsecretario de Estado de Industria y Comercio; 1 Subadministrador de comedores económicos; 1 Subdirector del Programa de Medicamentos Esenciales; 1 Subdirector del INAPA; 1 Subdirector del IAD; 1 Subadministrador del Banco Agrícola; y 1 Subsecretario de Salud Pública

${ }^{154}$ Rodolfo Rincón del PRD, Vincho Castillo del FNP, Andrés Vanderhost del Partido Liberal de la República Dominicana, Ángel Lockward del PRSC y Miguel Mejía del MIU.

${ }^{155}$ Carlos Morales Troncoso, presidente del PRSC y Canciller de Relaciones Exteriores bajo el gobierno de Joaquín Balaguer 1994-1996 y en las administraciones del PLD 2004-2008, 2008-2012 y 2012-2016; y Max Puig, presidente del APD, partido aliado al PLD, ejerció como Ministro de Medio Ambiente y Trabajo en 2008-2012.

${ }^{156}$ Polarización medida como distancia que separa en el espectro ideológico a los partidos políticos siguiendo la escala izquierda-derecha (Downs 1957). Autoubicación ideológica diputados 1994-1998: PLD 4,54; PRD 5,17; PRSC 6,5. En 1998-2002: PLD 4,24; PRD 4,85; PRSC 8. En 2002-2006: PLD 6,72; PRD 5,06; PRSC 5,72. En 2010-2016: PLD 6,18; PRD 5,1; PRSC 5,75. Se calcula dividiendo entre 100 el porcentaje de escaños de cada partido, multiplicado por la posición que ocupa cada en la escala 1-10 menos el promedio de las posiciones de cada partido en la escala, al cuadrado. 
Esta afinidad ideológica entre partidos mayoritarios facilita el acercamiento de la veintena de partidos registrados ante la JCE como potenciales aliados. Sin embargo, en la palestra pública se mantiene una retórica de distinción que rememora los tiempos en que los tres líderes carismáticos dominaban la política dominicana. La mayoría de los partidos emergentes han surgido de escisiones de las tres fuerzas tradicionales, por lo que la aproximación es mayor. La adaptación pragmática actual puede observarse en el listado de alianzas y en la variabilidad de las lealtades de una contienda a otra. Tal es el caso del PUN, PQDC y el PRN, aliados del PRD en 2004 y compañeros de boleta del PLD en 2008, o el PPC de ideología socialcristiana, nacido de una escisión del PRD, aliado del PRSC en 2002 y compañero del PLD de las últimas citas electorales.

La elasticidad ideológica de las alianzas ha sido una constante en la política dominicana. En 1994, bajo el "Acuerdo de Santo Domingo" se reunieron alrededor del PRD un total de 16 partidos cercanos a la socialdemocracia como el PTD, pero también de centro derecha como el PNVC y el PQDC $^{157}$. Por el otro lado, el PLD decidió buscar apoyo en la conservadora FNP a pesar de ser el primero un partido que se reconocía de centro izquierda en sus estatutos. La victoria de José Francisco Peña Gómez en la primera vuelta unirá a dos enemigos históricos -Bosch y Balaguerquienes bajo el nombre de «Frente Patriótico» defenderán la patria ante la previsible victoria del líder negro y de origen haitiano. Este apoyo histórico marcará el punto de referencia para la atracción de las fuerzas conservadoras reformistas a las filas peledeístas en la etapa post caudillos (Lozano 2004). Estas dos alianzas formalizadas en 1994, serían las únicas en las que la orientación generalista - de vocación socialdemócrata la primera y nacionalista patriótica la segunda- prima sobre la naturaleza particularista de la colaboración.

La clave del éxito del partido oficialista PLD radica en su paulatina desideologización, virando desde el marxismo de las fuerzas vinculadas a Juan Bosch en la década de 1970 al pragmatismo conservador actual. Ello se traduce en la arena electoral en una habilidad camaleónica del ex Presidente Leonel Fernández para presentarse ante los votantes como "heredero de las fuerzas históricas del balaguerismo" por un lado, legatario del boschismo y continuador de su revolución democrática por otro, y anfitrión de los tránsfugas del PRD y de los pequeños partidos aliados (Benito 2011:381). Bajo la sombrilla del «Bloque Progresista» aliado al PLD se concentraron en 2010 partidos tan dispares como el BIS, nacido de una escisión del PRD; el PPC de ideología socialcristiana fundado por un disidente del PRD; el PLRD de Andrés Van der Horst, quien por más de 20 años permaneciera junto a Joaquín Balaguer; el Partido de los Trabajadores (PTD); el PUN que recoge en su declaración de principios el humanismo cristiano; o el APD de ideología socialdemócrata.

Los resultados de las últimas contiendas revelan el valor estratégico de las alianzas y confirman la hipótesis de la señalización en el sistema de partidos dominicano. El estrecho margen de victoria y la volatilidad «disparan la señal de alarma y hace que los partidos se alíen en la siguiente elección con la expectativa de producir un resultado más favorable» (Reynoso 2011:15). El coste de una hipotética pérdida de registro y quedar fuera del reparto de los recursos del Estado por no alcanzar el umbral del $2 \%$, superan el coste del menoscabo en la identidad partidaria propia, obligando a los minoritarios a competir en alianza con los mayoritarios PLD y PRD. Esta dinámica observada en República Dominicana confirma la hipótesis que apuntara Cox (1997) acerca de la reducción del número de contendientes y la reacción por parte de los partidos que imitan la estrategia aliancista en

${ }^{157}$ El PQDC ha sido aliado del PRSC en 1986 y 1990; del PRD en el año 2000; y del PLD en 2008, 2010 y 2012. Gracias al apoyo su presidente se ha desempeñado como Secretario de Estado sin cartera, en la Dirección de Pasaportes y en la de Bienes Nacionales. En 2012 destituido por acusaciones de corrupción en su gestión. 
un escenario de reñida competencia. El número de contendientes en las elecciones presidenciales se ha reducido en la última década, pasando de 11 candidaturas en 2004 a solo 6 en 2012, pero no así el número de partidos, que ha ido en aumento y en la actualidad alcanza la cifra de 26 registrados ante la $\mathrm{JCE}^{158}$.

En las congresuales de 2010, la diferencia del 3,24 \% que separó a PLD y PRD se convirtió gracias a los aliados del oficialismo en un $12,04 \%$. Esta circunstancia fue más notoria en el ámbito municipal, en el que el PRD superó en número de votos a su contrincante -con una diferencia de un $4,37 \%$ - y que gracias a las alianzas parciales municipales, reduce a un $1,72 \%$ y revierte los resultados, otorgando al partido oficialista el control del 59,3\% de los Ayuntamientos del país. El aumento de los votos nulos -de un 3,2\% en 2006 a un 4\% en 2010- da idea de la complejidad de la boleta electoral dominicana, que entre las razones de nulidad contempla marcar a dos partidos que no pertenezcan a una misma alianza. Circunstancia ésta nada fácil de conocer teniendo en cuenta que son 26 partidos, que partidos aliados en un municipio pueden ser opositores en el municipio vecino y a la vez adversarios a nivel provincial, o que en la pasada contienda fueran compañeros de boleta del PRD y en la actual del PLD.

Tabla 3.4.2.4 Volatilidad electoral agregada, elecciones legislativas 1978-2010

\begin{tabular}{|c|c|c|c|c|c|c|c|c|c|}
\hline & & $78-82$ & $82-86$ & $86-90$ & $90-94$ & $94-98$ & 98-02 & 02-06 & 06-10 \\
\hline \multicolumn{2}{|l|}{ Volatilidad } & 6,6 & 19,65 & 19,7 & 26,2 & 27,17 & 12,68 & 26,35 & 11,0 \\
\hline & 1978 & 1982 & 1986 & 1990 & 1994 & 1998 & 2002 & 2006 & 2010 \\
\hline Margen Victoria & 9,0 & 10,0 & 7,08 & 0,54 & 0,74 & 17,0 & 13,81 & 15.32 & 3,24 \\
\hline
\end{tabular}

Fuente: Elaboración propia a partir de datos de PELA, Universidad de Salamanca

Tabla 3.4.2.5 Resultados \% elecciones legislativas 2002-2010

\begin{tabular}{|l|c|c|cc|cc|}
\hline \multirow{2}{*}{} & \multicolumn{2}{|c|}{$\mathbf{2 0 0 2}$} & \multicolumn{2}{c|}{$\mathbf{2 0 0 6}$} & \multicolumn{2}{c|}{$\mathbf{2 0 1 0}$} \\
\cline { 2 - 7 } & $\begin{array}{c}\text { Sin } \\
\text { Alianzas }\end{array}$ & $\begin{array}{c}\text { Con } \\
\text { Alianzas }\end{array}$ & $\begin{array}{c}\text { Sin } \\
\text { Alianzas }\end{array}$ & $\begin{array}{c}\text { Con } \\
\text { Alianzas }\end{array}$ & $\begin{array}{c}\text { Sin } \\
\text { Alianzas }\end{array}$ & $\begin{array}{c}\text { Con } \\
\text { Alianzas }\end{array}$ \\
\hline PRSC & 24,49 & 25,04 & 10,96 & 22,51 & 6,17 & -- \\
PRD & 41,21 & 42,41 & 31,03 & 23,74 & 38,40 & 39,67 \\
PLD & 28,81 & 30,36 & 46,35 & 52,31 & 41,64 & 51,71 \\
\hline
\end{tabular}

Fuente: Elaboración propia a partir de datos de la JCE

Tabla 3.4.2.6 Alianzas totales elecciones legislativas 1994-2010

\begin{tabular}{|c|c|c|c|c|c|c|c|c|c|c|c|c|c|}
\hline \multicolumn{3}{|c|}{1994} & \multicolumn{3}{|c|}{1998} & \multicolumn{3}{|c|}{2002} & \multicolumn{3}{|c|}{2006} & \multicolumn{2}{|c|}{2010} \\
\hline $\begin{array}{l}\text { PLD } \\
\text { Aliados }\end{array}$ & $\begin{array}{l}\text { PRD } \\
\text { Aliados }\end{array}$ & $\begin{array}{l}\text { PRSC } \\
\text { Aliados }\end{array}$ & $\begin{array}{l}\text { PLD } \\
\text { Aliados }\end{array}$ & $\begin{array}{l}\text { PRD } \\
\text { Aliados }\end{array}$ & $\begin{array}{l}\text { PRSC } \\
\text { Aliados }\end{array}$ & $\begin{array}{l}\text { PLD } \\
\text { Aliados }\end{array}$ & $\begin{array}{l}\text { PRD } \\
\text { Aliados }\end{array}$ & $\begin{array}{l}\text { PRSC } \\
\text { Aliados }\end{array}$ & \begin{tabular}{|l|} 
PLD \\
Aliados
\end{tabular} & $\begin{array}{l}\text { PRD } \\
\text { Aliados }\end{array}$ & \begin{tabular}{|l|} 
PRSC \\
Aliados
\end{tabular} & $\begin{array}{l}\text { PLD } \\
\text { Aliados }\end{array}$ & $\begin{array}{l}\text { PRD } \\
\text { Aliados }\end{array}$ \\
\hline $\begin{array}{l}\text { PLD } \\
\text { ASD } \\
\text { FNP }\end{array}$ & $\begin{array}{l}\text { PRD } \\
\text { BIS } \\
\text { CD } \\
\text { PPC } \\
\text { PTD }\end{array}$ & $\begin{array}{l}\text { PRSC } \\
\text { MCN } \\
\text { PDI } \\
\text { PDP } \\
\text { PLRD } \\
\text { PNVC } \\
\text { PPD } \\
\text { PQD } \\
\text { PRN }\end{array}$ & $\begin{array}{l}\text { PLD } \\
\text { FNP }\end{array}$ & $\begin{array}{l}\text { PRD } \\
\text { PRI } \\
\text { ASD } \\
\text { BIS } \\
\text { PNVC } \\
\text { PPC } \\
\text { PQD } \\
\text { PTD } \\
\text { UD }\end{array}$ & $\begin{array}{l}\text { PRSC } \\
\text { PDP } \\
\text { PLRD } \\
\text { PNVC } \\
\text { PPD } \\
\text { PQD } \\
\text { PNR }\end{array}$ & $\begin{array}{l}\text { PLD } \\
\text { APD } \\
\text { BIS } \\
\text { FNP }\end{array}$ & $\begin{array}{l}\text { PRD } \\
\text { ASD } \\
\text { PRN } \\
\text { PUN } \\
\text { PHD }\end{array}$ & $\begin{array}{l}\text { PRSC } \\
\text { PPC }\end{array}$ & \begin{tabular}{|l|} 
PLD \\
APD \\
BIS \\
FNP \\
PLRD \\
PTD \\
UDC
\end{tabular} & $\begin{array}{l}\text { PRD } \\
\text { ASD } \\
\text { PQDC } \\
\text { PRN } \\
\text { PUN } \\
\text { UD } \\
\text { PHD }\end{array}$ & $\begin{array}{l}\text { PRSC } \\
\text { PDP }\end{array}$ & $\begin{array}{l}\text { PLD } \\
\text { PRSC } \\
\text { APD } \\
\text { BIS } \\
\text { FNP } \\
\text { PQDC } \\
\text { UDC } \\
\text { PTD } \\
\text { PPC } \\
\text { PLRD } \\
\text { PUN } \\
\text { PASOVE } \\
\text { PDP } \\
\text { PAL }\end{array}$ & $\begin{array}{l}\text { PRD } \\
\text { MIUCA } \\
\text { MODA } \\
\text { PCR } \\
\text { PDI } \\
\text { PHD } \\
\text { PNVC }\end{array}$ \\
\hline
\end{tabular}

Fuente: Elaboración propia a partir de datos de la JCE

${ }^{158}$ En 2004: PLD, PRD, PRSC, PRI, PPC, ASD, FR, PDP, PNA, MSN, PAD. En 2008: PLD, PRD, PRSC, PRSD, PRI y MIUCA. En 2012: PLD, PRD, PRSC, APD, FA, DXC, ALPAIS. 
En las presidenciales de 2012, el PRD acudió aliado con 5 partidos minoritarios mientras que el oficialista PLD lo hizo de la mano de 13 partidos que transformaron un insuficiente $37,7 \%$ en un victorioso 51,2\% librándole de la temida segunda vuelta. Entre los aliados se encontraba el PRSC que aportó el 5,87\% de los votos a la alianza oficialista con el que eleva su cotización en la negociación por el acceso a los cargos ${ }^{159}$. El PLD no consiguió superar en votos propios al opositor PRD que fue el partido más votado (42,13\%), pero el empuje de sus 5 aliados -con los que sumaba el 46,95\% - no fue suficiente para alzarse vencedor en este juego de suma cero.

Tabla 3.4.2.7 Volatilidad electoral agregada, elecciones presidenciales 1978-2012

\begin{tabular}{|c|c|c|c|c|c|c|c|c|c|c|}
\hline & $\mathbf{7 8 - 8 2}$ & $\mathbf{8 2 - 8 6}$ & $\mathbf{8 6 - 9 0}$ & $\mathbf{9 0 - 9 4}$ & $\mathbf{9 4 - 9 6}$ & $\begin{array}{c}\mathbf{9 6 - 9 6} \\
\mathbf{( 2 a v})\end{array}$ & $\mathbf{9 6 - 0 0}$ & $\mathbf{0 0 - 0 4}$ & $\mathbf{0 4 - 0 8}$ & $\mathbf{0 8 - 1 2}$ \\
\hline Volatilidad & 10,24 & 12,37 & 14,56 & 27,03 & 28,79 & 10,0 & 40,85 & 38,6 & 14,75 & 15,25 \\
\hline & $\mathbf{1 9 7 8}$ & $\mathbf{1 9 8 2}$ & $\mathbf{1 9 8 6}$ & $\mathbf{1 9 9 0}$ & $\mathbf{1 9 9 4}$ & $\mathbf{1 9 9 6}$ & $\mathbf{2 0 0 0}$ & $\mathbf{2 0 0 4}$ & $\mathbf{2 0 0 8}$ & $\mathbf{2 0 1 2}$ \\
\hline Margen Victoria & 9,7 & 10,14 & 7,05 & 0,29 & 2,49 & 2,51 & 17,49 & 18,35 & 6,37 & 4,4 \\
\hline
\end{tabular}

Fuente: Elaboración propia a partir de datos de la JCE

Tabla 3.4.2.8 Resultados \% elecciones presidenciales 2000-2012

\begin{tabular}{|c|c|c|c|c|c|c|c|c|}
\hline & \multicolumn{2}{|c|}{2000} & \multicolumn{2}{|c|}{2004} & \multicolumn{2}{|c|}{2008} & \multicolumn{2}{|c|}{2012} \\
\hline & $\begin{array}{c}\text { Sin } \\
\text { Alianzas }\end{array}$ & $\begin{array}{c}\text { Con } \\
\text { Alianzas }\end{array}$ & $\begin{array}{c}\text { Sin } \\
\text { Alianzas }\end{array}$ & $\begin{array}{c}\text { Con } \\
\text { Alianzas }\end{array}$ & $\begin{array}{c}\text { Sin } \\
\text { Alianzas }\end{array}$ & $\begin{array}{c}\text { Con } \\
\text { Alianzas }\end{array}$ & $\begin{array}{c}\text { Sin } \\
\text { Alianzas }\end{array}$ & $\begin{array}{c}\text { Con } \\
\text { Alianzas }\end{array}$ \\
\hline PRSC & 24,60 & -- & 8,14 & 8,65 & 4,59 & -- & 5,87 & -- \\
\hline PRD & 44,84 & 49,87 & 30,67 & 33,65 & 38,57 & 40,48 & 42,13 & 46,95 \\
\hline PLD & 23,58 & 24,94 & 49,02 & 57,11 & 44,94 & 53,83 & 37,7 & 51,2 \\
\hline
\end{tabular}

Fuente: Elaboración propia a partir de datos de la JCE

Tabla 3.4.2.9 Alianzas electorales totales elecciones presidenciales 2000- 2012

\begin{tabular}{|c|c|c|c|c|c|c|c|c|c|c|c|c|c|c|c|c|c|}
\hline \multicolumn{4}{|c|}{2000} & \multicolumn{6}{|c|}{2004} & \multicolumn{4}{|c|}{2008} & \multicolumn{4}{|c|}{2012} \\
\hline $\begin{array}{c}\text { PLD y } \\
\text { Aliados }\end{array}$ & 24.9 & \begin{tabular}{|c} 
PRD y \\
Aliados
\end{tabular} & 49.8 & $\begin{array}{c}\text { PLD y } \\
\text { Aliados }\end{array}$ & 57.1 & $\begin{array}{c}\text { PRD y } \\
\text { Aliados }\end{array}$ & 33.6 & $\begin{array}{l}\text { PRSC y } \\
\text { Aliados }\end{array}$ & 8.6 & $\begin{array}{c}\text { PLD y } \\
\text { Aliados }\end{array}$ & 53.7 & $\begin{array}{c}\text { PRD y } \\
\text { Aliados }\end{array}$ & 40.5 & $\begin{array}{l}\text { PLD y } \\
\text { Aliados }\end{array}$ & 51.2 & $\begin{array}{c}\text { PRD y } \\
\text { Aliados }\end{array}$ & 46.9 \\
\hline PLD & 23.5 & PRD & 44.8 & PLD & 49.0 & PRD & 30.6 & PRSC & 8.1 & PLD & 44.8 & PRD & 38.6 & PLD & 37.7 & PRD & 42.1 \\
\hline BIS & 1.3 & UD & 1.9 & BIS & 2.7 & PQDC & 0.6 & PNVC & 0.5 & APD & 1.9 & PVUD & 0.7 & PRSC & 5.8 & MODA & 2.0 \\
\hline & & PRI & 0.5 & APD & 2.3 & PRN & 0.3 & & & BIS & 1.2 & ASD & 0.4 & BIS & 1.5 & PRSD & 1.3 \\
\hline & & PQD & 1.6 & PTD & 0.6 & PUN & 1.2 & & & PUN & 0.3 & MODA & 0.4 & UDC & 0.7 & PHD & 0.7 \\
\hline & & PNVC & 0.2 & UDC & 0.8 & UD & 0.5 & & & PTD & 0.7 & & & PQDC & 1.3 & PDI & 0.2 \\
\hline & & PDP & 0.3 & PLRD & 0.3 & PHD & 0.1 & & & PQDC & 0.9 & & & FNP & 0.7 & ASD & 0.4 \\
\hline & & ASD & 0.2 & FNP & 1.0 & & & & & PLRD & 0. & & & PTD & 0.5 & & \\
\hline & & & & & & & & & & UDC & 0.9 & & & PPC & 0.4 & & \\
\hline & & & & & & & & & & PRN & 0.2 & & & PDP & 0.2 & & \\
\hline & & & & & & & & & & PDP & 0.2 & & & PCR & 0.5 & & \\
\hline & & & & & & & & & & PPC & 0.5 & & & PUN & 0.2 & & \\
\hline & & & & & & & & & & & 1.1 & & & PLRD & 0.2 & & \\
\hline & & & & & & & & & & & & & & PAL & 0.4 & & \\
\hline & & & & & & & & & & & & & & PASOVE & 0.3 & & \\
\hline
\end{tabular}

Fuente: Elaboración propia a partir de datos de la JCE

En cuanto a los incentivos desde el sistema electoral, como se argumentara en el apartado dedicado a las reglas electorales, la desproporción, la doble vuelta y el umbral electoral son las variables que inciden en la mayor propensión a la formación de alianzas. En las legislativas de 2006, la

\footnotetext{
${ }^{159}$ Solo una semana después de la cita con las urnas, el vocero del Bloque de Diputados del PRSC pedía la presidencia de la Cámara de Diputados ante la sorpresa de los legisladores peledeístas quienes aseguraban que esta posición nunca fue objeto de la negociación. Ver noticia en "Genao pasa factura y pide la presidencia de la Cámara de Diputados". En periódico Diario Libre de 31 de Mayo de 2012.
} 
desproporción era de 12,85 pasando a ser de 1,26 tras el cómputo del voto aliado ${ }^{160}$. El voto por el senador -uninominal y mayoritario- arrastra al del diputado - plurinominal y proporcional- por lo que la ayuda de los compañeros de boleta facilita la conquista del escaño. El sistema de doble vuelta impuesto en 1994 ha convertido a los partidos aliados en piezas clave para alcanzar el 50+1. En las elecciones de 2012, los cuatro candidatos de los partidos que osaron presentarse en solitario no alcanzaron la barrera del $2 \%$ y perdieron su registro. Por el contrario, aquellos que apoyaron a los dos mayoritarios, quedaron doblemente protegidos: por la Ley Electoral (no pierden su registro) y si acompañaron al ganador, tienen asegurada presencia en las redes de patronazgo de las agencias públicas.

Los partidos minoritarios aliados aceptan ser relegados a la administración pública en una especie de contrato de "outsourcing de personal" por el que éstos pueden seleccionar a su clientela y donde la tipología del "profesional camuflado" deviene necesaria para engrasar la maquinaria del partido clientelar. En esta tarea, como muestra la casuística, perviven los patrones neo patrimoniales y nepotistas que han caracterizado el ejercicio de la política en República Dominicana ${ }^{161}$. El aumento progresivo del respaldo electoral a los partidos aliados confirma la eficacia de esta modalidad de presidencialismo que comparte la gestión clientelar del Estado con sus aliados. Esta modalidad afecta al sistema de partidos, en el que proliferan los nuevos patronos, pero no nuevas opciones partidistas con capacidad de ejercer la oposición. Los resultados electorales de 2012 reflejan la encrucijada que enfrentan los partidos clientelares en el poder: el aumento de las expectativas clientelares por un lado, impide al partido oficialista dar satisfacción a todas ellas y por otro, incrementa la distancia e intermediarios entre el patrón y los nuevos clientes. Estos nuevos clientes se insertan en un círculo de confianza más cerrado -el del partido minoritario aliado- con menor competencia entre clientes, lo que les permite estrechar lazos con un patrón más accesible y que cuenta con la autorización del patrón principal para acceder al botín del Estado. Pero no se comparte el gobierno, que sigue quedando en manos del partido mayoritario y donde el hiper presidencialismo informal minimiza las posiciones ministeriales.

\section{$\checkmark \quad$ La Trashumancia partidaria en República Dominicana}

En la República Dominicana las migraciones partidarias tienen lugar en los meses previos a la consulta en las urnas y en la etapa de conformación de la boleta electoral. Este fenómeno abarca tanto a candidatos oficiales a cargos electivos como a la dirigencia alta y media de las organizaciones partidistas. Si los primeros buscan mayores posibilidades de elección, el resto muestra su lealtad al partido con mejores opciones y que controlará las redes de patronazgo tras la victoria $^{162}$. Puesto que en ambos casos los electores no han emitido el mandato de representación y son conocedores de las intenciones de los políticos, se trataría de "trashumantes" o simples

\footnotetext{
${ }^{160}$ Calculada según Índice de cuadrados mínimos de Gallagher.

${ }^{161}$ La gestión de la Lotería Nacional ha recaído en las últimas administraciones en manos del BIS como pago por su apoyo al PLD. Al frente de la institución estuvo Francisco Peña Guaba, hijo del histórico José Francisco Peña Gómez y presidente del BIS, y en 2012 pasó a manos de su hijo, Francisco Peña Tavárez, en lo que algunos analistas interpretaron como una estrategia de Leonel Fernández para conquistar de nuevo al presidente del BIS como aliado en las presidenciales de 2012. La Liga Municipal Dominicana ha sido un feudo del PRSC y del senador Amable Aristy. Obligado a renunciar por las sospechas de corrupción, dejó en 2010 su presidencia en manos de su primo Fidias Aristy.

${ }^{162}$ Reformistas tránsfugas como Humberto Salazar fueron nombrados en COPRESIDA, Ángel Lockward embajador en Colombia, Héctor Rodríguez Pimentel en el INDRHI, Modesto Guzmán en INPOSDOM, Arístides Fernández Zucco en la CNE durante la gestión 2008-2012. Durante las negociaciones en posible alianza PRSC-PLD en 2010, Antún Batlle, ex presidente del PRSC fue nombrado gerente del Banco Nacional de Fomento de la Vivienda y la Producción. En periódico Hoy, del 17 de marzo de 2010.
} 
nómadas oportunistas. La mayoría de las trashumancias han tenido lugar desde las filas del PRSC. Durante los meses previos a las elecciones legislativas de 2010 cinco legisladores reformistas se juramentaron por el PRD, mientras que otros presentaron su renuncia formal ${ }^{163}$. Tras la muerte de Joaquín Balaguer, se ha producido una estampida de dirigentes que negocian de forma individual su apoyo al partido gobernante a cambio de mantenerse en de las instituciones públicas. El ejemplo más notorio es el del otrora presidente del PRSC y Ministro de Relaciones Exteriores en los gobiernos del PLD (2004-2014), líder del segundo partido opositor, parte del ejecutivo oficialista e imagen del gobierno dominicano en el exterior. Una presencia institucional que no guarda relación con su desempeño en las urnas y que desdibuja las fronteras entre partidos gobernantes y partidos en la oposición. Con ocasión de las legislativas de 2010, reformistas disidentes organizados bajo el nombre de "Balagueristas Auténticos", "Consenso Electoral" y "Corriente Balaguerista"164, se integraron a la alianza oficialista conocida como "Bloque Progresista". A cambio, el Presidente Fernández acordó proporcionarles lugares en la papeleta electoral ${ }^{165}$. La naturaleza ad hoc de estas agrupaciones obstaculiza el realineamiento del sistema de partidos, ya que, como ha sucedido en algunos casos, nada impide que sus integrantes regresen a la organización matriz o cambien de compañero en una próxima contienda. Este baile de disidencias fueron denunciados por el presidente de la Cámara de Diputados que se lamentaba de que los partidos se convirtieran en "carros fúnebres...que recogen dirigentes derrotados u olvidados por sus organizaciones" ".

El transfuguismo en República Dominicana ha pasado a formar parte del repertorio de recursos movilizadores de los partidos en las contiendas electorales. Junto a las tradicionales actividades proselitistas, se realizan actos de exhibición transfuguista en los que grupos de dirigentes exhiben su nueva lealtad partidista. La mutación se reconceptualiza así como muestra del poder de atracción y fuerza entre los contendientes mayoritarios. Los bajos costes de salida de la organización originaria hacen que el trashumante sea una nómada de ida y vuelta. Muchos de estos hijos pródigos de la política dominicana regresan al seno partidista y en los casos más pintorescos, incluso después de haber abrazado el "rojo", el "morado" y el "azul"167. No hay sanción legal, ya que la expulsión de más de 200 reformistas tránsfugas adoptada por el PRSC fue revocada por el Tribunal Superior Electoral en $2013^{168}$. Con esta decisión se daba cobertura judicial a la trashumancia partidaria, favoreciendo las migraciones oportunistas y menoscabando la institucionalidad del sistema de partidos. El país se distanciaba así de otras democracias de la Región como Colombia o Brasil, que ponían freno a la infidelidad partidaria con el Acto Legislativo 1 de 2009 o la sentencia del Tribunal

163 Con Víctor Gómez Casanova se sumaron al proyecto de Miguel Vargas Maldonado del PRD los dirigentes reformistas Annie Felipe, de la Comisión de Finanzas, y el senador de La Altagracia, Germán Castro; los diputados Agne Berenice Contreras de Elías Piña, Remberto Cruz, de Espaillat, Sergio Cedeño de La Altagracia y Radhamés Fermín, de Santiago. El senador Noé Sterling Vásquez de la provincia de Barahona presentó su renuncia, alegando que "en el PRSC se habían invertido los valores del código político que Balaguer nos enseñó”. En periódico Clave, de 4 de junio 2009 y Listín Diario, de 22 de mayo de 2009.

${ }_{164}$ Lideradas por Modesto Guzmán, Alexandra Izquierdo y Héctor Rodríguez Pimentel respectivamente.

165 Así lo reconocían los protagonistas tras la negociaciones que tuvieron lugar en el Palacio Nacional dos meses antes de las elecciones: "Nos sentimos muy satisfechos con la recepción y con las decisiones del presidente Fernández a favor de los grupos que han estado gravitando a su alrededor, y él nos ha dejado un espacio en la boleta electoral". Declaraciones en periódico Listín Diario de 14 de marzo de 2010

${ }^{166}$ Declaraciones de Julio César Valentín, en periódico Hoy de 3 de marzo de 2010. Uno de los casos más significativos ocurrió en Santiago, feudo del PRSC durante más de dos décadas. La alianza PLD-PRSC desplazó a un histórico del partido oficialista que se pasó al PRD y se hizo con las preferencias del $45 \%$ del electorado, poniendo por primera vez en manos perredeístas la segunda ciudad del país.

${ }^{167}$ Colores identificativos del PRSC, PLD y PRD respectivamente. Tal es el caso del alcalde de San Cristóbal, quien siendo elegido por el PRSC se pasó al PLD durante su gestión 2006-2010, luego al PRD cuando el partido no respaldó su candidatura en 2010 y regresó al PLD en 2012.

${ }^{168}$ Sentencia del Tribunal Superior Electoral del 1 de Febrero de 2013. 
Supremo brasileño de 2007 que otorgaban al partido la propiedad del escaño. La supervivencia y efectividad del fenómeno en el país parece evidenciar que tampoco existe sanción ciudadana.

Las opiniones de los diputados dominicanos acerca del transfuguismo parlamentario han fluctuado en las últimas dos décadas (PELA 1998-2010). En la legislatura actual el porcentaje mayor de diputados se sitúa entre aquellos que consideran que el representante que abandona su vinculación política debe conservar su escaño. Como muestra la Tabla 3.2.b) 2.1 en 1998 los legisladores perredeístas se posicionaban mayoritariamente a favor de la renuncia al escaño, frente a las opiniones más divididas de PLD y PRSC. Esta opción ha ido perdiendo adeptos progresivamente, con la excepción de la legislatura 2006-2010, cuando perredeístas y reformistas cierran filas frente los posibles desertores de su Alianza Rosada y se posicionan a favor de renunciar al escaño con un $76,9 \%$ y el $83,3 \%$ respectivamente. Solo cuatro años después los representantes del PRD opinaron mayoritariamente que el diputado habría de conservar su escaño. Así lo consideraron el 60,6\% de los perredeístas entrevistados frente al 19,2\% de la legislatura anterior y el 55.3\% de los peledeístas.

Gráfico 3.4.2.1 El diputado debe conservar su escaño si pasa a las filas de otro partido durante la legislatura (\%) 1998-2016

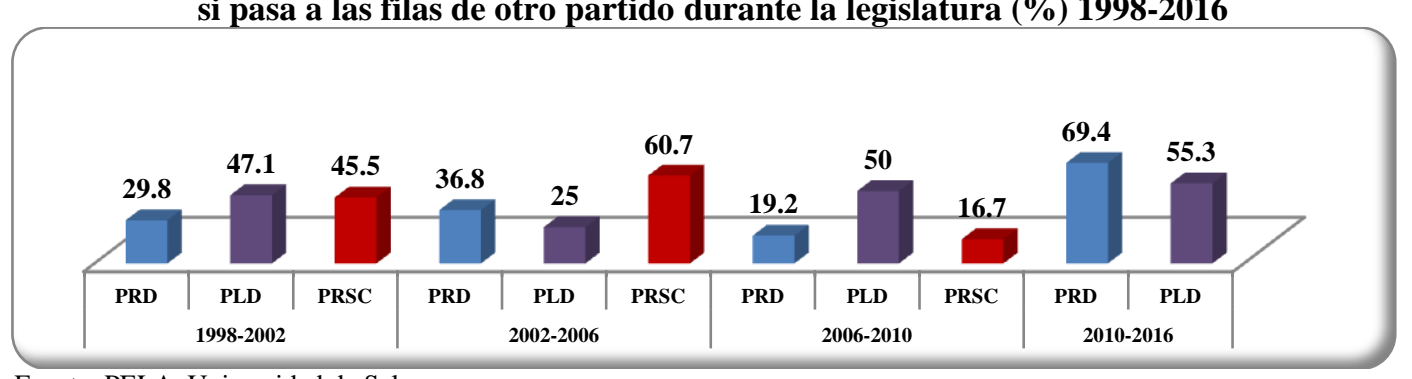

Fuente: PELA, Universidad de Salamanca

La debilidad ideológica de los partidos dominicanos es el caldo de cultivo de la práctica transfuguista, y la politización de la Administración Pública al servicio del partido ganador, el incentivo de la trashumancia de ida y vuelta. Esta cooperación estratégica entre candidatos apunta a un escenario de tipo cartel informal en el que la política deviene una profesión en sí misma y en la que los políticos «tienen carreras de larga duración, acaban por considerar a sus oponentes como colegas profesionales, enfrentados a las mismas presiones, con similares deseos de seguridad laboral y con los que habrá que compartir asuntos a largo plazo. La estabilidad se convierte en algo más importante que el triunfo» (Katz y Mair, 2004, p.36). Y como ejemplo, resultan ilustrativas las justificaciones de algunas de las trashumancias y transfuguismos más mediáticos:

«No ingreso en esta organización política, sino que retorno de unas vacaciones. El retorno no era para buscar posiciones ni candidaturas, sino para ayudar a mi amigo Miguel Vargas Maldonado a consolidar su proyecto presidencial. Cuando me retiré del PRD y pasé a las filas del PLD, lo hice para ayudar a mi otro amigo» 169

[Pedro Caro, peledeísta que pasó a las filas del PRD]

«Rafael Calderón es una persona sensata, de actuar comedido y sería buen candidato, no sólo en el PLD, sino en cualquier partido» 170

[Reinaldo Pared, Presidente del Senado, alabando el paso del líder perredeísta al PLD]

\footnotetext{
${ }^{169}$ En periódico Listín Diario de 12 de enero de 2010.
}

${ }^{170}$ En periódico Hoy de 23 de noviembre de 2009. 
«En política no se debe guardar rencor» ${ }^{171}$

[Amable Aristy, Senador PRSC expulsado por apoyar al PRD y reincorporado por sentencia del TSE]

«En la boleta a la sindicatura de Sosúa hay candidatos reformistas, peledeístas, perredeístas y empresarios» ${ }^{172}$.

[Candidato a alcalde por el PLRD al municipio de Sosúa]

Estos testimonios revelan que la amistad, versatilidad, benevolencia y concierto... se imponen frente a la adscripción partidista, el compromiso ideológico, la rivalidad política y el ejercicio de oposición. El falseamiento de los resultados electorales y la quiebra del mandato de representación son los costes sistémicos del transfuguismo que pueden socavar la confianza de la ciudadanía. En este sentido, República Dominicana ejemplifica la combinación actitudinal que predomina en las democracias de la tercera ola definida como «desafección democrática» (Torcal, 2006), en las que el descontento y la desafección institucional caracterizan la relación de los dominicanos con sus políticos e instituciones. En 2012 el país se situaba por debajo de la media Regional en confianza en las instituciones clave de la representación, siendo los partidos políticos los menos valorados $(32,3 \%)$ y la iglesia católica la institución en la que más confían (72\%) (LAPOP, 2012:143).

Con la cobertura judicial de la trashumancia en la República Dominicana, las fuerzas mayoritarias aseguran su feudo, convirtiendo al resto de los partidos en fuente inagotable de futuros colegas al servicio del mejor postor en una interacción que asegura su dominio cartel del sistema. La decisión judicial que ordena reincorporar al partido a los que se fueron a otras fuerzas políticas, frena el proceso de realineamiento de las terceras fuerzas: su desaparición definitiva o su incorporación a otra fuerza partidista afín. De esta manera se estimula la división y el conflicto, un caldo de cultivo que favorece al partido que domine el arte de conquistar y premiar aliados. La pérdida de identidad partidaria retroalimenta el personalismo caudillista de las élites políticas dominicanas y les evita el coste de la institucionalización.

Las relaciones de cooperación "partido-partido" bajo la forma de alianzas, pactos y trashumancias, siguen un patrón particularista análoga a la relación "políticos-ciudadanos" en la que se fragua la representación en el país. En todas ellas, el consenso genera fluidez institucional inmediata pero a la larga se agudiza la debilidad institucional. Los incentivos que se derivan de la competencia del sistema de partidos permiten que los políticos dominicanos puedan operar bajo esquemas de maximización de sus intereses personales y de su carrera política. La legitimación clientelar del sistema limita el coste electoral del transfuguismo y de las alianzas de ida y vuelta, y re-orienta el ejercicio de accountability hacia uno de tipo particularizado.

\footnotetext{
${ }^{171}$ En periódico Listín Diario de 3 de Febrero de 2013.

172 En Blog del Partido Liberal de República Dominicana (PLRD) http//plrdestructura.blogspot.com/ consultado el 10 de marzo de 2010.
} 


\title{
3) El enemigo en casa: caciques y facciones en los partidos políticos dominicanos.
}

\author{
¿Por qué pelean los compañeros de partido?
}

El objetivo de este epígrafe es mostrar que el faccionalismo en la República Dominicana es la estrategia elegida por los actores políticos frente a las discrepancias internas. Esta opción potencia la lealtad personal frente a la partidista, dificulta la cooperación intrapartidaria en la agregación de intereses colectivos y genera un sistema particularizado de lealtades y recompensas. El repaso a las disputas internas en los tres partidos mayoritarios desde la transición a la actualidad, evidencia que el objeto de las mismas no es ideológico sino de carácter organizativo y de oportunismo electoral. Las facciones en los partidos políticos dominicanos funcionan a modo de maquinaria política y económica para apoyar las aspiraciones personalistas de los sublíderes y canalizar los beneficios del compadrazgo, respondiendo a la tipología de facciones por interés o client group factions. Como demostrara Geddes (1991), existe un nexo causal entre política particularista y faccionalismo al ser éste un obstáculo añadido en la probabilidad de que se lleven a cabo reformas en la profesionalización de la administración pública, ya que el control por el patronazgo se traslada también al ámbito interno del partido.

El grupismo es un fenómeno que caracteriza la vida interna de los tres partidos mayoritarios dominicanos. Lejos de ser una manifestación de la diversidad del debate ideológico interno, refleja el excesivo personalismo en el ejercicio del liderazgo y la representación. Las luchas por el control del partido dividen hoy a «leonelistas» y «danilistas» en el PLD y a «miguelistas» e «hipolitistas» en el PRD. En el caso del PRSC, la búsqueda de rentabilidad en ausencia de un liderazgo aglutinador, despedaza a los reformistas tras la sombra caciquil de Morales Troncoso y Rogelio Genao (partidarios de aliarse al oficialista PLD), Amable Aristy (partidario de aliarse con el opositor PRD) e Ito Bisonó. Un escenario que rememora el antagonismo estratégico entre «oportunistas» y «renovadores» en el PLD de los 90's, las reyertas entre «jorgeblanquistas» y «majlutistas» en el seno del PRD o la adhesión competitiva de los caciques provinciales al líder del PRSC en los años 80's. El grupismo político se remonta al proceso de creación del Estado Nación Dominicano, cuando las luchas por el reclutamiento de clientelas «duartianas», «santanistas», «baecistas», «jinetistas», «colituertas», «velazquistas», «pataprietas» o «patablancas» obstaculizaron el proceso de state-building en el siglo XIX y condicionaron la formación de los protopartidos (Jiménez Polanco 1999: 31). Como evidenciara Shefter (1994), en estos dos momentos históricos se gesta el grado de distinción organizativa entre el espacio de la política y el Estado, determinando que el patronazgo se convierta o no en una herramienta de movilización.

Facción es «toda agrupación al interior de un partido cuyos miembros comparten un sentido común de identidad, propósito y están organizados para actuar colectivamente como un bloque distinto dentro del partido para alcanzar sus metas. Estas metas pueden incluir alguna, varias o todas las siguientes: patronazgo -control del partido y el gobierno por los miembros de la facción-; la satisfacción de intereses locales, regionales o de grupo; influir en la estrategia del partido; influir en la orientación de la política del partido o del gobierno; y/o la promoción de determinados valores con los que los miembros de la facción se identifican» (Zariski 1960:33). En la misma línea, atendiendo a la motivación, Sartori (1980) las agrupa en "facciones por interés" para la obtención de ventajas y prebendas y "facciones por principio" surgidas para la promoción de ideales (Gamboa y Salcedo, 2009:670). Por el contrario, otros autores como Beller y Belloni (1978) en su clasificación trasladan el foco de atención a la estructura organizativa que las sustenta. Así, distinguen entre "factional cliques" o tendencias, "client group factions" o facciones personales y facciones institucionalizadas. Mientras que las primeras se caracterizan por compartir un interés común ya sea de tipo ideológico o material y están escasamente organizadas, las segundas destacan por su nivel de organización y reclutamiento directo por el líder que ejerce un dominio personal sobre los miembros. Por último, las facciones institucionalizadas, cuentan con una estructura 
organizativa altamente burocratizada. Frente a los fines y estructura de las facciones, la literatura contemporánea se ha acercado al fenómeno del disenso partidista a partir del tipo de dinámica que se genera entre ellas para evidenciar la distinta funcionalidad y consecuencias en los sistemas de partidos. En esta investigación sobre las facciones en los partidos políticos dominicanos se utiliza la clasificación de Boucek (2009), que define el fenómeno del faccionalismo como uno de tres caras: una cara cooperativa, una competitiva y una degenerativa.

Tabla 3.4.3.1 Las tres caras del faccionalismo

\begin{tabular}{|c|c|c|c|}
\hline & Cooperativa & Competitiva & Degenerativa \\
\hline $\begin{array}{l}\text { Faccionalismo } \\
\text { como proceso de } \\
\text { Facciones son }\end{array}$ & $\begin{array}{l}\text { División bajo incentivos } \\
\text { centrípetos } \\
\text { Grupos separados }\end{array}$ & Grupos opuestos & $\begin{array}{l}\text { Fraccionamiento por el } \\
\text { excesivo foco en los } \\
\text { intereses propios de las } \\
\text { facciones } \\
\text { Autosuficientes }\end{array}$ \\
\hline $\begin{array}{l}\text { Condiciones para } \\
\text { la existencia del } \\
\text { faccionalismo }\end{array}$ & $\begin{array}{c}\text { Transición a democracia } \\
\text { Formación de partido, } \\
\text { escisiones y fusiones } \\
\text { Realineamiento del sistema de } \\
\text { partidos }\end{array}$ & $\begin{array}{l}\text { Rivalidades, disenso } \\
\text { intrapartidario } \\
\text { Opiniones internas polarizadas } \\
\text { Incentivos a la fragmentación }\end{array}$ & $\begin{array}{c}\text { Incentivos privatizados } \\
\text { Clientelismo } \\
\text { Máquinas políticas }\end{array}$ \\
\hline $\begin{array}{l}\text { Función del } \\
\text { faccionalismo }\end{array}$ & $\begin{array}{l}\text { Construcción de consenso } \\
\text { Agregar grupos separados, } \\
\text { difuminar hendiduras, articular } \\
\text { las preferencias e intereses de } \\
\text { los subgrupos partidistas... } \\
\text { Facilitar la consolidación de } \\
\text { partido y la coordinación } \\
\text { electoral a nivel de distrito. }\end{array}$ & $\begin{array}{c}\text { Difuminar el conflicto } \\
\text { internamente, facilitar la } \\
\text { circulación de las élites, ampliar } \\
\text { las opciones de los votantes, } \\
\text { moderar a líderes y políticas, } \\
\text { empoderar a militantes y } \\
\text { simpatizantes del partido. } \\
\text { Peligros: Crecimiento del } \\
\text { número de facciones, Juegos de } \\
\text { veto faccional, Voto partidario } \\
\text { fragmentado }\end{array}$ & $\begin{array}{l}\text { Promueve la búsqueda de } \\
\text { rentabilidad y el } \\
\text { intercambio de votos, } \\
\text { Estructura la división del } \\
\text { botín, Fomenta el juego de } \\
\text { maniobras entre facciones, } \\
\text { Cambia el foco de atención } \\
\text { alejándolo de los objetivos } \\
\text { colectivos de partido }\end{array}$ \\
\hline Resultados & $\begin{array}{c}\text { Armonía intrapartidaria } \\
\text { Partido integrado } \\
\text { Preservación de identidades de } \\
\text { subgrupos en partidos de amplio } \\
\text { espectro }\end{array}$ & $\begin{array}{c}\text { Democracia intrapartidaria, } \\
\text { Balance de poder interno, } \\
\text { Cambio moderado, Renovación } \\
\text { partidaria, Rejuvenecimiento de } \\
\text { las políticas } \\
\text { Peligros: Agitamiento interno, } \\
\text { inestabilidad de las coaliciones } \\
\text { entre facciones, atascos } \\
\text { intrapartidarios... } \\
\text { Políticas a la deriva, sin rumbo }\end{array}$ & $\begin{array}{l}\text { Cooptación faccional, } \\
\text { Inestabilidad, Impasse } \\
\text { decisional, Despilfarro de } \\
\text { los recursos públicos, } \\
\text { Corrupción perjudica el } \\
\text { valor de la marca-partido, } \\
\text { Riesgo potencial de } \\
\text { rompimiento del partido o } \\
\text { colapso. }\end{array}$ \\
\hline
\end{tabular}

Fuente: Francoise Boucek (2009) "Rethinking factionalism: Typologies, Intra-Party Dynamics and Three Faces of Factionalism"[Traducción propia]

La activación de cada una de ellas depende de la estructura de oportunidad que los actores encuentran dentro de sus organizaciones y en el contexto político nacional. La forma en que se relacionan las facciones produce resultados diversos al interior del partido y condiciona la competencia interpartidista. La interacción cooperativa entre facciones tiende a producirse en los procesos de transición y la formación de partidos a partir de múltiples identidades intrapartidarias (e.g. Partido Socialista Obrero Español en los 70's, Democracia Cristiana Italiana en los 50's); la de naturaleza competitiva tiene su origen en la polarización de opiniones (e.g. Conservadores 
Ingleses en los 90's; Partido Liberal Japonés a mediados de los 70's); y la degenerativa es la forma de interrelación típica de partidos clientelistas (e.g. Democracia Cristiana desde finales de los 70's hasta su colapso en 1994). Mientras que la cooperativa produce partidos de amplio espectro ideológico donde conviven armónicamente los distintos subgrupos, la competitiva tiende a moderar políticas. La tercera cara del faccionalismo, la degenerativa, convierte la competencia entre facciones en una lucha por la conquista de los recursos del partido que pone a éste al borde del colapso y la ingobernabilidad (Boucek, 2009:470). Mientras que en la cara cooperativa las facciones son grupos separados en competencia centrípeta, en la competitiva los grupos se relacionan en competencia centrífuga. La autosuficiencia es por el contrario la característica de las facciones que se relacionan en forma degenerativa y cuyo nacimiento obedece a la excesiva atención a los intereses particularistas de sus miembros que a la polarización de posturas. La cooperación entre grupos de un mismo partido se pone al servicio del consenso y la coordinación electoral, frente a la búsqueda de la rentabilidad en la carrera por la conquista del botín que opera bajo la cara degenerativa del faccionalismo. La competición entre grupos políticos amplía el espectro de alternativas para las élites y los militantes del partido diversificando y estimulando la innovación política por un lado, pero bajo la amenaza del agitamiento interno y políticas sin rumbo por otro lado.

Los partidos no son bloques monolíticos y al igual que en el resto de organizaciones, el disenso forma parte del ejercicio democrático plural y competitivo La selección de candidatos o la renovación de cargos han demostrado ser los asuntos más conflictivos. De hecho, la judicialización de la vida partidaria dominicana es un fenómeno en auge y prueba de ello es que desde la creación de la Cámara Contenciosa Electoral en 2003 como órgano especializado de la JCE, se dictaron apenas 13 resoluciones en 2003 y 10 en 2004, frente a las 172 resoluciones emitidas con ocasión de las primarias en las municipales y congresuales de 2006. En las elecciones de 2010 se interpusieron 256 recursos, un fenómeno que llegó a poner en peligro la confección de la boleta en los plazos establecidos por la Ley en espera de la inclusión de los candidatos definitivos (Benito Sánchez 2011:394). La desconfianza entre grupos parece ser una de las razones por la que se traslada la solución de controversias a un órgano externo en detrimento de las instancias internas que velan por la legalidad, la protección de los derechos de los miembros y la disciplina partidaria:

«No hay arbitraje creíble... los árbitros de turno defienden los intereses de grupo. Esto ha provocado que en los últimos procesos internos del partido, que las comisiones organizadoras terminen desmoralizadas. Nadie les cree (...) los estatutos tienen mecanismos de disciplina y control, pero en las comisiones se eligen personas recomendadas por los grupos de poder dentro del partido o representantes de grupos minoritarios como compensación» (Benito y Rosales 2011:30)

El repaso a las "salidas", las "voces" y "lealtades" (Hirschman 1970) detrás de los conflictos intrapartidarios en República Dominicana desde la transición a la actualidad, permite una clasificación de la motivación y dinámica de la interacción faccional en el país y su conexión con los intercambios particularizados entre partidos.

\section{$\checkmark$ Dos gallos en el mismo corral o... cómo pelearse en el PRD}

La historia del PRD ejemplifica el efecto degenerativo de la interacción faccional y la balcanización de la competencia entre liderazgos personalistas. Desde los albores de su fundación, la omnipresencia carismática de Juan Bosch resultó incompatible con el liderazgo del también fundador del partido Jiménes Grullón. La disputa se resolvió optando este último por la salida y fundando en 1961 la Alianza Social Demócrata (ASD), partido en el que pudo satisfacer sus aspiraciones a la Presidencia de la República que finalmente conquistara Bosch en 1962. Una 
década después, las discrepancias ideológicas del máximo líder -convencido de que era marxista y no tenía cabida en el PRD- llevaron a la facción de los denominados «permanentistas» a abandonar el partido y fundar el Partido de la Liberación Dominicana (PRD) en 1973. Tras la salida de Juan Bosch, el modelo organizativo de cuasi federación de tendencias con recursos propios y líderes protagónicos, ha dominado la vida interna perredeísta.

«Convención igual a división, igual a atomización» ${ }^{173}$. La selección de cargos ha sido escenario de hostilidad recurrente desde finales de los 70 a la actualidad con episodios de batallas campales como la acontecida en 1985 -conocida como "el Concordazo"- o la más actual de 2013, en la que seguidores «hipolitistas»y «miguelistas» resolvían sus diferencias de forma violenta ${ }^{174}$. Las Convenciones no han hecho más que exteriorizar la bicefalia y el matrimonio mal avenido que conforman las distintas familias perredeístas. En ellas se ha escenificado la lucha sin cuartel por alcanzar la presidencia del partido y el impasse es resuelto repartiendo el control de la organización y el acceso a las instituciones entre facciones. Así sucedió con el Pacto de Honor (1977) entre «guzmanistas» y «jorgeblanquistas»; con el Pacto de la Unión (1985) entre «majlutistas» y «jorgeblanquistas»; o con el Acuerdo de Congelación (1987), por el que Francisco Peña Gómez y Jacobo Majluta formalizan ante la JCE sus facciones con el nombre de Bloque Institucional (BIS) y Partido Revolucionario Institucional (PRI) para competir como agrupaciones independientes en las elecciones de 1990. Ambos partidos perviven en la actualidad, el primero de ellos, en manos del hijo del histórico caudillo Peña Gómez, que ostenta la presidencia.

Durante los gobiernos perredeístas (78-82 y 82-86) la incompatibilidad de liderazgos y sus clientelas traspasó el umbral doméstico y la batalla se extendió al Ejecutivo -presidido por Antonio Guzmán- y el Legislativo -dominicano por Jorge Blanco-. La conflictividad entre ambos poderes generó situaciones propias del gobierno dividido bajo esta modalidad sui generis de enemigos de una misma familia y en la que el gobierno boicoteaba las iniciativas legislativas de su propio partido. En otros partidos caracterizados por el faccionalismo, como el Partido Socialista de Chile, esto no ha impedido el trabajo colectivo en el proceso legislativo, siendo escasas las situaciones de divergencia (Gamboa y Salcedo 2009:679). Una década después, las aspiraciones del diputado Rafael Peguero Méndez a la Presidencia de la Cámara de Diputados en contra de la decisión de su partido, provocaron otra de las sonadas salidas de la matriz perredeísta. Peguero y los nueve diputados que conformaban su cortejo adquirieron la franquicia del Partido Popular Cristiano (PPC) en 1998 tras su expulsión. Hoy, como aliado del oficialista PLD en las últimas contiendas, se ha mantenido en las instituciones como Ministro sin Cartera y director de agencias gubernamentales $^{175}$.

Con la vuelta al poder del PRD en el año 2000, de nuevo se optó por la inserción clientelista de las distintas facciones en cargos públicos y partidarios para evitar que las disputas sectaristas desestabilizaran el gobierno (Espinal 2008:148). Sin embargo, las aspiraciones reeleccionistas de Hipólito Mejía - que llegó a reformar la Constitución para revocar la fórmula de la no relecciónchocaron con las del histórico Hatuey De Camps, que optó por la salida y formó el Partido Revolucionario Social Demócrata (PRSD). Como sucede en los litigios de divorcio, el reparto de

\footnotetext{
${ }^{173}$ Entrevista a Hatuey De Camps, en"El gobierno de la mañana", Programa de radio, Santo Domingo, Z101.3, del 7 de julio de 2009.

${ }^{174}$ La Convención de 1985 se celebraba en el Hotel Concorde, la tendencia de Jorge Blanco interrumpió el recuento de votos. En 2013, Ver noticias de los disturbios y disparos entre facciones durante la reunión del Comité Ejecutivo Nacional celebrado el 27 de enero de 2013. "Batalla de sillas y tiros en el congreso del PRD dominicano", En http://www.lavanguardia.com/internacional/20130128/54363202999/batalla-sillas-tiroscongreso-prd-dominicano.html

${ }^{175}$ Director del Instituto de Desarrollo del Suroeste (2008-2002 y 2012-2016)
} 
los bienes comunes fue decidido en los tribunales y De Camps se llevó al nuevo partido uno de los locales en los que se ubicaba la antigua sede del PRD.

Las dos últimas citas con las urnas de 2010 y 2012, volvieron a despertar las luchas tribales en el partido. La facción liderada por el ex presidente Hipólito Mejía, impugnó en 2009 la XXVII Convención Nacional Ordinaria que proclamaba a Miguel Vargas Maldonado como presidente del partido y candidato presidencial para 2012, contraviniendo así sus estatutos que no permitían la combinación de ambos cargos en una misma persona. El triunfo de la corriente liderada por Miguel Vargas desplazaba al resto de las facciones de los cargos directivos y electivos ${ }^{176}$. La JCE anuló la mayoría de las resoluciones adoptadas en la Convención Ordinaria del PRD pero respetó la juramentación de Vargas Maldonado como presidente y los nombramientos que hizo en el Comité Ejecutivo. La exclusión de candidatos dio paso a las protestas de aquellos que se sentían desplazados por pertenecer a la facción contraria y comenzó su peregrinación en busca de oportunidades en las listas del oficialista PLD (Benito Sánchez 2011: 395).

En esta atmósfera el PRD acude a las elecciones presidenciales de 2012 y tras su derrota se desencadena una guerra de suspensiones y expulsiones que termina con la entrega de la custodia de la sede del partido a la policía nacional. El Tribunal Superior Electoral (TSE) dejó sin efecto las medidas adoptadas contra el grupo de Miguel Vargas con lo que el partido quedaba expuesto a la bicefalia sectarista. Mientras se resuelve el impasse -que se prolongó por más de medio año- cada una de las facciones eligieron sendos portavoces en la Cámara de Diputados de un mismo PRD que en la legislatura 2010-2016 se atomiza entre "el grupo de Miguel Vargas" (45 diputados), "el grupo de Hipólito" (11 diputados), "el grupo de Abinader" (6 diputados) y "el grupo mediador" (6 diputados $)^{177}$. Un río revuelto del que parece sacar ganancia el pescador oficialista ${ }^{178}$ :

«Indudablemente que el PRD está dividido. Esa división se expresa en la Cámara, en algunos proyectos de ley en los que, por ejemplo, Miguel Vargas puede tener una visión y ordena a sus diputados votar de una determinada manera, y el grupo que no lo sigue vota de otra [...] Cuando un diputado del PRD vota a favor de las posiciones del PLD corre la voz de que ha vendido su voto...» ${ }^{179}$ (Dipp 2012).

Al momento de la redacción de esta Tesis, la guerra de secesión en el PRD sigue abierta, a pesar de que el TSE decretaba por sentencia la entrega de la Casa Nacional del Partido al presidente del PRD Miguel Vargas Maldonado. En espera de nuevos acontecimientos, la eterna batalla entre facciones se resolverá con la guerra fría entre caudillos y sus séquitos o con el nacimiento del partido número veintiocho en el país. Esta fue la opción del grupo de Hipólito Mejía y Abinader, que crearon en agosto de 2014 el Partido Revolucionario Moderno renombrando el antiguo ASD.

Como se desprende del relato histórico de las discrepancias en el PRD, el sectarismo intrapartidista se asemeja a las facciones por interés descritas por Sartori (1980) y a las client group factions, centradas en la obtención de prebendas, cargos y control de los órganos del partido (Beller y Belloni 1978). La facción es el vehículo para la competir por el control de la organización y en este proceso resulta vital la lealtad de la red de apoyo de compañeros, a quienes luego habrá que premiar en el reparto de los bienes públicos y partidistas. Las facciones funcionan a modo de pseudo maquinaria política y económica para apoyar las aspiraciones personalistas del jefe y canalizar los beneficios

\footnotetext{
${ }^{176}$ La Comisión Política se reservaba el 30 por ciento de las candidaturas a senador, diputado y síndico; 155 puestos para negociar las alianzas con otros partidos, y el 50 por ciento de las nominaciones para regidores y directores de los distritos municipales.

${ }^{177}$ Ruddy González portavoz diputados Miguel Vargas y Eugenio Cedeño portavoz diputados Hipólito Mejía.

${ }^{178}$ Luis Abinader fue candidato vicepresidencial junto a Hipólito Mejía, que ha declarado sus intenciones de aspirar a la Presidencia por el PRD en las elecciones de 2016.

${ }^{179}$ Entrevista al diputado perredeísta Hugo Tolentino Dipp, en Revista La Lupa, del 19 de diciembre de 2012.
} 
del compadrazgo a la camarilla que le acompaña ${ }^{180}$. Una dinámica típica de la amistad instrumental que rige en el Clientelismo de Partido: influencia partidista a cambio de apoyo político:

\begin{abstract}
«Miguel ha cometido el error de considerarse dueño del PRD, cuando debería recordar que fue ministro de Obras Públicas en los 4 años del gobierno que yo presidí y fui yo quien le endosó el apoyo para que fuera candidato presidencial en el 2008 [...] Los perredeístas sabían que iban para el gobierno y tenían los dientes preparados para llegar a las posiciones oficiales, pero el acuerdo de Miguel con el PLD y su traición nos despojaron del poder. ¿Usted sabe cómo se sanciona la traición? Con la muerte moral de los que traicionaron"181 (Mejía 2013).
\end{abstract}

Las dos únicas salidas de tipo ideológico en el historial de escisiones partidarias fueron las de Juan Bosch en 1973 y la de Hatuey De Camps en 2004. La defensa del marxismo del primero y de los valores primigenios perredeístas amenazados por la eliminación de la no relección del segundo, dieron nacimiento al PLD y al PRSD, aunque ambas son también producto de la imposibilidad de convivencia de liderazgos colegiados y del exacerbado personalismo. La dinámica de interacción entre las facciones y sus caudillos ha tenido un carácter predominantemente degenerativo, pero lejos de llevar al partido al colapso, se ha convertido en el modus vivendi y no ha impedido que el PRD fuese el partido más votado en las presidenciales de 2012 y en las municipales de 2010. El duelo entre el BIS y el PRI de finales de los años 80, ejemplifica la cara competitiva del faccionalismo descrita por Boucek (2009) que permitió difuminar el conflicto entre Peña Gómez y Majluta en una situación de competencia centrífuga y opiniones polarizadas.

También ha existido dinámica cooperativa entre facciones. El Movimiento Democrático Alternativo (MODA) creado en 2007 por Emilio Rivas, nació inicialmente como un movimiento de apoyo a la candidatura presidencial de Hipólito Mejía en 2000 y 2004, pero en aquel entonces con el nombre de Movimiento Organizador de Aliados (MODA). La misma ruta siguió el Partido Cívico Renovador del Ex Jefe de la Policía Nacional Jorge Radhamés Zorrilla, que nació siendo un movimiento de apoyo y en 2010 oficializó su registro ante la JCE como partido independiente. Ambos son tradicionales aliados del PRD en las contiendas electorales. Del mismo modo, el movimiento de apoyo a la candidatura de Majluta en 1986 La Estructura, se convirtió en Partido Liberal La Estructura (PAL) y su presidente Andrés Van Der Horst ha sido aliado tanto del PRD como del PLD y un habitual en las instituciones del Estado ${ }^{182}$.

\footnotetext{
${ }^{180}$ En su carrera por alcanzar la candidatura presidencial por el PRD en el 2016, Luis Abinader ya ha conseguido el apoyo de la tendencia política que encabeza Roberto Fulcar, y que dice contar con más de 500 dirigentes. Ver noticia "Corriente de Roberto Fulcar en el PRD apoya a Luis Abinader", en periódico HOY, del 2 de junio de 2013, http://www.hoy.com.do/el-pais/2013/6/2/483311/Luis-Abinader-recibe-respaldo-decorriente-Roberto-Fulcar-en-el-PRD

${ }^{181}$ Entrevista al ex presidente Hipólito Mejía en Diario Digital De3, del En http://diariode3.com/y-ustedqueopina-hipolito-dice-que-le-tiene-lastima-a-danilo-medina-por-los-lios-que-deja-lf/

${ }^{182}$ Director de la Comisión de Aeropuertos 2004-2008. Su nombre apareció en WikiLeaks por pedir sobornos a empresas estadounidenses para la concesión de licencias. En periódico Diario Libre del 17 de diciembre de 2012. Su hijo Andrés Van Der Horst Alvarez es director del Consejo Nacional de Competitividad 2012-2016.
} 


\section{$\checkmark$ El disenso en el PLD: De la excomunión a la cooperación}

En 1973, Juan Bosch y los «permanentistas» abandonan el PRD por discrepancias ideológicas para crear un partido leninista de cuadros. Bajo el liderazgo carismático del profesor descansaban el control de la organización de la vida partidaria: "centralismo democrático" y la cosmovisión político doctrinaria: "el boschismo"183. En este escenario, el disenso y la contestación al viejo caudillo y guía eran consideradas traiciones al principio boschista de la desconfianza y castigadas con la pena de excomunión (Jiménez 1999:438). La primera desavenencia tuvo lugar en 1978, con el enfrentamiento ideológico entre el grupo de «los diez» y el de «la trilogía» -liderados por Antonio Abreu y Rafael Alburquerque respectivamente- por el giro derechista del partido. El apoyo de Bosch a este último forzó la salida de Antonio Abreu, quien formó con sus seguidores el partido Unidad Democrática (UD). Aplastado el primero de los delfines, Bosch eliminó al segundo acusándolo de grupismo y expulsándolo en 1984, fecha en la que Rafael Alburquerque crea el Partido del Pueblo Dominicano (PPD). Desde entonces, Alburquerque se ha mantenido ininterrumpidamente en primera línea de las instituciones, siendo Ministro de Trabajo con Balaguer-PRSC (1991-2000) y Vicepresidente en las Administraciones del PLD (2004-2008 y 2008-2012).

El boschismo exigía lealtad absoluta y las voces por la resistencia del anciano líder al relevo generacional o los conflictos por el reparto de cargos, eran castigadas con la suspensión o la expulsión ${ }^{184}$. Otros, como Max Puig, optan por la salida estratégica en busca de mayores oportunidades y funda en 1992 el Partido Alianza por la Democracia (APD). La rentabilidad de esta opción, llegará una década después cuando el valor estratégico de los partidos aliados minoritarios puede inclinar la balanza electoral. Gracias a su alianza con el PLD, Max Puig se ha desempeñado como Ministro de Trabajo y de Medio Ambiente, además de otras posiciones gubernamentales en las administraciones del PLD 2004-2008 y 2008-2012.

Tras la retirada de Juan Bosch en 1994, se inicia la lucha interna por el poder que enfrentará a «renovadores»y «oportunistas» partidarios de preservar los fines originarios del partido unos y del pragmatismo político otros, en la que vencerán estos últimos recibiendo a cambio la Presidencia de la Cámara de Diputados por apoyar a Balaguer. También comienza aquí la competencia de liderazgos entre Leonel Fernández y Danilo Medina, ex Presidente y Presidente actual de la República Dominicana. En 2007, con la frase "Me venció el Estado", Danilo Medina se retiraba del escenario público resentido con su compañero de partido tras su derrota en las primarias internas, acusando a Fernández de utilizar a su favor la maquinaria del Estado. Cinco años después, esa misma maquinaria estatal y el uso de los recursos públicos otrora denunciados, fueron puestos a su servicio de la mano del Presidente Fernández para alcanzar la Presidencia en $2012^{185}$.

Hoy esas líneas políticas parecen difuminadas y el divisionismo responde a la identificación de clientelas y patrones en su acceso a la cúpula partidista. El poderoso Comité Político peledeísta lo conforman un grupo de escogidos que dirigen la maquinaria partidista y estatal. En la actualidad, 14 son «leonelistas», 6 «danilistas» y 5 son catalogados como «neutrales» ${ }^{186}$. Conocido como el "mini gabinete", todos sus miembros se desempeñan como funcionarios de alto rango, por lo que controlan la red de patronazgo de los niveles intermedios. Un selecto grupo conforma a su vez el núcleo duro del Comité Político conocido como "la OTAN"; una especie de intelligentsia o consejo

\footnotetext{
${ }^{183}$ El "boschismo" fue adoptado como teoría política en el PLD en 1988.

${ }^{184}$ Tal fue el caso de Vicente Bengoa, Nélsida Marmolejos en los 90's.

185 Tabaré Vázquez, Jefe de la Misión de Observación Electoral de la Organización de Estados Americanos (OEA) en las elecciones presidenciales de 2012, adelantaba a la prensa que una de las observaciones del Informe Final sería la recomendación al Presidente electo de no involucrarse en procesos electorales futuros. Ver noticia, en periódico Listín Diario de 20 de Mayo de 2012.

${ }^{186}$ Ver noticia en periódico Diario Libre, de 6 de junio de 2013.
} 
de sabios con gran poder en el control de los recursos del Estado e independencia económica. Este monopolio partidista y estatal ha llevado a sus detractores a desautorizar las condiciones de la competencia en el sistema de partidos dominicano calificándolas de «dictadura constitucional de la corporación PLD» ${ }^{187}$. Las resistencias a abandonar este selecto grupo han provocado que la ampliación sea una opción más factible que la renovación de sus miembros. Un atrincheramiento que ejemplifica la pervivencia de las prácticas de cooptación propias de los partidos de notables y que en los sistemas de partido tipo cartel se traduce en el fortalecimiento de las elites en las estructuras del partido y en las instituciones (Gunther y Diamond 2001).

Extender las mieles del poder más allá de este exclusivo círculo de confianza desata la guerra entre facciones. Las voces en el PLD no se exteriorizan al modo de sus oponentes perredeístas - que enarbolan sus diferencias en exhibición violenta del exceso de democracia interna- sino en la más silenciosa en la que se solventan los equilibrios de poder entre clanes ${ }^{188}$. La presencia de hombres de confianza del ex Presidente Leonel Fernández en el ejecutivo de Danilo Medina ha sido calificado por los analistas como «El gobierno de Danilo bajo el reinado de Leonel» (Ruiz 2012) y recordaría a esa otra frase de «ser el árbitro cuando no se era el presidente» de épocas y caudillos pasados (Benito y Toribio 2013:1), pero también responde al pago por el apoyo brindado entre facciones.

El centralismo democrático boschista parece haber mutado en la etapa post caudillos a la autocracia del Comité Político bajo la dirección de líder carismático de turno. Militantes y dirigentes tratan de entrar en el grupo de confianza; un botín de cargos y contratos que despierta el recelo y la competencia entre las milicias que apoyan a los líderes. Las lealtades de ida y vuelta de los disidentes y su permanencia en las instituciones evidencian salidas estratégicas de los actores en busca de mejores opciones (rent seekers). La división bajo incentivos centrípetos caracteriza hoy la rivalidad entre «leonelistas» $\mathrm{y}$ «danilistas» y muestra la cara cooperativa del faccionalismo descrita por Boucek (2009). Ambas son facciones reclutadas en base a la lealtad personal al líder (client group factions) que cooperan para alcanzar el éxito electoral. Una cooperación que genera conflicto entre los sectarios de la facción que abraza las mieles del gobierno y la que controla el partido, pero que en ningún caso amenaza su integridad. En el actual gobierno de Danilo Medina, la Vicepresidencia está en manos de Margarita Cedeño, esposa del ex Presidente Leonel Fernández; un ejemplo del canje y pago entre grupos por la coordinación electoral en $2012^{189}$.

\footnotetext{
${ }^{187}$ Argumento del Movimiento Contra el Continuismo formado por un grupo de intelectuales dominicanos durante la campaña electoral de 2012 en la que advertían del peligro de la concentración de poderes económicos y políticos del PLD y el camino hacia el sistema de partido único. El 4 de marzo de 2012, un manifiesto firmado por 57 intelectuales, activistas sociales y artistas dominicanos alertaba por primera vez de los peligros de este tipo de dictadura que nace en los espacios de la democracia y de la tipología del partidocorporación. Ver noticia en Periódico 7 Días, del 12 de marzo de 2012, http://www.7dias.com.do/elpais/2012/03/31/i117237_panel-reitera-advertencia-sobre-dictadura-constitucional.html

${ }^{188}$ Y prueba de ello, es el ataque a través de un libelo anónimo que en mayo de 2013 recorría el los correos electrónicos del país con el título de "El Presidente Medina ante un grave peligro", y donde se acusaba de abuso de poder, enriquecimiento ilícito y conspiración para entregar el poder a personas ajenas a la dirección, a compañeros del partido. Ver noticias sobre el pasquín distribuido en periódico digital Acento, del 9 de mayo de 2013

189 Ver ratificaciones de puestos de la Administración anterior en Decreto 472-12, 475-12, 476-12, 477-12, 483-12 y 484-12, emitidos el 21 de agosto de 2012, tres meses después de las elecciones presidenciales.
} 


\section{$\checkmark$ El neocaciquismo democrático reformista}

El liderazgo de Joaquín Balaguer ejemplifica el prototipo de caciquismo tradicional y el dominio de la vida política a través del entramado de relaciones sociales. El viejo caudillo contaba con una red de caciques provinciales leales a los que concedía el disfrute selectivo de bienes públicos y privados $^{190}$. Su resistencia a ceder el control de la maquinaria reformista le mantuvo apegado al poder a pesar de su ceguera y avanzada edad. El viejo caudillo no admitía competencia y las aspiraciones de los posibles delfines fueron castigadas con la expulsión, la salida voluntaria o la retirada del apoyo en las urnas. Así sucedió con Francisco Augusto Lora, vicepresidente del partido, quien en 1970 fundó el Movimiento de Integración Democrática Antireeleccionista (MIDA) o en 1994, cuando Fernando Álvarez Bogaert funda el partido Unión Democrática Cristiana (UDC) que apoyará al PRD en las elecciones de 1996, fecha en la que aplastó el liderazgo de Jacinto Peynado favoreciendo al candidato del PLD Leonel Fernández en el "Frente Patriótico". Los que aspiraban lo hacían dejando claro su adhesión incondicional al líder primigenio (Jiménez 1999:400):

«... ni busco, ni espero, ni acepto que alrededor de mi persona se forme una de esas cosas a las que llaman tendencia. En el Partido Reformista no hay alas ni de izquierda ni de derecha, y no existe pugna por el poder ni por el liderato del partido, ya que todos reconocemos que existe un único líder» ${ }^{191}$.

Y cuando las cosas pintaban mal, el estratega Joaquín Balaguer forzaba la cooperación entre facciones ficticias. De esta manera, indujo la creación del Movimiento Nacional de la Juventud (MNJ) en 1970 y del Partido Nacional de Veteranos y Civiles (PNVC) en 1973 por si se complicaba su presencia en las urnas como candidato. La desaparición del viejo caudillo en 2002 dejó al Partido Reformista huérfano de un liderazgo aglutinador y exteriorizó el conflicto entre facciones y sus jefes políticos, que se agudiza con cada contienda electoral. Su condición de partido bisagra, resulta atractiva para los juegos de alianza y las facciones buscan la mayor rentabilidad negociando por separado con los potenciales aliados.

En 2009, la renovación de los órganos partidarios fue motivo de agria disputa entre facciones y en lugar de una se celebraron tres accidentadas Asambleas: la oficial, donde se eligió presidente a Carlos Morales Troncoso ausente en la reunión; una improvisada en la segunda planta de la sede reformista a cargo de un grupo de dirigentes; y una paralela, en la que se proclamaba a Leonel Fernández "líder viviente de los balagueristas". Aquellos que no vieron satisfechas sus aspiraciones optaron por el camino de la disidencia organizados bajo el nombre de "Balagueristas Auténticos", "Consenso Electoral" y "Corriente Balaguerista" bajo el liderazgo de Modesto Guzmán, Alexandra Izquierdo y Héctor Rodríguez Pimentel respectivamente. Los tres fueron recompensados tras las elecciones de 2012 como director del Instituto Postal Dominicano (INPOSDOM) el primero, Secretaria de Estado sin cartera la segunda y director del Instituto Dominicano de Recursos Hidráulicos (INDRHI) el último en la Administración oficialista. Los tres cuentan con poder de nombramiento en las redes de patronazgo en las instituciones bajo su responsabilidad.

La contienda presidencial de 2012 volvió a desatar la rivalidad y desavenencias por la elección de compañero aliado. Mientras que la cúpula del PRSC optaba por la alianza con el PLD -en la que el Presidente del partido Carlos Morales Troncoso fungió como Ministro de Relaciones Exteriores- ,

\footnotetext{
${ }^{190}$ En la década de los ochenta, los más prominentes eran Francisco Augusto Lora, Ramón Emilio Jiménez Reyes, Donald Reid Cabral, Fernando Álvarez Bogaert, Mario Vinicio Castillo, Juan Arístides Taveras Guzmán, Juan Rafael Peralta, Mario Read Vittini y Julio César Castaños Guzmán.

${ }^{191}$ Palabras de Julio César Castaños Guzmán, en periódico El Caribe de 16 de julio de 1983. Citado en Jiménez Polanco 1999:400).
} 
otro de los tradicionales jefes políticos del reformismo -Amable Aristy Castro- optaba por dar su apoyo al PRD. Aunque éste último fue expulsado, en febrero de 2013 el TSE declaró nula la decisión adoptada por el PRSC quien tuvo que readmitir a Aristy y a los 261 dirigentes que le acompañaban.

La atomización faccional de los dirigentes reformistas y su competencia centrífuga en las citas electorales ejemplifica la dinámica competitiva descrita por Boucek (2009) que permite la circulación de las élites y amplía las opciones de los votantes, quienes pudieron elegir en las elecciones de 2012 entre "reformistas con papá" o " reformistas con mamá"192; pero también muestra el peligro de las políticas a la deriva y partidos sin rumbo.

A pesar de la competencia entre jefes políticos reformistas, no parece que esta guerra aniquile el partido, ya que los patronos han encontrado en las instituciones el nuevo brío para mantener a sus clientelas políticas: Carlos Morales Troncoso, Canciller de Relaciones Exteriores (2004-2014) en las Administraciones del oficialismo, ha convertido la carrera consular y diplomática en un feudo reformista que pone en cuestión el uso eficiente de los recursos públicos, con misiones diplomáticas desorbitadas para un país de 10 millones de habitantes ${ }^{193}$.

En el otro extremo, Amable Aristy, tradicional cacique adiestrado en las formas balagueristas atrincherado en la poderosa Liga Municipal Dominicana durante décadas y Senador por la provincia de La Altagracia. Este amigo de los pobres, repartidor de pollos, salchichones y dinero en las campañas electorales, es un prominente empresario de la zona que controla empleos públicos y privados ${ }^{194}$. Su círculo de influencia se ve reforzado a través de apéndices familiares como su hija Karina Aristy, alcaldesa del principal municipio de su provincia, o su sobrino Fidias Aristy, quien le sustituyó al frente de la Liga Municipal Dominicana cuando vio imposibilitada su reelección. En esta batalla, algunos han optado por independizarse. Tal es el caso de Amilcar Romero, que fundó en 2006 el Partido Popular Reformista (PPR) y de Eduardo Estrella, quien creara el Partido Dominicanos por el Cambio (DxC) en 2009, alegando irregularidades en la elección de Amable Aristy como candidato presidencial.

\footnotetext{
${ }^{192}$ Eslóganes de la campaña presidencial de 2012. El candidato del PRD Hipólito Mejía se hacía llamar "papá" y con la incorporación de la primera Dama Margarita Cedeño como candidata vicepresidencial por el PLD, surgió el contrario con el apelativo de "mamá".

${ }^{193} \mathrm{Y}$ entre las que destacan por pintorescas 61 ministros consejeros en Haití, o en la Sede de Naciones Unidas donde República Dominicana cuenta con la segunda representación más numerosa. En 2008, el partido MIUCA denunció el aumento de la nómina en el consulado dominicano en Nueva York, en el que fueron nombrados 13 nuevos vicecónsules (que se sumaban a los 29 existentes), 27 auxiliares consulares y 25 ayudantes civiles. Ver noticias al respecto en periódico DiarioDigitalRD.com, de 28 de julio de 2008 y en Revista La Lupa, de 22 de mayo de 2012, en http://www.lalupa.com.do/2013/05/los-ministros-consejeros/ 194 Ver reparto de dinero en http://www.youtube.com/watch? $v=R W q W Q F u f F s A ;$ http://www.calle56.com/2012/04/amable-reparte-dinero-militantes-en-sfm.html ; http://w ww.acento.com.do/index.php/news/4673/56/Amable-Aristy-Castro-tres-decenios-en-el-cacicazgo-de-lainmunidad.html
} 
Como se desprende del relato de las desavenencias intrapartidarias, dependiendo de los protagonistas y de la coyuntura, las facciones de los tres partidos mayoritarios:

1) Cooperan para maximizar sus opciones, preservando las identidades de subgrupos en momentos de alta competencia electoral. Ej. Apoyo de Leonel Fernández a la candidatura de Danilo Medina en las presidenciales de 2012.

2) Compiten entre ellas difuminando el conflicto, ofreciendo mayores opciones a los votantes, a quienes trasladan el veredicto en la medición de fuerzas entre facciones. El agitamiento no pone en peligro la unidad del partido pero sí provoca recelos internos. Ej. Las principales figuras de los subgrupos reformistas apoyaban uno al PRD y otro al PLD en las presidenciales de 2012, ejemplificando el peligro de las políticas y partidos a la deriva descrito por Boucek (2009).

3) Se disgregan buscando la rentabilidad individual, en donde la carrera por el acceso al botín de cargos pone en riesgo la unidad del partido y conduce a la parálisis institucional. Este tipo de competencia degenerativa ha sido exclusiva del PRD, un partido cuyo modelo organizativo responde a una cuasi federación de facciones. Ej. Los impasses en la Cámara de Diputados de los años 80 y la actual crisis por la custodia del partido.

Tabla 3.4.3.2 Las tres caras del faccionalismo en República Dominicana

\begin{tabular}{|c|c|c|c|}
\hline & Cooperativa & Competitiva & Degenerativa \\
\hline PLD & $\begin{array}{c}\text { «Leonelistas»y «Danilistas» } \\
\text { (2012) }\end{array}$ & $\begin{array}{c}\ll \text { Los } 10 » \text { y «La Trilogía» } \\
\text { (1978) } \\
\text { «Renovadores»y } \\
\text { «Oportunistas» }(1994) \\
\text { «Leonelistas»y «Danilistas» } \\
(2007)\end{array}$ & \\
\hline PRD & $\begin{array}{c}\text { MODA (2000 y 2004); MCR } \\
\text { (2005); } \\
\text { La Estructura (1986) }\end{array}$ & $\begin{array}{c}\text { BIS (Peña Gómez) y PRI } \\
\text { (Majluta) (1987) } \\
\text { Partido Revolucionario } \\
\text { Moderno (2014) }\end{array}$ & $\begin{array}{c}\text { «Guzmanistas»y } \\
\text { «Jorgeblanquistas» }(1978) \\
\text { «Jorgeblanquistas»y } \\
\text { «Majlutistas» (1985) } \\
\text { «Miguelistas»e } \\
\text { «Hipolitistas» }(2012-2013)\end{array}$ \\
\hline PRSC & $\begin{array}{l}\text { Caciques provinciales en los } \\
\qquad 80 \text { 's } \\
\text { MNJ (1970) y PNVC (1973) }\end{array}$ & $\begin{array}{c}\text { «Balagueristas Auténticos», } \\
\text { «Consenso Electoral»y } \\
\text { «Corriente Balaguerista» } \\
\text { (2010) } \\
\text { Amable Aristy (Reformistas } \\
\text { con PRD) } \\
\text { y Morales Troncoso } \\
\text { (Reformistas con PLD) } \\
(2012)\end{array}$ & \\
\hline
\end{tabular}

Fuente: Elaboración propia a partir de la tipología de Boucek (2009) 
Como ya apuntara Geddes (1991), el faccionalismo obstaculiza la probabilidad de que se llevan a cabo reformas que introduzcan el principio de mérito en el acceso y permanencia en la administración pública, porque también para los jefes políticos el patronazgo es un arma para mantener y premiar la lealtad de sus sectarios. El monopolio de prebendas derivadas del ejercicio del poder ha reconvertido al Director, Jefe de Agencia Pública o Secretario Gubernamental, en el nuevo señor feudal o neocacique que reparte cargos entre compadres. Si los propios actores políticos son jugadores de veto en la promoción del servicio civil de carrera en el país -ya que la promesa de empleo público es una de las principales armas de movilización electoral- también lo son en el ámbito interno, donde las primarias resultan ser la manzana de la discordia partidista. Indicador de esta resistencia y veto es la declaración de inconstitucionalidad de la Ley 286-04 de Primarias Internas Obligatorias en 2005, bajo la argumentación de que los partidos son organizaciones privadas que tienen derecho a determinar libremente cómo seleccionar a sus candidatos ${ }^{195}$. Y es que las elecciones internas abiertas $-o$ principio de mérito partidista- amenazan la competencia sesgada por la endogamia, la red clientelar, el compadrazgo y la militancia vegetativa (Hernández Valle 2002).

Como se señalaba en el apartado dedicado a la formación política, el divisionismo segrega en diferentes centros de formación la socialización de los futuros dirigentes. Este divisionismo dificulta el establecimiento de concepciones políticas unitarias o trabajo ideológico de los partidos y condiciona la actividad legislativa en diferentes aspectos:

$\checkmark$ La lucha faccional se traslada a las instituciones provocando impasses, como sucedió con el bloqueo perredeísta a las iniciativas propias en la década de los 80 's.

$\checkmark$ El mandato de representación nacional se supedita a las instrucciones de los jefes políticos a sus sectarios, lo que popularmente se conoce como "bajar línea".

$\checkmark$ Fomenta el personalismo legislativo en el trabajo parlamentario. Antes que colaborar con el compañero contrario, los diputados prefieren actuar en solitario. Como muestran los datos de esta investigación, la actividad propositiva de los diputados dominicanos se realiza de manera individual, siendo minoritario el porcentaje de proposiciones presentadas por la bancada o grupo.

${ }^{195}$ El recurso fue interpuesto por Julio Cesar Castaños, en representación de la Fundación Derecho y Democracia. Cercano al oficialista PLD, un año después de la sentencia fue nombrado presidente de la JCE (2006-2010), anteriormente fue Consultor Jurídico del Poder Ejecutivo (1994-1996) en la Administración de Balaguer y Secretario de Estado en el primer gobierno de Leonel Fernández (1996). Es hijo de Julio César Castaños Espaillat, sublíder reformista de los ochenta, un perfil que ejemplifica la ruta profesional de los "amigos de amigos". Ver sentencia de la Suprema Corte de Justicia Número 17 del 16 de marzo de 2005. 


\subsection{RECAPITULACIÓN}

En las páginas previas se han identificado los factores que determinan desde la oferta el particularismo en las relaciones Partido-Partido, destacando el poder autónomo de los políticos en la elección de la estrategia clientelar.

Con este propósito, el capítulo trata de evidenciar que las principales fuerzas dominicanas no compiten en su función movilizadora de cleavages representativos sino en su efectividad para distribuir bienes selectivos. Para ello, en primer lugar se presentan algunas decisiones de organización que adoptan los partidos y que podrían ser indicadores del modelo organizativo cartel informal. En este sentido, el fenómeno del llamado "sector externo" ilustra la naturaleza de la maquinaria política, compuesta por subunidades autónomas lideradas por operadores políticos de turno ajenos a la burocracia oficial partidaria. En el apartado dedicado a las decisiones de acción social de los partidos dominicanos, se constata la debilidad de los condicionantes favorables de largo plazo para estructurar y mantener un sistema de partidos programáticamente estructurado (SPPE) identificadas por Kitschelt, Hawkins, Rosas y Zechmeinster (2010), pero también la falta de voluntad de los actores nacionales de aprovechar los espacios de oportunidad que generan condicionantes favorables de corto plazo, como la bonanza económica y las reformas institucionales para (re)construir programáticamente la vinculación con los electores.

A partir del Índice de Estructuración Programática propuesto por estos autores, se analiza la dimensionalidad del espacio ideológico, la cohesión ideológica de los partidos, la representación sobre issues y las semánticas de izquierda derecha en la etapa de la consolidación democrática en la República Dominicana. Para el estudio de las tres primeras se utilizan las opiniones de los diputados dominicanos del Proyecto Elites Parlamentarias Latinoamericanas (PELA 1994-2010). El tratamiento estadístico de los datos revela que la simpatía es el lazo de unión entre representante y representados; que desde 2002 no existe diferencia significativa en la auto ubicación ideológica de los diputados de los tres partidos mayoritarios; que existe afinidad en torno a su posicionamiento en el eje neoliberalismo-estatismo y en el eje conservadurismo-progresismo; y que en los tres partidos la coherencia ideológica se ha ido difuminando en la etapa post carismática. Por el contrario, el focus distrital ha ido ganando importancia con la mayor vinculación de las elites al territorio que impone el sistema electoral y que convierte a los legisladores en brokers resolutivos en el distrito más que en agentes propositivos en el Congreso Nacional. Con respecto a la semántica izquierdaderecha, los datos de la Encuesta de Opinión Pública y Comportamiento Electoral (OBSEROP) revelan una cierta confusión en el uso de estos términos entre los ciudadanos dominicanos y que se refleja de manera anecdótica en que el 67,9\% de los entrevistados ubicaron la palabra "socialismo" en los principios defendidos por la derecha.

En la cooperación estratégica entre partidos, el relato de los pactos, alianzas y trashumancias en el periodo 1978-2012, sirve para mostrar que los incentivos que se derivan de la competencia en condiciones de oligopolio (Kitschelt y Wilkinson 2012) hacen que los políticos dominicanos operen bajo esquemas de maximización de sus intereses personales y de su carrera política. El "Pacto por la Gobernabilidad y el Desarrollo Nacional y Local" de 2006, ejemplifica la vocación particularista de las élites dominicanas y resuelve el dilema que han de enfrentar: élites para el patronazgo o para la autonomía burocrática. En esta elección racional, los costes derivados de la cooperación estratégica de vocación particularista - pérdida de identidad partidaria, conflictos internos y voto de castigo por incumplimiento del mandato de representación- son menores a los beneficios aportados en el corto plazo, e incluso se tornan en ventajas en la carrera política. La experiencia dominicana demuestra que la capacidad consociacional no siempre se pone al servicio de la gobernabilidad democrática, sino que puede reforzar el proceso de institucionalización perversa. 
Por último, en las relaciones de conflicto, el relato de las desavenencias internas desde la transición a la actualidad, muestra que el ejercicio del liderazgo en la República Dominicana parece seguir la senda del personalismo y el compadrazgo de épocas pasadas. La razón aglutinadora no es ideológica sino de carácter organizativo y de oportunismo electoral, respondiendo a la tipología de facciones por interés (Sartori 1980) o client group factions (Beller y Belloni 1978). La facción es una de las formas que adopta la maquinaria política informal en los partidos dominicanos en donde prima la lealtad instrumental típica de las relaciones patrón-cliente. A través de ella, acceden a los puestos dentro del partido y del Estado, por lo que los propios políticos serán actores de veto en el establecimiento del principio de mérito en la administración pública, porque también para los jefes políticos el patronazgo es un arma para mantener y premiar la lealtad de sus sectarios. De esta manera, la legitimidad clientelar del sistema político dominicano se reproduce al interior del partido y los políticos enfrentan las mismas decisiones estratégicas que los electores, tal como demostrara Geddes (1991). Siguiendo la clasificación de Boucek (2009) esta investigación muestra que dependiendo del escenario de oportunidad, las facciones de los tres partidos dominicanos cooperan o compiten, aunque solo el PRD parece entablar batallas degenerativas.

Existe una relación causal entre divisionismo y particularismo legislativo en la Cámara de Diputados, ya que el mandato de representación nacional no está circunscrito a la concepción unitaria o trabajo ideológico, sino a las instrucciones que los jefes políticos dan a sus sectarios. Además, fomenta el personalismo en el trabajo parlamentario ya que antes que colaborar con un compañero de partido pero de otra facción, los diputados prefieren actuar en solitario. 


\section{CAPÍTULO 4}

\section{FACTORES QUE DETERMINAN LA POLÍTICA PARTICULARISTA DESDE LA DEMANDA}

\subsection{INTRODUCCIÓN}

Tras examinar los incentivos del lado de la oferta que favorecen la política particularista en las Relaciones Estado-Partidos y en las Relaciones Partido-Partido, el siguiente paso en esta investigación es analizar el contexto del intercambio particularizado identificado como propicio desde el lado de la demanda. Se explora aquí la tercera de las relaciones que contempla las secuencias de interacción del Estado con la Ciudadanía. En esta lectura de los condicionantes del entorno social y actitudinal no se trata de culpar a la cultura política de una determinada comunidad, sino de advertir cómo ésta ha sido modelada por las contingencias históricas en su relación con el Estado (Papakostas 2001:32).

Los primeros trabajos que se acercaron al particularismo desde la perspectiva culturalistadesarrollista lo consideraron un resabio de sociedades tradicionales que desaparecería con la modernidad (Tarrow 1977; Landé 1977; Eisenstadt y Lemarchand 1981). La pobreza se convertía así en la variable independiente necesaria y suficiente que justificaba los vínculos clientelares de los países de renta baja con democracias no consolidadas. Bajo esta perspectiva, el panorama socioeconómico de la República Dominicana pareciera el más idóneo para que el vínculo clientelar se tornase endémico en el país. Con una tasa de pobreza total del 41\% (PNUD 2011), es poco probable que alcance la meta de los Objetivos del Milenio que estima este porcentaje en un 5,5\% para el 2015 (PNUD 2013). En 2013, el 78,9\% de la población trabajadora recibía menos de $\$ 400$ USD mensuales y más de la mitad de los dominicanos no había alcanzado el nivel de estudios secundarios. La tasa de analfabetismo ronda el $13 \%$ llegando al $37,66 \%$ en las provincias del Sur (ONE 2012). La desigualdad de ingresos coloca al país en el puesto 113 de los 137 considerados, lejos de Argentina que en 2013 ocupaba el puesto 85 y era el menos desigual de América Latina. La República Dominicana, junto con Guatemala y Colombia son los únicos países de la región donde creció la desigualdad entre 1990 y 2008 (CEPAL 2010:37), siendo de 0,51 el Coeficiente de Gini (Banco Mundial 2011) ${ }^{196}$. Los bajos niveles de gasto social per cápita situaban al país en el grupo de los rezagados, al igual que en la deficiente cobertura de los programas de transferencias, que en 2008 cubrían las necesidades solo del 36,4\% de los indigentes y del 18,5\% de los pobres (CEPAL 2010).

Sin embargo, bajo la óptica instrumentalista el poder explicativo del empoderamiento ciudadano ha perdido la condición de suficiencia y carácter unidireccional, para ser analizado desde una perspectiva dinámica y relacional. La imparcialidad en el ejercicio de los derechos políticos, sociales y económicos, la integración horizontal de los ciudadanos en la política y el aislamiento de la burocracia frente a las particularidades de la vida civil favorecen la representación universal de intereses. Por el contrario, la preferencia sesgada, una incorporación vertical de corte paternalista o plebliscitaria en la política nacional y la influencia de grupos familiares y empresariales en la res pública favorecen la representación particularista.

${ }^{196}$ En la pasada década el $20 \%$ de la población más pobre recibió el 4,3\% del ingreso nacional (OMS 2012). 
Los incentivos desde el lado de la demanda que dibujan el paisaje social y actitudinal del clientelismo en la República Dominicana son analizados en esta investigación desde una dimensión macro y micro sociológica:

\section{A) Nivel macro de la cultura política:}

En comunidades caracterizadas por una cultura organizacional integradora y participativa los actores sociales resuelven las dificultades para la acción colectiva. La agregación de intereses encuentra mayores obstáculos allí donde las organizaciones sociales entablan relaciones de subordinación frente al Estado, ya que la competencia se impone a la colaboración. El estudio de la cultura organizacional como variable independiente se aborda en la dirección causal propuesta por Papakostas (2001:37): "clientelism as a problem of boundary setting and of intertwining between different types of organizations, where complicated historical sequences of organization establishment create different boundaries and intertwinings between different types of relatively modern organizations. Perceived from this angle, both clientelistic and universalistic practices are consequences of different historical ways of drawing up organizational boundaries".

La aproximación a las raíces de la comunidad cívica (Putnam 1993) o a la historia colectiva del sistema político dominicano en el lenguaje de Almond y Verba (1965), aporta información relevante acerca de las singularidades del activismo que dificultan la acción colectiva. El repaso a la historia y rasgos de la cultura organizacional muestra las relaciones interconectadas entre el activismo civil y el partidista, el acceso preferente de los seguidores del gobierno de turno a la burocracia, la incorporación prebendalista de los ciudadanos y la penetración de intereses económicos en los estamentos de decisión. Si en la primera transición dominicana la ciudadanía dirigió sus esfuerzos hacia la conquista de derechos democráticos, en la etapa de la consolidación la conquista de los derechos socioeconómicos ha quedado envuelta en una atomización de actores que compiten en lo que en el refranero popular dominicano se conoce como "buscarse lo suyo".

Gráfico 4.1.1 Relación Causal Cultura Organizacional - Política Universalista/Particularista

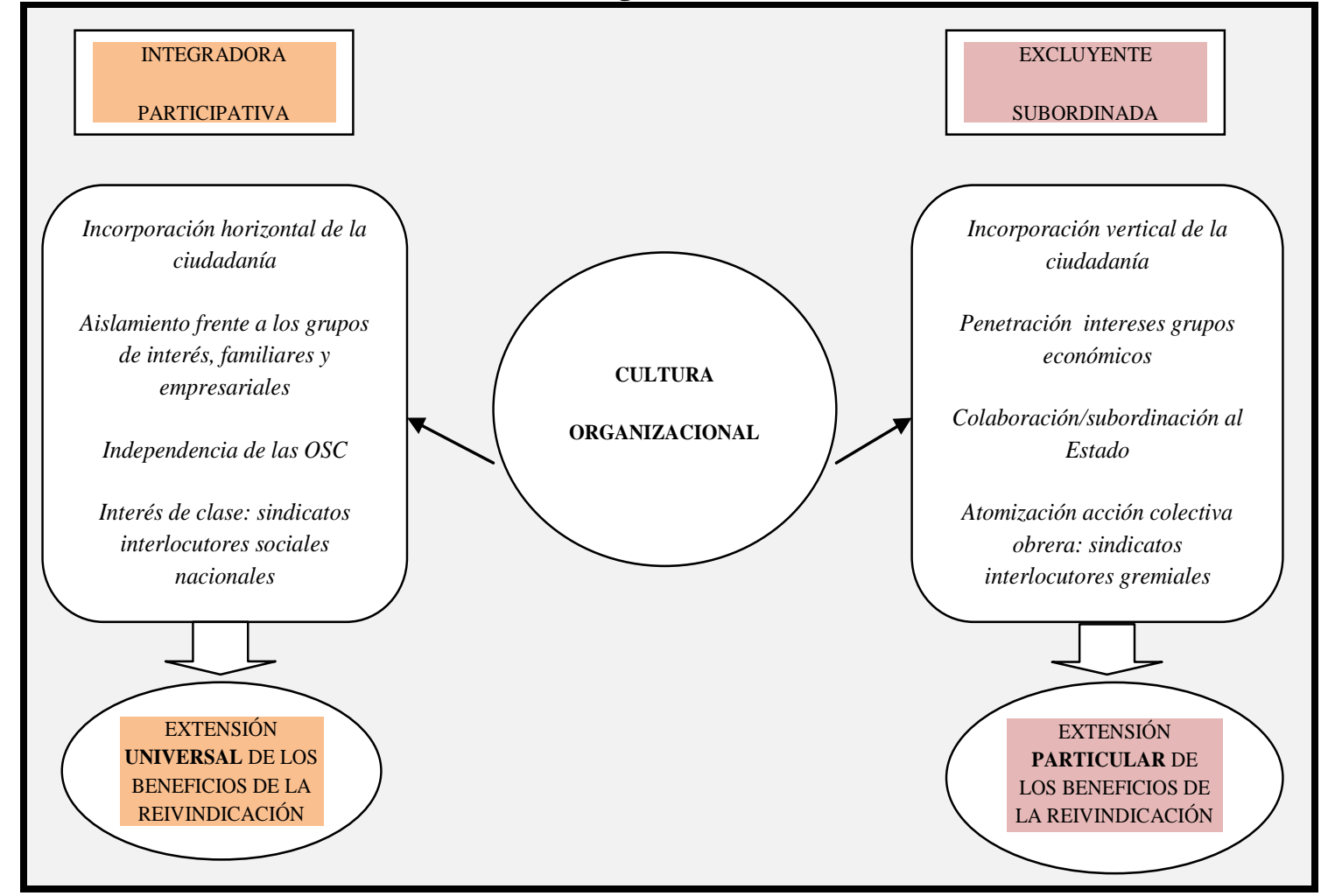

Fuente: Elaboración propia a partir de análisis de Papakostas (2001) 
B) Nivel micro de la cultura política:

El estudio del capital social o compromiso cívico de participación y sentimiento de eficacia (Putnam 1993) permite identificar la presencia en la sociedad dominicana de los rasgos de la cultura política participativa o subordinada y por extensión, la mayor o menor predisposición a aceptar la política particularista como estrategia de movilización y representación. Como ha demostrado la literatura (Almond y Verba 1963; Putnam 1993; Uslaner 2002; Costa y Kahn 2003), existe un iter causal entre cultura política y nivel de inclusión de los resultados democráticos. Los rasgos de la cultura política subordinada caracterizan un tipo de capital social de bajo perfil y múltiples agentes de acción corporativa en una estrategia de relación con el Estado que disminuye la efectividad de sus conquistas. Por el contrario, la política universalista es resultado de una estrategia de relación beligerante con el Estado caracterizada por la acción colectiva y la interlocución social. En un escenario de confianza generalizada, pluralismo, secularización, solidaridad, primacía de la colectividad frente al personalismo, es más probable la existencia de una sociedad civil cohesionada y proclive a la cooperación.

Desde el revelador estudio de Almond y Verba (1963), la importancia de la cultura política como institución informal ha ocupado un lugar destacado en el estudio de las democracias contemporáneas. Las virtudes del capital social han sido destacadas por gran número de autores que siguiendo el trabajo seminal de Putnam (1993) han evidenciado la relación causal entre esta variable y diferentes outcomes políticos. Gobiernos con un alto sentido de la responsabilidad y el compromiso (Putnam 1993); más redistributivos (Uslaner 2002); mayor bienestar económico y competitividad del mercado nacional (Fukuyama 1995); estructuras políticas menos centralistas y restrictivas (Fukuyama 1995); mayor porcentaje de gasto público (Costa y Kahn 2003); o con un menor fraude fiscal y corrupción (Putnam 2002), son algunas de las bondades cívicas atribuidas al activismo y a la reciprocidad que genera la confianza generalizada. Desde el otro lado del prisma metodológico, es decir, considerando la cultura política como variable dependiente, autores como Uslaner (2002) o Collier (2002) han demostrado que la desigualdad -económica y social- es el clivaje con mayor fuerza desestabilizadora por su capacidad para erosionar la confianza y determinante a la hora de identificar en una sociedad la presencia de rasgos de la cultura política participativa y/o parroquial.

El repaso a estos indicadores en los últimos años en República Dominicana arroja el siguiente panorama:

La eficacia gubernamental y la seguridad jurídica se situaban en el percentil medio/bajo (38,6 y 28,3 respectivamente) en los indicadores de Gobernanza del Banco Mundial. En cuanto al mercado y la competitividad nacional, el país ocupa el puesto 84 de un total de 183 países en incumplimiento de contratos y el puesto 114 en problemas relativos al registro de propiedad, mientras que el empleo vulnerable alcanzaba al $42 \%$ de la población activa en 2007. La estructura centralista y presidencialista del país deja sin efecto la limitada autonomía fiscal, política y administrativa de los municipios dominicanos, siendo de un 56,1 su posicionamiento en el Índice de Percepción de la Autonomía Municipal (IPAM). En el año 2008 el gasto público representó el 16,2\% del PIB, siendo las partidas en educación y salud (2,3\% y 5,9\% del PIB 2009) las más bajas de la región Latinoamericana. En 2010 la organización Transparencia Internacional ubicaba a la República Dominicana entre los países con mayores niveles de corrupción en el sector público $(3,0)$. En cuanto a la desigualdad, el Coeficiente de Gini rondaba el 0,59 en 2004 y el 0,56 en 2007; el 20\% más rico de la población dominicana disfrutaba del 56,5\% y 53,6\% de los ingresos en 2006 y 2007 respectivamente; y en 2004, el quintil más rico ganaba 28 veces más que el quintil más pobre, una proporción que descendió a 26 en 2007. 
Gráfico 4.1.2 Relación Causal Cultura Política - Política Universalista/Particularista

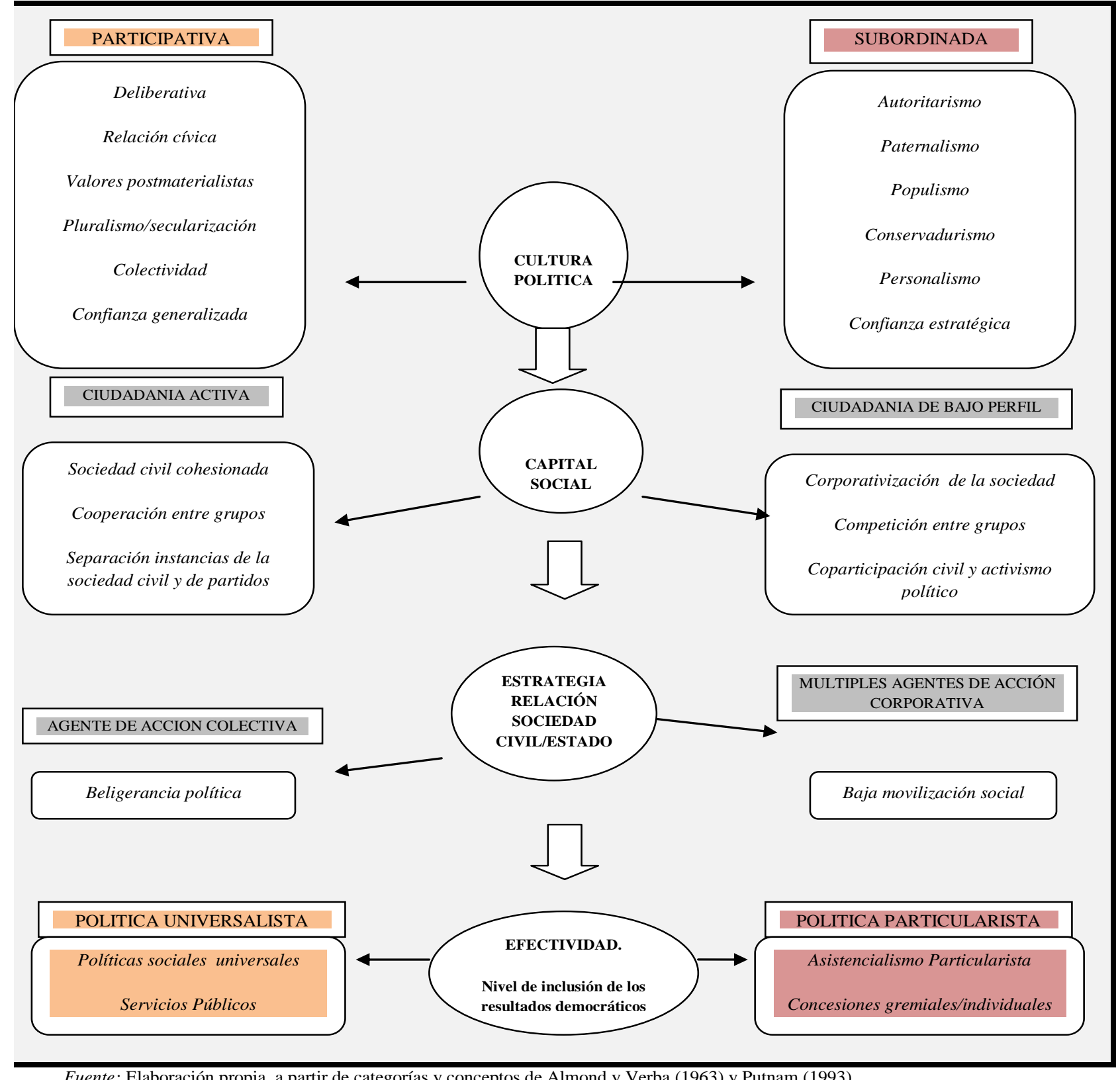

Fuente: Elaboración propia, a partir de categorías y conceptos de Almond y Verba (1963) y Putnam (1993)

El propósito de este capítulo es mostrar una fotografía del paisaje social del clientelismo a través de las particularidades de la relación Estado-Ciudadanía en la etapa de la consolidación democrática en la República Dominicana. La tercera y última de las relaciones que contempla esta investigación trata de explicar porqué la infraestructura social que sustenta la democracia en el país es más proclive a la competición clientelar que a la cooperación colectiva. Mostrando las secuencias y modos históricos de relación entre el Estado y la ciudadanía, es posible advertir si se han generado en el proceso espacios de oportunidad para que el clientelismo aflore o se debilite. 


\subsection{RELACIONES DEL ESTADO CON LA CIUDADANÍA}

\subsection{A) CULTURA ORGANIZACIONAL EN LA REPÚBLICA DOMINICANA}

Cuando la sociedad civil es fuerte y tiene capacidad de presión en el sistema político logra expandir los beneficios sociales a los grupos que representa. Cuando es débil, ya sea por su bajo nivel organizativo o porque se supedita a los dictados de los partidos políticos o el Estado, resulta difícil que incida de manera significativa en las reformas (Espinal, Morgan y Hartlyn 2010:40). Bajo esta premisa, el diagnóstico histórico y actual de la estructura de la cooperación en la República Dominicana permite identificar los condicionantes de la baja incidencia de la sociedad civil en los asuntos públicos. Las relaciones interconectadas entre la vida social y la vida política, la incorporación vertical de los ciudadanos y la penetración de los intereses económicos, favorecen la representación particularista de intereses (Papakostas 2001). En contextos de focalización de la confianza los vínculos tienden a particularizarse (Roginer 1990) y en este capital social "perverso" emerge y se reproduce el clientelismo (Máiz 2003). Los distintos grupos se vuelven competitivos, se bloquea la cooperación entre clientes en una batalla donde los más poderosos asumen la articulación de las demandas. Estas "élites extractivas" se organizan y acceden a las débiles instituciones políticas y económicas haciéndolas más propensas a sus intereses bloqueando la redistribución e institucionalizando el particularismo (Acemoglu y Robinson 2006). La coparticipación en las organizaciones sociales y políticas reduce la capacidad de presión de ciudadanía neutralizando su combatividad. Como demostraran Espinal, Morgan y Hartlyn (2010:38), en la República Dominicana, el peso de la relación clientelar convierte a las organizaciones civiles en dependientes del aparato estatal y de los partidos.

Teniendo en cuenta las anteriores premisas, el objetivo de este epígrafe es mostrar que la legitimidad del Estado dominicano descansa en la incorporación prebendalista de las clases populares («clientes pobres pero ricos en votos») y la penetración de los intereses de los grupos económicos («clientes ricos pero pobres en votos»). Asimismo, se acredita que la estructura de la cooperación social en el país está poco articulada y dispersa, es agente de acción corporativa, persigue la concesión de bienes tipo club, es poco combativa y está envuelta en una relación de complicidad con los agentes políticos y estatales. En este escenario la representación laboral y el interés de clase se diluyen en un mar de mini sindicatos que reducen al ámbito particular-gremial la conquista de sus reivindicaciones obreras.

\section{1) La promoción estatal del poder empresarial}

¿Cómo fue la ubicación de la clase dominante y las clases populares en la vida política y social dominicana?

En el momento fundacional o proceso de state building se toman decisiones en torno al modo de inclusión de las clases populares en la política nacional: incorporación vertical versus integradora/horizontal y respecto al grado de aislamiento frente a los grupos económicos: penetración social versus aislamiento (Papakostas 2001). Mientras que las primeras opciones de incorporación favorecen el particularismo, las segundas lo previenen. En la República Dominicana, ambos procesos se caracterizaron por la interconexión, la penetración de intereses empresariales y la incorporación prebendalista de las masas populares tal como se relata a continuación:

La relación del Estado con las clases bajas se ha caracterizado por la verticalidad en la concesión de prebendas. La política social desde la era Trujillo a la actualidad ha estado caracterizada por el asistencialismo. De aquella entrega de alimentos en el "día del pobre" con ocasión del natalicio de 
Trujillo, perviven prácticas en eventos colectivos de reparto de cestas navideñas, lavadoras en el día de las madres, utensilios escolares con la apertura del curso escolar por parte de legisladores o la tradicional recepción presidencial de primeros de año donde se aprovecha para buscar la mano amiga del mandatario en la solución del asunto propio. La herencia balaguerista en la creación de redes clientelares para la asignación de bienes ha pervivido junto al populismo asistencialista de los gobiernos del PRD y se ha complejizado con los programas focalizados de los gobiernos del PLD. Las experiencias de integración participativa de las comunidades en la acción estatal contra la pobreza como la antigua PRO-Comunidad o la actual Comunidad Digna, han estado bajo la sospecha de cooptación clientelista del activismo barrial. La inexistencia de una única autoridad en la asistencia social en la República Dominicana (Cañete y Dotel 2007), dispersa la acción entre múltiples instancias: la liberalidad del Presidente en su asignación a organizaciones de la sociedad civil, el Gabinete Social de la Presidencia, el Despacho de la Primera Dama, los programas que perviven de gestiones anteriores y todas las agencias gubernamentales dominicanas que dedican una parte de su presupuesto a fines asistenciales.

Por su parte, los sectores dominantes -militares, grupos empresariales e iglesia católica- han aprovechado la crisis del sistema de partidos y las debilidades de la representación para ejercer su capacidad de influencia y presión. Dependiendo del momento histórico y de la coyuntura política, estos grupos han adoptado en el país distintas estrategias: en pugna por el poder, en connivencia interesada, en relación jerarquizada de dependencia, o verdaderos articuladores del sistema político en otras. Situaciones todas lejos del ideal pluralista de grupos de intereses diversos que encuentran su equilibrio en las instituciones (Dahl 1961). Durante la dictadura de Trujillo (1931-1961), la clase empresarial adoptó una relación de distancia y cautela con el primer empresario del país. Un respaldo básico para no ser acusados de traición, pero sin colaboración activa con la parodia constitucional trujillista. Desde entonces, los grupos económicos y familiares han controlado la riqueza productiva del país: los Vicini-Cabral, Corripio, Bonetti, Viyella-San Miguel, Hazin, Cáceres-Troncoso, Brugal, Barceló, León, Lama, Pellerano, Báez-Romano, Najri, Spaillat, Marranzini, no más de veinte familias que hoy están presentes en los consejos directivos de las grandes empresas, universidades privadas, medios de comunicación, los organismos de decisión económica del Estado, los monopolios agroindustriales, la propiedad de la tierra, la industria exportadora, las inversiones turísticas y el sector financiero.

Durante los convulsos años que siguieron al asesinato de Trujillo (1961-1965), la oligarquía tradicional y los empresarios se organizaron para adaptarse al cambio de escenario bajo las siglas de la Unión Cívica Nacional. Temerosos de los cambios, respaldaron el derrocamiento del gobierno constitucional en 1963 y la intervención norteamericana que tildó de comunista el proyecto de justicia social de Juan Bosch. La posterior instauración del Triunvirato (1963-1965) encabezado por el empresario Donald Reid Cabral, les dejaba de nuevo al mando del estado y controlando el ritmo de las reformas. El poder de los empresarios tuvo su recompensa legislativa en la promulgación en 1963 de la Ley que creaba la Comisión Nacional de Exenciones, el órgano encargado de legitimar la discrecionalidad de las exoneraciones a las principales firmas y hombres de negocios del país (Benito 2012:213)

Durante el gobierno de los "Doce años" de Balaguer (1966-1978), continuó el reparto de prebendas y beneficios para hacerles partícipes de su proyecto de modernización conservadora autoritaria. La penetración de los intereses económicos de la élite empresarial tuvo su máxima expresión durante el mandato del caudillo conservador ${ }^{197}$. A través del Consejo Nacional de Desarrollo las familias empresariales participaban de la toma de decisiones políticas. La más importante vino de la mano

${ }^{197}$ Gracias al "Presidente Constructor", se hicieron ricos el grupo de agraciados por las obras publicas, conocidos como "Los 300 millones". 
de la Ley de Protección e Incentivo Industrial de 1968 y del Directorio de Desarrollo Industrial que fijaba un listado de empresarios habilitados para acogerse a los beneficios de la Ley elegidos clientelarmente para ser beneficiados por las exenciones y cuotas de importación. Con la llegada al poder del PRD en 1978 gracias a los sectores empresariales descontentos, este lobby pasó a disfrutar de gran poder de presión sobre el Congreso. Y muestra de ello es la promulgación de las Leyes 409 y 145 en el año 1982 y 1983 para establecer un régimen de incentivos y exenciones de impuestos a los importadores. Bajo la presidencia de Hipólito Mejía-PRD (2000-2004), el Congreso aprobó los "sacrificios fiscales" recomendados por el Ejecutivo que se estimaron en 100 mil millones de pesos ${ }^{198}$ (Rosario 2008:290). Todas estas leyes tenían como precedente la Ley 299 de 1969, promulgada bajo el primer gobierno de Balaguer, lo que demuestra su capacidad negociadora y presiones al Ejecutivo, cualquiera que sea la Administración.

Los analistas han destacado como uno de los factores que explican el conservadurismo político en las reformas el hecho de que «los sectores empresariales no muestran fisuras irreconciliables entre ellos ni tampoco en su relación con los gobiernos convirtiéndose así en actores con poder de veto que utilizan el chantaje de la ingobernabilidad» (Espinal 2006:28). Hoy el sector financiero dominicano sigue siendo relativamente pequeño y altamente concentrado. Solo cuatro bancos representan el $71 \%$ del mercado (Banco Mundial 2012) y son propiedad de las grandes familias: Vinici, Grullón, Mera, Caro, Conde, León, Bonetti y Barletta. En este sentido, en el año 2004, el $85 \%$ de los encuestados consideraba que el país estaba gobernado para el beneficio de unos cuantos intereses poderosos (DEMOS 2004) y en 2008, el 50,45\% denunciaba que el mayor obstáculo para el progreso del país era la oligarquía dominicana (LAPOP 2008).

La variedad de organizaciones empresariales (COPARDOM, CNHE, CONEP, AIRD, ANJE, ADAVIT, ONEC, CORFITUR, FEDECO, AIREN, APEDI, ASONAIMCO, MIPYMES, CODOPYME, ACOPROVI, CADOCO, ASONAHORES, ADOEXPO.... $)^{199}$ contrasta con el perfil de vida asociativa de la ciudadanía. En 2004 el 50,5\% de los dominicanos no participaba en ningún tipo de organización y en el año 2006, los que sí lo hacían, el 12,4\% colaboraba con organizaciones civiles, el 17,8\% lo hacía en organizaciones de carácter político y el 56,0\% en organizaciones religiosas (LAPOP 2006). Con ocasión de las sesiones de trabajo de la Asamblea Revisora que dio forma a la nueva Constitución de la República Dominicana de 2010, el lobbying de los grupos de interés más influyentes se intensificó: la AIRD mostró su rechazo por "exceso de regulación y abuso de discrecionalidad" la posible inclusión del término "economía social de mercado" ${ }^{200}$; el CONEP se movilizó para evitar la consagración constitucional del derecho al trabajo y el rol activo del Estado en la economía ${ }^{201}$; y las presiones del lobby hotelero al frente de la ASONAHORES lograron la consagración constitucional de la restricción al libre acceso de playas y ríos (Benito 2012:216). Resulta significativo que a pesar del alto grado de asociacionismo civil en el país, haya sido una organización empresarial -la AIRD- la responsable de convocar y moderar el único debate entre candidatos presidenciales en 2012.

\footnotetext{
${ }^{198}$ Equivalentes a 2,514,818 USD.

199 Confederación Patronal de la RD, Consejo Nacional de Hombres de Empresa, Consejo Nacional de Empresas Privadas, Asociación de Industrias de la República Dominicana, Asociación de Jóvenes Empresarios, Asociación Dominicana de Agentes de Viajes, Organización de Empresas Comerciales, Corporación Dominicana de Industria Turística, Federación de Comerciantes, Asociación para el Desarrollo de Santiago, Asociación de Industriales de Muebles, Colchones y Afines, Asociación de la Micro, Pequeña y Mediana Empresa, Confederación Dominicana de Pequeña y Mediana Empresa, Asociación Dominicana de Constructores y Promotores de viviendas, Cámara Dominicana de Comercio, Asociación Nacional de hoteles y restaurants, Asociación Dominicana de Exportadores.

${ }^{200}$ En periódico El Caribe, 17 de febrero de 2009.

${ }^{201}$ En periódico Listín Diario, 24 de marzo de 2009.
} 
Otros ejemplos de cómo las elites extractivas bloquean la redistribución y favorecen sus intereses propios en el sentido descrito por Acemoglu y Robinson (2006) se manifiestan en el sistema impositivo y fiscal dominicano. Las ganancias de capital están exentas y los impuestos sobre las propiedades inmobiliarias gozan de exenciones que representan el 12,6\% del total de los gastos tributarios nacionales. La presión fiscal en el país es una de las más bajas en la región latinoamericana (13\% PIB) y centrada en impuestos indirectos al consumo. Los impuestos directos representan el $27 \%$ de la recaudación e incluyen gravámenes sobre la renta personal (menos del 1\% del PIB), corporativa y los de la propiedad (Ministerio de Finanzas 2012).

La penetración de los grupos empresariales en la gestión pública se manifiesta también a través de lo que Kitschelt (2007) denomina "capitalismo coordinado". La existencia de empresas públicas, subsidiadas o con regímenes diferenciados, crea una peculiar atmósfera de cultura corporativa que moviliza a empresarios y trabajadores en busca de vínculos clientelares («business-mediated clientelism»). Tal es el caso de los regímenes de Zona Franca en el país, uno de los principales motores productivos conformado por 578 empresas -de las que 208 son nacionales- que operan bajo un régimen fiscal y de exportación favorable en territorio dominicano. La aprobación de nuevas empresas de zonas francas en 2012 provocaba el rechazo de la Asociación de Industrias de la República Dominicana quien pedía prudencia al Consejo Nacional de Zonas Francas y solicitaba a las autoridades no profundizar la inequidad fiscal entre el sector nacional y el sector de la zona franca:

«Al aprobarse este tipo de nuevas empresas se está montando un aparato industrial paralelo con condiciones y privilegios de los que carece la industria local» ${ }^{202}$.

Entre 2008-2010, el Gobierno dominicano dejó de recibir 35,408,723 USD por concepto de exenciones de impuestos en distintos sectores de la economía. Para el año 2012 la estimación equivalía al 5.0\% del PIB (Ministerio de Hacienda 2011). Como reconocía el propio Ministro de Hacienda en 2011, la mayor eficiencia del gasto público pasaba por lograr que «todos paguen impuestos, se eliminen las exenciones y se reduzca el número de instituciones» ${ }^{203}$. El sector eléctrico nacional es el prototipo de sector subsidiado que genera grandes costes en la economía nacional. El problema histórico de la electricidad en República Dominicana ejemplifica el poder de los «clientes ricos pero pobres en votos» y la ineficiencia que genera la promoción clientelar en los servicios públicos. Además de los continuos apagones por las deficiencias técnicas, se suman los llamados "apagones financieros" de las empresas eléctricas y que consisten en cortar intencionadamente el suministro en respuesta bien al retraso en el pago del subsidio, bien para forzar acuerdos con el Estado ${ }^{204}$. El particularismo como política del mejor postor genera una guerra de subsidios entre clientes que dispara el déficit fiscal. Así lo reconocía en 2012 la misión del Fondo Monetario Internacional en el país apuntando que los subsidios a la electricidad condujeron a un déficit del sector público consolidado del $3.3 \%{ }^{205}$.

La mayor influencia de los grupos empresariales se ha manifestado en el rechazo al Sistema de Seguridad Social. Sus representantes en el Consejo Nacional, órgano rector del SDSS (Sistema Dominicano de Seguridad Social), logaron la promulgación de la Resolución 72-03 que redefinía el concepto de salario cotizable en violación de la Ley 87-01 de Seguridad Social y el Código de Trabajo. Por esta vía, los empresarios han reducido sus cotizaciones al mínimo y más de 27.000 empresas (el 64\% del tejido empresarial dominicano) evaden sus responsabilidades con este sistema

\footnotetext{
${ }^{202}$ En periódico Diario Libre, 17 de abril de 2012.

${ }^{203}$ Palabras del Ministro de Hacienda Daniel Toribio, en periódico HOY, 4 de agosto de 2011.

${ }^{204}$ Ver noticias sobre apagones financieros en periódico El Día, 19 de diciembre de 2012.

${ }^{205}$ El gasto público aumentó en un $40 \%$ en 2010 y 2011 y la deuda pública representaría en 2012 el equivalente al $44 \%$ del PIB nacional.
} 
de protección de los trabajadores ${ }^{206}$. La Resolución 72-03 venía acompañada de la solicitud de posponer la entrada en vigor del régimen contributivo. Esta aspiración se materializó en abril de 2009 cuando los legisladores aprobaron en sesión nocturna y por vía de urgencia una amnistía a los empresarios públicos y privados en el pago al Sistema de la Seguridad Social y contemplaba la devolución a aquellos que habían cumplido con sus responsabilidades. Un perdón de más de 5 mil millones de pesos, en conceptos de seguros de vejez, discapacidad, salud y riesgos laborales, que junto a las exenciones impositivas, son ejemplo de la denominada "generosidad clientelar" identificada por Hopkin y Mastropaolo (2001:158).

Por el contrario, el Régimen Subsidiado de la Seguridad Social y el Sistema único de Beneficiarios (SIUBEN) de reciente creación deberán enfrentar obstáculos estructurales como la falta de complementariedad de los programas, la duplicidad y baja cuantía de las asignaciones ${ }^{207}$. Las reticencias a incluir a las trabajadoras domésticas en el sistema subsidiado de la seguridad social ejemplifican la mayor probabilidad de bloqueo de las reformas cuando los costes están concentrados en un grupo reducido de potenciales perdedores -pero influyente y organizado- y cuando los beneficios recaerán en un grupo amplio, difuso y desorganizado de la población. En 2007 el sector de las empleadas domésticas representaba el 5,6\% de las personas ocupadas, conformado principalmente por mujeres pobres, muchas de ellas de origen haitiano y sometidas a largas jornadas de trabajo ${ }^{208}$. En octubre de 2012 el presidente de la Confederación Patronal de la República Dominicana (COPARDOM) alentaba a los diputados a rechazar la ratificación del Convenio 189 de la OIT sobre trabajo doméstico, para evitar que el país fuera penalizado por incumplimientos y amenazando con "despidos masivos de domésticas"209.

\section{2) El activismo civil subsidiado en la etapa de la consolidación democrática}

¿Cuáles son las raíces de la comunidad cívica dominicana? ¿Cómo es la estructura social de la cooperación?

Rafael Leónidas Trujillo "El Jefe", "El Benefactor" y "El Padre de la Nueva Patria" controló durante treinta años cada uno de los engranajes de la sociedad civil dominicana. Desde 1930 hasta su asesinato en 1961 su régimen de terror aniquiló a 50,000 opositores y condenó a la sumisión y al agasajo a la población. Su fórmula de represión y cooptación subordinó la ciudadanía al Estado sentenciándola a la desmovilización. El aparato represivo del régimen (Policía, Ejército, Servicio de Inteligencia Militar, Partido Dominicano, Los Jinetes del Este, Los Cocuyos de la Cordillera...) contaba con la ayuda de fieles esbirros que denunciaban a los desafectos quienes automáticamente caían en desgracia y dejaban de recibir los favores del pater. Tras su asesinato en 1961, las elites empresariales asumieron el control del Estado en el Triunvirato (1963-1965). Se inicia una época de de protestas lideradas principalmente por estudiantes y organizaciones de mujeres en una época convulsa a la que siguió la Guerra Civil y la intervención norteamericana de abril de 1965. La

\footnotetext{
${ }^{206}$ En periódico Clave, 16 de abril de 2009.

${ }^{207}$ El Régimen Subsidiado de la Seguridad Social se puso en marcha en 2003 y en el 2010 contaba con 1,769,167 afiliados (18\% de la población dominicana). El SIUBEN está adscrito al Gabinete de Coordinación de Políticas Sociales bajo la responsabilidad directa del Vicepresidente de la República. Es responsable de crear y administrar la base de datos de hogares pobres del país y el padrón de hogares elegibles para los beneficios que ofrecen los distintos programas sociales y subsidios monetarios del gobierno.

${ }^{208}$ La vulnerabilidad es mayor en la modalidad de puertas adentro o "con dormida", donde no hay separación entre jornada laboral y familiar. En ocasiones se incluyen como sueldo vivir en la casa y la alimentación.

${ }^{209}$ Ver noticias al respecto en periódicos nacionales del 28 y 31 de octubre de 2012.
} 
guerra popular entre constitucionalistas y golpistas terminó con la victoria de estos últimos y con la vida de más de 4,000 dominicanos (Moya Pons 2008).

Con el anuncio de la convocatoria de elecciones en 1966, Joaquín Balaguer regresa del exilio y gana la presidencia de la República Dominicana al frente del Partido Reformista. Durante los "Doce Años" de su gobierno autoritario (1966-1978) la sociedad civil tuvo un limitado desarrollo. Organizaciones de estudiantes, campesinos y jóvenes urbanos desafiaron la represión estatal y paraestatal $^{210}$, pero sin llegar a ensombrecer la legitimación prebendalista del caudillo entre las masas pobres del país. En el nuevo escenario que inaugura la alternancia y la llegada al poder del PRD en 1978, el activismo civil recupera el espacio negado. Las fuertes medidas de ajuste impuestas en los ochenta desencadenaron una ola de protestas y reivindicaciones de centenares de Comités de Lucha Popular. Este estallido social liderado por activistas de barrio no contó sin embargo con el apoyo de la clase sindical. El protagonismo alcanzado por el Comité para la Defensa de los Derechos Barriales-COPADEBA fue contrarrestado desde el gobierno con la creación de la JUNTAPO, una red coordinadora de las Juntas de Vecinos cuyos líderes fueron cooptados «enrolados en el tren gubernamental, con dádivas, retribuciones de todo tipo, que contribuirán a la paralización y desaparición de ese tipo de defensa de barrio» (Chantada 2010:276). A lo largo de la década de los noventa y bajo el gobierno de Joaquín Balaguer, se acentuarán la división y politización del movimiento sindical y social.

En la etapa de la consolidación democrática, el "quieto desencanto" (Artiles 2010) de la sociedad civil dominicana ha convivido con esporádicas movilizaciones e intentos de institucionalizar la auditoria social en episodios conflictivos de la historia del país. Así sucedió en la crisis postelectoral de 1994 y durante el impasse que provocó el enfrentamiento entre el Gobierno y la Liga Municipal en $1999^{211}$. De ambas coyunturas surgirán el Grupo Acción por la Democracia y el Foro Ciudadano respectivamente, aunque no de una movilización popular de base sino a iniciativa de un "grupo de notables" representantes de los sectores y élites sociales con mayor visibilidad. Así lo reconocía un actor clave, quien fuera en la época miembro activo de tales instancias y de otras más actuales como el Consejo Económico y Social ${ }^{212}$ :

«Al final se planteaba el mismo interrogante... ¿a quién llamar para que represente a la sociedad civil? El Foro Ciudadano representaba la frustración de la articulación de la sociedad civil en una entidad. Estaban los de siempre... PROFAMILIA, FINJUS, el CONEP ${ }^{213} \ldots$ "los fuertes". Pero luego las iniciativas languidecían porque nadie quería perder su protagonismo individual. Y hoy... ¿Con quién se puede hablar de la sociedad civil, a quién de todos ellos se convoca?» (Toribio 2012).

En esta lucha de liderazgos por monopolizar la visibilidad de la representación civil, también ha influido la omnipresente mediación de la iglesia católica, representada en la figura de Monseñor Agripino Núñez:

«Igual que sucediera con el Grupo Acción por la Democracia en el pasado, hoy el Consejo Económico y Social es lo que quiera Agripino. Intentamos que fuese algo diferente, potenciar el lado institucional del diálogo... pero fracasó» (Toribio 2012).

\footnotetext{
210 "La Banda Colora" - color identificativo del Partido Reformista- atemorizaba a los opositores y activistas durante el primer gobierno de Balaguer.

${ }^{211}$ Crisis política ocasionada por la lucha entre los tres partidos por hacerse con el control de la Liga Municipal. Esta institución maneja los fondos a repartir entre los municipios del país.

${ }^{212}$ Entrevista con Rafael Toribio, realizada el 20 de noviembre de 2012.

213 Asociación Dominicana Pro Bienestar de la Familia, Fundación Institucionalidad y Justicia, Consejo Nacional de la Empresa Privada.
} 
El diálogo y la concertación social han adoptado diferentes formas en la historia reciente del país: "Dialogo Social de Jarabacoa, 1985-1988"; "Acuerdo Bipartito, 1989"; " Pacto de Solidaridad Económica, 1990"; "Consenso Tripartito, 1993". Todos ellos se caracterizaron por la cooptación de la representatividad por parte de los empresarios y sindicatos del transporte lo que menoscababa la la legitimidad de los interlocutores. En negociaciones sectoriales como la del Plan Decenal de Educación, los éxitos de la mayor representatividad de la participación comunitaria fueron aniquilados por la «intromisión de la política en asuntos técnicos» (Chantada 2010:290) y por la «burocratización y la apropiación del Ministerio de Educación» (Toribio 2012). En los últimos años, el balance del "Diálogo Nacional" celebrado en 1997, la "Consulta Popular por la Reforma Constitucional" de 2002 y 2010 y la "Estrategia Nacional de Desarrollo", muestran la debilidad de la contraloría social en República Dominicana. En la primera no se contemplaban mecanismos de fiscalización entre poderes públicos y la sociedad civil (Leger et al 2002), las segundas no fueron vinculantes y la tercera es un marco de referencia de extensión y pormenores desproporcionados. Como reconocen algunos de los protagonistas entrevistados:

«El diálogo social se convierte en un escaparate de pluralidad y participación, pero la falta de seguimiento de los acuerdos e incluso la utilización interesada de algunos de ellos, han llevado a la desilusión y apatía de los actores civiles. También la incertidumbre sobre si éstas serán asumidas en hipotéticos cambios de gobierno por fuerzas políticas distintas bajo las que fueron convocadas» ${ }^{214}$.

El diagnóstico sobre el tejido asociativo dominicano elaborado por el Banco Interamericano de Desarrollo (BID) y OXFAM, alertaba de la tendencia hacia la privatización de lo público por las organizaciones civiles en detrimento de la participación ciudadana en los asuntos públicos ${ }^{215}$. En aquella radiografía de las organizaciones dominicanas se destacaba la falta de organización, coordinación y la naturaleza localista de sus reivindicaciones. La escasa capacidad para generar recursos propios las hacía dependientes de la cooperación internacional y orientadas a sus líneas de actuación. En esta visión cortoplacista se limitaban a resolver problemas que iban surgiendo sin generar capacidades transformadoras en las comunidades (CIPROS 1996). Por el contrario, las asociaciones religiosas destacaban por su nivel de organización, centralización y fuertes lazos con el Estado, los empresarios y los partidos políticos. El diagnóstico sobre el tejido asociativo de finales de la década de los noventa denunciaba los rasgos caudillistas, demagogos, sectaristas y no tan democráticos en su actuar como le reclaman a los demás. Estas características dificultaban la coordinación entre organizaciones y en la práctica se traducía en una competencia entre asociaciones (Manzanillo 1999).

La politización de las organizaciones y el tráfico de influencias, eran también especialmente significativas en el sector de las profesionales liberales, donde el liderazgo corporativo parecía ser la vía de ascenso de sus líderes (Collado 1999). La mayoría de las organizaciones de la sociedad civil analizadas adolecían de falta de democracia interna, con presidentes cuasi vitalicios que se adueñaban de las organizaciones y renovaciones con "planchas consensuadas" que desvirtuaban las elecciones. Todas ellas tenían un exagerado aparato burocrático, eran dependientes de partidos, iglesias y Estado y eran poco agresivas en sus reivindicaciones. Lograr el equilibrio entre lo particular y lo colectivo en el seno de las organizaciones civiles constituía en 2002 uno de los mayores retos que debía afrontar la sociedad civil organizada en República Dominicana (Cela y Pedrazuela 2002).

\footnotetext{
${ }^{214}$ Entrevista con ex dirigente de organización barrial del Distrito Nacional, realizada el 4 de febrero de 2010.

215 BID: Programa de Fortalecimiento de las Organizaciones de la Sociedad Civil, Cooperacion Técnica no Reembolsable (ATN/SF-6142-DR; ATN/SF-7247-DR). Convenio con OXFAM (DMR-611-A9/AO).
} 
El subsidio público fue ya identificado en los años noventa como uno de los factores responsables de la politización y docilidad del activismo organizado, considerado «un mecanismo poco democrático de relación entre el Estado y las asociaciones por la falta de definición sobre la función de los fondos, la ausencia de control y la discrecionalidad de la autoridad estatal en el otorgamiento de este regalo para que se utilice como se quiera» (Quezada 2002:18). La liberalidad en el otorgamiento de los subsidios propiciaba el reparto clientelar e incluso de beneficio personal, ya que fundaciones de antiguos funcionarios resultaron ser favorecidas con subsidios ${ }^{216}$. En la actualidad estas prácticas siguen estando vigentes. Como revelaba el segundo de los indicadores de esta investigación, en el análisis cualitativo de las concesiones que otorgan los diputados se hallaron asignaciones mensuales a organizaciones cuya presidencia recaía en el propio legislador o para actividades de autopromoción política. Si en los años noventa "todos los días surgían y desaparecían asociaciones al amparo del subsidio estatal, lo que perpetuaba su debilidad, la cultura de dependencia y la visión paternalista del Estado" (Quezada 2002:19), hoy son los propios diputados los que dan cuenta en la página web del Congreso de la República, de su trabajo como conseguidores de regalías públicas:

«También ha sido un fervoroso defensor de diferentes organizaciones que gozan de mucho prestigio en la sociedad de Santiago, tales como Alianza Cibaeña y Corazones del Cibao, instituciones dedicadas a promover la cultura y ofrecer servicios de salud sin fines de lucro. Ambas fueron incluidas en el Presupuesto de Ingresos y Ley de Gastos Públicos, a partir del año 2007, en gran medida por el esfuerzo del legislador ${ }^{217}$

En 2005 existían alrededor de 10,000 organizaciones y en 2011 cerca de 3,900 estaban incluidas en el Centro Nacional de Fomento de las Asociaciones sin Fines de Lucro, requisito previo para acceder a la subvención estatal (ONAPLAN 2011) ${ }^{218}$. Como muestra la Tabla 4.2.A.2.1 los subsidios directos a organizaciones de la sociedad civil constituyen una partida presupuestaria que representa entre el $0,31 \%$ y el $0,70 \%$ del presupuesto nacional. El número de organizaciones beneficiadas se ha mantenido estable en los últimos cuatro años pero no así en el cuatrienio anterior, en el que se aprecian fluctuaciones en las que se triplican las asociaciones agraciadas. Tal es el caso de los años 2006 y 2008, ambos años electorales. Cada ministerio asume la transferencia a las organizaciones sin fines de lucro de su área: el de Deportes a asociaciones de boxeo, ciclismo, baloncesto y cronistas deportivos, el de Educación a asociaciones de estudiantes, el de Salud y Asistencia Pública a organizaciones de beneficencia etc. Aunque también se aprecia un cierto grado de arbitrariedad, con casos en los que el Ministerio de Educación subvenciona al colegio dominicano de periodistas de varios municipios, el de Deportes a la Fundación Jacobo Majluta fenecido presidente del PRI en $2006^{219}$, o el del Ministerio de la Presidencia al Instituto de Formación Política del PRD en 2007. En todos ellos son visibles la falta de criterio en la cuantía de la asignación a organizaciones con similares fines y número de asociados y especialmente significativas en las asociaciones de estudiantes o en las centenares de agencias de desarrollo local de los municipios del país. En ambas, dependiendo del año y sin alteración objetiva de la naturaleza de la organización, aparecen aumentos y disminuciones de la cuantía asignada ${ }^{220}$.

\footnotetext{
${ }^{216}$ En los 90's se destaparon casos de legisladores que habían creado ONGs de asistencia social que recibían estas regalías. Algunas de ellas resultaron ser ONGs fantasma, creadas para financiar la candidatura del legislador.

${ }^{217}$ Diputado por el PRD provincia Santiago 2010-2016, Ver CV en http://www.camaradediputados.gob.do/serve/listfile_download.aspx?id=791\&num=1

${ }^{218}$ En 2012, un total de 5,280 estaban registradas en la Procuraduría General de la República.

${ }^{219}$ Y cuya subvención se prestaría a recompensar su no alianza con el PRD, partido matriz y del que naciera como escisión y así dividir el voto de la oposición.

${ }^{220}$ Ver presupuestos proyectados en la página web de la Dirección General de Presupuesto, DIGEPRES.
} 
La disgregación de intereses afines en varias asociaciones es otro de los rasgos identificados en la lectura de los informes presupuestarios nacionales. En el caso de los consumidores, el Consejo Nacional de Consumidores y usuarios (6,000 USD), la Fundación del Consumidor Dominicano (6,500 USD), la Red Nacional de Asociaciones de Consumidores (6,000 USD) y la Unión de Consumidores Progreso y Desarrollo (3,000 USD) se reparten la representatividad y regalías presupuestarias entre 2012 y 2010. El Ministerio de Educación distribuye el presupuesto dedicado a las ONG`s entre un centenar de parroquias, obispados e iglesias católicas y algunas evangélicas, pero también en asociaciones como la Fundación para la promoción Política y Social ${ }^{221}$. El Ministerio de Salud Pública y Asistencia Social es el que maneja la mayor partida presupuestaria para repartir dinero entre organizaciones no gubernamentales -seguido por el Ministerio de la Presidencia- distribuyendo subvenciones entre asociaciones de rehabilitación de adicciones, discapacitados, hogares de ancianos y diversos hospitales privados. En el país de América Latina que menos presupuesto destina a salud, en 2010 las transferencias directas del Ministerio a las ONGs igualaban en cuantía al rubro para financiar los servicios públicos de emergencia, representando cada una de ellas el 1,21\% del presupuesto del Ministerio de Salud Pública y Asistencia Social.

Tabla 4.2.A.2.1 Transferencias directas a Organizaciones No Gubernamentales en Presupuestos Formulados 2005-2012

\begin{tabular}{|c|c|c|c|c|c|c|c|c|}
\hline \multirow[b]{3}{*}{$\begin{array}{l}\text { Transferencias } \\
\text { corrientes ONG`s }\end{array}$} & \multicolumn{2}{|l|}{2012} & \multicolumn{2}{|l|}{2011} & \multicolumn{2}{|l|}{2010} & \multicolumn{2}{|l|}{2009} \\
\hline & $\mathbf{Q}$ & $\%$ & Q & $\%$ & Q & $\mathbf{N}$ & Q & $\%$ \\
\hline & $32,099,594$ USD & 0,34 & $29,406,181$ USD & 0.36 & $26,206,342$ USD & 0.34 & $25,165,970$ USD & 0.35 \\
\hline \multirow{2}{*}{$\begin{array}{l}\text { Presupuesto total } \\
\text { N }\end{array}$} & $9,401,633,493$ USD & 100 & $8,210,222,378$ USD & 100 & $7,810,636,849$ USD & 100 & $7,105,374,809$ USD & 100 \\
\hline & \multicolumn{2}{|l|}{$\mathbf{7 7 0}$} & \multicolumn{2}{|l|}{771} & \multicolumn{2}{|l|}{764} & \multicolumn{2}{|l|}{781} \\
\hline
\end{tabular}

\begin{tabular}{|c|c|c|c|c|c|c|c|c|}
\hline \multirow{5}{*}{$\begin{array}{l}\text { Transferencias } \\
\text { corrientes a ONG`s } \\
\text { Presupuesto total } \\
\text { N }\end{array}$} & \multicolumn{2}{|l|}{2008} & \multicolumn{2}{|l|}{2007} & \multicolumn{2}{|l|}{2006} & \multicolumn{2}{|l|}{2005} \\
\hline & $\mathbf{Q}$ & $\%$ & $\mathbf{Q}$ & $\%$ & $\mathbf{Q}$ & $\%$ & Q & $\%$ \\
\hline & $24,584,054$ USD & 0.38 & $17,192,714$ USD & 0.31 & $32,815,688$ USD & 0.67 & $27,132,310$ USD & 0.70 \\
\hline & $6,527,242,978$ USD & 100 & $\begin{array}{c}5,563,098,424 \\
\text { USD }\end{array}$ & 100 & $\begin{array}{c}4,879,067,817 \\
\text { USD }\end{array}$ & 100 & $\begin{array}{c}3,882,261,597 \\
\text { USD }\end{array}$ & 100 \\
\hline & 1,001 & & 471 & & 3,649 & & $\mathbf{3 , 3 7 3}$ & \\
\hline
\end{tabular}

Fuente: Elaboración propia en base a presupuestos formulados disponibles en la Dirección General de Presupuesto-DIGEPRES.

Resulta significativo que el Ministerio de la Presidencia sea quien subvencione las fundaciones que tienen como misión mantener vivo el legado de los tres caudillos: la Fundación Juan Bosch, la Fundación Balaguer y la Fundación Francisco Peña Gómez ${ }^{222}$. Esta fuente alternativa y constante de financiamiento de los tres partidos tradicionales es otro indicador de la posición hegemónica que disfrutan PLD, PRD y PRSC frente a la veintena de partidos minoritarios en la competencia imperfecta de los sistemas cartel, tal y como se argumentó en el apartado correspondiente a la estabilidad del sistema de partidos dominicano. Desde 2005 y de forma ininterrumpida las tres han sido beneficiarias independientemente del color de gobierno de turno aunque con variaciones en el monto total dada la naturaleza discrecional de estas regalías otorgadas por Presidencia.

Siguiendo con la atomización del activismo civil, en el ámbito municipal, la Federación Dominicana de Juntas de Vecinos en el año 1998 cuantificaba en 10.723 el total de estas organizaciones barriales en los 115 municipios del país. En la actualidad esta cifra se ha

221 Esta Fundación recibió 106,902USD en 2006.

${ }^{222}$ En 2012 recibieron 226,133 USD la Fundación Juan Bosch; 175,880 USD la Fundación Balaguer; y 25,125 USD la Fundación Francisco Peña Gómez. 
multiplicado aunque solo 217 estaban registradas en la Procuraduría General de la República en el año $2012^{223}$. El mero recuento del número de asociaciones no es indicador de calidad de la política (Boix y Posner 2000) ya que hay que tener en cuenta el fin asociativo y su capacidad para generar bienes que puedan ser disfrutados por toda la comunidad. República Dominicana se encontraba en 2010 entre los países con mayor porcentaje de peticiones sometidas por la ciudadanía a una instancia de gobierno municipal $(15,2 \%)$, siendo los factores que aumentaban la disposición a presentar solicitudes el de vivir en ciudades pequeñas o distritos rurales, tener una percepción negativa de la situación económica familiar y asistir a reuniones municipales (LAPOP 2010:159).

En 2012 y también encabezando la comparativa regional latinoamericana, este porcentaje se elevó al 18,3\% (LAPOP 2012:32) destacando 2006 y 2010 -años en que se celebraron contiendas electorales municipales- por el aumento significativo en la participación de reuniones municipales. Y según la misma fuente, en 2010 el país contaba con el promedio más alto de la región en participación comunitaria y en asociacionismo vecinal (24,7\% y $25 \%$ respectivamente). Sin embargo, y como alertaban los autores «lamentablemente, no hay datos para determinar si las solicitudes tienen fundamentalmente un propósito personal o de mejoría comunitaria» (Morgan, Espinal y Seligson 2010: 159). Aunque referido a las solicitudes realizadas a los representantes del Poder Legislativo con cargo al "barrilito", la lectura desagregada del segundo de los indicadores de particularismo legislativo de esta investigación "¿Qué conceden los ciudadanos a sus Diputados?” (Fondo de Gestión Legislativa o "Barrilito" 2008-2009), muestra un panorama de rasgos mutualistas y de protección de socios propio de contextos de confianza particularizada. Así, el $74,2 \%$ de las solicitudes que contaron con el beneplácito del diputado no beneficiaban a la generalidad de los munícipes, sino que eran bienes de club $(45,7 \%)$ y ayudas de socorro a alguno de sus miembros $(28,5 \%)$. Si bien la decisión del otorgamiento de la regalía es un acto de liberalidad del diputado que sigue un iter subjetivo en el canal particularizado de atención ciudadano-político, ofrece una idea del nivel de particularismo del universo de solicitudes de las organizaciones de comunitarias y vecinales. En estas concesiones se aprecian los rasgos sectaristas del activismo vecinal, ya que de un total de 35 peticiones, solo el $25,71 \%$ beneficiaban a la generalidad de la comunidad, mientras que el $45,7 \%$ eran beneficios concedidos a sus socios (bienes de club) y el $28,5 \%$ eran regalías de tipo individual para uno de sus asociados. Destaca por significativa la Provincia 3 - la del nivel más bajo en el Î́ndice de Empoderamiento Económico (PNUD 2010)- donde todas las solicitudes benefician a la totalidad de los munícipes.

Tabla 4.2.A.2.2 Concesiones del Fondo de Gestión Legislativa o "Barrilito" (2008-2009) asignadas a las asociaciones vecinales (av) por nivel de inclusión de beneficiarios

\begin{tabular}{|c|c|c|c|c|c|c|c|c|c|c|c|c|c|}
\hline & \multicolumn{5}{|c|}{ Provincia 1} & \multicolumn{3}{|c|}{ Provincia 2} & \multicolumn{2}{|c|}{ Provincia 3} & \multirow{2}{*}{\multicolumn{2}{|c|}{ TOTAL }} \\
\hline & & PRSC & \multicolumn{2}{|c|}{ PRD } & \multicolumn{2}{|r|}{ PLD } & PRD & \multicolumn{2}{|c|}{ PLD } & PRSC & PLD & & \\
\hline \multirow{5}{*}{ av } & & $\mathbf{N} \quad \%$ & $\mathbf{N}$ & $\%$ & $\mathbf{N}$ & $\%$ & n $\%$ & $\mathbf{N}$ & $\%$ & \begin{tabular}{|l}
$\mathbf{N}$ \\
\end{tabular} & N $\%$ & $\mathbf{N}$ & $\%$ \\
\hline & g & & & & & & $15,0 \%$ & & & $562,5 \%$ & $337,5 \%$ & & 25,71 \\
\hline & c & $457,14 \%$ & 1 & $14,28 \%$ & 1 & $14,28 \%$ & $5 \quad 25,0 \%$ & 5 & $25,0 \%$ & & & 16 & 45,71 \\
\hline & $\mathbf{i}$ & $14,28 \%$ & & & & & $840,0 \%$ & 1 & $5,0 \%$ & & & 10 & 28,57 \\
\hline & & & & & & & & & & & & 35 & 100 \\
\hline
\end{tabular}

Fuente: Elaboración propia. Codificación: (g) beneficia a la generalidad; (c) a una colectividad determinada; (i) beneficia a un individuo.

Atendiendo a la finalidad de la ayuda concedida por el diputado a las organizaciones vecinales, se observa que el porcentaje mayor corresponde a la categoría denominada "contingencias varias" y que contempla aquellas situaciones de necesidad relacionadas con la propia supervivencia de la

${ }^{223}$ A pesar de la solicitud, no fue posible obtener el dato de cuántas asociaciones de vecinos existen en la actualidad. 
organización como pagar el alquiler del local, el recibo de la luz, el teléfono, mobiliario para la sede de la asociación entre otros. Esto confirma la hipótesis que ya apuntara Vargas (1994) en su análisis de las organizaciones de base dominicanas, de las que se destacaba que el mayor logro era el simple hecho de su existencia dadas las dificultades económicas en las que operaban. Le siguen en número las de infraestructura barrial (arreglo de calles, asfaltado, riego...) con el 25,7\%, y las de carácter lúdico/recreativo (cena de navidad, regalo del día de la madre, fiestas para los asociados) con un $22,8 \%$.

En menor cuantía le siguen las concesiones para materiales de construcción $(11,4 \%)$, gastos médicos $(5,7 \%)$ o gastos de carácter educativo $(2,8 \%)$ para alguno de los socios de las agrupaciones vecinales. Mientras que en la provincia 1 -la de nivel más alto en el Índice de Desarrollo Humano (PNUD 2010)- el $71,42 \%$ de las concesiones a las asociaciones vecinales tienen un fin lúdico/recreativo, en la provincia 2 -la de nivel medio en el IDH- el grueso de la concesiones tienen la finalidad de sufragar contingencias varias (50\%); y en la provincia 3 última en el IDH, el $100 \%$ se dedican a infraestructuras municipales. Estos datos contradecirían desde el lado del principal el determinismo de la relación causal entre pobreza y clientelismo, ya que las asociaciones de vecinos de las comunidades más pobres resultan ser las más solidarias y las que solicitan bienes que pueden ser disfrutados por todos. Desde el lado del agente, podría tratarse de una estrategia de diversificación en la que se combina la asignación de bienes privados con bienes públicos que pueden ser disfrutados por opositores moderados como estrategia de persuasión (Rosas y Hawkins 2008).

Tabla 4.2.A.2.3 Concesiones del Fondo de Gestión Legislativa o "Barrilito" (2008-2009) asignadas a asociaciones vecinales (av) por tipología de la finalidad de la ayuda

\begin{tabular}{|c|c|c|c|c|c|c|c|c|c|c|}
\hline & \multicolumn{3}{|c|}{ Provincia 1} & \multicolumn{2}{|c|}{ Provincia 2} & \multicolumn{3}{|c|}{ Provincia 3} & \multirow{2}{*}{ TOTAL } \\
\hline & & PRSC & PRD & PLD & PRD & PLD & PRSC & \multicolumn{2}{|c|}{ PLD } & \\
\hline \multirow{8}{*}{ av } & & $\mathbf{N} \%$ & N $\%$ & N $\%$ & N \% & N $\%$ & $\mathbf{N} \%$ & & $\%$ & N \% \\
\hline & il & & & & $15 \%$ & & $562,5 \%$ & & $37,5 \%$ & 25,71 \\
\hline & gm & $1 \quad 14,28 \%$ & & & $15 \%$ & & & & & $2 \quad 5,71$ \\
\hline & ge & & & & & $15 \%$ & & & & $1 \quad 2,85$ \\
\hline & me & & & & $4 \quad 20 \%$ & & & & & $4 \quad 11,42$ \\
\hline & cv & & & $1 \quad 14,28 \%$ & $5 \quad 25 \%$ & $5 \quad 25^{c}$ & & & & 1131,42 \\
\hline & ar & $57,14 \%$ & $1 \quad 14,28 \%$ & & $3 \quad 15 \%$ & & & & & $8 \quad 22,85$ \\
\hline & & & & & & & & & & $35 \quad 100$ \\
\hline
\end{tabular}

Fuente: Elaboración propia. Codificación: (il) infraestructura local; (gm) gastos médicos; (ge) gastos educativos; (mc) materiales de construcción; (cv) contingencias varias; (ar) actividades recreativas.

\section{3) Del exilio a los despachos: calamidades y conquistas del sindicalismo dominicano}

\section{¿Cuáles son los límites a la acción colectiva?}

Si en el escenario político los partidos son los encargados de agregar los intereses y preferencias de los ciudadanos, en el escenario laboral, los sindicatos están llamados a agregar los intereses de los trabajadores. El objetivo de este epígrafe es identificar la falta de espacios de oportunidad para la conformación de un interés de clase y la concertación social en la República Dominicana. Como se relata a continuación, la atomización sindical ha convertido a algunos sindicatos en clientes poderosos que negocian de tú a tú con el gobierno mientras que a otros más modestos han de competir para ser beneficiarios de las regalías públicas. 
Los orígenes del sindicalismo en el país se remontan a la década de los cuarenta en plena dictadura trujillista. En esos años se crean los primeros sindicatos azucareros y se convocan las primeras huelgas en el sector (1942 y 1946). Como detallara Galíndez (1956), la represión llevó al exilio o la tumba a los principales dirigentes sindicales de la época. La industria azucarera representaba el $85 \%$ de la actividad productiva nacional y estaba llamada a liderar el proceso de proletarización en el país. Sin embargo, este proceso se encontró con numerosas dificultades. La primera, la desnacionalización y precariedad de la fuerza de trabajo formada mayoritariamente por trabajadores haitianos y $\operatorname{cocolos}^{224}$. La segunda, el control policial de trabajadores y organizaciones sindicales que logró mantener separados el mundo obrero del campo y el de la ciudad, evitando la conformación de una comunidad de intereses y acciones. Estas circunstancias obstaculizaron el surgimiento de un interés de clase y un actor sindical representativo.

El separatismo y la división parecen formar parte de la idiosincrasia del sindicalismo dominicano. Tras el asesinato del dictador Trujillo, se crea en 1961 el Frente Obrero Unido Pro Sindicatos Autónomos (FOUPSA) y solo un año después ya se encontraba dividido en cinco facciones independientes: FOUPSA LIBRE cercana al sindicalismo norteamericano y que pasó a llamarse Confederación Nacional de Trabajadores Libres (CONATRAL), la Confederación Autónoma de Sindicatos Cristianos (CASC), la Central Sindical de Trabajadores Dominicanos (CESITRADO) auspiciada por un sector del PRD, y la Unión de Trabajadores Sindicalizados, de orientación marxista. Tras el derrocamiento del gobierno constitucional de Juan Bosch en 1963 y la Guerra Civil de 1965, el movimiento sindical quedó subsumido por el movimiento popular pro democrático, recluido en la clandestinidad o el exilio y dirigiendo su acción al ámbito de las libertades más que a la organización de la fuerza laboral (Alburquerque 1995:8). La represión de opositores durante los "Doce Años" del gobierno autoritario de Joaquín Balaguer, dejó un historial de más de 40 sindicalistas, estudiantes y dirigentes de frentes campesinos desparecidos o asesinados como Henry Segara o Mamá Tingó.

Con la llegada del PRD al poder en 1978 se inicia la segunda transición democrática en un nuevo clima de libertad en el que florece el activismo obrero, aunque se acentúa también la división de las centrales sindicales por los intereses particulares de sus dirigentes tratando de buscar las ventajas ofrecidas por el sindicalismo internacional (Faxas 2007:78). Tras las medidas de ajuste del Plan de Estabilización Económica aprobado por el FMI, tiene lugar la "Revuelta del Hambre" de abril de 1984 con violentas protestas ciudadanas por la subida de los precios de productos de primera necesidad. El ejército salió a las calles en una batalla campal que dejó un balance de más de cien muertos y cinco mil arrestados. Esta intervención significó por un lado, la ruptura del PRD con los sectores sociales y por otro, el desplazamiento del actor sindical por los nuevos movimientos urbanos y barriales. Desde 1983 a 1987 se suceden las luchas y huelgas de profesionales urbanos de capas medias, mientras que los sindicatos, en particular los del sector transporte, van perdiendo legitimidad como interlocutores sociales acusados de corrupción, complicidad frente al poder y corporativización de sus demandas. La década de los ochenta marca el punto de inflexión en el activismo social y laboral, replegándose sobre sí mismo y buscando soluciones individuales a los problemas colectivos en una lógica de "sálvese quien pueda" (Faxas 2007:200).

Una década después el país asistirá al boom de las zonas francas. Esta modalidad industrial protegida por beneficios laborales y exenciones tributarias es en la actualidad uno de los sectores que más empleos directos genera y por tanto llamado a recoger el testigo del sector azucarero en el fallido intento de la representación obrera en República Dominicana ${ }^{225}$. Sin embargo, las veladas

\footnotetext{
${ }^{224}$ Inmigrantes de origen africano provenientes de las Antillas anglófonas.

${ }^{225}$ En 2011, la zona franca empleaba a 125,117 trabajadores según el Informe Estadístico del Consejo Nacional de Zonas Francas y Exportación.
} 
limitaciones a la formación de sindicatos encontraron también los obstáculos de la atomización de los actores sindicales. En la actualidad, FEDOTRAZONAS, UNATRAZONAS y FENATRAZONAS ${ }^{226}$, aglutinan a decenas de mini sindicatos de las 578 empresas que operan en las zonas francas de propiedad privada, pública, mixta y especial. Cada una de ellas está afiliada a diferentes centrales sindicales: Confederación Nacional de Unidad Sindical (CNUS), Confederación Autónoma Sindical Clasista (CASC), y Confederación Nacional de Trabajadores Dominicanas (CNTD). El llamamiento a la unidad sindical frente al sectarismo ha sido un reclamo constante y la enemistad sindical se ha escenificado en momentos cruciales de la historia económica del país como la firma del Pacto de Solidaridad Económica de 1990. Así se desprende de los testimonios de los dirigentes en las diferentes asambleas y congresos:

«Hay que procurar la unidad de acción, eliminar la competencia intersindical que genera desenfrenadas carreras de formación de sindicatos endémicos por no contar con apoyo de las masas de los trabajadores (CIDHLS, 1994:17)».

La escasez y antigüedad de las fuentes secundarias sobre el sindicalismo dominicano dan cuenta de la actual debilidad y el repliegue del movimiento obrero en el país ${ }^{227}$. La mayoría de las fuentes bibliográficas narran los hitos del activismo asociados a las luchas populares de los ochenta, junto a publicaciones de la primera década de los noventa relativas a los obstáculos a la libertad sindical en el nuevo escenario de zonas francas y maquilas.

Desde la segunda mitad de los noventa a la actualidad, el silencio sindical ha dado paso a otro tipo de movilización caracterizada por el particularismo, la fragmentación y la cooptación política. Una lucha en la que compiten entre sí las miles de organizaciones sindicales por lograr los favores públicos (ya sea en forma de exenciones, puestos en la administración, pensiones o financiamiento sostenido), en un estilo propio del socorro mutuo gremialista y lejos de la interlocución social del sindicato moderno de rama de actividad. Choferes (transportistas) y maestros monopolizan hoy la visibilidad de reivindicaciones obreras y ambos han encontrado en los partidos y las instituciones la vía para la representación de sus intereses corporativos. Los escenarios pre electorales suelen ser los más propicios para la conquista de beneficios y también donde aparecen con mayor claridad las relaciones interconectadas o de intromisión entre actores sindicales y políticos.

En las elecciones legislativas de mayo de 2010, el Presidente de la Federación Nacional del Transporte La Nueva Opción (FENATRANO) el sindicalista Juan Hubieres, conquistó un escaño de diputado por las listas del PRD. El ahora diputado y también Presidente de este gremio de pequeños empresarios transportistas comparte asiento en la comisión legislativa de transporte con el diputado Aquilino Serrata, ex Presidente de la Asociación Dominicana de Empresas del Taxi. Por lo tanto, parece que el malogrado sistema público de transporte dominicano tiene como "aliados" a dos de los grupos de interés menos interesados en que florezca la ya lánguida red de autobuses de la Autoridad Metropolitana de Transporte. En el Ejecutivo también cuentan con aliados. Así lo evidencia el indulto presidencial de 2008 a Antonio Marte, Presidente de la Confederación Nacional del Transporte (CONATRA) y filial de la Confederación Nacional de Trabajadores Dominicanos (CNTD), condenado y encarcelado por corrupción en la renovación a de la flota pública de automóviles ${ }^{228}$. En otros escenarios, el Banco Mundial (2013) identificaba a los

\footnotetext{
${ }^{226}$ Federación Dominicana de Trabajadores de Zonas Francas, Industrias Diversas y de Servicios; Unión Nacional de Trabajadores de Zonas Francas; y Federación Nacional de Trabajadores de Zonas Francas.

$227 \mathrm{Si}$ bien recientemente se han publicado varias obras sobre el tema (Faxas 2007, Evertsz 2011) ambas delimitan temporalmente su objeto de estudio a 1990 y 1981 respectivamente.

${ }^{228}$ Bajo la administración de Hipólito Mejía (2000-2004) se supo en funcionamiento el "Plan Renove", en el que se otorgaban subvenciones a transportistas para promover la renovación de la flota de automóviles.
} 
sindicatos médicos como "jugadores con poder de veto" en la política de salud pública ante sus reticencias a la implementación del programa de atención primaria que rechazan por considerar que favorece a los hospitales públicos en detrimento de los privados.

El actual presidente de la Asociación Dominicana de Profesores (ADP) Eduardo Hidalgo compagina su actividad sindical con la de diputado por el PLD. También así lo hizo el pasado presidente del sindicato magisterial mayoritario Radhamés Camacho, que ostentaba simultáneamente la presidencia de la organización y era diputado por el oficialista PLD. Es común que la renovación de los cuadros dirigenciales de los sindicatos se realice a través de las populares "planchas consensuadas" auspiciadas por los diferentes partidos políticos. De esta manera, la lucha por el control del sindicato se convierte en un reflejo de la contienda electoral partidista nacional. Esta intromisión neutraliza la beligerancia del movimiento obrero y sus líderes, quienes pasan de la calle y la pancarta al despacho y la nómina pública:

«Hoy todos los viejos robles del sindicalismo dominicano están en las oficinas de las agencias de la Seguridad Social, la Tesorería General o la Dirección de Información y Defensa del Afiliado... son funcionarios públicos. Digamos que han pasado a ser embajadores sindicales... porque son los primeros en viajar a cualquier congreso obrero donde quiera que sea, pero dentro del país están muy cómodos en sus despachos oficiales...» ${ }^{229}$

En el caso del sector magisterial, el apoyo del partido político resulta fundamental para lograr la designación del cargo de "director de distrito educativo". Este cargo de confianza del director regional lo componen un centenar de funcionarios que realizan funciones de inspección y que «actúan como verdaderos caciques, porque tienen el poder sobre todos los maestros y escuelas bajo su jurisdicción...para mantenerse en la escuela hay que contar con su beneplácito» ${ }^{230}$.

La atomización de la acción colectiva y modus operandi particularista del sindicalismo dominicano se refleja en el elevado número de organizaciones obreras que han existido desde la transición hasta nuestros días. En 1998 operaban 3.485 sindicatos (Secretaría de Estado de Trabajo 1998), la mayoría de los cuales eran sindicatos locales. Actualmente constan 3.737 sindicatos en el Registro del Ministerio de Trabajo (Marzo 2012), aunque tras las averiguaciones pertinentes, se estima que sólo un 33, 5\% (1.253) permanecen activos. Según datos del Banco Central de la República Dominicana, la población ocupada en el sector formal ascendía a 1.631 .129 personas en 2010, representando el 43,45\% de la fuerza laboral. La falta de depuración del padrón sindical nacional y el crecimiento desproporcionado de organizaciones en relación a la limitada fuerza laboral formal dominicana, «son vicios interesados y consentidos producto de la lucha entre centrales sindicales por medir su fuerza y lograr beneficios públicos» ${ }^{231}$. El sector transporte sigue aportando el mayor número de agrupaciones creadas con el fin exclusivo de hacerse con el control de una ruta. Los sindicatos de este sector que agrupa a miles de pequeños empresarios obstaculizan la implementación de una red de transporte público eficiente en República Dominicana. Este papel protagónico y sectarista de los sindicatos del transporte a quienes popularmente se les conoce como "los dueños del país", ilustra la batalla entre clientes y sus efectos en la delimitación de las políticas públicas. El fracaso del proyecto de colectivización del transporte durante el primer

Varios dirigentes sindicales, empresarios del transporte y funcionarios fueron condenados por estafa contra el Estado en la concesión de estas subvenciones.

${ }^{229}$ Entrevista con activista sindical dominicana. Entrevista realizada el 23 de septiembre de 2012.

${ }^{230}$ Entrevista con educadora y Ex Rectora Universidad, realizada el 28 de noviembre de 2012.

${ }^{231}$ Entrevista con especialista en Derecho Laboral, abogado y ex asesor de alto Funcionario del Ministerio de Trabajo. Realizada el 10 de octubre de 2012. 
gobierno del PRD en 1978 y que consistía en forzar la transición del sistema de "conchos" 232 a la red de autobuses, se debió a «razones políticas, la influencia de los choferes y la corrupción del Estado para controlar este sector» (Faxas 2007:247). En 2012, este poder se escenificó en la negociación para consensuar la reforma fiscal en la que los sindicatos del transporte lograron el compromiso del presidente electo de excluir al gremio de determinados gravámenes. Una conquista que la prensa tituló «Reforma fiscal grava pequeños negocios y complace a choferes» ${ }^{233}$.

¿Cómo afectan estos condicionantes al grado de particularismo en la representación laboral?

La tipología del historial de sindicatos de nueva creación registrados ante la Secretaría de Estado de Trabajo de la República Dominicana desde 1956 a 2011, permite conocer cómo es la naturaleza de la representación de los intereses laborales y la extensión de los beneficios de la negociación colectiva. Como muestra la Tabla 4.2.A.3.1, el carácter particularista es mayor en los sindicatos de empresa, ya que el interés de los representados se reduce a los empleados, la acción involucra a un solo patrón/empleador y los beneficios se circunscriben al espacio laboral de la propia empresa. En el nivel medio de particularismo estaría el sindicato de oficio, que amplía sus representados a una categoría profesional que labora para múltiples patronos/empleadores en una acción corporativa que extiende los beneficios a ese determinado gremio. En el extremo opuesto de la escala de particularismo estarían los sindicatos de rama de productividad, que ostentarían la representación más amplia de los intereses de clase y por tanto con mayor legitimación como interlocutores sociales, ya que su acción colectiva es la que conlleva una extensión de los beneficios que más se acerca a la concertación social.

Tabla 4.2.A.3.1 Tipología Sindicatos según interés representado, acción y beneficios de la negociación

\begin{tabular}{|c|ccc|}
\cline { 2 - 4 } & $\begin{array}{c}\text { INTERÉS } \\
\text { REPRESENTADO }\end{array}$ & ACCIÓN & $\begin{array}{c}\text { EXTENSIÓN } \\
\text { BENEFICIOS } \\
\text { NEGOCIACIÓN }\end{array}$ \\
\hline $\begin{array}{c}\text { DE RAMA } \\
\text { PRODUCTIVA }\end{array}$ & Clase & Colectiva & Concertación Social \\
\hline DE OFICIO & $\begin{array}{c}\text { Gremial } \\
\text { Interprofesional }\end{array}$ & $\begin{array}{c}\text { Corporativa } \\
\text { Individualizada }\end{array}$ & $\begin{array}{c}\text { Concertación Sectorial } \\
\text { Concertación Particularizada }\end{array}$ \\
\hline
\end{tabular}

Fuente: Elaboración propia

En República Dominicana, el sindicato de empresa constituye la modalidad de organización obrera más extendida desde la década del noventa hasta nuestros días, representando el $84 \%$ de total de las organizaciones en 1992, el 90\% en 1998 y 2002 y el 92\% en el año 2010. El sindicato de oficio compitió en importancia numérica durante los turbulentos años que van del Golpe Militar y la Guerra Civil de 1965 al regreso de Joaquín Balaguer en 1986. Los porcentajes oscilaban entre un $54 \%$ en 1965, un 62\% en 1975, un $79 \%$ en 1985 y un 52\% en 1990.

Las opiniones de los líderes sindicales de la época reflejan la preocupación por el particularismo de la lucha obrera nacional:

\footnotetext{
${ }^{232}$ El "concho" es el sistema de transporte más popular y generalizado que opera en el país. Automóviles de particulares hacen la ruta de calles recogiendo y dejando usuarios a su petición, sin paradas predeterminadas y superando el número de pasajeros permitido por razones de seguridad. En un automóvil pueden ser transportados cuatro pasajeros atrás y dos en el asiento del copiloto. Un total de siete personas con el conductor. También hay variantes como la "voladora" o pequeño mini bus, o el "moto concho", una motocicleta en la que se pueden transportar hasta cuatro personas. Aunque existen autobuses públicos de la Autoridad Metropolitana de Transportes, no cubren todas las rutas y su servicio es muy limitado por la resistencia de los sindicatos de transporte a cederlas las vías más importantes.

${ }^{233}$ En periódico Diario Libre de 25 del 10 de 2012.
} 
«Nuestro sindicalismo sigue siendo esencialmente de oficio, lo que supone que a final de siglo será gremial... Es por ello que creemos necesario crear organizaciones sindicales fuertes, no sindicatos de oficio sino industriales, y no crear sindicatos paralelos llevándonos de un concepto de libertad sindical mal interpretado» (CIDHLS, 1994:29).

Por el contrario, el sindicato de rama de productividad ha sido la modalidad sindical minoritaria salvo durante el breve gobierno de Juan Bosch, en el que esta tipología representó el 59\% del total de los nuevos registros. En solo dos años se registraron un total de 870 nuevos sindicatos, un indicador del clima de libertad tras las elecciones de 1962.

\section{Gráfico 4.2.A.3.1 Promedio \% Registro Sindicatos en el Ministerio de Trabajo 1956-1995}

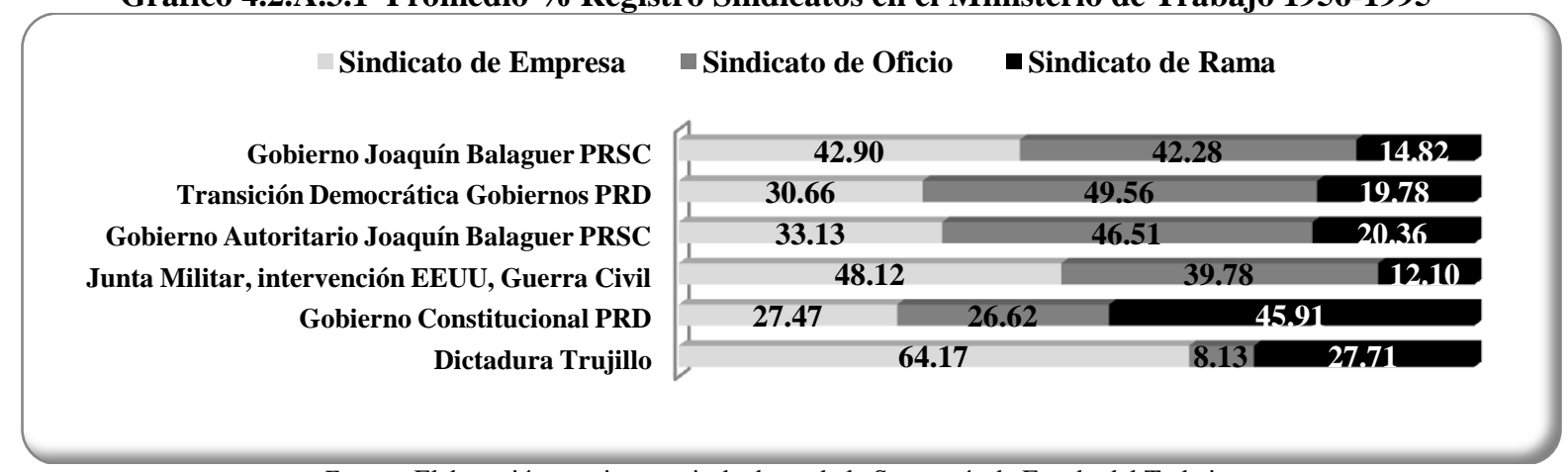

Fuente: Elaboración propia a partir de datos de la Secretaría de Estado del Trabajo

Gráfico 4.2.A.3.2 Promedio \% Registro Sindicatos en el Ministerio de Trabajo 1996-2010

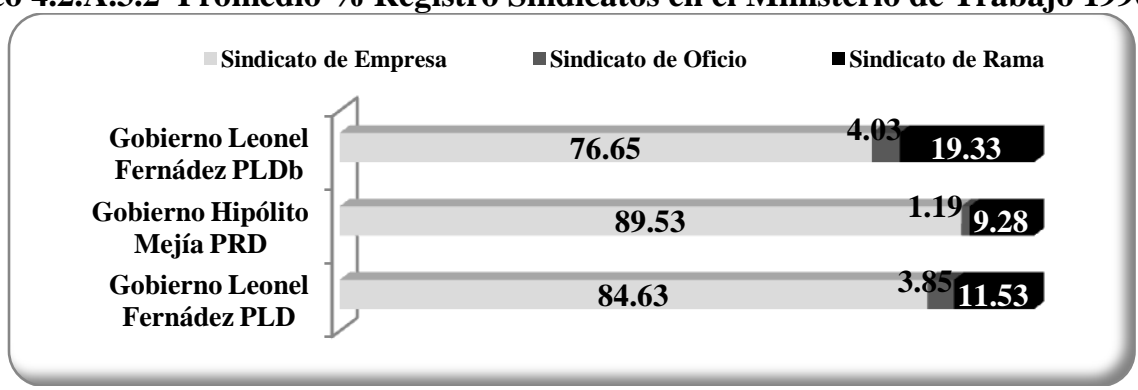

Fuente: Elaboración propia a partir de datos de la Secretaría de Estado del Trabajo.

La creación de sindicatos ha ido decreciendo y en la última década alcanza en número a los registrados en la dictadura de Trujillo y el primer gobierno de Joaquín Balaguer. En las administraciones del PLD y PRD la cifra rondaba los 20 sindicatos por año. No obstante, en este progresivo repliegue del registro sindical se observan varios picos de crecimiento superando el centenar, que corresponden a momentos transicionales y gobiernos perredeístas:

1) Tras la muerte del dictador Trujillo en el gobierno de Juan Bosch (1962-1963)

2) Inicio de la transición democrática tras el gobierno de Joaquín Balaguer (1978)

3) Entre 1984 y 1987 durante las revueltas por la crisis y las medidas de ajuste. 
Si bien el registro de nuevos sindicatos podría ser considerado un indicador viciado por la naturaleza decreciente de nuevos oficios, sigue siendo valioso dada la corta vida de las organizaciones y aporta datos sobre la naturaleza del activismo obrero dominicano.

Tabla 4.2.A.3.2 Registro Sindicatos en Ministerio de Trabajo Etapa Consolidación Democrática 1996-2010

\begin{tabular}{|c|c|c|c|c|c|c|c|c|}
\hline & & \multicolumn{2}{|c|}{$\begin{array}{l}\text { Sindicado de } \\
\text { Empresa }\end{array}$} & \multicolumn{2}{|c|}{$\begin{array}{l}\text { Sindicado de } \\
\text { Oficio }\end{array}$} & \multicolumn{2}{|c|}{$\begin{array}{l}\text { Sindicado de Rama } \\
\text { de Actividad }\end{array}$} & \multirow{2}{*}{$\begin{array}{c}\text { Total } \\
\text { T }\end{array}$} \\
\hline & & $\mathbf{N}$ & $\%$ & $\mathbf{N}$ & $\%$ & $\mathbf{N}$ & $\%$ & \\
\hline \multirow{5}{*}{$\begin{array}{c}\text { Gobierno Leonel Fernández } \\
\text { PLD }\end{array}$} & 1996 & 17 & 65.38 & 0 & 0.00 & 9 & 34.62 & 26 \\
\hline & 1997 & 17 & 62.96 & 3 & 11.11 & 7 & 25.93 & 27 \\
\hline & 1998 & 18 & 90.00 & 1 & 5.00 & 1 & 5.00 & 20 \\
\hline & 1999 & 15 & 88.24 & 0 & 0.00 & 2 & 11.76 & 17 \\
\hline & Media & & 76.65 & & 4.03 & & 19.33 & 90 \\
\hline \multirow{5}{*}{ Gobierno Hipólito Mejía PRD } & 2000 & 20 & 95.24 & 1 & 4.76 & 0 & 0.00 & 21 \\
\hline & 2001 & 20 & 86.96 & 0 & 0.00 & 3 & 13.04 & 23 \\
\hline & 2002 & 20 & 90.91 & 0 & 0.00 & 2 & $\begin{array}{l}9.09 \\
\end{array}$ & 22 \\
\hline & 2003 & 17 & 85.00 & 0 & 0.00 & 3 & 15.00 & 20 \\
\hline & Media & & 89.53 & & 1.19 & & 9.28 & 86 \\
\hline \multirow{8}{*}{$\begin{array}{c}\text { Gobierno Leonel Fernández } \\
\text { PLD }\end{array}$} & 2004 & 8 & 61.54 & 0 & 0.00 & 5 & 38.46 & 13 \\
\hline & 2005 & 15 & 75.00 & 1 & 5.00 & 4 & 20.00 & 20 \\
\hline & 2006 & 25 & 92.59 & 2 & 7.41 & 0 & 0.00 & 27 \\
\hline & 2007 & 15 & 78.95 & 2 & 10.53 & 2 & 10.53 & 19 \\
\hline & 2008 & 18 & 100.00 & 0 & 0.00 & 0 & 0.00 & 18 \\
\hline & 2009 & 23 & 92.00 & 1 & 4.00 & 1 & 4.00 & 25 \\
\hline & 2010 & 36 & 92.31 & 0 & 0.00 & 3 & 7.69 & 39 \\
\hline & Media & & 84.63 & & 3.85 & & 11.53 & 161 \\
\hline
\end{tabular}

Fuente: Elaboración propia en base a datos de la Secretaría de Estado de Trabajo, República Dominicana

Esta radiografía de la tipología sindical en República Dominicana es indicador de la atomización de la voluntad laboral y el particularismo de la reivindicación obrera en el país. Un escenario de múltiples actores, que fracciona la negociación reduciéndola al espacio físico de la empresa y que debilita el papel de los sindicatos como interlocutores sociales. Sindicatos de rama de actividad, como los que agrupan a trabajadores del campo o del comercio, conviven con sindicatos de oficio como el del poderoso sector transporte que a su vez se atomiza en mini sindicatos de cobradores, de choferes, choferes turísticos y choferes de maquinaria pesada entre otros. Estos sindicatos de oficio se desintegran y desmenuzan aún más por provincias, municipios y rutas de viaje, convirtiéndose en competidores. Esta competencia entre sindicatos que pertenecen a diferentes centrales sindicales en ocasiones se convierte en una guerra campal que termina en tragedia ${ }^{234}$.

\footnotetext{
${ }^{234}$ Son numerosos los incidentes de vehículos de distintos sindicatos por el control de una ruta o la captación de pasajeros y que adoptan la forma de carreras entre los propios choferes o la obstaculización de vías. Ver por ejemplo incidentes por control de la ruta Da jabón-Santiago en periódico Puerto Plata Digital del 26 de mayo de 2011.
} 
Tabla 4.2.A.3.3 Registro Sindicatos en Ministerio de Trabajo Dictadura-Transición-Alternancia 1956-1995

\begin{tabular}{|c|c|c|c|c|c|c|c|c|}
\hline & \multicolumn{2}{|c|}{$\begin{array}{c}\text { Sindicato de } \\
\text { Empresa }\end{array}$} & \multicolumn{2}{|c|}{$\begin{array}{l}\text { Sindicado } \\
\text { de Oficio }\end{array}$} & \multicolumn{2}{|c|}{$\begin{array}{c}\text { Sindicato de Rama } \\
\text { de Actividad }\end{array}$} & \multirow{2}{*}{$\begin{array}{c}\text { Total } \\
\mathbf{T}\end{array}$} \\
\hline & & $\mathbf{N}$ & $\%$ & $\mathbf{N}$ & $\%$ & $\mathbf{N}$ & $\%$ & \\
\hline \multirow{7}{*}{ Dictadura Trujillo } & 1956 & 1 & 50.00 & 0 & 0.00 & 1 & 50.00 & 2 \\
\hline & 1957 & 1 & 50.00 & 0 & 0.00 & 1 & 50.00 & 2 \\
\hline & 1958 & 9 & 90.00 & 1 & 10.00 & 0 & 0.00 & 10 \\
\hline & 1959 & 4 & 100.00 & 0 & 0.00 & 0 & 0.00 & 4 \\
\hline & 1960 & 9 & 45.00 & 4 & 20.00 & 7 & 35.00 & 20 \\
\hline & 1961 & 8 & 50.00 & 3 & 18.75 & 5 & 31.25 & 16 \\
\hline & Media & & 64.17 & & 8.13 & & 27.71 & 54 \\
\hline \multirow{3}{*}{ Gobierno Constitucional Juan Bosch } & 1962 & 104 & 32.00 & 117 & 36.00 & 104 & 32.00 & 325 \\
\hline & 1963 & 125 & 22.94 & 94 & 17.25 & 326 & 59.82 & 545 \\
\hline & Media & & 27.47 & & 26.62 & & 45.91 & 870 \\
\hline \multirow{3}{*}{$\begin{array}{l}\text { Golpe de Estado, Junta Militar, Rebelión } \\
\text { militar y Guerra Civil }\end{array}$} & 1964 & 37 & 58.73 & 16 & 25.40 & 10 & 15.87 & 63 \\
\hline & 1965 & 9 & 37.50 & 13 & 54.17 & 2 & 8.33 & 24 \\
\hline & Media & & 48.12 & & 39.78 & & 12.10 & 87 \\
\hline \multirow{13}{*}{ Gobierno autoritario Joaquín Balaguer } & 1966 & 12 & 25.53 & 24 & 51.06 & 11 & 23.40 & 47 \\
\hline & 1967 & 14 & 50.00 & 4 & 14.29 & 10 & 35.71 & 28 \\
\hline & 1968 & 6 & 54.55 & 3 & 27.27 & 2 & 18.18 & 11 \\
\hline & 1969 & 8 & 53.33 & 5 & 33.33 & 2 & 13.33 & 15 \\
\hline & 1970 & 7 & 36.84 & 7 & 36.84 & 5 & 26.32 & 19 \\
\hline & 1971 & 8 & 42.11 & 9 & 47.37 & 2 & 10.53 & 19 \\
\hline & 1972 & 10 & 18.87 & 26 & 49.06 & 17 & 32.08 & 53 \\
\hline & 1973 & 8 & 33.33 & 12 & 50.00 & 4 & 16.67 & 24 \\
\hline & 1974 & 15 & 38.46 & 16 & 41.03 & 8 & 20.51 & 39 \\
\hline & 1975 & 6 & 22.22 & 17 & 62.96 & 4 & 14.81 & 27 \\
\hline & 1976 & 6 & 10.71 & 46 & 82.14 & 4 & 7.14 & 56 \\
\hline & 1977 & 5 & 11.63 & 27 & 62.79 & 11 & 25.58 & 43 \\
\hline & Media & & 33.13 & & 46.51 & & 20.36 & 381 \\
\hline \multirow{9}{*}{ Transición democrática Gobiernos PRD } & 1978 & 73 & 65.18 & 26 & 23.21 & 13 & 11.61 & 112 \\
\hline & 1979 & 29 & 35.37 & 31 & 37.80 & 22 & 26.83 & 82 \\
\hline & 1980 & 30 & 31.58 & 42 & 44.21 & 23 & 24.21 & 95 \\
\hline & 1981 & 21 & 32.81 & 31 & 48.44 & 12 & 18.75 & 64 \\
\hline & 1982 & 22 & 30.14 & 38 & 52.05 & 13 & 17.81 & 73 \\
\hline & 1983 & 11 & 13.92 & 49 & 62.03 & 19 & 24.05 & 79 \\
\hline & 1984 & 31 & 25.41 & 60 & 49.18 & 31 & 25.41 & 122 \\
\hline & 1985 & 25 & 10.87 & 183 & 79.57 & 22 & 9.57 & 230 \\
\hline & Media & & 30.66 & & 49.56 & & 19.78 & 650 \\
\hline \multirow{11}{*}{ Gobierno Joaquín Balaguer } & 1986 & 50 & 15.67 & 229 & 71.79 & 40 & 12.54 & 319 \\
\hline & 1987 & 12 & 8.82 & 100 & 73.53 & 24 & 17.65 & 136 \\
\hline & 1988 & 13 & 16.67 & 53 & 67.95 & 12 & 15.38 & 78 \\
\hline & 1989 & 13 & 20.31 & 43 & 67.19 & 8 & 12.50 & 64 \\
\hline & 1990 & 8 & 12.31 & 34 & 52.31 & 23 & 35.38 & 65 \\
\hline & 1991 & 40 & 42.55 & 35 & 37.23 & 19 & 20.21 & 94 \\
\hline & 1992 & 77 & 84.62 & 5 & 5.49 & 9 & $\begin{array}{l}9.89 \\
\end{array}$ & 91 \\
\hline & 1993 & 49 & 83.05 & 7 & 11.86 & 3 & 5.08 & 59 \\
\hline & 1994 & 31 & 81.58 & 7 & 18.42 & 0 & 0.00 & 38 \\
\hline & 1995 & 26 & 63.41 & 7 & 17.07 & 8 & 19.51 & 41 \\
\hline & Media & & 42.90 & & 42.28 & & 14.82 & 985 \\
\hline
\end{tabular}

Fuente: Elaboración propia en base a datos de la Secretaría de Estado de Trabajo, República Dominicana 
El escaso número de pactos colectivos registrados ante la Secretaría de Estado de Trabajo, dan cuenta también del exiguo poder de negociación de los actores laborales dominicanos ${ }^{235}$. Este instrumento democrático de consenso que persigue la paz social a través del acuerdo de las condiciones laborales ha tenido un impacto limitado. En el año 2011, en un tejido industrial de 47,774 empresas solo se registraron 15 convenios colectivos, lo que supone un $0.03 \%$ en el escenario laboral del país.

Tabla 4.2.A.3.4 Relación de Pactos Colectivos y Empresas Registradas

\begin{tabular}{|c|c|c|c|c|c|c|c|c|c|c|c|c|c|c|c|}
\hline & 2011 & 2010 & 2009 & 2008 & 2007 & 2006 & 2005 & 2004 & 2003 & 02 & 01 & 00 & 99 & 98 & 97 \\
\hline $\begin{array}{l}\text { EMPRESAS } \\
\text { REGISTRADAS }\end{array}$ & 47,774 & 44,392 & 39,407 & 38,243 & 33,674 & 25,012 & 22,134 & 17,608 & 16,339 & nd & nd & nd & nd & nd & nd \\
\hline $\begin{array}{l}\text { PACTOS } \\
\text { COLECTIVOS }\end{array}$ & 15 & 22 & 26 & 14 & 15 & 22 & 10 & 3 & 16 & 10 & 18 & 29 & 13 & 21 & 3 \\
\hline$\%$ & 0.03 & 0.05 & 0.07 & 0.04 & 0.04 & 0.09 & 0.05 & 0.02 & 0.10 & -- & -- & -- & -- & -- & -- \\
\hline
\end{tabular}

Fuente: Elaboración propia a partir de datos de la Tesorería General de la Seguridad Social y de la Secretaría de Estado del Trabajo, República Dominicana. La Tesorería General de la Seguridad Social comenzó a operar en 2002.

Entre las conquistas de este más de un millar de sindicatos que operan en una población ocupada en el sector formal que representan el 43,45\% de la población activa (1,631,129 empleados) se encuentra el de ser uno de los países de América Latina con el salario mínimo más bajo, junto con Cuba, Bolivia, El Salvador, Guatemala y Nicaragua (FMI 2012). Además, es el único país de la región en el que el salario mínimo promedio real ha retrocedido en la última década (OIT, 2011).

En contraste y según un estudio del capítulo nacional de Transparency International-RD algunos de los sueldos de los funcionarios de las instituciones del Estado dominicano multiplican 119 veces el salario mínimo, 110 veces el salario de un maestro de escuela y 25 el de un médico. El salario más bajo entre los funcionarios públicos nacionales, multiplica por 30 el sueldo mínimo de un operario medio, por 25 el de un maestro y por 6 el de un médico (Participación Ciudadana 2012). Con el último aumento de salario que se aplicó en el país en marzo de 2011, las escalas salariales mínimas oscilan entre los 250 y los 150 dólares mensuales. La diferencia de salarios entre profesionales con especialización y asistentes genera una relación laboral paternalista entre jefeempleados, siendo usual que subordinados apelen al superior para que éste les financie las estrecheces que impiden llegar a fin de mes ${ }^{236}$.

Tabla 4.2.A.3.5 Escalas salariales y salario mínimo mensual en República Dominicana 2011

\begin{tabular}{|lll|}
\hline Primera escala salarial & RD \$ 9,905 & USD \$ 248 \\
Segunda escala salarial & RD \$ 6,810 & USD \$ 170 \\
Tercera escala salarial & RD \$ 6,035 & USD \$ 151 \\
\hline
\end{tabular}

El perfil mutualista que caracteriza a las organizaciones sindicales dominicanas se refleja en la naturaleza de las ayudas solicitadas a los diputados del indicador de particularismo legislativo de esta investigación. De las 14 peticiones realizadas por organizaciones sindicales y profesionales que fueron atendidas por los legisladores en los años 2008 y 2009, solo una de ellas -la realizada por un sindicato de trabajadores del campo- tiene como beneficiario final a la comunidad [infraestructura

\footnotetext{
${ }^{235}$ El Codigo de TRabajo Dominicano exige para la negociacion colectiva que el sindicato cuente con la representacion de 50+1 (mayoría absoluta) de los trabajadores de le empresa o gremio.

${ }^{236}$ Es habitual que los trabajadores de las escalas más bajas se inserten en redes adicionales de multi empleo informal. En el caso de las mujeres, la más común es la venta de ropa en el mismo centro laboral formal, así como la red de prestamistas informales entre propios compañeros de trabajo con intereses usureros.
} 
local (il), ayuda para la canalización del agua]. El resto son bienes de club que benefician exclusivamente a los afiliados al sindicato [6 actividades recreativas (ar), sufragar gastos para la cena de Navidad, tres excursiones, elección de la reina de las fiestas patronales y fiesta de aniversario del sindicato; y 7 contingencias varias (cv), cuatro ayudas económicas para la propia supervivencia organizacional, arreglo de computadoras, máquinas de coser y pago del alquiler del local]. Entre estas últimas destaca la ayuda solicitada por un sindicato de transporte para la compra de chalecos reflectantes de seguridad para los choferes y que llevaban el nombre del diputado del partido oficialista PLD que los patrocina. Esta politización y la naturaleza clientelar del vínculo que evidencia entre ambas instancias, reduce la beligerancia de los sindicatos, supeditados a los actos de liberalidad de los poderes públicos que sufragan las vicisitudes y actividades del sindicato.

Tabla 4.2.A.3.6 Concesiones del Fondo de Gestión Legislativa o "Barrilito" (2008-2009) asignadas a las organizaciones sindicales y profesionales (osp) por nivel de inclusión de beneficiarios

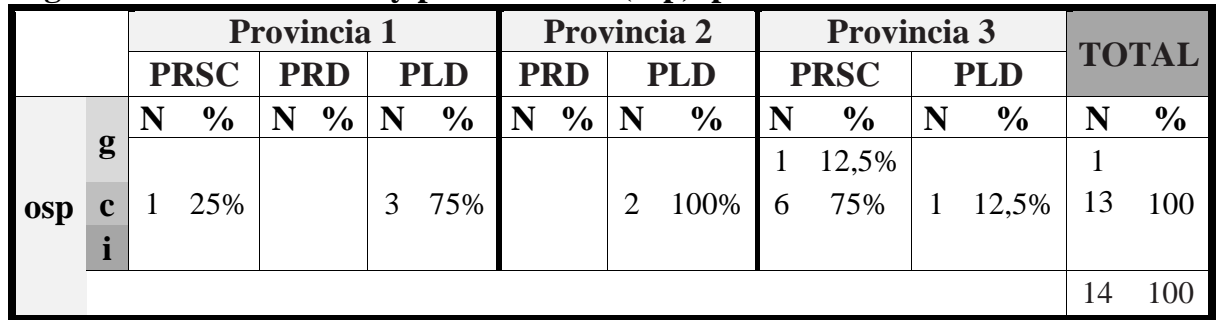

Fuente: Elaboración propia. (g) beneficia a la generalidad; (c) beneficia a una colectividad determinada; (i) beneficia a un individuo.

Tabla 4.2.A.3.7 Concesiones del Fondo de Gestión Legislativa o "Barrilito" (2008-2009) asignadas a las organizaciones sindicales y profesionales (osp) por tipología de la finalidad de la ayuda

\begin{tabular}{|c|c|c|c|c|c|c|c|c|c|c|c|c|c|c|}
\hline & \multicolumn{4}{|c|}{ Provincia 1} & \multicolumn{3}{|c|}{ Provincia 2} & \multicolumn{4}{|c|}{ Provincia 3} & \multicolumn{2}{|c|}{ TOTAL } \\
\hline & & PRSC & PRD & \multicolumn{2}{|c|}{ PLD } & PRD & \multicolumn{2}{|c|}{ PLD } & \multicolumn{2}{|c|}{ PRSC } & \multicolumn{2}{|c|}{ PLD } & \multirow[b]{2}{*}{$\mathbf{N}$} & \multirow[b]{2}{*}{$\%$} \\
\hline \multirow{8}{*}{ osp } & 1 & N $\%$ & N \% & $\mathbf{N}$ & $\%$ & N\% & $\mathbf{N}$ & $\%$ & $\mathbf{N}$ & $\%$ & $\mathbf{N}$ & $\mathbf{N}$ & & \\
\hline & 11 & \multirow{6}{*}{$125 \%$} & & \multirow{6}{*}{\multicolumn{2}{|c|}{$375 \%$}} & & & \multirow{6}{*}{$100 \%$} & & $12,5 \%$ & \multirow{6}{*}{1} & \multirow{6}{*}{$\begin{array}{c}12,5 \\
\%\end{array}$} & 1 & 7,14 \\
\hline & gm & & & & & & & & & & & & & \\
\hline & ge & & & & & & & & & & & & & \\
\hline & mc & & & & & & & & & & & & & \\
\hline & cv & & & & & & & & & & & & 7 & 50 \\
\hline & ar & & & & & & & & 6 & $75 \%$ & & & 6 & 42,85 \\
\hline & & & & & & & & & & & & & 14 & 100 \\
\hline
\end{tabular}

Fuente: Elaboración propia.(il) infraestructura local; (gm) gastos médicos; (ge) gastos educativos; (mc) materiales de construcción; (cv) contingencias varias; (ar) actividades recreativas.

En cuanto a los solicitantes de las regalías legislativas, cinco provienen de sindicatos locales afiliados a la Asociación Dominicana de Profesores (ADP) (35\%); seis organizaciones de diferentes perfiles profesionales tales como médicos, periodistas o artesanos (42\%); dos sindicatos de trabajadores del campo (14\%); y un sindicato del transporte (7\%). La cuantía de las ayudas oscila entre los 15,000 y los 3,000 DOP (400 y 100 USD respectivamente).

La competencia por alcanzar los favores públicos entre organizaciones sindicales se pone también de manifiesto en los Informes de Ejecución Presupuestaria Nacional. Desde 2005 a la fecha, en el apartado dedicado a "Transferencias Directas a ONGs" de cada uno de los Ministerios, se puede observar que el Ejecutivo ha financiado regularmente a la Central General de Trabajadores-CGT, la Confederación Autónoma de Sindicatos Clasista (CASC), la Confederación de Trabajadores 
Unitarios (CTU) y la Confederación Nacional de Trabajadores Dominicanos (CNTD). Dependiendo de la liberalidad y el criterio del favor presidencial, variadas y variopintas organizaciones sindicales se han visto beneficiadas por estas subvenciones. Como muestra la Tabla 4.2.A.3.8 en los últimos cinco años y sin aparente atención al criterio de representatividad, una federación de campesinos de Salcedo -municipio de 40,000 habitantes dedicado a la cosecha del plátano y la yuca- y un sindicato de oficio que agrupa a las secretarias recibieron transferencias directas. En 2006 y 2005 gozaron del favor del Ejecutivo una asociación de choferes pensionados de las fuerzas armadas y un sindicato de periodistas del pueblo de Bonao. Este municipio de 115,000 habitantes depende de la empresa minera internacional Falconbridge, por lo que esta asignación podría hacer dudar de la independencia de los medios locales frente a los posibles daños de la deforestación que han venido denunciando los grupos ambientalistas del país. En esos años, también se otorgó la regalía a dos organizaciones empresariales metalúrgicas de la región este del país y a dos organizaciones de promoción industrial y de investigación económica, cuyo financiamiento pareciera más propio del Ministerio de Industria y Comercio, que del Ministerio de Trabajo $^{237}$.

Esta liberalidad en la asignación de transferencias directas es escenario de un ejercicio oportunista y clientelar en el que se intercambian favores por votos. En el año 2007 no se asignaron transferencias directas a otras organizaciones según consta de la revisión de este rubro presupuestario, sin embargo, en el apartado dedicado a "Contribuciones Especiales" el Ministerio de Trabajo financió la Caja de Pensiones y Jubilaciones para Choferes y las pensiones del Sindicado de Trabajadores Portuarios de Arribo (POASI). Como informaba la propia página web de la Presidencia de la República, un mes después de las elecciones legislativas de mayo de 2010, el Plan de Asistencia Social de la Presidencia repartía ayudas para materiales de construcción a los trabajadores de POASI en la sede del sindicato ${ }^{238}$. En las pasadas elecciones presidenciales de 2012, los intereses de clase se disgregaron en un millar de gremios que se repartían los apoyos de ambos candidatos: "Joyeros con Papá", "Constructores con Papá", "Profesionales egresados de Rusia y la Europa del Este con Danilo", "Abogados de Monseñor Nouel con Danilo", "Choferes urbanos Los Ríos con Danilo", "Artesanos con Danilo".

En ausencia de un sistema de previsión de contingencias de cobertura universal, la concesión de pensiones en el país adopta un carácter prebendalista y arbitrario. La conquista de la pensión no es un derecho adquirido, sino una regalía por la que compiten gremios contra gremios, trabajadores contra trabajadores en un universo de clientes y patronos públicos. Como mostrara esta investigación, el asistencialismo particularista es utilizado tanto por el Ejecutivo como por el Legislativo. Solo en la legislatura 2006-2010, la concesión de pensiones por parte de los diputados a ciudadanos particulares constituyó el $23 \%$ de las proposiciones de Ley elevadas a trámite. En la campaña electoral por la conquista de la Presidencia de 2012, el primer mandatario concedió pensiones mediante decreto presidencial a grupos seleccionados de trabajadores de diversos colectivos profesionales. En el caso de los músicos la conquista se anunciaba con el titular: "Por fin! Un cariñito para los músicos dominicanos!" y en la que daba cuenta del Decreto Presidencial Núm. 721-11 donde 27 profesionales de la música eran pensionados con cantidades que oscilaban

\footnotetext{
${ }^{237}$ A pesar de las investigaciones no se pudo comprobar la identidad del Grupo Desarrollo y Democracia. Los confidentes consultados afirmaron que se podría tratar o de la Fundación Global Democracia y Desarrollo presidida por el ex Presidente Leonel Fernández, o del Grupo Economía y Desarrollo, un think tank dedicado a promover el pensamiento neoliberal dirigido por Andy Dauhajre, relacionado con un importante grupo de comunicación y actualmente embajador en EEUU designado por el partido oficialista.

${ }^{238}$ Ver página web del Plan de Asistencia Social de la Presidencia del 23 de Julio de 2010 «Ayudas para los trabajadores de POASI». En http:www.pasp.gob.do/site/Default.aspx?tabid=76\&itemld=133. Consulta realizada 13 del noviembre de 2012.
} 
entre los 1,250 USD y 500 USD $^{239}$. La palabra "cariñito" ejemplifica el concepto de regalía y paternalismo en el acto de concesión de la pensión. El Decreto no especificaba el principio de mérito para asignar las diferentes cuantías salvo su contribución al arte.

Sin embargo, otros colectivos como el de los cortadores de caña, no contaron con el favor presidencial a pesar de ser históricas sus reivindicaciones ${ }^{240}$.

El repaso a la historia y condicionantes de la movilización obrera en República Dominicana, permite esbozar los obstáculos a la acción colectiva en el país. La atomización multiplica los agentes de la acción sindical, que pasa de ser colectiva a corporativa, en una competencia que convierte en enemigos a obreros de un mismo oficio pero afiliados a distintas centrales sindicales. En esta batalla, se diluye el interés de clase. El carácter gremialista de las organizaciones favorece la conquista de bienes de club que solo disfrutan sus afiliados y la cooptación política reduce la beligerancia de sus acciones y reclamos. Resulta significativo que los presidentes del sindicato de maestros que se ha sumado al movimiento ciudadano "Coalición Digna por la Educación" que persigue que se asigne el 4\% del PIB a la educación, sean a la vez, legisladores del partido cuyos representantes se opusieron a la propuesta. Todas estas circunstancias han afectado la confianza de la ciudadanía en los sindicatos. En el año 2004, solo el 20,8\% de los entrevistados decía confiar mucho/bastante en ellos (LAPOP 2004). La movilización obrera ha de enfrentar un escenario de informalidad que alcanza el $56 \%$ de la población económicamente activa y la presencia de trabajadores haitianos. Esta fuerza laboral informal se caracteriza por la precariedad, desprotección y vulnerabilidad. La limitada afiliación sindical, que ronda actualmente el 13\% se ve condicionada también por el género y el menor activismo de las mujeres, orientado a otro tipo de organizaciones.

\footnotetext{
${ }^{239}$ En periódico El Día, de 22 de noviembre de 2011.

${ }^{240}$ Se estima que unos 22.000 trabajadores de la caña llevan esperando más de una década sus pensiones. En mayo de 2012 solo 139 estaban pensionados. Una de las primeras medidas del electo presidente Danilo Median fue pensionar a 2.000 cañeros.
} 
Tabla 4.2.A.3.8 "Transferencias a ONGs" del Ministerio de Trabajo en el Presupuesto Nacional 2005-2012

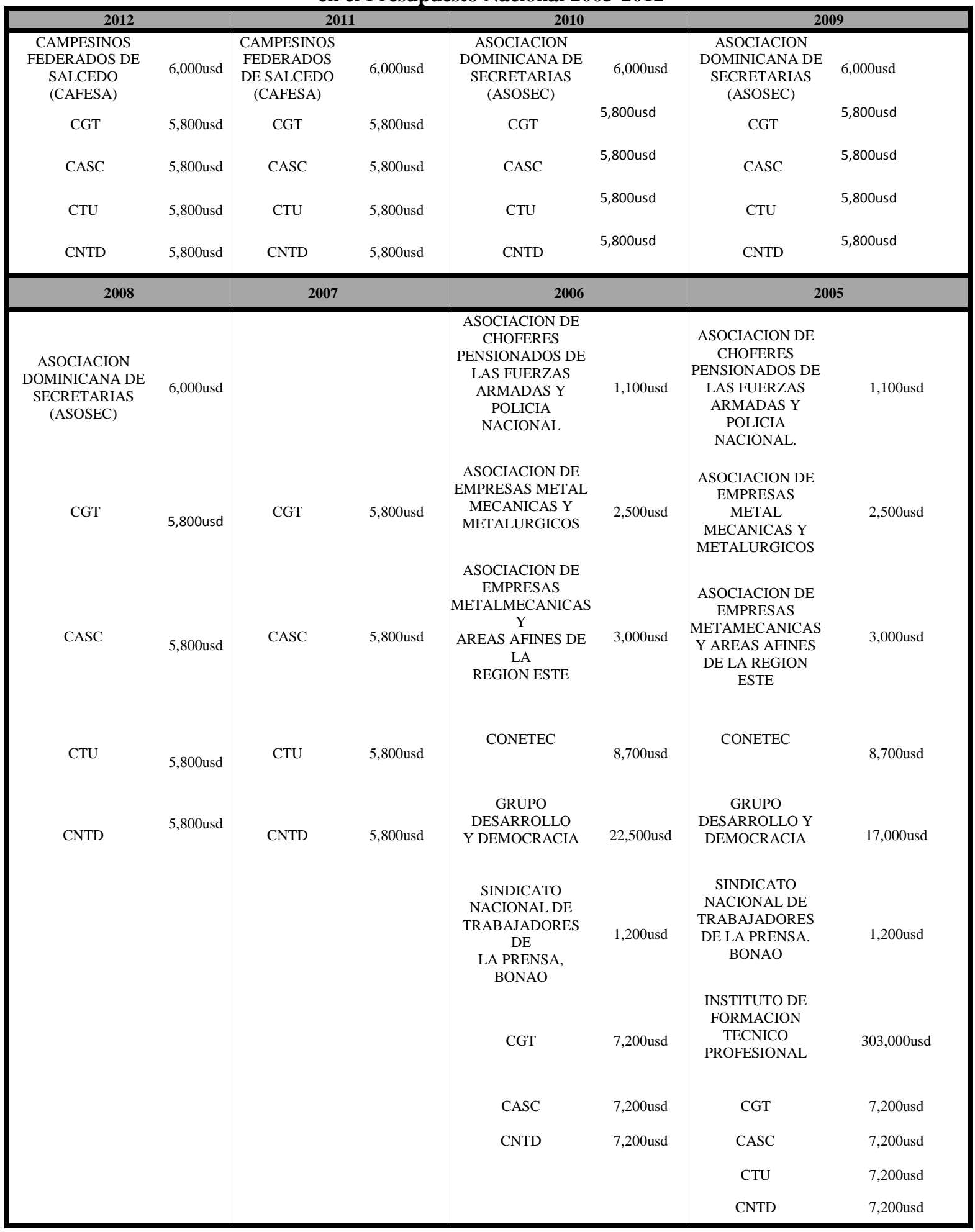

Fuente: Elaboración propia en base a los Informes de Ejecución Presupuestaria, en la Dirección General de Presupuesto, DIGEPRES. Aunque están disponibles los presupuestos de 2004 a 1990, no existe información desagregada hasta 2005 de estas transferencias. 


\title{
4.2.b) CAPITAL SOCIAL y POLÍTICO: VALORES, ACTITUDES Y PERCEPCIONES DE LOS CIUDADANOS DOMINICANOS
}

\author{
¿Qué elementos de la cultura política inciden en la mayor predisposición de los dominicanos a \\ aceptar la política particularista como estrategia viable de movilización y representación?
}

Como se argumentó en la introducción del presente capítulo, el análisis de las percepciones de los ciudadanos que aquí se realiza, no tiene una finalidad determinista y dicotómica -buena o mala cultura- sino que trata de evidenciar que estos rasgos en interacción relacional con el Estado impiden aprovechar los espacios de oportunidad que podrían hacer languidecer la prevalencia del particularismo. Las ideas y valores compartidos por la ciudadanía influyen en el rumbo de las democracias. Así, cuando los ciudadanos se interesan en los asuntos públicos, se asocian y participan, el sistema político es más proclive a solucionar los problemas que afectan a toda la comunidad. La mayor conformidad con las prácticas autoritarias para garantizar el orden social, la concepción paternalista del disfrute de los derechos como actos de concesión y la cosmovisión populista del liderazgo, influyen en la aceptación desde la demanda del carácter clientelar de la movilización y representación.

Como demostrara Putnam (1993), actitudes proclives a la deliberación, preeminencia de la naturaleza cívica de la relación gobernantes-gobernados frente a la subordinación sentimental y valores de autorrealización y participación, tienen el poder de engendrar comunidades cívicas más inclinadas a la cooperación que a la competición entre grupos. Mientras que el conservadurismo ralentiza los cambios en pro del pluralismo, el personalismo circunscribe el activismo al individualismo protagónico frente a la abstracción anónima de la colectividad. Estos valores restringen la extensión de la confianza social a grupos conocidos unidos por lazos de familia o amistad, que en su estrategia de relación con el Estado reivindican beneficios para aquellos que están dentro del círculo de confianza (asistencialismo particularista) frente a la solidaridad (política universal).

El objetivo de este epígrafe es identificar los rasgos de la cultura política subordinada o parroquial en el imaginario político colectivo que hacen viable desde la demanda la política particularista en la República Dominicana. Para ello se utilizan las encuestas nacionales DEMOS 1994, 1997, 2001 y 2004, así como el Barómetro de las Américas y su Proyecto Opinión Pública de América Latina (LAPOP) de 2006, 2008, 2010 y 2012. Durante estas dos décadas los tres partidos han ocupado el ejecutivo, en los tres se ha producido un relevo generacional tras la muerte de los caudillos y han sido participes de acontecimientos políticos de gran relevancia como la crisis electoral de 1994 o el inicio del proceso de consolidación democrática en 1996. También han tenido lugar cambios institucionales clave como la Ley Electoral de 1997 o las reformas constitucionales de 2002 y de 2010. Este amplio espectro temporal permitirá verificar cambios y tendencias en las percepciones, actitudes y prácticas de la ciudadanía dominicana respecto a la democracia y su funcionamiento. 


\section{$\checkmark$ Autoritarismo}

«... Aquí todos tenemos un "trujillito" dentro...». Con esta frase un líder comunitario entrevistado reconocía el peso socializante del pasado político en el compromiso cívico de los dominicanos ${ }^{241}$. La dictadura de Rafael Leónidas Trujillo (1930-1961) ejemplificó el prototipo de sultanismo ${ }^{242}$ en la tipología de regímenes no democráticos (Linz y Stepan 1996). En presencia de los tres líderes carismáticos Bosch, Balaguer y Peña Gómez, el 50,4\% de los entrevistados respaldaba la afirmación de que "un líder fuerte haría más por el país que todas las leyes e instituciones juntas" y el 66,5\% eran partidarios de "más orden aunque hubiese menos democracia" (DEMOS 1994:11). Estos rasgos autoritarios en los que la fuerza política se impone al entendimiento persistirán una década después. La adhesión a un líder fuerte de perfil dictatorial que actuase por encima de leyes e instituciones recibió similar adhesión en 1997 y 2001, así como la preferencia por el orden en sacrificio de la democracia que concitaba las preferencias del 64,7\% de los entrevistados en 1997, de un $61,8 \%$ en 2001 y del $67,3 \%$ en el año 2004. La mayoritaria predilección por las formas autoritarias mostraba conexión con las variables de urbanización y nivel socioeconómico. A mayor urbanidad y nivel de ingresos, menor era la inclinación de la población a aceptar estas opciones autoritarias (DEMOS 1994-2004). La preferencia por más orden en sacrificio de la democracia, era la opción elegida en 2004 por el 67,3\% de los entrevistados.

Al desagregar los resultados por simpatía partidaria, no existían diferencias significativas entre militantes de los tres partidos principales aunque los seguidores reformistas lideraban la propensión al autoritarismo con un 54\%, al igual que a la hora de mostrar su predilección por un "gobierno de mano dura" (el 81,5\%). Estos datos evidenciarían el mayor peso del liderazgo autoritario de Joaquín Balaguer (1966-1978) y el del caudillo conservador (1986-1996) en la socialización política de los simpatizantes reformistas, aunque no muy distantes de las bases del PRD y PLD, cuyos líderes José Francisco Peña Gómez y Juan Bosch dejaron su impronta autoritaria en el imaginario político de los dominicanos. Los eslóganes "Lo que diga Balaguer" o su contraparte "Lo que diga Peña es lo que va..." se convirtieron en lemas de campaña durante décadas y ambos ilustran la sumisión autoritaria del ejercicio político en el país. En el caso de Juan Bosch, el "centralismo democrático" peledeísta no era más que «la fórmula para oficializar las decisiones del omnipresente Juan Bosch en todos y cada uno de los asuntos del partido» ${ }^{243}$.

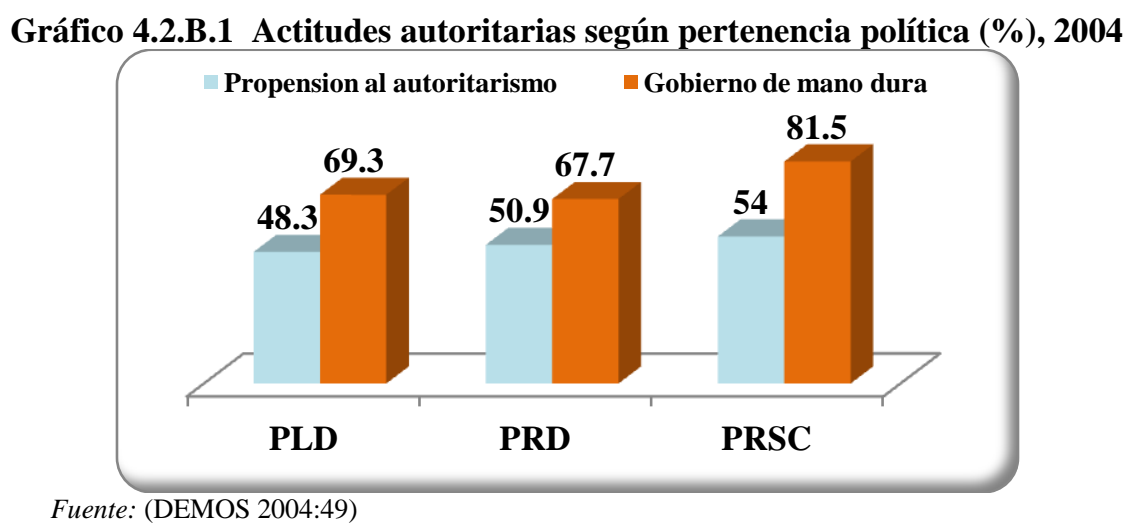

\footnotetext{
${ }^{241}$ Entrevista a activista comunitario, realizada el 7 de marzo de 2011.

242 Régimen autoritario caracterizado por la fusión de lo público y privado, la ausencia de ideología, glorificación del líder, la sumisión basada en el temor y las recompensas personales

${ }^{243}$ Entrevista con actor clave, militante peledeísta, realizada el 4 de febrero de 2012.
} 
Desde 2004 a 2012, las preferencias autoritarias de los dominicanos han disminuido significativamente, ya que si en 2004 el $65,74 \%$ de los entrevistados consideraba que en país hacia falta un gobierno de mano dura, este porcentaje se reducía al 38,39\% en 2012 (LAPOP). Este punto de inflexión también se observa en la relación entre legitimidad y tolerancia política. La "estabilidad autoritaria", caracterizada por el apoyo a las instituciones pero escasa tolerancia hacia las manifestaciones pacíficas, derecho de voto, libertad de expresión y postulación a cargos públicos de minorías y oposición, muestra una tendencia ascendente en los últimos años que parece interrumpirse en 2012, cuando el porcentaje desciende 10 puntos porcentuales (21,8\%). Por el contrario, disminuye el apoyo al sistema político y en 2012 el mayor porcentaje de entrevistados se sitúa en la casilla de "democracia inestable".

Tabla 4.2B.1 Relación apoyo al sistema y tolerancia política (\%) República Dominicana 2004-2012

\begin{tabular}{|c|cc|cc|}
\hline \multirow{2}{*}{$\begin{array}{c}\text { LEGITIMIDAD } \\
\text { SISTEMA }\end{array}$} & \multicolumn{3}{|c|}{ AIta } & \multicolumn{2}{c|}{ Baja } \\
\cline { 2 - 5 } & \multicolumn{3}{|c|}{ DEMOCRACIA ESTABLE } & \multicolumn{2}{c|}{ ESTABILIDAD AUTORITARIA } \\
\multirow{4}{*}{ Alto } & 2004 & 18,1 & 2004 & 20,8 \\
& 2006 & $\mathbf{3 8 , 2}$ & 2006 & 23,0 \\
& 2008 & 29,0 & 2008 & 31,2 \\
& 2010 & 24,8 & 2010 & $\mathbf{3 2 , 5}$ \\
& 2012 & 24,3 & 2012 & 21,8 \\
\hline & 2004 & 21,9 & 2004 & $\mathbf{3 9 , 3}$ \\
& 2006 & 22,7 & 2006 & 16,1 \\
Bajo & 2008 & 20,5 & 2008 & 19,3 \\
& 2010 & 19,3 & 2010 & 23,4 \\
& 2012 & $\mathbf{2 8 , 6}$ & 2012 & 25,3 \\
\hline
\end{tabular}

Fuente: LAPOP (2012:30), LAPOP (2012:18) y DEMOS (2004:274).

Teniendo en cuenta el mayor de los porcentajes en cada casilla, las percepciones de los dominicanos acerca de la legitimidad del sistema y la tolerancia ubicaban al país en la categoría de "democracia en riesgo" en 2004, recuperaba la estabilidad democrática en 2006, daba un giro autoritario en 2010 y se tornaba inestable en 2012. El contexto de estos cambios se corresponde con el colapso financiero y fiscal de 2003 durante administración del PRD y la recuperación del ritmo macroeconómico de 2006. El control oficialista de las instituciones democráticas en 2010 y la pérdida de confianza por las acusaciones de corrupción en 2012 bajo las administraciones peledeístas podrían haber condicionado los cambios en estos dos últimos periodos. La sumatoria de los porcentajes de la población ubicada en las casillas en las que es deficitaria la tolerancia política arroja un balance en el que la mitad de los dominicanos encuestados manifiestan actitudes autoritarias, con un $60 \%$ en 2004, un 39\% en 2006, un 50\% en 2008, un $55 \%$ en 2010 y un $47 \%$ en 2012. Como puede observarse, el porcentaje de ciudadanos ubicados en la casilla "democracia en riesgo" compuesta por aquellos que no apoyan el sistema y manifiestan poca tolerancia política aumenta ligeramente cada año tras el punto de inflexión al alza de 2004.

En la comparación regional, en 2004 República Dominicana ocupaba los puestos inferiores en apoyo a las instituciones y alta tolerancia política situándose a nueve puntos porcentuales de Paraguay -país con el menor porcentaje de apoyo a la democracia estable- y a trece puntos porcentuales de Costa Rica (DEMOS 2004:127). En 2010 Paraguay ocupaba de nuevo el último lugar en el listado regional, mientras que en 2012 lo hacía Honduras, con un escaso 7,2\% de la población ubicado en la casilla de "democracia estable"(LAPOP 2012:29). Estos dos países han experimentado en los últimos años crisis institucionales con episodios de golpes de estado ${ }^{244}$.

\footnotetext{
${ }^{244}$ En 2009 Honduras, tras el enfrentamiento del presidente Manuel Zelaya con el Congreso Nacional, el Tribunal Supremo Electoral y la Corte Suprema de Justicia. En 2012 Paraguay tras la moción de censura de la Cámara de Diputados al Presidente Fernando Lugo.
} 
Gráfico 4.2.B.2 Apoyo a la democracia estable en perspectiva comparada en América Latina 2010

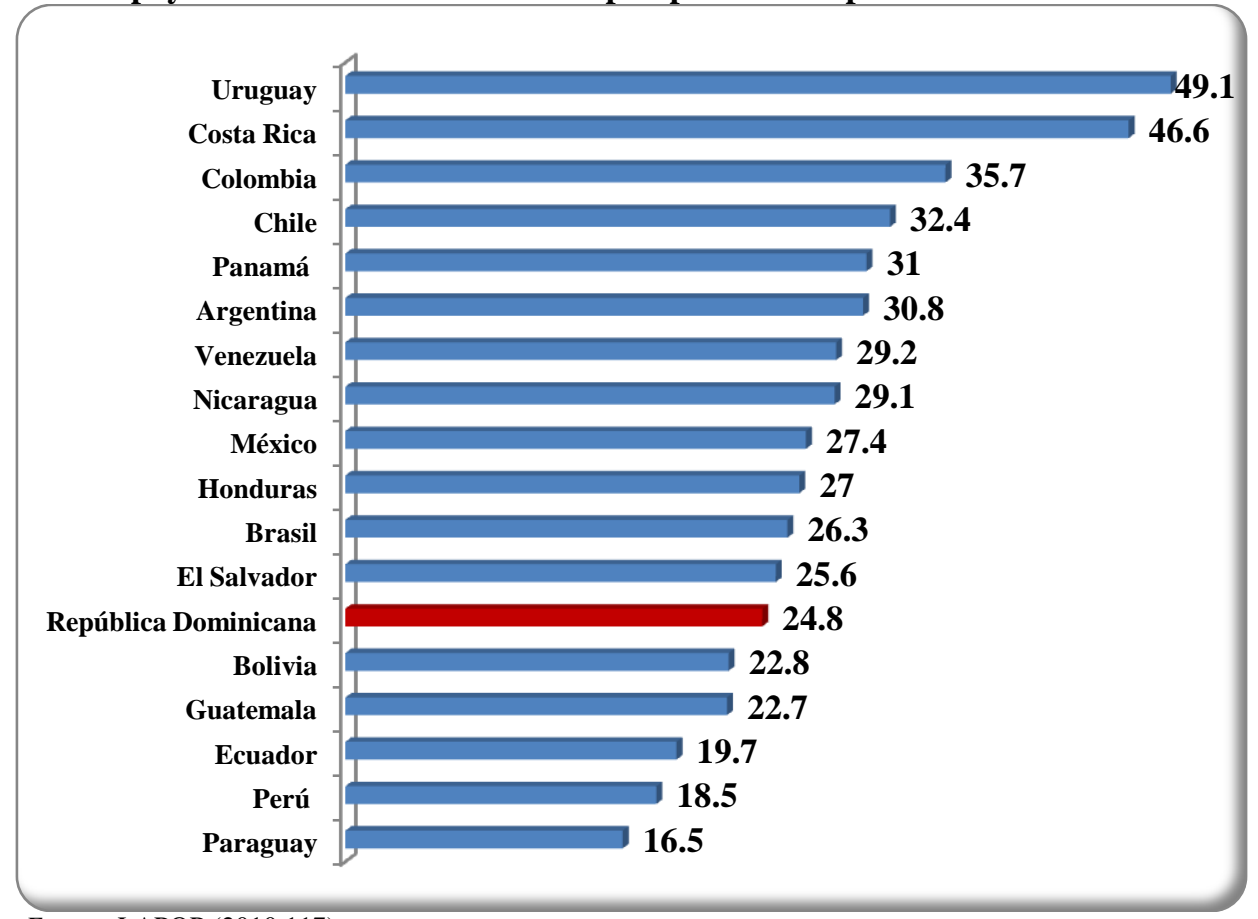

Fuente: LAPOP (2010:117)

\section{$\checkmark$ Paternalismo}

El paternalismo es una modalidad del autoritarismo que se caracteriza por un ejercicio del poder en el que el pater dispensa protección y satisface las necesidades básicas de unos hijos desprovistos de autonomía e independencia. Las decisiones del pater son inapelables y sus premios y castigos tienen una raíz de subordinación sentimental. En la esfera pública, el paternalismo gubernamental asistencialista es una deformación del Estado del Bienestar que dispensa protección, favores y compensaciones donde los ciudadanos no son sujetos de derechos sino beneficiarios de los favores del pater. En contextos de diseño institucional hiperpresidencialista como el dominicano, el Presidente ha sido históricamente la figura dispensadora de soluciones análoga a la paterna a quien atribuir la autoría de obras y políticas. El eslogan del candidato PRD en la pasada contienda presidencial de 2012, es ejemplo de los rasgos paternalistas de la cultura política en República Dominicana y de las connotaciones de familiaridad que rodean los vínculos entre políticos y electores en el país. El ex presidente Hipólito Mejía se presentaba ante el electorado con el eslogan de «iLlegó Papá!», enfatizando la concepción del ejercicio de la política como distribución de favores y cuidados y no como el ejercicio ciudadano de derechos adquiridos. Diez años después de la desaparición de tres caudillos Balaguer, Bosch y Peña Gómez, la mayoría de la población dominicana entrevistada consideraba que "un buen Presidente debe ser como un padre a quien hay que acudir para que resuelva los problemas". La mayor inclinación hacia esta figura del padrepresidente se daba entre la población rural $(90,8 \%)$, en los estratos socioeconómicos bajos $(87,7 \%)$ (DEMOS 1994:12) y entre aquellos con menores años de escolaridad (94,2\%) (DEMOS 1997:25). 
Tabla 4.2.B.2 Visión del Presidente como Padre (\%)

\begin{tabular}{|c|c|c|c|c|}
\hline $\begin{array}{c}\text { Un buen presidente deber ser como un padre a quien } \\
\text { hay que acudir para que resuelva los problemas }\end{array}$ & $\mathbf{1 9 9 4}$ & $\mathbf{1 9 9 7}$ & $\mathbf{2 0 0 1}$ & $\mathbf{2 0 0 4}$ \\
\hline
\end{tabular}

Fuente: DEMOS (1994-2004)

En 2014, ser «padre para los ciudadanos» y «hombre de familia» fueron señalados por el $85 \%$ y el 99\% de los entrevistados por CID-Gallup como atributos que describen al actual Presidente Medina y su gestión al frente del ejecutivo dominicano (2012-2016) ${ }^{245}$. Con la incorporación de la que fuera Primera Dama Margarita Cedeño a la candidatura vicepresidencial por el partido oficialista en la contienda de 2012, el escenario se repartía en aquella ocasión entre los seguidores de "papá" (Hipólito Mejía-PRD) y "mamá" (Margarita Cedeño-PLD). Electores y partidos minoritarios decidían -su voto unos y su alianza otros- entre ambos progenitores políticos. En esta lucha por conquistar la paternidad del pueblo dominicano, el presidente Leonel Fernández se hizo cargo de los hijos huérfanos del reformismo balaguerista, a quienes tratando de conquistar su voto recibía en campaña con estas palabras:

«Cuánta alegría estar aquí con los que se han denominado los nietos y biznietos de Joaquín Balaguer. Con mucho gusto acepto la invitación de que me convierta en el padre adoptivo de ustedes» ${ }^{246}$ (Fernández 2012).

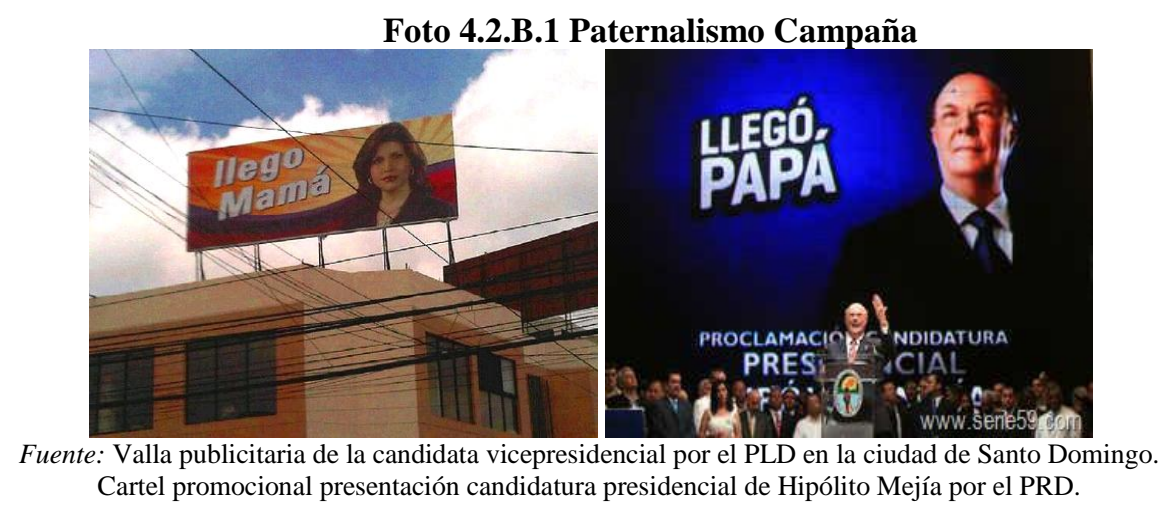

El cuidado maternal tiene su espacio institucional en el Despacho de la Primera Dama, una oficina gubernamental que convierte en política pública la beneficencia social a cargo de la esposa del mandatario de turno. Aunque anecdótico, la validación materna parece incluso ocupar un espacio en el control de poderes horizontal. En el discurso de Rendición de Cuentas que el primer mandatario presenta al Congreso al inicio de cada legislatura ordinaria, el Presidente Fernández destacaba en 2012 la aprobación materna a su gestión:

«Al llegar al término de este mandato presidencial, he vuelto donde doña Yolanda para indagar su opinión acerca de lo alcanzado durante estos intensos y absorbentes ochos años de gestión pública. Ella me contestó: La verdad, mi hijo, orgullosa del deber cumplido. Satisfecha de la dignidad y el decoro con que has asumido tu compromiso con la Patria ${ }^{247}$.

\footnotetext{
245 Ver encuesta en periódico Hoy, de 13 de abril de 2014.

${ }^{246}$ Palabras del entonces Presidente Fernández en la juramentación del "Frente de Reformistas con Danilo", en periódico Telegrama Digital, 10 de mayo de 2012.

247 Discurso del Presidente Leonel Fernández ante la Cámara de Diputados, el 27 de febrero de 2012.
} 
El populismo es una estrategia política que considera las pasiones en la construcción de la identidad. En su discurso se mezclan formas autoritarias y excluyentes en las que el líder reivindica las supuestas formas de vida de los pobres y de un pueblo que es la esencia de la nación (De la Torre 2007). Desde que surgiera en la Segunda Guerra Mundial en reacción a los gobiernos oligárquicos su presencia se ha revitalizado en los gobiernos de mandatarios como Alan García, Hugo Chávez, Abdalá Bucaram, Néstor Kirchner o Evo Morales. En la República Dominicana, la relación de los tres caudillos con sus seguidores estuvo marcada por un patrón populista es su vertiente socialdemócrata, autoritaria y paternalista/reformista. En la etapa de la consolidación democrática el porcentaje de entrevistados que respaldan actitudes populistas supera el 50\%, ocupando en 2008 el primer lugar en la escala de apoyo al populismo en la región.

Gráfico 4.2.B.3 Apoyo al populismo en América Latina (\%), 2008

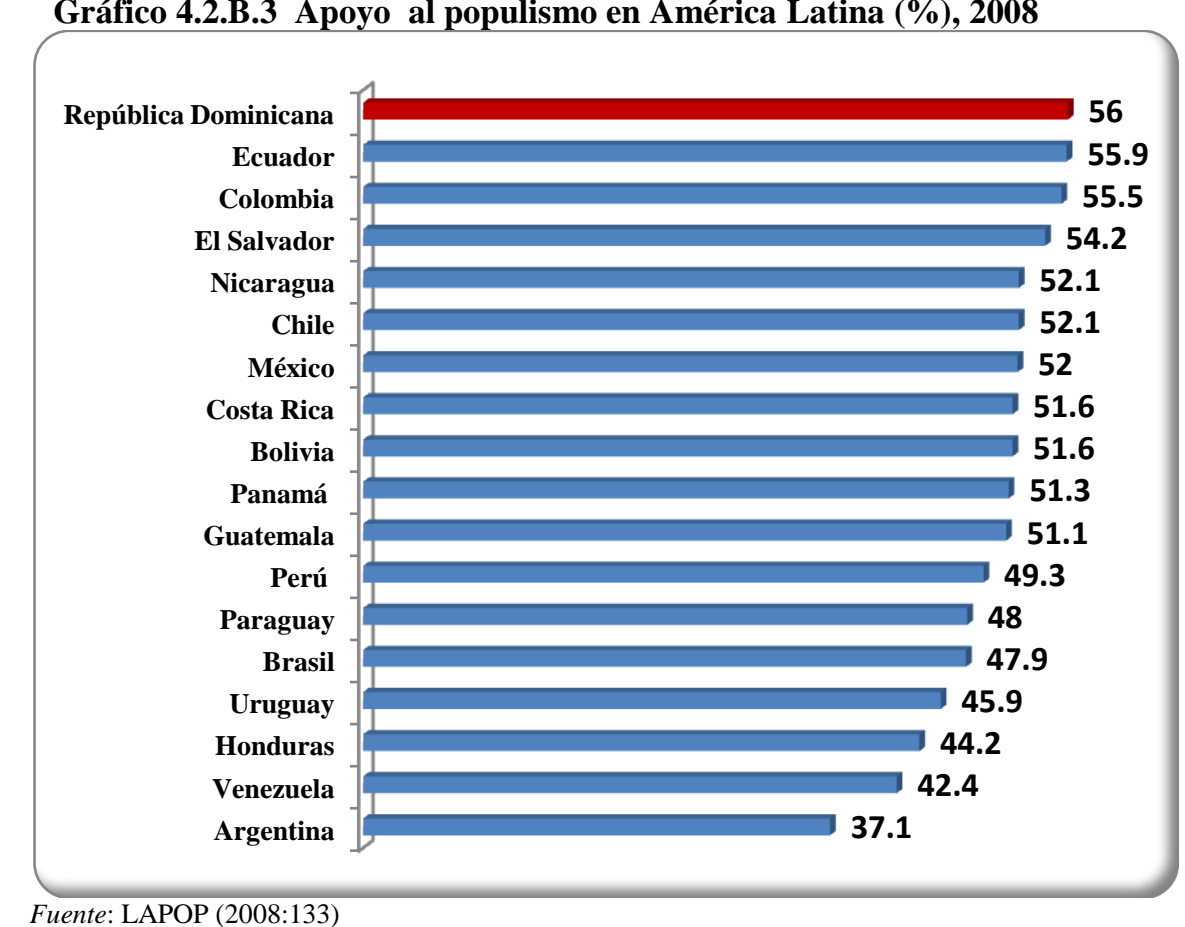

Estas actitudes no parecen amenazar el orden democrático, ya que más que un rechazo a los canales institucionales de canalización del conflicto (gobernar sin Congreso, ignorar la Suprema Corte de Justicia...) son los referentes simbólicos del imaginario populista los que concitan la mayor aprobación, tales como la dicotomía entre el bien y el mal $(80,4 \%)$ o la percepción de que la clase dominante se aprovecha del pueblo (66\%). El análisis realizado por LAPOP identificó el menor nivel educativo y la población más joven como variables que favorecen el respaldo a las actitudes populistas (LAPOP 2008:135). En 2004, el 85\% de los encuestados consideraba que el país estaba gobernado para el beneficio de unos cuantos intereses poderosos y en 2008 el 50,45\% denunciaba que el mayor obstáculo para el progreso era la oligarquía dominicana. 
Gráfico 4.2.B.4 Apoyo al Populismo República Dominicana (\%), 2008

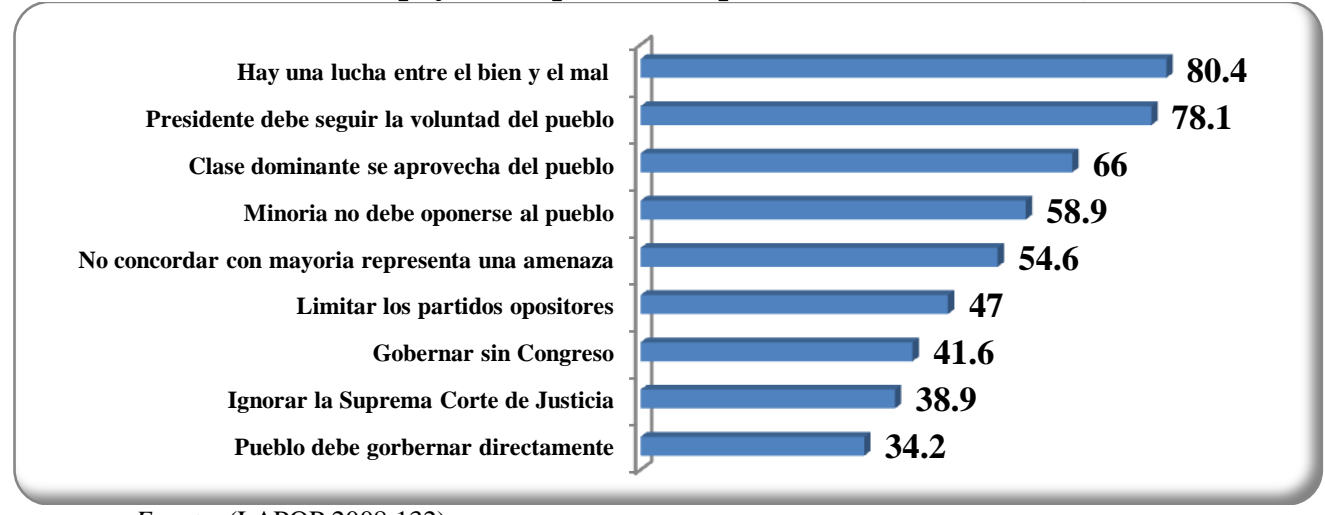

Fuente: (LAPOP 2008:132)

El liderazgo providencial caudillista tuvo su expresión máxima en la figura de Joaquín Balaguer de quien se decía a si mismo ser un «instrumento en manos del destino», aunque estos rasgos de predestinación se aprecian también en los líderes contemporáneos:

Foto 4.2.B.2 Providencialismo Campaña

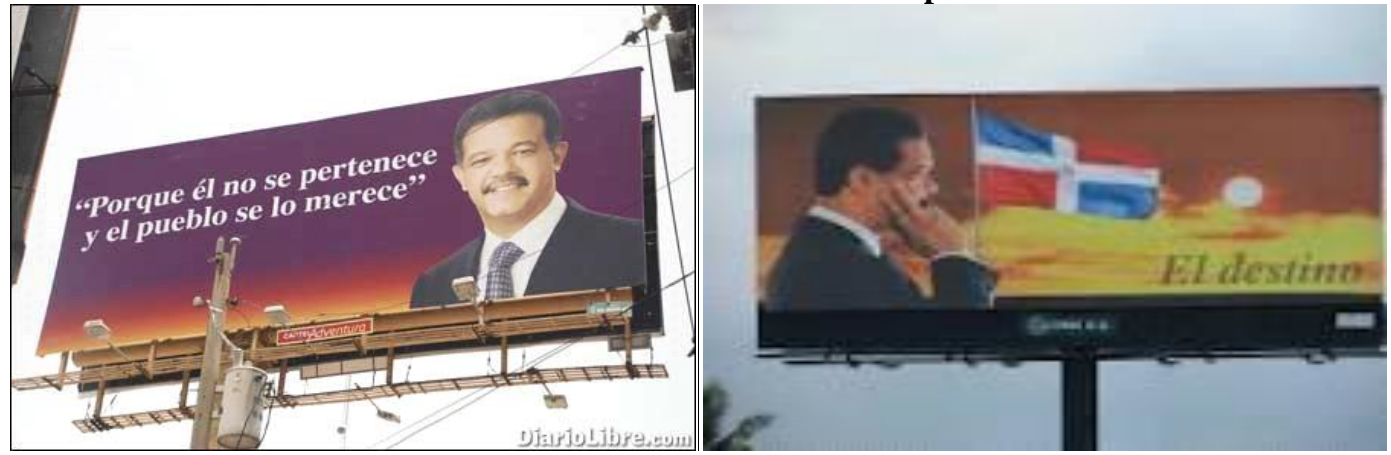

Fuente: Carteles publicitarios en apoyo de la reelección presidencial del entonces Presidente Leonel Fernández en la Avenida 27 de Febrero en Santo Domingo. Julio de 2010.

La cosmovisión populista de la dirigencia cívica y política dominicana se refleja en manifestaciones públicas en relación a asuntos nacionales de gran relevancia como las siguientes:

"Somos un país pobre y además la Banca Privada no va a prestar dinero para eso [política de desarrollo agrícola]. Lo haremos nosotros" (Mejía 2012) ${ }^{248}$.

Estas palabras del candidato presidencial Hipólita Mejía ilustran la eterna dicotomía populista de ellos (la élite) y nosotros (el pueblo), la división entre el pueblo y el poder económico (Laclau 2005). En el liderazgo civil se aprecian también rasgos populistas en la apelación del pueblo (pobre) como fuente de poder en la reivindicación social. Los representantes de la Asociación Dominicana de Profesores criticaban que la ocupación de una escuela para reclamar que se destine el $4 \%$ del PIB a la educación fuera liderada por un "grupo de jóvenes que proceden de colegios privados",249.

${ }^{248}$ Palabras de Hipólito Mejía en el "Encuentro con candidatos presidenciales" celebrado en la Universidad INTEC, el día 8 de febrero de 2012.

249 "Devuélveme mi escuela", en periódico Listín Diario de 8 de noviembre de 2011. 
La preferencia por el orden y la seguridad son reclamos populistas en aquellas sociedades que no han experimentado la transición hacia valores postmaterialistas (Inglehart 1970). En este sentido, el sentimiento de desprotección ha ido creciendo entre los ciudadanos dominicanos desde 1994 a la actualidad, cuando más de la mitad de los entrevistados afirmaron sentirse menos seguros que hace cinco años.

Tabla 4.2.B.3 Sentimiento de inseguridad en República Dominicana (\%)

\begin{tabular}{|c|c|c|c|c|c|c|c|c|}
\hline \multirow{2}{*}{$\begin{array}{c}\text { Se siente menos seguro } \\
\text { que hace 5 años }\end{array}$} & $\mathbf{1 9 9 4}$ & $\mathbf{1 9 9 7}$ & $\mathbf{2 0 0 1}$ & $\mathbf{2 0 0 4}$ & $\mathbf{2 0 0 6}$ & $\mathbf{2 0 0 8}$ & $\mathbf{2 0 1 0}$ & $\mathbf{2 0 1 2}$ \\
\cline { 2 - 10 } & 41,6 & 50,5 & 67,9 & 74,8 & 79 & 59 & 73 & 64,85 \\
\hline
\end{tabular}

Fuente: DEMOS y LAPOP.

República Dominicana ocupaba en 2010 el segundo lugar en la comparativa regional a la hora de considerar la delincuencia una amenaza para el futuro del país. El 90\% de los entrevistados así lo percibían, solo superado por El Salvador a tres puntos porcentuales y donde la violencia de las maras representa una amenaza para el 93,4\% de los entrevistados. El "populismo punitivo" en la política de seguridad ciudadana es la respuesta a la inseguridad en las calles dominicanas. Bajo este nombre se denomina la creencia de que el aumento de la pena persuade de la comisión del delito. Se caracteriza por legislar modificando el código penal generalmente aprovechando coyunturas de indignación popular por hechos delictivos de gran impacto social. Así lo ejemplifican los proyectos de reforma del Código del Menor y Código Penal, o la propuesta que varios legisladores hicieran en 2012 al Jefe de la Policía en la Comisión de Interior y Policía de la Cámara de Diputados «matar a criminales sin dejar que los medios les vean» ${ }^{250}$. Actuar al margen de la ley para capturar a delincuentes recibía la aprobación del 40,55\% de los entrevistados en 2006, cifra que se reducía con el paso del tiempo alcanzando el 33,7\% en 2008 , el 32,7\% en 2010 y el $27,1 \%$ en 2012 (LAPOP).

\section{$\checkmark$ Conservadurismo}

El conservadurismo en la cultura política se manifiesta en el predominio de valores sociales y morales tradicionales y la resistencia a los cambios radicales. La visión conservadora del acontecer social tiene un carácter dependiente que atribuye a la providencia, la buena suerte o a los poderosos la resolución de los problemas, mientras que en las sociedades modernas el individuo se reconoce como un ente autónomo capaz de engendrar el poder de la colectividad social. Estos rasgos dependientes han sido explicados en la visión mágico-religiosa de la cultura dominicana en la que «el individuo rehúye asumir sus responsabilidades y espera paciente y conformista a que otros hagan lo que él debe hacer o a que la suerte o cualquier otra concepción mágica haga su aparición para atribuirle responsabilidad» (Asuad 1985:5). En 1994 el 59\% de la población entrevistada declaró estar de acuerdo con la expresión "por más que se quieran cambiar las cosas todo permanecerá igual", el 63,3\% opinaba que "los problemas del país solo se resuelven si Dios mete su mano" y solo el 7\% de los entrevistados entendían que "los problemas del país solo se

\footnotetext{
250 "Y cuando vayan a darle pa'bajo (asesinar) a delincuentes, no se dejen ver de los medios de comunicación" recomendó el diputado Héctor Darío Feliz, representante de Pedernales por el PRD. La propuesta también incluía el fusilamiento de criminales y contaba con el respaldo de dos diputados del PLD y uno del BIS. En la Comisión de Interior y Policía de la Cámara de Diputados el Jefe de la Policía estaba llamado a explicar los abusos de los agentes en los casos del estudiante Willy Wander Florián Ramírez, muerto en la manifestación contra el paquetazo fiscal en la UASD y del reo Jeffry Sandoval en Santo Francisco de Macorís. Ambos recogidos en video cámara. Ver noticia en periódico El Caribe del 7 de diciembre de 2012.
} 
resuelven con una revolución". Esta propensión a la dependencia no emancipadora o "propensión a la externalidad" (Brea, Duarte y Tejada 1998) se ha mantenido vigente entre la población dominicana, superando el $50 \%$ a lo largo de una década.

Tabla 4.2.B.4 Propensión a la externalidad en República Dominicana (\%)

\begin{tabular}{|l|c|c|c|c|}
\hline & $\mathbf{1 9 9 4}$ & $\mathbf{1 9 9 7}$ & $\mathbf{2 0 0 1}$ & $\mathbf{2 0 0 4}$ \\
\hline Baja y nula & 50 & 44,8 & 35,4 & 39,6 \\
\hline Alta y media & 50 & 55,2 & 64,6 & 60,4 \\
\hline
\end{tabular}

La relevancia de los valores religiosos en la vida pública es otro de los rasgos del conservadurismo en la cultura política. Aunque la Constitución establece que la República Dominicana es un estado laico, la iglesia católica disfruta de un estatuto diferenciado gracias al Concordato de 1954, siendo habitual en el país que aniversarios y conmemoraciones de instituciones públicas se celebren con una eucaristía ${ }^{251}$. Desde aquel "Dios y Trujillo" de la época del dictador, la iglesia ha desempeñado un papel protagónico como mediador y garante de la estabilidad ${ }^{252}$. En la segunda transición dominicana este papel fue ejercido en dos escenarios de conflicto: las revueltas urbanas en la crisis económica de 1984 y la crisis post fraude de 1994. En la reforma constitucional de 2010 la iglesia fue abanderada de los sectores conservadores en su oposición al aborto. La campaña liderada por el Cardenal Nicolás de Jesús López incluía "Vigilias por la Vida" frente al Congreso en las que instaba a los parlamentarios a defender la vida desde el momento de la concepción sin posibilidad de aborto terapéutico:

"El pueblo dominicano está atento a su decisión, viendo quién apoya la vida y quién la muerte, y eso se reflejará en las votaciones" ${ }^{253}$ (De Jesús 2009).

En las vigilias los feligreses mostraban pancartas en las que se leía: "Legisladores, los que votamos por ti te pedimos que el artículo 30 diga SI". La noche anterior a las elecciones se convocaba a una gran cadena de oración y se distribuía el folleto "Los diez mandamientos de los votantes" entre los que destacaban: "irás a votar en las elecciones ejerciendo tu derecho con responsabilidad, por amor a Dios y a tus hermanos", "votarás por los candidatos que respeten los valores y principios de la fe cristiana", votarás por candidatos que honren a sus padres y respeten los valores de la familia o "no votarás por gente que no respeta el derecho a la vida y propicia el aborto". La voz autorizada de la iglesia católica en los asuntos laborales, económicos y políticos del día a día, cuenta con el respaldo de uno de los electorados más conservadores de América Latina (LAPOP 2008), siendo además la institución mejor valorada y en la que más confían los ciudadanos dominicanos (LAPOP 2012) y con el respaldo de toda la clase política ${ }^{254}$. Las apariciones en la prensa nacional del Cardenal y el

251 Así sucedió en el 86 aniversario de la JCE en 2009, o en otros acontecimientos públicos de menor relevancia como la bendición de los nuevos equipos de la policía nacional en $2012 \ldots$ entre otros.

${ }^{252}$ En los meses previos a las elecciones de 2012 las sospechas de falta de independencia de los responsables del centro de cómputos de la JCE, desataron un conflicto en el que Monseñor Agripino Núñez Collado fue mediador del impasse, logrando un acuerdo firmado por los presidentes del PLD y PRD para buscar una solución a la crisis y en el que se proponía una Gerencia Informática Colegiada.

${ }^{253}$ En periódico Listín Diario y HOY de 4 de septiembre de 2009.

${ }^{254}$ En 2004 el Secretario General del PRD, miembro de la familia de la Internacional Socialista, proponía potenciar la visión política de la Conferencia Episcopal para que expresase su voz en "asuntos como la globalización, el sistema de partidos, el endeudamiento externo y otros temas de interés social, a través de un organismo conjunto en el que participarían también políticos laicos" En pagina web del Secretario General del PRD Orlando Jorge Mera en http://www.orlandojorgemera.com.do, de 24 de septiembre de 2004. Consultado el 23 de abril de 2009. La vinculación del PRD con la Iglesia Católica cuenta con una larga tradición. Bajo la administración de Antonio Guzmán (1978-1982), su equipo de ministros y funcionarios de confianza 
Arzobispo comentando los acontecimientos políticos nacionales son habituales y casi diarias, y en muchas ocasiones realizadas desde el propio púlpito ${ }^{255}$. Desde 1994, ha ido en aumento el porcentaje de personas entrevistadas que consideraba que la iglesia debería tener más poder. Así lo manifestaba el $75 \%$ de los entrevistados en 2004, al igual que el apoyo a su papel mediador $(60,4 \%)$.

Tabla 4.2.B.5 Aceptación de la intervención de lo religioso en la vida política (\%)

\begin{tabular}{|l|c|c|c|c|}
\hline & $\mathbf{1 9 9 4}$ & $\mathbf{1 9 9 7}$ & $\mathbf{2 0 0 1}$ & $\mathbf{2 0 0 4}$ \\
\hline $\begin{array}{l}\text { Los problemas del país solo se resuelven si Dios } \\
\text { mete su mano }\end{array}$ & 63,3 & 64,7 & 74,4 & 75,9 \\
\hline La iglesia debe tener más poder & 48,8 & 47,1 & 53,1 & 57 \\
\hline $\begin{array}{l}\text { La iglesia sólo debe intervenir cuando hay crisis } \\
\text { o los dirigentes no se ponen de acuerdo }\end{array}$ & 52,7 & 56,9 & 61,6 & 60,4 \\
\hline
\end{tabular}
Fuente: DEMOS (2004:42)

En la actual administración 2012-2016, los representantes de la iglesia están presentes en todas las Comisiones de Veeduría Ciudadana nombradas por la Presidencia para vigilar las compras y contrataciones de agencias públicas y Ministerios ${ }^{256}$. Paradójicamente, mientras proliferan estos instrumentos de accountability vertical de la democracia participativa sin poder sancionador, se limitan otros como la facultad ciudadana para querellarse contra funcionarios por actos que violen los derechos humanos en el ejercicio de sus funciones ${ }^{257}$. También hoy sigue ejerciendo el papel de mediadora ante el empresariado ${ }^{258}$ y en la competencia interpartidista, en la que ha retomado junto con la JCE la tarea de sensibilizar a las cúpulas partidistas acerca de la necesidad de la aprobación

provenía principalmente de la cantera de profesores de la Pontificia Universidad Católica Madre y Maestra, creada en 1962 y dependiente del Episcopado dominicano.

${ }^{254}$ En 2009, en la misa aniversario celebrada en honor de Peña Gómez el párroco de Las Mercedes exhortaba al PRD a solucionar sus problemas interno en la homilía: " los enemigos quieren ver dividido al PRD, lleguen a un consenso por el amor de Dios, no le den gusto a la oposición (...) no hagan como los partidos que se venden y acuden dizque a conversaciones, diálogos...Ya esos perdieron la razón de ser como partidos". En periódico HOY, de 13 de mayo de 2009. En 2012, el Cardenal se pronunciaba en contra de las protestas sociales por el déficit fiscal y apoyaba al electo Presidente pidiendo un voto de confianza a la ciudadanía, confirmando que "los fondos de los que dispone no son suficientes para resolver los problemas del país, pero hará lo que pueda porque no es un mago". En periódico HOY, de 1 de septiembre de 2012.

${ }^{255}$ En 2009, en la misa aniversario celebrada en honor de Peña Gómez el párroco de Las Mercedes exhortaba al PRD a solucionar sus problemas interno en la homilía: " los enemigos quieren ver dividido al PRD, lleguen a un consenso por el amor de Dios, no le den gusto a la oposición (...) no hagan como los partidos que se venden y acuden dizque a conversaciones, diálogos...Ya esos perdieron la razón de ser como partidos". En periódico HOY, de 13 de mayo de 2009. En 2012, el Cardenal se pronunciaba en contra de las protestas sociales por el déficit fiscal y apoyaba al electo Presidente pidiendo un voto de confianza a la ciudadanía, confirmando que "los fondos de los que dispone no son suficientes para resolver los problemas del país, pero hará lo que pueda porque no es un mago". En periódico HOY, de 1 de septiembre de 2012.

${ }^{256}$ Por ejemplo, la comisión de Veeduría del Ministerio de Salud Pública nombrada en octubre de 2013 está formada por Miguel Antonio Montalvo Batista, ginecólogo y representante de la iglesia católica y el reverendo Lorenzo Mota King, en representación de la iglesia evangélica. Junto a ellos, integran la Veeduría Bernardo Vega, historiador y economista; Fernando Contreras, gastroenterólogo; Elena Viyella, empresaria; Patricia León, odontóloga; Casimiro Velasco, endocrinólogo.

${ }^{257}$ El 27 de marzo de 2014 los legisladores eliminaron el párrafo III del art. 85 del Código Procesal Penal a la espera de que sea aprobado por el Poder Ejecutivo. Ver noticia en periódico El Nacional del 28 de marzo de 2014, en http://www.elcaribe.com.do/2014/03/28/codigo-quito-calidad-para-querellarse-contra-funcionarios.

${ }^{258}$ En la ronda de conversaciones que llevo a cabo el electo Presidente Danilo Medina con los empresarios del país, la iglesia católica fue la anfitriona del encuentro celebrado en la Universidad Pontificia con los empresarios de la provincia de Santiago, Ver noticia del 13 de diciembre de 2013, en http://eldia.com.do/danilo-medina-se-reune-con-empresarios-en-santiago/ 
del Proyecto de Ley de Partidos ${ }^{259}$. En este sentido, los datos de opinión pública sugieren la existencia de un voto religioso en República Dominicana, ya que en las legislativas de 2010 el nivel de religiosidad correlacionaba positivamente con el oficialista PLD y negativamente en el caso del opositor PRD (OBSEROP 2010:19). Entre aquellos que decían asistir casi todos los días a oficios religiosos el 69,1\% votaba al PLD mientras que el 27,2\% lo hacía por el PRD. Resulta significativo que el acto de toma de posesión de los escaños de los legisladores electos en 2010-2016 tuviera lugar en el Auditorio Casa San Pablo perteneciente al episcopado, en la sala presidida con la frase: "Jesucristo, ayer, hoy y siempre".

La resistencia a la aceptación de relaciones igualitarias hombre-mujer constituye otro de los rasgos definitorios del conservadurismo social y político. Desde que en 1994 el 51\% de los entrevistados afirmase su conformidad con la idea de que la política es cosa de hombres, pocos parecen haber sido los cambios en la opinión pública dominicana en la aceptación de la igualdad. En el año 2012 Dominicana ocupaba el primer lugar en América Latina en considerar que los hombres deben tener prioridad en el mercado laboral. El 54,9\% de los entrevistados respaldaban está afirmación frente al $21,7 \%$ de los ciudadanos uruguayos que ocupaban el último lugar en la comparativa regional. Estas actitudes reticentes se observan también en el escenario político. En 2008 se ubicaba en el último lugar en la comparativa en porcentaje de población que apoyaba las mujeres como líderes políticas con un $43,5 \%$, frente al $67,3 \%$ de los ecuatorianos que encabezaban el listado. El país lidera también el porcentaje de aquellos que consideran que los hombres son mejores líderes políticos que las mujeres (47,9\%), lejos de Uruguay donde el 26,6\% así lo considera (LAPOP 2012:13).

Las mujeres constituyen el 51,4\% de la población dominicana y el 56\% del electorado, pero su presencia en los órganos directivos de los partidos apenas llega al 15\%. El sistema de cuota femenina se estableció en 1997, fijándose en el $25 \%$ y posteriormente elevada al $33 \%$ en el año 2000. En las elecciones de 2010 se postularon 16.190 candidatos, de los que 6.914 eran mujeres $(42,7 \%)$. A pesar de la discriminación positiva, las listas presentadas en 2010 por el PLD y PRD, fueron rechazadas por la JCE, que obligó a los dos partidos mayoritarios a cumplir con la cuota legal del $33 \%$ en cada circunscripción y no en base a la composición total de sus nominaciones. En los municipios, cuando la candidatura a síndico recaiga en un hombre, la de vicesíndico -cargo con escasas funciones- ha de ser asignada a una mujer ${ }^{260}$. En la práctica, las Secretarías de la Mujer de los partidos funcionan como meros agentes de movilización en las contiendas eleccionarias, asignándoles tareas de logística y organizativas. Estos órganos han asumido funciones asistencialistas ayudando a las compañeras mujeres con asuntos como la muerte de un familiar o situaciones de desamparo de diversa índole por lo que se reproduce en el ámbito partidario y público el tradicional reparto de roles y responsabilidades (Benito y Rosales 2011:24).

La República Dominicana ocupa una posición intermedia en representación legislativa femenina. En la legislatura 2010-2016, las legisladoras dominicanas ocupaban el 19,6\% en la Cámara de Diputados y el 9,3\% en el Senado. Argentina, con un 36,1\% y un 38,6\% en la Cámara Alta y Baja (2009) lidera esta posición en América Latina, mientras que Colombia ocupa el último lugar en representación femenina con un 9,6\% y un 11,7\% (2006) (OIR 2010).

259 Ver noticia en periódico Diario Libre de 24 de febrero de 2014, en http://www.diariolibre.com/dialogolibre/2014/02/24/i496541_roberto-rosario-vamos-sensibilizar-las-cpulaspara-aprobar-ley-partidos.html

${ }^{260}$ Sirva como ejemplo, que el $91 \%$ de las vicealcaldesas no tienen asignadas funciones y la mayoría carecen de oficina. Ver noticia en periódico Diario Libre de 15 de noviembre de 2013. 


\section{Gráfico 4.2.B.5 Representación femenina en la Cámara de Diputados 1998-2016}

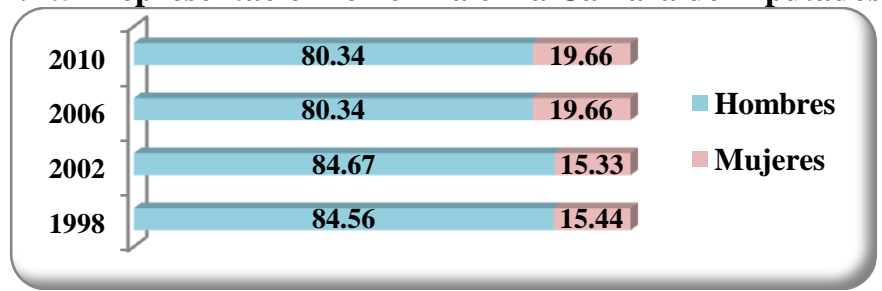

\section{Gráfico 4.2.B.6 Representación femenina en el Senado 1998-2016}

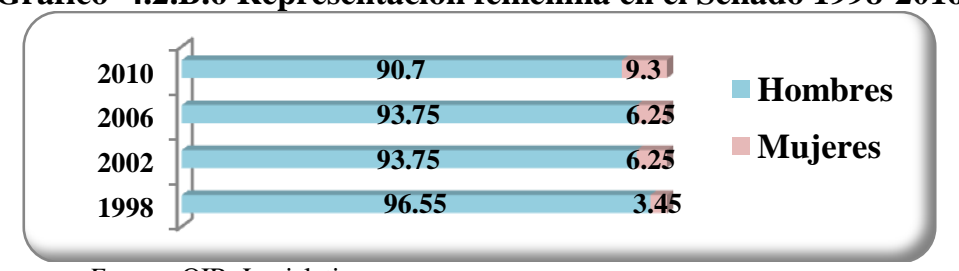

Fuente: OIR, Legislatina.

De los 27 partidos registrados en la JCE en 2010, solo el 16\% contemplaba en sus estatutos cuota femenina en la composición de los órganos de dirección del partido, que oscilaba entre el 33\% (PRD, PRSC, PASOVE) y el 20\% (BIS). Con respecto a los cargos de elección popular, el 76\% de los partidos políticos dominicanos no establece previsión alguna en sus estatutos, el $12 \%$ remite a lo que establezca la legislación nacional y el 8\%, fijaba el 33\% (Benito Sánchez 2014: 377).

Con el título "El glamour femenino en las elecciones", un editorial en la prensa nacional en la campaña de 2010 recogía los principales estereotipos de la cultura machista en la participación de la mujer en política:

«Una de las pocas cosas positivas que está ofreciendo esta descolorida campaña electoral es la sorprendente hermosura de las candidatas a cargos municipales y legislativos, cuya juventud y lozanía contrasta con la pobre representación masculina.(...) Apenas faltan diez días para las elecciones y lo único que va perdurando son las imágenes de las bellas candidatas, muchas ofreciendo demostraciones de capacidad y que bien podría ser catalizador para ver si la fiereza de los políticos es frenada (...) El que tantas mujeres bellas hayan decidido insertarse en los partidos es un síntoma alentador que abre una grieta de esperanza en el firmamento de la política criolla que reemplazará a los que han hecho una política de pocilga (...) Es necesario reconocer la valentía de esas mujeres, que dejando la tranquilidad de sus hogares o el placentero discurrir de sus existencias con sus círculos íntimos de familia y sociales, han decidido lanzarse a participar» ${ }^{261}$.

Esta hiperbolización de la virtuosidad femenina cuenta con el respaldo del 64,6\% de los entrevistados que en 2012 dijeron creer que un hombre sería más corrupto como político que una mujer (LAPOP 2012:15).

${ }^{261}$ En periódico HOY, de 5 de mayo de 2010. 


\section{$\checkmark$ Personalismo}

El personalismo se caracteriza por la individualización frente a la abstracción de la colectividad. En el ejercicio político, el liderazgo personalista es un liderazgo no institucional que reclama crédito personal por las obras públicas. De esta manera, el agente intermediario usurpa el protagonismo del principal a quien le debe la fuente de legitimación de su mandato. Desde el lado de la demanda, la sobrestimación del agente es el caldo de cultivo donde florecen los lazos no racionales afectivos entre político y elector ${ }^{262}$. Los "valores morales" fueron identificados por el 52,1\% de la población entrevistada como la cualidad más importante de un dirigente político confiable, frente a la capacidad gerencial, intelectual o la preocupación por los necesitados, que obtuvieron el 7,4\%, el 6,3\% y el 5,2\% respectivamente (DEMOS 1997:72). En la valoración de los primeros dos años de la gestión del Presidente Medina (2012-2016) al frente del Ejecutivo nacional, ser "hombre de familia" ocupaba el primer lugar en el listado de aspectos reconocidos por los ciudadanos, a distancia de otros como "obtiene resultados"(CID-Gallup 2014). Estos datos reflejan que en la cultura política dominicana el liderazgo que concita las preferencias mayoritarias entre los encuestados no tiene un corte institucionalista, sino que prioriza cualidades personales del candidato frente a las más técnicas de eficiencia referentes a la gestión pública. A pesar de ello, resulta paradójico que figuras públicas envueltas en escándalos de corrupción han contado elección tras elección con el respaldo de los votantes de su circunscripción ${ }^{263}$.

La lealtad personal al político se extiende más allá de las contiendas, en incluso se exterioriza de forma que se hace saber al candidato que recibe su apoyo solo porque existe un vínculo superior con otra persona a la que en el futuro otorgarán su confianza. Así ha sucedido con la imposibilidad constitucional de reelección que afectaba al entonces Presidente Leonel Fernández en 2012, en la que movimientos de apoyo a la candidatura oficialista dejaban claro su adhesión primaria al líder que en esa ocasión tenía imposibilitada su elección bajo los nombres de "Movimiento Comerciantes Leonelistas con Danilo" o "Movimiento con ella seguimos con él".

Foto 4.2.B.3 Personalismo Campaña

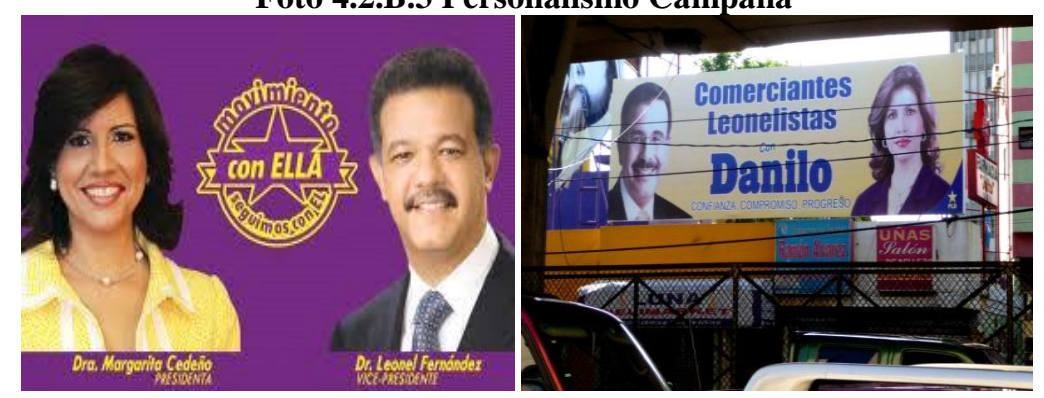

Fuente: Foto1: publicidad del movimiento de apoyo a la candidatura vicepresidencial de Margarita Cedeño, esposa del ex presidente Leonel Fernández En web del Sector Externo PLD, 26 de febrero de 2012. Foto 2: Tomada el 23 de junio de 2012.

Como se argumentaba en los capítulos anteriores, los rasgos personalistas en el lado de la oferta se manifestaban el individualismo de la actividad propositiva de los diputados. Del total de las 885 Proposiciones del Ley de carácter general -aquellas en las que la representación y el interés protegido abarcaba a toda la ciudadanía- el 18,6\% tenían un carácter testimonial, no implicaban

${ }^{262}$ En el acto de entrega de las nuevas aulas en el pueblo de Miches, los estudiantes expresaban lo "eternamente agradecido que estaban al Presidente Medina por haberles hecho parte de su proyecto de nación". Ver noticia en pagina web Presidencia de la República Dominicana del día 25 de abril de 2014, en http://presidencia.gob.do/comunicados/miches-\%E2\%80\%9Ceternamente-agradecido\%E2\%80\%9D

${ }^{263}$ Es el caso de los diputados del PRD Guillermo Radhames Ramos García condenado por tráfico de personas o de Ramón Fernández por sustracción de menores. 
prestación de servicios o ejercicio de derechos. El análisis desagregado de estas proposiciones revela que las de carácter personalista constituyen el rubro más elevado en dos de las tres legislaturas consideradas ${ }^{264}$.

Gráfico 4.2.B.7 Clasificación Proposiciones de Ley Generales de contenido Testimonial 1998-2010

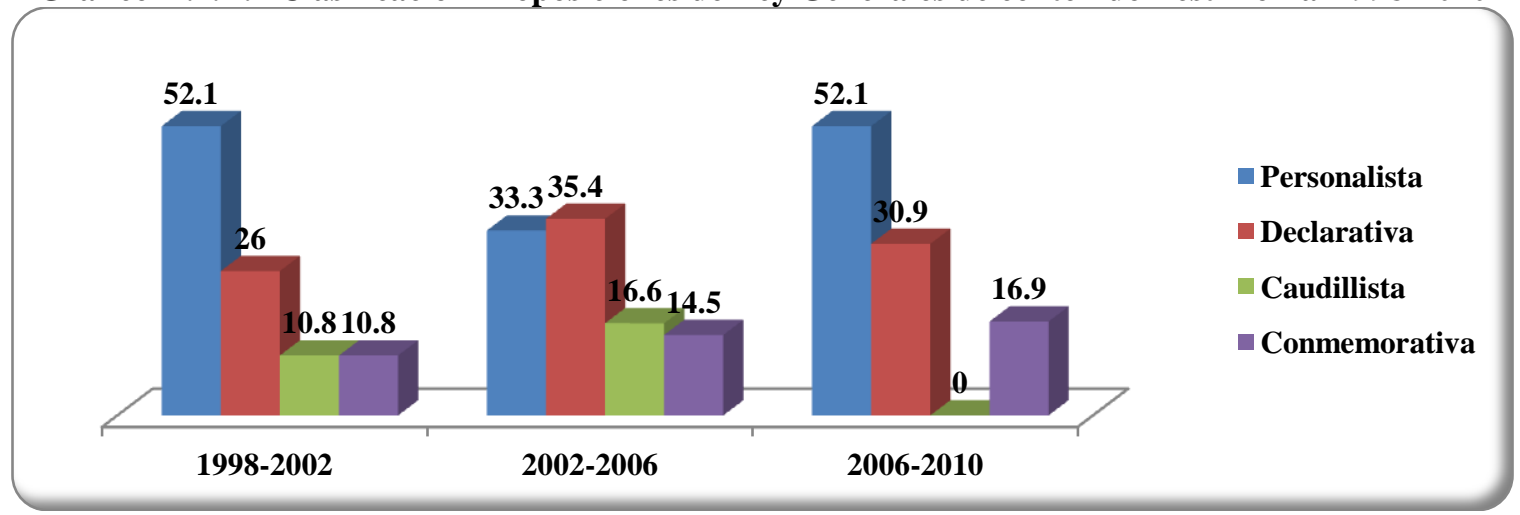

Fuente: Elaboración propia

En las proposiciones de ley catalogadas como "personalistas" se clasifican aquellas que tiene como objetivo renombrar edificios públicos con el de una persona reconocida en algún ámbito profesional. Escuelas públicas, oficinas gubernamentales, juzgados, instalaciones deportivas, sectores de carreteras, avenidas y parques reciben el nombre de antiguas profesoras, médicos distinguidos, viejos alguaciles, literatos o atletas de reconocimiento nacional, local o barrial. En ocasiones estas personas han tenido significancia política y partidista, tal es el caso de iniciativas como apodar una avenida con el nombre de Winston Arnaud (p101786) o con el de Emil Kasse Acta (p100906), líderes del PRD y PLD respectivamente. Otras veces el mérito se desvanece y escuelas como la "Pedro Lamarche" del municipio de La Vega reciben el nombre de profesores más queridos como "Profesora Toñita" (p105844). Dentro de las testimoniales, las proposiciones de ley catalogadas como "caudillistas" tienen por objeto nombrar alguna obra pública con el nombre de Joaquín Balaguer, Juan Bosch o Francisco Peña Gómez y son indicadores del peso de los tres líderes carismáticos en la memoria colectiva del país. El caudillismo constituye la expresión máxima de personalismo en el imaginario político. Desde 1998 a 2006 se propusieron 12 iniciativas para renombrar tramos de avenidas, institutos, parques o aeropuertos con el nombre de los caudillos: Joaquín Balaguer (6); Juan Bosch (2); y José Francisco Peña Gómez (4). Todas ellas a iniciativa de diputados de sus partidos de referencia, salvo dos en las que se honraba a Joaquín Balaguer a iniciativa de diputados perredeístas.

La valoración de la persona por encima de la colectividad o institución a la que representan dificulta la agregación colectiva de intereses y la creación de comunidades cívicas horizontales. En el ejercicio de la política, la sobrestimación del agente por parte de los ciudadanos potencia el vínculo personal con el principal frente al del proyecto colectivo que representa.

\footnotetext{
${ }^{264}$ Las proposiciones de ley catalogadas como "declarativas" clasifican propuestas de los diputados en las que manifiestan su adhesión a determinadas realidades, como por ejemplo fijar el día del "Del niño por nacer (p101811)", el "Día de regocijo provincial (p14713)" o el "Día nacional del merengue (pl04694)". En las "conmemorativas" los diputados proponen la celebración institucional de eventos significativos de la historia nacional como "Declarar héroes nacionales a los coroneles Francisco Caamaño y Rafael Fernández (p100816), "Día nacional del héroe restaurador Gregorio Luperón (pl04648)" o declarar "patrimonio histórico nacional la catedral San Pedro Apóstol (p106919)" [Ver Capítulo 2, Epígrafe 3.1 Particularismo Legislativo].
} 


\section{$\checkmark$ Confianza estratégica particularizada}

La confianza interpersonal es una de las variables determinantes en la conformación del capital social ya que facilita la acción coordinada. Las sociedades con altos niveles de confianza generalizada muestran mayor desarrollo económico, más compromiso cívico, menor corrupción, servicios públicos más efectivos y ciudadanos más involucrados en política (Putnam 1993; Inglehart 1997; Uslaner 2002; Fukuyama 1995). Los datos de confianza interpersonal sitúan a la República Dominicana en una posición intermedia en el contexto latinoamericano con 57,7 puntos en la escala de confianza y en descenso desde 2004 (LAPOP 2010). Encabezando el listado se encontraba Costa Rica con 70,2 puntos mientras que los ciudadanos peruanos mostraban el menor nivel de confianza generalizada con 46,2 puntos. En 2008 el 96,66\% de los dominicanos entrevistados consideraba que uno tenía que ser muy cuidadoso cuando trataba con los demás, el 67,6\% decía confiar poco/nada en la gente que conoce por primera vez y en 2012 el $31 \%$ consideraba que la gente de su comunidad era poco o nada confiable. Estas cifras pronostican el clima de alerta frente a la astucia del otro y que popularmente se conoce como la "ley del tigueraje ${ }^{\prime 265}$.

Tabla 4.2.B.6 Confianza interpersonal en República Dominicana (\%) 2004-2010

\begin{tabular}{|c|c|c|c|}
\hline $\mathbf{2 0 0 4}$ & $\mathbf{2 0 0 6}$ & $\mathbf{2 0 0 8}$ & $\mathbf{2 0 1 0}$ \\
\hline 64,9 & 60,4 & 59,4 & 57,7 \\
\hline \multicolumn{4}{|c|}{ Fuente: LAPOP $(2010: 133)$}
\end{tabular}

Tabla 4.2.B.7 Otros indicadores de confianza República Dominicana (\%) 2004-2008

\begin{tabular}{|l|c|c|c|}
\hline & $\mathbf{2 0 0 4}$ & $\mathbf{2 0 0 6}$ & $\mathbf{2 0 0 8}$ \\
\hline La gente del vecindario es poco/nada confiable & 33,6 & 25,6 & 23,1 \\
La gente se preocupa sólo por sí misma & 63,62 & 63,08 & -- \\
Si tuvieran la oportunidad, la gente se aprovecharía de Usted & 68,15 & 63,56 & 79,21 \\
\hline
\end{tabular}

Fuente: LAPOP 2004, 2006 y 2008.Porcentaje de los que están de acuerdo con la afirmación.

La aceptación del nepotismo en República Dominicana es manifestación del predominio de la confianza estratégica en la interacción social. En 2010, la población dominicana ocupaba el primer lugar en la comparativa regional en considerar no corrupto que un político utilizase su influencia para conseguir un empleo público a un familiar. El 75,6\% opinaba que no se trataba de un acto de corruptela y que en el caso de serlo, estaba justificado ${ }^{266}$. En el sector privado, las relaciones familiares son la llave de acceso al mercado laboral en el que priman los contactos y la inserción en el círculo cerrado de confianza, además de reflejar la escasa movilidad social en el país. La Encuesta Nacional de Fuerza de Trabajo mostraba la incidencia del parentesco en el escenario laboral, en el que el 39,5\% y el 37,4\% dijo ser hijo/a del jefe en 2008 y 2013 respectivamente $^{267}$.

En la cultura popular dominicana abundan las manifestaciones populares en que se expresa la distorsión de la confianza estratégica particularizada. Los "comesolos", "boroneadores", "tígueres", "sankis", "hoseadores", "turpenes" y "yuleidys" representan actitudes no cooperativas y de astucia para entrar en el círculo de confianza gracias al cual se accede a las mieles de la abundancia. Todas éstas podrían resumirse en la célebre frase «Primero nosotros, luego nosotros y si sobra algo

\footnotetext{
${ }^{265}$ Ver al respecto Cultura del Tigueraje en la República Dominicana de José Dunker (2011) o los ensayos de Lipe Collado (2004). Ver referencias en http://hoy.com.do/el-tiguere-dominicanoen-el-fondo-de-la-sicologiade-muchos-dominicanos-hay-un-tiguere-2/. En periódico Hoy de 15 de marzo de 2012.

${ }^{266}$ Esta postura indulgente con el nepotismo se ha puesto de manifiesto públicamente en numerosas ocasiones. En 2009 el vicepresidente de la Corporación Dominicana de Empresas Eléctricas Estatales confirmaba que unos 40 parientes trabajaban en esa institución del Estado, sin embargo rechazaba que fuese un acto de corrupción. Ver noticia en periódico HOY de 3 de julio de 2009.

${ }^{267}$ Ver estadísticas y bases de datos en línea del Banco Central de la República Dominicana.
} 
también para nosotros» ${ }^{268}$ de un conocido dirigente perredeísta al referirse al reparto de los recursos y puestos del Estado o el lema de campaña presidencial en 2012 del partido oficialista "!Danilo es de los míos!". Mientras que el apelativo de "comesolo" está reservado para aquellos que no quieren repartir los beneficios del poder o situaciones de abundancia con otras personas, el que "boronea" es más solidario porque en ese desfalco de recursos deja caer unas migas que pueden ser disfrutadas por otros $^{269}$. En ausencia de cooperación, la astucia aviva el ingenio por la supervivencia y aparecen personajes como el "tíguere" -experto en buscarse la vida a cualquier precio-, el "sanky" - experto en vivir a costa de los demás- y el "hoseador", aquel con buen olfato para descubrir situaciones de las que sacar ventaja. En el terreno de la política, el "turpén" es el prototipo de hombre con cargo público que abusa de los recursos del Estado con fines particulares y la "yuleidy" la amante que vive a costa de los beneficios que le facilita el turpén.

Conocer a alguien en alguna dependencia administrativa -ya sea el portero que evita hacer la fila, un familiar con rango medio en la agencia que te debe un favor- agiliza los trámites en la administración pública dominicana. Este canal informal de acceso preferente es reminiscencia de aquellos populares "tributarios" de épocas pasadas y que ejercían de intermediarios buscavidas que ayudaban a gestionar cualquier papeleo administrativo a los incautos campesinos en la ciudad. Como reconocía un actor clave entrevistado «hoy en cada institución siempre hay un buscón... un tipo con contactos que te facilita el procedimiento» ${ }^{270}$. La amistad instrumental en el país impregna las relaciones sociales así como la exteriorización de la amistad para indicar que se pertenece al círculo cerrado de confianza, con expresiones populares como: ¡Ese es mi "canchanchán"!, ¡mi "pana"!, ¡mi "comadre"!, ¡Ese es de los míos!... Como destacara Moreno (1995:195) «el lenguaje utilizado allí donde existe el patronazgo subraya el afecto real o fingido entre las partes. "Amigo" ha sido el apelativo preferido por los componentes de las clientelas políticas para dirigirse unos a otros donde quiera que han existido». Esta confianza particularizada intragrupos obstaculiza la concertación social y favorece la respuesta pública particularizada en la que predominan los bienes de club y las respuestas individualizadas en todos los niveles de renta. Las percepciones de los ciudadanos dominicanos así lo respaldan. En 2004 solo el 7,4\% consideraba que los partidos políticos defendían los intereses de toda la sociedad, frente al 44,9\% que consideraba que solo atendían a los algunos grupos y personas.

Tabla 4.2.B.8 Los partidos políticos defienden intereses y necesidades (\%), 1997-2004

\begin{tabular}{|l|c|c|}
\hline & $\mathbf{1 9 9 7}$ & $\mathbf{2 0 0 4}$ \\
\cline { 2 - 3 } Solo de los partidos & 47.7 & 47,7 \\
Solo de algunos grupos y personas & 38,3 & 44,9 \\
De toda la sociedad & 8,3 & 7,4 \\
\hline
\end{tabular}

La distribución de la riqueza es la variable con mayor poder desestabilizador de la confianza (Collier 2002; Uslaner 2002; Zak y Knack 2001). La desigualdad de ingresos aviva el temor y el resentimiento entre los sectores de la sociedad y limita la creación de redes de compromiso cívico. En América Latina el 10\% más rico de la población recibe el 32\% de los ingresos totales, mientras que el $40 \%$ más pobre recibe el $15 \%$. La República Dominicana se encuentra entre el grupo de

\footnotetext{
268 Palabras de Guido Gómez Mazara (PRD), Consultor Jurídico del Ejecutivo (2000-2004).

${ }^{269}$ El mono es el prototipo de comesolo porque al comer coge las migas con la otra mano y se las vuelve a comer. La cotorra picotea y deja migajas que pueden ser disfrutadas por otros. Popularmente se dice que el PRD es una cotorra porque al menos deja "caer" algo que otros más allá de su círculo de confianza.

${ }^{270}$ Para lidiar con estas costumbres patrias, en la Embajada de EEUU o de la República Francesa en Santo Domingo son visibles los carteles en los que se advierte a los que van a gestionar visados acerca de los buscones o que se abstengan de indagar si existe un "protocolo" preferente.
} 
países por debajo del promedio regional donde la concentración de la riqueza es aun mayor y esos porcentajes se acercan al $40 \%$ de los ingresos para los más ricos y el $11 \%$ para los más pobres (CEPAL 2012:20). La corrupción y la percepción de inseguridad son variables que también erosionan la confianza interpersonal necesaria para la cooperación social. Los datos de opinión reflejan que la ciudadanía dominicana percibe altos niveles de corrupción en el país y en la comparativa regional se sitúa a solo 3.6 puntos de Colombia que encabeza el listado con 81,7 puntos. El Global Competitiveness Index (2011) situaba a la República Dominicana en la posición 107 de un listado de 142 países en pagos irregulares y sobornos e identificaba la corrupción como el principal obstáculo para hacer negocios en el país. El control de la corrupción en el país se ha debilitado en los últimos años, situándose en 2011 en el percentil bajo (10-25) con un puntaje de 22,3 frente al 58,6 en América Latina (World Governance Indicators, 2010). República Dominicana cuenta además con un porcentaje relativamente alto de ciudadanos que justifican pagar un soborno y que alcanza el 17,7\% de los entrevistados, solo detrás de México y Colombia que encabezan el listado con un $20,9 \%$ y un 19,1\% respectivamente (LAPOP 2010). En 2012 consideraron justificado el soborno el 17,16\%.

Tabla 4.2.B.9 Percepción de la corrupción (\%), 2004-2012

\begin{tabular}{|c|c|c|c|c|}
\hline $\mathbf{2 0 0 4}$ & $\mathbf{2 0 0 6}$ & $\mathbf{2 0 0 8}$ & $\mathbf{2 0 1 0}$ & $\mathbf{2 0 1 2}$ \\
\hline 80,9 & 78,9 & 74,5 & 77,6 & 78,1 \\
\hline
\end{tabular}

Fuente: LAPOP (2012:104)

Tabla 4.2.B.10 Percepción de la inseguridad (\%), 2006-2012

\begin{tabular}{|c|c|c|c|}
\hline $\mathbf{2 0 0 6}$ & $\mathbf{2 0 0 8}$ & $\mathbf{2 0 1 0}$ & $\mathbf{2 0 1 2}$ \\
\hline 50,7 & 39,5 & 46,5 & 43,6 \\
\hline
\end{tabular}

\section{$\checkmark \quad$ Participación y movilización social}

La construcción de ciudadanía es uno de los grandes retos de los procesos de democratización en las democracias de la Tercera Ola (Huntington 1991). En las democracias delegativas (O’Donnell 1997) los ciudadanos son meros espectadores de la "cosa pública" con poca capacidad para intervenir en la formulación y fiscalización de las políticas. Esta ciudadanía de bajo perfil fuertemente individualista no genera acción colectiva, ya que la construcción de lo público solo es posible con el compromiso cívico y la deliberación colectiva de los problemas que afectan a la comunidad política (Arendt 1997). Por el contrario, la ciudadanía efectiva amplía los horizontes inclusivos del sistema democrático a través de la participación en el dialogo político de todos los sectores sociales y no solo en las citas electorales.

Los datos de participación en las urnas han sido elevados desde la transición, manteniéndose por encima del 70\%, salvo en las conflictivas elecciones de 1990 y en las fraudulentas de 1994. Con la separación de las elecciones en 1994, el nivel de participación en la contienda legislativa disminuyó significativamente y desde 1998 el promedio ronda el 56,7\%. A pesar de que según las encuestas los dominicanos no confían en los partidos políticos, este nivel de afluencia confirma por un lado la rutinización de las elecciones y por otro, que la insatisfacción y la desconfianza hacia la clase política no pone en peligro el compromiso democrático de la ciudadanía. La divergencia en el nivel de participación en las presidenciales frente a las legislativas que ronda los 20 puntos porcentuales, obedece a la atribución de mayor importancia a la figura presidencial en un contexto de hiperpresidencialismo informal y al carácter mayoritario que caracteriza a las democracias delegativas. 
Tabla 4.2.B.11 Participación y abstención (\%) elecciones presidenciales

\begin{tabular}{|c|ccccccccccc|}
\hline & $\mathbf{1 9 7 8}$ & $\mathbf{1 9 8 2}$ & $\mathbf{1 9 8 6}$ & $\mathbf{1 9 9 0}$ & $\mathbf{1 9 9 4}$ & $\mathbf{1 9 9 6}$ & $\mathbf{1 9 9 6}(\mathbf{2 v})$ & $\mathbf{2 0 0 0}$ & $\mathbf{2 0 0 4}$ & $\mathbf{2 0 0 8}$ & $\mathbf{2 0 1 2}$ \\
\cline { 2 - 12 } Participación & 72,5 & 73,8 & 72,2 & 59,4 & 91,5 & 77,6 & 76,4 & 76,1 & 72,8 & 70,0 & 71,2 \\
Abstención & 27,5 & 26,1 & 27,7 & 40,6 & 8,5 & 22,3 & 23,5 & 23,8 & 27,1 & 29,9 & 28,8 \\
\hline
\end{tabular}

Fuente: Elaboración propia, datos de la JCE

Tabla 4.2.B.12 Participación y abstención (\%) elecciones legislativas

\begin{tabular}{|l|ccccccccc|}
\hline & $\mathbf{1 9 7 8}$ & $\mathbf{1 9 8 2}$ & $\mathbf{1 9 8 6}$ & $\mathbf{1 9 9 0}$ & $\mathbf{1 9 9 4}$ & $\mathbf{1 9 9 8}$ & $\mathbf{2 0 0 2}$ & $\mathbf{2 0 0 6}$ & $\mathbf{2 0 1 0}$ \\
\cline { 2 - 9 } Participación & 72,5 & 73,8 & 72,2 & 59,4 & 91,5 & 52,96 & 49,1 & 58,3 & 56,4 \\
Abstención & 27,5 & 26,1 & 27,7 & 40,6 & 8,5 & 47,04 & 50,9 & 41,7 & 43,6 \\
\hline
\end{tabular}

Fuente: Elaboración propia, datos de la JCE

Por el contrario, el nivel de participación de los ciudadanos dominicanos en acciones reivindicativas por la conquista de mejoras públicas ha sido muy limitado. Las encuestas de opinión de la década 1994-2004 destacaban la poca propensión de la ciudadanía a participar en manifestaciones en lugares públicos, huelgas y paros, en un porcentaje que no alcanzaba el $12 \%$ de los entrevistados (DEMOS 1998:88). Las formas más moderadas de reivindicación eran las de mayor aceptación entre los dominicanos. Así, el $80 \%$ se mostraba a favor de que se firmasen documentos de reclamos y manifestaciones autorizadas frente al escaso $7 \%$ partidario de realizar huelgas nacionales (DEMOS 1994). En el año 2001 las opciones pactistas recibían la aprobación del $91 \%$ y el $80 \%$ respectivamente, mientras que las opciones beligerantes como la ocupación de tierras $(17 \%)$, de lugares públicos $(16,5 \%)$ o el ejercicio del derecho de huelga de alcance nacional (14\%) contaban con un respaldo significativamente menor. Esta actitud más propensa al pacto que a la conquista beligerante se confirma en las encuestas de opinión de los últimos años y es reflejo en el lado de la demanda, de la tradición pactista de las elites en el lado de la oferta. Desde 2006 el porcentaje de entrevistados que participa en una protesta pública ronda el 5\%, siendo mayor entre las personas de más alto nivel educativo (DEMOS 2006:179). El aumento de tres puntos porcentuales observado en 2012 reflejaría la incidencia de campañas ciudadanas con gran poder movilizador, como la Coalición Digna por la Educación que reclamaba un aumento de gasto público en educación y el Movimiento Justicia Fiscal en contra de la reforma fiscal, el despilfarro público y la corrupción.

Tabla 4.2.B.13 Participación en protestas en el último año (\%)

\begin{tabular}{|cccc|}
\hline $\mathbf{2 0 0 6}$ & $\mathbf{2 0 0 8}$ & $\mathbf{2 0 1 0}$ & $\mathbf{2 0 1 2}$ \\
\hline 5,3 & 4,8 & 5,3 & 8,1 \\
\hline
\end{tabular}

El periodo de mayor beligerancia ciudadana en la reciente historia política dominicana corresponde a los años de la segunda transición democrática. En esa década, las huelgas fueron el instrumento de acción más utilizado, especialmente durante los años 1985-1987 y en 1990, fecha en que se convocaron tres huelgas generales durante el impasse provocado por el fraude electoral. Hoy la competencia entre sindicales hace difícil la convocatoria de huelgas nacionales y salvo los paros de ciertos sectores como el de los transportistas (choferes) para forzar la negociación de ventajas para su gremio, la huelga no es un recurso de reivindicación colectiva sino de acción corporativa de los grupos de interés más influyentes ${ }^{271}$. La convocatoria nacional ha sido sustituida por protestas localizadas en los sectores de bajos ingresos en los que se protesta por las deficiencias en los servicios básicos. La falta de cooperación se ha resuelto buscando soluciones privadas a problemas

\footnotetext{
${ }^{271}$ Ver noticia de protestas de esposas de transportistas en periódico El Nuevo Diario de 10 de abril de 2014 en http://www.elnuevodiario.com.do/app/frontpage. $a s p x / i m g /$ stor/banners/article.. aspx $? \mathrm{id}=370627$
} 
colectivos. Tal es el caso de las deficiencias históricas en la prestación de servicios básicos como el suministro de agua, la electricidad o la seguridad pública, que han poblado el paisaje dominicano de "tinacos", "botellones", "inversores" y "guachimanes"272. A pesar de ser éstos problemas históricos que afectan a todo el país, no han concitado en la etapa de la consolidación democrática una convocatoria nacional de protesta. Las respuestas privadas a problemas colectivos frente a las deficiencias en la prestación de servicios han atomizado, sectorizado y territorializado la acción colectiva en los últimos años. Destaca por novedoso el protagonismo de movimientos juveniles en los que se agrupan estudiantes de universidades privadas de la clase media-alta lejos del perfil de los jóvenes de barrio y a los que despectivamente se les acusaba de ser "resentidos sociales" (De la Cruz 2010:15). Aunque estos movimientos juveniles comparten reivindicación y mensaje en la lucha contra la corrupción, no existe una coordinación entre ellos ${ }^{273}$.

El bajo nivel de participación podría estar afectado por el miedo a las represalias. En la pasada década el 72,4\% de los entrevistados en 1994 consideraba que en el país se podía ejercer la libertad de expresión sin temor a la represión ${ }^{274}$. No obstante, en este contexto de ciudadanía de bajo perfil, destacan por exitosas y visibles, movilizaciones como el rechazo de organizaciones juveniles a la instalación de una empresa cementera en el Parque Nacional de los Haitises en 2009 y la Coalición Educación Digna que persigue que se destine el $4 \%$ del PIB a la educación no universitaria ${ }^{275}$. El movimiento Justicia Fiscal lidera las protestas ciudadanas contra la reforma fiscal para afrontar el déficit generado en la administración anterior. Las concentraciones en parques y otros espacios públicos del país fueron contestadas por las fuerzas de seguridad, que acabaron con la vida de un manifestante en noviembre de $2012^{276}$.

\footnotetext{
${ }^{272}$ Un guachimán es un guardia de seguridad privado, su nombre tiene origen en la palabra inglesa watchman, por ser americana una de las primeras compañías de seguridad privada en el país. El perfil suele ser el de un hombre adulto, la mayoría de origen haitiano, con largas jornadas y sueldo paupérrimo. Se estima que de cada 10 hogares de los barrios acomodados cuentan con guachimán. Un tinaco es un tanque de almacenamiento de agua para uso doméstico. Un botellón es una botella de 10 litros de agua para consumo doméstico, presente en todos los hogares dominicanos. Un inversor es una planta eléctrica que suple de electricidad a hogares privados para suplir los cortes en el suministro público de electricidad.

${ }^{273}$ Algunos de estos movimientos son "Toy jarto... pero creo en mi país", "Ahí e’que prende", "La multitud", "Germinando ideas", "Justicia Global", "La Revuelta", "Juventud Caribe", "Autoconvocados" y "Jóvenes unidos por un Estado sano", entre otros.

${ }^{274}$ Son frecuentes las detenciones de manifestantes en actos reivindicativos tanto en sectores populares como en los de renta media-alta. Ver noticia de arrestados en la comunidad de Camarón, en acto de protesta por el arreglo de las calles y el suministro de agua en Noticias SIN, del 10 de febrero de 2014; detenciones de manifestantes del grupo de jóvenes "La Multitud" ante FUNGLODE, en periódico Diario Libre del 29 de diciembre de 2013, en http://www.diariolibre.com/noticias/2013/12/29/i417351_apresan-jvenes-multitudcelebraban-cumpleaos-leonel-frente-funglode.html; muerte del estudiante Willian Florián en manifestación en contra de la reforma fiscal, en periódico Diario Libre del 9 de noviembre de 2012, en http://www.elcaribe.com.do/2012/11/09/policia-mata-estudiante-campus-uasd

${ }^{275}$ Las movilizaciones paralizaron el proyecto de construcción de una cementera en el municipio de Gonzalo. El Gobierno solicitó un Informe al PNUD sobre la viabilidad legal y técnica del proyecto que corroboró la informalidad del procedimiento de concesión de licencia ambiental. El Consorcio Minero Dominicano desistió del proyecto y anunció que buscaría nueva ubicación.

${ }^{276}$ El estudiante Willy Florián moría en el campus de la Universidad Autónoma de Santo Domingo el 8 de noviembre de 2012. Dos días después moría la profesora Ángela Moquete herida en las protestas por la falta de agua en el Sector Villa Estela. La represión durante el primero gobierno de Joaquín Balaguer se llevó a cabo mediante la Operación Chapeo que tenía como finalidad la desaparición de los izquierdistas que participaron en la Revolución de Abril y más tarde, el grupo paramilitar denominado La Banda, fue el encargado de atemorizar y exterminar a los opositores al régimen.
} 
Tabla 4.2.B.14 Libertad de expresión sin temor a la represión

\begin{tabular}{|cccc}
$\mathbf{1 9 9 4}$ & $\mathbf{1 9 9 7}$ & $\mathbf{2 0 0 1}$ & $\mathbf{2 0 0 4}$ \\
72,4 & 66,3 & 65,9 & 57,3 \\
\hline
\end{tabular}

Fuente: DEMOS (2004:32)

Con respecto al asociacionismo, en los últimos años la República Dominicana se sitúa en la comparativa regional entre los cinco primeros países con mayor porcentaje (LAPOP 2010). Teniendo en cuenta que solo el 5,4\% de la población entrevistada participaba en protestas, hay que deducir que se trata de un activismo con un alto grado de organización pero escasa movilización ${ }^{277}$. Sin embargo, el grado de asociacionismo no es por sí mismo indicador de ciudadanía activa o del poder político de los actores sociales. Las asociaciones cívicas son agentes democráticos inclusivos en la medida en que generan confianza generalizada inter grupos, tolerancia y acción colectiva.

Los datos revelan que la vida asociativa en República Dominicana tiene un marcado componente de religiosidad ya que más de la mitad de los entrevistados afirmaron pertenecer a una organización religiosa, representando el 55,8\%, el 57,2\% y el 60,5\% en 2006, 2008 y 2010 respectivamente. Un activismo que ha ido en aumento, ya que en 1994 este tipo de participación representaba el 40,9\% (DEMOS 1994). En 2012, el 38,81\% decía asistir una vez por semana a reuniones de un grupo religioso, frente al 27,8\% en la región latinoamericana. Mientras que el activismo religioso tiene un carácter de externalidad -encomienda a una autoridad superior divina la resolución de los problemas- y estrecha lazos entre pares que comparten la misma fe, el activismo secular reconoce la autonomía y el poder solidario de la colectividad social. En este sentido, destaca la ausencia de organizaciones de la llamada "nueva política" como las ecológicas.

Gráfico 4.2.B.8 Participación en reuniones de organizaciones cívicas

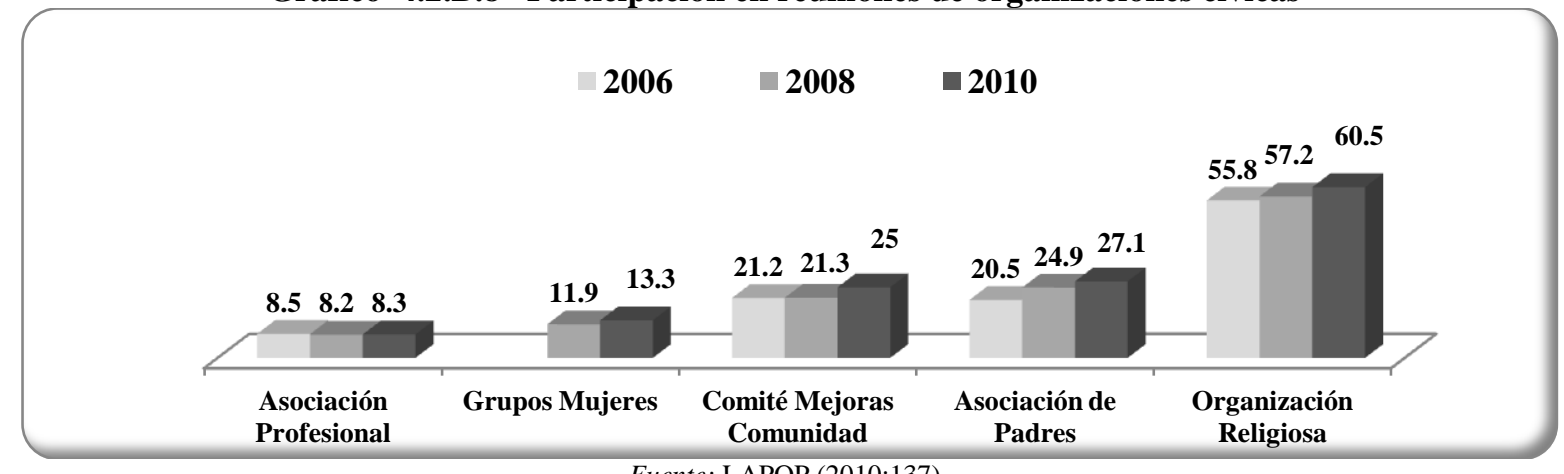

Fuente: LAPOP (2010:137)

Diferentes estudios sobre el activismo civil dominicano en la consolidación democrática han demostrado que la co-participación en organizaciones sociales y políticas es una variable que condiciona la baja movilización en el país. La doble membrecía reduce la capacidad de presión de la sociedad civil sobre los partidos y el Estado, ya que quedan atrapadas en sus redes clientelares de intercambio de favores. En 2004, la doble militancia se revelaba como la situación más proclive en la mayor aceptación del clientelismo medida en base a la aprobación de favores, reparto de bienes, la aceptación de soborno y el empleo de familiares de políticos. La posición más baja correspondía a aquellos entrevistados que solo tenían membrecía civil $(33,4 \%)$ y la más alta a aquellas con doble militancia social y política (41,1\%) (DEMOS 2004).

\footnotetext{
277 Argentina lideraba con un 15,4\% la participación en protestas y El Salvador ocupaba la última posición
} con un 4,3\% (LAPOP 2010:141). 
Gráfico 4.2.B.9 Impacto del perfil organizativo en el clientelismo, 2004

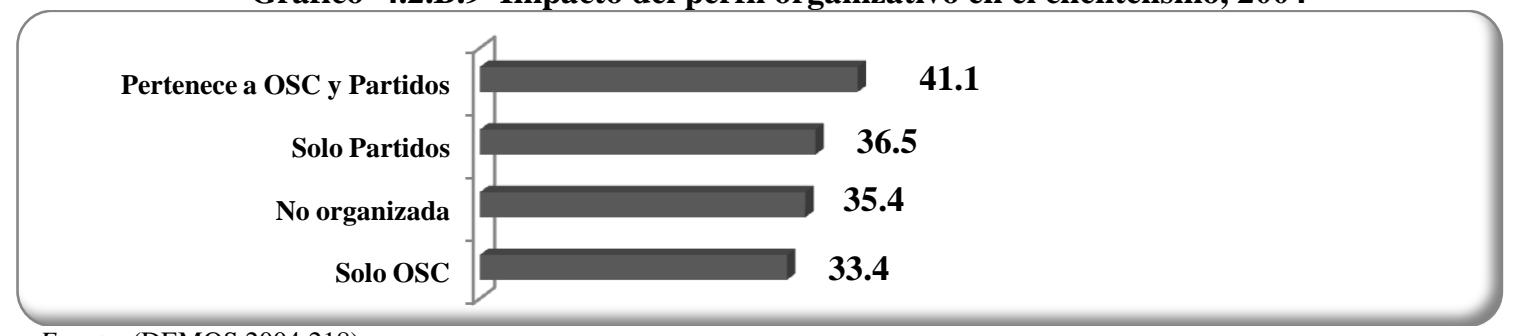

Fuente: (DEMOS 2004:218)

En 2010, la asistencia a reuniones de partidos políticos era mayor entre aquellos que pertenecían a una organización de la sociedad civil, siendo la diferencia estadísticamente significativa, como demostraran Espinal, Morgan y Hartlyn (2010:49).

Gráfico 4.2.B.10 Relación entre participación cívica y asistencia a reuniones de partidos, 2010

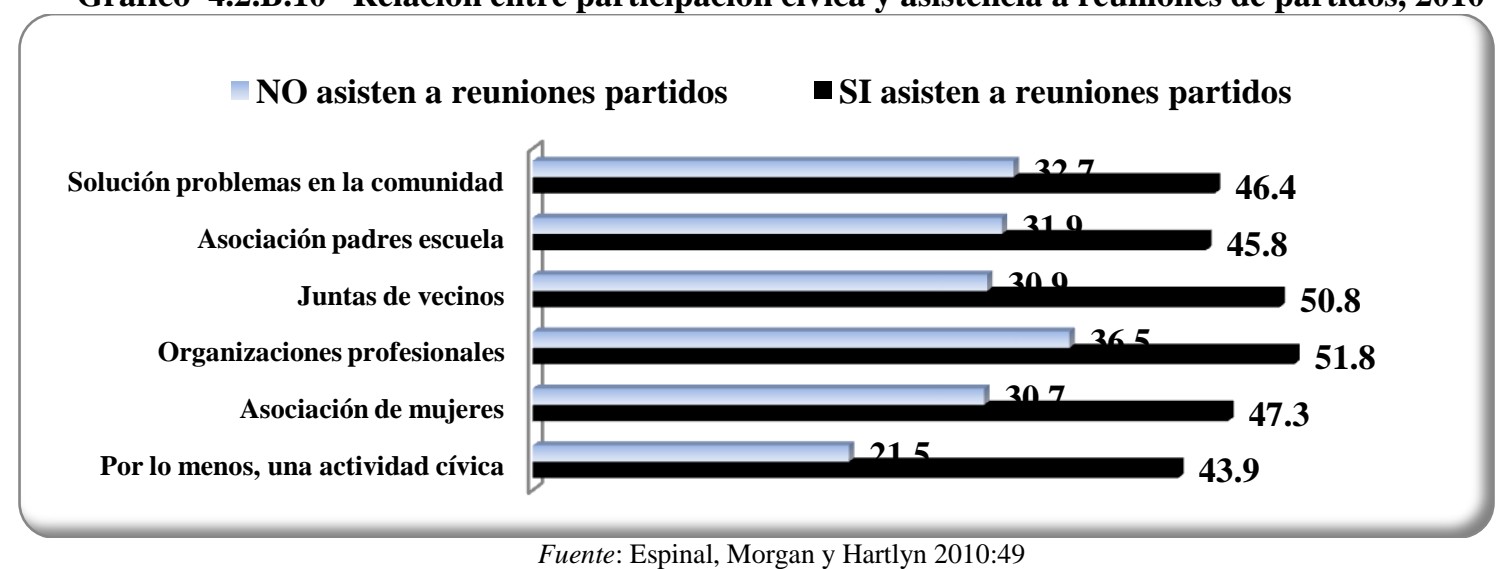

Para verificar si esta relación entre activistas civiles y partidos políticos tiene una naturaleza clientelar, los autores cruzaron los datos con aquellos relativos a las ofertas clientelistas que los candidatos hacen en campaña y con los beneficiarios de la Tarjeta Solidaridad (programa focalizado de subsidios). Como muestra el Gráfico 4.2.B.11 participar en alguna de estas instancias civiles aumenta la posibilidad de recibir ofertas clientelistas, siendo esta relación estadísticamente significativa (Espinal, Morgan y Hartlyn 2010:50). Aquellos que participan en reuniones de juntas de vecinos o de organizaciones profesionales recibieron ofertas clientelares $(23,2 \%$ y $23,1 \%)$ en un porcentaje cercano al experimentado por los miembros de un partido político (25\%). 
Gráfico 4.2.B.11 Distribución de las ofertas clientelistas por participación cívica y política (\%), 2010

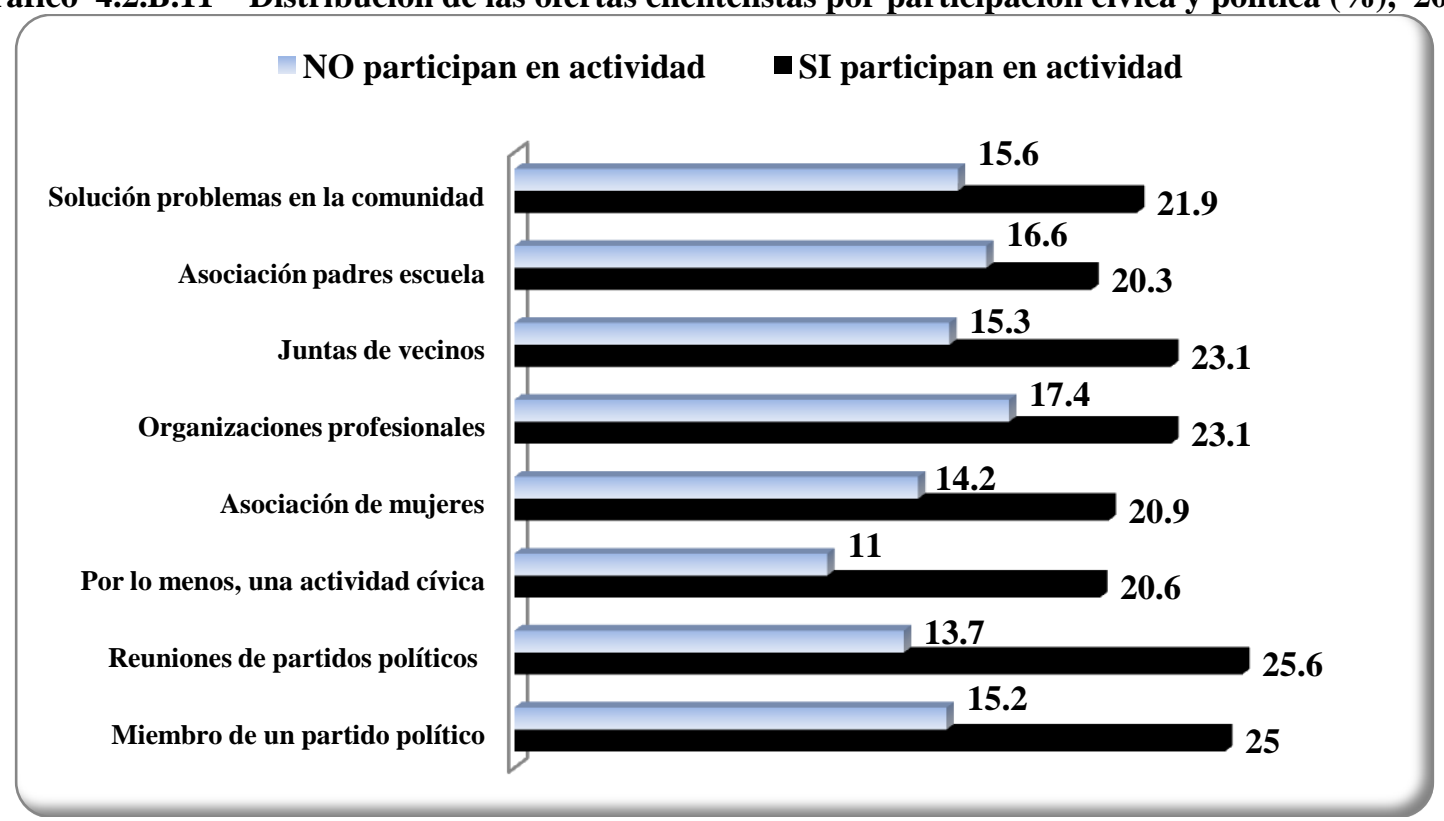

Fuente: Espinal, Morgan y Hartlyn 2010:51

En la movilización y participación en actividades de naturaleza política, República Dominicana ocupa la primera posición en la comparativa regional. En 2012 lideraba el porcentaje de entrevistados que afirma haber trabajado para un partido o candidato con un $16,8 \%$, siendo este porcentaje del $19,9 \%$ en 2010 , del $18,12 \%$ en 2008 y del $19,97 \%$ en 2006 . Un indicador de la movilización de la ciudadanía en actividades de naturaleza política es el llamado "Sector Externo". Este fenómeno movimientista en República Dominicana lanza a la arena política a personajes de significancia social de toda índole como deportistas, cantantes, académicos ... para que acerquen a sus hinchas, fans o seguidores a las filas del candidato de turno. En las elecciones presidenciales de 2012, el ex Rector de la Universidad Autónoma de Santo Domingo, lideraba el movimiento "Usadianos con Papá", con el que decía reunir:

«A más de tres mil miembros de los diferentes centros de la UASD en todo el país y cuya meta es garantizarle 500 mil votos de amigos, allegados y familiares de sus afiliados, a favor de la candidatura de Hipólito Mejía en las elecciones generales de mayo del 2012» ${ }^{278}$ (García 2012).

La República Dominicana también lideraba en 2012 la comparativa regional en porcentaje de entrevistados que trató de convencer a otros para votar por un partido. No parece que existan diferencias entre año electoral presidencial o legislativo/municipal, lo que habla de la estabilidad de la red informal de los partidos y de la partidización de la vida pública en el país. Como se verá en el apartado siguiente, los ciudadanos dominicanos no confían en los partidos políticos, sin embargo trabajan para ellos en espera de la correspondencia recíproca de la relación clientelar aceptada.

\footnotetext{
${ }^{278}$ Palaras de Franklin García Fermín, ex Rector de la UASD, en periódico Diario Digital de 23 de abril de
} 2012. 
Gráfico 4.2.B.12 Porcentaje que trabajó para partidos o candidatos 2012

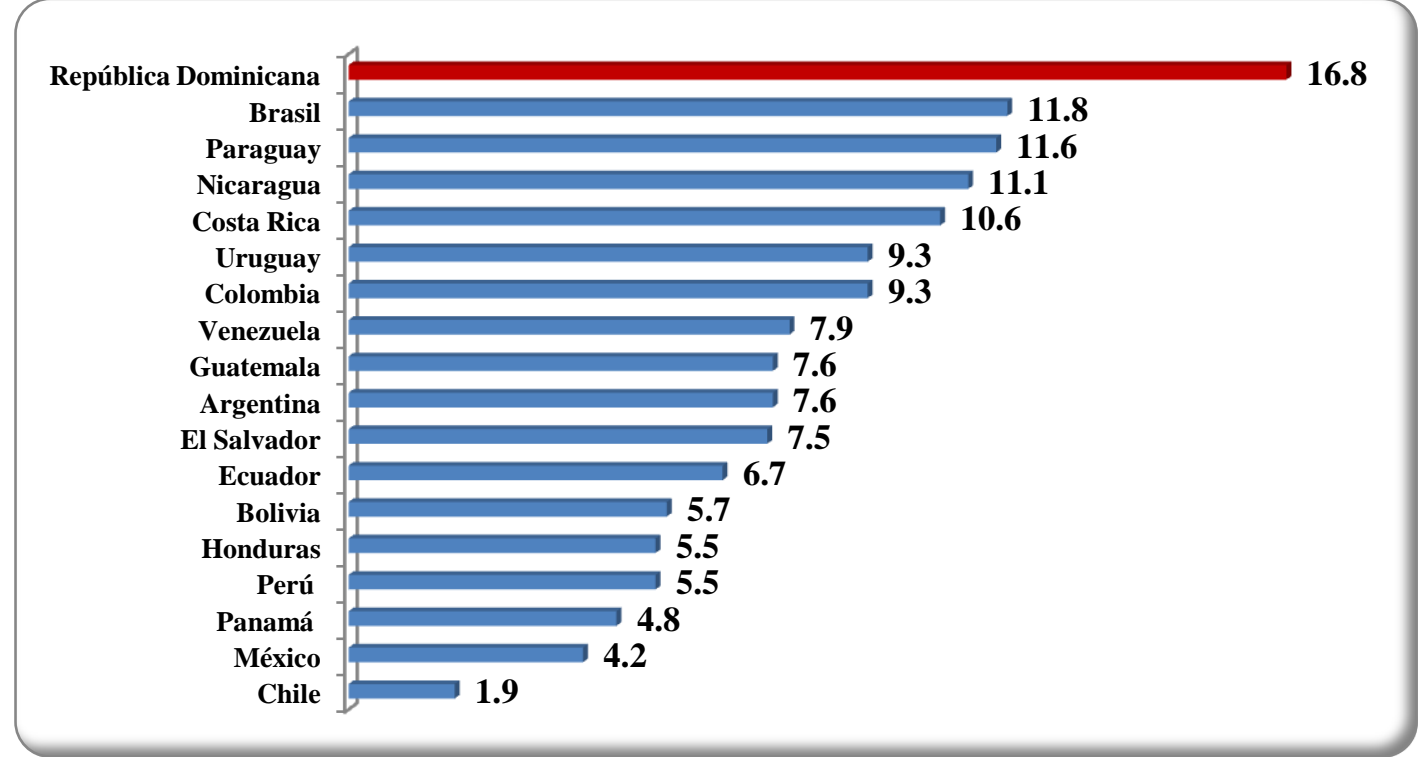

Fuente: LAPOP (2012:53)

Gráfico 4.2.B.13 Trató de convencer a otros para que voten por un partido o candidato, 2012

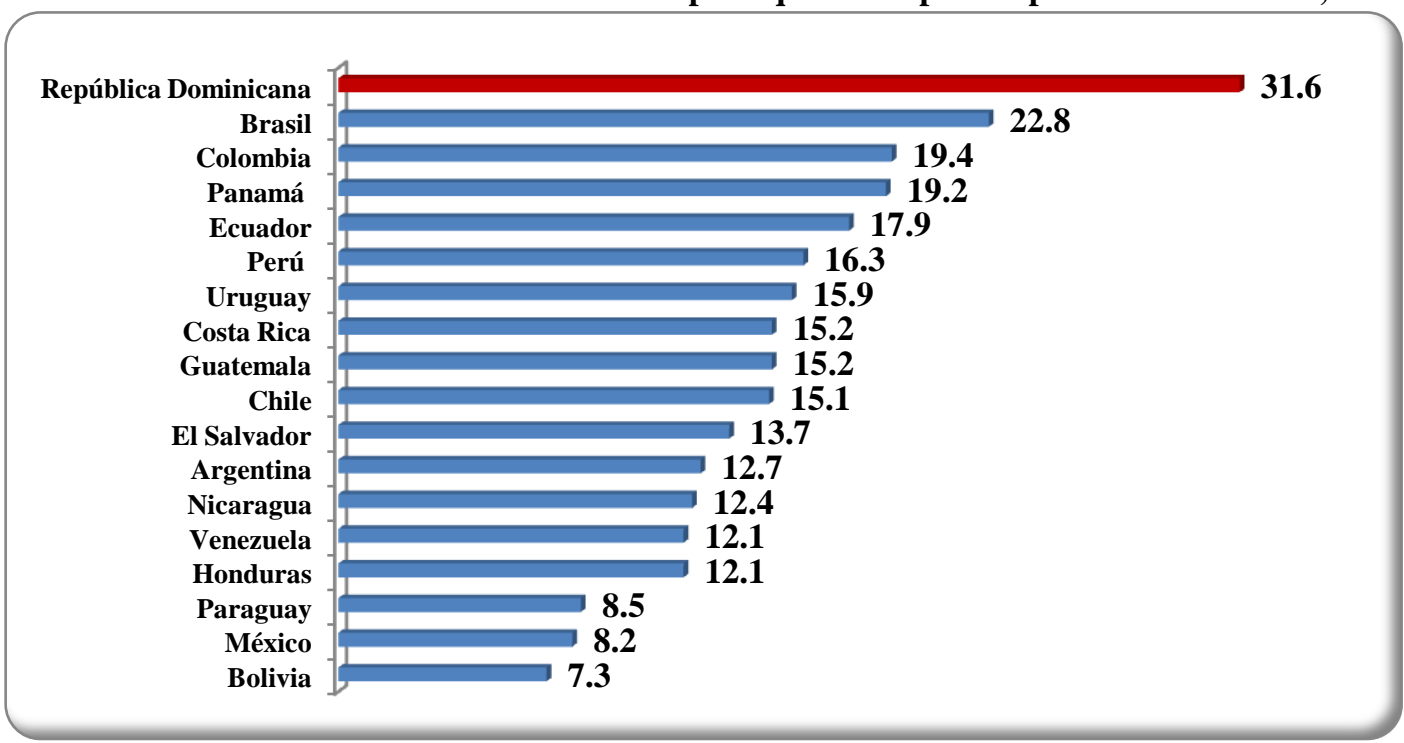

Fuente: LAPOP (2012:3)

Tabla 4.2.B.14 Trató de convencer a otros para que voten por un partido o candidato

\begin{tabular}{|cccccc|}
\hline $\mathbf{1 9 9 4}$ & $\mathbf{1 9 9 7}$ & $\mathbf{2 0 0 6}$ & $\mathbf{2 0 0 8}$ & $\mathbf{2 0 1 0}$ & $\mathbf{2 0 1 2}$ \\
\hline 26,4 & 33,8 & 48,8 & 40,4 & 33,5 & 31,6 \\
\hline
\end{tabular}




\section{$\checkmark$ Legitimidad democrática, descontento político y desafección institucional}

República Dominicana ejemplifica la combinación actitudinal que predomina en las nuevas democracias de la "Tercera Ola" catalogada como "desafección democrática" (Torcal 2006). El apoyo al régimen democrático contrasta con los bajos niveles de eficacia -descontento- y con la escasa confianza en las instituciones - desafección institucional-. El peso socializante del pasado reciente (con experiencias pseudo-democráticas, corrupción, prácticas clientelares...) es responsable de no generar actitudes más positivas en la etapa de la consolidación democrática que rompan el círculo de desafección política del pasado autoritario. Como consecuencia, mientras que la presencia de ciudadanos críticos o desafectos demócratas en las viejas democracias genera un efecto dinamizador de la vida democrática, en las nuevas democracias este efecto transformador y movilizador está ausente (Torcal 2006:4). Las encuestas de opinión pública muestran el apoyo decidido de los dominicanos a la democracia en un porcentaje por encima del $70 \%$ en la última década. En la comparativa regional, Uruguay con un 86,5\% y Honduras con un 52,6\% ocupan la primera y última posición respectivamente (LAPOP 2012:31).

Tabla 4.2.B.15
\begin{tabular}{|cccccc|}
\hline $\mathbf{2 0 0 1}$ & $\mathbf{2 0 0 4}$ & $\mathbf{2 0 0 6}$ & $\mathbf{2 0 0 8}$ & $\mathbf{2 0 1 0}$ & $\mathbf{2 0 1 2}$ \\
\hline 77,0 & 74 & 78,7 & 74,9 & 68,6 & 70,0 \\
\hline
\end{tabular}
Fuente: DEMOS y LAPOP

Por el contrario, el sentimiento de eficacia política de los ciudadanos dominicanos muestra valores decrecientes. Con respecto a las variables que miden la eficacia externa -idea que tiene el ciudadano acerca de la disposición y capacidad de los dirigentes e instituciones de responder a las demandas de la población- se ha producido un declive estadísticamente significativo en la valoración de los partidos políticos como artífices de la representación. En 2004 el 47,7\% de los entrevistados consideraba que los partidos se representaban a ellos mismos y a determinados grupos y personas $(44,9 \%)$, frente a un escaso $7,4 \%$ que consideraba que el ejercicio de la representación era inclusivo y respondía a los intereses y necesidades de los dominicanos. En 2008, el 49,8\% de los entrevistados consideraba que los partidos políticos dominicanos representaban bien a sus votantes, porcentaje que descendió al 41,6\% en 2012. En la comparativa regional solo Venezuela, Uruguay y Nicaragua superaban el 50\% ocupando las posiciones más altas en la percepción positiva, frente a Costa Rica, país en el que el 30,5\% de los ciudadanos entrevistados así lo consideraba (LAPOP 2012). A la hora de valorar la eficacia gubernamental en la prestación de los servicios públicos, la mejor y peor valoración corresponde a la administración de Hipólito Mejía (PRD 2000-2004) donde el 32\% de los entrevistados consideraba en 2001 que funcionaban bien y tres años después cuando la crisis financiera sumió en la pobreza a más de un millón de personas, el $65,8 \%$ consideraron que funcionaban mal.

Tabla 4.2.B.16 Valoración funcionamiento servicios públicos (\%) en República Dominicana

\begin{tabular}{|c|cccc|}
\hline & $\mathbf{1 9 9 4}$ & $\mathbf{1 9 9 7}$ & $\mathbf{2 0 0 1}$ & $\mathbf{2 0 0 4}$ \\
\cline { 2 - 5 } & $\begin{array}{c}\text { Joaquín } \\
\text { Balaguer }\end{array}$ & $\begin{array}{c}\text { Leonel } \\
\text { Fernández }\end{array}$ & $\begin{array}{c}\text { Hipólito } \\
\text { Mejía }\end{array}$ & $\begin{array}{c}\text { Hipólito } \\
\text { Mejía }\end{array}$ \\
\cline { 2 - 5 } Mal funcionamiento & 60,4 & 59,0 & 46,6 & 65,8 \\
Funcionamiento mediano & 15,2 & 19,2 & 21,2 & 18,5 \\
Buen funcionamiento & 24,3 & 21,8 & 32,1 & 15,7 \\
\hline
\end{tabular}

Fuente: DEMOS (2004:66) 
La República Dominicana se encuentra entre los países con menor puntuación en la escala de eficacia gubernamental junto con Costa Rica, Paraguay y Honduras, con un 40,7\%, un 39,7\%, un $38,5 \%$ y un 30,5\% respectivamente (LAPOP 2012:219). En las administraciones del PLD bajo la administración de Leonel Fernández, la satisfacción ciudadana ha ido descendiendo progresivamente.

Tabla 4.2.B.17 Eficacia del gobierno (\%) en República Dominicana

\begin{tabular}{|cccc|}
\hline $\mathbf{2 0 0 6}$ & $\mathbf{2 0 0 8}$ & $\mathbf{2 0 1 0}$ & $\mathbf{2 0 1 2}$ \\
\hline \multicolumn{4}{|c|}{ Leonel Fernández } \\
\hline 55,8 & 54,6 & 50,3 & 40,7 \\
\hline
\end{tabular}

Igual tendencia muestra la evaluación de los servicios del gobierno local en el país. Resulta significativo que cuanto más se avanza en el proceso de descentralización nacional, mayor sea la insatisfacción de los ciudadanos con los servicios municipales. En 2012 la República Dominicana ocupaba junto con Perú el último lugar en satisfacción con los servicios de los gobiernos locales, con un $47,5 \%$ y un $46,9 \%$ respectivamente. Argentina por el contrario lideraba el porcentaje de ciudadanos satisfechos con el gobierno municipal con un $59,1 \%$.

Tabla 4.2.B.18 Evaluación de los servicios del gobierno local (\%) en República Dominicana

\begin{tabular}{|cccc|}
\hline $\mathbf{2 0 0 6}$ & $\mathbf{2 0 0 8}$ & $\mathbf{2 0 1 0}$ & $\mathbf{2 0 1 2}$ \\
\hline 57,7 & 56,9 & 48,8 & 47,5 \\
\hline
\end{tabular}

Con respecto a la eficacia interna o grado en que las personas se consideran competentes en política, en el año 2012 la mitad de los entrevistados (50,6\%) dijeron entender los asuntos más importantes del país, situándose en una posición intermedia en la región latinoamericana, donde Venezuela lidera con un 57,6\% y Paraguay ocupa la última posición $(38,8 \%)$. El análisis de regresión lineal realizado por LAPOP mostraba la relación estadísticamente significativa entre interés político, nivel de educación y edad (LAPOP 2012:78). A mayor nivel de estudios y mayor edad, aumentaba la compresión de los asuntos importantes del país.

La escasa confianza en las instituciones de la democracia representativa es la segunda dimensión actitudinal de la desafección democrática. La desafección política es el sentimiento subjetivo de impotencia, cinismo, falta de confianza en los políticos e instituciones democráticas que genera distanciamiento, alienación y falta de interés en la política y los asuntos públicos, pero que no pone el peligro ni cuestiona la legitimidad del régimen democrático (Torcal y Montero 2006). La República Dominicana se sitúa por debajo de la media regional en confianza en las instituciones de la representación, salvo en la valoración de la Junta Central Electoral, la iglesia católica y los medios de comunicación. Los partidos políticos y la policía son las instituciones peor valoradas en el país. Ambas han experimentado un declive aunque sin llegar a los niveles de 2004, siendo el año 2008 el punto de inflexión, donde todas las instituciones muestran el nivel más alto de confianza.

En ese año se celebra la contienda presidencial, en la que Leonel Fernández revalida su mandato con mayoría absoluta $-53,83 \%$ - el mayor porcentaje con el que un candidato alcanza la presidencia desde 1990. República Dominicana se situaba en 2012 en los últimos lugares en confianza hacia la policía, a 30,8 puntos de Chile, primero del listado y a 6 puntos de Honduras (LAPOP 2012:38). Las ejecuciones sumarias en alegados "intercambios de disparos" entre policías y supuestos delincuentes han sido práctica habitual y noticia en las últimas dos décadas. En 1999 murieron 250 personas a manos de la Policía, 171 en 2001, 437 en 2005 y 455 en 2008 según registran las estadísticas de la Procuraduría General de la República. 
Gráfico 4.2.B.14 Confianza en las instituciones en la República Dominicana, 2012

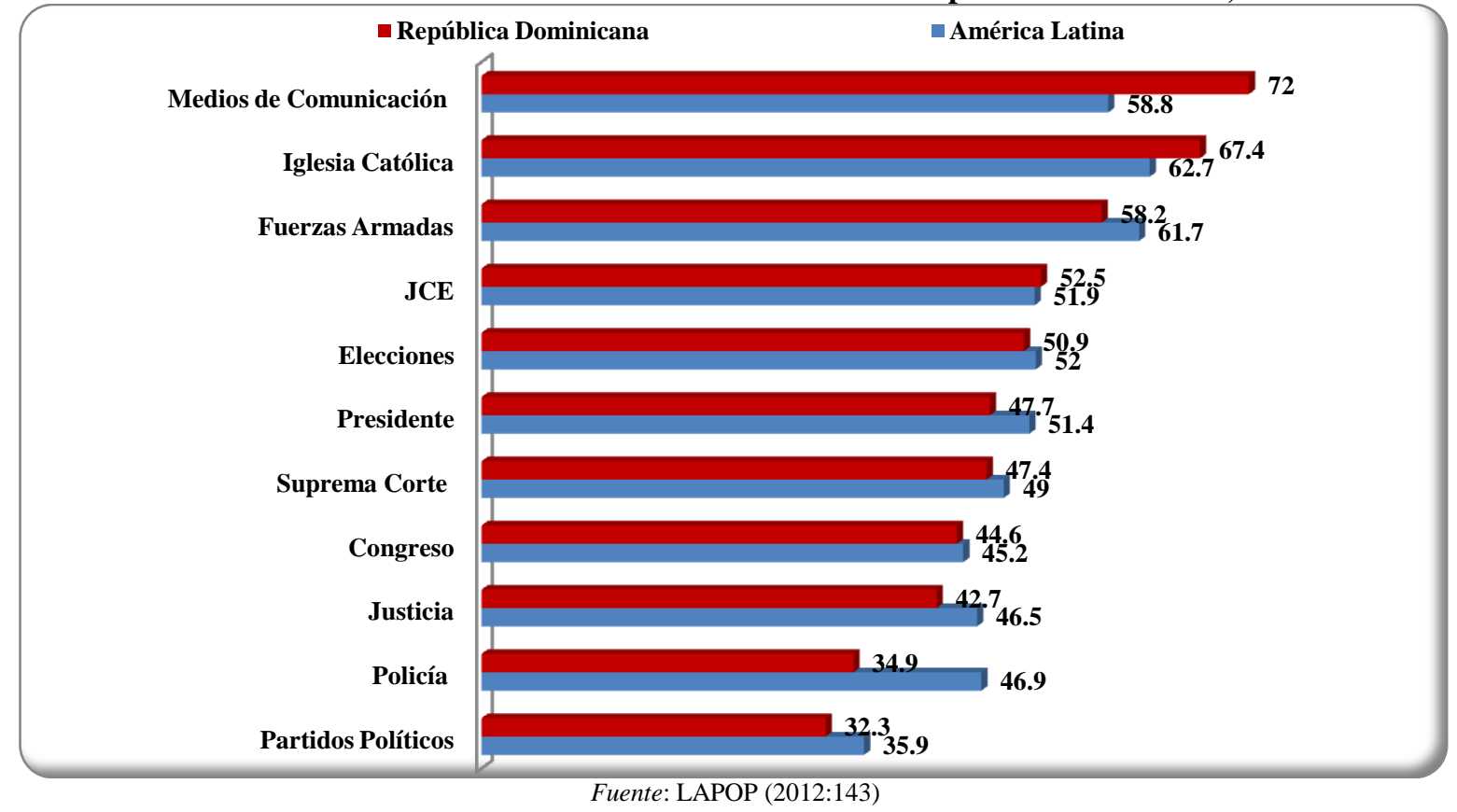

Gráfico 4.2.B.15 Confianza ciudadana en las instituciones en la República Dominicana (I), 2004-2012

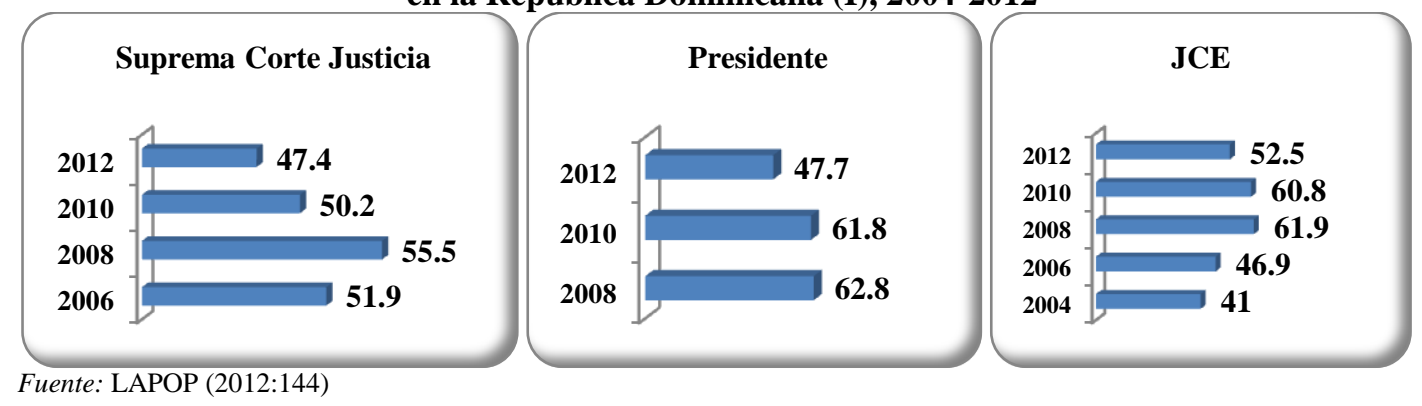

Le siguen en porcentaje el sistema de Justicia y el Congreso dominicano, instituciones en las que confía el 45,1\% y el 44,6\%. Nicaragua y Uruguay son los únicos países de la región latinoamericana donde la confianza supera el $50 \%$.

Gráfico 4.2.B.16 Confianza ciudadana en las instituciones en la República Dominicana (II), 2004-2012

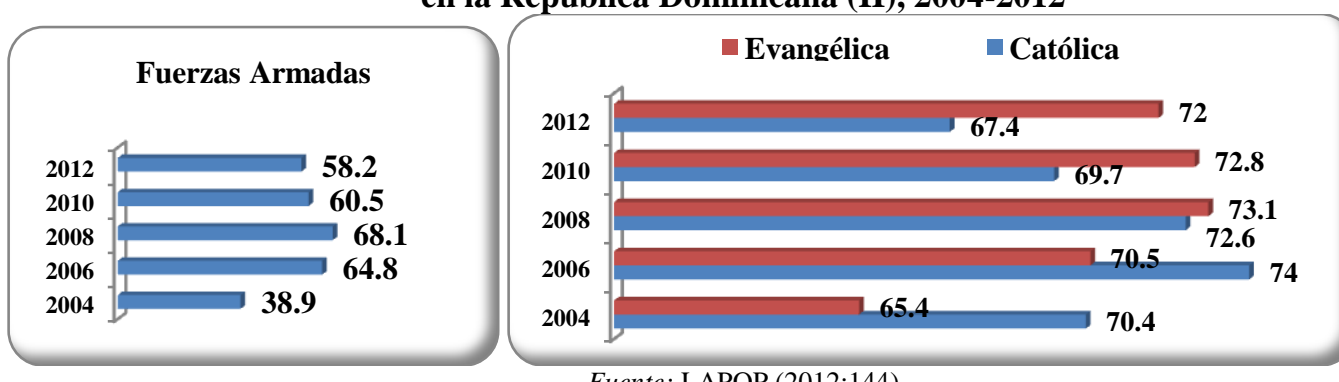

Fuente: LAPOP (2012:144) 
La Suprema Corte de Justicia y la figura del Presidente muestran también declive en los niveles de confianza a lo largo de los últimos seis años. El sistema de justicia fue objeto de reforma en la nueva Constitución de 2010. A pesar de los esfuerzos modernizadores, las mayores críticas se han centrado en el peligro de la politización de la justicia, dado el papel preponderante del Presidente en la designación de los miembros del Tribunal Constitucional, la Corte Suprema de Justicia y del Tribunal Superior Electoral. Esta tarea corresponde al Consejo Nacional de la Magistratura y tras la incorporación del Procurador General a su seno, confiere al Gobierno un peso político mayor del que disfrutaba antes de la reforma constitucional de 2010. El declive es más pronunciado a la hora de expresar la confianza en el Presidente Leonel Fernández, que pasa del 62,8\% al inicio de su gestión al 47,7\% con el que cierra el mandado. Además del natural desgaste en el decimosegundo año de mandato, podrían haber influido las críticas a su gestión por el gasto excesivo y denuncias de corrupción en su círculo de confianza ${ }^{279}$.

Las instituciones que cuentan con la aprobación de la mayoría de la población dominicana entrevistada son la Junta Electoral Central, las Fuerzas Armadas y las Iglesias. Con respecto a la Junta Central Electoral, destaca la recuperación de confianza que ha experimentado en la etapa de la transición de la democracia, tras épocas históricas en las que estuvo en el punto de mira por la complicidad en la manipulación y poca transparencia. Con respecto a las Fuerzas Armadas, se observa un repunte en la confianza desde 2004, año en el que la derrota del entonces presidente Hipólito Mejía, llegó a circular el rumor de que las tropas saldrían a la calle a defender una supuesta victoria. De nuevo, 2008 marca el punto de inflexión y descienden los niveles de confianza. Junto con la escasa confianza en los partidos, el relativo poco interés en la política que muestran los ciudadanos dominicanos contrasta con los altos niveles de simpatía partidaria en el país. El desinterés y desconfianza no se traducen en un distanciamiento de los dominicanos hacia los partidos políticos. Por el contrario, la República Dominicana encabeza la comparativa regional de ciudadanos latinoamericanos que manifiestan preferencias partidarias.

Tabla 4.2.B.19 Ningún interés en la política República Dominicana

\begin{tabular}{|l|cccc|}
\hline \multirow{2}{*}{ Ningún interés en la política } & $\mathbf{2 0 0 6}$ & $\mathbf{2 0 0 8}$ & $\mathbf{2 0 1 0}$ & $\mathbf{2 0 1 2}$ \\
\cline { 2 - 5 } & 59,42 & 51,18 & 52,95 & 49,07 \\
\hline \multicolumn{5}{c|}{ Fuente: LAPOP 2012 } \\
\hline
\end{tabular}

Tabla 4.2.B.20 Simpatía partidaria República Dominicana

\begin{tabular}{|l|cccc|}
\hline \multirow{2}{*}{ Simpatiza por un partido } & $\mathbf{2 0 0 6}$ & $\mathbf{2 0 0 8}$ & $\mathbf{2 0 1 0}$ & $\mathbf{2 0 1 2}$ \\
\cline { 2 - 5 } & 60,4 & 70,3 & 54,5 & 63,4 \\
\hline
\end{tabular}

Fuente: LAPOP (2012:198)

\footnotetext{
279 El Índice de Competitividad del Foro Económico Mundial 2011-12 coloca a la República en la posición 110 entre las 142 naciones evaluadas, con un descenso de 17 puestos desde el año 2007 en que el país ocupaba el puesto 93. Ocupa además la primera posición en "despilfarro en el gasto gubernamental y la segunda en favoritismo de los funcionarios del Gobierno y en desvíos de los fondos públicos.
} 
Gráfico 4.2.B.17 Simpatía partidaria América Latina, 2012

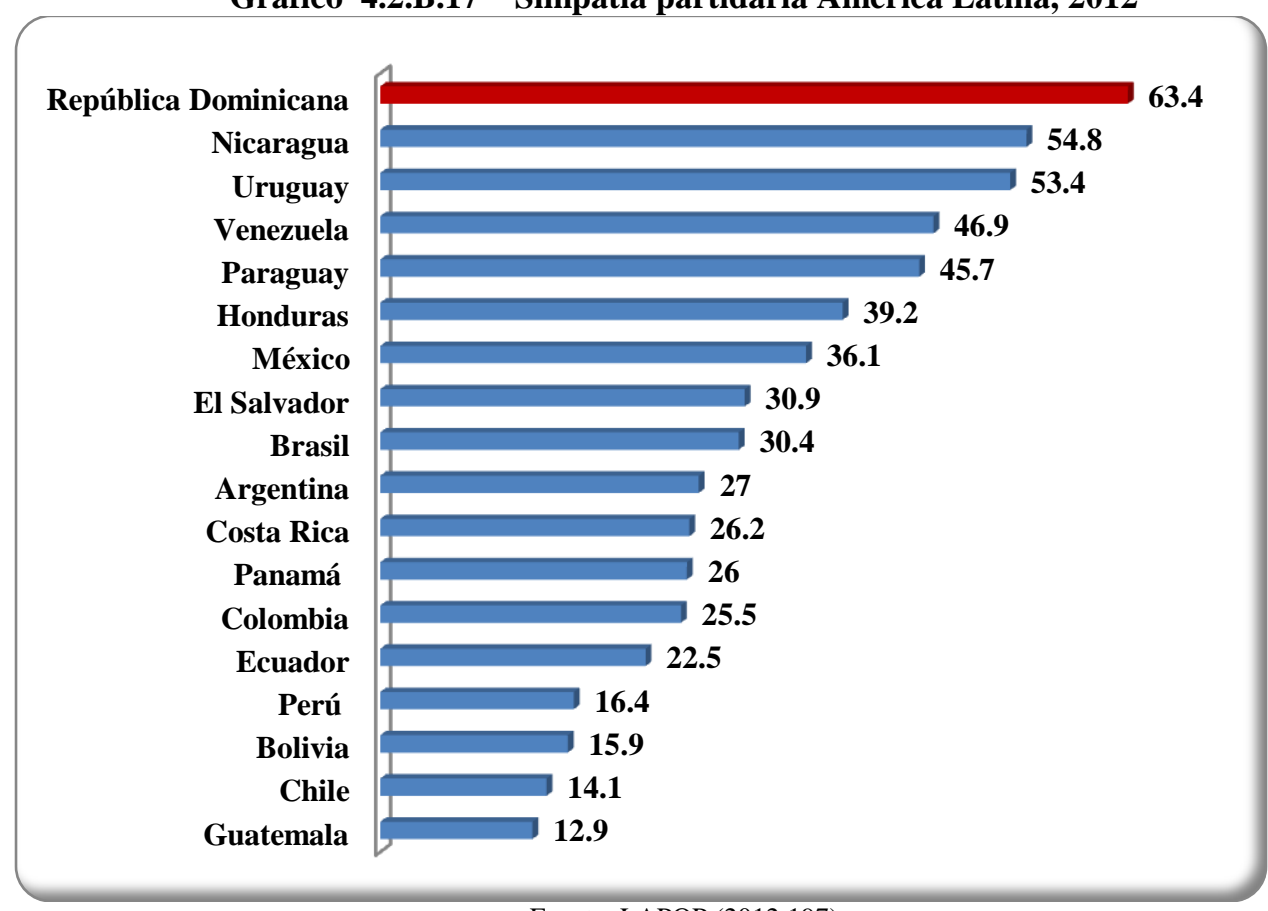

Fuente: LAPOP (2012:197)

La simpatía partidaria en estos últimos años se ha mantenido alta y con repuntes al alza en año electoral presidencial. El análisis de regresión logística mostraba que la ideología de derecha, ser empleado público y la mayor edad tenían una relación positiva con la simpatía partidaria (LAPOP 2012:199). Teniendo en cuenta que actualmente los seguidores del oficialista PLD son los que se ubican más a la derecha $(69,1)$ y que la administración pública está al servicio del partido gobernante de turno, se podría concluir que la identificación con un partido es reflejo de la reciprocidad y gratitud por la recompensa particularizada de acceso al patronazgo con la que han sido beneficiados. 


\subsection{RECAPITULACIÓN}

En las páginas previas se ha ofrecido una panorámica del entorno social y actitudinal que sirve de contexto a las relaciones del Estado con la Ciudadanía en la República Dominicana.

En el nivel macro relativo a la cultura organizacional, para mostrar que la infraestructura social que sustenta la democracia en el país es más proclive a la competición que a la cooperación colectiva, se da cuenta en primer lugar del poder negociador del empresariado frente al Estado. Las exenciones, subvenciones y regímenes especiales son ejemplo del "capitalismo coordinado" identificado por Kitschelt (2007), del poder negociador de las elites extractivas para evitar la redistribución (Acemoglu y Robinson 2006) y de la interconexión (Papakostas 2001) que boicotean la política universal desde la demanda.

En segundo lugar se justifica la docilidad del activismo civil dominicano en su dependencia de la subvención estatal, su carácter mutualista y el localismo de las reivindicaciones. Para confirmar que está envuelto en una relación con el Estado marcada por la competencia entre organizaciones para ser beneficiarias del asistencialismo particularista público, se presentan las transferencias directas a ONG's en los Presupuestos Formulados de la República Dominicana de los años 2005-2010 y las regalías de los diputados a las asociaciones de vecinos de los años 2008 y 2009, sobre las que no existe rendición de cuentas. La auditoría social ciudadana que emerge de las relaciones fronterizas entre Estado-Ciudadanía es sustituida en el país por la privatización de lo público. Y prueba de ello es que en 2010, las transferencias directas que el Ejecutivo reparte discrecionalmente a ONG's del sector salud, igualaban en cuantía al rubro aprobado en la Ley de Presupuestos para los servicios de emergencia nacionales, y por lo tanto, sometido a la fiscalización del control entre poderes.

Para cerrar el apartado dedicado a la cultura organizacional en la República Dominicana y su conexión con la extensión particular de los beneficios de la reivindicación desde el lado de la demanda, se dibuja el perfil histórico y actual del sindicalismo en el país. El análisis cualitativo muestra que la representación obrera nacional ha estado marcada por la cooptación política y las relaciones de interconexión, mientras que el análisis cuantitativo revela el progresivo proceso de fraccionamiento que diluye el interés de clase en un mar de sindicatos que compiten entre ellos. Con el predominio de la tipología del "sindicato de empresa" frente al de "rama de actividad", no hay espacio de oportunidad para la concertación social asociada a la representación laboral pero sí para la concertación particularizada. La nimia relación de pactos colectivos registrados ante la Secretaría de Estado de Trabajo refleja el escaso poder de negociación colectiva de los trabajadores en las empresas dominicanas y el rubro de las Transferencias Directas a ONG's del Ministerio de Trabajo en los presupuestos nacionales 2005-2012 la competencia entre trabajadores para ser agraciados con las regalías públicas. De nuevo, como sucediera para el caso de las asociaciones de vecinos, los sindicatos acuden al diputado de su provincia para que éste les sufrague las vicisitudes profesionales y de ocio de la organización.

En el nivel micro, las percepciones, actitudes y valores de los dominicanos en las encuestas de opinión publica DEMOS (1994-2004), LAPOP (2006-2012) y OBSEROP (2010) muestran una ciudadanía de bajo perfil, condescendiente con el nepotismo, organizada pero escasamente movilizada, que espera y pide, poco partidaria de los cambios radicales y fraccionada en clientelas que buscan la asistencia paternalista del líder. Se desconfía de los partidos pero se simpatiza con ellos y para ellos se trabaja en la campaña, porque es a través del vínculo partidario que se accede a las redes de patronazgo y a los bienes selectivos. El descontento y desafección institucional que muestran los datos, ejemplifican la combinación actitudinal identificada por Torcal (2006) en las nuevas democracias latinoamericanas, donde los desafectos demócratas son menos beligerantes en su relación con el Estado. 


\title{
CAPÍtUlO 5
}

\section{CONCLUSIONES}

\subsection{PRINCIPALES HALLAZGOS CONTRIBUCIÓN DEL ESTUDIO Y LÍNEAS FUTURAS DE INVESTIGACIÓN}

\begin{abstract}
¿Por qué el clientelismo funciona en democracia? A partir del caso dominicano, este trabajo ha examinado la política particularista como un modo racional de representación en condiciones de competencia electoral, desde el inicio de la consolidación democrática en 1996 hasta la actualidad.
\end{abstract}

En el Capítulo 1 se presentaron los elementos teóricos y metodológicos para el estudio de la política particularista que guían esta investigación:

En la conceptualización de la variable dependiente se utilizaron las definiciones instrumentalistas de Kitschelt y Wilkinson (2012) y Piattoni (2001) que conciben el particularismo como un modo de vinculación racional entre principal-agente y una estrategia política de ambos actores en el escenario de la democracia representativa. A partir de la clasificación de Corzo (2002) se reelaboraron las categorías distinguiendo las asignaciones selectivas de bienes realizadas por los agentes que ostentan un mandato de representación o designación en los tres escenarios: particularismo ejecutivo (programas focalizados), particularismo burocrático (empleos en la administración) y particularismo legislativo (derechos selectivos y favores personales). En la segunda parte del capítulo se presentó el marco teórico que sirve de referencia analítica a los interrogantes que plantea esta investigación y se expusieron las hipótesis planteadas por la literatura instrumentalista acerca de la incidencia de factores de la demanda y la oferta en la pervivencia del clientelismo. Para limitar el determinismo de la corriente culturalista/desarrollista en la demanda y la sobrestimación de las estructuras formales de los institucionalistas en la oferta, se abordó el análisis desde la triple dinámica relacional en la que se desenvuelve el comportamiento estratégico de políticos y ciudadanos.

En el Capítulo 2 se llevó a cabo el análisis empírico descriptivo de la Política Particularista en la República Dominicana:

En primer lugar, se presentó el repertorio de la acción particularista y se midió el fenómeno en los escenarios en que opera el Clientelismo Oficial. Esta investigación demostró que el asistencialismo particularista se ha impuesto en los últimos años al sistema de protección universal y que el patronazgo estatal prevalece frente a la profesionalización. El análisis de las partidas dedicadas a "asistencia social" y "seguridad social" en los Presupuestos nacionales (2006-2011) y el ritmo de 
incorporación de funcionarios al Sistema de Administración de Servicios Públicos (2010-2012) confirman la prevalencia en el país de este modo de responsiveness estratégica.

Para contextualizar los cambios y continuidades en el ejercicio particularista de la representación, se analizaron pormenorizadamente la naturaleza y fluctuaciones del fenómeno en la liza legislativa. En el escenario legislativo, los datos revelaron la particularización de la función normativa tanto en el contenido, promocionando intereses individuales y de tipo club (gremial y local), como en la forma, ya que la mayoría de las propuestas son elevadas a título individual y no por toda la bancada. La promoción de intereses parroquiales de los distritos y la nula fiscalización, apuntaría a una distribución de tareas que confirmaría en el país la antítesis del "secreto de la eficiencia" (Amorim Neto y Santos 2003) en la relación Legislativo-Ejecutivo que identificara Cox (1987) y la imposibilidad de concretar políticas públicas a nivel nacional en el Legislativo dominicano. En consecuencia, se reduce el campo de la acción legislativa a la micro política y la representación a un mar de particularismo que no pone en peligro la fluidez institucional ni el liderazgo nacional. Esta autonomía limitada de la que disfrutan los legisladores legitima el sistema a través de un modo de responsiveness focalizado que da continuidad al propio sistema. Atender a los electores del distrito prevalece sobre la abstracción, la impersonalidad y el largo plazo de tener un programa para ser reelecto diputado. Para ello, el legislador dominicano ejerce de mediador-conseguidor de derechos selectivos y favores personales con recursos públicos para los electores de su distrito cuyo crédito hace valer en la rendición de cuentas electoral.

El tratamiento estadístico de los datos muestra que la relación entre particularismo y partido político en la República Dominicana es estadísticamente significativa. Las legislaturas en las que el PRD contaba con la mayoría y dominaba el Ejecutivo, eran las más propensas a promover intereses particularistas. La legislatura 2006-2010 marca un punto de inflexión al alza en la representación del interés general en la Cámara de Diputados. Sin embargo, este cambio podría reflejar la predilección del oficialista PLD por otros escenarios e instrumentos como el asistencialismo selectivo a través del Ejecutivo o el patronazgo en la Administración. Teniendo en cuenta el peso de los partidos en la Cámara, el coeficiente de ponderación de la actividad propositiva particularizada evidenció el predominio del PRSC en la tramitación de beneficios selectivos para sus electores durante las tres legislaturas, seguido en los últimos años por el PRD.

Con respecto a la utilización del Fondo de Gestión Social o "barrilito" se observa una estrategia de asignación de bienes que premia a los leales con bienes selectivos y trata de persuadir a los opositores moderados con bienes de disfrute general en las tres fuerzas políticas. En este reparto no se aprecian diferencias significativas por partido aunque es el oficialista PLD el que cuenta con la mayor red de brókeres para realizar este tipo de asignaciones y es el que destina mayor número de regalías a bienes de club a colectivos determinados en la provincia con el nivel de empoderamiento socioeconómico más elevado. Esta diversificación confirma el patrón apuntado por Rosas y Hawkins (2008). La maximización de votos, la visibilidad de su mérito como gestor, la disponibilidad de recursos y el nivel de empoderamiento socioeconómico parecen influir en la decisión del diputado a la hora de elegir el nivel de inclusividad de las asignaciones en sus distritos.

La reciente medida adoptada por la Presidencia de la Cámara de retirar el "barrilito" a los diputados para ser repartido por este órgano administrativo a partir del año 2015, institucionaliza el papel de conseguidor del Presidente de la Cámara en detrimento de los legisladores de cada provincia. En consecuencia, se vislumbra el riesgo de que la asistencia social se tiña del color del partido oficialista de turno que controle este órgano legislativo. Esta medida disminuye el número de patronos, pero los clientes siguen compitiendo por conseguir la regalía pública, ya que los fondos del "barrilito" no se añadirán al rubro destinado a política social en los presupuestos nacionales. Por lo tanto, la medida profundiza la desmaterialización, empresarialización de la política social y desresponsabilización del Estado en el bienestar ciudadano, reconduciéndolo a un acto de 
voluntariado asistencial no sujeto a control de legalidad o justicia social (Adelantado y Scherer 2008:21). Esta decisión es ejemplo del poder de manipulación del agente para hacerse con el control oligopólico de los recursos del Estado y una de las formas a través de las cuales el clientelismo se adapta y pervive en diferentes contextos.

En la segunda parte del capítulo se presentó diagnóstico actual de la variable dependiente y su ubicación en el contexto mundial y regional con datos de encuestas de opinión de expertos, élites legislativas y ciudadanos. En 2009, el país lideraba junto con Senegal y Mongolia la comparativa en esfuerzos clientelares de los partidos, efectividad de la movilización y monitoreo de votantes. A nivel regional, el 75\% de los diputados dominicanos afirmaba en 2010 que la utilización de incentivos selectivos era muy importante para obtener votos frente al $45,7 \%$ de sus colegas salvadoreños y también en ese año, los dominicanos eran los latinoamericanos que más ofrecimientos de favores y beneficios recibían a cambio de votar a un candidato.

Tras el diagnóstico y medición de la VD, los capítulos explicativos de esta tesis evaluaron la triple dinámica relacional en la que se desenvuelve el comportamiento estratégico de los actores implicados en el intercambio. En ellos se explora el nexo causal de factores contextuales, institucionales y actitudinales que influyen en la elección de la estrategia particularista y condicionan la mayor o menor prevalencia del clientelismo en democracia:

En el Capítulo 3, dedicado las RELACIONES ESTADO-PARTIDO se presentó en primer lugar la hipótesis neoinstitucionalista del peso de las coyunturas históricas en la orientación de las políticas en el largo plazo. Esta investigación demostró que se confirma en el país la "Teoría de la Experiencia Crítica" que formulara Shefter (1994) para explicar la tendencia al patronazgo en los partidos de Estados Unidos y Europa del siglo XIX y XX. En la República Dominicana la democratización precedió a la burocratización, por lo que en ese momento fundacional clave en que se gesta la separación entre la política y el Estado, la burocracia dominicana quedó envuelta y se hizo porosa a las particularidades de la vida política. El desajuste de tiempos es un lastre que opera como punto de veto a la innovación institucional. Como muestra esta investigación, la resistencia de las agencias públicas a someter sus finanzas a la cuenta única del Tesoro, la duplicidad institucional, la demora a la aplicación efectiva del servicio civil de carrera o la ausencia de instancias colegiadas de diseño de políticas públicas, son mecanismos actuales de reproducción de los constreñimientos institucionales del pasado. En estas circunstancias, los procesos de reforma implementados en la etapa de la consolidación democrática podrían confirmar la amenaza del "potencial antidemocrático de la burocratización" en contextos neopatrimoniales identificado por Mancilla (1991:118).

Con respecto a la transición y segunda de las coyunturas históricas críticas, se argumentó que la naturaleza clientelar de los partidos políticos dominicanos no se explica en el bagaje social o en la herencia cultural de sus bases como defendía la teoría neoclásica de Epstein (1967), sino en la procedencia de sus élites. Tal como demuestra Shefter (1994), los partidos fundados por élites del régimen anterior tienden a estar orientados al patronazgo y a usar su acceso privilegiado a los recursos del Estado en la competencia política que se inicia con la apertura transicional. Así sucedió con el Partido Reformista Social Cristiano y su líder Joaquín Balaguer. Este partido -protagonista y mediador en la vida política dominicana desde 1963 hasta 1996- es el prototipo de partido "internamente movilizado" sin incentivos para acometer los procesos de elección social y organización bajo criterios programático ideológicos, que optó por movilizar a sus bases a través de vínculos personalizados y prebendalistas. 
En el apartado dedicado a las reglas que establecen cómo acceden los partidos a las instituciones del Estado, se examinaron aquellos aspectos del sistema electoral que favorecen el particularismo en la movilización y representación de intereses. La investigación revela que desde el establecimiento del voto preferencial en el año 2002, se ha incrementado el trabajo en solitario de los diputados dominicanos y en los tres tipos de Proyectos de Ley -representación individual, corporativa y general- la mayoría de las iniciativas son elevadas a trámite por un solo diputado. En el caso de aquellos proyectos en los que se promueven intereses que afectan a todos dominicanos, el 60,3\% son tramitadas a título individual, lo que revela que ni si quiera en los asuntos generales el consenso de la bancada del partido en la Cámara se impone al personalismo individualista. La opción de actuar en solitario se impone racionalmente, ya que la iniciativa de la bancada diluye el éxito de su gestión personal como agente, lo que le impediría reclamar crédito propio por la conquista del bien público. El restablecimiento en 2013 del voto preferencial por parte de los legisladores a pesar de su eliminación por la JCE en 2010, evidencia la resistencia de los actores a pasar de un modo de relación directo particularizado a uno indirecto donde prime la abstracción de la gestión del grupo parlamentario.

Con respecto al tamaño promedio de la magnitud de los distritos electorales en el país, éste se sitúa en el rango de las circunscripciones pequeñas $(3,70)$ y varía entre un mínimo de 2 representantes y un máximo de 8. Las circunscripciones con menor número de diputados son además las provincias más pobres del país, lo que confirmaría la tesis defendida por Guevara (2004) de que en ausencia de servicios básicos, la cercanía tiende a reproducir el prebendalismo en la relación del legislador con del electorado. Para probar el efecto de la magnitud del distrito sobre el particularismo de la representación y el personalismo en el trabajo legislativo, se analizaron los Proyectos de Ley de los 5 diputados de la circunscripción nacional electos en el periodo 2010-2016. Los datos reflejan que estos diputados nacionales no están apegados a los intereses parroquiales como el resto de sus colegas electos en la circunscripción provincial, ya que el $60 \%$ de sus iniciativas tienen un carácter general y ninguna de ellas beneficia a un particular en concreto. Además de la mayor inclusividad de su actividad propositiva, los diputados nacionales tienden a actuar menos en solitario que los diputados provinciales, aunque la ausencia de iniciativas de la bancada partidista refleja que siguen prefiriendo la visibilidad personal -aunque sea compartida- que la visibilidad partidista.

En cuanto a la fragmentación territorial, la creación de unidades municipales desde el inicio de la consolidación democrática en 1996 hasta la actualidad se ha incrementado en un $60 \%$ y apunta a la utilización del territorio como prebenda de movilización política. Los picos de creación de nuevos municipios durante estos quince años se ubican en periodos post electorales. No obstante, el mayor porcentaje corresponde al año 2004, cuando se crearon 48 unidades administrativas nuevas y cuyo nacimiento pudo estar motivado en servir de acicate en la reñida contienda presidencial entre Hipólito Mejía-PRD y Leonel Fernández-PLD. En este escenario, el focus distrital de los diputados dominicanos es la respuesta ante la imposibilidad y/o la falta de voluntad de ejercer las funciones de orientación de políticas y fiscalización del Poder Ejecutivo en la Cámara. De esta manera, el legislador dominicano se convierte en un eslabón más en la dinámica de constituency service en el país y en la que rivaliza con el gobernador, con el alcalde y con el presidente de la Liga Municipal.

Con respecto a otras características del sistema electoral como la desproporción, la doble vuelta y el umbral electoral, este trabajo muestra su influencia en la dinámica aliancista entre partidos. Las alianzas electorales amplían el foco de la representación agregando intereses diversos en una misma candidatura, pero en ausencia de competición programática, el partido mayoritario recompensa a sus aliados con intercambios directos particularizados que no ponen en peligro su control oligopólico del Estado. Ante las limitaciones del sistema electoral en el acceso de las fuerzas minoritarias a las instituciones de la representación -y que menoscaban la vocación pluralista de la 
democracia- los partidos minoritarios aliados aceptan ser relegados al escenario de la Administración Pública en una especie de contrato de "outsourcing de personal" por el que pueden seleccionar a su clientela y donde la tipología del "profesional camuflado" deviene necesaria para engrasar la maquinaria del partido clientelar. En esta tarea, como muestra la casuística, perviven los patrones neo patrimoniales y nepotistas que han caracterizado el ejercicio de la política en la República Dominicana ${ }^{280}$. Con respecto al financiamiento, el mayor coste de las campañas de los partidos clientelares ha incrementado la necesidad de acudir a recursos privados, de los que la legislación dominicana no obliga a detallar procedencia ni cuantía. Estas circunstancias fomentan la penetración de intereses particulares en la política dominicana, a los que habrá que compensar cuando se conquiste el poder. La debilidad de los organismos fiscalizadores nacionales ejemplifica el reto de la aplicación efectiva de los marcos regulatorios y sanciones por el uso indebido de fondos identificado por Gutiérrez y Zovatto (2011), así como el peligro de la progresiva imbricación de las redes corruptas y las redes clientelares que apuntara Máiz (2005) en los países de la tercera ola democratizadora.

Con respecto a quiénes son los intermediarios en las relaciones Estado-Partidos, esta investigación muestra que la falta de exclusividad dibuja un perfil del profesional político dominicano en el que predominan los patronos privados con funciones públicas. La satisfacción del bien común en los asuntos públicos dominicanos está en manos de profesionales camuflados (Panebianco 1982) y políticos semi amateurs (Straus 2002) que cuentan con cierta experiencia indirecta y suelen tener parientes en política, gracias a los cuales son ubicados en las redes de patronazgo de las agencias gubernamentales. En la República Dominicana el capital para lanzarse a la arena política procede principalmente de fuentes que fomentan el particularismo, como son el legado familiar y los recursos económicos propios. Por un lado, las redes familiares limitan el universo de los que acceden a la res pública impidiendo que las instituciones capturen la diversidad y generen cohesión social. Por otro, la compatibilidad con el ejercicio empresarial crea conflictos de interés en los que el agente puede particularizar el mandato institucional para que se acomode al suyo propio corporativo. Estos condicionantes reviven desde el lado de los actores el legado neopatrimonial en la articulación de las demandas, particularizando la participación como ya apuntara Hartlyn (1998) en el inicio de la etapa de la consolidación de la democracia.

La debilidad y disgregación de la formación política en el país incentiva el particularismo en la agregación de intereses y fomenta el grupismo partidario. Mientras que en el PRD la formación de los futuros cuadros se imparte en el Instituto de Formación Política Peña Gómez, en la Secretaría de Educación y en el Centro de Estudios de Políticas Públicas; en el PLD el Instituto de Formación Política Juan Bosch cohabita con FUNGLODE; y en el PRSC la Escuela Nacional de Formación Política, convive con el Centro de Análisis de Políticas Públicas.

El Índice de Expertise Institucional elaborado con las opiniones de los diputados dominicanos (1994-2010) del Proyecto Elites Parlamentarias Latinoamericanas (PELA) muestra que, contrario a las bondades anunciadas por los neoinstitucionalistas acerca de su responsabilidad en la calidad de la democracia, el paso por las instituciones de los legisladores dominicanos no ha extendido la inclusividad del mandato. El tratamiento estadístico de los datos muestra que el mayor grado de

\footnotetext{
${ }^{280}$ La gestión de la Lotería Nacional ha recaído en las últimas administraciones en manos del BIS como pago por su apoyo al PLD. Al frente de la institución estuvo Francisco Peña Guaba, hijo del histórico José Francisco Peña Gómez y presidente del BIS, y en 2012 pasó a manos de su hijo, Francisco Peña Tavárez, en lo que algunos analistas interpretaron como una estrategia de Leonel Fernández para conquistar de nuevo al presidente del BIS como aliado en las presidenciales de 2012. La Liga Municipal Dominicana ha sido un feudo del PRSC y del senador Amable Aristy. Obligado a renunciar por las sospechas de corrupción, dejó en 2010 su presidencia en manos de su primo Fidias Aristy.
} 
expertise afecta a la mayor atención concedida a los grupos de interés y a la extensión de sus redes familiares en política, pero no afianza el vínculo programático indirecto con el elector.

Puesto que el capital político del que disponen se engendra en las redes familiares, los recursos provienen de sus actividades empresariales y su popularidad deriva del trabajo asistencialista privado más que de la visibilidad de su compromiso político, el ejercicio de las funciones públicas queda enredado en círculos y lealtades superpuestas de confianza particularizada. En consecuencia, el ideal del mandato nacional no imperativo que han de representar los hombres/mujeres de Estado, se particulariza en manos de estos representantes del partido e incluso del gremio profesional al que pertenecen, tal como muestra el análisis cualitativo de esta investigación. Este sello particularista impide dar continuidad a las políticas públicas y generan un mar de políticas inconexas. El perfil empresarial de los diputados dominicanos de la legislatura 2010-2016, revela la potencial amenaza de actuaciones oportunistas asociada a la profesionalización de las comisiones legislativas que apuntara Krehbiel (2004). En este sentido, se confirma en el país la tesis de Acemoglu y Robinson (2006) sobre la cooptación de los espacios de la democracia para institucionalizar el particularismo por parte de las "élites extractivas". Estas élites acceden a las débiles instituciones de las democracias emergentes para hacerlas favorables a sus intereses. Así, los políticos, más que estimular y liderar los cambios en las instituciones para alcanzar la "felicidad pública" (Arendt 1963), perpetuán estratégicamente el statu quo.

La segunda de las relaciones en la que se desenvuelve el comportamiento estratégico de los actores son las RELACIONES PARTIDO-PARTIDO. Su estudio como variable explicativa del particularismo se aborda desde la corriente teórica que lo concibe como una cuestión de elección de los actores, lejos del determinismo del enfoque cultural y el de la modernización que sobredimensionaban las variables de la demanda. Aunque los políticos están constreñidos por las instituciones, son también capaces de sortearlas y redefinirlas (Piattoni 2001:18), por lo que ante circunstancias institucionales idénticas pueden encontrarse resultados variados. Los políticos conseguidores pueden alterar la estructura de incentivos para que la política particularista de racionalidad individual sea la más atractiva para los electores y la de menor coste en el corto plazo tal y como apuntara Dowding (1991). Como trata de evidenciar esta investigación, los actores son libres de elegir bajo qué criterios se establece el vínculo con los votantes y con otros actores del sistema en las relaciones de competición, de cooperación y de conflicto:

En las relaciones de competición del sistema de partidos de la República Dominicana, la debilidad de los mecanismos de agregación de intereses sociales a nivel colectivo (programa e ideología) y la identidad en torno a los principales valence issues, influyen en que el ejercicio de la función de representación sea más personalizada, cortoplacista y focalizada. En primer lugar, se expuso la debilidad de los condicionantes favorables de largo plazo identificados por Kitschelt, Hawkins y Zechmeinster (2010) para estructurar y mantener un sistema de partido programáticamente estructurado (SPPE). Como se relató en el trabajo, tras la bonanza económica de la Primera Guerra Mundial conocida como la "Danza de los Millones" (1918-1921), el país se sumió en una grave crisis a la que siguió el manejo sultanístico de la economía durante la dictadura de Trujillo (19301961). El escenario de oportunidad democrática también estuvo ausente, ya que desde 1930 hasta 1978 el único periodo con plenas garantías fue el breve gobierno de Juan Bosch (1963). Con respecto a las conquistas o bastiones políticos de naturaleza redistributiva, el modelo de ISI implementado ente 1968-1974 no produjo los resultados esperados en el proceso de proletarización de la fuerza laboral ni en la conformación de un interés de clase. El alto grado de informalidad del mercado laboral limitó las políticas de protección social orientándolas hacia modelos clientelares de auxilio. En cuanto a los condicionantes de corto plazo -aquellos en los que el papel de los actores resulta decisivo para establecer políticas redistributivas- esta investigación muestra que la voluntad 
de los actores no se ha orientado a afianzar el intercambio de votos por políticas, sino a potenciar la vinculación personal con el agente (voto preferencial) y a la implementación de programas selectivos focalizados a pesar del auge económico que ha experimentado el país en los últimos años, permitiría apostar por la universalización de las prestaciones públicas.

La valoración de la dimensionalidad del espacio ideológico, de la semántica izquierda-derecha, la cohesión ideológica de los partidos y de la representación sobre issues del Índice de Estructuración Programática (Kitschelt, Hawkins, Rosas y Zechmeinster 2010) muestra que no hay en el sistema de partidos dominicano elección social sino elección particular. Esta modalidad de unión entre candidato-votante que encajaría en la tipología de "vínculos partidarios no programáticos a nivel individual" en la clasificación de Luna (2007:418) es propia de partidos institucionalizados, ausencia de movilización en función de cleavages y nivel no colectivo de agregación de intereses. Como revelan las percepciones de los diputados dominicanos (PELA 1994-2010), la identidad en torno a los ejes neoliberalismo-estatismo y conservadurismo-progresismo lleva a que los partidos compitan entre ellos como suplidores de beneficios más generosos, confiables y mejores cumplidores de promesas particularizadas que sus oponentes. Las autoubicaciones ideológicas de los diputados dominicanos a lo largo de estos veinte años recogidas en el Proyecto Elites Parlamentarias Latinoamericanas (PELA) muestran la evolución hacia el centrismo, mientras que el Test de Anova revela que desde 2002 -año en que desaparecen los tres caudillos de la escena pública y se establece el voto preferencial- no existen diferencias significativas entre los tres principales partidos dominicanos. Las percepciones de los legisladores revelan también el focus distrital de la representación y la importancia de atender a los electores durante su mandato, lo que convierte a las unidades administrativas inferiores en objeto del intercambio entre actores y a la división territorial, en una prebenda al servicio de la movilización proselitista y del clientelismo de partido.

De aquella competencia programática débilmente estructurada de la época de los caudillos, el sistema ha evolucionado hacia el afianzamiento de la política clientelar en la etapa de la consolidación democrática post carismática. Sin embargo, en otros escenarios y con similares puntos de partida, un débil SPPE ha evolucionado hacia el "neosocialismo" (e.g. Venezuela, Bolivia) mientras que en escenarios con herencia de fuertes sistemas de partidos programáticamente estructurados, la competencia ha derivado en una de tipo "liberalismo social" (e.g. Chile, Costa Rica) (Kitschelt, Hawkins, Luna, Rosas y Zechmeister 2010:338). Como demostraron estos autores, corresponde a los partidos y sus actores principales afrontar el desafío de construir bastiones políticos redistributivos alrededor de los cuales edificar la competencia programática. Sin embargo, parece una tarea difícil en el país con resistencias desde la oferta y limitantes desde la demanda. Como reconocía un representante político entrevistado:

"Una de las grandes debilidades de los partidos en la República Dominicana es su pérdida de identidad (...) los partidos políticos hemos influido en que los dominicanos no podamos trascender el inmediatismo, trascender de lo personal a lo colectivo, los liderazgos no se desarrollan en base a proyectos de país, sino a proyectos personales, las aspiraciones colectivas fueron desplazadas por las individuales (...). La gente entiende que eres un buen líder en la medida en que resuelves sus problemas personales, no los problemas colectivos" (Benito y Rosales 2011:11).

El paso de un modo racional de relación directa en el que un grupo obtiene una gratificación inmediata -dinero, empleo, vivienda, trasferencias focalizadas, reglas favorables de regulación o contratos del Estado- a uno indirecto redistributivo en el que los costes se reparten entre las categorías abstractas de votantes, depende de las opciones estratégicas que enfrentan los políticos. En este sentido, se verifica en el país la premisa identificada por Kitschelt y Wilkinson (2012) 
acerca de las condiciones de oligopolio de la competición partidista, en la que una sola de las opciones de gobierno se hace con el control total de los recursos del Estado dominicano. Si en mercados oligopólicos las empresas generan perjuicios a los consumidores que se concretan en precios altos, baja calidad productiva y obstáculos a la entrada de nuevos oferentes, los partidos dominicanos con opciones de poder son partidos oligopólicos responsables de la baja calidad de la democracia dominicana (V-Dem 2014), con servicios caros e ineficientes como el de la luz ${ }^{281}$ o el transporte (Sánchez y Senderowitsch 2012) y que impiden la entrada a nuevos partidos, a quienes permiten solo el disfrute limitado del botín estatal. Atender a los electores del distrito prevalece sobre la abstracción, la impersonalidad y el largo plazo de tener un programa para ser reelecto diputado. Ello reduce el campo de la acción a la micro política y la representación a un mar de particularismo que no pone en peligro la fluidez institucional ni el liderazgo político nacional. Al contrario, esta autonomía limitada de la que disfrutan los actores legitima el sistema a través de un modo de accountability y responsiveness focalizado que da continuidad al propio sistema.

Con respecto a las decisiones de organización colectiva, este trabajo muestra que la maquinaria política descansa en una red estable pero altamente informal y flexible como el "sector externo" o las caramillas de los candidatos. Estos grupos autónomos de brókeres organizados piramidalmente son operadores políticos que dinamizan las débiles e ineficientes estructuras formales. Su funcionalidad, es ejemplo de la presencia de las "competing informal institution" (Helme y Levitsky 2004) en el sistema de partidos dominicano. Las estrategias de cartelización informal han dado continuidad al sistema de partidos y los nuevos actores han adaptado el vínculo particularizado al escenario de la consolidación democrática, de tal manera que el clientelismo como apuntara Piattoni (2001) para el contexto europeo, se hace resistente a través de la adaptabilidad.

En cuanto a las relaciones de cooperación "partido-partido" bajo la forma de alianzas, pactos y trashumancias, esta investigación demuestra que siguen un patrón particularista análoga a la relación "políticos-ciudadanos" en la que se fragua la representación en el país:

$\checkmark$ El reparto de las instituciones del Estado entre partidos prima frente a la definición de una agenda de Estado para el desarrollo nacional e institucional

$\checkmark$ El acceso a la red de patronazgo por parte del partido oficialista y sus aliados prevalece frente a la presentación al electorado de un paquete de políticas públicas consensuadas entre fuerzas aliadas

$\checkmark \quad$ En los cambios de partido de los tránsfugas se privilegia el puesto en la boleta electoral o el cargo directivo en la agencia pública en cada contienda sin compromiso con la organización de acogida, frente al realineamiento definitivo del sistema de partidos.

En todas estas acciones de cooperación interpartidaria, el consenso genera fluidez institucional inmediata pero a la larga se agudiza la debilidad institucional.

Una de las aportaciones de esta tesis es la presentación de un patrón de cooperación para catalogar la orientación universal o particular de la estrategia de colaboración entre actores políticos, distinguiendo el objetivo, los costes e incentivos en cada uno de los tres instrumentos utilizados. ¿Negociación para consensuar agendas políticas y de gobierno o compadrazgo en la transacción? En esta decisión, el papel de los políticos resulta fundamental para marcar la diferencia. Como muestra este trabajo, la peor solución colectiva emerge cuando en la racionalidad estratégica prima la opción utilitarista individual, tal y como describiera Olson (1965). Este trabajo aporta nuevos datos para la reflexión acerca de las formas que adopta la cooperación estratégica en contextos de debilidad institucional y laxitud del anclaje programático. La experiencia dominicana demuestra

\footnotetext{
${ }^{281}$ En 2008 la electricidad no estaba disponible el 20\% del tiempo y en 2012 se contabilizan una media de 25 apagones al mes según los datos de la Superintendencia de Electricidad de le Republica Dominicana.
} 
que la capacidad consociacional no siempre se pone al servicio de la gobernabilidad democrática, sino que puede reforzar el proceso de institucionalización perversa.

El aumento progresivo del respaldo electoral a los partidos aliados confirma la eficacia de esta modalidad de presidencialismo que comparte la gestión clientelar del Estado con sus aliados. Esta modalidad afecta al sistema de partidos, en el que proliferan los nuevos patronos pero no nuevas opciones partidistas con capacidad de ejercer la oposición. Los resultados electorales de 2012 reflejan la encrucijada que enfrentan los partidos clientelares en el poder: el aumento de las expectativas clientelares por un lado, impide al partido oficialista dar satisfacción a todas ellas y por otro, incrementa la distancia e intermediarios entre el patrón y los nuevos clientes. Estos nuevos clientes se insertan en un círculo de confianza más cerrado -el del partido minoritario aliado- con menor competencia entre clientes, lo que les permite estrechar lazos con un patrón más accesible y que cuenta con la autorización del patrón principal para acceder al botín del Estado. Pero no se comparte el gobierno, que sigue quedando en manos del partido mayoritario y donde el hiper presidencialismo informal minimiza las posiciones ministeriales. Dada la competitividad en condiciones de oligopolio en relación al dominio de los recursos públicos, los mismos partidos políticos serán los principales actores de veto al establecimiento del servicio civil y el principio de mérito. En 2008, un total de 23.179 funcionarios (SASP 2008) habían sido incorporados a la carrera, lo que supone apenas el 6,22\% del total de servidores públicos dominicanos de la administración central. A pesar de que la Ley de Función pública de 2008 ha supuesto avances en materia de estabilidad, la entrada sigue estando en manos de los partidos políticos. Otro ejemplo del poder de manipulación de los agentes es la preferencia por la vía más subjetiva de la valoración del desempeño frente al concurso en la estabilización de la carrera civil. Desde 2004 a 2012 solo 217 personas habían accedido a la carrera administrativa por concurso, lo que representaba el $0,04 \%$ del total.

El "Pacto por la Gobernabilidad y el Desarrollo Nacional y Local" de 2006 en el que se estipulan los criterios para repartir el botín estatal entre aliados, ejemplifica la vocación particularista de las élites dominicanas y resuelve el dilema que han de enfrentar: élites para el patronazgo o para la autonomía burocrática. En esta elección racional de los actores, los costes derivados de la cooperación estratégica de vocación particularista -pérdida de identidad partidaria, conflictos internos y voto de castigo por incumplimiento del mandato de representación- son menores a los beneficios aportados en el corto plazo, e incluso se tornan en ventajas en la carrera política. Con la cobertura judicial de la trashumancia en la República Dominicana las fuerzas mayoritarias aseguran su feudo, convirtiendo al resto de los partidos en fuente inagotable de futuros colegas al servicio del mejor postor en una interacción que asegura su dominio cartel del sistema. La decisión judicial que ordena reincorporar al partido a los que se fueron a otras fuerzas políticas, frena el proceso de realineamiento de las terceras fuerzas: su desaparición definitiva o su incorporación a otra fuerza partidista afín. De esta manera se estimula la división y el conflicto, un caldo de cultivo que favorece al partido que domine el arte de conquistar y premiar aliados (Benito y Toribio 2013). La pérdida de identidad partidaria retroalimenta el personalismo caudillista de las élites políticas dominicanas y les evita el coste de la institucionalización.

En cuanto a las relaciones de conflicto en la etapa de la consolidación democrática, el ejercicio del liderazgo en República Dominicana parece seguir la senda del personalismo y el compadrazgo de épocas pasadas. Las facciones son la maquinaria poco burocratizada pero altamente informal que acompaña a los jefes políticos y sus clientelas. El relato de las vicisitudes de las relaciones de conflicto en los partidos dominicanos desde la primera transición a la actualidad, muestra que la razón aglutinadora no es ideológica sino de carácter organizativo y de oportunismo electoral respondiendo a la tipología de facciones por interés (Sartori 1980) o client group factions (Beller y Belloni 1978). Entre jefes y dirigentes medios prima la lealtad instrumental típica de las 
relaciones patrón-cliente, en la que se intercambian bienes particularizados y selectivos a cambio de apoyo. El grupismo es la respuesta a las discrepancias internas: bicefalias carismáticas y lealtades instrumentales dominan hoy las relaciones de conflicto entre compañeros de partido. La arbitrariedad particularista de la élite política (favoritismo) se impone a criterios universalistas como el trabajo ideológico y en este escenario los lazos de interés (amigos de amigos) resultan clave para entrar en el círculo de confianza. De esta manera, la legitimidad clientelar del sistema político dominicano se reproduce al interior del partido y los políticos enfrentan las mismas decisiones estratégicas que los electores. En los tres principales partidos, la competencia entre facciones y la búsqueda de rentabilidad individual son origen de la mayoría de las desavenencias intrapartidarias en el PLD, PRD y PRSC. Siguiendo la clasificación de Boucek (2009) esta investigación muestra que dependiendo del escenario de oportunidad, las facciones de los tres partidos dominicanos cooperan o compiten, aunque solo el PRD parece entablar batallas degenerativas que sin embargo, no sentencian de muerte a la organización.

Como ya apuntara Geddes (1991), el faccionalismo obstaculiza la probabilidad de que se llevan a cabo reformas que introduzcan el principio de mérito en el acceso y permanencia en la Administración Pública, porque también para los jefes políticos el patronazgo es un arma para mantener y premiar la lealtad de sus sectarios. El monopolio de prebendas derivadas del ejercicio del poder ha reconvertido al Director, Jefe de Agencia Pública o Secretario Gubernamental, en el nuevo señor feudal o neocacique que reparte cargos entre compadres. Si los propios actores políticos son jugadores de veto en la promoción del servicio civil de carrera en el país -ya que la promesa de empleo público es una de las principales armas de movilización electoral- también lo son en el ámbito interno, donde las primarias resultan ser la manzana de la discordia partidista. Indicador de esta resistencia y veto es la declaración de inconstitucionalidad de la Ley 286-04 de Primarias Internas Obligatorias en 2005, bajo la argumentación de que los partidos son organizaciones privadas que tienen derecho a determinar libremente cómo seleccionar a sus candidatos $^{282}$. Y es que las elecciones internas abiertas o principio de mérito partidista, amenazan la competencia sesgada por la endogamia, la red clientelar y el compadrazgo (Hernández Valle 2002).

El uso neopatrimonialista de los recursos públicos y partidistas cual feudos privados por parte de los políticos dominicanos se asemeja al descrito por Boucek al referirse al Partido de la Democracia Cristiana Italiana en la década de los ochenta: « los líderes de las facciones hicieron del reparto del botín una habilidad artística exquisita (...) Se adjudicaron los contratos de las construcciones públicas, especialmente de la oficinas de correos y autopistas, y en otras agencias y corporaciones del Estado como las cajas de ahorros, donde los nombramientos de alto rango fueron hechos estrictamente según la afiliación a las facciones ${ }^{283}{ }$ (Boucek 2009:478). La escasez de recursos para la distribución pone a los patronos en una disyuntiva que exige creatividad. En el pasado, el histórico Francisco Peña Gómez optó por el popular "2x2” en el PRD: decisión salomónica por la que los candidatos a diputados de una circunscripción se repartían el escaño por períodos de tiempo (dos años un candidato y el resto de la legislatura el otro candidato). Hoy la tradicional renovación

${ }^{282}$ El recurso fue interpuesto por Julio Cesar Castaños, en representación de la Fundación Derecho y Democracia. Cercano al oficialista PLD, un año después de la sentencia fue nombrado presidente de la JCE (2006-2010), anteriormente fue Consultor Jurídico del Poder Ejecutivo (1994-1996) en la Administración de Balaguer y Secretario de Estado en el primer gobierno de Leonel Fernández (1996). Es hijo de Julio César Castaños Espaillat, sublíder reformista de los ochenta, un perfil que ejemplifica la ruta profesional de los "amigos de amigos". Ver sentencia de la Suprema Corte de Justicia Número 17 del 16 de marzo de 2005.

${ }^{283}$ En República Dominicana, uno de los casos más mediáticos fue el del Senador de San Juan de la Maguana Félix Bautista y Secretario de Organización del PLD. Siendo director de la Oficina de Ingenieros Supervisores de Obras del Estado (OISOE), adjudicó obras multimillonarias a empresas de su propiedad o de relacionados. Ver noticias en periódico digital Acento del 21 de marzo del 2012. 
de cargos mediante Decreto presidencial cada 27 de febrero (Día de la Independencia) y 16 de agosto (Día de la Restauración), ofrece una nueva posibilidad de alternarse en el acceso a los puestos públicos. Ambas son derivaciones autóctonas que se asemejan al viejo "sistema de turno pacífico" de la España de la Restauración del siglo XIX y época de esplendor de la política caciquil.

Este divisionismo dificulta el establecimiento de concepciones políticas unitarias o trabajo ideológico de los partidos y condiciona la actividad legislativa en diferentes aspectos:

$\checkmark$ La lucha faccional se traslada a las instituciones provocando impasses, como sucedió con el bloqueo perredeísta a las iniciativas propias en la década de los 80 's.

$\checkmark$ El mandato de representación nacional se supedita a las instrucciones de los jefes políticos a sus sectarios, lo que popularmente se conoce como "bajar línea".

$\checkmark$ Fomenta el personalismo legislativo en el trabajo parlamentario. Antes que colaborar con el compañero contrario, los diputados prefieren actuar en solitario. Como muestran los datos de esta investigación, la actividad propositiva de los diputados dominicanos se realiza de manera individual, siendo minoritario el porcentaje de proposiciones presentadas por la bancada o grupo.

El relato de las opciones de los actores políticos dominicanos en sus relaciones de competición, cooperación y conflicto reveló las estrategias adoptadas en las distintas coyunturas, demostrando que los líderes pueden hacer diferentes elecciones que afectan a las circunstancias del contexto y por lo tanto, pueden enfrentar o consolidar el clientelismo (Piattoni 2001:18). Se cierra así el apartado dedicado a los factores que determinan la política particularista desde la oferta que destacan el papel de los políticos en aprovechar los espacios de oportunidad que generan los booms económicos, las reformas institucionales o el acceso al gobierno.

El Capítulo 4 inaugura el análisis de los condicionantes de la demanda que inciden en la mayor prevalencia de la política particularista en democracia. En este capítulo se presentó el poder explicativo de las RELACIONES DEL ESTADO CON LA CIUDADANíA tercera de las relaciones consideradas en esta investigación- en la que se concibe el empoderamiento ciudadano y su capacidad de acción colectiva como réditos de las contingencias históricas que han modulado el engarce del Estado con sus ciudadanos (Papakostas 2001).

El balance tras el repaso histórico y actual de estas relaciones en la República Dominicana muestra un panorama marcado por la interconexión, la preferencia sesgada en el ejercicio de los derechos ciudadanos, la integración paternalista y la penetración de los intereses económicos. La estructura de la cooperación cívica en el país está inmersa en una relación con los actores políticos contaminada por la dependencia y subordinación que han limitado la efectividad de los resultados democráticos. Estos condicionantes han afectado a la demanda, restringiendo su poder de acción colectiva.

La historia colectiva del sistema político dominicano revela el predominio de los rasgos excluyentes y subordinados de su cultura organizacional. La relación del Estado con las rentas altas se ha caracterizado por un ejercicio de «generosidad clientelar» (Hopkin y Mastropaolo 2001) en la que los «clientes ricos pero pobres en votos» conquistan exenciones y subvenciones ${ }^{284}$. La permeabilidad de los intereses económicos y las particularidades de la vida civil en la gestión

\footnotetext{
${ }^{284}$ A pesar del déficit fiscal generado en la administración 2008-2012, una de las primeras medidas de la nueva administración fue decretar una amnistía a determinados sectores del pago del impuesto de la renta, sucesiones y propiedad inmobiliaria. Ver periódico Listín Diario de 16 de noviembre de 2012. En julio de 2012, en trámite de urgencia el Senado aprobaba el Presupuesto Complementario y la Ley de Emisión de Bonos para poder subsidiar una vez más a las empresas eléctricas.
} 
pública evidencian la porosidad de las fronteras entre el Estado y las clases dominantes. En el año 2011 el grueso de transferencias sociales en la Republica Dominicana representaba el 0,8\% del PIB nacional mientras que los subsidios a la electricidad -uno de los lobbies empresariales más importantes- alcanzaban el 1\% del $\mathrm{PIB}^{285}$. En el activismo civil, los menos afortunados se asocian buscando la protección mutualista de la organización y el favor público. Este carácter mutualista de las organizaciones sociales, su dependencia de la subvención estatal y la atomización de la acción civil, limitan la extensión de los beneficios de las luchas ciudadanas. La atomización de la voluntad popular desde el lado de la demanda favorece la respuesta pública particularizada desde el lado de la oferta («particularistic public regardeness»).

Como muestra esta investigación, el aparatado de "Transferencias directas a ONG's" en los Presupuestos Formulados (2005-2012) revela la competencia entre organizaciones de la sociedad civil por resultar agraciadas con la regalía presidencial, ya sea para la defensa de derechos colectivos o para la supervivencia y agasajo de la propia organización. También reveló su utilización proselitista, ya que se apreciaron fluctuaciones en las asignaciones que se corresponden con los años electorales así como la disgregación de intereses afines en múltiples asociaciones. De esta manera, la autoridad pública delega la acción universal de hacer política pública en múltiples actores particulares elegidos arbitrariamente y sobre los que no ejerce control alguno, ya que se trata de una asignación sobre la que no hay que rendir cuentas. Este modo de proceder, confirma en el país la amenaza de la desmaterialización y empresarialización de la política social que identificaran Adelantado y Scherer (2008) en América Latina. En la interlocución social -siempre con la mediación conservadora de la iglesia católica- algunas organizaciones asumen la representatividad de la totalidad del tejido asociativo dominicano, mientras que el liderazgo personalista y poco colaborador hace languidecer las instancias comunes de concertación en favor del protagonismo individual.

Con respecto a la concertación laboral en la República Dominicana, dista mucho de ser colectiva con la preeminencia actual del sindicato de empresa, que en 2010 representaba el 84,63\% del total de los sindicatos registrados en el país. En esta modalidad se sobredimensionan algunos sectores históricamente privilegiados y se reduce el escenario de la negociación colectiva a espacios insignificantes, ya que el tejido industrial dominicano está formado por micro, pequeñas y medianas empresas $^{286}$. El peligro de la atomización del movimiento obrero ya estaba en la mente de los constituyentes de 1963 durante el breve gobierno democrático de Juan Bosch, en el que se prohibió la existencia de más de un sindicato por rama de actividad. En el año 2011, en un escenario de 47.774 empresas dadas de alta en la Tesorería General de la Seguridad Social y más de un millar de sindicatos, solo se registraron 15 pactos colectivos, es decir el $0,03 \%$ del tejido empresarial. Hoy la multiplicidad sindical enfrenta a trabajadores de un mismo gremio y empresa.

Las acciones de las élites extractivas para atomizar los intereses de clase y el activismo civil generan múltiples agentes de la acción corporativa en todos los niveles de renta, por lo que no habrá acción colectiva ni concertación social, sino una de carácter sectorial corporativa. La acción corporativa y la confianza estratégica favorecen el ejercicio de accountability particularizado por parte de los múltiples actores cuya acción no busca beneficios sociales sino bienes de club o de socorro mutuo para sus asociados. Así lo muestran las concesiones de las regalías legislativas a asociaciones vecinales y sindicatos de los años 2008- 2009 que se presentaron en esta investigación y las "Transferencias directas a ONG's" del Ministerio de Trabajo en los Presupuestos nacionales (2005-2012). Estas últimas dejan ver que la selección de sindicatos beneficiarios es un acto de liberalidad en el que pueden primar criterios oportunistas y

\footnotetext{
${ }^{285}$ Dirección General de Presupuesto de la República Dominicana, DIGEPRES 2011.

${ }^{286}$ En 2011 el 98,2\% de las 44.774 empresas eran catalogadas como micro, pequeña y mediana empresa.
} 
clientelares. En escenarios de "industrialización sin desarrollo" (Chubb 1981) como el Dominicano, el clientelismo es la vía para mantener el control de las masas populares. El poder sectario de los sindicatos de transporte queda patente en su poder de negociación con el Estado ya que son el único colectivo profesional beneficiario de un programa de asistencia focalizado -el "Bono gas para choferes"- con la asignación mensual más alta de los siete que operan en la actualidad ${ }^{287}$.

Con respecto al capital social, las actitudes y percepciones de los dominicanos entrevistados por las encuestas DEMOS (1994-2004) y LAPOP (2006-2012), muestran una ciudadanía de bajo perfil, condescendiente con el nepotismo, organizada pero escasamente movilizada, que espera y pide, poco partidaria de los cambios radicales y fraccionada en clientelas que buscan asistencia. Como reflejan los datos de opinión, se desconfía de los partidos pero se simpatiza con ellos y se trabaja para ellos en campaña, porque es a través del vínculo partidario que se accede a las redes de patronazgo. El autoritarismo, las pasiones populistas y el sentimiento de protección que unen a políticos y electores, son muestra de la pervivencia de los rasgos de la cultura política parroquial en el país. La República Dominicana ocupaba en 2012 el primer lugar en la comparativa regional en porcentaje de entrevistados que apoyaban el populismo y mostraba preferencia por el hombre sobre la mujer en el mercado laboral y en la política. Son también los ciudadanos latinoamericanos que más trabajan en campaña para candidatos, aunque, dada la debilidad programática de las fuerzas políticas, no parece que sea para alcanzar victorias colectivas sino para ser beneficiarios de las asignaciones particulares públicas y pertenecer al círculo de confianza. El peso socializante del pasado impregna de carácter autoritario, sentimental y personalista la relación con el líder, mientras que la coparticipación civil y política contamina la relación haciéndola porosa a las particularidades del círculo de confianza, bien por amistad, bien por preferencia partidista. La escasa confianza en los actores e instituciones de la democracia y los bajos niveles de eficacia malogran las virtudes cívicas de un asociacionismo marcado por el tamiz religioso y conservador.

Todas estas vicisitudes revelan que son pocos los escenarios de oportunidad y limitadas las potencialidades desde la demanda para que el clientelismo deje de ser la forma predominante de relación de la ciudadanía organizada con el Estado.

Esta investigación ha tratado de explicar cómo y por qué asumen los costes e incentivos los actores dominicanos mostrando la importancia del entorno institucional en el que se relaciona el Estado con los Partidos, el entorno decisional de las relaciones Partido-Partido y del entorno social/actitudinal que modula las relaciones del Estado con la Ciudadanía. En determinadas circunstancias de estas interacciones bidireccionales de causalidad mutua florece el particularismo, pero su adaptabilidad o debilitamiento depende de la voluntad de las élites políticas. La experiencia dominicana evidencia que la pujanza económica y el arraigo de la democracia electoralista (legitimación de entrada) no transcurren por un sendero lineal que desemboca en la redistribución ni esculpe la representación política. Mientras el PIB per cápita crecía en la República Dominicana a un ritmo del $50 \%$ en el periodo $2000-2010$, solo el $2 \%$ de la población dominicana escaló a un grupo de mayor ingreso en esos años frente al 41\% del promedio latinoamericano (Báez y López-Calva 2014:6).

En esa misma década como ha tratado de evidenciar esta investigación, la legitimidad y estabilidad del sistema dominicano se asentaba en la eficiencia sub óptima clientelista. En países de renta media alta, el mayor coste de los bienes particularizados intercambiados tiende a obligar a los actores a incluir en su menú distributivo servicios públicos, manteniendo aquellos selectivos que maximizan sus opciones de poder. Sin embargo, en la República Dominicana se observa un patrón que comparte con otros países de la Región y que se caracteriza por la resistencia de la clase media a contribuir con los bienes públicos, optando por soluciones privadas a problemas colectivos

\footnotetext{
${ }^{287}$ Este colectivo recibe 80\$USD mensuales como beneficiarios del programa "Bono gas para choferes",
} mientras que las familias reciben 5\$USD mensuales del programa "Incentivo a la Asistencia Escolar". 
(Sánchez y Senderowitsch 2012; Ferreira et al 2012). Estos condicionantes apuntan a que el particularismo seguirá siendo el modelo de competición estratégica por el que opten los actores políticos en la República Dominicana.

Esta tesis doctoral sobre la persistencia y adaptabilidad de los vínculos racionales particularizados, aporta evidencia acerca de la instrumentalidad de la representación política en democracias emergentes. El cálculo estratégico de costes y beneficios que realizan los actores de la oferta y los de la demanda converge en la opción del bien individual, reforzando la exclusión y socavando la legitimación de salida que ha de acompañar al proceso de consolidación democrática (Nohlen 2004). El trabajo muestra que la construcción institucional convive en la República Dominicana con esa "otra institucionalización" (O’Donnell 1988) en que se desdibujan las fronteras entre lo público y lo privado y donde la irrelevancia de los mecanismos de accountability horizontal permite a la élite política seguir actuando bajo los mismos esquemas particularistas. 


\section{BIBLIOGRAFÍA}

ABRANCHES, Sergio H. (1988), "Presidencialismo de coalizao. O dilema institucional brasileiro". En Dados. Revista de Ciencias Sociais, Vol. 31, Núm. 1, pp.5-34.

ACEMOGLU, D. y Robinson, J (2006). The economic origins of democracy and dictatorship. Cambridge University Press.

ACEMOGLU, D. y Robinson, J (2012). Why nations fail. The origins of power, prosperity and poverty. New York: Crown Publisher.

ADELANTADO, José y SCHERER, Elenise (2008). "Desigualdad, Democracia y Políticas Sociales Focalizadas en América Latina". En Revista Chilena de Administración Pública, No 11 Junio, pp.117-134.

AECID-PNUD (2008). Consultoría para la elaboración de un diagnóstico sobre los mecanismos de formación de los partidos en República Dominicana y elaboración de una propuesta de mejora. Santo Domingo, Leticia Ruiz Rodríguez (Consultora). Proyecto No. 00061534.

ALBURQUERQUE, Rafael (1995). Manual de Derecho del trabajo: introducción, los sujetos del derecho del trabajo. Santo Domingo: Editora Lozano. Tomo I.

ALCÁNTARA, Manuel (2008): "The political competence of representatives in Latin America: an analysis of eleven national cases". Prepared for delivery at the Annual Meeting of the American Political Science.

ALCÁNTARA, Manuel (2012). El oficio de político. Madrid: Tecnos.

ALCÁNTARA, Manuel (2013). "De políticos y política: profesionalización y calidad en el ejercicio público". En Revista Perfiles Latinoamericanos, 41, Enero-Junio, pp. 19-44.

ALDRICH, J.(1995). Why Parties?. Chicago: University Press.

ALEMÁN, Eduardo y CALVO, Ernesto. (2006). "Analyzing Legislative Success in Latin America: The Case of Democratic Argentina". Working paper, pp.1-51.

ALMOND, Gabriel y VERBA, Sydney (1963). The Civic Culture: Political Attitudes and Democracy in Five Nations. Princeton, N. J.: Princeton University Press.

ALTMAN, David (2000), "Coalition formation and survival under multiparty presidential democracies in Latin America: between the tirany of electoral calendar, the irony of ideological polarization and inertial effects", Latin American Studies Association Congress, Miami, March 16-18.

AMES, Barry (1995) . "Electoral rules, constituency pressures, and pork barrel: Bases of voting in the Brazilian Congress". En Journal of Politics, Num. 57, (2), pp.324-343.

AMES, Barry (2000), "Disciplina partidaria en la legislatura brasileña", en Revista Política y Gobierno, vol. VII, núm. 1, primer semestre, pp.15-60.

AMORIM NETO, Octavio y SANTOS, Fabiano. (2003). "The Inefficient Secret Revisited: The Legislative Input and Output of Brazilian Deputies". Legislative Studies Quarterly, Vol. 28, No. 4, pp.449-479.

AMORIM, Neto y Cox, Gary (1997). "Electoral institutions, cleavage structures and the number of parties". En American Journal of Political Science, 41, Vol.1, pp.149-174.

AMORIN, Octavio (1998), "Cabinet formation in presidential regimes: an analysis of ten Latin American countries, Latin American Studies Association Congress, Chicago.

AMORIN, Octavio (2002), "Presidential cabinets, electoral cycles and coalition discipline in Brazil". En Legislative Politics in Latin America, eds. Morgenstern, Scott y Nacif, Benito. New York: Cambridge University Press.

AMORIN, Octavio (2006), Presidencialismo e gobernabilidades nas Americas. Rio de Janeiro, Editora FGV e Konrad Adenauer Stiffung. 
ANSOLABEHERE, Stephen y SNYDER, James (2003) "Party control of state government and the distribution of public expenditures", Scandinavian Journal of Economics, 108(4), pp.547569.

ARENDT, Hannah (1963). On Revolution. New York: Penguin Books.

ARENDT, Hannah (1997) ¿Qué es la política? Barcelona, Paidós.

ARROW, Kenneth J. (1951). Social Choice and Individual Values. New York: John Wiley \& S.

ARTILES, Leopoldo (2010) "Estado, sociedad civil y democracia en la República Dominicana". En La sociedad civil dominicana. Contribucion a su historia. ÁLVAREZ, LOZANO, PIETER, POLANCO y THEN (Coord.). Santo Domingo: MUDE.

ASUAD, M. (1985). La Externidad en Niños Dominicanos. Santo Domingo: Investigación INTEC.

AUDELO, Jorge (2004). "¿Qué es el clientelismo? Algunas claves para comprender la política en los países en vías de consolidación democrática". En Estudios Sociales, vol. 12, núm. 24, Hermosillo, pp. 124-142.

AUYERO, Javier (1997). ¿Favores por votos? Estudios sobre clientelismo político contemporáneo, Losada, Buenos Aires.

AUYERO, Javier (1999). "From the client's point of view: how poor people perceive an evaluate political clientelism". En Theory and Society, Núm.28, pp.297-334.

AXELROD, Robert (1970), Conflict of Interest. A theory of divergent goals with applications to politics. Chicago: Markham.

BÁEZ, E. y LÓPEZ-CALVA, Luis (2014). Cuando la prosperidad no es compartida. Los vínculos débiles entre crecimiento y equidad en la República Dominicana. Washington DC: Banco Mundial.

BANCO MUNDIAL. Estadísticas. En http://datos.bancomundial.org/

BANDFIELD, E.C (1958). The moral basis of backward society. Nueva York, Free Press.

BANEGAS, Richard (2011). "Clientelismo electoral y subjetivación política en África. Reflexiones a partir del caso de Benin". En Revista Desacatos, Mayo-Agosto, pp.33-48.

BARTLOW, John (1975) El destino dominicano: la crisis dominicana desde la caída de Trujillo hasta la guerra civil. Santo Domingo: Editora de Santo Domingo.

BELLER, Dennis y BELLONI, Frank (1978). "Party faction: Modes of Political Competition". En Faction Politics. Political Parties and Factionalism in Comparative Perspective, Santa Bárbara: BBC-Clio, pp. 417-450.

BENITO SÁNCHEZ, Ana Belén (2011). "La marea morada: elecciones congresuales y municipales de 2010 en la República Dominicana", en M. AlCÁNTARA y M.L. TAGinA (eds.), América Latina: Política y Elecciones en el Bicentenario (2009-2010). Madrid: Centro de Estudios Políticos y Constitucionales, pp.379-411.

BENITO SÁNCHEZ, Ana Belén (2014) "Política en femenino singular. La participación de las jóvenes políticas dominicanas en el Programa de Formación y Gerencia Política (20052012)". En CONTRERAS, Lourdes (Coord.). Miradas desencadenantes. Hacia una construcción de la autonomía de las mujeres. INTEC: Santo Domingo, pp. 369-386.

BENITO SÁNCHEZ, Ana Belén (2014)."Caciques y facciones en República Dominicana". En Revista Mexicana de Sociología, 76, Num.4. México: UNAM, pp.529-556.

BENITO SÁNCHEZ, Ana Belén and LOZANO, "Wilfredo (2012). "Clientelistic Stability and Institutional Fragility: The Political System in the Dominican Republic (1978-2010) ". Latin American Perspectives, Vol. 39 (6), November, pp.198-211.

BENITO SÁNCHEZ, Ana Belén (2012). "Expertise Institucional y Representación Política en la República Dominicana (1994-2010). En Revista Ciencia y Sociedad, Santo Domingo: INTEC, Vol. XXXVII, Núm.2, Abril- Junio, pp 198-226.

BENITO SÁNCHEZ, Ana Belén (2015). "Pactos, Alianzas Electorales y Trashumancias: Patrones de la cooperación estratégica en el sistema de partidos de la República Dominicana". En Revista Política y Gobierno. México: CIDE, Vol. XXII, No.1 (próxima publicación). 
BENITO SÁNCHEZ, Ana Belén y ROSALES, Rotsay (2011). "Marco normativo del sistema de partidos en República Dominicana: las reglas del juego interpartidario e intrapartidario". En PROGRAMA DE FORMACIÓN Y GERENCIA POLÍTICA (ed.), Diagnóstico sobre la situación del sistema de partidos en República Dominicana 2005-2010. Santo Domingo: USAID, IIDH-CAPEL, pp.13-31.

BENITO SÁNCHEZ, Ana Belén. y Toribio, Rafael. (2013), "Hegemonía de un líder y de un partido: Las elecciones de 2010 y 2012 en República Dominicana". En M. Alcántara y M.L. Tagina (coord.), Procesos Políticos Electorales en América Latina (2010-2013). Argentina: Editorial Eudeba, pp.281-315.

BENITO SÁNCHEZ, ANA BELÉN. (2010), "La política del poder: alianzas e interacciones partidistas estratégicas en República Dominicana", en Revista de Ciencia Política, Santiago de Chile: Universidad Católica de Chile, Vol.30, Núm. 3, pp. 751-772.

BERTINO, María Paula (2012). "La producción legislativa como variable dependiente. Apuntes para una agenda de investigación en América Latina". Trabajo presentado en el Cuarto Congreso Uruguayo de Ciencia Política, "La Ciencia Política desde el Sur", Asociación Uruguaya de Ciencia Política, 14-16 de noviembre de 2012, pp.1-26.

BICCHIERI, Ch. Y DUFFY, J. (1997). "Corruption cycles". En Political Studies, Num. XLV, pp.447-495.

BOIX, Carles y POSNER, Daniel (2000). "Capital social y Democracia”. En Revista Española de Ciencia Política, Vol.1 N².

BORCHERT, Jens (2003). "Professional politicians. Towards a comparative perspective. En Jens BORCHERT y Jurgen ZEISS (ed). The political class in advance democracies. A comparative handbook. Oxford University Press.

BOUCEK, Francoise (2009) "Rethinking factionalism: Typologies, Intra-Party Dynamics and Three Faces of Factionalism". En Party Politics, Vol.15, Núm. 4, pp. 455-485.

BREA, Ramonina, DUARTE, Isis y SELIGSON, Mitchelt. (2005). La democracia vulnerable: insatisfacción y desconfianza (1994-2004). Santo Domingo: PUCMyM, CUEPS, CESDEM.

BREA, Ramonina, DUARTE, Isis y TEJADA, Ramón (1998). La cultura política dominicana: entre el paternalismo y la participación. Santo Domingo: PUCMM: Proyecto para el Apoyo a Iniciativa Democráticas.

BRUSCO, Valeria, Marcelo NAZARENO y Susan STOKES, (2004). "Vote Buying in Argentina", en Latin American Research Review, vol. 39, núm. 2, pp. 66-88.

BUNKER, Kenneth y NAVIA, Patricio (2009) " Explicando la desproporcionalidad en América Latina: magnitud de distrito, malapportionment y fragmentación partidaria". Paper presented at 21st IPSA World Congress of Political Science "Global discontent? Dillemas of change", Santiago 2009.

BURNS, Nancy, Laura EVANS, Gerald GAM y Corrine Macconaughy (2004) "Pockets of expertise. Carrers and professionalism in $20^{\text {th }}$ century state legislators". Presentado en la Conferencia Anual de la American Political Science Association (APSA), Chicago.

CABEZAS, Lina M. (2012). Profesionalización de las elites legislativas en Bolivia, Ecuador y Perú. Tesis Doctoral, Universidad de Salamanca, España.

CAIN, B., FEREJOHN, J. FIORINA, M. (1987). The personal vote. Cambridge: Cambridge University Press.

CAMPBELL,J.K.,(1964). Honour,Family and Patronage:Study of Institutions and MoralValues in a Greek Mountain Community. oliOxford: Oxford University Press.

CAÑETE, Rosa y DOTEL, Olaya. (2007) Política social en República Dominicana 1930 al 2007 ¿Inclusión o Asistencialismo?Santo Domingo: Centro de Estudios Sociales Juan Montalvo.

CAREY, John (2009)" Ingeniería electoral ¿Qué nos muestran las investigaciones académicas sobre los efectos anticipados de las reformas electorales?. En Reforma del Sistema Electoral Chileno. Arturo FONTAINE, Cristián LARROULET, Jorge NAVARRETE e Ignacio 
WALKER (editores), Santiago: PNUD, CEP, Libertad y Desarrollo, Proyectamérica y Cieplan, pp. 233-244.

CAREY, John y SHUGART, Mattew (1995) «Incentives to cultivate a personal vote: a rank ordering of electoral formulas». En Revista Electoral Studies, Núm. 14, pp.417-439.

CASTELlANO, P. (1994), "Tránsfugas, trashumantes y travestis". En Diario 16, el 9-01-94.

CAZORLA, José (1992). "Del clientelismo tradicional al clientelismo de partido. Evolución y características". En Working Paper, Barcelona: Num. 55.

CELA, Jorge y PREDAZUELA, Isabel (2002). "Clasificación de las organizaciones de la sociedad civil en la República Dominicana. Descripción de sus características". En Programa de Fortalecimiento de las organizaciones de la sociedad civil. Santo Domingo: BID, OXFAM, INTEC.

CENDALES, Andrés (2012)"¿Son los pobres las únicas víctimas con la compra de votos? Un caso de competencia política con expropiación generalizada". En Revista Cuadernos de Economía, Vol.31, Núm. 56. pp.281-308.

CEPAL (2012). Panorama social de América Latina. Naciones Unidas.

CEPAL. Comisión Económica para America Latina y el Caribe. Estadísticas, en http://estadisticas.cepal.org/cepalstat/WEB_CEPALSTAT/Portada.asp

CHANTADA, Amparo (2010). "Los movimiento sociales urbanos en República Dominicana". En La Sociedad Civil Dominicana. Contribución a su historia. Santo Domingo. MUDE, CIESUNIBE.

CHASQUETTI, Daniel (1999), "Compartiendo el gobierno: multipartidismo y coaliciones en el Uruguay (1971-1997), En Revista Uruguaya de Ciencia Política, Núm. 10, Montevideo: FCU-ICP.

CHASQUETTI, Daniel (2001), "Democracia, multipartidismo y coaliciones en América Latina: evaluando la difícil combinación". En lanzaro, J. Tipos de Presidencialismo y Modos de Gobierno en América Latina. CLACSO.

CHEIBUB, PRZEWORSKI, A. y SAIEGH, S. (2004), "Government coalitions and legislative success under Presidentialism and Parliamentarism" En British Journal of Political Science Núm.34, pp.565-587.

CHUBB, J. (1981). "The social bases of an urban political machine: the case of Palermo". En Political Science Quartely, Num. 96, pp. 107-125.

CIDHLS (1994). Libertad sindical en República Dominicana. Santo Domingo, CTU.

CIPROS (1996). Centro para la promoción y la investigación social. En http://cipros.org.do/

COLEMAN, J. (1990). Foundations of social theory. Cambridge: Harvard University Press.

COLLADO, Faustino (2014). Estructuras del Estado Dominicano: Hacia una renovación pertinente. Santo Domingo: Oxfam-Participación Ciudadana.

COLLIER, Paul (2002). "Social capital and poverty. A microeconomic perspective". En Grotaert, C. y Bastelaer, T. The Role of Social Capital in Development. An Empirical Assessment. New York. Cambrigde University Press.

COLOMER, José M. (1990), El arte de la manipulación política. Barcelona: Anagrama.

COLOMER, Josep (2004). "Taming the tiger. Voting rights and political instability in Latin America" En Latin American Politics and Society, Num. 46, II, pp.29-58.

COMBES, Helene (2011), "¿Dónde estamos con el estudio del clientelismo?", En Revista Desacatos, no.36, México, mayo-agosto, pp. 13-32.

CORZO, Susana (2002)."El clientelismo político como intercambio". En Working Papers, núm. 206 Barcelona: Institut de Ciències Polítiques i Socials. pp. 1-66.

COSTA, D., KAHN, M. (2003). "Understanding the American Decline in Social Capital 19521998". Kyklos, 56 (1), 17-46.

COX, Gary (1997), Making votes count. Strategic coodination in the worlds electoral systems. Nueva York: Cambridge University Press. 
COX, Gary. (1987). The Efficient Secret: The Cabinet and the Development of Political Parties in Victorian England. Cambridge: Cambridge University Press.

COX, Pamela (2010), "América Latina: oportunidad de un crecimiento sostenido". En La Nación, Argentina, 28 de agosto.

CRESPO, Ismael (2009). "El ballotage en América Latina". En La Democracia en su contexto: un homenaje a Dieter Nohlen en su septuagésimo aniversario. REINOSO, José y SÁNCHEZ Herminio (Coord.). México : UNAM, pp. 157-172.

CUETO, Francisco (2011). "Financiación de los partidos políticos en República Dominicana". En Financiación de los Partidos Políticos en América Latina. GUTIERREZ, Pablo y ZOVATTO, Daniel (Ed.) México : UNAM, IDEA, pp. 483-503.

DAHL, Robert (1961). Who Governs? Democracy and Power in an American City. Yale Studies in Political Science.

DE LA CALLE, Luis (2005) "Carreteras y votos: el PSOE y las políticas territoriales de construcción de coaliciones de apoyo, 1982-1996"; RIPS, Vol. 4, Num. 1, pp.65-96.

DE LA CRUZ, Serafino (2010). Las protestas sociales en República Dominicana. Santo Domingo, FUNGLODE: OPD.

DE LA TORRE, Carlos: «¿Es el populismo la forma constitutiva de la democracia Latinoamericana?» en Julio AIBAR (ed.): Vox Populi. Populismo y democracia en Latinoamérica, Flacso, México, DF, 2007, pp. 55-83.

DEMOS (1994-2004). Encuesta sobre cultura política y democracia. Santo Domingo: PUCMMAID.

DIRECCIÓN GENERAL DE PRESUPUESTO, DIGREPRES

DOSEK, Tomas (2011). «¿Diferencia la izquierda y la derecha a los políticos de América Latina?. En Boletín PNUD \& Instituto de Iberoamérica, Universidad de Salamanca, Núm.3, Marzo 211.

DOWDING, K. (1994). "The compatibility of behaviouralism, rational choice and new institutionalism". En Journal of Theoretical Politics, Num. 6, pp.105-117.

DOWNS, Anthony (1957), An Economic Theory of Democracy, New York: Harper.

DOWNS, Antony (1957). "An economic theory of political action in Democracy". En Journal of Political Enonomy, Vol. 65, 2, pp.135-150.

DUVERGER, Maurice (1954). Los partidos políticos. México [2001]: Fondo de Cultura Económica.

EISENSTADT, Shmuel y LEMARCHAND, René (1981). Political Clientelism, Patronage and Development, Beverly Hills, Sage.

ELSTER, Jon (1986). Rational Choice. New York: NYU Press. En http://americo.usal.es/oir/Elites/PapersELITES/APSAEnglish.pdf

EPSTEIN, Leon (1967). Political parties in Western Democracies. New York: Praeger.

ESPINAL, Rosario (2006), Democracia Epiléptica en la Sociedad del Clic. Santo Domingo: Editora Clave.

ESPINAL, Rosario (2010), "Matemática del transfuguismo". En Hoy, de 30-03-2010.

ESPINAL, Rosario, MORGAN, J y HARTLYN, J. (2010). "Sociedad Civil y Poder Político en República Dominicana", en Revista América Latina Hoy, Salamanca: Instituto de Iberoamérica de la Universidad de Salamanca, Núm. 56, Diciembre.

ESPINAL, Rosario, MORGAN, Jana y SELIGSON, Mitchelt (2006). Cultura Política de la Democracia en República Dominicana. Vanderbilt University, LAPOP.

ESPINAL, Rosario, MORGAN, Jana y SELIGSON, Mitchelt (2008). Cultura Política de la Democracia. El impacto de la gobernabilidad. Vanderbilt University, LAPOP.

ESPINAL, Rosario, MORGAN, Jana y SELIGSON, Mitchelt (2010)Cultura Política de la . Democracia. Consolidación democrática en las Américas en tiempos difíficles. Vanderbilt University, LAPOP. 
ESPINAL, Rosario. Autoritarismo y democracia en la política dominicana. San José, Costa Rica: Instituto Interamericano de Derechos Humanos (IIDH), 1987.

EVERTSZ, Carlos (2011). Partidos políticos y movimiento popular en la República Dominicana. Santo Domingo: Betania.

FAXAS, Laura (2007). El mito roto: Sistema político y movimiento popular en la República Dominicana, 1961-1990. México: Siglo XXI, FUNGLODE y FLACSO.

FERNÁNDEZ, Beatriz (2012), Cultura política de las elites parlamentarias y agenda legislativa municipal en República Dominicana: El territorio como prebenda. Trabajo Final Procesos de Democratización en Centroamérica, Universidad de Costa Rica (inédito).

FERRARO, Agustín (2009). Reinventando el Estado. Por una administración pública democrática y profesional en Iberoamérica. Madrid: INAP.

FERREIRA, F., MESSINA, J., RIGOLINI, J. LÓPEZ-CALVA, L., LUGO, A. \& VAKIS, R. (2012). Economic mobility and the rise of the Latin American middle class. Washington, D.C.: World Bank.

FILGUEIRA, F. (1998). "El Nuevo Modelo de Prestaciones Sociales en América Latina: Residualismo y Ciudadanía Estratificada". En Ciudadanía y Política Social. San José: Costa Rica, FLACSO/SSRC, pp.71-116.

FIORINA, Morris y MOLL, Roger (1978). "Voters, bureaucrats and legislators. A rational choice perspective on the growth of bureaucracy. En Journal of Public Economics, num. 9, pp. 239-254.

FMI (2012). Fondo Monetario Internacional. Estadísticas, en http://www.imf.org/external/index.htm

FRANCO, Franklin (2006). Historia del Pueblo Dominicano. Santo Domingo. UASD. Colección Historia y Sociedad, No. 120.

FUKUYAMA, Francis (1995). Trust: The Social Virtues and the Creation of Prosperity, London, Hamish Hamilton.

FUNDACIÓN DEMUCA (2011) Índice de Percepción de la Autonomía Municipal en Centroamérica y República Dominicana. Costa Rica.

GALÍNDEZ, Jesús de (1956). Trujillo's Dominican Republic: A case study of Latin American Dictatorship. Phd. Columbia University.

GALLAGHER, Michael (1991). "Proportionality, disproportionality and electoral systems". En Electoral Studies, Num. 10, I, pp.33-51.

GAMBETTA, D. (1988). Trust: Making and breaking cooperative relations. Oxford and New York: Basil Blackwell.

GAMBOA, Ricardo y SALCEDO, Rodrigo (2009). "El Faccionalismo en el Partido Socialista de Chile (1900-2006). Características y efectos políticos en sus procesos de toma de decisión". En Revista de Ciencia Política, Vol. 29, Núm. 3, pp. 667-692.

GARCÍA Díez, Fátima (2001). "Reformas electorales y sistemas de partidos parlamentarios en América Central". En Revista América Latina Hoy, 27, pp. 37-65.

GARCÍA DÍEZ, Fátima (2008). "Sistemas Electorales". En Materiales Docentes, Departamento de Ciencia Política y de la Administración, Universidad de Salamanca.

GEDDES, Barbara (1991) "A Game Theoretic Model of Reform in Latin American Democracies"En The American Political Science Review, Vol. 85, No. 2 (Jun., 1991), pp. 371-392.

GEDDES, Barbara (1994). Politician's Dilemma. Berkeley: California University Press.

GLEIJESES, Piero (2011). La esperanza desgarrada. La rebelión dominicana de 1965 y la invasión norteamericana. Santo Domingo: Editorial Búho.

GONZÁLEZ ACOSTA, Edward (2009). The power of political parties. Political Participation, clientelism and remittances in the Dominican Republic. Tesis Doctoral, New School for Social Research. 
GONZÁLEZ, Fernán (2006), "El fenómeno político de Álvaro Uribe Vélez", En Instituto de Investigación y Debate sobre la Gobernanza, 18 de septiembre de 2006. En http://www.institut-gouvernance.org/es/analyse/fiche-analyse-245.html

GRAMSCI, A. (1970). Antología. Madrid, Siglo XXI.

GUERRING, John, KEEFER,Philip, MORRISON, Kevin y ONCEL, Erzen (2012). Global Leadership Project. Clinton Global Initiative at Boston University. http://www.globalleadershipproject.org/sites/default/files/GLP_Project_description_201208-12.pdf

GUEVARA, Carlos (2004). "Calidad de la representación política y tamaño de las circunscripciones electorales: una comparación de las asambleas panameñas de 1945 y 1999". En Revista de Ciencia Política, Santiago de Chile, Vol. XXIV, nº 2, pp.94 - 115.

GUNTHER, Richard y DIAMOND, Larry (2001), "Types and functions of parties", en Political Parties and Democracy, Jhons Hopkins Univesity Press, pp. 3-39.

GUTIÉRREZ, Pablo y ZOVATTO, Daniel (2011). "Balance regional: Financiamiento de los partidos políticos en América Latina". En Financiación de los Partidos Políticos en América Latina. GUTIERREZ, Pablo y ZOVATTO, Daniel (Ed.) México : UNAM, IDEA, pp.3-16.

HALL, P.; TAYLOR, R. (1996) "Political Science and the three new institucionalisms". En Political Studies, Vol.44, N. 5, Cambridge, pp.936-957.

HAMILTON y MADISON (1978) The Federalist. La Cámara de Representantes. El correo de Nueva York, 8-Febrero-1978.

HARTLYN, Jonathan (1995), "Crisis electoral (una vez más) y regresión autoritaria: un análisis de las elecciones de 1994 en la República Dominicana". En Alcántara, M. Límites de la consolidación democrática en América Latina. 1995. Salamanca: Ediciones Universidad. Pages 173-202.

HARTLYN, Jonathan (1998), "The Struggle for Democratic Politics in the Dominican Republic", The University of North Carolina Press.

HELMKE, Gretchen y LEVITSKY, Steve (2004) "Informal institutions and comparative politics: a research agenda". En Perspective on Politics, December, Vol.2, num. 4, pp.725-740.

HERNÁNDEZ VALLE, Rubén (2002). "La democracia interna de los partidos".En Hernández, M.P, (Coord) Partidos Políticos: democracia interna y financiamiento de precampañas. VII Congreso Iberoamericano de Derecho Constitucional, México.

HEVIA DE LA JARA, Felipe (2010). "Uso político de programas sociales y nuevos intermediarios institucionales: el Programa Progresa/Oportunidades en el sur de Veracruz". En Revista Desacatos, núm. 34, septiembre-diciembre, pp. 119-132.

HIRSCHMAN, Albert (1970). Exit, Voice and Loyalty: Responses to Decline in Firms, Organizations and States. Cambridge, MA: Harvard University Press.

HOPKIN y MASTROPAOLO (2001) "From patronage to clientelism: comparing the Italian and Spanish experiences". En Clientelism, Interests, and Democratic Representation: The European Experience in Historical and Comparative Perspective. Cambridge University Press, pp.152-171.

HOPKIN, Jonathan (2002), "The Emergence and Convergence of the Cartel Party: Parties, State, and Economy in Southern Europe", Paper, presented at the Conference of Europeanists, Chicago, 14-16 March 2002. Department of Political Science and International Studies, University of Birmingham.

HUNTINGTON, Samuel (1991) The third wave. Democratization in the late twenty century. Norman: University of Oklahoma Press.

HUNTINGTON, Samuel P. (1968). Political order in changing societies. New Haven, CT: Yale University Press. 
ICAP (2010). "Estadísticas de empleo público bajo el régimen de servicio civil", En Revista Centroamericana de Administración Pública. Costa Rica, (58-59), pp. 227-268.

IGRs (2012) Institutional and Governance Reviews. Banco Mundial.

IKENBERRY, G. (1994). "History's heavy hand. Institutions and the politics of the State", En New Perspectives on Institutions, University of Maryland, October, 1994.

IMMERGUT, Ellen (1992). Health Politics: Interests and Institutions in Western Europe. Cambrigde Studies in Comparative Politics.

INACIO, Magna y NUNO, Allan (2005), "Competicao política e estabilidades sob o Presidencialismo de Coalizao na América do Sul. En Teoría e Sociedade, número especial, Belo Horizonte, pp.12-45.

INDRIDASON, Indridi H. (2007). "Duration of Coalition Bargaining:The Impact of Particularistic Politics". Paper prepared for presentation at the 2007 Annual Meeting of the Midwest Political Science Association, London, UK.

INGLEHART, Ronald (1970). The Silent Revolution. Princeton University Press.

INGLEHART, Ronald (1997). Modernization and Postmodernization: Cultural, Economic, and Political Change in 43 Societies. Princeton.

JIMÉNEZ POLANCO, Jacqueline (1999), Los partidos políticos en la República Dominicana. Santo Domingo: Centenario.

KATZ, Jonathan y Brian, SALA (1996) "Carrerism, Committee Assignments and the Electoral Connection". En Revista American Political Science Review, Vol. 90, No.1, pp. 21-23.

KATZ, Richard y MAIR, Peter (2004), "El partido cartel. La transformación de los modelos de partidos y de la democracia de partidos". En Revista Zona Abierta, Madrid: Pablo Iglesias, Núm. 108, pp.9-39.

KIEWIET, D. Roderick,\& MCCUBBINS, MathewD. (1991). The logic of delegation. Chicago: University of Chicago Press.

KIRSCHHEIMER, Otto (1966), "The Transformation of the Western European Party Systems" in Joseph LAPALOMBARA \& Myron WEINER (eds.), Political Parties and Political Development, Princeton University Press.

KITSCHELT, Herbert (2000). "Linkages between citizens and politicians in democratic politics". En Comparative Political Studies, 33 (6-7), pp.845-879.

KITSCHELT, Herbert y KSELMAN, M. (2011), Organizational Extensiveness and Political Clientelism: The Formal and Informal 'Ties that Bind'. Disponible en: http://papers.ssrn.com/sol3/papers.cfm?abstract id=1671548

KITSCHELT, Herbert y Steven WILKINSON (2007). Patrons, Clients, and Policies. Patterns of Democratic Accountability and Political Competition, Cambridge University Press, Cambridge.

KITSCHELT, Herbert y WILKINSON, Steven (2007). Patrons, Clients and Policies. Cambridge University Press.

KITSCHELT, Herbert y WILKINSON, Steven (2012), "Vínculos entre ciudadanos y políticos: una introducción. En Documentos de Trabajo, Instituto de Iberoamérica: Universidad de Salamanca, Núm. 11.

KITSCHELT, Herbert, HAWKINS, Kirk, LUNA, Juan Pablo, ROSAS, Guillermo y ZECHMEISTER, Elizabeth (2010) Latin American Party System. Cambridge: Cambridge University Press.

KNIGHT, J. (1992). Institutions and social conflict. Cambridge University Press.

KREHBIEL, Keit (2004). "Legislative organization". En Journal of Economic Perspectives. Vol. 18, Num. 1, pp.113-128.

KRISHNA, Anirudh (2007). "Politics in the Middle: Mediating Relationships between Citizens and the State in Rural North India." En Herbert KITSCHELT and Steven WILKINSON, (eds) Patrons, Clients, and Politics. Cambridge: Cambridge University Press, pp.141-158. 
KUZNETS, S. (1955). "Economic growth and income inequality. En American Economic Review, Num. 45, pp.1-28.

LANDÉ, Carl (1977). "The dyadic basis of clientelism", en SCHMIDT, Steffen et al. (eds.): Friends, Followers and Factions: A Reader in Political Clientelism, Berkeley, University of California Press: xiii-xxxvii.

LAPOP. The Americas Barometer by the Latin American Public Opinion Project. http://www.lapopsurveys.org

LECA, Jean y SCHEMEIL, Yves (1983). "Clientelisme et patrimonialisme dans le monde arabe". En International Political Science Review Vol. 4, No. 4, pp. 455-494.

LEGER, Bethania, MATIAS, Domingo, MARTINEZ, Radames y QUEZADA, Tirsis (2002). "Dialogo nacional. Propuestas para la articulación Estado-Sociedad Civil". En Programa de Fortalecimiento de las organizaciones de la sociedad civil. Santo Domingo: BID, OXFAM, INTEC.

LEMARCHAND, R. y LEGG, K. (1972). "Political clientelism and development". En Comparative Politics, Vol. 4, pp.149-178.

LEVITSKY, Steven (2007) «From populism to clientelism? The transformation of labor-based party linkages in Latin American», en KITSCHETL, Herbert y WILKINSON, Steven(2007). (ed) Patrons, Clients and Policies. Patterns of Democratic Accountability and Political Competition. Cambridge University Press.

LIJPHART, Arend (1971). "Comparative politics and the comparative method". En American Political Science Review, Vol. 65, No. 3, pp. 682-693.

LIJPHART, Arend (1994). Electoral systems and party systems. A study of 27 Democracies, 19451990. Oxford: Oxford Universtiy Press.

LINZ, Juan (1978). El quiebre de los regímenes democráticos. Crisis, caída y reequilibrio. Hopkins University Press.

LINZ, Juan y STEPAN, Alfred (1996). Modern Nondemocratic Regimes, en Problems of Democratic Transition and Consolidation. Baltimore: Johns Hopkins University Press.

LINZ, Juan. (1990), “The perils of Presidentialism”. En Journal of Democracy, Núm.1, pp. 51-69.

LLAMAZARES, Iván (2008) "Economic trajectories, social inequalities and economic preferences among Latin American legislators". Paper prepared for the Annual Meeting of the American Political Science Association, Boston 2008.

LOOSEMORE, John y HANBY, Victor (1971). "The theoretical limits of maximum distortion. Some analytic expressions for electoral systems". En British Journal of Political Science, Num. 1, pp.467-477.

LORA, Quisqueya (2010). "Historia dominicana y sociedad civil, 1935-1978". En La Sociedad Civil Dominicana. Contribución a su historia. Santo Domingo. MUDE, CIES-UNIBE.

LOWI, T. J. (1964). "American business, public policy, case studies, and political theory". World Politics, num.16, pp.677-715.

LOZANO, Wilfredo (2004), Después de los caudillos: ensayos sobre política y sociedad en la República Dominicana contemporánea. Santo Domingo: Librería La Trinitaria.

LOZANO, Wilfredo (2010). "Sistema de partidos y cambio democrático: aproximaciones al caso dominicano", en Revista América Latina Hoy, Salamanca: Instituto de Iberoamérica de la Universidad de Salamanca, Núm. 56, Diciembre, pp. 15-36.

LOZANO, Wilfredo (2013). La razón democrática. Santo Domingo: Unibe.

LUCE, R.D y H. RAIFFA, H. (1957). Games and Decisions. Wiley, N. York.

LUNA, Juan Pablo (2007) "Representación política en América Latina: el estado de la cuestión y una propuesta de agenda", En Revista Política y Gobierno, México: CIDE, vol. 14, núm. 2, pp.391-435.

MADISON, James, HAMILTON, Alexander y JAY, John. [1787]. The Federalist Papers. Isaac Kramnick (ed), 1987. Harmondsworth: Penguin.

MAINWARING, Scott and SCULLY, Timothy (1995) Building democratic institutions: Party 
systems in Latin America. Stanford: Stanford University Press.

MAINWARING, Scott y TORCAL, Mariano (2005), "La institucionalización de los sistemas de partidos y la teoría del sistema partidista después de la tercera ola democratizadora". En Revista América Latina Hoy, diciembre, vol. 41, pp.141-173.

MAIR, Peter (1997). Party System Change: approaches and interpretations, Oxford University Press, Oxford.

MÁIZ, Ramón (2003), "Jama, caleta y camello: la corrupción como mecanismo de autorrefuerzo del clientelismo político". Revista Mexicana de Sociología, Año 65, I, pp. 3-39.

MÁIZ, Ramón (2005), “El clientelismo de partido y la corrupción política”. En MONTABES, Juan (Coord), Instituciones y Procesos Políticos.

MANCILLA, H.C.F (1991) "Neopatrimonialismo, elite de poder y expansión de la burocracia". En Revista Política y Sociedad. Madrid, Núm. 8, pp.113-124.

MANIN, B., A. PRZEWORSKI y S. STOKES (1999)."Introduction". En Democracy, Accountability and Representation, en A. PRZEWORSKI, S. STOKES y B. MANIN.(Comp.) Cambridge: Cambridge University Press.

MANZANILLO, Dennis (1999). "La sociedad civil y los partidos políticos", en Estudios Sociales, año XXXII, n. ${ }^{\circ} 117:$ 13-22.

MARCH, James y OLSEN, Johan (1984): "The New Institutionalism: Organizational Factors in Political Life", American Political Science Review, No 78. pp.734-745.

MARENGUI, Patricia y GARCIA, Mercedes (2006). "El rompecabezas de la representación: qué intereses defienden y cómo se comportan los legisladores latinoamericanos", en ALCÁNTARA, Manuel (ed), Políticos y Política en América Latina. Madrid: Siglo XXI, pp.29-82.

MARSTEINTREDET, Leiv (2004). Det demokratiske problem i den Dominikanske Republikk.. LatinAmerika. (2/juni), s 10- 11.

MARSTEINTREDET, Leiv (2004): Political institutions and their effect on democracy in the Dominican Republic: a critical assessment. Ph.D Dissertation, University of Bergen, Department of Comparative Politics.

MARSTEINTREDET, Leiv (2008), "Executive-Legislative Deadlocks in the Dominican Republic", en Latin American Politics and Society, 50 (2), pp. 131-160.

MARTINEZ ROSON, Mar (2006) "Carrera parlamentaria ¿La calidad importa?", En Políticos y Política en América Latina, Manuel ALCANTARA (ed). Madrid: Siglo XXI, pp. 91-125.

MARTÍNEZ, María Antonia. (2004) "La representación política y la calidad de la democracia". En Revista Mexicana de Sociología, año 66, núm. 4, octubre-diciembre, México, D. F., pp. 661-710.

MATEOS, Araceli (2013) " Selección de candidatos en la Republica Dominicana. El triunfo del clientelismo", en Selección de candidatos y elaboración de programas en los partidos políticos Latinoamericanos, En ALCANTARA, CABEZAS y SANCHEZ (ed). España: Tirant lo Blanch, pp.225-269.

MEDINA, Luis F. y STOCKES, Susan (2007). "Monopoly and monotoring: an approach to political clientelism". En Herbert KITSCHELT and Steven WILKINSON, (eds), Patrons, Clients, and Politics. Cambridge: Cambridge University Press, pp. 68-83.

MEJÍA ACOSTA, Andrés; PEREZ LIÑAN, Anibal; SAIEGH, Sebastián. (2006). "The Partisan Foundations of Legislative Particularism in Latin America". Working Paper, pp.1-32.

MELTZER, A. y RICHARD, S. (1981). "A rational theory of the size of government". En Journal of Political Economy. Vol. 89, núm. 5, pp.914-927.

MINISTERIO DE HACIENDA DE LA REPÚBLICA DOMINICANA. http://www.hacienda.gov.do/

MITCHELL, Ken (2010), "An institutional anomaly, longevity and competition in the Dominican Republic party system". En Revista The Latin Americanist, Shotheastern Council on Latin American Studies and Wiley Periodicals, Inc, September, pp. 53-74. 
MITCHELL, Kenneth (2009)"Democratisation, external exposure and state food distribution in The Dominican Republic". En Bulletin of Latin American Research, Vol. 28, No.2, pp.204-226.

MOE (2012). Informe verbal de la Misión de Observación Electoral en la República Dominicana Elecciones Ordinarias Generales Presidenciales y Vicepresidenciales y de Diputadas y Diputados de Ultramar del 20 de mayo de 2012. Organización de Estados Americanos (OEA) Disponible en http://acento.com.do/wp-content/uploads/InformeVerbal2012.pdf

MOLINA, J. Enrique (2009). Personalización radical de la política y nivel de institucionalización del sistema de partidos en la Región Andina. Causas y consecuencias. Trabajo preparado para el III Congreso Internacional de Estudios Electorales. Salamanca, España, del 28 al 30 de octubre.

MORENO LUZON, Javier (1995) "Teoría del clientelismo y estudio de la política caciquil". En Revista de Estudios Políticos (Nueva Época) Núm. 89. Julio-Septiembre, pp.191-224.

MORENO, Guillermo (2008), Alianza. Una propuesta de país. Santo Domingo: Búho.

MORGAN, Jana; HARTLYN, Jonathan y ESPINAL, Rosario, (2008). "Party System Institutionalization in the Dominican Republic: Ideology, Ethnicity and Migration." Trabajo presentado en el Annual Meeting of the American Political Science Association, 28-31 de Agosto, 2008. Aproximacion historica institucionalista

MORLINO, Leonardo (2005): Democracias y democratizaciones, México, Cepcom.

MOYA PONS, Frank (2008) Manual de Historia de la Republica Dominicana. Santo Domingo: Editorial Búho.

MULLER, W. y STROM, K. (2003), Coalitions governments in Western Europe. Oxford: Comparative Politics.

MUÑOZ, Juan Manuel (2011), "Cambio en el sistema electoral y personalismo de los diputados hondureños", En Boletín Datos de Opinión, Elites Parlamentarias Latinoamericanas, Universidad de Salamanca, núm. 30, octubre.

NITCHER, Simón (2008) "Vote buying or tornout buying? Machine politics and the secret ballot". En American Political Science Review, Volume 102, Issue 01, pp 19-31.

NOHLEN, Dieter (2004). Justicia electoral y consolidación Democrática. Conferencia Magistral pronunciada el 16 de octubre de 2004 en la clausura del II. Congreso Iberoamericano de Justicia Electoral, en Acapulco, México.

NOHLEN, Dieter (2004). Sistemas Electorales y Partidos Políticos. Tercera Edición. México, D.F.: Fondo de Cultura Económica.

NORRIS, Pipa (1997) Passages to power. Legislative recruitment in advanced democracies. Cambridge: Cambridge University Press.

NOUZELIS, N. (1985) " On the concept of populism. Populist and clientelist modes of incorporation in semiperipheral societies". En Politics and Society, Num. 14 (3), pp. 329348.

O`DONNELL, Guillermo (1992), "Delegative Democracy?", WP, Kellogg Institute, Núm. 172.

O’DONNELL, Guillermo (1988): "Transições, continuidades e alguns paradoxos" en F. Wanderley y G. O’Donnell (eds.), A Democracia no Brasil e Perspectivas. São Paulo: Vértice.

O’DONNELL, Guillermo (1997). Contrapuntos: ensayos escogidos sobre autoritarismo y democratización, Buenos Aires.

OBSEROP (2010), Primera Encuesta de Opinión Pública y Comportamiento Político, En, Proyecto de Apoyo al Proceso de Modernización del Sistema de Partidos Políticos en República Dominicana, AECID-PNUD, Mariano Tocal (dir).

ODH-PNUD (2010).La política social. Capacidades y Derechos. Santo Domingo: ODH-PNUD.

OECD. Organización para la Cooperacion y el Desarrollo Económico. Estadísticas en línea. En http://www.ocde.org

OIT (2014), Organización Internacional del Trabajo. Estadísticas en línea. http://www.ilo.org/global/statistics-and-databases/lang--es/index.htm 
OLIVARES, Frank Elías (2013) "Conceptos Jurídicos de la Organización Administrativa en la República Dominicana". Tesis Maestría en Administración Pública. Santo Domingo: FUNGLODE, USAL.

OLSON, Mancur (1965), Logic of collective action. Cambridge: Harvard University Press.

OMLAD. Observatorio del Mercado Laboral Dominicano. En http://www.omlad.gob.do/

OMS (2014). Organización Mundial de la Salud, Datos y Estadísticas http://www.who.int/research/es/

ONAPLAN (2011). Oficina Nacional de Planificación de la República Dominicana. Estadísticas, en http://www.onaplan.gov.do/new_site/Inicio.html

ONE. Oficina Nacional de Estadística de la República Dominicana. En http://www.one.gob.do/

ONU-Habitat - United Nations Human Settlements Programme. En www.unhabitat.org

OSTROM, E. (1990). Governing the commons: the evolution of institutions of collective action, Cambridge University Press.

OVIEDO, José (2005). "La reforma en la macroestructura del Estado: retos fundamentales". En Mesas de búsqueda de consenso para la implementación de la ley de servicio civil. Santo Domingo: Participación Ciudadana.

OVIEDO, Jose y ESPINAL, Rosario (1986). Democracia y proyecto socialdemócrata en República Dominicana. Santo Domingo, Taller.

PACTO INTERPARTIDARIO ENTRE EL PLD, PRD Y PRSC Por la Gobernabilidad y el Desarrollo Local y Nacional. Santo Domingo, 11 de agosto del 2006.

PANEBIANCO, Ángelo (1982). Modelos de partido. Madrid: Alianza Editorial.

PAPADOPOULOS, Yannis y VANNER, Semih (1995). "Les transformations du clientélisme de parti en Europe du Sud", Cahiers d'Etudes sur la Méditerranée Orientale et le monde Turco-Iranien. En URL: http://cemoti.revues.org/235 [Consultado el 28 de Agosto de 2014].

PAPAKOSTAS, Apostolis (2001). "Why is there no clientelism in Scandinavia? A comparison of Swedish and Greek sequence of development. En Clientelism, Interests, and Democratic Representation: The European Experience in Historical and Comparative Perspective. Cambridge University Press, pp.31-53.

PARTICIPACIÓN CIUDADANA (2005). Estructura y Funcionamiento de la Administración Pública. Manual de capacitación. Programa de Transparencia de la Gestión Pública. Santo Domingo: Participación Ciudadana.

PARTICIPACION CIUDADANA (2012). Niveles de Disparidad en los Salarios en la Administración Pública, Participación Ciudadana. Santo Domingo.

PELA. Manuel Alcántara (dir.) Proyecto Élites Parlamentarias. Universidad de Salamanca. (19942014).

PÉREZ, Omar (2012), "Los aliados en el gobierno de Medina". En Observatorio Político Dominicano, FUNGLODE. En http://www.opd.org.do/

PÉREZ, Omar (2013). "Sistema Electoral y voto preferencial en la Republica Dominicana. En Observatorio de Partidos Dominicano (OPD), Unidad de partidos Políticos. FUNGLODE.

En http://www.opd.org.do/index.php?option=com_content\&view=article\&id=1309:sistem a-electoral-y-voto-preferencial-en-republica-dominicana-\&catid=70:analisis-p

PETERS, Guy (2003), El nuevo institucionalismo: la teoría institucional en ciencia política Barcelona, Gedisa

PIATTONI, S. (2001). Clientelism, Interests, and Democratic Representation: The European Experience in Historical and Comparative Perspective. Cambridge University Press.

PITKIN, H. (1985) [1967]. El concepto de representación política. Madrid: Centro de Estudios Constitucionales.

PITT-RIVERS, J. (1971). Un pueblo de la sierra: Grazalema. Madrid: Alianza Editorial.

PNUD (2008). Informe sobre Desarrollo Humano en República Dominicana. Santo Domingo. 
PNUD (2010). Informe sobre Desarrollo Humano en República Dominicana. Santo Domingo.

PRZEWORSKI, Adam (1985). Capitalism and Social Democracy. New York: Cambridge University Press.

PUTNAM, Robert (1994): Making Democracy Work. Civic traditions in modern Italy. Princeton University.

PUTNAM, Robert (1995). Bowling Alone: America's Declining Social Capital. Journal of Democracy, vol. 6, n. ${ }^{\circ}$ 1: 65-78.

PUTNAM, Robert (2002). Democracies in Flux: The Evolution of Social Capital in Contemporary Society. New York: Oxford University Press.

PUTNAM, Robert.(1993). Making Democracy Work: Civic Traditions in Modern Italy. Princeton: Princeton University Press.

QUEZADA, Tirsis (2002). "Las relaciones Estado-Sociedad Civil en la República Dominicana". En Programa de fortalecimiento de las organizaciones de la sociedad civil. Santo Domingo: BID, OXFAM, INTEC.

RAMIREZ, Adriana (2010), El sistema de partidos multinivel en estados unitarios: un estudio de la competencia electoral en República Dominicana (1978-2010), Trabajo Fin de Máster en Ciencia Política, Universidad de Salamanca (inédito).

RANDALL, Vicki. (1988). Political parties in the Third World. London: Sage.

REYNOSO, Diego (2011), "Aprendiendo a competir. Alianzas electorales y margen de victoria en los estados mexicanos, 1988-2006". En Revista Política y Gobierno, México: Vol. XVIII, Núm. 1, pp. 3-38.

ROCHA , Alina (2001). "Do Old Habits Die Hard? A Statistical Exploration of the Politicisaction of Progresa, Mexico's Latest Federal Poverty-Alleviation Programme, under the Zedillo Administration", En Journal of Latin American Studies, vol. 33, pp. 513-538.

RODRÍGUEZ, Leticia y OTERO, Patricia, (2013): Indicadores de partidos y sistemas de partidos, Cuaderno Metodológico, núm. 51, Centro de Investigaciones Sociológicas (CIS), Madrid.

ROGINER, Luis (1990). Hierarchy and Trust in Modern Mexico and Brazil. Praeger Publishers.

ROSAS, Guillermo y HAWKINS, Kirk (2008) "Turncoats, true believers, and turnout: machine politics in the absence of vote monitoring", Manuscript, Washington University in St. Louis and Brigham Young University.

ROSENTHAL, Alan (1996). State legislative development. Observations from three perspectives. En Legislative Studies Quartely, Vol.2, pp.169-198.

RUIZ, Edwin. 2012. "El gobierno de Danilo bajo el reinado de Leonel". En Revista La Lupa. Santo Domingo, Núm. 36.

SÁNCHEZ, Miguel Eduardo y SENDEROWITSCH, Roby (2012). The Political Economy of the Middle Class in the Dominican Republic: Individualization of Public Goods, Lack of Institutional Trust and Weak Collective Action. World Bank, Washington, DC.

SANTOS, Fabiano (2006) "Governos de Coalizão no sistema presidencial: o caso do Brasil sob a égide da Constituição de 1988 in Avritzer, L. y Anastasia, A.(orgs.) Reforma Política no Brasil. Belo Horizonte: editora UFMG.

SARTORI, Giovanni (1980). Partidos y sistemas de partidos. Madrid: Alianza.

SARTORI, Giovanni (2003) ¿Qué es la Democracia?, Madrid, Taurus.

SARTORI, Giovanni. (1986). "The Influence of electoral systems: Faulty laws or faulty method? " En GROFMAN \& LIJPHART (Eds.), Electoral laws and their political consequences. New York: Agathon, pp. 43-68.

SASP. Sistema de Administración de Servidores Públicos. Ministerio de Administración Pública de la República Dominicana. En http://map.gob.do/sasp/

SCHEDLER, Andreas (2004). "El voto es nuestro. Como los ciudadanos mexicanos perciben el clientelismo electoral”, en Revista Mexicana de Sociología, Vol. 66, núm. 1, pp.57-97.

SCHEINER, Ethan (2007) «Clientelism in Japan: the importance and limits of institutional explanations», en KITSCHETL, Herbert y WILKINSON, Steven(2007). (ed) Patrons, 
Clients and Policies. Patterns of Democratic Accountability and Political Competition. Cambridge University Press.

SCHRANK, Andrew (2009) "Professionalization and probity in a patrimonial state: labor inspectors in the Dominican Republic". En Latin American Politics and Society, Num.51, Vol.2, pp.91-115.

SEDDON, Jessica; GAVIRIA, Alejandro; PANIZZA, Ugo; STEIN, Ernesto H. (2002). "Political Particularism around the World". En Working Paper, Inter-American Development Bank, Research Department, No. 463.

SEIJAS, Esther (2000), "Representación democrática, partidos políticos y tránsfugas". En Teoría y realidad constitucional, Núm. 6, pp.163-190.

SHEFNER, Jon (2001) . "Coalitions and clientelism in Mexico". En Theory and Society, Num. 30, pp.593-628.

SHEFTER, Martin (1994). Political parties and the State. The American Historical Experience Princeton University Press.

SHEPSLE, Kenneth y BONCHEK, Mark (2005) Las formulas de la política. Santillana Ediciones Generales.

SHEPSLE, Kenneth y BONCHEK, Mark (1997). Analyzing politics. Rationality, Behavior and Institutions. Norton.

SHUGART, Matthew S. y CAREY, John M. (1992). Presidents and Assamblies: Constitutional Design and Electoral Dynamics . Cambridge: Cambridge University Press.

SHUGART, Matthew S., Melody E. VALDINI, and Kati SUOMINEN (2005). "Looking for Locals: Voter Information Demands and Personal Vote-Earning Attributes of Legislators Under Proportional Representation." En American Journal of Political Science 49 (2), pp.437-449.

SIAVELIS, Peter (2004), "Sistema electoral, desintegración de coaliciones y democracia en Chile, ¿el fin de la Concertación?", en Revista de Ciencia Política, Vol. XXIV, Núm.1, Santiago de Chile: Universidad Católica de Chile.

SIAVELIS, Peter y MORGENSTERN, Scott (2008), Pathways to power: political recruitment and candidate selection in Latin America, University Park: Penn State University Press.

SOTCKES, Susan, DUNNING, Thad, NAZARENO, Marcelo, BRUSCO, Marcela (2013). Brokers, Voters, and Clientelism: The Puzzle of Distributive Politics. Cambridge University Press: Cambridge Studies in Comparative Politics.

SQUIRE, Peveriel (1993) "Professionalism and public opinion in state legislators". En Journal of Politics, Vol. 55, No.2, pp.479-491.

STOCKES, Susan (2007)"Political Clientelism", en The Oxford Handbook of Comparative Politics, BOIX, Carles y STOCKES, Susan (ed), Osford University Press, p. 499-521.

STOKES, Susan (2005). "Perverse Accountability. A Formal Model of Machine Politics with Evidence from Argentina", en American Political Science Review, vol. 99, núm. 3, pp. 315325 .

STRAUS, Jacob (2002). Balance of power. Amateus and professionals in the House of Representatives. Documento presentado en la Annual Meeting of the American Political Science Association. Boston, MA. August 29-1 September, pp.29.

STROM, Kaare (1990), Monority Government and Majority Rule. Cambridge University.

SUAREZ, Nelson (2013). Primer Informe de Monitoreo Aplicación de la Ley de Función Pública No. 41 de 2008 y su Reglamento. Santo Domingo: Participación Ciudadana.

TAKAHASHI, Yuriko (2007). "The Political Economy of Targeted Poverty Alleviation: Distributive Politics, Electoral Cycles, and Progresa-Oportunidades in Mexico", ponencia, Latin American Studies Association, International Congress-2007, 5-8 septiembre, Montreal.

TARROW, Sidney (1977). Between Center and Periphery: Grassroots Politicians in Italy and France, Yale University Press. 
TAYLOR-ROBINSON, Michele M; DIAZ, Chris. (1999). "Who Gets Legislation Passed in a Marginal Legislature and is the Label Marginal Legislature Still Appropriate? A Study of the Honduran Congress". En Comparative Political Studies, 32, pp.589-625.

TEJADA, Ramón (2007) "El fundador del clientelismo post-trujillista no puede ser el padre de la democracia", En Desde el País de Alicia, (Blog).http://desdeelpaisdealicia.blogspot.com/2007/04/el-fundador-del-clientelismopost.html

TELLERÍA, Gabriel (2011). "A Two-Headed Monster: Bicaudillismo in Nicaragua." En Latin American Policy, Vol. 2, 1, pp.32-42.

THELEN, Kathleen y STEINMO, Sven (1992), "Historical institucionalism in comparative politics", en VV.AA, Structuring Politics: Historical Institucionalism in Comparative Analysis, New York, Cambridge University Press.

TORCAL, Mariano (2006), "Desafección institucional e historia democrática en las nuevas democracias", en Revista SAAP (ISSN 1666-7883) Vol. 2, Nº3, 2006, 591-634

TORCAL, Mariano y MONTERO, José Ramón (2006). Political Disaffection in Contemporary Democracies. Social Capital, Institutions, and Politics, Londres, Routledge.

URIARTE, Edurne (2000). "La política como vocación y como profesión. Análisis de las motivaciones y de la carrera política de los diputados españoles. En Revista Española de Ciencia Política, Núm. 3, octubre, pp.97-124.

USLANER, E. (2002). The Moral Foundations of Trust. Cambridge: University Press.

VALENZUELA, Arturo y LINZ, Juan (1994), The Failure of Presidential Democracy. Baltimore: Johns Hopkins University Press.

VALENZUELA, J. Samuel (1992): "Democratic Consolidation in Post-Transitional Settings: Notion, Process, and Facilitating Conditions". MAINWARING, O’DONNELL \& VALENZUELA (eds.) Issues in Democratic Consolidations: The New South American Democracies in Comparative Perspective, Notre Dame.

VARGAS, Tahira (1994). "Las organizaciones de base en Santo Domingo", en Estudios Sociales, año XVII, n. ${ }^{\circ}$ 97: 91-112.

V-DEM (2014) Varieties of Democracy Project. Kellogg Institute, Michael Copedge (dit) En https://v-dem.net/DemoComp/en/

WARE, Alan. (1987). Citizens, parties, and the state. Princeton, NJ: Princeton University Press.

WARNER, Carolyn M. (2001), "Mass parties and clientelism in France and Italy". En Piattoni, S. Clientelism, Interests, and Democratic Representation. The European Experience in Historical and Comparative Perspective. Cambridge.

WARWICK, Paul (1994), Government survival in parliamentary democracies. Cambridge: Cambridge Univsersity Press.

WEBER, Max (1919). El político y el científico. Madrid: Alianza Editorial.

WEBER, Max (1991). ¿Qué es la Burocracia?. Editorial Leviatán, Buenos Aires.

WILKINSON, Steven I. (2007)"Explaining changing patterns of party-voter linkages in India". En Herbert KITSCHELT and Steven WILKINSON, (eds), Patrons, Clients, and Politics. Cambridge, UK: Cambridge University Press, pp. 110-139.

ZAK, Paul J.and KNACK, Stephen (2001). "Building Trust: Public Policy, Interpersonal Trust, and Economic Development". En, Social Science Research Network, November 30.

ZARISKI, R. (1960). "Party Factions and Comparative Politics: Some Preliminary Observations". En Midwest Journal of Political Science, Vol. 4, pp. 27-51.

ZELAZNIK, Javier (2001), "The building of coalitions in the Presidential systems of Latin America: an inquiry into the political conditions of governability". Tesis Doctoral, Departament of Government, University of Essex.

ZOVATTO, Daniel (2010), "Las instituciones sí importan". En Infolatam, 05-09-2010. 


\section{SIGLAS PARTIDOS POLÍTICOS}

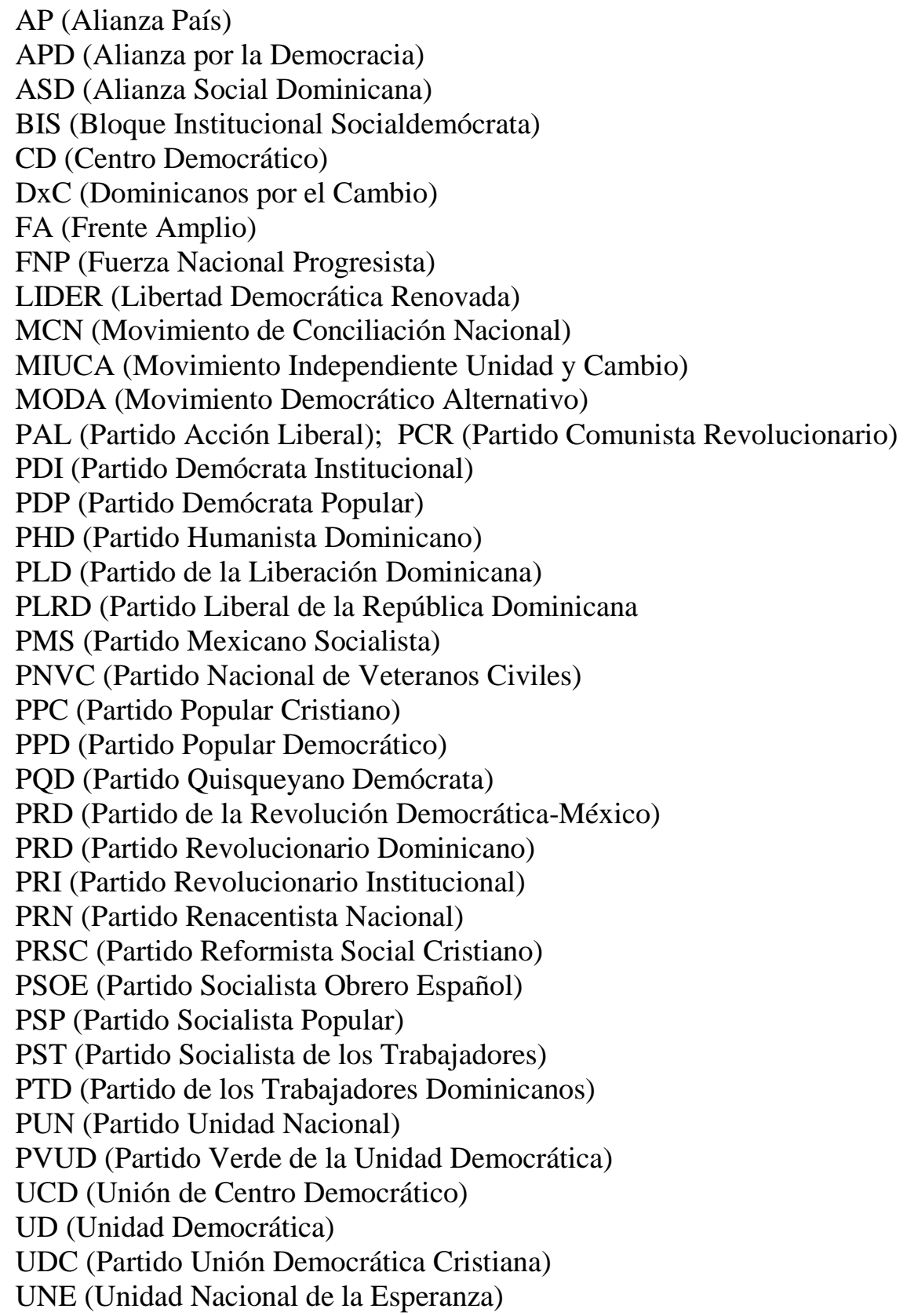




\section{ANEXOS (Listado de entrevistas actores clave nacionales)}

Abogado laboralista Santo Domingo [14-04-2014]

Activista comunitaria, ex consultora de la Fundación Friedrich Ebert-RD [4-02-2010]

Activista movimiento juvenil Toy Jarto [9-10-2013]

Activista movimiento juvenil La Multitud [1-12-2013]

Activista organización social Coalición Digna por la Educación [2-09-2013]

Activista sindical Confederación Nacional de Transporte (CONATRA) [13-12-2010]

Candidato a síndico por el PLD provincia Elías Pina [28-02-2010]

Candidato a síndico por el PRD provincia La Esperanza [21-02-2010]

Candidato a síndico por el PRSC provincia Elías Pina [28-02-2010]

Consultora Federación Dominicana de Municipios (FEDOMU) [12-08-2010]

Coordinador Políticas Publicas Movimiento No Partidista Participación Ciudadana [6-04-2013]

Diputado PLD provincia Distrito Nacional [30-05-2011]

Diputado PLD provincia Santiago [7-06-2011]

Diputado PRD provincia Santo Domingo [4-05-2011]

Diputado PRSC aliado al PLD, Distrito Nacional [12-11-2010]

Director Centro de Estudios Sociales, UNIBE [2-07-2011]

Director Centro de Gobernabilidad y Gerencia Social, INTEC [ 20-11- 2012]

Director Ejecutivo Movimiento Cívico No Partidista Participación Ciudadana [ 15-08-2010]

Director FLACSO-RD [11-06-2009]

Directora Centro de Investigación en la Educación, Ex Rectora INTEC [28-11-2012]

Dirigente medio Partido Revolucionario Dominicano (PRD) [21-08-2013]

Dirigente medio Bloque Institucional Socialdemócrata (BIS) [18-06-2009]

Dirigente medio Nueva Generación Reformista [5-05-2012]

Dirigente medio Partido Liberal de la República Dominicana (PLRD) [1-07-2010]

Dirigente medio Partido Nacional de Veteranos Civiles PNVC

Dirigente medio Partido Quisqueyano Demócrata Cristiano (PQDC) [25-01-2013]

Dirigente medio Partido Reformista Social Cristiano (PRSC) [8-07-2011]

Dirigente medio Partido Revolucionario Social Demócrata (PRSD) [23-07-2010]

Dirigente nacional Alianza Por la Democracia (APD) [22-01-2013]

Dirigente nacional Partido de la Liberación Dominicana (PLD) [5-02-2012]

Dirigente nacional Partido Popular Cristiano (PPC) [9-08-2012]

Dirigente nacional Partido Revolucionario Dominicano (PRD) [17-10-2014]

Dirigente provincial Partido de la Liberación Dominicana (PLD) [7-09-2014]

Dirigente provincial Partido Reformista Social Cristiano (PRSC) [6-03-2010]

Ex Dirigente Partido Comunista Dominicano, investigador INTEC [3-12-2013]

Funcionaria Despacho de la Primera Dama [14-03-2010]

Funcionaria Junta Central Electoral (JCE) [23-08-2009]

Funcionario Instituto Nacional de Administración Pública [7-04-2011]

Funcionario rango medio Junta Central Electoral (JCE) [11-01-2013]

Investigador inmigración y organizaciones juveniles FLACSO-RD [23-03-2009]

Investigadora ONU Mujeres-RD [01-02-2014]

Presidente Cámara de Diputados de la República Dominicana [5-11-2009]

Representante Asociación Nacional de Jóvenes Empresarios-RD [16-05-2012]

Representante Federación Trabajadores Zonas Francas (FEDOTRAZONAS) [5-08-2013]

Representante Fundación Institucionalidad y Justicia (FINJUS) [17-08-2011]

Representante movimiento social Justicia Fiscal [15-11-2013]

Representante sindical Confederación Autónoma Sindical Clasista (CASC) [7-07-2009]

Representante sindical de la Asociación Dominicana de Profesores (ADP) [29-06-2014] 
